COPYRIGHTED BY

JAMES IRVING MATRAY

ALL RIGHTS RESERVED

AUGUST 1977 
THE RELUCTART CRUSADE:

American Foreign Policy in Korea 1941-1950

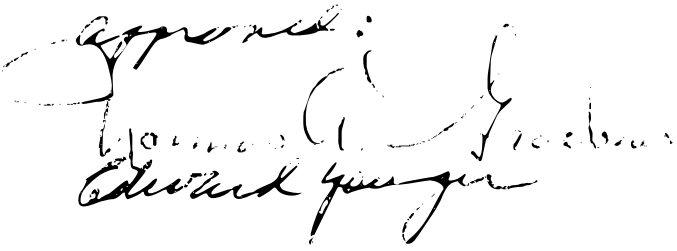

James Irving Natray

Evergreen Park. Illinois

B.A. Lake Forest College, 1970

M.A.. University of Virginia, i9?3

A Dissertation Presented to the

Graouate Faculty of the University of Virginia in Candidacy for the Degree of Doctor of Philosophy

Corcoran Department of History

University of Virginia

August

1977 


\section{DISSERTATION A.3STRACM}

The Reluctant Crusade: American Foreign Policy in Korea 1941-1950

James Irving inatray

Inirersity of vinginia

This dissertation is an investigation of Americar. foreign policy in Korea from the beginning of Norld var II until the outbreak of the korean war. It focuses particum larly on evaluating the wisdom of American leaders in racosrizing the limitations on the power of the United States in formulating poliey objectives in Korea. In additicn, the study analyzes America's Korea policy in the larger contex: of the postwar international struggle between the United States ard the Soviet Union. Previousiy, most schoiars nave agreed that the irmuman Doctrine marked the crucial turring point in postwar Anerican forsign poicy. In reajity, the Korean war withessed the emergence of America's unimitad commitment to dafend the worid from the threat of soviet domination.

Prior to 1341, the United States had been indifferent to Korea's fate. During World War II, however, Franklin D. Roosevelt developed the realistic policy of pursiling a fourpower trusteeship for Korea, to include the United States, Britain, Crina, and the Soviet Union. When Harry S. Truman 
became President in 1945. Soviet expansionism in Eastern Europe had begun to alarm American leaders. As a result, Truman attempted to liberate Korea unilaterally and thus reconstruct this nation without Soviet interference. Stalin's decision to send the Red Army into Korea before the United States had an opportunity to land troops in the peninsula forced Truman to settle for a line dividing Korea at the 38 th parallel into zones of occupation. The Soviet-American partition of Korea meant that a civil war was likely unless the major powers could agree to peaceful reunification. After 1945. Truman sought to reunify Korea under a Eovernment that reflected the American, rather than the Soviet, model of political and economic development. At the Moscow Conference in December, 1945, the United States and the Soviet Union appeared to agree on trusteeship as a soiution to the Korean problem. When Stalin refused to accept the American interpretation of the Moscow Decision, Truman rejected further negotiations and turned to the containment policy to break the Koraan deadlock. Containment sought to build a strong, democratic, Western-oriented government in South Korea capable of self-defense, thus permitting American withdrawal. At the same time containment would act as a liberating force. When the North Koreans recofnized the benefits involved in accepting Amerisan economic aid and diplomatic support, they would oust the Communists and seek reunification under the South Korean regime.

By the fall of 1948, Scuth Korea emerged as Truman's 
test case of containment in Asia. Success in Korea poula resoive two difficuit problems. Pinst, Fruman coulc utilize limited amounts of economic aid and technical advice to halt the Soviet acvance without having to resort to American military power. Second, the Adninistration sought to atone for America's failure in China and trus eliminate Republican criticism of mruman's foreign policy, Containment promised to achiere a great deal at home and abroad, but at a relatively linited cost in torms of men and material.

Unfortunately, the Nortin Koreans decided to invade Souti Korea in June, 1950. This attempt at forcible reunification shattered the foundation of Truman's postwar foreign policy. American prestige and credibizity demanded that the united States act to defend the South Koraans. Tragicaliy, the Administration adopted an overly emotional and simplistic justification for intervention. Far from being a local civil war, mmunan viawed the Korean conflict as nothing less than the initial phase in a Soviet campaign for world conquest. Eneviously, the United Statos was uncertain regarding the nature and magnitude of the Soviet threat. After 1950, Hoscow's aims appeared global and aimed ultimately at tine United States. In the wake of the Korean War, the United States embarked again on a global crusade for tine achievement of universal principles of law and justice. 
Whe activities of the U.N. in Korea rave been described as "the reluctant orusade."

Korea's significance is not the final crusade. It is not finally making valid the idea of collective security. . .

Collective security is not something which is established once and for all by some dramatic gesture. Collective security is like a bank account. It is kept alive by the resources which are put into it. In Korea the Russians oresented a check which was drawn on the bank account of collective security. The Russians thought the cheok would bounce. They thought it was a bad check. But to their great surprise, the teller paid it. The important thing was that the check was paid. The importance will be notring if the next check is not caid and if the bank account is not kept strong and suficicient to cover ali checks which are drawn luon it.

.... Dean Acheson

June 29,1951 
American diplomatic historians have devoted considerable attention in recent years to an analysis of SovietAmerican relations after World war II. Initially, scholars praised the United States for abandoning prewar isolationism and adopting a posture of determined opposition to the perceived threat of Soviet ideology and power. During recent years, however, some historians have questioned the motives and objectives of postwar American foreign policy. "New Left" historians have attempted to portray the United States as an imperialist nation determined to astablish global hegemony for trie benefi.t of an American business elite. Others have questioned the techniques and scholarship of the "New Ieft," arguing that these writers intentionally distort reality, Yet, few scholars have successfully formulated a realistic and accurate appraisal of the Soviet-American confrontation.

Scholars have concentrated primarily on assiznning blame to Moscow or Washington for the emergence of the Cold War. For some, particular issues sucri as Poland on the Atomic Bomb were prime movers in producing the costwar confrontation. Still other historians argie that the United States and the Soviet Union could have rasoived 
their differences had it hot been for misunderstanding and misconception. These evaluations dismiss the more obvious conclusion that Soviet-Americen disagreements after Norio War II were inevitable. Diplomacy could never completely eliminate the problems of postwar Soviet-American relations, because the principal cause of the dispute was a basic divergence in national interests. Yat. if the two nations had been able to acceot their differences as the nomai outgrowth of changing conditions in international affairs, then negotiations might have reduced resultant animosity and tension. Unfortunately, neither the United States nor the Soviet union respected the right of its adversary to possess complete freedom of action in areas of paramount concern, In fact, neither Washington nor Moscow remained uninvolved in areas where its adversary possessed a greater historic national interest or a superior strategic position. This mutual failure was responsibla for the transformation of a major conflict of interest into a "cold war." Events in Korea from 1941 to 1950 illustrate clearly the nature of the Soviet-American confrontation. After dividing Korea at the 38 th parallel in 1945, Washington and Noscow pursued unilateral policies of zonal reoonstruction that totaliy disregarded the other's interests. Each nation's approach was a reflection of its own poilticai, economic, and social system. Both American and Soviet, leaders wanted Korea to emulate its model for national 


\section{ii i}

development. Tragically, the result was the emergence of two incompatible Koreas. The price of liberation was dismemberment and permanent partition. Eerhaps worse, for as one American official wrote, "In both north and south Korea the drive for national unification was to ce a primary political force: neither area could be expected to be satisfied with the status quo."

Soviet-American relations in Korea thus represent in microcosm the nature of the Cold Har confrontation. Korea unwillingly accepted two utterly opposed systems of political and economic development. The two Koreas thus emerged as an excellent example of the "absorption of external iorces into a political vacuum." 3 Both the United States and the Soriet Union were dissatisfied with the situation not only in Korea but in other areas of the world as well. Yet, the major powers averted an open military conflict with one another because both realized that any attempt to alter the status quo would be far too expensive in men and naterial. In Korea, however, the logic of the Cold war was unrestrained and led inexorably to the outbreak of civil war. In the

\footnotetext{
George M. NoCune and Arthur I. Grey, Jr., Korea Today (Cambridge: Harvard University Press, 1950$), \frac{\frac{K}{271 .}}{271}$ 2U.S. Department of State, North Korea: A Case Study in the Techniques of Takeover, Far Eastern Jeries \#1.03 (Washington, D.C.: Government Frinting Oifice. January 1961), 11. 3

Joungwon A. Kim, Divided Korea: The Politics of $\frac{\text { Development }}{\text { Press, 1975). }} \frac{194}{3 .}-1972$ (Cambridge: Harvard University
} 
spring of 1950, George Mccune observed, "The fact that the 'cold war' has reached an advanced form in Korea with the establishment of separate fully recognized governments does lend some logic to looking toward Korea ior signs of a turning point in international relations." Thus, the logic of the Cold War meant that, in Korea, civil war was both predictable and probably unavoidable.

Previous studies of the Korean tar have, as a rule, either disregarded entirely or dealt crily superficially with the events prior to 1950. A proper understanding of American foreign volicy during the korean Nar is impossible without first grasping the nature of united states aims in the peninsula prior to the attack. Similarly, it hampers a proper perception of the impact of the Korean War on the fundamental aspects ol American postwar policy outside of Western Europe. Many scholars have subsequently lauded "Iimited war" in Korea, arguing that it is ar example of realism and represents the only answer to Soviet "salami tactics." 5 in the words of the British writer David Rees, the Korean intervention was "the greatest and noblest act of recent American history." Hopefully, a closer

McCune and Crey, Korea Ioday, 271.

5 John W. Spanier, The Truman-Macenthur Controversy and the Korean War (New York: w. Wh Nonton, 296.5), 3; Robert osgood, whe Limited War: whe Challenge to American Strategy (Chicago: University of Chicago press, 1957), 1.63. David Reos, Korea: The Limited Nar (Now Yorl: St. Nartin's Press, 1.964$), 445$. 
examination of American foreign policy in Korea from $194 i$ to 1950 will reduce such hyperbolic evaluations to more manageable proportions.

At this point, I would like to acknowledge several individuals whose assistance was indispensible in the research and writing of this dissertation. Regardiess of where I traveled to engage in research, the stafis of these institutions were uniformily pleasant and exceedingly helpful. In particular, John Taylor, william Cunlifise, and Edward Reese of the Modern Military Branch at the National Archives devoted considerable time and energy to removing unnecessary barriers in my investigations. At the Princeton University Library, Nancy Bressier permitted my access to the Dulles Papers despite the fact that she was then engaged in the arduous task of reclassifying these manuscripts. While visiting the Macerthur Iisrary, Larry Redford's efficiency in locating and proviaing documents ensured that none of my Iimited time was wasted. I would also like to express my thanks to the Eiplomatic Branch at the National Archives, the Library of Congress, the University of Virginia Library, and the Clemson University Iibrary for their assistance.

I am particularly grateful to the Harry S. Iruman Iibrary Institute for awarding me a research grant during 1975. During both of my visits to Independence. Dennis Bilger spent many hours uncovering and bringing to my 
$v \mathbf{i}$

attention new and significant information. His friendiy attitude and propessional competence is characteristic of the entire archival staff thus making the Iruman Library an outstanding institution for research.

I am deeply indebted to Norman A. Graebner for his guidance and assistance not only on this project, out throughout my graduate career. His sincere concern for my intellectual and professional progress continue to provide a source of personal inspiration. His stylistic criticisms and comments on content were indispensible for the completion of the dissertation in its final form. Edward $E$. Younger read parts of the manuscript in its initial rorm and reminded me of the importance of objectivity and balance in historical writing.

While engaged in research in Washington, D.C., I was invited to stay at the nome of Tony Lerner and his family, who reside in Vienna. Virginia. I owe the Lerners a deep debt of gratitude ior making my frequent visits both comfortabie and inexpensive, Finally, I wish to dedicate this stuay to Karin in appreciation for her wiliingness to sacrifice personal interests so that I could pursue my career amititions. Without Karin's moral suppori during the past years, I could never have cursuad or octained $a$ doctoral degree. Clearly, the credit for my success belongs largely to her. 
vii

\section{Table of Contents}

Preface . . . . . . . . . . . . .

List of Abbreviations .......... . viii

Introduction . . . . . . . . . . . . 1

Chapters:

I: An End to Irdifference . . . . . 15

II: Captive of the Cold War........ 70

III: In Search of a Settlement, . . . . 129

IV: Patience with Firmness . . . . . . 180

V: An Avenue for Escape ....... 235

VI, The Dilemma of Withdrawal . . . . 300

VII: Test Case of Containment . . . . . 369

VIII: Preiude to Civil Nar . . . . . . 437

IX: America's Reluctant Crusade...... 505

Conclusion . . . . . . . . . . 555

Selected Bibliography . . . . . . . . 573 


\section{viii}

\section{Iist of Abbreviations}

ANiG: $\quad$ American Military Government

CUI: Clemson University Iibrary

DMMi: Douglas MacArthur Memorial Library

DPRK: Democratic People's Republic of Korea

DSB: Department of State Bulletin

ECA: Economic Cooperation Administration

FRUS: Foreign Relations of the United States

HSTI: Harry S. Truman Library

KMAG: Korean Military Advisory Group

KFG: Korean Provisionai Government

LOC, Library of Congress

DPD: Operations Planning Division

OSS: Office of Strategic Services

P\&O: Planning and Operations

PUL: Princeton University Library

ROK: Republic of Korea

SANACC: State-Army-Navy-Air Force Coordinating Committer

SKIG: South Korean Interim Government

SKIIA: South Korean Interim Legislative Assembly

SWNCC: State-War-Navy Coordinating Committee

UNCOK: Unitad Nations Commission on Xorea

UNTCOK: United Nations Temporary Commission on Korea

USAFIK: United States Armed Forces in Koroa

UVAL: University of Virginia Iibrary 
Introduction 
Under the leadership of Harry S. Truman, the United States committed its power and prestige in a worldwide stmaggle to preserve peace and security. As a result, American foreign policy exporienced a fundamental transFormation during the Truman years as the nation abandoned isolationism and embraced globalism as the central feature in its approach to international affairs. The crucial turning point in postwar American diplomacy arrived in June, 1950, when the United States intervened in the Korean war. In his memoirs, Truman himself indicates the significance of the evert: The United States had Iearned the principal lesson of the interwar period and now recognized that, far from halting aggression, appeasement oniy guaranteed a future war and reduced the chances for successful resistance. 1 Truman enthusiastically stressed that American intervention in Korsa symbolized the determination of the united states to use force to resist Communist imperialism and Scviet inspired military aggression. Thus, in his farewell aduress in 1953 , Truman pointed to the Korean decision as "the most

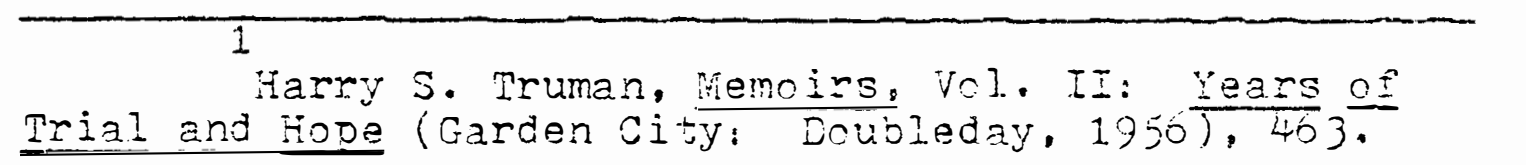


important in my time as President."

World War II convinced Anerican leaders that the United States could no Ionger avoid active political involvement in international affairs without seriousiy endangering national security. Policy-makers remained in doubt, however, regarding the nature and extent of the new American commitment to act positively for the creation and maintenance o: world stability. Soviet expansion into Eastern Europe alarmed American leaders and added urgency to the task of defining specific postwar objectives and formulating realistic policies that would achieve success at reasonable cost. When Franklin D. Roosevelt died in April, 1945 , however, the United States had done little to reorient its. foreign policy to correspond with its new role as world leader. Aside from a commitment to support an international security organization, american leaders had not prepared the nation to meet adequately the multiple challenges of postivar foreign affairs.

Harry S. Truman thus assumed the direction of American foreign policy at a crucial point in the nation's history. The new president faced the difficult task of resoliting two basic problems. First, American leacers, even before

Tmuman, "The Challenge of the Cold iar," Devartment of state Bulzetin, XXIII, 709 (January 26, $1 . \overline{953), 127 . ~}$

Stephen E. Ambrose, Rise to Glocalisin: Ameriean Foreign Policy 1938-1970 (3altimore: Penguin Bosks, 1972), 111. 
Roosevelt's death, perceived the challenge of Soviet ideology and power, but remained uncertain as to the magnitude of the resultant threat to national security. Once Truman defined his perception of Soviet intentions, he would face, secondly, the more difficult matter of devising an appropriate response. In essence, the postwar foreign policy debate revolved around these tivo fundamental issues, out Truman benefited from a bipartisan consensus that supoorted an American posture of opposition to any perceived danger to world stability. The signisicant aspect of the initial American reaction to the Cold War, however, was tha determination of policy-makers, domestic politicians, and journalists to secure American objectives through limited international involvement. American leaders thus focused attention on a choice between several strategic and tactical alternatives in confronting the soviet challenge all of which empiasized restraint.

Inexperience alone was sufficient to dictats calition, since the United States faced unprecedented problems. Sweeping and complex change characterized the postwar period and the world experienced extreme difficulties in readjustment and transition. Defeat of the Axis required the destruction of the prewar international system in

Milliam Reitzel, Morton A. Kaplan, and Constarie G. Collenz, United States Foreign Policy 1.945-1955 (Washingtor, D.C.: The Brookings Institute, 1950), ?4. 
Europe and Asia. As a result, a rapid restoration of peace and stability was an urgent necessity. Korea was then only one facet of a much larger problem, but, in many respects, the American response to the challerge of instability in Korea typified postwar policy throughout Asia. Toward the end of World War II, the United States faced the dilemma in Korea and elsewhere in Asia of "how simultaneously to drive out the Japarese, to prevent the resurgence of European colonialism, and to foster the gronth of democratic, capitalistic local governments, all without actually making the effort necessary to put the man with the gun on the soot."

After years of colonial domination, Koreans in particular lacked sufficient poljtical experience to solve the manifold social and economic problems confronting their nation. Nevertheless, they demanded immediate independence and self-government. Thus, as the United States commenced occupation of Korea in September, 1945, American leaders faced not only enormously complex problems, but also the likelinood of local opposition to American advice and assistance. Perhaps worse, uncertainty over Soviet aims in Korea prevented an accurate perception of the problen and

David S. McIellan, Commentary, in The mruman Per-

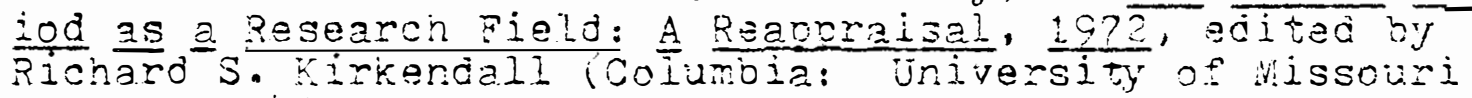
Press, 1974$), 159$.

Amorose, Rise to Globalism, 83 . 
the formulation of effective solutions.

Truman resvonded to postwar international instability in a thoroughiy predictable fasnion that reflected a desp devotion to the American tradition of political liberalism. Consinced of America's altruism and the superiority of its political system, Truman hoped to utilize the nation's power and influence to guarantee to Iiberated peoples freedom of choice in the political, economic, and social reconstruction of their nations. Trumar was convinced that the realization of the wilsonian dream of nationai selfdetermination throughout the world would produce an international system of maximum stability. In addition, is nations shared American values and institutions, they would be less Iikely to threaten the security of the United States. Such an evaluation round substantiation in Korea. In March, 1946, occupation commander Iieutenant General John Reed Hodge stressed that the United States was determined to see that "a government that corresponds to the views of the majority is established." only national self-determination. Hodge argued, could produce "the political, economic, and social progress of the Korean people, the development of democratic self-government, and the establishment of national independence of Korea." The success of this

Alonzo L, Hamby, Beyond the New Deal: Marry $\underline{\text { S. }}$ mruman and Amerian Liboralism (New York: Columbia University Press, 1973), 1.15.

Ibid.; Ambrose, Rise to Globaiism, 15. 
approach in Korea would ioster internal prosperity and international stability, thus serving weli the economic and security interests of the United States.

For the Soviet Union, on the other hand, Korea was perhaps second only to Eastern Europe in strategic importance for Russian national security. Korea played a prominent role in precipitating the Russo-Japanese Har of 1904 which had been so completely disastrous for Tsarist Russia. As a result, it was improbable that the Soviet union would entrust $i$ ts security interests in Korea to the principle of national self-determination. Colonel General Terenty $F$. Shtikov illustrates quite clearly the validity of this conclusion in his response to General Hodge's statement of American objectives. Shtikov pointed out that the Soviet Union sought the realization of "a true democratic and independent country, friendly to the Soviet Union, so that in the future it will not become a base for an attack on the Soviet Union."

Soviet-American negotiations during 1046 and $194 ?$ failed to reunify Korea and revealed with striking clarity the incompatibility of the two nation's objectives in that country. Thus, Korea emerged from World War II as not a liberated nation, but "a hostage to the strategies and

Hodge's statement is printed in full in Mccune and Grey, Korea Today, 2?ó-278. 10 Shtikov's statement is MicCune and Grey, 279-281. 
ambitions oI the cold war..." Truman refused to accept Soviet intransigence in Korea much as he had in Eastern Europe, but lacked the power to force Soviet compliance with American policy objectives in Korea. Lacking an overall plan to counter the challenge of Soviet expan1.2

sion, American foreign policy manifested considerable irresolution during the early years of the Cold war. George F. Kennan's formulation of the containment polisy and its subsequent application in Europe during 1947 ended a great deal of the uncertainty and vacillation.

Kennan's containment sirategy had a powerful impact on Truman and his advisors because it answered the most, vital questions confronting the Administration since its assumption of power. Containment not only defined the nature of the Soviet chailenge, it also cutlined an appropriate response. Kennan's policy promised to halt the Soviet advance and preserve American security at the relatively low cost of economic, technical, and military limited regarding the extent to which the United States would have to commit its power to ensure success. Finus,

11 Frank Baldwin, Introduction, in without Paral1el: American Korean Relationship Since 1945, edi ted by Frank Baldwin (New York: Fantheor Books, 1974). 3. 1.2

John Lewis Gaddis, "Nas the Truman Doctrine a Real Turning Point?," Foreisn Affairs, III, 2 (January 1974), 391.

${ }^{13}$ George F. Kennan, Memoirs 1925-1950 (Boston: Iittle, Brown and Company, 196?), 354-36?. 
Harry J. Middieton distorts the meaning of Kennan's policy recommendations, when he refers to them as "containment-byforce-if-necessary." In reality, Truman and his advisors hoped that containment would remove the necessity for using American troops to counter Soviet expansionism.

Ironically, although containment diverged sharply from traditional tenets of non-involvement, the policy sought to maintain some degree of continuity with previous principles of American diplomacy. For example, Americans had long viewed war as an aberration and an unpleasant interruption in domestic pursuits. Once forced to engage in conflict, the nation had always appised maximum force for quick and total victory. An American attempt to defeat the Soviet Union militarily after World War II would not only have seen costly, but exceedingly unpopular with the general public. Containment provided an attractive alternative, since it promised the avoidance of war and ultimate victory in the Cold War. Although success would not emerge quickly, Moscow's defeat would eventually occur in "either the breakup or the gradual mellowing of Soviet power."

Containment would also facilitate the realization

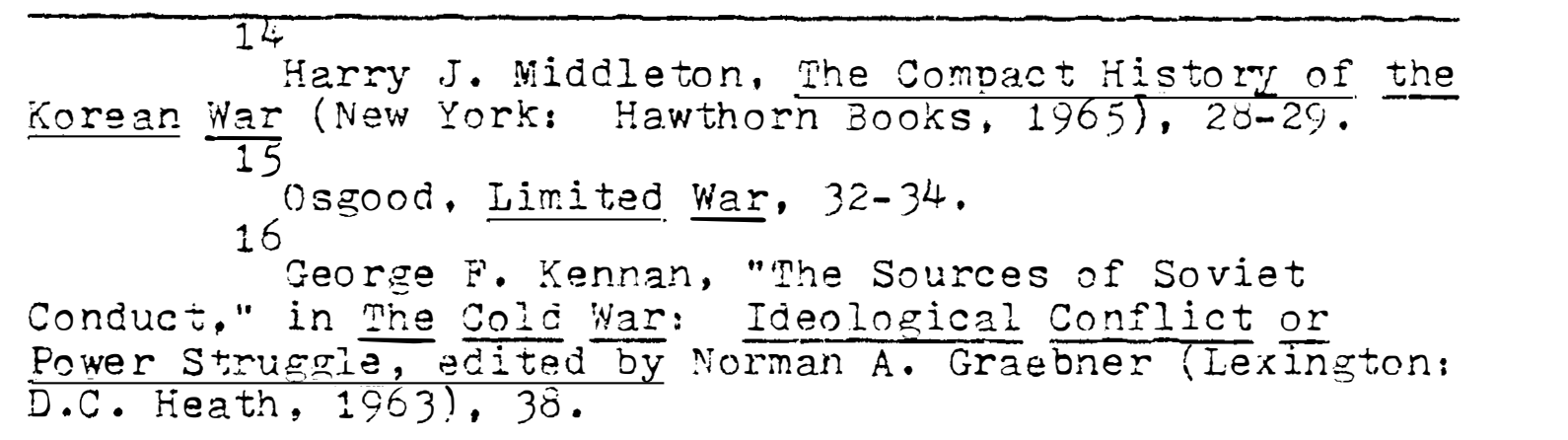


of Truman's goal of national self-determination. The Soviet Union, Truman believed, exploited postwar economic distress to foster civil strife that allowed Communist minorities to seize power and prevent freedom of choice. Application of containment was then perfectly designed to "aid the nations in the creation of such stability as makes free choice possible." I? Ignoring the crucial importance of the Red Army to Communist expansion, Kennan's formula sought to dery the Soviet inion an environment conducive to expansion, while promising success at a relatively limited cost to the United States. As Truman explains in his memoirs, the purpose of containment was much broader than it appeared after a superficial examination, since it aimed at "a united, free, and prosperous wo:ld." 18 Few American leaders could forsee that, as walter Iippman explained at the time, the imolementation of containment would be neither easy nor inexpensive. 19

Containment appeared especialiy successful in Europe, largely because the Soviet Union never seriously challenged the American security system. The Truman Doctrine and the Marshall Plan both contributed mightily to European economic and poiftical stability because of a series of fortuitous

1 ?

Jonathan Daniels, The Man of Independence

(Philadelohia: J.3. Lippincott, $\frac{19}{190}, \frac{\text { Indener }}{368 .}$

18 19

Truman, years of Trial and Hoce, 290 . Walter Iippman, The Cold Nar: A Study in U.S.
Foreign Policy (New York: 
circumstances. The United States was, after all, operating in an area of historic national interest and was applying the proper remedy to easily defined problems. Most important, the containment poilicy had the support of those people it sought to help and protect. In Asia, however, containment would not benefit from these advantages and its uitimate objective was much broader. Truman and his advisors hoped to utilize economic aid and technical advice to foster the emergence of prosperous, democratic states. Although Asia did not share western traditions, the Truman Administration anticipated the adoption of the American model for economic and political development once Asians recognized the superiority and benefits of the system.

Despite America's failure in China after world War II, Truman maintained confidence ir the ultimate promise of containment in Asia. By 1948, Korea had emerged as the test case for the policy. In April. Truman approved NiSC-8 which provided for a three-year economic assistance orogram and a military advisory group. In a revealing letter to State Department official James K. Penfield, Arthur $C$. Bunce, as Hodge's economic advisor, clarified the ultimate objective of containment in Korea. Bunce stated his hope

\footnotetext{
Ronald Steel, Pax Americana (New York: Viking Press, 1972), 11 . 21

NSC-8, April 2, 1948. U.S. Department of state, Foreign Relations of the United States, 1948, Vol. VIII: The Ear East and Australasia (Nashington, D.C.: Government Printing ()fice, 1974), 1163-1168.
} 
that the new South Korean leaders "will institute a whole series of necessary reforms which will so appeal to the North Koreans that their army will revolt, kill all the nasty Communists, and create a lovely liberal democracy to the everlasting credit of the U.S.A.!" ${ }^{22}$ Containment in Korea was intended to defeat Soviet expansion and register a victory for national self-determination. In fact, the Truman Administration viewea containment as a liberating force throughout Asia. At least that was the hope.

Containment in Korea never reached the level of success that mruman and his advisors had anticipated. The nation remained politically divided and economically weak at the outset of 1950 and the future of containment as a liberating force in Korea remained in doubt. At this juncture, as Kennan Iater explained, the North Korean attack on South Korea in June "stirred us up like a stone thrown into a beenive."

For Truman and his advisors, the North Korean agoression was Soviet inspired and represented "nothing less than the beginning of a general assault on the free worla." The Soviet threat now appeared global in scope and

Bunce to Penfield, January 20,1948, U.S. Department of State Arcinives, Record Group 59, 895.00/ 1-2048, National Archives, Nashington, D.C. 23 Kennan, Memoirs 192 $=-1950,500$. 24

Norman A. Fraebner, Cold War Diplomacy 1945-

1960 (Frinceton: D. Van Norstand, 1962 ), 54. 
determined ultimately to conguer the entire world through armed invasion. On June 26, Tmman indicated to his special advisor George M. Elsey the magnitude of the chailenge:

Korea is the Greece of the Far East. If we are tough enough now, if we stand up to them like we did in Greece three years ago, they won't take any next steps. But if we just stand by, they'll take over the whole Middle East. There's no telling what they'll do, if we don't put up a ilight now. 25

For Truman and his advisons, the Korean attack indicated a Soviet threat of dire proportions and demanded a comparable American response. Containment revealed its inadequacy, for the challange of Soviet ideology and power was not only economic, but also military in nature. In the wake of the outbreak of civil war in Korea, the United States overreacted and embarked upon a global crusade that committed the nation's power and prestige in areas that frequentiy bore no relationship to historically established national interests.

American intervention in Korea produced a fundamental alteration in postwar foreign policy assumptions. The United States now perceived the Soviet threat as global. To ensure Anerican security, Truman inaugurated a trend toward large defense spending, increased presidential poiver,

George H. Elsey Notes, June 26, 1950, George N. Elsey Papers, File 71, Harry $S$. Truman Library, Indevendence, Missouri. 26

Norman A. Graebner. Ijeas and Diclomacy (New York: Dxford iniversity Press, 1964), $720 ;$ Steei, Pax Americana, 23; See also, Lippman, The Cold Nar. 
and intense suspicion of revolutionary nationalist move27

ments. Tragically, this transformation was not based on a calcuiated estimate of means and ends in diplomacy, but rather on an axiom rooted in the lessons of history. As Truman indicates in his memoirs, the Soviet union, in ordering the attack, "was acting in Korea just as Hitler, Mussolini, and the Japanese had acted ten, fifteen and twenty years earlier." 29 Such assumptions confirmed the Americar suspicion that Communism was a monolithic movement, but failed to reflect the reality of the situation. It was improbables that Stal in could have ordered an attack on South Korea unless the North Koreans themselves were dedicated to forcible reunification. In addition, while purportedly fighting the Soviet union, the United States never engaged Soviet combat forces,

Several scholars have pointed to the Truman Doctrine and the Marshall Flan as the crucial turning point in

$2 ?$

Lloyd C. Gardner, Introduction, in The Korean War, edited by Lloyd C. Gardner (New York: auadrangle Books, 1970), 24; See also, Richard J. Barnet. Intervention and Revolution: The United States in the Third World (Clevaland: The world Publishing Company. 1968). 28

Ernest R. Nay, "The Nature of Foreign Policy: The Calculated Versus the Axiomatic," Daedalus, XCI, 4 (Fall 1962), 660́-66?. 29

Truman, Years of Trial and Hove, 333; the lessons of history also snaped to outlook of secretary of State Dean Acheson. Gaddis Smith argles that he was obsessed with the memory of Hitler, Dean Acheson, Vol. XVI: American Secretaries of State $\frac{\text { and }}{\text { Dinheir }}$ Ferrel. (New York: Cooper Square Publishers, 1972), 423. 
ocstwar American foreign policy. 30 In a recent article, John Lewis Gaddis disputes the accuracy of such a judgment. when he observes:

- - despite its sweeping language the Truman Administration, between 194 ? and 1950, had neither the intertion nor the capability of policing the rest of the world; . . the real commitmert to contain communism everywhere originated in the events surrounding the Korean War, not the crisis in Greece and Turkey. 31

Prior to 1950 , the United States remained uncertain as to the nature of the Soviet threat, but the Korean War removed such doubts. Unfortunately, the Korean War also lodged a series of erroneous assumption into the American approach to international affairs. Suddenly, American leaders attributed any evidence of political instability in the international system to the manipulations of "World Communism." As a result of the Korean War, the United States became incapable of formulating a realistic assessment of the Soviet challenge and the requirements of an effective American response.

\footnotetext{
30

Joseph Mi. Jones, The Fiftean Weeks (February 21June 5. 1947) (New York: Harcourt Brace and World, 1955); Charles E. Bohlen, The Transformation of American Foreign Policy (New York: W.W. Norton, 1969); Selig Adler, The

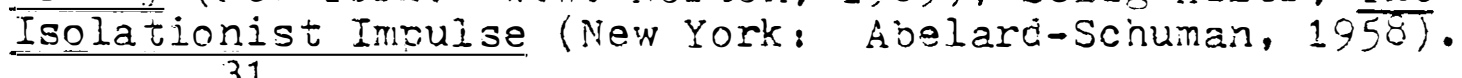
Gaddis, "Was the Truman Doctrine a Real iturning Point?," Foreign Affairs, 386.
} 
Chapter I:

An End to Indifference 
Korea had lorg been the object of American indifference until world War II destroyed that tradition. Until then, however, American disinterest was completely justified. The United States possessed no vital national interests in Koraa and thus was never compelled to formulate policy objectives regarding that nation. Instead, Korean affairs were the exclusive concern of closer and more powerful neighborsChina, Russia, and Japan. Korea was, in fact, the strategic focal point of northeast Asia and, as a result, the korean. people became the long suffering victims of great power rivalry throughout most of their history. In the wake of Norld War II, Korean affairs again centered around a struggle for influence among external powers. The oniy difference was that in 1945 the United States emerged as a principal contestant in the competition to determine Korea's destiny. Early Korean-American relations centered around the attempts of the United States to expand trade in the Pacific. During their tenures as Secretary of State, both WiIliam it. Seward and lamilton Fish endeavored to negotiate treaties of

Glenn Paige, The Xorean People's Democratic Renublic, Hoover Institution Studies J.1 (stancorat Hoover Institution, 196ó), 18; See also, N.D. Peeve, The Republic of Korea: A Political and Economic Study (London: Oxiorc University Press, 1953), 4-6. 
comerce, but the Koreans resisted with force. ${ }^{2}$ American and Korean leaders finally established relaticns on a regular basis largely as the result of sino-Japanese rivalry over control in the peninsula. In 1876, Japan negotiated a commercial convention with Korea that fostered economic penetration at the expense of the traditional chinese influence in the area. In response, China encouraged American economic involvement in Korea as a counterweight to Japan and contributed to the successful signing of a Korean-American treaty of friendship and commerce in 1881 . One provision of the treaty carried particular importance for the future of Korean-American relations. The United States promised that in the event "other powers deal unjustly or oppressively with either government, the other will exert their good offices on being informed of the case, to bring about an amicable arrargement. . .." Despite this pledge, Washington instructed its representatives

U.S. Department of State, A Historical Summary of United States-Korean Relations 1834-1962, Far Eastern Jeries \#115 (washington, D.C.: Government Printing office, 1962), 3; Gregory fienderson, Korea: Politics of the Vortex (Cambridge: Harvard University Press, 1968), 121; Robert T. Oliver, Syngman Rhee: The Nan Behind the Nvth (New York: Dodd Viead and Company, $1 9 5 5 \longdiv { 1 . 3 0 - 3 1 . }$

Robert K. Sawyer and Wal ter G. Hermes, Military Acivisors in Korea: KMAG in Peace and War, U.S. Decariment of the Army (Washington, D.c.: Government Printing office, 1962), 4; james F. Schnabel. Policy and Direction: The First vear, U.S. Department os the Army ('Nasinington, D.C.: Government frinting Office, 1972), 3-4; Oliver, Syngman Rhee, 33; State Department, A Historical Summary, 4-5. 
in Seoul to maintain impartiality in the Sino-Japanese tug of war and concentrate on improving commercial activities alone. In 1894, a political coup d'etat in seoul orought Chinese military intervention and japan quickly declared war. After the American minister made a feeble attempt to Iimit the conflict, the Japanese systematically defeated the militarily inferior Chinese.

After the Sino-Japanese War, American officials in Korea were under strict instructions to avoid involvement in Korean internal affairs. While attempting to maintain an equal opportunity for American commercial ventures, the United States endeavored to remain uninvolved in the emerging Russo-Japanese competition for control of Korea. Despite the efforts of American minister Horace N. Allen, the United States refused to increase American commitments and persisted in its policy of indifference toward korea. This policy reflected a clear recognition of American interests, since the United States possessed no vital political or eccnomic concerns in the peninsula. In February, 1.904, Japan staged

U.S. Department of State, The Record on Korean Unification 1943-1960, Far Eastern Series \#101 Twashington, D.C.: Covornment Prínting ()ffice, () tober 1960), 2-3; State Department, A Historical Summary, 5-6; Robert R. Simmons, The Strained Alilance: Peking, Pyongyang, Noscow and the poIitics of the Korean Civil War TNew York: The Free Press, 1975), $4-10$. 5

Henderson, Politics of the Vortex, 121; OIiver, Sungman Fhee, 21-22; See also, Fred H. Harrington. God, Mammon, and the Jananese (Madison, 1944). 
a surprise attack on the Russian fleet at Port Arthur and thus initiated the Iong-expected Pusso-Japanese War. Japan's quick military victory confirmed its linchalIenged control over Korea. Despite the Korean Ambassador's appeals, Washington remained indifferent to Korea's fate. President Theodore Roosevelt accepted Japanese control over Korea, realizing that he could do little to alter the situation. Instead, Roosevelt attempted to limit Japanese expansion in other areas. In July, 1905, the united states, in the Taft-Kutsuru Memorandum, Formally recognized Japan's control of Korea in return for similar considerations with regard to the Philippines. Korean leaders who left their homeland to escape Japanese repression never forgave Roosevelt for his betrayal of their country. Yet, Japan's protectorate over Korea was not within the power of the united States to prevent. Verbal protests would not gain Korean independence and would only create Japanese hostility regarding other matters of greater importance to the national interests of the United States.

Korean opposition to Japanese imperialism centered around the attempts of exiled leaders to enlist foreign support for liberation. As Korean exiles scatiered to

Graebner, Ideas and Didomacy, 344. 
China, Russia, and the United States, however, they developed different beliefs, values, and ways of thinking that were a reflection of the nations in which each lived. The resultant diversity in the exile movement profoundly effected disagreements over tactics and strategies for achieving Korean independence. From the outset, the exile movement lacked linity in outlook and objectives and this situation rendered common purvose under one leader impossible.

Factionalism was, in fact, a hallmark of Korean society and politics. At the same time, the competition for colitical power focused on individual ambition, rather than on the achievement of social or ideological objectives. These conditions produced an atomized society that gravitated toward centralized power rather than the formatinn of cohesive, professional institutions for the accomplishment of political, economic, and social change. As Gregory Henderson explains, political incohesiveness and factioralism have been "a theme of korean history, chronic, endemic, extreme." These uniquely Korear characteristios have virtually precluded the development of democracy, let

Chong-sik Lee, The Politics of Korean Nationalism (Berkeley: University of California Press, 1963), 154; David J. Dallin, Soviet Russia and the Far East (New Haven: Yale University press, 1948), $2 \overline{5 t-25 ? .}$ 8 MoCune and Grey, Korea Today, 16; Simmons, The $\frac{\text { Strained Alliance, }}{9}$.

Henderson, Politics of the Vortex, 7 and 361 ; See also, Lee, The Politics of Korean Nationalism, 270 . 
alone the maintenance of national sovereignty. Without understanding the nature of domestic Korean politics and society, no one can explain the traditional terdercy of the nation's leaders to seek personal power and orestige through dependence on Korea's powerful neighbors.

Japanese control over Korea was initially confined to the direction of external affairs. But in August, 1910, Japan formally annexed Korea and began to systematically integrate the peninsula into its imperial structure. Japan gradually achieved complete dominance over the political, social, and economic life of the nation. ${ }^{10}$ Koreans played no major role in the governing and judicial system of their country. Although Japan created an "Advisory Council" composed of Koreans, the body dealt with a Iimited range of issues and the Japanese Governor retained veto power. This denial of self-government meant that by 1945 Korea possessed few leaders experienced in governmental affairs.

Japan also attempted to destroy Korea's culture. "Japanization" characterized the educational and judicial systems, as the Japanese eliminated the Korean language, customs, and traditions from all official functions. In addition, Japan established control over the best farms

MeCune and Grey, Korea Today, 24-26; Department of State, A Historical Summary, 8 . 11

Faige, the Korean People's Democratic Republic, 18-19; See also, Henderson's illuminating chapter on the Korean use of "council politics" for personal advancement in Politics of the Vortex. 
and major factories, while enjoying unhampered expioitation of Korean mineral resources. 12 George Mccune effectively summarizes the impact of Japanese imperialism on Korea when he conciudes that the "net effect. . . was a thirty-five-year intermission in political responsibility and administrative experience at a time when the Korean people needed education, training, and practice in modern techniques of democratic government if they were ever to become self-governing in a modern world." Opposition to Japanese imperialism reached an early climax. Using the death of the erstwhile Korean emperor as a catalyst, religious leaders and foreign missionaries entered into a conspiracy to stage a peaceful demonstration to publiciza Japanese exploitation. On Narch 1, 1919, the conspirators issued a Declaration of Independence in the name of Woodrow Wilson's Fourteen Points and demanded Korean self-determination. 14 The Manifesto's eloquent and moving words sparked nationwide demonstrations, as students and religious leaders marched through the streets of major cities chanting and carrying banners protesting Japanese

U.S. Department of Commerce, Economic Conditions in South Korea, 1947, International Reference service, $V$, 131 (December 1948). 1; Kim, Divided Korea, 23-24. 13 McCune and Grey, Korea Today, 26. 14

Henderson, Politics of the Vortex, 80-82; Lee,

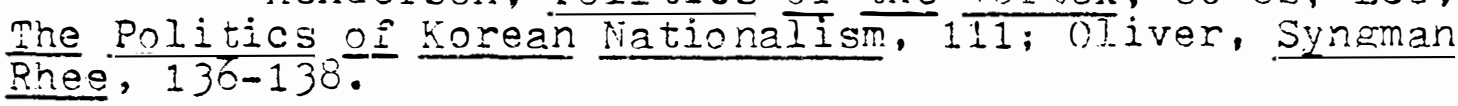


should have recognized the KPG as the legitinate heir of $1 ?$ political authority in korea. In reality, the KPG never possessed strong organizational support within Korea and the motley group of exiles engaged in bitter factional disputes from the outset. By 1921, the KPG was defunct and its claim to legitimacy during World War II bore no relationship to the reality of the Korean independence movement.

Korean radicals were particularly dissatisied with the KPG's emphasis on propaganda and diplomacy as tactics in the fight for independence. The Russian Revolution and Bolshevik ideology convinced many Koreans that a more violent and extremist strategy was necessary. Thus, in 1921, radicals formed the Korean Communist Party, which quickly established close ties with the Soviet union. Noscow not only provided considerable amounts of financial assistance to the Korean Communists, but also trained many 17

Leland M. Goodrich, Korea: A Study of U.S. POI.icy in the U.N. (New York: Council on Foroign Relations, 1950). 9i Das-Sook Suh, "A Preconceived Formula for Sovietization: The Communist Takeover of North Korea," in The Anatomy of Communist Takeovers, edited by Thomas $\mathrm{T}$. Hammond (New kaven: Yale University Press, 1975), 475; OIiver calls the KPG "the longest-lived government-in-exile in modern history." Syrgman Rhee, 143 .

"Korean Independerce Wovement," Reseazch and Analysis Report $629 \mathrm{~A}$, April $25,1943, \mathrm{U} . \mathrm{S}$. Ofíice of Strategic Serrices Archives, NA; William L. Langer, R3A Report 41 . Vay 14, 1942, RG 59, 895.01/60-21-26, NA; The KFG supplied Clarence Gauss, American Ambassador in China, with an account of its own history in Gauss to Huli, February 12, 1942, Enclosure 1, RG 59, 895.01/78, NA; Henderson, Politics of the Vortex, 86; Lee, The Politics of Korean 
of the party's leaders in Soviet schools.

Communism was particularly appealing for young Koreans seeking a clear program for the defeat of imperialism. In addition, many individuals hoped to rise quickly in the party's hierarchical structure to a position of power and influence in Korean society. Gregory Henderson suggests another reason for the popularity of Communism in Korea during the interwar period:

A jail senterce, especially for political crimes, was a badge of distinction . . . Among a people long famous for good manners and conduct, crime, stealing, smuggling, opium dealing, illegality as a way of life made gradually increasing inroads. Like the child disciplined by an unloved parent, Korean society struck back at its tamers with unruliness.

Nationalism, the appeal of secrecy and adventure, and $a$ sense of participation all combined to foster the steady increase of the Communist Party's power and influence in Korea after 1921. In comparison to Communist emphasis on direct action, the KPG's reliance on verbal protests inspired the support of few Koreans.

\section{III}

American contacts with Korea during the interwar

\footnotetext{
19

John N. Washburn, "Soviet Russia and the Korean Communist Party," Pacific Affairs, X.XII, i (Narch 1950), 60: Dallin, Scviet Russia and the Far Fast, 255-256; Henderson, politics of the Vortex, 313-314. 20 Nenderson, Politics of the Vortex, 79; Lee,
} 
period were largely confined to missionary activities and a limited amount of trade. Korean attempts to enlist American support for the liberation of their nation intensified after tine outbreak of World war II. Almost immediately, several exile groups appealed to the State Department for recognition and assistance. Invariably, they stressed Korea's readiness for independence, Theodore Roosevelt's betrayal of Korea, and the need for vigorous action to resist Japanese imperialism. Dr. Edward Lim appealed to the United States "not to discourage us again." one particularly active Korean exile was Kilsoo Haan, representative of the "SinoKorean People's League." In May, 1941, Haan urged the united States to tighten its economic restrictions against Japan. He also pledged that the korean guerilla army fighting in North China would continue to actively oppose Japanese expansion. Haan requested in return that the United States issue a public statement advocating Korean independence and commending Korean guerilla actions. Kim Koo, the president of the KPG, strongly opposed the attempts of Kilson Haan and other exiles to gain American support. While in exile in chungking, the KPG conducted an organized campaign to gain Chinese ard American recognition. Foreign vinister Tjo Sowang

The Politics of Korean Nationalism, 270; Washburn, 21

Iim to HuIl, November 7, 1941, RG 59, 395.00/ 730, NA; Gaan to Full, May 13,1941, KG 59, 895.00/727. NA. 
appealed to Secretary of State Cordell Hull on several occasions for Lend Lease assistance to help the KPG fight for Korean independence. In Jine, 1.941, Tjo sent papers of accreditation for Syngman Rhee, now the KPG's official representative in Washington. 22 The United States rejected this and all other Korean requests for recognition and assistance, maintaining a position of impartiality toward all rival exile factions. Franklin D. Roosevelt and his advisors realistically recognized that aid to the korean exiles would not halt Japanese expansion and might even increase Japan's aggressive tendencies. Perhaps more important, President Roosevelt still hoped to avoid war. Pearl Harbor forced the United States to alter its Asian policy and formulate a course of action that would foster peace and security in the Pacific. The KPG was determined to piay a significant role in Washington's formulation of a policy toward Korea. Almost immediately, Syngman Rhee oegan to apply political pressure of the Administration to gain recognition. On December $9,19+1$, Kim Koo formally requested that the united States recognize the $\mathrm{KPG}$ and extend Lend Lease assistance.

Kim Koo's request was hardly unique. Countless exila 729, NA.

Tjo Sowang to Full, June 5, 1941, RG 59,895.00/ 23

rim Koo to Roosevelt, December 9, i941, RG 59, 895.01/48, NA; jornbeck llemorandum, April 20, 1042, RG 59, 895.01/102, NA; OIiver, Syngman Rhee, 181-182. 
groups representing other countries inundated the state Department with requests for recognition. As a result, the Roosevelt Administration publicly announced a policy regarding all "free movements." The United States stressed that it would not tolerate any efforts to divide the American people and urged its citizens not to participate directly in any efforts to gain recognition for any particular exile group. The Administration also announced that it had not extended recognition to any particular group and would require all exile leaders to register as foreign representatives. State Department officials did, however, conduct investigations into each individual exile claim to legitimacy in anticipation of adopting a more definitive policy at some future date. For example, on December 1.8, Stanley K. Hornbeck and Alger Hiss conferred with Syngman Rhee regarding Korea. Rhee urged that the United States join China in recognizing the KPG. He discounted Haan's political influence in the Korean exile movement and criticized his rival for lack of judgment. Hiss responded that the United States could not alter its policy of impartiality until washington had consulted not only China, but also the Soviet Union. He emphasized that Moscow possessed a major interest in the fate of Korea, but could not engage in consultations until it was

24

"Policy Regarding 'Free Movements' in the United States," December 10,1941, Department of State Bulletin, V, 129 (December 13, 1941), 519-520. 
at war with Japan. 25 Thus, Rnee was disappointed in his early attempts to influence American poilicy.

Rhee was able to enlist the support of some American political leaders, among them Pennsylvanria Congressman Charles I. Faddis. Faddis wrote to full urging recognition of the KPG and arguing that such action would "assist in oringing wholly sic $\bar{l}$ war of all the down trod orisntal peoples against the Japanese. . .." Hull's response was cordial, but non-committal. 26 Several private American citizens were also active in seeking American support for Kim Koo's regime. John W. Staggers and Jay Jerome Williams were particularly prominent in pressing the Administration, but remained unable to alter the American stance. The State Department dismissed recognition as an impossibility at that time, but approved continued contacts with Rhee. American officials urged staggers and Williams to keep the government informed on the KPG's activities.

Roosevelt's advisors refused to coinmit themselves for good reason. As Hornbeck explained, recognition of the KFG "might involve responsibilities which in the light of later events it might have been better for this Government not to

25

Hiss Memorandum, December 18, 1941, RG 59,895.01/ 60-5/26, NA; Oliver arglies that Hiss was acting under orders from Noscow in opposing Rhee, Synoman fhee, 178. 26

Faddis to Hull and Hull to Fadis, December 8 , 1941, RG $59,895.01 / 49$. NA. $895.01 / 52 \frac{1}{2}, \mathrm{NA}$. 
have assumed." 28 As a result, the state Department returned Rree's credentiais to Tjo Sowang without comment. In a letter to Iowa Senator Guy Gillette, Secretary hull elaborated upon the reasons for non-recognition, Hull pointed out that precipitate action regarding Korea might endanger the lives of American citizens still located inside the Japanese Empire. In addition, the United States did not intend to formulate a specific policy on Korea until it consulted the other Allies. Such explanations never satisfied Xim Koo and Rhee. The KPG continued to stress the moral obligations of the United States under the treaty of 1.882 and the military contribution that Koreans in China could make to the war effort with Lend Lease aid.

Despite the appearance of inaction, the State Department was formulating a more definite aprroach toward Korea. In a crucial memorandum written in Fobriary, 1942, william R. Langdon of the Division of Far Eastern Affairs orovided the founciation for American wartime policy. Langdon noted that the vast majority of Koreans were poor and illiterate, politically inexperienced, and economically backward. After forty years of domination, only the older Koreans could even remember freedom. One can pinpoint the origins of American

28

Hornbeck Memorandum, December 20, 1941, RG 59, $895.01 / 54, \mathrm{NA}$. 29

Hull to Gillette, January 6. 1942, R. 59.895.01' 59, NA; Gillette had written Fuli after Rhee had requested his support for recognition of the KPG. Oliver, Syngman Rhee, 176 . 
support for a Korean trusteeship in Langdon's observation that "for a generation at least Korea would have to be protected, suided, and aided to modern statehood by the great powers." Langdon went on to suggest that the United States should focus attention on supporting those korean exiles with proven ties inside Korez and avoid being "stampeded" into recognition of any "shadow orzanization." Even an American promise of postwar independence would be ill-advised, since such action "would only do the Korean cause ham, give the Japanese and their allies a good laugh, and irritate our own friends if we promised independence to one Asiatic people as we were being pushed out of our own possessions in Asia by the Japanese."

Roosevelt's awareness of the events surrounding Korea during the early stages of the war remains in doubt. Yet, the President did refer to the Korea "experience of enslavement" under Japan in his radio address of February $23,1942$. Roosevelt then guaranteed that the promise of hational selfdetermination enunciated in the Atiantic Charter appliec "to the whole world. . ." Significantly, the statement corresponded precisely with Langdon's recommendation that the United States, "until the situation becomes clearer, not go beyond referring. . . to the third principle for a better. world proclaimed in the joint Anglo-American deciaration of

\footnotetext{
30

Langdor Memorandum, February 20, 1942, RG 59 , $895.01 / 79$, NA.
} 
August 14, 1941, nameiy our 'wesped of the right of all people's to choose the form of government under which they will live' and our 'wish to see sovereign rights and selfgovernment restored to those who have been forcibly deprived of them." 31

IV

Rooserelt and his advisors thus decided at an early date not to support the immediate independence of Korea, because of Korean factionalism and political inexperience. Instead, American policy would seek to foster Korean unity in making positive contributions to the defeat of Japan. Nevertheless, factionalism within the Korean exile movement remained intense. In January, 1942, Staggers demanded that Haan direct all ris activities through the "Korean Commission" of Syngman Rhee, alleging that the United States had recognized Rhee as the legitimate representative of the Korean government in exile. Haan immediately sought verification. Horndeck and Under-Secretary of State Sumner 'Welles quickly disavowed Staggers' allegations and reaffirmed American impartiality.

31

Ibid.; Roosevelt, Radio Address, February 23. $1942, \frac{D S B}{32} \cdot \frac{1}{V I,} 140$ (Feoruary 28, 1942), 183-188.

Salisbury Memorandum, March 14 and 31, 1942, RG 59, 395.01/86. NA; Staggers to Haan. January 30, 1942, RG 59, 895.01./60-10/26. NA; Hornbeck and Welles to Haan, Eebruary 9,1942 , RG 59, $395.01 / 92, \mathrm{NA}$. 
After Staggers' scheme failed, Rhee decided to approach Hull again with a iormal request for recognition. In response, Assistant Secretary of State Adolph A. Eerle referred Rhee to the stated American policy of non-recognition of all "free movements." Rhee's consternation was apparent, as he denied that the policy bore any relationship to the KPG and demanded consideration under the terms of the treaty of 1882.33 Korean leaders now turned to the American public in an effort to stimulate support for the KPG. On Feoruary 28, 1942, a three day "Liberty Conference" opened in Washington. D.C., which publicized the KPG's demand for recognition. Welles perceived the need for some clarification and, during a March press conference, stated his sympathy for all free movements. He noted, however, that the korean case involved complex problems that required delay. The United States had Korea under consideration and would announce any policy change.

Rhee's strategy focused on enlisting the support of private American citizens who possessed influence in the

Rhee to Hull, February 7, 1942, Berle to Rhee, February 19, 1942, and Rhee to Berle, ivarch 24, 1942, FRUS, 1942. Vol. I: General, The British Commonwealth, the Far

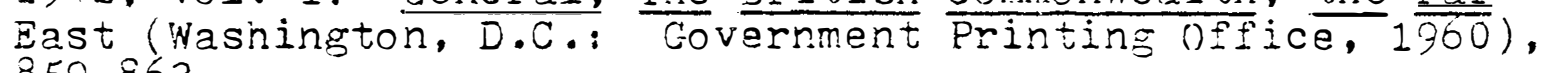
$859-863$. 34

Hornbeck and Iangdon attended the Conference and commented later that it "impressed one as a publicity stunt." Nemorandum on Korean Liberty Conference, Narch 3, 1942, RG 50, 895.01/84. NA; New York Times, Narch 1, 1042, 10:1-3 and March 2, 1942, 7:7; Washington Post, Marcin 1, 1942, 11:4; Welles Press Conference Remarks, March 2, 1942, FRUS, 1942, Vol. I, 864; New York Times, March 3, 1.942, 7:6. 
Roosevelt Administration. One such individual was James $H$. R. Cromwell, former ambassador to Canada, who became particuiarly outspoken in his advocacy of the KRG. Cromweil, in a letter to Hull, insisted that the United States was refusing to honor its traaty commitments to korea and thus discrediting itself in Asia. After insisting that the services of Korean patriots were not for sale, he proceeded to contradict himself and level a thinly disguised threat:

The young Koreans are straining at the leash

but Dr. Rhee will not release them. Not until

the State Department, by recognizing the defacto government of the Republic of Korea, fulfills the pledge of the President. . . to see sovereign rights and self-government restored to those who have been forcibly deprived of them.

Hull responded that the United States would not engage in any action that deprived captive peoples of the freedom of choice. After noting Cromwell's attempt at blackmail, HuIl observed that the KPG could support the Atlantic Charter regardless of American action on recognition.

Cromwell continued, however, to press the United States for recognition of the Kim Koo regime. Unable to gain Hull's support, he turned to his old friend Adolph Berle and pleaded for Berle to propose a program for positive support to the KPG. Cromell termed American inaction "criminal

Cromwell to Full, viay 5, 1942, RG 59, 895.01/123, NA; Hull to Cromweli, July 3, 1042, RG 59,895.01/137. NA; Saan immediately exploited the situation, assuring the State Department that "true Korean patriots" would fignt Japan to the death and did not expect independence on a "silver platter," July 3, 1942, RG 59, 895.01/137, NA. 
negligence," since it would be inexpensive to organize and inaugurate a disciplined and systematic campaign of sabotage and subversion inside Korea. As Cromwell pointed out, "Adolon, you are about the only firecracker I know in the State Department-why don "t you do it?" Cromwell insisted that implementation of his plan would create a "bonfire" in Japan's "backyard." 36

Berle referred Cromwell's proposal to the Joint Intelligence Committee for consideration on July 31, 1942. The Committee report reaffirmed opposition to recognition, but did support the maintenance of contacts with various Korean nationalist groups. At the appropriate time, the United States might consider a plan for espionage and sabotage. The report thus recommended contacting General Joseph Stilwell in China for comments on the plan's feasibility. In response, Stilwell completely rejected Cromineli's scheme, arguing that it would be a waste of money, provide no tangible benefits, and entail serious political scnsequences. Army Chief of Staff George C. Marshall also opposed recognition of the KPG, observing that it would be "doubtful policy to blindly pick some one group. . . thus antagonizing the other groups . . which might emerge

Cromwell to Berle, July 17,1942 , RG 59,895.01/ 153, NA: Cromwell to Berle, July 27, 1042, RG 59, 895.01./ 165. NA.

37

Berle to Cromwell, Iuly $31,1942, \operatorname{Rg} 59,895.01$, 165. NA; JIC Report ?1, Aligust 9, 1.942, U.S. Ioint Chiefs of Staff Archives, Record Group 218, CCS 092 Korea (8-5-42), National Archives, Washington, D.C. 
later." Thus, the Combined Chiefs of Staff joined in rejecting Cromwell's proposal and informed Berle of the decision on September 24, 1942. These American military leaders urged Berle to explain to the KPG's supporters that recognition alone could not produce a rebellion in Korea. Even if such an uprising did occur, they reasoned, japan would easily quell such a poorly prepared operation.

Hornbeck completely agreed with the appraisal of the American military leaders, emphasizing that at such a difficult stage in the war the united states could spare little material for any free movements. As a result, he expressed admiration for the Korean guerillas operating in Siberia and Manchuria. Although these Korean exiles demonstrated an affection for Communist ideology, Hornbeck admired their willingness to fight for freedom without American assistance. In contrast, the old conservatives in chungking appeared self-seeking and amitious. ${ }^{39}$ such conclusions found suostantiation in the oiservations of American diplomats and missionaries fleeing Korea aboard the Gripsholm during the summer of 1942. These individuals stressed the totality of Japanese control and the virtual incapacity of koreans for self-governmert, let alone hostile action against the

Stilwell to War, August 15, 1942, Narshall Viemoranoum, August 11, 1942, and CCS to Berle, septemier 24 , 1942, RG 2.18, CCS 092 Korea $(8-5-42), \mathrm{NA}$. 39

Hornbeck ijemorandum, August 13,1942, RG 59, 895.01/98, NA; Taan to Hornbeck, July 24, 1942, RG 59, $895.01 / 156$, NA. 
40

Japanese.

Arthur B. Emmons III, prewar Vice Consul in Seoul, played a significant role in confirming America's determination to negotiate a trusteeship for Korea. Upon his return on the Gripsholm, Emmons submitted a memorandum emphasizing that the isolation and economic backwardness of the average Korean produced incredible political apathy. At the same time, Korea suffered from a precarious geographic position among China, Japan, and Russia. Ore-power dominance or prolonged international intrigue, Emmons argued, would probably mark Korea's future "unless such pressure could be neutralized by some effective form of international agreement to which Far Eastern Countries concerned would give their sincere effective support." 41 once again, available information and expert analysis dictated non-recognition of the KPG and impartiality toward all Korean exile groups.

\section{V}

Information originating in chungking regarding the Korean exile movement was particularly important in the formulation of American policy. Throughout 1942, Amoassador Clarence Gauss noted in his cables to Hull the extreme

40

Hamilton to Berle, July 23, 1942, RG 59, 395.01/ $156 \mathrm{~A}$. NA; Oliver insists that all Americans in seoul supported Rhee's claim of popularity, Syngman Rhee, 183. 41 157, NA.

Emmons Memorandum, August 14, 1942, PG 59, 895.01/ 
factionalism in the KPG. At the same time, he suspected that Chiang Kai-shek possessed undue influence over Kim Koo and his supporters, because of Tjo Scwang's evasive and secretive responses to questions pertaining to the KPG's financiai resources. Gauss stressed that the KPG suffered from a lack of organization and a concrete plan of action for achieving independence. Hull informed Gauss in varch, 1942 , that the United States and Great Britain had agreed to defer action on Korea until the onset of Allied military victory in the Pacific.

Evidently, the Administration had not consulted Chiang on Korean policy. Rumors began to emerge that the Chinese intended to recognize the KPG and extend a promise of postwar independence. Welles thus cabled Gauss requesting information. The American Ambassador's resporse confirmed the rumors as accurate, but stressed the unlikelihood of precipitate action. 43 Gauss had already forwarded a memorandum in which John Stewart Service emphasized the increasing factionalism in the KPG, as well as its lack of significant support inside Korea. In view of the circumstances, Gauss completely supported the American policy of delay, but did stress the need for consultation with China prior to any

42

Gauss to Hull, January 3, 1942, RG 59, $895.01 / 56$, NA; Gauss to Huli, March 17, 1942, RG 59, 895.01/81, NA; Hull to Gauss, Marsh 20, 1.942, RG 59, 895.01/56. NA. 43

Welles to Gauss, March 25, 1.942, Gauss to Welles, Narch 28, 1942, ERUS, 1942, China (Washington. D.C.: Government Printing ()fice, 1956), 730-732. 
reversal in policy.

44

Chiang applied heavy pressure on the United States to force the abandonment of an impartial posture. On April 8, Chinese foreign minister T.V. Soong proposed to Roosevelt that the Allies create and equip a "Korean People's Army" to engage in sabotage and espionage inside Korea. At the same time, the Allies would publicly recognize the KPG as Korea's legitimate government and promise Korean independence at the end of the war. Roosevelt referred the proposal to Welles for comment and the subsequent response conformed to Langdon's recommendations. While Welles admitted that support for an irregular Korean army possessed some merit, he stressed the lack of realism in a promise of independence and the extreme factionalism in the Korean exile movement.

Welles relied upon Hornbeck's judgment in opposing Soong's plan. Hornbeck drew up a memorandum stressing that Koreans were incapable of immediate postwar self-government. In all probability, considerable political chaos would prevail in Korea at the end of the war. He thus recommended some form of "dominion status" prior to complete independence. For the present, the proper course of action was delay, since "the work of the peacemakers [should] be not impeded by

44

Gauss to Hull, Narch 25, 1942, Enclosure 1, Service Niemorandum, RG 59,895.01/104, NA; Gauss to Welles, FRUS, 1942, Vol. I, 866-867. 45 $96^{1} / 3$, NA; FRUS to Roosevelt, April 8, 1942, RG 59, 895.01/ April 13, 1942, FRUS, 1942, Vol. I, 870-871. 
hampering antecedent commitments to a greater extent than is necessary."

The Pacific War Council considered the matter of rorean recognition on April 15, 1942. Although the State Lepartment had drafted a statement promising independence, the Administration deoided to postpone action until Korean exiles gained more unity and the military situation improved. In apprising Roosevelt of the decision, Hull emohasized the dubious nature of the KPG's support inside Korea and the reed to avoid any action depriving the koreans of freedom of choice. Hull had already cajled to Gauss instructions to urge Chiang to delay action on Korea. since "parallel and cooperative action. . would be desirable so far as practical." Crina agreed to wait, but continued to urge recognition of the KPG as soon as possible.

China's position on Korea was a reilection of Chiang's Fears of Soviat intentions. He was well aware of Soviet and Chinese Communist support, both moral and financia?, to the Korean guerillas fighting in northern Cnina. Chinese leaders recognized that when Noscow entered the war against

Hornbeck Vemorandum, April 1.1, 1942, RG 59, $895.01 / 96^{2} / 3$. NA; Hamilton Memorandum, April 25,1942, RG $59.895 .01 / 118 \frac{1}{2}, \mathrm{NA}$. 47

Elsey Nemorandum, August 6,1948 , RG 59, 895.01, 8-ó48. NA; Hull to Roosevelt, April 29, 1942, ERUS, 1942, Vol. I, 873.

Hull to Gauss, Aoril 11., 1942, RG 59, $395.01 / 96$, NA; Gauss to Full, April 18, 1942, FruS, 1.942, vol, I, 673. 
Japan, Stalin would utilize the Korean exiles in Siberia and Manchuria as a vehicle for exerting influence inside Korea after the war ended. At a very early date, China and the KF stressed Soviet designs on Korea in urging an end to American impartiality. 49 yet, petty political intrigues and personal differences continued to plague Kim Koo's regime. In the absence of unity, the United States wisely refused to support recognition or material aid to any Korean exile group.

Interestingly enough, the United States was far more concerned about chinese rather than Soviet aspirations in Korea during the early years of World iar II. Chiang and T.V. Soong never ceased emphasizing China's determination that Korea would be free and independent. Chinese leaders insisted that they sought international responsibility, not domination, in the postwar world. 51 yet, the United States found ample reason for doubting China's motives. In 1942 , Kim Koo granted Chiang control over his military forces in return for financial assistance. Rumors spread that the

Gauss to Nelles, April 10, 1942, RG 59, 895.01/ 9ó. NA; Hornbeck Conversation with Staggers, Narch 27, 1942, RG 59, 895.01/101, NA; Reverend Donald Grey Barnhouse to Berle, April 10, 1942, PG 59,895.01/103, NA. 50

Hull to Gauss, May 8,1942 , Gauss to Hull, hay 1.3 , 1942, FRUS, 1942, Vol. I, 876-877; Hull to Gauss, May 6, $1942, \overline{R G} 59,895.01 / 102, \mathrm{NA}$; Gauss to Ful1, Nay 16,1942, RG 59, 895.01/130, NA; Viricent Memorandum, Nay 1942, 895.01/ 148 , NA.

51

U. Alexis Johnson Comments, in E.W. Koons to H.B. vuarton, August 13, 1942, RG 59, 895.01.1157. NA; Gauss to Hull, November 5,1942, FRUS, China, 1942, 740; New York Times, () tober $12,1942, \frac{9}{9: 0}$. 
agreement also bound "Korea to China in any postwar scheme in the orient." 52

American diplomats in chungking immediately requested information from the KPG regarding the terms of their arrangement with Chiang. Tjo Sowang explained to Vice Consul 0. Edmund Clubb that the KPG's financial Iimitations necessitated Korean dependence on China. He then suggested that Kim Koo could terminate the relationship if the United States agreed to extend Lend Lease assistance. Tjo also insisted that factionalism in the exile movement had ended and all Koreans now supported the KPG. He expressed regret over the "misunderstanding" which had resulted from the "alleged" threat that the KPG would not participate in the war unless it received recognition. Korean exiles were determined to destroy Japan and placed no price tag on support for the Allied cause. 53

Tjo Sowang's argument failed to convince American representatives in Chungking. All available evidence indicated that Kim Koo's political support was tenuous at best.

Gauss to Hul1, June 19, 1942, RG 59, 895.01/148, $\mathrm{NA}$; Gauss to $\mathrm{Hull}$, December 11, 1942, RG 59,895.01,228, NA contains the complete text of the Sino-Korean military agreement; Gauss to Kull, November 25, 1942, RG 59, 895.01/ 199. NA; Gauss to Full, January 15, 1943, RG 59, 895.01/ 213. NA: Lee, The Politics of Korean Nationalism, 222-224. 53

Gauss to Hull, Novenber 25, 1942, R: 59, 895.01/ 199. NA; Causs to Full, December 9, 1942, RG 59, 895.01/197, $\mathrm{NA}$; New York Times, October 26, 1942, 2:6; Tjo Sowang to Hull, octoder 1, 1942, RG 59,895.01/183, NA; Roy P. VicNair, Ir., october 28, 1942, "Analysis of Political Parties," RG 226, OSS Report 24638 , NA. 
In addition, Chinese influence in the KPG continued to grow. Late in 1.942. Chiang created a "Sino-Korean Cultural Association" which Gauss suspected was interded to foster Chinese control over postwar development of Korea. The Roosevelt Administration agreed that Chiang was qualified to assist in the formation of Allied policy on Korea. In fact, John Carter Vincent suggested that the United States urge Chiang to press the KPG to broaden its support. China's historic national interest in the Korean peninsula did not, however, justify undue influence in the exile movement, let alone outright control.

Korea's future depended more upon Aliied cooperation during and aiter World Nar II than on the intrigues of Korean exiles in China and the United States. If Korea was to obtain self-government, the Allies would have to negotiate an agreement that protected the interests of all nations directly involved in the peninsula. Roosevelt believed that China's role would be crucial to the success of American policy in Korea and elsewhere in Asia. Chiang had to develop sufficient power to participate in an active and meaningful manner for the preservation of peace in Asia.

54

Gauss to Huil, Decomber 19, 1942, PRYS, 1942 , China, 748; Dae-sook Suh, "A Preconceived Forinula for Sovietization," in tammond, 476 ; Vincent iremorandum, hay $1942,895,01 / 148$, NA. 
Wartime policy towara Korea effectively illustrates Poosevelt's approach toward the achievement of Americar security interests in Asia. In a letter written to chiang (which Roosevelt revised and approved), Owen iattimore stressed the importance of China as a "policeman" in Asia. He warned Chiang, however, that the views of the Soviet Union were extremely important. As a result, "it would be uncesirable to exclude Russia from such problems as the independence of Korea," since such action would only sreate fresh tensions.

Anerican leaders began to devote attention to the development of specific plans for postwar reconstruction of Asia during the fall of 1942. The Division of Far Eastern Affairs proposed that China, New Zealand, and the united States appoint representatives to a committee that would formulate a united Allied policy on Korea. This committee would seek "to cooperate with the Korean people in setting up and establishing a national government of Korea and. . . to assist in forming a temporary trusteeship under which there would be given advjce and tecnnical assistance." State Department officials also proposed measures for policy coordination with the Soviet Union.

Tmasteeship thus emerged at an early date as the central

\footnotetext{
55

Eraft Letter, Lattimore to Chiang, Decemben 18 , 1942 , FRUS, 1942 , Cnina, $186-187$.

Far Eastern Affairs Vemorandum, () tober 10, 1.942 , RG 59, 89,5.00/840, NA.
} 
feature of Roosevelt's approach to the Korean issue. The

President even issued a public statement indicating that the Philippine experience would provide the model for the future development of small nations in Asia. He observed that American policy toward the Philippines was

based on two important factors. The first is that there be a period of preparation, through the dissemination of education and the recognition and fulfillment of physical and social and economic needs. The second is that there be a period of training for ultimate independent sovereignty, through the practice of more and more self-government, beginning with local government and passing on through various steps to complete statehood.

Roosevelt argued that the stability of independence depended upon training and experience in self-government. 5 ? clearly, the Administration intended to rely on the Philippine model in formulating a plan on trusteeship for korea.

Significantly, the Institute of Norld Affairs provided something of a trial balloon for Roosevelt's Korea policy. In December, 1942, the organization recommended trusteeship for Korea, producing an exile reaction that was immediate and hostile. The KPG derounced the proposal as "Japaneseinspired" and promised to resist any postwar mandatory status. Kim Koo insisted that Korea "must secure her. . absolute independence." Tjo Sowang protested that the decision "does not accord with the Atlantic Charter, is

Franklin D. Roosevelt, Radio Address, in mhe Public Papers and Addresses of Franklin D. Roosevelt, edited by Samuel I. Rosenman, Vol. XIV, 1942 (New York: Random House, 1950), 475 . 
against the will of 30.000 .000 Koreans and ever endangers peace in Eastern Asia." Both Syngman Rhee and Kilsoo raan argued that Koreans had earned immediate postwar independence through resisting Japanese imperialism. Roosevelt definitely read these protests and was aware at an early date that the most vocal Korean exiles opposed the heart of his Korean policy. Yet, Korean exiles failed to alter the President's commitment to trusteeship.

Roosevelt's policy in Asia also alarmed Great Britain, but for difierent reasons. Winston Churchill had made it clear that the British Empire would remain intact after the war ended. As a result, Lord Halifax submitted a proposal on Allied policy in colonial areas to the United States in February, 1943. Halifax recommended that the Allies issue a devlaration promising the destruction of the Axis aggressors and the creation of postwar international peace. Fe then notec that, while some colonial peoples were sufficiently advanced to ensure their own security and prosperity, others required experience in self-government and international guidance prior to independence.

Britain's plan provided for Allied designation of

\footnotetext{
58

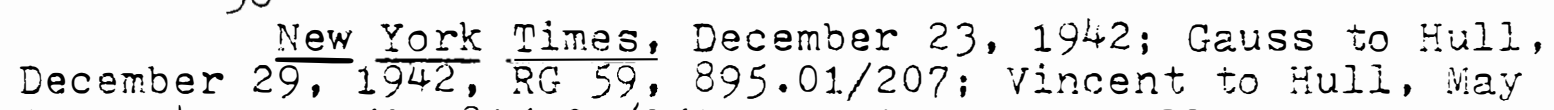
11, 1943, RG 59, 895.01/251, NA; Gauss to Hull, June 11., 1943, RG 59, 895.01/269. NA; Rhee to Roosevelt, Miay 15, 1943, RG 59, 895.01/257. NA; Roosevelt to Rhee, May 12 . 1943, RG $59,895.01 / 256$, NA. 59

Halifax to Hull, February 4, 1943, Cordell Hull Papers, Reel 30, Box 59, Folder 216, Library ô Congress, Washington, D.C.
} 
"trustee" nations to develop social, economic, and political institutions in the more backward colorial areas in the interests of world peace and commercial activity. The trustee nation and other interested countries would comprise a. "Regional Commission" under an international organization that would provide for consultation and collaboration in the furtherance of the interests of the colonial people involved and the international community. Colonial policy was an important item on the agenda for Anglo-American discussion in March, 1943, when Eritish Foreign Minister Antiony Eden visited Washington.

Eden conferred primarily with Roosevelt, Welles, and Harry fopkins while in tine united States. Secretary HuIl was determined, however, to discuss the Halifax proposal and met with Eden privately on March 22. After Eden summarized the British position, Hull stressed that any colonial policy had to focus on the development of sufficient experience in seli-government to guarantee complete independence without external interference of any kind. Thus, $601 \mathrm{H} I$ believed that Britain's proposal did not go far enough.

Hull then presented an alternate plan which emphasized maximum local participation in self-government and rapid

Herbert Feis, Churchill, Roosevelt, Stalin: The War They Waged and the Peace They Sought (Princeton:

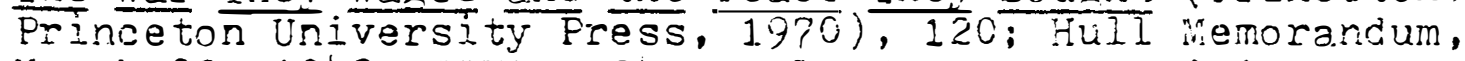
March 22, 1943. FRUS, 1943, Vol. III: The Eritisn Commonwealth, Eastern Euroce, the Far East (Washingtor, D.C.: The vemoirs of Cordell Huli, Vol. II (New York: Nacmilian, $1 9 4 8 \longdiv { , 1 2 3 6 } .$ 
realization of independence. The trusteeship machinery largely followed the British proposal, tut increased the supervisory powers of the international organization. During his discussions with Roosevelt that same day, Eden expressed concern over too iroad an application of trusteeship and overreitiance on China's role in postwar affairs. Hopkins noted later the divergence of opinion between the United States and Eritain, when he observed that "it becomes clearer all the time that Eden thinks very littie of trusteeship and would rather have the full responsibility in the hands of one colintry."

on March 27. Roosevelt expressed to Eden his gereral approval of Hull's proposal. The President stressed that the Allied policy toward dependent peoples nad to possess universal appliaability. Roosevelt favored international control over Indochina and the Japanese mandated islands. In addition, "Korea might be placed under an international trusteesnip with China, the Unitea States, and one or two other colintries varticipating." 63 Although Ejen reacted favorably to Roosevelt's comments, he insisted that Hull's

61

U.S. Draft Declaration, March 9, 1.943, FRUS, 1.943, Vol. I: General (Washington, D.C.: Government printing Uffice, $\frac{19 \overline{96} 3), 747-749 ;}{62}$ Hull, Nemoirs, 1235-1236. Hopkins Memoranoum, March 22, 1943, FRUS, 1943, Vol. III, $34-36$. 63

HulI, Memoirs, 1234 and 1595-1.596; Henry I. Stimson and Micheorge Bundy. On dictive Service in Deace and War (New York: Harper and Bros., 1947), 599-600; Full Nemorandum, March 27, 1943. ERUS, 1943, VoI. III, 37; Feis, Churchill, Roosevelt, stalin. 124. 
proposal was not the final word. Both Hopkins and Full expressed optimism, believing that Britain would not demand a restoration of colonial rule in all areas.

In reality, the American proposal deeply disturbed Eden, who feared its wider implications for the British Empire. Eden decided nevertheless to hold his criticism in reserve until a later date. Roosevelt, in his public evaluation of the conference, noted the inconclusive nature of the results. Yet, the ambiguity of the outcome permitted the United States to develop comprehensive plans for a Korean trusteeship. 65 In April, the State Department produced a specific plan providing for machinery to implement, supervise, and finance a program of international control in dependent areas. The memorandum stated that Korea was one of several areas suitable for trusteeship and thus would "be temporarily administered oy the Council, anticipating independence probably with close economic ties with china."

Obviously, the State Department pian required that the United States fully inform China of the results of the RooseveIt-Eden discussions. On March 29, Nelles informed

Hopkins Nemorandum, Niarch 27,1943 and Hull vemorandum, Varch 29, 1943, FRUS, 1943, Vol. III, 39-40. 65

Anthony Eden, The Reckoning (Boston: Houghton Nifflin, 1960), 595; Pooseve it Press Conference Remarks, Niarch 30,1943 , in Rosenman, Vol. XV, 1943, 132-143.

Memorandum on International Trusteeship, April 15, 1943, FRUS, The Conferences at Washingtor and Quevec 1943 (Washington, D. . : Government Printing () Ifice, 1970), 720-726. 
T.V. Soong that the United States and Britain had agreed to treat China as a major power aiter the war and support the return of Eormosa to China. He then explained that Roosevelt and Eden were in agreement that Korea would become independent only after a period of international trusteeship. Berle later informed Soong that the Allies could not recognize the KPG because it lacked popular support inside Korea. Thus, Berle reaffirmed the American policy of impartial delay.

\section{VII}

Roosevelt and his advisors had firnly tied American policy in Korea to trusteeship early in 1943, bit wasington never clearly vocalized the decision. The State Department would only issue a public promise that the Allies intended to strip Korea from Japan and accord it national seli-determination at the end of the war. Such a policy offered little to the KPG, but Kim Koo had some reason for optimism. Late in 1942, Rhee had been able to enIist the support of Colonel Preston Goodfellow of the iffice of Strategic Services (OSS). Together Rhee and Goodfellow formulated a olan to recruit, train, and equip one hundred koreans for

\section{7}

Welles Nemorandum, March 29, 1943, FRUS, 1943, China (washington, D.C.: Government Printing Office, 1957), 845; Hamilton Nemorandum, April 22, 1943 and Berie Viemorandum, April 22, 1943, FRIS, 1943, Vol. III, 1090-1092. 68

Welles, Press Conference Remarks, New York Times, April 8, 1943, 11:1; Territorial Committee, 消inutes, $\frac{1}{\text { July }}$ 16. 1943, Full Papers, Reel 49, Box 35-86, Folder 366, iod. 
espionage ano sabotage activities inside Korea. Goodfellow then urged the State Department to adopt the program and recognize the $K P G$, warning that ary delay "might be of benefit to the Soviet Union in any plans the latter mignt have in respect to Korea."

State Department officials quickly rejected Goodfellow's plan, doubting the unity and ability of the Kim Koo regime. More important, the united states feared that "to try to steal a march on the Soviet union might create fresh difficulties." Hull was determined to maintain impartiality and even urged Congress not to pass resolutions supporting recognition of the $\mathrm{KFG}$. Such action, he argued, would serve "no useful purpose . . but create confusion, misunderstanding, and embarrassment. ..." 70 Yet, Allied military victories against Japan during 1.943 forced the United States to consider more seriously the impact of soviet entry into the Pacifie war.

In August, 1943, Fornbeck prepared a memorandum outIning Soviet objectives in Asia. He argued that Stalin placed paramount importance on Russian national security and sought "the creation of well disposed and ideologically

Rhee to Goodfellow, October 10,1942 , and Goodfellow to War, Feorliary 17, 1943, RG 59, 895.01/231, NA; oliver, Syngman Shee, 185 .

Hamilton Nemorancum, February 26,1943, RG 59, 80,5.01/218, NA; Fuli to Sol Bioom, April 1, 1943, RG 59, 895.01./232, NA; Sull to Tom Connally, June $i 8,1943$, RG $59,895.01 / 263$, NA. 
sympathetic governments in nearby areas." Hornbeck noted that vioscow maintained close ties with Korean guerilias in Siberia and thus possessed an excellent vehicle for exerting influence in Korea. In a letter to Hull, Horrbeck indicated the danger inherent in the Korean situation:

The future of Korea, . ., will, it is believed, be of paramount importance to Soviet Russia and to China. The Soviet Union may be expected to exert efforts to assure that the future government of Korea is favorabiy disposed and ideologically sympathetic to the Government of the U.S.S.R. Such a policy, if vigorously pursued by the U.S.S.R., would almost certainly conflict with Chinese policy in regard to Korea.

Thus, Soviet agreement to trusteeship, not to mention that of China and Britain, took on added importance.

While the Roosevelt Administration favored trusteeship in some areas for moral reasons, strategic considerations dominated American thinking in regard to Korea. Only an international agreement to neutralize korea would prevent the resumption of fostwar conflict in that area and ensure peace. Chiang certainly recognized the Soviet challenge and instructed Soong during the fall of 1943 to support a Korean trusteeship. Thus, the Roosevelt Administration embarked on a determined attempt to obtain an agreement among the major powers in support of trusteeship.

\footnotetext{
71

Hornbeck Memorandum, August 19, 1.943. Hull Papers, Reel 23, Box 51-52, Folder 159, InC; Hornbeck to Hull, September 30, 1943, Hull Papers, Reel 24, Box 52-53, Folder 160. LOC. 72

Hornibeck to Hull, October 1. 1943, Full Papers,
} 
Hull immediately experienced difficulties with the British at the First Quebec Conference in August, 1943. After twice refusing to discuss the trusteeship issue, Eden finally stated his opposition to the emphasis on "independence" in the American proposal. Despite the liberty to request independence at any time, he argued, several British Dominions preferred continued imperial ties. Hull assured Eden that the United States did not favor immediate independence, but believed it necessary to emphasize freedom as the U.Itimate objective. Eden remained unmoved and sritain opposed Hull's plan for the duration of the war.

In October, 1943, Hull traveled to Moscow for a meeting of the Allied foreign ministers. Prior to his departure, Roosevelt instructed his Secretary of state to gain support for wide application of the trusteeship principle. 74 The President hoped that through publicizing the plan, popular support would force British, Chinese, and Russian compliance.

Reel 24, Box 52-53, Folder 160, LOC; In a recent dissertation, William G. Norris overemphasizes moralism and ethnocentrism in explaining American support for a Korean trusteeship, "The Korean Trusteeship 1941-1947," Unoublished Ph.D. Dissertation, University of Texas, 1975, Atcheson to Hull, August 20,1943, RG 59, 895.01/286, NA; Hornbeck Memorandum, September 28,1943 . FRUS, 1943, Cnina, 133-136. 73

Hull Memorandum, August 20, 1943. Pasvolsky Memorandum, August 18,1943 , and $4 u 11$ Memorandum August 21 , 1943; Conference Notes, August 21, 1943, FRUS, Conferences at Washington and Quebec, 91.4, 919, 717, and 926-927; HuII, ivemoirs, $1237-1238$. 74

Pasvolsky Nemorandum, 0ctober 3, 1943, FRUS, 1943. Vol. I, 542-543; Hull, Memoirs, 1304-1305 and 1596. 
Thus, on october 29, Hull raised the issue of dependent peoples and distributed his proposal. He expressed regret that there would not be enough time to discuss colonial policy in depth. Eden then reminded Kull that Britain had expressed opposition to his plan just three days earlien. Molotov, on the other hand, agreed that the issue was of vital importance and deserved study and discussion. As a result, the other Allies could expect the United States to raise the issue of trusteeship during the upcoming meetings at Cairo and Teheran in November, 1943.

Roosevelt arrived at Cairo determined to obtain British and Chinese support for a three-power trusteeship for Korea and was confident of Chiang's support. 75 on November 23. however, Chiang strongly supported the issuance of an immediate statement promising Korean inderendence. This apparently revived Roosevelt's apprehensions, since he expressed concern over China's "wide aspirations" to winston Churchill the following day. Roosevelt suspected that Chiang sought military occupation of Korea at the end of

Feis, Churchill, Roosevelt, Stalin, 21.4-215; Admiral william D. Leahy never accepted the wisdom of universal application of trusteeship. particularly for Japanese mandated islands, I Was There (New York: McGraw Hill, 1950), 210 and 258. Secrétary of War Jenry I. Stimson and harshall agreed; Conference Notes, ()c tober 29, 1943. FRUS, 1943, General, 666-667; Hull, Memoirs, 1305. 76

Memorandum of Conversation. November 11,1943 , ERUS, The Conferences at Cairo and Tenran 1943 (Washington, D.C.: Government Printing Office, 1951), 257 ; Hopkins stated in a separate memorandum of November 23 that it was consistent with Soviet policy to expect Stalin's support, 376. 


\section{4}

the war.

77

Despite such suspicions, Roosevelt, Churchill, and Chiang agreed to issue the famous "Cairo Declaration" which promised the Iiquidation of the Japanese Empire and the restoration of China's control over Vianchuria and Formosa. With respect to Korea, the Cairo Declaration stated that the Allies, "mindful of the enslavement of the people of Korea. are determined that in due course Korea shall becoine free and indeperdent." ${ }^{78}$ While the Allies may have drawn the other sections of the Declaration. in haste, the provision regarding Korea was the product of considerable American preparation. Allied policy avoided any reference soecifically to trusteeship, since the united States expected a hostile Korean reaction. In addition, the United States had not formulated a complete and detailed proposal.

Many scholars have criticized Roosevelt for including the phrase "in due course" in the Cairo Declaration, arguing that the United States should have satisited Korean demands for immediate postwar independence. Even HuIz criticized Roosevelt for not consulting the Soviet Union and appearing to justify korean fears of Chinese intentions. In reality,

Th Conference Notes, November $23,1.943$, and RooseveltChurchill Neeting, November 24,1943 , EPUS, the Conferences e.t Cairo and Tehran, 334 and 389 .

DSB, IX, No. 232 (january 4, 1944), 393; Hopkins composed the Korean section and Roosevelt substituted "in due course" for "at the proper moment," FRUS. The Conferences at Cairo and Tenran, 403.

Soon-sung Cho, Korea in Worid Politics: An 
the President recognized that only an Allied agreement would guarantee postwar peaze and security in Asia. Realizing that Chiang's aspirations in Korea would alarm Stalin, Roosevelt pursued an international trusteeship to reassure both nations and preserve Korean independence.

Thus, Roosevelt left Cairo for Teheran with the intention of gaining Stalin's assent for the Cairo Declaration and a Korean trusteeship. On Novemoer 30 , stalin indicated that, although he could make no comitments, he approved of the Far Eastern Communique. Rooseveit later suggested that Stalin had specifically agreed that "the Koreans are not yet capable of exercising and maintaining independent government and that they should be placed under a 40 year tutelage." 81 Roosevelt must have been pleased about Korean policy when he left Teheran; the Allies now appeared urited in support for trusteeship.

Upon his return to Washington, Roosevelt explained that the Cairo Declaration involved "the restoration of

Evaluation of American Responsibility (Berkeiey: University of California Fress, 196?), 23; Cho is clearly in error when he argues that Roosevelt did not consult his advisors about Korea. Langdon, Hornbeck, and even kill supported the trusteeship policy as the best means for ensuring Korean independence; Hull, Nemoirs, 1584. 80

Herbert Feis, The China Tangle (Frinceton: Princeton University Press, $\frac{1953), 106 .}{106}$ 81

Conference Notes, November $30,1.943$ and Pacific Council Notes, January 12,1944 , ERUS. Whe Conferances at Cairo and Tehran, 566 and 869; Cho speculates that Roosehis "lack of insight," Korea in Norld Folities, 23. 
stolen property to its rightful owners and the recognition of the rights of millions of people in the Far East to build up their own forms of self-government without molestation." Despite Roosevelt's promise of eventual independence, the Korean exile movement was extremely dissatisfied with the phrase "in due course" and demanded a clarification. Kim Koo denounced the Cairo Declaration as disgraceful and insulting, since it meant a continuation of outside control. Kilsoo Haan joined the leaders of the KPG in demanding immediate independence and self-government for Korea after liberation. Korean exiles were unable to accept the American argument that a unified and viable civil government would probably not emerge immediately after the defeat 82 of Japan.

)bviously, the emergence of a new balance of power in Asia was vital to Roosevelt's strategy. Success depended to a large extent upon China's development into a great power. If the President was gamoling with American security in the Pacific, one can hardly argue that American policy lacked realism and wisdom in regard to Korea. All indications pointed to Korean unpreparedness for independence and the

Roosevelt, Fireside Chat, December 24, 1943, in Roserman, Vol. XV, 555-556; New York Times, December 6. $1943,6: 7$, December 15, 1943, 22:6, and varoh 2, 1.,44, 8: 7. Gauss to Hull, December 7, 1943, FRUS, 1943, Vol. III, 1096; Haan to Roosevelt, December 14, 1.943, RG 59, 895.01/315, NA; Gauss to HuII, Niay 19,1944, RG 59, 895.01/338, NA. 83

Feis, The China Tangle, 106; Feis, Churchill, Roosevelt, Stalin, 254 . 
probability of Sino-Soviet disagreement over how best to reconstruct the Korean nation. Trusteeship provided the dual benefit of ensuring that the Koreans could protect their own sovereignty and security, while reducing the likelinood of great power conflict in a strategic area. To argue that Korea's long history of self-government negated forty years of Japanese domination was patently absurd.

VIII

Americans generally recognized that Cairo marked the end of American indifference toward Korea and the beginning of attempts to realize Korean independence. It was quite clear that "in due course" meant some form of guardianship for Korea to prepare it for self-government. Some observers hoped that this qualified promise of independence would spark open resistance to Japanese imperialism inside Korea. Thus, by the end of 19,43 . Americans began to focus greater attention on the fate of the Korean nation.

Arthur C. Bunce, who would later become ar economic advisor to the American occupation commander in Korea, wrote two articles during 1944 discussing Korea's future. He warned that, in the absence of internationally guaranteed

Che relies on this argument, as did the KPG, to portray the American trusteeship policy as "ill-considered." Korea in World Politics, 23.

ton Post, New York mimes, December 2, 1943, 25:3; Washing- 
peace and security, Korea would again become the victim of great power competition for control. Korea ceserved independence, but it would be meaningless unless tied to some postwar security system in Asia. Bunce recommended that the United States recruit Korean exiles and train them in government administration, economics, and education, thus providing for the rapid assumption of governmental responsibilities after the war. Korea's ecoromic problems would be serious. Thus, Bunce also urged American supoort for land redistribution, confiscation of Japanese holdings, technological improvements in agriculture, and the development of new industries.

Early in 1.944 , the State Department also began to formulate more concrete plans for the occupation and administration of Korea. In March, the Inter-Divisional Committee on the Far East produced three papers dealing with American policy aims in Korea. Miss and Clubb were principally responsible for the proposals dealing with occupation and administration. 87 The first paper stressed that Korea had been subject to Japanese rule for decades and exiles possessed doubtful local support and negligible

86

Arthur C. Bunce, "The Future of Korea: Part I," Far Eastern Survey, 23, 8 (April 19, 1944), 67-70; Arthur C. Bunce, "The Future of Korea: Part II," Far Eastern Survey, 23, 10 (May 1?, 1.944), 85-88. $8 ?$

Nemorancum, Narcin 19,1944, gRUS, 1944, Vol. V:

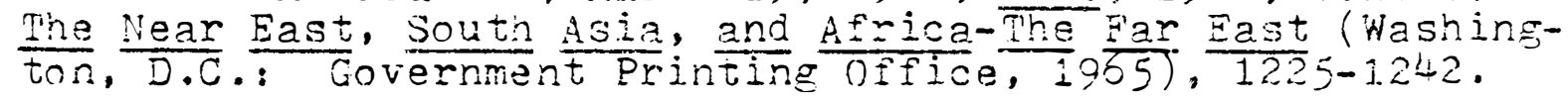


administrative experience. It, also noted that the largest group of exiles were Soviet-trained and imbued with Communist ideology, numbering approximately 35,000 as compared to 1,000 located at Chungking.

The second paper emphasized that the United States, Britain, China, and the Soviet Union all possessed legitimate interests in the peninsula and should all participate in the occupation and administration of the country. The Allies had to avoid one-power control at all costs. If zonal division proved unavoidable, the occupying nations should fashion a unified administration as quickly as possiole. The United States would play a major role in the civil administration of Korea and strive to maximize Korean participation in self-government. The paper provided for military responsibility in civil affairs at the outset and postponed outlining the final details of trusteeship.

The third paper dealt with the utilization of tapanese technical personnel; it would have considerable inportance at a later date. It stressed that the Allies might not be able to keep industrial activity in operation with Korean and military personnel alone. Thus, the United States

"Korean Political Problems," PiNC-124a, May 4 , 1.944, Edward R. Stettinilus Pacers, Box 380 , Postivar Committee Documents, 120-140, University of Virginia Library, Charlottesville, virginia. 89 "Composition of Korean Cccupation Forces," PWC125. Narch 29, 1944, Stettinius Papers, Box 380, Postwar Committee Documents, 120-140, UVAL. 
intended to permit japanese technicians to continue to function where security allowed and when qualified Koreans were not available. Events soon demonstrated that the paper grossly miscalculated when it argued that "politically undesirable results of the use . . of Japanese technical (including administrative) personnel can to a great extent be controlled and will be more than offset by the practical need for the use of such personnel."

On May 3, 1944, the State Department Postwar Programs Committee discussed and approved the three papers with minor alterations. The Committee members generally agreed that an international trusteeship was "absolutely necessary" for Korea becalise of past competition among the great powers over the strategic area. Interestingly enough, the only change provided that the United States should, under no circumstances, accept an exclusive mandate in Korea.

While the United States formulated more definite plans for Korea, the KPG continued its efforts to gain suficicient unity to warrant recognition. Reports from Chungking indicated that Kim Koo had finally agreed to broaden the representation of the KPG in hopes of ending disunity in the

90

"Japanese Technicai Personnel," PWC-126, Narch 29, 1944, Stettinius Papers, Box 380, Postwar Committee Documents, 120-140, UVAI.

$$
91 .
$$

Minutes, 27th Neeting, vay 3, 1944, Stettinius Papers, Box 382, Fostwar Programs Committee, February 1May 31., 1944, UVAL; The final position paper was numbared PNC-105, April 4, 1944, Stettinius Fapers, Box 380, Postwar Committee Documents, 100-1.20, UVAL. 
exile movement. 92 Evidently, Chiang was responsible for the decision, since he had threatened to terminate Kim Koo's subsidy unless the KPG eliminated its factional disputes. Such highhanded treatment drew criticism from not oniy the Koreans, but also the American diplomats in Chungking. Clubb warned Chiang that the United States would not tolerate any interference in the rights of China's neighbors to determine their own destiny. Perhaps more important, service observed that Chiang's otsession with Soviet expansion was producing divisions in the Kuomintang. Political weakness would only contribute to economic deterioration and force china's neighbors to reach an accommodation with the Soviet Union. clubb and Service stressed that only cooperation, nct unilateral action, would guarantee Chinese security. American leaders not only attempted to limit Chinese influence in the Korean exile movement, but also exercised indirect pressure on the koreans in hopes of fostering unity. Syngman khee rad requested American assistance in transporting five representatives of the KPG to Washington, but the United States rejected the proposal because the KPG did not represent all exile factions. 94 For similar

\section{2}

Gauss to Hull, May 1.5, 1944, RG 59, 895.01/337, NA; Gauss to Hull. June 1, 1944, RG 59, 895.01/343, NA. 93

CIubb Nemorandum, Nay 19,1944 , Service Niemorandum, April 7, 1944, FRIS, 1944, Vol. VI: China, (Washington, D.C.: Government Printing Office, 196?), 780-790.

Gauss to Hull, April 18, 1944, RG 59, 895.01/ 335. NA: Gauss to Full, April 26, 1944, RG 59, 895.01/333. 
reasons, the Administration refused to grant Korean representation on UNRAA. If the KPG obtained such status, it would axploit the act for political gain. American leaders believed that "the efforts of each faction are directed towara obtaining political capital, prestige and monetary assistance for that faction and not for the benefit of a concerted effort directed toward liberation of Korea." Until the soreans attained unity, the united States would refuse to recognize any single claimant.

\section{IX}

Soviet agreement to a specific trusteeship agreement became even more important during the summer of 1944. In July, Roosevelt aporoved General Douglas NacArthur's plans for the invasion of the Philippines and the final assault on Japan. American military leaders had already convinced the President that Soviet participation in the Pacific War would render the defeat of Japan infinitely easiex. 96 vet, it was clear that Stalin would not enter the Pacific War until victory in Europe was certain. The OSS speculated that if,

NA; Sprouse iviemorandum, Warch 27, 1944, RG 226, OSS Report 71682 , Ni ${ }_{95}$ Lee, The Politics of Korean Nationalism, 225. Minutes, Policy Committee, July 17, 1944, 72nd Vieeting, Stettinius Papers, Box 378, UvAI; Stettinius to Roosevelt, July 27 . 1944, Stettinius Papers, Box 219, UncirSecretary File, UVAL; Stettinius to Roosevelt, october 27, 1944, Stetinius Papers, 3ox 216, UVAL. 96 Leahy, I Was There, 250-259. 
at the moment of Soviet entry, "the trend in Europe is toward competition among the powers, a corresponding competition can hardly fail to arise in the Far East." Stalin would not, for example, accept a Korean government more favorable toward China than the Soviet Union. In view of Chiarg's determination to reestablish predominant chinese influence in Asia, the report predicted that Sino-Soviet conflict in Korea was highly probable.

America's dilemma was clear. The United States desired Soviet entry into the war against Japan, but feared that China would be unable to cooperate wi th Moscow for the preservation of peace and security in the area. Hull believed that trusteeship would prevent any undesirable political ramifications stemming from Soviet participation in the Pacific war, while at the same time reassure china. Huil thus intended to finalize Allied policy on dependent peoples at the Dumbarton Oaks Conference in August, 1944. American military leaders forced Full to postpone action on colonial policy, fearing that disagraements among the Allies would delay Soviet entry into the Pacific War. The War Department offered the pessimistic observation that the entire trusteeship issue was academic, since "the fall of Japan will leave Russia in a dominant position on continental Northeast Asia, and, . "able to impose ner will in all that area."

9 "Russia, China, and the Far Eastern Settlement," June 5, 1944, RG 226, iSS Report. RicA 2211, NA. 98 Hull, Memoirs, 1599; E.F. Cress Memorandum, JuIy 
State Department officials manifested less pessimism relative to Korea, but did recognize the deIicate nature of the situation. Berle, for example, now urged that the United States implement Rhee's plan for the creation of a Korean espionage force. Emphasizing the previous successful cooperation between Rhee and Goodfellow, Berle argued that utilization of the KPG would constitute a positive contribution to the defeat of Japan. Hornbeck, on the other hand, urged the adoption of a plan to provide Chiang with enough military aid and support for the creation of a strong china that could act as a barrier to Stalinist expansion. Since the United States and Britain would be concentrating on the defeat of Japan, only china could deter Soviet occupation of Manchuria, Vongolia, and Korea at the end of the war.

Unfortunately, Chiang's expansionist tendencies continued to alarm American leaders and thus undermine the logic of Hornbeck's stratesy. Iangdon, now Consul General at Kunming, reported that the chinese were far more concerned with establishing predominant influence in Tibet, Mongolia, and Korea than with fighting Japan. 100 Roosevelt himseli

27, 1944, RG 319, ODerations Planning Division, 336 Korea, Top Secret, Naticnal Archives, Nashington, D.C. 99

Berle to Grew, July 21, 1944, RG 59, 895.01/72144. NA; New York Times, August 30, 1944, 11:1: Hornbeck to Hull, Jüly 18, 1944, Hull Papers, Reel 49, Sox 85-86, Folder 371, LuC; Feis, The China Tanole, 211-21.2. VI, 495 Langdon to HuIl, August 1, 1944, FRUS, 1944, VoI. 
was beginning to express concern over china's future. At a caoinet meeting in Nay, 1944, the President suggested that Chiang's regime would not survive for the duration of the war. Allied agreement still appeared the only logical course for the preservation of peace. During the summer of 1944, Roosevelt dispatched Vice President Henry A. Wallace on a mission to China and the Soviet Union. Among other things, Wallace was to urge unity among Korean exiles and obtain Stalin's views toward the KPG. By Augist. 1944, the United States was considering an Allied conference to raach agreement on military government in Korea and other areas recaptured from Japan.

Moscow satisfied American desires for a Soviet commitment to enter the Pacific War in October, 1944. Stalin informed American Ambassacior w Avereli iarriman that the Soviet Union would declare war on Japan within three months after the defeat of Germany. He then inquired as to the concessions trat the Soviet union could expect in return for participation in the war. Harriman warned Roosevelt that China's future would be in jeopardy unless the Allies reached agreement on postwar reconstruction of Asia. Secretary of war Henry I. Stimson agreed, pointing out that only

101

Minutes, 4? th Mieeting, May 19, 1944, Stettinilis Papers, Box 3?0. Policy Committee, UVAL; Stettinius to Grew, Nay 5, 1.944, Stettinius Papers, Box 216, Division of Far Eastern Affairs, UVAT; Hull to Gauss, June 12, 1944, ERUS, 1944, Vol. VI, 1295; Gauss to Full, June 29, 1944, RG 59, 895.01./6-2944. NA; stettinius to Gauss, Auglist 3, 1944, Stettinius Fapers, Box 730, Memos to Hull, UVA.L. 
firm agreements would guarantee support for the postwar peace 102

settiement and ensure American security in the Pacific.

American military strategy continued to play a crucial

role in the formulation of a specific proposal on norea

during the first month of 1945. The chiefs of Staff even

recommended that the Soviet Union occupy the entire peninsula

at an early date to prevent Japanese reinforcement of the

home islands prior to American invasion. Despite the

opposition of Admiral William D. Leary, Roosevelt supported

Soviet participation in the Pacific War at the earliest

possible moment to ensure a quicker and less costly 103

victory. The Administration also rejected any action

that might rouse Soviet suspicion of American intentions.

Any effort to Iimit Soviet participation in the postwar

reconstruction of Asia would jeopardize China's position 104

and place Korean independence ir doubt.

As Rooserelt left for Yalta, his main objeotive was

102

Feis, The China Tangle. 228-233; See aiso, FRUS, 1945, The conferences at lialta and Yalta (Wiashington, D.C.: Government Printing (1)ice, 1955). 103

Stimson and Bundy, (On Active Service in Peace and War, 600-603; Feis, The China Tancle, 232-233. 104

The United States refused to implement a Korean proposal to land forces at vladivostok and occupy Korea prior to invading Jacan, December 7, 1944, RG 226, OSS Report 105310, NA; It also rejected Rhee's espicnage plan, because of China's proven desire to control the Kim Koo regime, Grew to Berle, July 31, 1944, RG 59 , 895.01/7-3144, NA; The State Department even rejected a British proposal to quickly restore trade with Japan at the end of the war, Grew to Stettinius, January 22,1945 , Stettinius Papars, Box 721, Japan, UVAI. 
to finalize plans for Soviet, entry into the Pacific Viar, while gaining Stalin's support for an agreement that would produce a strong China and an independent Korea. The State Department had drawn specific plans for Korea which followed the recommendations of the Pacific War Council reports formulated during the spring of 1944. The Briefing Book Paper stressed the necessity for inter-Allied participation in the occupation and civil administration of Korea, suggesting a four-power trusteeship if the Soviet union entered the Pacific War. The paper pointed out, however, that it "would seem advisable to have soviet representation on an ihterim administration regardless of whether or not the soviet Union enters the war...." 105

On February 8,1945 , Roosevelt raised the issue of korea during his discussions with Stalin and recommended a threepower trusteesnip. The President pointed to the American experience in the Philippines and observed that the Korean trusteeship would probably last twenty or thirty years. Stalin replied that the shorter the duration the better and then inquired as to the stationing of foreign troops in the peninsula. After agreeing that there should be no foreign military forces in permanent occupation, Rooseveit raised the "delicate" matter of excluding the British from participation in the arrangement. The President believed that

105

Briefing Book Paper, "Inter-Aliied ConsultationKorea," Undated, FRUS, 1945, The Conferences at inalta and Yalta. 358-361. 
British inclusion in the trusteeship was unnecessary. Stalin disagreed, pointing out that Churchill would be offended and might "kill us." Thus, Roosevelt and Stalin agreed to support a four-power trusteeship for Korea. 106 Roosevelt must have left Yalta confident that Soviet-American cooperation had increased the likelihood that Korea would energe after the war as an independent and sovereign nation.

Scholars have debated at length the wisdom of the Yalta Agreement on the Far East. With the benefit of hindsight, many have argued that Soviet participation in the Pacific War was unnecessary. Some observers have termed Roosevelt's failure to consult China as "unpleasant and iminoral" while others insist that he "gave away" more than was required. Regardiess of the larger aspects of the Yalta Agreements, one can hardly find fault with the Korean arrangement. AII Korean experts in Washington agreed that Korea was not prepared for self-government and American experiences with the exile movement added credence to such conclusions. Roosevelt speculated that with international ouidance and assistance

\section{0}

Bohlen Minutes, February 8,1945 , FRUS, 1945, The Conferences at Nalta and Yalta, 770; James F. Byrnes, who was present $\overline{a t}$ Yalta, later argued erroneously that Stalin and Roosevelt agreed to a Korean trusteeship only "if a transition period were necessary," Speakins Frankly, (New York: Harper and Brothers, 1947), $2 . \overline{21 .}$ 107

Joseph C. Grew and Walter Johnson, Turbilent Era: A Diolomatic Record of Forty Years 1904-1945, Vol. II (Boston: Houghton Miffiln, 1.952$)$, 1444; Charles . Bonlen, The Transformation of American Foreign Policy (New York: W.W. Norton, 1969), 36; Cho, Korea in world Politics, 33. 
Korea could develop sufficient political skill and experience for the maintenance of independence.

Strategic considerations underlined the realism of the trusteeship policy. In view of past Sino-Soviet competition for control in Korea, it was clear that only an Allied agreement could ensure an atmospere of stability in that area. Success would depend upon mutual trust, harmony, and cooperation, which would be impossible if Korea obtained sovereignty and independence prematurely. 1.08 mrusteeship, however, would foster Allied cooperation and coordination, thus ensuring Korean protection until it was capable of self-direction. In pursuing Allied support for trusteeship, Roosevelt had clearly followed the advice of his korean experts. In the absence of such an agreement, the United States could guarantee Korea's independence only through the application of considerable military power. Such an alternative was not feasible in view of the priority given to the defeat of Japan. Thus, after forty years of Japanese domination, Korea became "the test case in international cooperation and international good faith." American indifference toward 1.09

Korea was at an end.

\section{8}

Tyler Dennett, "In Due Course," Far Eastern

Survey, XIV, 1 (January $1.7,1945$ ), 1-3. 109

Ibid., 4; American support for trusteeship began early in 1.942. Thus, U-Gene Lee clearly errs when he argues that Rocsevelt turned to trusteeship only after the British rejected immediate independence, "American Folicy Toward Korea 1942-1947: Formulation and Execution," UnpubIished Ph.D. Dissertation, Georgetown University, 1973, 8-11. 
Chapter II:

Captive of the Cold war 
Soviet-American objectives in Korea at the end of World War II were not entirely incompatible. Both nations sought Korean independence and self-government throligh the creation of political and economic stability. Stalin was, however, more determined to preserve Soviet security interests in the Korean area. He would not permit the emergence of a Korean government hostile to the Soviet Union if at all possible. Roosevelt, it wolld appear, recognized the strategic nature of the Korean peninsula, but was also devoted to the principle of national selfdetermination. After all, if the Koreans chose a government hosilile to the United States, it would present only a remote threat to American security interests. Yet, despite the difference in emphasis, Roosevelt anc Stalin had agreed at Yalta that trusteeship would satisfy their objectives in Korea. Soth leaders seemed to believe that through cooperation and coordination the Allies could eliminate korea from the arena of great power nivalry and conflict.

Realism thus characterized Roosevelt's aporoach to the problems surrounding postwar reconstruction of Korea. Two factors emerged, however, to frustrate the american 
attempt to balance divergent interests and arrive at a new balance of power underwriting Korean independence. First, Soviet actions in Eastern Europe greatly alarmed Roosevelt and his advisors. Marry S. Truman, Roosevelt's successor, was even more suspicious of Soviet intentions and easily concluded that the United States could expect "sovietization" in the Far East as well. Secona, Korea itself experienced a period of rapid and sweeping change in the wake of Japan's defeat. The Truman Administration neither understood nor reacted well in the face of such revolutionary turmoil. As a result, Korea did not emerge as a free and independert nation in 1945 , but as a captive of the emerging SovietAmerican Cold War.

Few observers anticipated that the Pacific Nar would end so quickly after the defeat of Germany. Thus, Roosevelt, Churchill, and Stalin had not engaged in a detailed discussion of trusteeship at yalta. Instead, the Allied leaders decided that a five-member committee, composed of representatives from those nations on the proposed security council of the United Nations, would meet prior to the San Francisco Conference to finalize the terms of an international trusteeship system. Significantly, the meeting would involve only preIiminary discussions, since the committee would not determine

Baldwin, Introduction, in without Parallel, 5. 2

Yalta Communique, International irusteeship, Frus, The Confersnces of BerIin (Potsdam) 1945. Vol. II (Washington, D.C.: Government Printing Office, 1960), 1568. 
which particular nations would fall under the arrangement and what specific provisions would apply in each case. China was clearly dissatisfied with such delay and lurged its allies to adopt a more definite program, particularly for Korea. Chiang still haroored fears of Stalin's intentions. He continued to press Kim Koo for the creation of a more representative and unified KPG, which would warrant American recognition. At the same time, China favored an Allied agreement for a three-power military administration of Korea, with Soviet participation if voscow entered the Pacific War. Joseph Ballantine of the Division of Far Eastern Affairs agreed to exchange proposals on Korea in preparation for future action, but reminded m.V. Soong that the United States opposed any bilateral discussions except on a "purely exploratory" basis. Prior to the simultaneous consultation of all concerned Allied nations, a final policy determination on Korea was simply not possible.

Syngman Rhee recognized that American victory over Japan was now certain and thus began to lobby more vigorously for American support. Shortly after Yalta, Rhee warned the

Ballantine vemorandum. Feoruary 5, 1.945, FRUS, 1945, Vol. VI: The British Commonwealth, The Far sast (Washington, D.C.: Government Printing (Office, 1969). 1018. Ballantine Memorandum, February 1.7, 1945, FRUS, 1945. Vol. VI, 1021; Viricent to stettinius, February 8 1945, FRUS, 1945, Vol. VII: The Far East: Cinina (Wasinington, D.C.: Government Printing Office, 1.959). 854 . 
State Department that Moscow had created a "Korean Liberation Committee" in Siberia. His attempt to compare Korea with

Poland was unmistakable. Rhee demanded an immediate investigation and reiterated the wisdom of recognition of the KPG. He also demanded Korean representation on any body considering the formulation and administration of occupation policy for Japan.

Rhee's reports of Korean Communist activity were far from unique. Sources indicated that Moscow had trained over 100,000 Korean guerillas for participation in the liberation of Korea. Reports also revealed that the Chinese Communists had created a "Korean Revolutionary Military-Political School" at Yenan to train Korean leaders for participation in the postwar administration of Korea. While the KPG argued that it was the strongest and best organized resistance group, such evidence provided abundant information to the contrary. Kim Koo's regime still manifested factionalism in the extreme, while its principal leaders appeared constantly preoccupied with personal ambitions and financial gain. American leaders thus confronted the fundarental problem of

\footnotetext{
Stettinius to Hurley, Feoruary 20, 1.945, ERTS. $1945, \mathrm{Vol} . \mathrm{VI}, 1022-1023$.

Major General H.A. Craig Summary, February 1.3, 1945, RG 319, OPD 381, China Theater of Operations, NA; Intelligence Report, February 27, 1945, RG 226, OSS 1.20760, NA; Intelligence Pecort, Warch 1, 1945, RG 226, OSS 11607?, NA.

'Atcheson to Stettinius, March 1, 1945, ERUS, 1945. Vol. VI, 1024.
} 
being unable to find a capable and popular exile group that warranted American aid and support.

Trusteeship and impartiality thus remained the hallmarks of Roosevelt's Korea policy. Yet, Stimson and Secretary of the Navy James $V$. Forrestal expressed concern that American responsibility and power in colonial areas lacked specificity. Both men feared that the United States would surrender strategically important areas in the Pacific, while other nations would not follow suit. Roosevelt refused to abandon HuIl's policy toward dependent peoples and, in ilarch, 1945, reaffirmed his support for one nation acting as a "trustee" and deriving its power from the United Nations as a whole. Korea remained part of this larger trusteeship arrangement. As a result, the state Department rejected the requests of both Rhee and Haan for Korean representation at the San Francisco Conference. Only those nations that the Allies recognized as of march 1,1945 , the Administration explained, would participate in the formation of the new international security organization.

In the meantime, American planning progressed on a specific program for the occupation and interim administration of Korea. In March, the State-War-Navy Coordinating

\footnotetext{
Walter villis, ed.. The Forrestal Diaries (New York: Viking Press, 1951), 33 and $37-38$. 9

Rhee to Stettinius, warch 8, 1945, RG 59, 500.C0/ 3-845, MA; Haan to Stettinius, March 9, 1945, RG 59, $500 . \mathrm{CC} / 3-945$, NA; New York Times, Narch $1,1945,3: 7$.
} 
Committee (SWNCC) completed a series of papers dealing with the treatment of the Korean population during occupation, the utilization of Koreans and Japanese in the military government, and the deportation of Japanese to the home islands. In addition, the SWNCC devoted attention to the composition of the occupation force and the relationship between the temporary military administration and the future international supervisory authority. ${ }^{10}$ Roosevelt had already decided that the War Department would control civil affairs in liberated areas. The President apparently accepted Stimson's argument that "the State Department by its nature was unequipped for major administrative chores" and "could not hope to equal the Army in the task of carrying them out." ${ }^{11}$ In May, 1942, the War Department created a school in Charlottesville, virginia to train military officers for civil administration. Thus, by April, 10,45, American plans for a temporary military government in Korea prior to the establishment of an international trusteeship were virtually complete.

Roosevelt's hope for postwar peace and security in Korea and elsewhere rested upon the success of Allied

10

SWNCC Papers 76, 77, 78, 99, and 1.01, rarch 19, 1945, RG 21.8, CCS 383.21. Korea (3-19-45), Section I, NA. 11.

Stimson and Bundy, on Active Service in Feace and War, 561 and 533 . 
cooperation and mutual trust. Soviet actions in Eastern Europe immediately following the Yalta Conference alarmed the United States, causing Roosevelt to question Stalin's willingness to fulfill Allied agreements. when Roosevelt died on April 12, however, he remained optimistic over the chances for continued Soviet-American cooperation, despite clear differences regarding such issues as the late of Poland. $^{12}$ While the future of Soviet-American relations in Eastern Europe appeared uncertain, American policy toward Korea remained intact.

Whether the United States would have become alarmed about Soviet aspirations in Asia had Roosevelt lived remains a matter of speculation. Harry S. Truman"s assumption of the presidency, however, clearly marks a turning point in. America's Korea policy. After 1.945, the United States anticipated that Soviet actions in Asia would parallel those policies foliowed in Eastern Europe. Although there existed no clear relationsip between the two areas, Truman preferred to view Soviet expansionism as a basically unchanging force in postwar international affairs. Less than a week after assuming office, Truman reversed Roosevelt's stand on territorial trusteeship and

John Lewis Gaddis, The United States and the Origins of the Cold War 1.941.-194? (New York: Columbia University Press, 1972), 1.72; Iisle A. Rose, Dubious Vic-

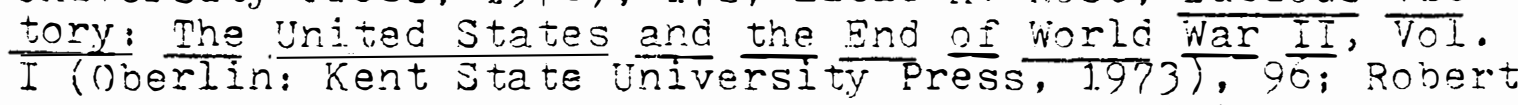
. Ferrell, "Truman's Foreign Policy: A Traditional view," in Tine mruman Period as a Research Field, 26. 
supported the views of stimson and Forrestal. As a result, the new Administration decided to oppose any detailed discussion of an international trusteeship machinery at the upcoming San Francisco Conference. 13

Harry $S$. Truman was poorly prepared for the presidency. Roosevelt had done little to inform his Vice President of major policy develooments, particularly in the area of foreign affairs. More important, Truman's political expertise was wholly in the realm of domestic politics and, as a result, he possessed a limited understanding of the complex nature of international diplomacy. American leaders, such as Senator Arthur $H$. Vandenberg, expressed justifiable concern over the 14 nation's future. Admiral leahy, for example, wondered how "the complicated and critical business of the war and the peace can be carried forward by a new President who is completely inexperienced in international affairs."

International Trusteeship, April 1.8, 1945, Stettinius Papers, Box 735, Nemoranda For the President, UVA: The decision indicates Truman's desire to keep nis options open in areas that the Red Army had not yet occupied. 14

Alonzo L. Hamby, The Imperial years: The United States Since 1.939 (New York: weybrignt and Taliey, 197ర), 1.10; Rose, Dubious Victory, 84-90; A than Theoharis, "The Rhetoric of Politics: Foreign Policy, Internal Sacurity, and Domestic Politics in the Truman Era, 1.945-1950," in Politics and Policies of the Truman Administration, edited by Barton J. Bernstein (chicago: Rliadrangle Books, Inc., 1970), 202; Louis w. Koenig, ed., The Truman Administration: Its Princinles and Fractice (New York: New York University Press, $1 . 9 5 6 \longdiv { , 2 }$. 15 William D. Leahy, Diary Notes, April 12, 1945, wilizam D. Leahy Pavers, Box 5, Diaries 1945. IOC. 
Truman's parochial and provincial political background certainly limited $\mathrm{nis}$ world view and rendered a baianced appraisal of the delicate problems of postwar diplomacy infinitely more difficult. At the same time, Truman's Midwestern conservatism Iostered inflexibility and impatience in regotiations. The new President thus lacked the temperament and understanding required for the tactful implementation of his predecessor's policies, In addition, Truman's diplomatic inexperience produced a penchant for oversimplification, wille impulsiveness compounded the dangers already inherent in following a leader possessing such serious personal shortcomings. As Bert Cochran explains, at times "some of his associates were not sure that Truman understood the implications of his decisions."

Truman's approach to diplomatic issues was a reflection and an extension of his response to domestic problems. He believed that local communities could solve their own particular problems with a minimum of outside interference. Thus, in foreign affairs, Truman was a staunch supporter of the principle of national self-determination as a panacea

Daniels, The lian of Independence, 16; irclellan, Commentary, in The Truman Period as a Research Field. 153; Gadis, The United States and the Origins of the Cold War, 197: Koenis, The Iriman Administration, 261.

Bert Cochran, Harry Truman and the Crisis Presidency (Niew York: Furk and Wagnalls, 1.973), 135; David K.E. Bruce, Oral History Interview Transcript, Warch 1., 1972, HSTL, 46-47; harry indaletor refers to Truman as "an expert at oversimplification," The Compact History of the Korean war, 97. 
for international problems. 18 Soviet actions in Eastern Europe deeply disturbed Iruman, because Stalin refused to accept the basic ingredient of Truman's postwar program. For Truman, only the worldwide realization of the liberal political ideal of national self-determination would ensure postwar peace and security. The new President was determined to force the Soviet Unjon to respect each nation's freedom of choice, although it was questionable that the United States possessed the means to achieve such an objective. Many of Roosevelt's advisors had become dissatisfied with a policy that continued to emphasize Noscow's willingness to cooperate with the United States after the war. These men welcomed the new President's decisiveness and urged the adoption of a firm posture of opposition to Soviet expansion. During private discussions, Harriman informed mruman that Stalin was imposing his will on Eastern Europe in direct violation of wartime agreements. Leany and Forrestal joined Harrimar in arguing that Soviet acticns represented a clear political and strategic threat to American security. In response, Truman assured his advisors that he intended to be firm in his dealings with stalin and insist upon the fulfillment of the Yalta Agreements.

Truman assumed the hardline attitude toward Stalin that 18 19 Hamby, Beyond the New Deal, 459.

Truman, Years of Decision, $72 ;$ Gaddis, The United States and the origins of the Cold War, 201-202; :aniels. The Van of Independence, 2 70 . 
Roosevelt's advisors recommended without hesitation. "To a man of Truman's biunt, contentious personality," John Lewis Gaddis observes, "this tough policy must have seemed particularly congerial." Almost immediateiy, Truman came to rely on those advisors most firmly committed to a policy of toughness toward the Soviet union. On April 23, 1945 , the President informed his advisors that, during his discussions with Molotov that day, he would assume a hard Iine on Poland and demand Soviet fulfillment of the Yalta Agreements. Although Truman had not abandoned the possibility of cooperation with the Soviet Union, it was doubtful whether tough rhetoric alcne would improve Soviet...American relations in the postwar world.

Leahy welcomed the change in American policy and noted that, with the imminent defeat of Germany, "no particular harm can now be done to our war prospects even if Russia should slow down or even stop its war effort in Europe and Asia." Thus, the Truman Administration was already besinning to question earlier support for the extension of Soviet influence in Asia. Harriman was already urging a hard line in the Far East, expressing the conviction that the United

Caddis, The united States and the oxicins of the

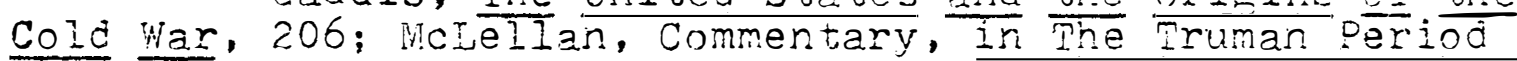
as a Research Field, 153; Georse Curry, James E: Bvrnes, VII. XIV: American Secretaries of State and Their Diolomacy. edited by Bemis and Ferreli (New york: Cooper Square Publishers, 1965$), 31.3$.

21

Rose, Dubious Victory, 104-105; Gaddis, The United States and the origins of the cold War, 198-206. 
States could expect the same pattorn of Soviet action in Nanchuria and Korea that existed in Poland and Rumania. Interestingly enough, George F. Kennan did not entirely agree. He dispatched a cable from ivoscow expressing doubts that the Soviets had created a "Korean Liberation Committee" in the "obviously unnatural surroundings" of siberia. Instead, if such a group existed at ail, it was probably located at Yenan with the Chinese Communists. Although American support for a Korean trusteeship had begun to waver, the Truman Administration decided to maintain impartiality toward the Korean exile movement.

\section{III}

Harsh words alone would not force the Soviet union to abandon its control over Eastern Europe. Yet, the United States could prevent a repetition of this unhappy set of circumstances in the Far East, since the Red Army was not in occupation of this area. American leaders certainly recognized that if American forces 1 iberated those areas

Leahy Diary Entry, April 23, 1945, Leahy Papers, Box 5, Diaries, 19,45, LOC; Ferbert Feis, Contest lver Janan (New York: N.W. Norton, 196?), 27-28. 23

Konnan to Stettinius, April 17, 1945, ERUS, Vol. YI, $1945,1026-1.027$. 24

Rinee quickly criticized the continued abserce of recognition, complaining that Korea was again the "victim of secret diplomacy," Rhee to Truman, Nay 15.1945, FRUS, 1945, Vol. VI, 1028-1029; Niew York Times, Vay 29, 1945, 3:4; Intellizence Report, June 25, 1945, RG 226, OSS 3201, NA. 
under Japanese domination, Soviet expansion in Asia would not emange as a serious problem. In viay, 1945, Harriman had reminded Truman that Soviet involvement in the Facific War would necessitate Soviet participation in the occupation of Japan. Relative to Korea, Harriman alleged that Stalin has questioned the need for trusteeship in the event that the Koreans could rule themselves during the Yalta conference. Although the record does not reveal such a statement, Truman was clearly impressed with Harriman's warning that Korean self-government maant "sovietization" if Stalin occupied the Korean peninsula.

under-Secretary of State Joseph C. Crew also expressed concern over the consequences of Soviet entry into the Pacific war. Fe urged Truman to obtain Stalin's assent to a number of conditions prior to the imolementation of the Yalta Agreement on the Far East. Grew desired Hoscow's specific support for Chiang kai-shek's regime, respect for Chinese control in Manchuria, and agreement to implenent a four-power trusteeship in Korea. Grew agreed with Harriman that the Soriet union, in refusing to fulfill its agreements in Europe, nad sacrificed American trust. Thus, the United States had every right to deny Stalin a free hand in Asiz. Korea's fate was, however, completely tied to American military capabilities and its strategy for the defeat of

\footnotetext{
Millis, The Porrestai Diaries, 56.

Grew and Johnson, Turbulent Era, 1456-1457.
} 
Japan. If Stalin refused to support a Korean trusteeship, only prior American occupation could guarantee Korea's incependence. American military leaders cortinued to insist upon military victory over Japan as the hignest priority. For example, ViacArthur urged Washington not to dalay a frontal assault on the heartland of Japan. He also favored early Soviet participation in the Pacific War, arguing that Noscow would inevitably seize rarchuria and korea and might as well earr such territorial acquisitions.

Grew strongly disagreed with Machrthur's conclusions. If Noscow entered the Pacific War, he predicted, the Soviet Union would emerge as the dominant power in postivar Asia and constitute an even larger threat than Japar to American security. Grew offered the dire prophesy that once rioscow entered the war "Mongnlia, Nanchuria, and Korea will gradually sip into Russia's oroit to be followed in tue course by China and eventually Japan. . .." Do avert such a catastrophe, the united States had to maintain its military power and control several strategic areas in the pacific. Wrile Grew kept these views largely to himself, Harriman expressed similar apprehensions to Truman and uriged the President to meet with Stalin and churchill within a few weeks to terminate the developing split among the Aliies.

\section{Herbert Feis, The Atomic Somo and the End of}

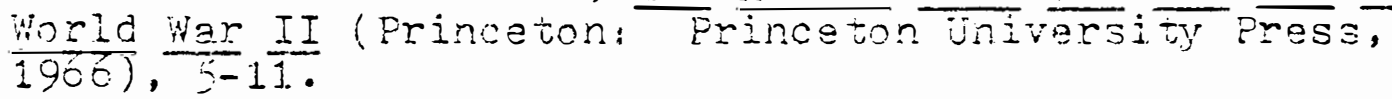
28

Grew and Johnson, Turbulent Era, 1.445-1446. 
In particular. Harriman pointed out that the Yalta Agreements on China and Korea were vague and ambiguous and in need of considerable clarification.

An insoluble dilemma thus faced the Truman Administration in Asia. Washington had to devise a military strateg.y for the defeat of Japan, which would provide a strategic position from which the united states could react in the face of anticipated Soviet duplicity. On Viay 2.1 , the war Department presented its case in support of VacArthur's two-phase plan for the defeat of Japan. It lirged rapid Soviet entry into the Pacific War in order to save American lives, while specifically rejecting Grew"s suggestion that the United States withrold the Yalta concessions until Stalin promised to respect the sovereignty of China ard horea. The War Department contended that the entire issue was academic because "Russia is militarily capaole of defeating the Japanese and ocoupyinz Karafuto, Nanchuria, Korea and North China before it would be possible for tre U.S. military forces to occupy these areas." In the face of conflicting advise, Truman rejected the State Department's advice and, on May 25, approved NacArthur's plan.

Truman really had no choice, because American alterratives

Grew Nemorandum, Way 15,1945 , ERUS, The Conference of Berlin (Potsdam), Vol. I (ivashington, D.C.: Government Printing (ffice, 1900). 14; Grew and Johnson. Turbulent Era, 1.462-3.464. 30

Rose, Dubious Victory, 132-133; Grew ard Johnson, Thrbulent Era, $1458 \cdot 1.459$. 
were few and far from promising. The SwNC did consider the option of adopting a program to train and equin a Korear military force in China, which could invade korea and establish control prior to Soviet entry. The War Department registersd its opposition to the plan, arguing that the Korean prisoners of war were of low caliber. As Assistant Secretary of Mar John J. VicCloy explained. it would be "impractical to make combat soldiers of such personnel."

State Department oficial Earl R. Dickover disagreed with MCCloy's judgment at the SWNCC meeting of May 1.8, 1945. He speculated that such a korean force would be a powerful propaganda weapon that would svark acts of sabotage against the japarese inside Korea. To resolve the dispute, the SilNic submitted the croposal to General Albert $c$. Wedemeyer in Chunghing for comment. In response, Wedemeyer strongly opposed the olan, because of insufficient transpontation facilities, trainers, and equipment which made the plan infeasible. On May 29, the SWNCC aropped the idea from consideration. It did, however, decide to increase American ties with important exile leaders in order to maintain influence over future developments.

Truman soon realized, as Roosevelt had, that if the

SWNCC 115, G-3 Comments, May 4, 3.945, RG 31.9 , OPD 336.2 (23 April 45), NA. 32

Summary, SwNCC ivesting, Nay 18, 1945, RG 218, CoS 370 Korea (April 23, 1945), NA; Nemorandum, Nay 19, 1.945. RG 319, OPD 335.2 (Korea), NA. 
United states could not use its military power in Asia to foster Soviet caution, diplomatic agreement was the only alternative. Rather than arranging for an early meeting of the Allies, as Harriman desired, Truman decided instead to send Harry Sopkins to Noscow in an effort to resolve outstarding differences and firm up the Yalta Agreements.

State Department officials formulated a detailed set of recommendations for the Hopkins Mission. The instructicns stressed the importance of obtaining Soviet supoort for $z$ four-power Korean trusteeship which guaranteed equal representation in the civil administration. In addition, Hopkins was to achieve Stalin's assurance that the international arrangement would concentrate on training reliable local Koreans for self-government. Fopefully, through Allied cooperation, the trusteeship would produce a Korean government that truly reflected the free will of the people. Both the War and Navy Departments supported these rocommendations, but urged delay regarding speoific military matters. Unfortunately, all the planning and preparation was wasted effort. At Moscow, Hopkins completely ignored the recommendations and refused to engage in a detailed discussion

Gaddis argues that the Hopkins mission was evidence of Truman"s conciliatory attitude, The United States and the origins of the Cold War, 232-233; Rose Suggests tiat Truman sought to trade Soviet control over Eastern Europe for an American sphere of influence in Asia, Dubious Victorv, 130-131. 34

Grew to MCC10y, May 21, 1.945. RG 319, 0PD 363 TS ( 5 June 45). NA; Grew to Forrestal, Nay 21, 1945 , FRijS, 1945 , Vol. VII, 882-883. 
of Korea. He merely pointed out that the Yalta Agreement only provided for a four-oower trusteeship, but did not specify its duration. Hopkins observed that the period of international guidance might last as long as twenty-îve years, but certainly a minimum of five to ten years. Stalin avoided specifics as well, but did reaffirm his complete support for a four-power trusteeship.

Clearly, the Hopkins Mission did not indicate that the Soviet Union intended to undermine the Korean trusteeship agreement. Yet, Soviet action in Europe did suggest the possibility of Stalinist expansion in Asia. Chang never doubted that Moscow had designs on Korea and continual.ly reminded Washington of the existence of Soviet-trained Korean guerillas in Siberia. In contrast to the exiles in Chungking and the United States, he observed, the Korean Communists possessed administrative experience, military skill, and political prestige.

Despite their apprehensions, Truman and his advisors decided to continue American reliance on the trusteeship policy and refusal to compromise Korean self-determination. In June, 1945, Grew announced that the KPG did not have "at the present time the qualifications requisite for obtaining

35

Menorandum of Conversation, May 28, 1945, FRUS. The Conference of Berlin, Vol. I, 47; See also, Herbert Feis, Between War and Peace: The Potsdam Conference (Princeton: Princeton University Press, 1960), 114-1.16. 36

Memorandum, D.C. Poole, May 20, 1945, EPUS, 1945, Vol. VII, 870-876. 
recognition." Early in July, the British indicated their complete support for the American position. Truman also informed T.V. Soong of his intention to abide by the provisions of the Yalta Agreements on the Far East. Based upon the results of the Hopkins Mission, the Fresident expressed confidence that $\mathrm{Stalin}$ intended to support Chiang's regime and international control over Korea. 37 Thus, the Truman Administration decided to trust stalin to fulfill his promises. In the absence of a willingness to use military power, Truman had little other choice.

\section{IV}

Nilitary strategy roinforced Truman's commitment to achieve a Korean trusteeship. In the wake of the Hopkins Mission, American military leaders continued to advocate direct invasion and Soviet entry into the Pacific ivar as the best method for defeating Japan. Late in May, the Joint Chiefs of Staff (JCS) rejected a proposal to land troops in Manchuria or Korea, because such action would prolong the war and have doubtful impact on the Japanese war machine. Since America's highest priority was the rapid defeat of Japan, "the employment of substantial United States forces

Grew Statement, DSB, XII, 311 (Jine 8, 1945), 1058-1059; Winant to Stettinius, July 2, 1945, RG 59, 711. $95,7-245$, NA; Elsey Memorandum, July 1, 1945. FRUS, The Conference of Eerlin. Vol. I, 309-3io; Feis, the Atomic Bomb and the End of Horld War II, 164-165; Grew and Jonnson, Turbulent Era, $1460-1468$. 
in Manchuria and Korea is not justified." ${ }^{38}$ such military strategy precluded the achievement of a sufficiently powerful military position after the war from which the United States could oppose Soviet expansion on the northeast Asian mainland.

Truman gave final approval to racArthur's invasion plan-code-named "Olympic"-at a White House strategy meeting on June 1.8, 1945. At that time, Narshall manased to convince Navy Chief of Staff Ernest R. King that the United States had to occupy Kyushu prior to an invasion of Japan. His strongest argument stressed that "Olympic" was the least expensive strategy available, particularly in comparison with a potential landing in Korea:

An outstanding military point about attacking Korea is the difficult terrain and beach conditions which appear to make the only acceptable assault areas Fusan. . . and Keijo . . .. To get to Fusan which is strongly fortified area, we must move large and vulnerable assault forces past heavily fortified Japanese areas. The operaticn appears more difficult and costly than assault on Kyushu. Keijo appears an equally difficult and costly operation. After we have undertaken either one of them we stili will not be as far forward as going into Kyushu. 39

Nevertheless, Truman decided to delay final approval for the second phase of the plan-actual invasion of Japan-since he

38

Cress to JCS, iray 31, 1945, RG 218, CCS 383.21. Korea, Section I $(3-1.9-45)$, NA; Feis, Churchill, Rooseve?t, Stalin, 288 . 39

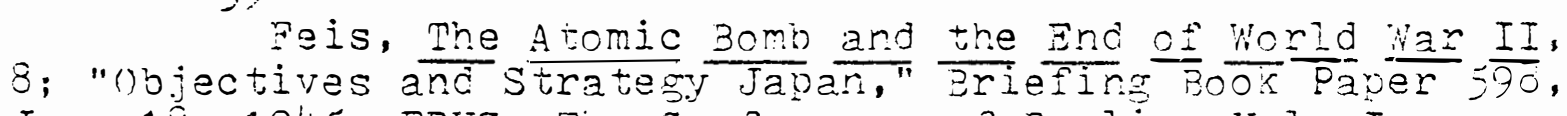
June 1.8, 1945, GRUS. The conference of Berlin, Vol. I, 903-10. 
was aware that the successiul testing of the atomic oomo might remove the necessity for this costly operation.

American military leaders had already begun creparations for a possible sudden collaose of Japan in the aftermath of an atomic attack. On June 14, the JCS instructed MacArthur and Facific Fleet Commander Nimitz to formulate plans for the early occupation of Japan. Truman approved this action. on June 29. On the same day, the President authorized an intensification of bombing and blockade operations against Japan in order to reduce the enemy's ability to resist the scheduled invasion on November 1., 1.945.

While completing military plans, Truman also prepared for the Potsdam Conference. On June 30, he announced is appointment of James F. Byrnes as secretary of State, arouing that only an individual who had held elective office should occupy the highest position in the abinet. In reality, Truman did not accept Edward R. Stettinius, Jr. and his devotion to the United Nations as congenial with an effective approach in Soviet-American relaticns. Ironically, Truman later regretted his choice of Byrnes. The new Secretary of

40

Feis, The A tomic Bomb and the End of World War II, 11. Leany believed that Japan would surrender before an
invasion of the islands was necessary, I was There, $384-385$. invasion of the islands was necessary, I Was There, 384-385. Memorandum of the chiefs of Staff, June 29, 1945, ERUS, The Conference of Berlin, Vol. I, 91.0-91.1.; Feis, Churchill, Roosevelt, Stalin, 296 ; Truman contirued to rely on Soviet entry as a means to hasten Japan's defeat. King, however, believed that Soviet aid was no longer indispensible and Truman did not have to "beg" for Stain's assistance. 
State was determined to perform an active role in policy formulation. Byrnes was confident of his own ability and his independent spirit would have a decisive impact on the Soviet-American dispute over Korea.

Stimson was also engaged in preparations for Potsdan. Early in May, 1945 , he requested a policy position paper on Korea from the state Department. The response stressed the likelihood of widespread unrest and demands for agrarian reform in korea after years of imperialist exploitation. The absence of an experienced and recresentative group of exiles to assume governmental responsibilities vould compound Korea's problems. In addition, the report predicted that Noscow would insist ucon establishing a "friendly" government in Korea. The State Department observed that the unfavorable conditions in postwar Korea would probably contribute to $a$ favorable reception of Communist ideology. Thus, a Sovietsponsored socialist regime "might easily receive popular support."

Final Briefing Book papers for Potsdam stressed that the United States had to obtain specific Soviet support for the Cairo Declaration and Korean independence. In order to

Richard D. Burns, "James F. Byrnes (1.945-1.94?)," in An Uncertain Tradition, 220; Truman later appointed Varshall as Secretary of State, thereby undermining his own justification; Curry, James g. Byrnes, 307; Gaddis, The

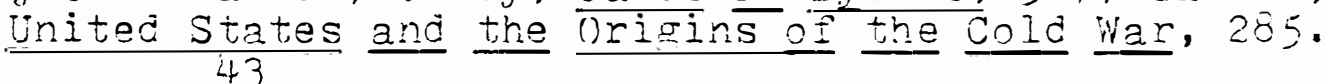

Policy Paper, State Department, June 22, 1945, FRUS, 1945, VOI. TI, 561-56́4. 
eliminate Korean suspicions, it would be important that none "of the interested countries alone. . invade Korea." The State Department urged that the Allies designate Korea a combined zone of operations under a single unified command. American planners hoped to obtain support for a multinational invasion force and "agreement among the three povers that, with China's anticipated cooperation, they will jointly support whatever measures appear best adapted to develop in Korea a strong, democratic, independent nation." A fourpower international supervisory body would replace tine military government, as quickly as possible to shorten the duration of occupation and decrease the chance of tension among the Allies. Although Soviet participation was vital, the State Department emphasized the importance of avoiding complete Soviet control at all costs.

America's Korean policy thus sought staged indeperdence in three phases, consisting of Allied occupation and military government, international administrative supervision, and finally the acrievement of complete sovereignty. Such an aporoach was not only realistic, but feasible, since the

Briefing Book Paper No. 505, "Relationship of the Soviet Union to the War Against Japan," and Brieing Book Paper No. 606, undated, PRUS, The Conference of Beriin, 924927; Briefing Book Paper 110. 251. June 29, 1.945, Fevs, The Conference of Berlin, 3i.1.; Briefing $300 \mathrm{k}$ Paper No. 252 , FRUS, The conference of Eerlin, vol. I, July $4,1945,311$.

Briefing 3ook Eaper No. 253, July 4, 1945, FRUS, and Leary Notes, Undated, FRUS, The Conference of Ber lin, vol. I, 314-31.5; Leany read these recommendations and added his support. ite probably informed Truman acoordingly. 
Soviet union continued to indicate support for trusteeship. In July, Stalin expressed interest in discussing the matter during consultations with $\mathrm{I} . \mathrm{V}$. Soong. Nolotov suggested the formulation of a detailed understanding on trusteeship, since the proposal was unusual and unvrecedented. Soong refused, however, to engage in specifics. He later informed Farriman of his fears that ivoscow interded to include Soviet-trained exiles in the postwar government and thereby dominate Korea. Harriman agreed that China's concern was justified. He urged Truman that, in preparation for Potsdam, the State Department should prepare "a detailed discussion of the character of the proposed four oower trusteeship for Korea." Evidently, the President approved the suggestion, since Leahy instructed Grew to prepare the study while enroute to Potsdam.

Truman insists in his memoirs that his main concern at Fotsdam was to outain from Stalin the specific time of the planned Soviet entry into the Paciric War. Fe also sought Stalin's assurances of support for the Cairo Declaration, al though American military advisors stressed that the United States "should not attempt to back up the Cairo Declaration with armed force." 47 News of the successful preliminary testing of the atomic bomb reached Truman on the day of his

Garriman to Byrnes, July 3, 1945, ERUs, 1945, 10.1. VII, 914; Tarrinan to Truman, July 9,1945 , EDJS, The Con-

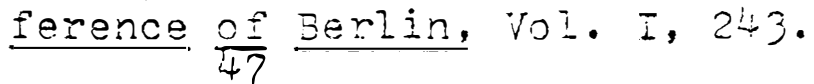

Truman, Years of Decision, 411-412; Chandler to Lincoln, July 6,1945 , R. 31.9 . OPD 014.1. TS, Section III, NA. 
arrival at Potsdam. Stimson testifies that at this point the President began "Iosing his interest" in Soviet entry into the Pacific War.

Truman and Byrnes, it seems clear, both hoped that the successful utilization of the atomic bomb against Japan would bring a quick end to the war. rot only would this save many American Iives, but it would remove the numerous complications entailed in Soviet participation in the deisat of Japan. It now seemed possible to achieve the unilateral occupation of Korea and avoid the distasteful necessity for trusteeship. Stimson harbored serious doubts about the wisdom of leaving anything to chance. He continued to urge an agreement on multinational occuration of kocea, because:

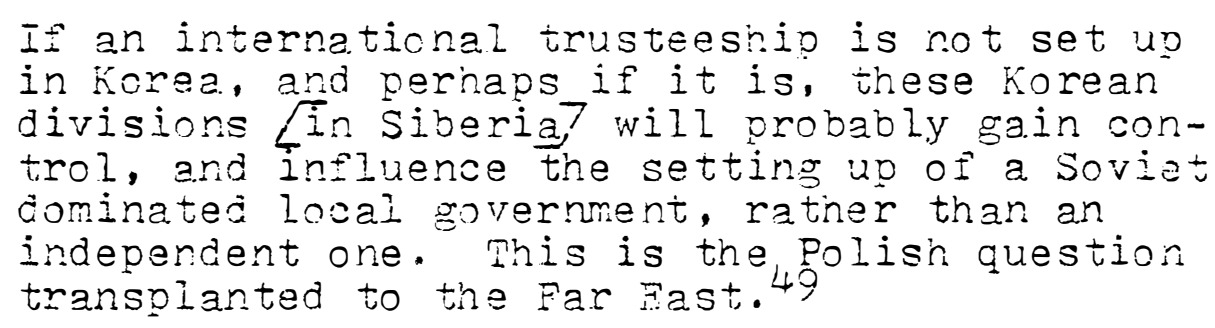

Yet, Truman and Byrnes believed that they had found an averue of escape from the Korean dilemma. The rapid surrender of Japan would proempt Soviet entry into the war ard eliminate the possibility of a "sovietized" Korea.

Stimson and Bundy, On Active Service in Peace and War, 63?; See also, Gaciis, The United States and the orieins

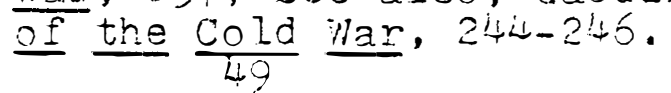

Stimson to Truman, july 1.6, 1.945, ERUS, The onference of Eeriin, vol. II, ó 31. 
Truman, Churchill, and Stalin met at Fotsdam in JuIy, 1945, to discuss the postwar settlement. On July 17, stalin stated that he would not declare war on Japan until china agreed to the terms of the Yalta Agrement on the Far East. Truman responded that there existed some misunderstandings about the terms of the agreement. For example, the united States believed that Dairen was to be a free port liltimately under chinese control. 50 The following day, Stalin observed that the Soviet Union would not be able to enter the war against Japan before August 1.5. These initial discussions reinforced America's determination to preempt Soviet entry into the Pacific War. Byrnes privately proposed that the Allies issue an ultimatum demanding japanese surrender within two weeks and threatening complete destruction after that deadline. He reasoned that if Soong stood firm and Stalin delayed entrance into the Facific War, the atomic bomo would bring the prompt defeat of Japan "and this will save China." auite obviously, such a chain of events would also preclude Soviet control over Dairen and Korea. ()n July 22, the Allisd leaders discussed the issue of international trusteeship. Stalin observed that rolotov

\footnotetext{
50

Feis, the Atomic Bomb and the End of World War II, 73. 51

Conference liotes, July 1?, 1.8, and 20, 1.945, James F. Byrnes Paoers, File 34 (1), Clemson University Library, Clemson, South Carolina.
} 
was the "expert" on the subject and suggested that the time had arrived to discuss specific areas, such as the Italian colonies and the mandated islands. Eden's sharp rejoinder was "Do you want our mandates?" Stalin responded that there were other mandates that deserved attention and the Allies could also exchange views on Korea. Churchill strongly opposed any further discussion of the matter, but Truman expressed his willingness to refer the matter to the council of Foreign Ministers (CFM). There then ensued an acrimonious and prolonged discussion of the fate of the Italian colonies as Churchill displayed a marked suspicion of Soviet motives in the vediterranean. Finally, Churchill reluctantily agreed to allow the CFM to consicer the Soviet proposal on trusteesinio. 52 unfortunately, Korea's future was now involved with the unrelated issue of Angio-Scviet competition in the Mediterranean. The best and last chance for ar amicabie settiement of the Korean issue was lost.

Leary later observed quite accurately that the long discussion of trusteeship actually revealed nothing specific about Soviet postwar intentions. 53 Britain's overreaction certainly made the task no easier. The Soviet trusteeship proposal was inoffensive enough, while vioscow possessed

\footnotetext{
Conference llotes, july 22, 1945, Fits, The Corference of Berlin, Vol. II, 264-266.

Leahy, I Was There, 408 ; Liary Entry, july 22 , 1945, Leany Fapers, 30x j, Diaries, 1.945, LOC; Cro, Korea in World Politics, 44
} 
a clear right to lay clain to sertain of the Axis mandates. In adition, the Yalta Agrements colled for negotiations to determine the specifics of international trusteeship. Events in Eastern Europe, however, prevented Truman from trusting Stalin. on July 23, Harriman visited Stimson and expressed great, apprahension over Stalin's motives in colonial areas. The Soviet union was no longer acting as a continental power, but was seeking "to branch out in all directions." Harriman speculated that Stalin favored immediate trusteeship in Korea in order to demand a similar settlement on riong Kong and Indochina. Aware that Britain and France would reject such action, Farriman believed that Stalin and holotov would "probably orop their proposal for trusteeship of Korea and ask for solitary control of it." 55 Stimson conveyed Farriman's scenario to Truman curing a meeting that afternoon. The President agreed that Stalin had demonstrated his expansionist intent, but believed the Soviet leader was blufing. Stimson reiated later that Truman then assured him that "the united States was standing firm and he was apparently relying greatly unon the information as to S-1.." That same day, Truman had received word that the United States colld drop the atomic bomb on Japan

\footnotetext{
Soviet Trusteesrip Prooosal, Document 733, July 20, 1945, BRUS, The Conference of Berlin, Vol. II, $632-535$. 55

Stimson Diary Note, July 23, 1.945 , FRUS, The Conference of Berlin, Vol. II, f250.
} 
during the first, week of August. Clearly, Truman and Byrnes hopes that if the United States used the bomb on schedile, the Soviet Union would not enter the Faoific viar and only Britain, China, and America would cccupy Korea.

General Viarshall did not fully share Trumar's confidence in the atomic strategy. ()n July 23, he expigined to Stimson that Soviet troops were already massing in Sibenia and the United States could do little to prevent the seizure of any territory Stalin desired. Narshall continued to support Soviet entry as the surest means for hastening the surrender of japan. During the Allied military meeting the following day, frarshal's views seemed to be the basic ingredient in the American approach. Soviet General Aiexei E. Antonov stated that the Soviet army would enter the war during the latter part of Augist. He then inquired as to American intentions to land in Korea. Jiarshall responded that the United States intended to concentrate on the occupation of Kyushu and thus did not contemplate entry into Korea in the near Iuture. Without control of Kyushu, any landing in Korea. would be open to air attack.

Allied military leaders met again on July 26 and agreed upon zones of air and naval operations, which resulted in II, $1.94-1.95$.

Feis, The Atomic Eomb and the End of World Var $5 ?$

Ibid., 89-90; Comoined Chiefs of Staliz Report, July 23, 1.945 and Tripartite Military veeting ininutas, July 23, 1945, ERis, the Conference of zerlin, Vol. II, $1452-1.459$ and $3+5-353$. 
the division of Korea just below the 41.st parallel. The Allies also provided for conrdination between zones, a liason apparatus after the Soviets entered the war, and the exchange of communications equipment. Antonov then asked for the specific date of the American landing on Kyushu. Narshall responded that the United States intended to begin operations in late ()ctober. While Antonov expressed approval, he also indicated a strong desire for the action to occur at an earlier date. Thus, American military leaders ignored the 3riefing Book papers and agreed to nothing specific regarding the multi-national occupation of Korea. Truman later explained that the Allies did not establish clear lines for ground action because "it was not anticipated by our military leaders that we would carry our operations to Korea." 59

American military leaders apparently acceoted Truman's argument that, Soviet participation in the Facific War was no longer necessary on July 25. On that date, rarshall requested ivacArthur's plan fon the occupation of Japan in the event of sudden surrender, as weIl as information on force requirements for a possible entry into Korea. NacArthur's office responded that, although the plan was incomplete, it provided for the occipation of Japan twelve

Soviet-American Chiefs of Staff leeting rinutes, July 26, 1945, FRUS, mine conference of Berlin, Vol, II, 41.0-41.5; Department of State, A Historical Summary, 60 . Truman, Years of Decision, 383. 
days after surrender and entry into Korea at a later date. Marshall immediately ordered liackrthur to prepare to enter Japan in the very near future and to establish occupation of Korea as the next priority. During discussions with Iieutenant General John $\Xi$. Hull, Narshall explained that, in the event of Soviet entry, the United States should control at least two major ports. Thus, Varshall and Full decided upon a Iine near the 38 th parallel, but both hoped that Japan's quick surrender would render soviet action unnecessary.

American policy toward Korea thus experienced a remarkable transformation during the Potsdam Conference. Truman and his advisors decided to abandon trusteeship in anticipation of a rapid end to the Pacific wer that would forestall Soviet occupation. At the can meeting on Jily 23 , Byrnes joined Eden in opposing any detailed discussion of trusteeship. Wolotov agreed io table his proposal, but requested that the final protocol provide soecifically for the inclusion of the trusteaship issue on the agenda for the London Foreign Ministars Meeting scheduled for Septenber, 1945.

60

Marshall to Nacsrthur, July 25,1945 and Crais to HuIl, July 25, 1945, RG 319, OPD 014.1. TS, Section III, MA; Schnabel, Policy and Direction, ?. 61.

Applemar, From the Iyctong to the Yalu, 2-3; Feis, The China mangle, 32 ; Strangely enough, the recollections of two military leadens difier greatly from reality. Vatthew 3. Ridgway argues that the Allies agreed at potsdam to a. Iive-year trusteeshio excluding the inited States, The Korean War (Carien City: Doubleday, 1967), 42-47; J. Lawton Collins contends that an Allied agreement vrovided for the division of Koraa at the 38 th paralie1, Nar in Peacetime (Boston: Houghton ivifilin, 1.969), 25. 
Eden objected and Nolotov then insisted that the protocol at least note Moscow's raising of the issue. After some discussion, Byrnes agreed to support volotov's request. When the Alijes drafted the final protocol, however, both Byrnes and Eden opposed the inclusion of a seneral statement on the trusteeship issue. Byrnes rejected the Soviet proposal because "trusteeship as presented in the Soviet request was much broader and it was not his urderstanding that the Big Three had agreed to refer it to the Council of Foreign Ministers." Molotov relented, observing that he did rot intend to press the matter. As a result, the final protocol only noted that the Allies had raised and examined the trusteeship issue, but referred specifically only to the Italian colonies. Stalin accepted this reluctartiy, pointing out that "the Russians were giver Iittle in this paper."

Potsdam thus witnessed tre emergence of no definitive agreement on Korea. It appears quite clear that the Soviet Union had genuinely sought to fulfill prior agreements for international cooperation in Korea, while the United states

\footnotetext{
62

CFM Meeting Minutes, July 23, 1945, FRUS, The Conference of Berlin, vol. II, $282-233$.

Soviet Draft Froposal on Trusteeship, FRUS, and CFiv reeting inutes, August 1., 1.945, FaUS, The conierence

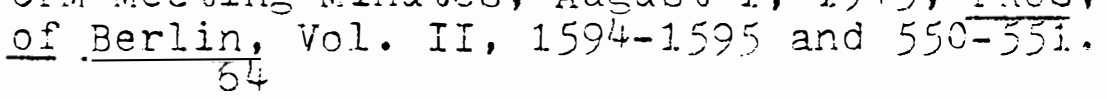

Yost remorandum, August ?, 1.945 and State Depart-. ment Ninutes, August 1,1945 , FuS. The Conference at Berlin, Vol. II, $636-637$ and 593 .
} 
and sritain now adopted a policy of delay. The Truman Administration was pursuing a strategy that required the quick defeat of Japan to ensure success. On July 28 , Byrnes observed that Soviet entry into Darien and Port Arthur would result in permanent control. Korea ciearly fell into the same category. Realism thus dictated Mruman's actions. If the atomic bomb brought Japan's rapid surrender, the United States could avert in Korea a repetition of the difficulties being experienced in Eastern Europe.

America's strategy for preventing Soviet ertry into the Pacific War proceeded according to plan. on July 26 , the United States and Britain issued the "Potsdam Declaration" demanding Japan's immediate surrender. In the absence of a response, the United States dropped the atomic bomb on Hiroshima and Nasasaki on August 6 and 9 respectively. In the interim, Noscow declared war on Japan and subscribed to the "Potsdam Declaration," which included a reaffirmation of the pledge to support the eventual independence of korea. Tragically, Stalin's decision to

Millis, The Forrestal Diaries, ?8; Feis, Between War and Peace, 321; Feis, The Atomic 3omb and the find of ivorld Nari, $330-331$.

Potsdam Declaration, Juiy źc, 1.945, FRUS, The Conference of jerlin, vol. II, fj. $474-1.475$. 
enter the war earlier than American leaders expected had destriyed Truman's strategy. Yet, one can hardly fault the Soviets for attempting to avert a fait accompli and ensure participation in the determination of Japan's future. At the same time, Soviet entry meant that the United States was not in a position to guarantee Korea's independence.

Byrnes observes in his memoirs that japan's surrender was no surprise. Soviet entry prior to August 15, however, was certainly unexpected. The SWNCC was already engaged in completing plans for the occupation of Japan. On July 28 , NacArthur had cabled his proposal-code-named "Blacklist"which anticipated unified Allied occupation and administration of Japan, Korea, Formosa, and the China coast. Nimitz opposed viacarthur's position and sent his own plan to king, which called for a more rapid occupation under the direction of the Navy. This inter-service rivalry forced tha JCS to delay action until NacArthur and Nimitz agreed on a unified operation. In the meantime, Narshall considered the inclusion of korea in the Chinese zone of operations and caoled Wedemeyer requesting his comments on the idea.

Soviet entry into the Pacific War meant that the united

\footnotetext{
$6 ?$

68 Feis, Contest Over Japan, 9.
69 Byrnes, Speaking Frank 2 y. 21.2.

Sutherland to Varshail, July 28, 1945, and Nemorandum for the chief of Staff, August 1, 1945, RG 319, OPD 014.1. TS, Section III, NA; irarshall to Wedemeyer, Ausust 9, 1.945, RG 31.9, OPD 371., TS, Korea, NA.
} 
States could not afford further delay. (In August 10, Washington ordered Wedemeyer to assist China in occupying Formosa and Korea, while the American force would concentrate on Japan. on the same day, Japan asked for terms and the United States made a final attempt to prevent unilateral Soviet occupation of Korea. Byrnes instructed. the SwNCC to prepare a plan for Soviat-American occupation of Korea, which would include a division of the peninsula into two zones with the line as far north as possible. American military leaders cautioned against such action, pointing out that the united States had limited men and material in that area, wille the Soviet Army was poised on the Korean frontier. Nevertheless, late in the evening on August 10, the SWNCC instructed Colonels C.H. Bonesteel III and Dean Rusk to find a line in Korea that would harmonize the poljtical desire to have American forces receive the surrender as far north as possible and the obvious limitations on the ability of American forces to reach the area. Bonesteel and Rusk decioed upon the 38 th parailel as a suitable dividing line and the SidCC incorporated th is provision into a preliminary draft of "General order Numoer One." Truman clearly recoenized that time was of the

SWrCo veeting irirutes, August 11, 1945, FRUS, 1.945, Vol. VT, 1.039; Truman, Years of Decision, 444. 71

Rusk to 0. Bernard inole, july 1.2, 1950, FRU.S, 1945, Vol. VI, 1038-1039; Schnajel, Policy and Oirection, 9 ; Collins notes that this division ironically resembled Japan's proposal to Russia in 1.896, Nar in Peacetime, 25. 
essence and thus informed the other Allies immediately of the general terms for accepting Japan's surrender. The President still hoped, however, that the United States could occupy most of Korea. (n August 1.1, he ordered Marshall to arrange for the occupation as soon as possible of Darien and 72

a port in Korea. In all probability. Truman was responding to an urgent cable from American Military Attache General

William Deane in Moscow on the same day:

Conclusions I have reached throligh discussion on reparations and otherwise . . lead me to the belief that our forces should occupy quickly as mich of the industrial areas of Korea and Vianchuria as we can, starting at the southerly tip and progressively northward. I am assuming ali of this will be done at no risk of American lives - - and occupancy to continue only until satisfactory agreements have been reached between the nations concerned with respect to reparations and territorial rights and other concessions.?3

Yarriman strongly supported such action the following day, urging that the United States estaolish a position in Korea and at Darien as soon as practicable.

At the SWric meeting of August 1.2, Admiral yi. 3 . Gardiner voiced support for Truman's desires. Fie proposed a revision of "General Order Number one" to include the 39 th parallel, thus providing for American occupation of

SWNCC Neeting rinutes, August 1.1, 1945, FPنS, 1.945, Vol. VI, 634-63?; Nemorandum for the Chief of Staff, Aligust 11., 1.945, RG 319, OPD 01.4.1. TS, Section III, NA.

Deane to Truman, August 11, 1045, Truman Papers, PSF (Pauley), HSTL.

74

Truman, Years of Decision, $433-434$. 
Dairen and a larger portion of Korea. After referral to the JCS, the SWNCC reaffirmed the 38 th parallel, probably because the Soviets entered Korea on August 12. General G.E. Iincoln explained that the Soviet Union certainly would not accept the new Iine, nor could the United States hope to reach a point any further north. 'Thus, the final draft of "General order Number one" possessed only minor chanzes on Korea and Truman dispatched it to the other Allies on Adoust 15 for approval. The JCS was satisfied that the 38 th parallel provided for not only American control over the capital of Korea, but also sufficient land to apportion zones of occupation to China and Britain. Yet, American leaders ojid recognize that the Allies had not agreed on administrative and governmental control in Korea after occupation. The ICS urged Truman to obtain a detailed agreement, while at the same time formulating a policy directive for the eventual American occupation commander.

Subsequent attempts to portray the 30 th parallel decision as the croduct of military expediency and convenience hardly reflect the reality of the situation. Political

SwNC Neeting Vinutes, Au@ust 1.2, 1.945, PRUS, 1945, Vol. VI, 645; Schnabel, Policy and Direction, 10. 76

JCS Nemorandum, August 14,1945 , ERUS, 1945, Vol.

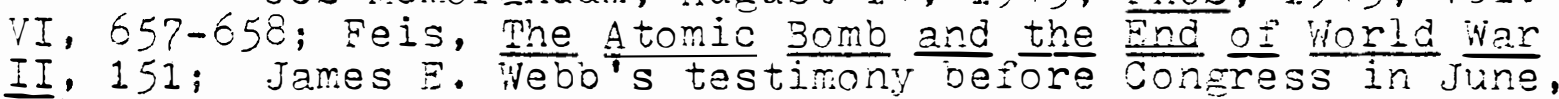
1949 . provides an accurate description of the events surrounding the proposal. and acceptance of "Cereral urder Number one" and the 38th paraliel, U.S. Congress, House, Committee on Foreign Affairs, Korear Aid, vearings on F.R. 5330 , 81.st Cong., ist sess., June 1949.1.18-1.19. 
and strategic considerations vere primarily responsible for $7 ?$

American actions. After mruman abandoned trusteeship, the United States lacked sufficient power to block Soviet expansion when Moscow entered the Pacific War. Nany American

leaders even doubted whether Stalin would accept the 38 th parallel. In anticipation of such a rejection, the JCS was prepared to order the immediate occupation of Pusan. Just as Stalin had maintained gocd faith on trusteeship, howevor, he also cooperated in quickly approving the terms for accepting Japan's surrender. 79 Rusk later expressed his surprise that lioscow accepted terms which clearly did not reflect the Soviet Union's superior military position.

Several scholars have criticized the 38 th parallel

Truman insists that "there was no thought at the time other than to provide a convenient allocation of responsibility for the acceotance of Japanese surrender. All previous aiscussions on the subject of Korea had shown the Russians agreed with us that Korea would pass throlign a trusteeship ohase before attaining independence," Years of Decision, 445; See also, "White Paper on Korea," Currert Fistory, XIX (september 1950), 1.70; Cabell Phillios, The

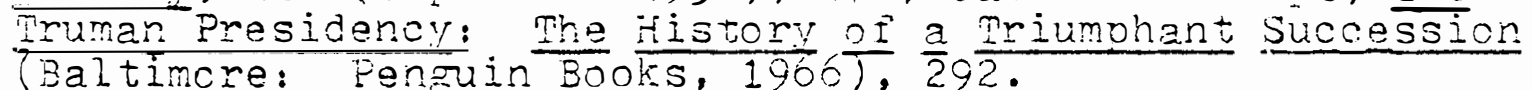
78

U.S. Department of State, united States Policy in the Korean Crisis, Far Eastern Series $\# 34$ (Washington, D.C.: Government Printing (ffice, July 1950), ix; Schnabel, Policy and Direction, 1.1

Stalin to Truman, August 12 and 16,1945 , FRUS, 1.945. Vol. VI, 634 and 667-668; Stalin also agreed without hestitation to Truman's appointmert of ilackrthur as supreme Commander (SCAP). Later, Truman arsued that "I forced an agreement out of the Pussians to accept nim in that position," Truman to riacCormick, september 7,1950 , Truman Papers, PSF 129, General (VacArthur), HSTL. 80

Rusk to Noble, July 12, 1950, FRUS, 1945, Vol. 
decision, offering a variety of reasons. Certainiy the Iine was ill-advised as a permanent boundary, since it cut across natural areas of geographic, cultural, and cilimatic continuity. On the west coast, for example, a small peninsula was part of the American zone, yet possessed no land connection to that area. In view of the alternative of complete Soviet, control, however, Iruman believed he had scored a major success. Clearly, the decision meant de facto recognition of Soviet control in northern Korea, but Truman hoped to remove the barrier through subsequent negotiation. Soonsung Cho argues that the united States should have airlifted iroops into north Korea and that Truman's failure to do so was an indication of shortsightedness and indifference. Yet, the United States had formulated plans for the occupation of Korea, but Noscow's rapid movement into the peninsula precluaed implementation of the operation.

Stalin's decision to enter the Pacific War spoiled Truman's strategy for excluding noscow from Korea. As a result, the United States had to settie for half a loaf, since its troops were over $600 \mathrm{miles}$ away. In fact, the

VI, 1.039

81.

Middleton contends that it would be "difficult to conceive of a more unsatisfactory military boundary" "The Compact History of the Korean War; Shannon VeCune, "The Thirty-Eignth Paraligl in Korea." Norld Politics, I, 2 (January 1949), 227; Arthur I. Grey, Tr. "The Thirty Eighth Parallel," Foreign Affairs, XXIX (April 195i), 482; John . Caldwell, the Korea Story (Chicaso: Fenry Regnery, 1952), 10. Cho, Korea in World Politics, 52-58. 
Soviets could have occupied the entire peninsula before the United States troops could have reached Korea and Truman realized the political importance of avoiding such an event. If he had not, the United States would have never pressed for a zone of occupation in that area. 83 under these circumstances, control of southern Korea was the most that Truman or anyone else could expect. Stalin's willingness to respect the agreement on surrender made possible the American occupation of south Korea.

Stalin's acceptance of the 38 th parallel was not the product of altruism. In all probability, the soviet leader sought to maintain good relations with Truman to gain an eual voice in Japan. At the same time, stalin probably viewed the 38 th parallel as a suitable division of Korea into spheres of influence. Noscow certainly viewed the Iine as possessing some basis in history, while constituting a 85 rough halving of the country. Stalin would have preferred

Cho errs when he argues that the Administration overlooked the political implications of Soviet occupation, Knrea in World Folitics, 52; U.S. Department of State, The Fieht Against Agression in Korea, Far Eastern Series 37 (Washington, D.C.: Government Printing ()fice, Autumn 1.950), 3; Fermes, Truce Tent and Fignting Front, 5.

Goodrich, Korea, 1.3; Walt Rostow disagrees, arguirg that the Soviet Union would not challenge American authority in Korea "if the United States had the purpose and will to exercise it," The United States in the World Arena, 201.

Viartin Lichterman, "To the Yalu and Dack," in American Civil-military Decisions: A Book of $\frac{\text { Case }}{\text { edited by Harold Stein (Birmingham: }}$ Studes, Press, 1.963), f634; NcCune, "The Thirty-Eighth Farallel in Korea," 2.26; Bruce Cumings, "American Policy and Korean 
a unified and friendly Korea, but he would accept temporary division in the interests of Allied cocperation. If SovietAmerican relations deteriorated, he could always maintain control in the north and preserve Soviet national security. An attempt to seize the entire peninsula, on the other hand, would alarm the United States and regate possioje concessions in other important areas.

A concern over the future of Japan also dominated Truman's attitude toward Korea. The President beliaved that, if Stalin controlled the peninsula, the Soviet union could undermine Chiang's position in China and place the seculity of Japan in doubt. Thus, occupation of south Korea was Truman's second priority in Asia at the time of Japanese surrender. When Stalin requested a zone of occupation in Japan, Truman responded that racArthur wolild yossess complete control. Garriman enthusiastically supported this decision, observing that stalin scught complete dominance over Japar and Korea. On Aligust 27 . Harriman met with Stalin and apparently won his support for Americar occupation policy in Japan. Significantly, Stalin decided to

Liberation," in ilithout Parallel, 46-47; Beloff, Soviet Foreign Policy in the Far Fast, 1.56 . Grey, "The Thirty-Eighth Parallel," 486.

Feis, The China Tancle, 338 ; Ennest R. May offars the highly speculative aroument that Truman occupied Xorea in order to use withdrawal as a bargaining counter to sain Soviet concessions eisewhere at a later date, "Lessons" of

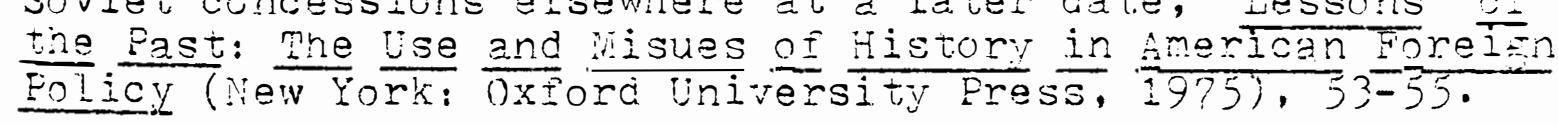


respect the Korean arrangement and halted the Soviet Army at the 38 th paraliel despite Truman's obdurance.

Infortunately for Korea, once the Soviet Union and the United States both entered the peninsula, only a diplomatic agreement could end the partition. Korea wolld soon become a captive in the developing Soviet-American Cold War, since both nations sought to determine the course of korea's political and economic development. Neither Stalin nor Truman would acquiese in any settlement that appreciably strengthened his adversary. 89 Thus, Korea was once again the pawn in a struggle between the major powers. For the United States, the 38th parallel decision constituted an overextension of American power and prestige into an area of marginal value to American national security.

Truman's refusal to grant Stalin an equal voice in Japan rendered an amicable solution to the Korean problem

Stalin to Truman, August $1.6,1.945$, Truman to Stalin, August 1.7, 1945, Harriman to Byrnes, August 23, 1.945, and Harriman to Truman, August $27,1.945$, FPUS, 1.945, Vol. VI, 667-670, 689-690, and 695-696. 89

Harold it. Vinacke, The united States and the Far East 1.945-1.951. (Stanford: Stanford university press,

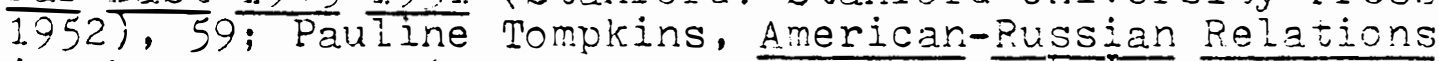
in the Far East (New York: Nacmillan, 1949), 31.9 .

Barton J. Bernstein, "American Foreign Policy and the origins of the Cold War," in Politics and Policies of the Truman Acministration, 16 . 
infinitely more difficult. Truman and Byrnes certainly recognized this fact, but remained optimistic nonethelass. At a press conference, Truman stated that the Allies had discussed Korea at Fotsdam and expressed confidence that Korea would eventually emerge as a free nation.' Such optimism lacked reality in view of the absence of any firm agreement among the Allies. Perhaps worse, the united States faced the formidable task of implementing change in Korea in an atmosphere of anarchy that prevailed throughout Asia at the end of World War II. Japan's defeat left vast areas struggiing for a new equilibrium and few Asian nations possessed experienced leaders with specific programs for postwar reconstruction. Competition for political control revolved around each rative group's ability to instigate anti-imperialist agitation and exploit revolutionary 92 nationalism.

Korean exiles also continued to press the United States for recognition. During the Potsdam Conference, Rhee charged iruman with entering into an illicit deal with Stalin confirming the "Yalta sell-out." Yo warned that "appeasing the Soviet Union, at the sacrifice of justice to

Feis, The China Tansle, 394; Truman Comments, August 16, 1945, U.S. Fresident, Fublic Fapers of the

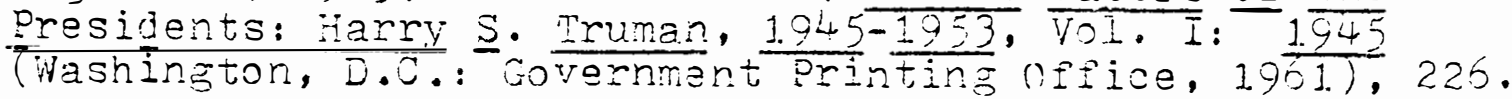
92

Steei, Fax Americana, 162; Robent T. 11iver,

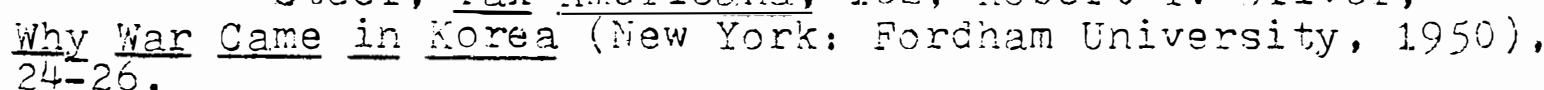


Korea, is cound to result in disaster." 93 "Nashington did consider aporoving phee's request to deliver shortvave broadcasts to Korea urging rebellion, as well as the "Napko Project" for introducing clandestine agents into Korea by submarine. With Japan's surrender on August 1.5, however, the JCS dropped both plans from consideration.

In Chungking, Tjo Sowang and Kim Koo successfully enlisted the support of the new American Ambassador Patrick J. Hurley. Tre KPG sought participation in the Allied acceptance of Japanese surrender and any postwar discussion Korea. Korean apprehension over Soviet influence and actions in Korea greatly imoressed Kurley. After noting Moscow's refusal to contact the KPG, Tjo urged the inited States and China to assist in transporting the lagitimate Korean government to its homeland. Hurley now began to dispatch alarming cables to Washington, strossing that the Korean Communists had left China for Korea with the intention of creating a Soviet puppet regime. He urged the Truman Administration to utilize the KPG leaders as assistants and interpreters, while sending missionaries to the north. 95 93 Rhee to Truman, July 21. 1.945, and Rhee to Lockhardt, July 25, 1.945, ERUS, 1.945, Vol. VI, 1031-1.036. 94

Full Memorandum, August 6 , 1.945, RG 31.9, opD 381, Cmo, NA; MacFarland to Nimitz, June 18,1945, RG 21.8, COS 385 , Korea $(3-1.5-45)$, NA. 95

Furley to Byrnes, August 14,1945 , Kin Koo to Rhee, August 1?, 1.945, and Hurley to Byrnes, August 29, 1945, FRTS, 1945, VoI. VI, 1.036-1.037 and Vol. VII, 540; Hurley to Byrnes, August 31, 1.945, RG 59, 895.01./8-3145, 
Despite fiurley's warnings and apprehension over Soviet intertions, Truman continued to maintain impartiality toward the KPG. On August 23, the var Department rejected Rhoe's request to accompany the American ccoupation force to 96

Korea. Significantly, America's attempt to be impartial was not a complete success. On August 18, villiam J. Donovan, director of the OSS, conveyed to Truman a ietter from Kim Koo requesting recognition. Donovan supported such action, noting the successful record of wartime cooceration between the OSS and the KFG. This clear violation of stated American policy on Korea upset Leahy, who urged irruman not to respond to Kim's note. Leahy recommended to Truman "a draft reply to General Donovan informing him that vou do not consider it proper for any agents of Donovan's office to transmit to the President messages from officials of selfstyled governments that are not recognized by the Government of the United States." "? Truman approved the suggestion, but it is doubtful that Goodfellow ceased his advocacy of diplomatic and material support for the KPG.

Inside Korea, the independence movement lacked unity, strength, and purpose, as well as experience in government

NA; New York Times, August $20,1345,2: 2$. 381. CTO, NA. Chandler to Rhee, August 23, 1945, RG 31.9, OPD 97

Donovan to Truman, August 1.8, 1945 and Leahy to Truman, August 22, 1945, Leany Papers, RG 218, Nemos to and From Truman, 1945, Na; Also in Tmuman Papers, White House Central Files, Corfidential, Box 30 , OSS, KSTL. 
affairs. Severai leaders vied for political power as provincialism and factionalism hampered united action. The only group that enjoyed some semblance of cohesion was the Communist Party, which had organized and controlled the Korean underground. The undisputed leader of the Korean resistance movement was a Communist named Pak Heun-yong, who organized local Comnunist cells and published a radical newspaper to foster rebellion. On the eve of Allied occupation, Communism was extremely popular, particularly among young Koreans. 98 Ir 1.945 , the Communist Farty was in control of korean nationalism and "unquestionably the country"s most important single political force."

Quite obviously, the Japanese were far more concerned about Pak and his underground movement than the feeble exile movement. News of Japan's surrender shocked the Korean people, because censorship and propagarda had isolated them from any knowledge of Allied military successes. Upon surrender, the Japanese were deathly afraid that their recent servants woula retaliate. The Koreans themselves fostered such fears, declaring a spontaneous holiday and staging wild parties and demonstrations. In the face of

98

E. Grant Meade, American Military Government in Korea (New York: King's Crown Press, 1.951), 32-33; Lee, The Politics of Korean Nationalism, 271.-278; Belofi, Soviet

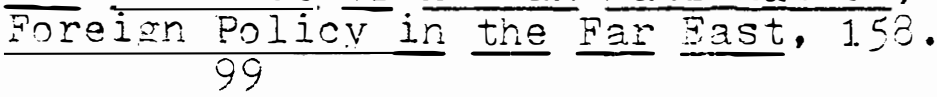

\footnotetext{
1.00

Henderson, Politios of the Vortex. 320-322.

Ibid., 11.t.
} 
such chaos, Japanese Governor Nobuyuki Abe decided to count local leaders in the hope of forming a pseudo-Korean government to maintain $l a w$ and order and protect Japanese lives and property. Local landiords and tine Communists rejected Abe's offer, fearing the onus of collaboration. Abe then turned to the prominent leftist leader Lyun Noon-heung, who possessed a considerable following both inside kcrea and overseas. Iyuh accepted, but only on the condition that Abe release political prisoners, guarantee freedom of speech and foreswear interference in his political activities. on August 15, Abe agreed and Lyuh formed the "Committee for the Freparation of Korean Independence." 101

$$
\text { Iyun's regime immediately set about creating local }
$$
"People's Committees" to assume administrative responsioilities. Nost, Koreans accepted Lyuh's authority, including professional people, landords, intellectuals, and students. Thus, Iyuh emerged as the unchallenged de facto leader 102

throughout Korea. By the end of August, one hundred thinty-ivive committees were in existence and Iyuh utilized the japanese communication, transportation, and admiristration network for considerable centralization. The main objective of the "People's Committees" was to expropriate

Cumings, "American Policy and Korean Liberation," in Without Paral Lel, 54-55; NcCune and Crey, Korea Lodav,

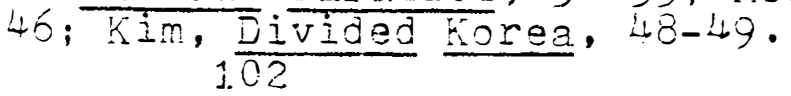

Fenderson, Politics of tine Vortax, 1.1.4-11.7; Dallin, Soviet Russia and the Far tast, 250. 
the land of the Japarese and their Korean collaborators, while releasing all political prisoners. Lyun's public pronouncements also reflected his extreme socialist philosophy, but such views corresponded "with reasonable accuracy to the views of the Korean majority." 103

Soviet entry into Korea only enhanced the leftward drift. Lyuh realistically recognized that he had to respect the views of the Communists if he hoped to enjoy Soviet support. Increasingly, weaithy Koreans became the objects of political repression, as the Lyuh regime denied conservatives any influence in the "People's Committees." Late in August, news of imminent American occupation caused Lyun to convene a national congress in seoul to provide his regime with the stamp of legitimacy. The Communists controllec the proceedings and formulated a. platform that guaranteed civil. liberties, called for the expropriation of Japanese croperty, recommended equal access to the militia and police force, and supported such reforms as the eighteen year old vote, child labor laws, and an eight hour work day. On September 6 , in the presence of $s i x$ hurired delegates, iyuh proclaimed the establishment of the "Korean People's Republic."

For a few days during the summer of 1945, then, Koreans

\subsection{3}

ivieade, American Nilitary Govarnment in Korea, 71-72; Allen, Korea's Syneman Rhee, 74; Eerger, Ire Korean knot, 52 . 104

Lauterbach, "Fodge's Korea," 350-351; Dallin, Soviet Russia and the Far East, 260. 
were relatively united in support of the People's Republic and Lyun's vision of Korea's future. Yet, few knowledgable Koreans believed that conservative exile leaders would support such a regine. Nore important, after the arrival of the United States and the Soviet Union, outside factors began to play a significant role in determining Korsa's destiny. Korea emerged as a true testing ground for sovietAmerican cooperation, because the two nations met on neutral territory and pursued policies reflecting vastly different ideologies. 3oth Truman and Stalin were determined that postwar Korea would reflect their own nationai values and institutions. Thus, both the United States and the Soviet Union sought to conquer, as well as liberate.

Unfortunately, the 38 th parallel separated two araas that were traditionally dissimilar, thus compounding the problem of zonal division. The north was rich in industry, nydroelectric power, and such minerals as coal, iron ore, and a variety of chemicals. The south, on the other hand, was much more agricultural and valuable for its production of rice and fish. 106 more important, the two zones manifested traditional sectional differences in social and

\footnotetext{
1.05

Lauterbach, "Hodge's Torea," 349; veade, Ameriilitary Government in rorea, 4-5; Robert $\mathrm{T}$. liviver, "Lus of war in torea." Current History, XIII, 74 (c)tober $1947), 222$. 1.06

U.S. Department of Commerce, Economic Conditions

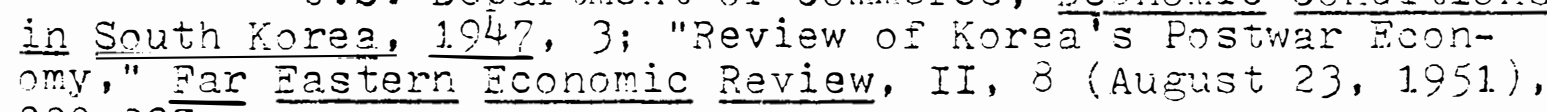
$230-23 ?$
} 
religious respects, while being separate politically during ancient times. North Koreans possessed a more radical ideological outlook, as well as an attitude of stubborn superiority which caused them to view southerners as lazy, effete, unambitious, and scheming rascals. 107

Differing systems of land tenure contributed to this divergence between north and south Korea. Iandordism was much less prevalent in the north, where plots were smaller and less productive. South Korea, however, experienced serious agrarian overpopulation and a higher rate of Japanese absentee-landownership. In addition, the American zone possessed an inordinate share of rich and conservative landlords, poverty-stricken farmer-tenants, dissatisfied workers, 1.08 and Japanese businessmen. Thus, the real tragedy of the 38 th parallel was that the line separated

regions with physical differences and long established economic, social and political diversity. The super-position of a rigid barrier over a pattern which already has latent divisive tendencies is most danperolis-The regional diversities, which were elements of strength when Korea was a unit - - Lbecame7 critical disruptive forces, jog

\section{7}

OSS Report, Undated, PG 226, XL 10423, NiA; Beloff, Soviet Foreian Policv in the Far East, 1.57; licCune and Grey,

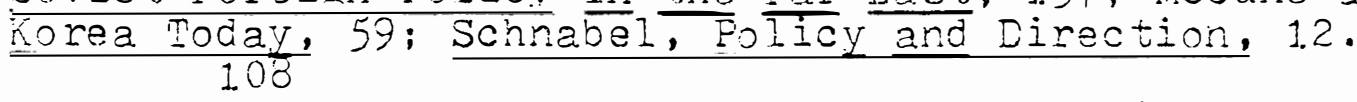

Miclune and Crey, Korea Today, 1.28; Lee, The Politics of Korean Vationalism, 229; Hagwon Sunoo and william N. Angus, "American Policy in Korea: Two Views," Far Fastern Survey, XXV, 1.5 (July 31., 1.946), 228-231.; Andrew J. Gradjdanzev, "Korea Divided," Far Eastern Survev, XIV, 20 (october 10,1945$), 283$. 109 Nocune, "The Thirty-Eighth Fanallel," 228. 
Such circumstances increased the likelihood that partition would be permanent. Perhaps worse, Japanese exploitation resulted in serious Economic deterioration during the war. Thus, when the United States occupied Korea, Truman and his advisors confronted extremely difficult problems.

\section{VIII}

American occupation of Korea experienced an inauspicious beginning. Originaliy, washington instructed stilwell's 10th Army to enter Korea, but on Algust 1.2 designatad the 24 th Corps as a reclacement. The jCS cccupation plan-code-named "Campus"-required three weeks to gather sufficient men and an aditional three weeks for the acquisition of assault ships to transport these troops to norea. Truman ordered American military leaders to occlipy Korea at an earlier date, thus forcing the uds to turn to the 24 th Corps which was stationed on okinawa. As a result, the American occupation force possessed little knowledge of the land and peovle it was to control, since availability and the need for quick action dictated its choice.

Uncertainty surrounded Amorica's Korean policy in

Gradjdanzev, "Korea Divided," 281. 111.

Wemorandum of the Assistant Chief of Staff, August 12, 1945 and Brief of JCS Study, Aligust 15, 1.945, PG 319, OPD 01.4. IS, Section IY, Mi. 1.12

Sawyer and Hermes, Nilitary Advisors in Korea, 3 . 
the summer of 1945 meant that there were no clear directives for the commander of the united States frmed Forces in rorea (USAFIK). On August 22, MacArthur requested information pertaining to any Allied agreements on Korea. He explained that he was formulating detailed instructions for the 2 th th Corps Commander and operating or the assumption of an occupation on a quadripartite basis. In response, the Jos informed MacArthur that the state Department had no knowledge of any agreement to four-power occupation. The AIIies had only settled upon a trusteeship after Japan's defeat. Thus, the State Depalmert urged the JCS to administer Korea's civil affairs in such a manrer as to facilitate the handing of the nation as a unit. In addition, the USAFIK Commander was to strive for the creation of an Allied control council which would hasten the implementation of the trusteeship arrangement.

In August 28, washington cabled a more specific directive to MacArthur. This swivc plan provided that the USAFIK Commander would treat Korea as a liberated area and attempt to contact the Soviet Commander as soon as practicable for the formation of an administrative body which would formulate unified policies for all of korea. In the meantime, the American Commander wolid cortinue the operation of the local judicial system and institute only

113

MacArthur to JCS, August $22,1.945$ and JCS Viemorandum, Urdated, EFTS, 1945, Vol. VI, 1037-1.038. 
recessary economic, social, and financial reforms. Host important, the JCS authorized the temporary use ci Javanese officials and Korean collaborators where security permitted and technical expertise was in short supply.

Japan's rapid defeat left the united States unprepared for the immediate occupation of Korea. Thus, the United Stz.tes instructed Japan to maintain law and order in Korea until. the arrival of the USAFIK. Interestingly enough, Aoe now reversed his support for the Lyuh regime, which had acted effectively to limit looting and bloodshed in the wake 1.15

of mass rioting. More important, the conservative elements now began to organize opposition to Lyuh's radicai philosopin, hoping to prevent expropriation and oossible imprisonment. Kim Sung-soo took the lead in forming the Korear Democratic Party, composed of conservatives, landlords and professional people, with collaoorationist support. As the People's Repulic became more radical, the Lemocratic Party increased its commitment to preserve the status quo. on september 1, 1.945, the united States dropoed leaflets in Korea announcing American occupation and thus removing the necessity for cooperation with Lyun. The conservatives no longer needed to fear soviet occupation of south korea.

SiN:CC to JCS, August 28,1945 , and ICS to NacArthur, september 2, 1.945, RG 218, CCAC 014.1. Section I, MA. 1.15

Neade, American Nilitary Government, in Korea, 71; Henderson, Politics of the vortex, 1.1.6́. 116 Berger, The Korean Knot, 49-50; Iee, "American 
American policy did not, however, seek to bolster weal thy landlords and prevent meaningful reform. Truman genuinely sought the creation of Korean political and economic independence through the elimination of Japanese colonialism and the formation of a self-governing, sovereign state that reflected the will of the people. On September 7. 1.945, NacArthur formally astablished Americar control in southern Korea and guaranteed the protection of individ117

lal and property rights. The following day, the 2tith

Corps landed in Korea under the command of ijieutenant

General John Reed Hodge. At that time, Washington had not completed occupation gridelines and the JCS could send only a summary of instructions. It would be nine months before Washington sent a final directive to Korea. Forced to rely on expediency and common sense, rather than long range plans, American occupation manifested uncertainty and vacillation in the extreme. At an early date, American Military Government (AliG) became known as "operation trial and error." 1.1 .8

Policy Toviard Korea," 1.08-1.1.1; Schnabel, Folicy and Direction, 1.ó; Henderson, politics of the Vortex, 278 ; Clmings, "American Folicy and Korean Iiberation." in Without $\frac{\text { Parallel, } 57}{1.1 . ?}$

U.S. Department of state, horea, Office of Public Affairs (Washingtor, D.C.: Government Printing ()ffice, August 1951), 7; NacArthur Proclamation, september 7, 1.945, ERUS, 1945, Vol. VI, 1043 . 1.1.8

JCS to Hodge, August 5, 1.945, PG 218, CCAC 014 Korea, Section I, VA; Neade, American Nilitary Government in Korea, 225; Viccune and Grey, Korea Today, 46. 
John R. Hodge was poorly prepared to deal with the complexities of the Korean situation. Born and raised on a Farm in Golconda, Illinois, Fodge graduated from the University of Illinois and later taught military science and tactics at a college in Mississippi. A tough, gristly combat soldier, who had fought with distinction at Leyte, Bougainville, and okinawa, he possessed little political or administrative experiance. 119 Upon arrival, tod hardly endeared himself to the local populace when he observed that "Koreans are the same breed of cats as the Japanese."

Declining morale compounded Hodge's problems, since the American soldiers in Korea were anxious to return home after Japan's surrender. The USAFIr also suffered from inadequate housing, irregular delivery of supplies, and inferior post exchange facilities. A total lack of familiarity with the Korean climate, customs, and culture, Let alone the languare, magnified the seriousness of the situation. Fodge quickly turned to missionaries and English-speaking Koreans for advice. The Alig soon earned the derisive sobriquet of "government by interpreter." In addition, washington informed rodge of its determination

119

Truman Fapers, PPE 3920, Jorn F. Fodge, FSTL; Tompkins, American-Russiar pelations in the Fas East, 322. 121.

Quoted in Gunther, The Ridale of wacarthur, 1.80. Neade, American Nilitary Government in Korea, Lee, "American Policy Toward Korea," 3.45 . 
to cut his force level in half within four months. Such circumstances forced Hodge to emphasize the preservation of law and order. Duite understandably, he refused to tolerate even remote threats to the security of his command.

A general atmosphere of anarchy prevailed in south Korea at the time of American occupation. Koreans used their new-found freedom to attack any symbol of Japanese authority. The japanese police reacted hysterically and, on the day of American arrival, massacred a large number of people massed to welcome the landing. Hodge's first action was to seek assistance from local leaders to deal with such problems. Upon requesting a meeting with two representatives from each party, however, a group of twelve hundred leaders confronted the startied USAFIK commander.

Korean leaders liniversally opposed any delay of complete independence, out could agree on little else. The ambiguity of the Cairo Declaration only worsened the situation. Korean exiles engaged in a propaganda campaign winch translated "in due course" as "immediately" or "in a 1. 24

few days." Iyuh quickly registered his olaim as the

C. Clyde Mitchell, rorea: Second Failure in Asia (Washington, D.C.: Public Affains Institute, 19,51.), 1.5; Henderson, Politics of the Vortex, 21.2-21.4; Gunther, The Ricile of ivactrtiur, 182 .

Lauterbach, "Hodge's Korea," 350; Suroo ard Angus, "American Policy in Korea: Two views," 230; Rew York Times; Seotember $9,1.945,1: 7$. 44. Meade, American rilitary Government in rorea. 
legitimate leader of Korea's national government, while Kim Sung-soo denounced the People's Republic for collaboration with the Japanese. In his initial report. Folitical Advisor H. Nerrell Benninghoff indicated the revolutionary nature of the situation when he observed that "southemkorea can best be described as a powder keg reacy to explode at the apolication of a spark." The widespread demand for radical chanse, Benninghoff surmised, was orobably Soviet-inspired. Ae tren offered the conclusion that occupation "by armed forces of nations having widely divergent political philosophies, with no common command, is an impossible situation." 125

Hodge strongly supported Benninghoff's assessment. ie began at an early date to urge Soviet-American agreement to the quick removal of the 38 th parallel, thus allowing the United states to withdraw. If there was to be a trusteeship, Hodge desired its immediate implementation and proposed skipoing the stage of interim civil administration. He noted that southern deficiencies in coal and electric powen were the result of partition ard were calising economic distress. Soviet Commancer Ivan Chistiakov initialiy refused to respond to Yodge's communications. Lodge thus warned Vashington that progress in the direction of Koroan

125

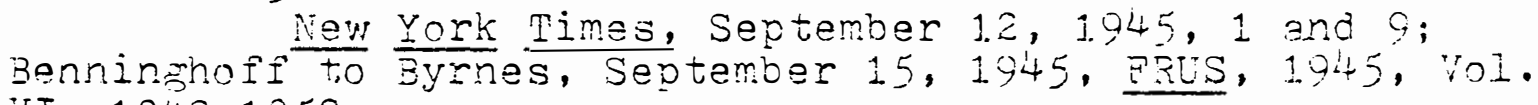
VI, 1.049-1.052. 1.26

Fodee to War, Septemior $1.9,1945$, RG 31.7, OPD 014.1. TS (18 September 45), Section $\forall$, NA. 
independence and solf-government was essential or the united States would sacrifice public trust and respect. The 38 th parallel decision "created a situation imoossiole of peaceful corroction with credit to the United States unless immediate action on an international level is forthcoming to establish an overall provisional government which will be fully supported by occupation forces under common volicy."

Soviet policy in north Koroa reprosented an additional spur to action. Hodge had foared that the Soviets would be in occupation of seoul upon his arrival, but his approhersion proved unwarranted. Early reports from the north indicated, howovor, that the Soviets were treating the people with "barbarous cruel ty" and attempting to destroy the existing order in favor of a "Bolshovik philosophy." One Australian journalist speculated that the Soviet purposo was

the establishment here not of a domocratio but a Communist type of govornment. Their concept - . embodies the comolete reduction of the social struoturo to chaos, absolute intogration and mass destruction. . .. I am convinced that they are in contact with the Japanese communistic wing which was forced underground during the last decade. . . I believe that you can anticipate agoressive action in support of their fundamental purpose which is not so much the establishment of a sound peace and its preservation as it is the imposition of thoir own philosophy of life in Japan and Korea. 120

Hodgo to MacArthur, Sectombor $24,1.945$ and Bonninghoff to Byrnos, September 26,1945 , FRUS, 1.245, Vol. VI, $1.054-1.060$.

1.28

Leahy Diary Note, Septembor 29, 1.945, Jeany Papors, Box 5, Diaries 1945, Lod; Schnabol, Policy and
Diroction, 14; NacArthur to War, September 28,1945 , 
Many wealthy Koroans flod southward aftor Soviet ontry and brought storios of looting, confiscation, and ovon saxual assaults. Communists were reportody soizing political power and Eonninghoif urgad Washington to provant Hoscow from

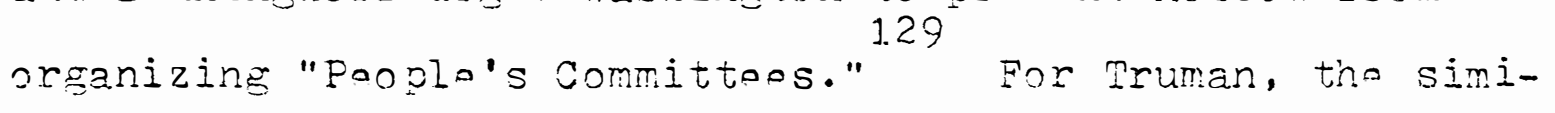
Iarity botwon koroa and Tastern Furopo was all too obvious. Amorica's koroan policy cloarly facod a crisis in tho fall of 1945. Iruman foared Soviot intontions in Asia and attompted to prevent "scvietization" in Koraa. Aftor Truman abandoned trustoaship at Fotsdam and Stalin ontorod tha Pacific Var, tho United States could onsure the implemontation of the Cairo Declaration only through the use of forco. This dilamma was. howaver, of Truman's own creation. on sevaral occasions, stalin indicatod his support for an Alliod agroomont on trustooship, but Truman hopod to ond tho war quickiy and oxcluda Moscow from Koraa altogothor. It romains a mattor of spocuiation whothor trustooship could havo roconcilod Soviot-American difforencos on Koroa. Yot, Mruman's rofusal to nogotiato a spocific agroomont guarantaoc Koroa's partition. Stalin's unwilzingness to discuss raunification at tho local level mado the division pormanont. Thus, Korea emenged at tho ond of lorld Nar II as a dividod ration that was not indopendant, but a captive oi the cold var.

Truman Papors, PSF 41 (KOrsa), HSTI. 129

Yincont to Achoson, ()ctobor 1, 1945 and Benninghoff to Byrnes, October 1., 1945, FRUS, 1945, Vol. VI, $1065-$ 106?; Dallin, Soviet Russia and the Far past, 285-206. 
Chapter III:

In Search of a settlement 
Soviet-American partition of Koroa in 1945 was among the most unfortunate outgrowths of World War II. The 38th. parallel docision transformed Korea into a major battleground in the emerging Cold War. After occupation, Soviet and American objectives in Asia bocame incompatible, which moant that Korean reunification without bloodshod was a virtual impossibility. As one critic explains:

In a sense, both struggled to create a nation to serve their own national interests. Noither wished to give up its prodominant role over half the country in exchang? for a united Korea that might end up in the rostils camp.1

Few observers could ignoie the symbolic nature of the Soviet-American confrontation in Korea. Une could be optimistic about the future of cooperation betwean the United States and the Scviet Union if the major powers agreed to remove the 38 th parallel and grant Koroan indepondonco. In the abserce of a sottloment, tho fulfillment of the Cairo Declaration was oxtromely unlikoly.

Both Truman and Stalin waro suspicious of each other's motives and intentions in Korea. Slearly, Moscow would not

Cho, Norea in World Politios, 156; soo also, Goodrich, Korea, $15-\overline{17}$.

2

Now York mimes, Novomber 25, 1945, IV, 8:2. 
accept anything less that a "friendly" Korea. Washington's policy, on the other hand, was far more contradictory and tragic. Truman sincerely sought to end colonial domination over Korea, but, in the main, political and strategic motives determined American actions. Increasingly, rising fears of the Soviet Union caused the Truman Administration to pervert its initially idealistic goals. American officials came to view the Koreans as impetuous children, unaware of the magnitude of the Soviet threat facing their nation.

Koreans criticized the American Military Government almost from the moment of its creation. Hodge annoúnced at a press conference his intention to use Japanese personnel because of the Iimitations on American manpower. Korean protests were immediate and violent, producing more chaos than the policy was designed to prevent. Adverse publicity in the United States and street demonstrations in Korea dictated a reversal of the policy. At a press conference, Truman defended the decision as a practical necessity, but promised that MacArthur would remove the Japanese as soon

Steel, Pax Americana, 269; Yoo, The Korean War and the United Nations, 49 .

Hodge was merely following orders in using the Japanese, but U. Alexis Johnson had warnod against the use of Japanese personnel in Korea under any circumstances, Steintorf to Byrnes, August 26, 1945, FRUS, 1.945, Vol. VI, 1041-1045; Nemorandum, "Japanese Capitulation, "Undated, Byrnes Papers, File 569 (2), CUL. 5

New York Times, Septemier $10,1945,1: 6$ and September $\frac{\text { New }}{11}, \frac{\text { ork }}{1: 0}$ and $22: 2$. 
as possible. The SWNCC informed MacArthur that the decision to use Japanese and collaborators was unfortunate and contrary to the overall intent of American policy. on September 12 , MacArthur announced that he had ordered Hodge to immediately remove Governor Abe.

Criticism refused to subside and Under-Secretary of State Dean G. Acheson urged Truman to issue a pubiic statemont clarifying American policy. He suggested that the President stress the temporary nature of tho decision to use Japanese technicians and the necessity for "time and patience" in the pursuit of Korean independence. The final statement also emphasized that any japanese retained in positions of importance were acting as "servants of the Korean people." The New York Times hailed the action as the proper decision. By octooer 18 , Hodge had removed virtually all Japanese from south Korea. Although the incident appeared trivial, it possessed great significance. In reacting quickly to popular protests, the United States had established a pattern of political action in wich Koroan leaders would use such prossure to influence American policy.

Truman Comments, September 12, 1945, Public Paoprs, Truman 1945, 318; SWNCC Memorandum, Septemoer 11, 1945, RG 218, CCAC O14 Korea $(8-23-45)$, Section I, NA; New york imes, Saptember $14,1945,1: 3$. $?$

Acheson to Truman, September 14,1945 , Truman Papors, OF 471, HSTI; "Statement on the Liboration of Koroa," Septomber 18, 1945, Pubija Papers, mruman $1.945,325$

$$
\text { Now York Iimes, Soptembor 21, 1945, 20:3. }
$$


Hodge's emphasis on security dominated his aporoach to local political developments. In response to the myriad of opposing political groups, fiodge came to rely upon the most educated and wealthy sector of Korean society. As Benninghoff explained in his initial report, the upper class supporters of the KPG were the most encouraging aspect of the Korean affair. From the outset, Hodge allied the united States with the landiords, capitalists, and conservatives, all of whom opposed major reforms. He urged Truman and Byrnes to facilitate the return of Kim Koo's regime as a "figurehead" government that would stabilize the situation. Hodge's attitude was essentially military, emphasizing law and order rather than the American ideals of political democracy and national self-determination.

Hodge's rejection of the People's Republic was a foregone corclusion. He easily accepted the argument that Lyun's regime was subversive and under Soviet domination. Rather than forcing an end to factionalism through support for the People's Republic. Hodge dismissed Lyuh's claim to legitimacy and argued that the regime represented only a minority of Koreans. 10 Although the People's Republic was

MeCune and Grey, Korea Today, 270; Kim, Divided Korea, 30-31; Goodrich, Kcrea, 15; Lee, "American Policy

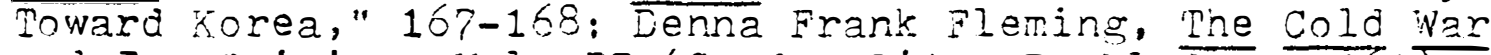
and Its Origins, Vol. II (Garden City: Doubleday, $\frac{1961 \text { ). }}{590 .}$ 590 .

10

Cumings, "Amorican Policy and Korean Iiberation," in Without Farallel, 50-51; veade, American Nilitary Goverrment in Korea, 235; Cho, Korea in world Politics, ?3. 
under virtual Communist domination, it was extremely popular and eficient during its short tenure of control. Hodge clearly contributed to the already pronounced polarization in Korean politics. While officially recognizing neither the conservatives nor the radicals, Hodge pursued policies favoring an increase of rightist political power.

Moscow was better informed than the United States on domestic affairs in Korea. The Soviet Union maintained a close relationship with the Korean Communists, while many returning Koreans were Soviet citizens and members of the 12

Red Army. Yet, it is doubtful that Stalin possessed a preconceived "blueprint for sovietization," as some scholars have suggested. In all probability, Moscow instructed the occupation commander. Ivan Chistiakov, to utilize those local Koreans that were not hostile to the Soviet Union and willing to support a "friendly" government. In its initial phase, Soviet occupation policy refiected considerable caution, as Chistiakov observed local political developments and supported such we?l-known nationalistic

Bertram D. Sarafan, "Vilitary Government: Korea," Far Eastern Survey, XV, 23 (November 20, 1946), 350; Gunther, The Riddle of MacArthur, 180-1.81; Cho, Korea in World Politios, ?0-73; Glenn D. Paige, "Korea," Communism and Revolution: The Uses of Political Violence, edited by Syril E. Black and Thomas P. Thornten T Princeton: Princeton University Press, 1964), 21?; McCune and Grey, Korea Today. 90; Berger, The Korean knot, 50 .

12

U.S. Department of State, North Korea: A Case Study in the Techniques of Takeover, 13; heade, American Military Government in Korea, 58-59; Simmons, The Strained Alliance, 22-23. 
leaders as Cho Man-sik.

on August 25 , Chistiakov recognized the authority of the "People's Committees" and began to support Iyuh. George McCune observes that the Soviet Union "actually did pernit the Koreans of their choice to exercise real authority, whereas in the American zone, the Korean employees of Military Government were allowed little power and no authority." 14 Moscow did not impose an alien puppet regime, but allowed sufficient local power to indicate its good intentions without losing ultimate control. In contrast to Eastern Europe, Stalin did not believe that national selfdetermination in Korea would necessarily produce an antiSoviet government in 1.945 .

For many north Koreans, Lyuh's program served best their needs and aspirations. Unlike the Western democratic model, the socialist system permitted the type of radical change that most Koreans favored. In addition, Japanese domination had accustomed the people to the imposition of authority from above. 15 Communist control of the Korean

Chong-sik Lee, "Kim II-song of North Korea," Asian Survey, VII, 6 (June 1967), 378; Simmons, The Strained Aliiance, 25; Suh, "A Preconceived Formula for Sovietization," in The Anatomy of Communist Takeovers, 475.

MicCune and Grey, Korea Today, 52; See also. Kim, Divided $\frac{\text { Korea, }}{15} 88$.

Cumings, "American Policy and Korean Liberation," in without Parallel, 55; Henderson, Folitics of the Vortex, $324-333 ;$ NcCune and Grey, Korea Today, 180-181; Sun, "A Preconceived Formula for Sovietization," in the Anatomy of Communist Takeovers, 480. 
underground at the time of liberation also facilitated the assumption of administrative responsibilities at the local level. One can also argue that many knowledgable Koreans accepted inordinate Communist influence after realizing that Korean independence would depend upon developing amicable relations with the Soviet Union. Criticism of Noscow would have been foolish and counter-productive.

Hodge believed that the Soviet Union was pursuing a pattern of "sovietization" from the outset and seeking ultimate control over the entire Korean peninsula. The USAFIK Commander later explained that his response to the threat was based upon MacArthur's personal advice "to be patient and not to give the Russians an inch." "His support for Korean conservatives and rejection of the Iyuh regime, however, only reinforced Noscow's determination to maintain complete control in the north. As early as september 3 , 1945, the Soviets indicated opoosition to the KPG and that group's claim to legitimacy. Corments in the Soviet press stressed that Korea had to rely on contacts with its closest neighicors for economic, social, and political development.

John N. Washburn, "Soviet Russia and the Korean Communist Party," Pacific dffairs, XXIII, 1 (Viarch 1950). 63; Lauterbach, "Hodges Korea," 358. 17

Hodge to MacArthur, August 28, 1948 , Douglas ViacArthur Papers, Box 5, Corresocndence, John $\bar{R}$. Hodge, Douglas NacArthur Memorial Liorary, Noriolk, Virginia. 
Noscow could never be certain of Koraa's friendship, if those individuals hostile to the Soviet union, such as Syngman Rhee, were able to obtain political control. Benninghoff was as certain as Hodge of Moscow's hostile intentions, Comparing Korea to Rumania, he observed that it was "more than a probability that they will sovietize northern Korea as they sovietized eastern Europe." He also noted that the Lyun group was more vocal and better organized than the "democratic conservatives" who favored the Western model of poiitical development. ${ }^{19}$ Hodge became increasingly disillusioned and frustrated as "every time two Koreans sit down to dirner they form a new political party."

Hodge attempted to foster the unity of all political groups in Korea except the extreme left and thus end factionalism. On nctober 5, Military Governor Archer V. Arnold appointed an Advisory Council of eleven prominent Koreans under the chairmanship of Kim Sung-soo. Hodge insisted that the action was a step toward Korean selfgovernment and independence. 21 Most Koreans, however,

18

Harriman to Byrnes, RG 59, September 3, 1945 , $895.01 / 9-345$, NA. 1.945 , Vol. VI, 1061 .

Benninghoif to Byrnes, September 29, 1945, FRUS, Sarafan, "Military Government," 354; See also, vieade, American Military Government in Korea, 151 .

Benninghoff to Atcheson, october 9, 1945, FRUS, 1945, Vol. VI, 1069; Lauterbach, "Hodge's Korea," 34 $\overline{9-350 ;}$ Henderson, Politics of the Vortex, 130. 
considered the body unrepresentative, since it included oniy wealthy businessmen, lardlords, and professional people. In addition, the appointment of a well-known collaborator ensured that the body would be "universally hated and distrusted throughout Korea." 22 The central purpose of the Advisory Council was, of course, to undermine Lyuh's popular support. Hodge also proceeded to outlaw the "People's Committees" and create new local councils under the control of the conservative elements. Yet, Hodge's expectation of the development of democracy based upon platforms and specific proposals never materialized. Individual leaders continued to compete for special status and privileges, thus compounding the already existing confusion.

Hodge soon determined that only the return of the KPG would restore stability. Chiang Kai-shek supported this conclusion, insisting that only active support for the Kim Koo regime would forestall soviet control throughout Korea. Chiang urged the United States to use KPG officials in the military government and even suggested recognition. 24 In response, Acheson remphasized that the United States

22

Sarafan, "Military Government," 353; Meade, American Military Government in Korea. 61; Tompkins, American-Russian Relations in the Far East, 323.

Sunoo and Angus, "American PoIicy in Korea," 228; Henderson, Politics of the Vortex, 130. 24

Hodge to War, September 29, 1945, RG 319, OPD 381 CTO. NA; Robertson to Acheson. September 25, 1945. FRUS, 1945. Vol. VI, 1057; Acheson Memorandum, RG 59, September 26. $1945,895.01 / 9-2645$. NA. 
favored no particular group and would allow anyone to join the AMG who was qualified and wished to serve. 25 on october 16. Acheson announced that the United States wolild provide transportation to Korea for any exile wishing to return. Byrnes cabled Hurley that the United States was particularly interested in the return of Kim Koo and Kimm Kui-sik.

A.l though Byrnes and his advisors agreed that Korean political stability was important, they were apprehensive about Rhee's rising influence. On September 5, Washington delayed approval of Rhee's return because his passport bore the title "High Commissioner." In all probability, the State Departmert was cautious because it realized that Rhee's anti-Sovietism would only hinder contacts with the Soviet Commander. At this point, Preston Goodfellow interceded on benalf of his old friend khee and convinced the Passport Division Chief, Ruth B. Shipley, to issue the necessary papers. Shipley granted a passport without the knowledge of Byrnes and evidently because she believed Rhee to be a "nice patriotic old gentleman."

Rhee stopped in Tokyo for discussions with NacArthur

\section{5}

Acheson to Robertson, September 27, 1945 and Acheson to Hurley, September 21, 1945, FRUS, 1945, Vol. VI, 1060 and 1046.

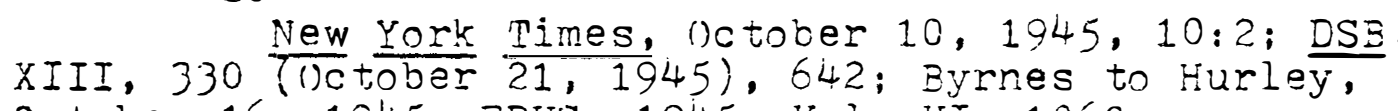
october 16, 1945, ERU'S, 1945. Vol. VI, 1060. 27 28

Oliver, Syngman Rhee, 210-211.

Henderson, Politics of the Vortex, 128. 
while enroute to Korea. Initially, ivacArthur confirmed that the United States intended to be impartial and would provide Rhee with no special considerations. 29 Folitical Advisor George Atcheson informed Washington that he possessed serious doubts regarding the wisdom of this approach:

I believe the time has come when positive American action, in the political field in Korea should be taken. I realize that to give open official approval or support to any one leader, group or combination, is contrary to past American thinking. But situation in Korea fully warrants such a. step and there is reason to believe that unless positive action is taken to give the Koreans a start in governmental participation and organization, our difficulties will increase rather than diminish, and the Communistic group set up and encouraged by the Soviets in northern Korea will manage to extend its influence into southern Korea 30
with results which can readily be envisaged.

Apparently, MacArthur agreed, since Rhee returned to Korea on October 16 aboard NacArthur's private plane. Hodge greeted Rhee with great fanfare and provided him with a room in the AMG hotel, gas coupons, and a personal body guard. Such favoritism hardly reassured the Soviets regarding American intentions and certainly aroused suspicion.

This rapid turn of events alarmed many American

29

MacArthur to irar and JCS, October 19, 1945, RG 319, OPD $381 . \mathrm{CTO}, \mathrm{NA}$.

Atcheson to Byrnes, October 15, 1945, ERUS, 1945, Vol. VI, 1091-1092.

31

Henderson. Politics of the vortex, 128-1.29; Kim, Divided Korea, 5?-58; Oliver, Syngman Rhee, 213-214; Cumings, "American Policy and Korean Liberation." in without Paraliel, 65. 
officials in Washington. Noting Soviet hostility toward Rhee, the War Department informed Hodge that the close relationship with Rhee tended "to jeopardize success of United States negotiations . . regarding $38^{\circ} . "$ Yet, as Truman explains in his memoirs, the absence of other pooular political leaders and the nature of the Korean situation left Hodge with little alternative but to support Rhee. Upon his return to Korea, all groups urged Rnee to accept a position of leadership in their parties in hopes of increasing thein popularity and political power. From the outset, however, Rhee rejected cooperation with any party and sought to unify all Koreans under his leadership. By 1945. Syngman Rhee considered himself the embodiment of "new Korea" ano embarked upon a determined course of action for the creation of a separate government in south Korea strong enough to force the Soviet Union to abandon the rorth. While overtly expressing his non-partisanship, he created a new party-"The Society for the Rapid Realization of Korean Independerice." 34

Rhee also benefited from the influence of Goodfel.low

\footnotetext{
War to NacArthur, Dctober 22, 1945, RG 218, Leahy Pacers, Korea 194ć-47. NA; Truman. Years of Trial and Hode. 329. 33 McCune and Grey, Korea Today, 244; 0liver, "Tug of War in Korea," 224 . Cumings, "American Policy and Korean Liberation," in without Faraliel, 65; Truman, Years of Trial and Hooe, 329 ; New York Times, october 18, 1945, 4:5; AIIen, Korea's Syngman Rhee, 71.
} 
and his other lobyyists in washington. On November 5, 1945. Jay Jerome williams asked Truman to approve the return of Goodfellow from terminal leave to serve as special advisor to the AIIG. He stressed that Hodge desired Goodfellow's advice. In addition, Goodfellow could utilize his long experience with the resistance movement to foster the unification of all faction. Vincent opposed the plan, pointing out that williams, Rhee, and Goodfellow had criticized the State Department during the war for nor-recognition of the KPG. Byrnes refused to send Goodfellow as Truman's personal representative, but agreed to allow him to join the ANG if Hodge requested such action. Truman instructed Byrnes to "handle the matter as you see fit." Thus, the secretary of State decided to permit Goodfellow to travel to Korea as special advisor to Hodge. Impartiality was at an end.

American leaders quickly recognized that events were overtaking the United States in Korea. Further delay only increased the permanence of partition. America's desire to demobilize added urgency to the task of achieving Korean reunification and independence, since only a settlement with Moscow would aliow the United States to withdraw. As early

Williams to Byrnes, Vincent Memorandum, Byrnes to Truman, and Truman to Byrnes, November 16, 1945, RG 59, 740.00119 (Control Korea)/11-1.645, NA. 
as september 30, the SWNCC turned again to trusteeship as the only solution to the Korean problem and began to formulate a specific proposal. Washington ordered Hodge to continue to seek coordination with Chistiakov to arrive at uniform and centralized occupation policies. In addition, the SiNCC instructed Hodge to create an administrative structure capable of extension throughout Korea in the hope that trusteeship would conform to the American model for Korean reconstruction. Hodge's response questioned the logic of these directives, since Chistiakov had already refused to engage in substantive discussions of any matter. He doubted if Moscow would agree to any steps toward reunification until the foreign ministers resolved the outstanding issues in the Korean impasse.

Moscow's refusal to engage in local negotiations coupled with the need to reduce the level of American forces in Korea forced the Truman Administration to consider a formal approach to the Soviet government. On October 4 , 1945, the JCS requested Hodge's comments on the feasibility of trusteeship and his recommenations for the specific provisions of the planned diplomatic overture. The State Department also ordered Benninghoff to return to the United States to offer his firsthand observations. In preparation

$$
36 \text { war to NacArthur, September } 30,1945, \text { RG 31.9, OPD }
$$
014.1 TS, Section IV, NA; Marshall to VacArthur, October 1, 1945, FRUS, 1945, Vol. VI, 106?; Berger, The Korean Knot, 56. JCS to Hodge, October 4, 1945, RG 218, CCAC 014 
for discussions in Washington, Hodge and Benningnoff formulated a series immediate needs in Korea, such as civilian advisors, economic aid, a "Iigurehead" government, and an end to the 38 th parallel. While in the United States, Benninghoff noted Korean factionalism and Soviet-directed political agitation as continuing solirces of difficulty. He emphasized that quick action was essential, because even the conservatives had begun to criticize the AMG.

In the meantime, the Nar Department was continuing to urge the rapid implementation of trusteeship. Secretary of War Robert P. Patterson emphasized that demobilization was reducing the number of troops available for the Korean occupation. He expressed the hope that a Korean Constaculary could assume responsibility for the preservation of law and order and thus permit the United States to maintain only a small force in Korea. ${ }^{39}$ Alaming news from Tokyo underlined the necessity for a Soviet-American agreement. WiacArthur reported that the Soviet Union was stripping factories and industrial installations in north Korea and shipping the materials to Russia. he informed Truman's personal representative, Edwin A. Locke Jr., that unless the United States

Korea $(8-28-45)$, Section II, NA.

Memorandum, october 16, 1945, RG 319, ODD 336

Korea, section I, NA; T.N. Dupuy to Lincoln, ()ctober 29, 1945, RG 319, OPD 336, Korea, Section I, NA. 39

1945. VOI. VI, 1111.

Fatterson to Byrnes, November 1., 1945, FPIS, 
acted immediately, Korea"s partition would be permanent.

As early as Dctober 8, 1945, tie State Department had prepared a draft proposal on Korean trusteeship, which the JCS approved ten days later. As something of a trial balloon, Jonn Carter Vincent publicly announced on october 21. that the United States supported the principie of Allied cooperation in the supervision and guidance of dependant peoples. Ire explained that the united States and Cinina had agreed to a period of preparation for seif-government in Korea and expressed hope for Soviet-American cooperation in that nation. The creation of an independent, democratio, and prosperous korea was not only just, but in the interests of Soviet-Anerican security.

on october 22 , the sirivo recommended that jymes oven negotiations as soon as possible for tre coordination of occupation policy in korea, the removal oi the 38 th parallel and the establishment of a trusteeship. The United Nations would possess ultimate responsinility and provide the supervisory machinery to ensure Korea's sovereignty, Under this arrangement, the United States could withdraw and the Koreans could assume as many governmental resoonsibilities

41 Truman, Years of Decision, 521-5,22.

Draft on korean Trusteesnip, (10 tojer 13, 19i5, 3yrres Papers, File 5ó (2), CUi; Bergor, The Korean nrot. 57 .

43

Vincent, "The Post-jar Period in the Par East," DSB, XIII, 10. 330 (nctober 2j, 1945), 644-6́t8. 
as possible. The SWNCC emphasized that the American public was demanding withdrawal from Korea, while the USAFIK appeared unable to resolva several complex problems.

Byrnes communicated the new American policy decision to Harriman on November 3, instructing him to approach the Soviets with a request to end the 38 th parallel as a closed barrier. The American proposal called for adequate and reguiar delivery of coal and electricity to the south, uniform fiscal policies, coastwide shipping, orderly resetthement of displaced persons, and the resumption of interzoral trade. The occupation commanders were also to begin immediate negotiations for the realization of Korean independence. On November 7, Byrnes further instructed Hariman to raise with Nolotor the issue of alleged Soviet removals of power station equipment along the Yalu River.

Harriman complied with the instructions, but exoressed pessimism regarding the chances for success. He insisted that Moscow would not foresake control over north Korea or allow the area to become a springboard for attack on Russia. From the Soviet viewpoint, Korea was no different, than Finland, Poland, or Rumania. Forrestal shared Harriman's

SWNCC to Byrnes, ()ctober 22, 1945 and SWNCC to JCS, nctober 24, 1945, ERUS, 1945, Vol. VI, 1094-1102. 45

Byrnes to Harriman, November 3, 1945 and November i, 1945, FRUS, 1.945, Vol. VI, 1106-11.09 and 1112-11i3;

Gilmer to Full, November 7 , i.945, RG 31.9, OPD 336 Korea, NA. 46

Harriman to Molotov, Novemier 8,1945 , FRUS, 1945 , Vol. II: General: Political and Economic Vatters (Nashington, 
pessimism, observing that the United States could expect Noscow to consolidate control over northern Korea. He agreed, however, that washington should protest Soviet dismantling of the power station, although stalin probably took the action because he felt surrounded.

() November 7. Byrnes informed Hodge of the decision to approach the Soviet Union and assured the commander that negotiations would now progress rapidly for the termination of the Korean partition, the creation of a trusteeship, and the withdrawal of American troops. Once again, he rejected support for the KPG or any other faction, since it "might greatly complicate the political problems facing military government, as well as encourage the Soviet commander to sponsor a similar group in his zore and thus postpone establishment $0 \ddot{i}$ a unified Korea." The ivar Department remained skeptical of Byrnes' policy and feared rising public criticism of American occupation. It began to formulate a public information program to apprise the American people of the complex and serious nature of the Korean situation. If Soviet-American negotiations fiailed, the War Department believed that continued occupation of

D.C.: Government Printing office, 1.957), 627; Harriman to Byrnes, November 12, 1945. FRUS, 1945, Vol. VI, 11.21. and RG $59,895.01 / 1.1-1245$, NA. 47 48

Millis, The Forrestal Diaries, 107-108.

Vincent to Vittrup, November $?, 1945$, ERUS, 1.945 , Vol. VI, 1113-1114. 
Korea would be a complete impossibility.

Despite widespread skepticism regarding the approach, the State Department completed a preliminary draft of a four-power trusteeship on November 6 . Some officials questioned the length of the document, since it contained no less than thirty-eight articles. Alger Hiss and others explained, however, that "it will be the first of several trusteeship agreements and should be a model for the in." Pernaps more important, Moscow had indicated on previous occasions a preference for detailed agreements, rather than ones "couched in general terms." Thus, the Korean trusteeship proposal possessed added significance.

America's proposal for trusteeship envisioned tine creation of an Executive Council and High Commissioner to organize and implement general policy directives in Korea. Representatives of China, Britain, the United States, and the Soviet Union would serve on the Council, which would base its decisions on majority rule. Within thirty days after the High Commissioner assumed control, Soviet and American troops would withdraw. The plan also provided for an elected legislature, judicial system, police force, constabulary army, constitution, technical aid, and

49

Hull to iittrup, November 10, 1945, RG 319, OPD 336, Korea, NA; New York Times, November $6,1945,18: 3$. 50

Trusteeship Froposai, November 6, 1945, Byrnes Papers, File 596 (2), CUI; Blakeslee to Vincent, November 14, 1945, RG 59, 740.00119 (Control Korea)/11.1.445, NA. 
participation in the secondary organizations of the united Nations. The trustaeship machinery would maximize Korean participation, thus fostering experience in self-government and speeding the termination of international control. Byrnes hoped that Stalin would accept this plan and that Korea would gain full independence on March 1, 1.951 .

George Atcheson, MacArthur's political advisor, had already advocated the adoption of positive steps for the realization of Korean independence. During October, 1945 , he recommended that Washington announce the legal separation of Korea from Japan and the consummation of Soviet-American negotiations to end the partition. On November 3 , the ICS ordered NacArthur to effect the complete governmental and administrative separation of Korea from Japan. At the same time, the state Department responded to Atcheson's other suggestion and fornulated a. "Joint Policy Declaration" on Korea. If accepted, the Allies would issue a puolia promise for the early fulfiliment of the Cairo Declaration through the negotiation of a specific trusteeship agreement.

During the fall of 1945 , the Truman Administration turned once again to the trusteeship formula as a means for ending the 38 th parallel. Or November 11, Truman received

51

Atcheson to Byrnes, ()ctober 4, 1945, FruS, 1945, Vol. VI, 1068; JCS to NacArthur, November 3, 1945, U.S. SCAP, Political Orientation of Jagan September 1.945 to September 1945, vol. I (iashington, D.C.: Government Printing (Pfice, 1749), 3; Joint Policy Declaration, November 13, 1945, Byrnes Papers, File 569 (2), CUI. 
British and Canadian support for the convening of an early meeting of the Council of Foreign ministers to discuss Korea and a number of other issues. According the Leahy, Britain and the United States "agreed as to the immediate desirability of establishing an international control of Korea for a period of five or more years in preparation for self-government, and that assent of China and the Soviet Republics should be obtained through diplomatic channels." 52 American policy toward Korea had then completed a full circle during 1945. Unfortunately, successful creation and implementation of a trusteeship agreement was now extremeiy difficuit, since both Noscow and Washington were firmly entrenched in the divided Korean perinsula.

On November 16,1945 , the State Department announced that the United States intended to approach the Soviet Union for the purpose of eliminating the 38 th varallal. The statement observed that Hodge had attempted to negotiate at the local level, but had been unable to remove the unnatural barrier. Washington also indicated its intention to foster the return of qualified and prominent korean exiles as quickly as possible "to work with local Korean leaders in the unification of the diverse political elements." The 52 Leany Diary Note, November 1.1, 1945, Leahy Papers, Box 5. Diaries 1945. IOC; Truman. Years of Decisior, 540. 
United States expressed confidence that Soviet-American negotiations and support for democracy would speed Korean reunification and independence.

If Truman and his advisors thought that the Koreans had changed their attitude of opposition to trusteeship, they were sadly mistaken. Rhee seized the initiative and inaugurated a program to unify all political elements around a demand for immediate self-government. Rhee's party became an outspoken critic of the 38 th parallel and mobilized opposition to trusteeship and cooperation with the Soviet Union. Early in November, Rhee convened a conference of forty-five political parties and demanded immediate freedom. In return for recognizing the KPG, Rhee and his followers promised elections within cne year. The conference drew up a resolution that expressed "shock and consternation" over Vincent's proposal for a joint trusteeship in Korea.

Such protests greatly disturbed Byrnes, who quickly instructed Hodge to Iimit Rhee's pronouncements. Byrnes warned that "unguarded references to the Soviet union ano the 38 th parallel" would only complicate negotiations with Moscow. Hodge and MacArthur were more concerned regarding

\footnotetext{
53 $1945), 812-813$ 54

1945: Rhe $\frac{\text { New }}{\text { to }}$ York Times, November 3, 1945 and October 14 , 11.10-1111; Cumings, "American Policy and Korean Liberation," in Without Paralle1, 76; Iimb to Vincent, November 11, 1945, FRUS, 1.945, Vol. VI, 1115-1117.
} 
Communist agitation in south Korea wich was thriving on increasing economic distress. Hodge believed that the People's Republic was pursuing a campaign of criticism which reflected the work of a "well trained group of outside experts." Rather than hampering Rhee's activities, Hodge urged actions to bolster the conservatives as the legitimate representatives of south Korea. He recommended recognition of the KPG, while vacArthur offered private transportation for the Kim Koo regime back to Korea.

Assistant Secretary of Har John J. MoCloy supported Hodge's assessment. On November 13 , he reminded Acheson that Syngmar. Rhee was not only reliable, but confident and unconfused in purpose. Since Moscow would probably refuse to negotiate, NCCloy suggested that the AMig maximize the use of Korean exiles to prepare them for the rapid assumption of governmental responsibilities. Acheson refused to go any farther than fostering the return of prominent exiles. Fe emphasized thet the ANG would treat all civilian employees as individuals without official status. Acheson's caution was justifjed. In Chungking, chiang had supolied Kim Koo with a sizable amount of money and group of Chinese advisors

Byrnes to Atcheson, ()c tober 25, 1945, Hodge to War, November 2, 1945 , and NacArthur to Narsiali, November 5. 1945, FRUS, 1945, Vol. VI, 1105-1106 and 1112; MacArtnur to NarshaIl. october 25, 1945, RG 319, OPD 335 Korea, NA. 56

NeCloy to Acheson, November 13,1945 and Vincent to Acheson, November 1ó, 1945, FRJS, 1945, Vol. VI, 1119 and 1127; Hull to Hodge, November 21, 1945, RG 319, OFD 336 Korea, NA; New York Times, November 20, $1945,4: 8$. 


\section{2}

prior to his departure. 57 Although the exact nature of China's intluence in the KPG remained a matter of doubt, Stalin certainly could not have been optimistic regarding the motives and intentions of the Kim Koo regime.

American officials in seoul refused to accept the logic of either impartiality or trusteeship. William $R$. Langdon, now political advisor, reported that the soviet Commander had issued a prociamation pledging his support for a democratic form of government, the protection of civil Iiberties, and the ouster of the Japanese. He urged Byrnes to support the Kim Koo regime, because the KPG was considered "quasi-legitimate by all elements and parties." More important, popular opposition to trusteeship meant that continued impartiality was foclish. Langdon offered a detailed plan for turning over control in Korea to Kim Koo with or without Moscow's approval. Hodge joined in urging positive action, noting the increased popularity of Lyuh among the uneducated and working masses. Since Lyuh refused to renounce his claim to legitimacy, Hodge informed VacArthur of his irtention to denounce Lyun's People's Republic and issue a "declaration of war" against its activities.

MoNair to War, November $16,1.945$, RG 226, OSS, XI 31447 , NA. 58

Langdon to Byrnes, November 18,1945 and November 20, 1945: FRUS, 1945, Vol. VI, 1129-1132.

Hodge to ivacArthur, Novemoer 25, 1945, FRUS, 1945, Vol. VI, 1133-1134. 
It seems clear that Hodge and Langdon were overreacting. Quite obviously, not all the leftists were under Soviet direction and many were only demanding change. 60 To preserve order, Langdon admitted, the USAFIK initially "picked out a disproportionate number of rich and conservative persons." Uncertainty remained, however, regarding which extreme really possessed a wider social base of support. In view of the inordinate amount of individual ambition, sectional rivalry, and intolerance of opposition. Langdon concluded that support for the KPG was the most logical course of action. Yet, even support for the conservatives would not resoive the American dilemma, since the leftists would oppose such a policy. Support for Kim Koo's regime, which arrived in Korea on November 23. 1945, was certainly not enough. Rising inflation, economic deterioration, and the steady influx of refugees from the north only compounded the problem of mounting tension and unrest in south Korea.

Hodge's extreme recommendations concerned secretary Byrnes greatly. While appreciating Hodge's problems, Bymes rejected any action that constituted a violation of national self-determination. Besides, Moscow would never accept a

\footnotetext{
60

November $2 \frac{\text { New }}{7}, \frac{y \text { ork }}{945}, \frac{\text { Times }}{3: 2 .}$ November $22,1945,11: 1$ and 61

Langdon to Byrnes, November 26,1945 , EPUS, 1945. Vol. VI, 1135 .

December $6 \frac{\text { New }}{1, \frac{\text { York }}{45},} 3: \frac{\text { Times }}{3: 2}$. December $4,19,45,2: 5$ and
} 


\section{4}

63

fait accompli. Hodge continued to stress the need for action nevertineless, arguing that Soviet "control probably exists" over the People's Republic. Lyun's regime was better organized and financed than any of its rivals. Langoion observed that a.l Koreans demanded self-government and warned that support for trusteeship would lead to civil strife. Both Hodge and Langdon recommended Soviet-American negotiations at the government level to allow a separate government in each zone, an end to the fortification of the 38 th parallel, and American access to north Korea. Despite Iangdon's warnings, Byrnes was determined to follow through on the trusteeship proposal. Significantly, Washington ordered MacArthur to delay the announcement of the policy until Hodge had time "to make necessary arrangements to prepare to counteract the expected unfavorable reception by the Koreans - - of the trusteeship plan."

Upon his arrival in Noscow for the Council of Foreign Vinisters meeting. Byrnes received a cable from seoul indicating that the Korean situation had reached crisis proportions. Hodge observed that, al though the Koreans were not ready for complete independence, popular opposition

Byrnes to Langdon, November 29,1945 , FRUS, 1945 , Vol. VI, 113?-1138.

Hodge to War, December 7, 1.945, RG 319, OPD 336 , Korea, Section I, NA; Langdon to Byrnes, December 1.1 and 14 , 1945, FRUS, 1945, Vol. VI, 1141.-1143.

Memorandum for the JCS, Lecember 11, 1945, RG 218, CCS 383.21 Korea $(3-19-45)$, Section III, NA. 
to the absence of self-government had produced a favorable atmosphere for "radical leftism if not raw Communism." The general public indicated an increasing tendency "to look to Russia for the future" because of "the usual oriental slart" of "doing homage to the man with the largest weapon." Quick action was essential. In the absence of a suitable agreement. Hodge urged that Korea be left to its "own devices and an inevitable internal upheaval for its self purification." Nost important, the USAFIK Commander strongly opposed any attempt at trusteesinio, since outside supervision constituted a "sword of Damocles" for Koraans. Byrnes persisted in his pursuit oi a trusteeship agreement nevertheless and the issue soon emerged as the crux of the Soviet-American impasse on the entire Korean issue.

In November, 1945, the Siric formulated a detailed policy paper on American policy in Asia. It included the thrust of the korean trusteeship olar, but stressed that success required compromise and cooperation between the United States and the Soviet Union. American officials had to avoid support for elements in Korea hostile to Moscow at all costs. In contrast to the united states, the soviet Union assigned special strategic significance to Korea. The

66

MacArtinur to JCS for Hodge, Decemoer 16, 1945 , FRUS, 1945, VOI. VI, 1144-1148. 
SWNCC then offered the following conclusion:

In this regard, we must recognize that the united States occupies an exposed and untenable position in Korea from both a military and political standpoint. A prolonged occupation of Korea on our part cannot but create suspicion by the USSR that we have advanced our military strength in East Asia to a point beyond those which are necessary and requisite for the security of the United States....

Washington should anticipate and accept vioscow's desire for special influence in Korea, while opposing excessive soviet interference. The SWNCC endcrsed trusteeship as a means of lessening the likelihood of Soviet domination, reducing tension in northeast Asia, and permitting American withdrawal. If Stalin insisted upon total control, however, the report recommended immediate termination of trusteeship and Korear self-government.

Byrnes travelled to Noscow in Decemcer 1945 in the hope of breaking the Soviet-American deadlock on a number of issues. An objective and cooperative atmosphere characterized the meeting, as the Allied foreign ministers discussed Korea in a frank and straightforward manner. 50 Byrnes placed Korea on the agenda on the same day that Hodge warned against trusteeship. Byrnes urged the acceptance of an agreement for the local commanders to engage in negotiations for the resolution of those issues Harriman had raised

Swicc Policy Faper, November 29, 1945, Byrnes Papers, File 569 (3), CUL. 68

Feis, Contest (1ver Japan, 34; Curry, James F. Byrnes, 17o-177; Gaddis, The United States and the Origins of the Cold War, 281. 
in November. The essential first step for the unification. trusteeship, and independence of Korea was the creation of a unified administration. Molotov responded that a general agreement on the formation of a Korean government and trusteeship was necessary prior to any discussion of specific issues relating to reunification. He requested a copy of the American proposal and time to study its provisions. Sritish Foreign Minister Aneurin Bevan wanted to see the original Soviet-American agreement, but violotov correctly observed that there had been only "an exchange of views." The foreign ministers agreed to defer the matter until Molotov studied the American proposal.

In the final American paper. Byrnes only summarized briefly his trusteeship proposal. He focused instead on the Harriman recommendations and the vital necessity for local coordination to end the 38 th parallel. It also included provisions for the possible extension of trusteesnip to ter years. On December 17, Bevan voiced strong support for the American proposal and urged its referral to committee to work out the details. Molotov explained that he had not had sufficient time to study the plan and requested a delay at that time and again on the following day.

\section{9}

Mioscow Conference Minutes, December 16, 1945. FRUS, 1945, Vol. II, 61?-621.

Ameriaan Froposal on Korea, December 17,1945 and Nioscow Conference Vinutes, December 17 and 18,1945 , FRUS, Vol. II, $639-643$ and 660 . 
other American leaders continued to press the state Department for a quick resolution of the Korean problem. Hodge explained that if Moscow agreed to guarantee unification and independence, perhaps trusteeship would not be necessary. Forrestal supported such action and recommended that, in the event of Soviet refusal, each nation should implement a five year trusteeship in its own zone. Patterson reminded Byrnes of the deteriorating situation in Korea and urged quick action. The JCS complained that it was unable to issue adequate directives to Hodge and drasticaliy needed advice. '1 Although Acheson agreed that a SovietAmerican settlement was necessary, he expressed doubt over the seriousness of the USAFIK position. He informed rodge that Byrnes was aware of his problems and intended to discuss Korea at Moscow. Wasington would inform Seoul of any progress in the negotiations.

on December 20, Molotov accepted the American argument that local discussion of "urgent" questions was needed, but recommended governmental agreement on a long-term trusteeship plan. Bevan inquired if Moscow was then approving the American plan. Molotov responded that he would distribute a counter-proposal that evening. Byrnes expressed his

71

Millis, Forrestal Diaries, 125; Patterson to Acheson. December 19, 1945, RG 319, OPD 336 , Korea, NA; Dunn to Byrnes, December 19, 1945, RG 218, CCS 014.1 TS, Korea, NA. 72

Acheson to Langdon, December 20, 1945, RG 59, 740 . 00119 (Control Korea)/12-2045. NA; War to MacArthur, December 20, 1945, RG 218, Leahy Fapers, Korea 1945-1947. NA. 
desire for cooperation, but, for some unexplained reason, argued that the American proposal was what Stalin had in 73

mind at Potsdam. In any event, Nolotov submitted the Soviet proposal, which contained four specific provisions. First, the major powers would create a Korean Provisional Government to undertake all necessary measures for. the development of Korean industry, transportation, agriculture, and culture. Second, Soviet-American representatives would form a Joint Commission to consult with local parties and social organizations and formulate the procedures for the creation of such a provisional government. Third, the Joint Commission would "help and assist (trusteeship)" in the political, economic, and social progress of Korea for democratic self-government and independence. It would also formulate a five year trusteeship plan and submit it for approval to the four powers. Finally, the Soviet-American occupation commanders would convene a Joint Conference within two weeks to answer "urgent" questions and begin permanent coordination in the administrative field.

Byrnes accepted Molotov's proposal on December 21 with only minor alterations. Clearly, the Korean agreement was eminently satisfactory for both the Soviet Union and the United States. Moscow accepted trusteeship because it

\footnotetext{
73

Moscow Conference Vinutes, December 20, 1945, ERUS, 1945, 101. VI, 697-698.

Soviet Eroposal on Korea, December 20, 1945, FRJS, Vol. II, 699-700.
} 
genuinely desired cooperation on the issue as it had from the outset. Opposition to such a pian would mean unilateral Anerican control in the south and a complete inabiiity for compromise and concession in other areas. Woscow still insisted upon a "friendly" Korea and thus reiused to agree to eliminate the 38 th parallel until the successful implementation of a specific plan for a provisional government and trusteeship. Byrnes also negotiated in good raith, patiently searching for a compromise that was satisfactory to both nations. He accepted the Soviet proposal in the interests of Soviet-American cooperation and because it differed from the Anerican proposal only in emphasis. only the most cynical observer could conclude that the United States "sold out" Korea at Noscow or resist the more cheerful expectation that Stalin wolla faithfully observe the trusteeship agreement.

As the Truman Administration had anticipated, the Moscow Decision pleased few Koreans. The United States believed, however, that Korean political immaturity justified the absence of immediate indepencence. Aiso, the temporary continuation of outside control seemed the only

Informal Neeting Vinutes, Lecember 21 and 22 , 1945, FRUS, 1945, Vol. II, 716-717; Goodrich, Korea, 21; Cho erroneously argues that there "was no reason to believe that the Soriet Union favored the idea 0 trusteeship, if indeed it did not actually dislike it," Korea in World Politics, 97 .

Byrnes. Speaking Frankly, 222; Curry, James $\underline{E}$. Bvrnes, 190; Feis, Contest ()ver Japan, 98. 
means for securing Soviet cooperation in reunification. In Korea, however, news of the trusteeship plan produced an immediate and violent outburst of opposition that bordered on mass hysteria. Extremists held demonstrations, closed stores and schools, and staged work stoppages. Rowdy youth groups roamed the streets intimidating AMG personnel, while distributing leaflets and posters protesting trusteeship. Hodge appealed to Washington to reconsider the policy and "kill the trusteeship idea for the Koreans." 7 " The JCS rejected the request and predicted that once Hodge fully explained the decision, the Koreans would accept it. Hodge remained unconvinced, since Kim Koo ordered his folLowers not to cooperate with the $A M G$ and even threatened to seize power. AlI civilian employees went on strike. Hodge now urged Washington to even avoid the use of the word trusteeship, since any mention of it "immediately precludes any normal orocess of reasoning of the Koreans."

Prior to the Noscow Conference, Korean leaders had curtailed political activism. During this period, the People's Republic continued to increase its popularity in

Langdon to Byrnes, December 30, 1945, RG 59, 740.00119 (Control Korea)!12-3045. NA; Emmons to Byrnes, December 30,1945 , and Fodge to NacArthur, Decemider 30 , 1945, FRUS, 1945, VOI. VI, 1152-1154; Hodge to Har, December $30,1945, \operatorname{Rg} 319$, OPD 336 Korea, NA.

Eisenhower to MacArthur for Hodge, December 30 , 1945, ERUS, 1945, Vol. VI, 1155.

Hodge to War, December $31,1.945$, RG 218, Leahy Papers, Korea 1.945-1947, NA. 
rural areas. The KPG quickly turned to the trusteeship issue in an effort to outflank its leftist opponert. The Communists initially joined all koreans in opposing trusteeship, but suddenly reversed themselves and became the most outspoken defenders of the Moscow Decision. During a demonstration on January 3, 1946, the leftists hastily substituted the word "up" for "down" on their signs which then read "Up with Trusteeship." Moscow undoubtedly ordered the switch, but certainly the Communists could not expect the United States to adopt a more favorable attitude toward their political aspirations if they opposed trusteeship. More important, the Korean leftists were far more realistic, since they realized that only through support for the Noscow Decision could Korea gain reunification and independence.

Byrnes reacted to the korean protests in an unexpected and extremely unfortunate manner. Upon his return from Moscow, he delivered a radio address summarizing the results of the conference. After expressing aispleasure over the absence of progress toward Korean unification, Byrnes voiced satisfaction that the United States and Soviet Union had agreed to open discussions to resolve immediate economic and administrative problems. Te then summarized the trusteeship agreement, but included the suggestion that the Joint

\section{0}

New York Times, December 20, 1945, 7:2, December 23, $1945, \frac{148}{81}$, and December 2?, 10,45, $4: 1$.

Divided $\mathrm{Ko}^{\frac{\text { New }}{\text { rea }}}, \frac{\text { York }}{62}$ Times, December $28,1945,12: 2 ; \mathrm{Kim}$, 
Commission "may find it possible to dispense with a trusteeship" since 82 ship," since the ultimate goal vas to hasten independence. This statement bore no relationship to the Noscow Decision and was a purely unilateral American action. In response to Korean complaints and without Soviet approval. Byrnes added a qualification to the settlement. Moscow's subsequent suspicion regarding American good faith and intentions was completely justified.

Hodge eagerly seized upon Byrnes' statement to reassure the KPG that the United States did not intend to implement trusteeship in Korea. Despite clear evidence to the contrary. Hodge privately told Kim Koo and Rhee that trusteeship was not an indispensible aspect of the Moscow Decision. In his public statement, Hodge explained that complete independence would rapidly follow reunification and the creation of a provisional government. 83 Such assurances placated the KFG and its supporters. Kim Koo ordered government employees to return to work, thus ending four days of mass chaos. Hodge could now reoort that the crisis had passed. The KPG had been able to retreat with a minimal loss of prestige, because Byrnes had provided "a very small hole for saving of Korean face . .." Hodge strongly urged

82

Byrnes Radio Acdress, Decemier 30, 1945, DSB, XIII, 340 (December 30, 1945), 1035-1036; Byrnes, Speaking Frankly, 222; Berger, The Korean Knot, 57-62. 83

Langdon to Eyrnes, December 30,1945 , RG 59, 740.00119 (Control Korea)/12-3045. NA; New York Times, December $31,1945,1: ?$ and January $2,1 \overline{946}, \frac{-12: 1}{2}$ 
Wasington to refrain from any future references to trusteesinip in the hope that the issue would disappear.

American actions in the wake of the Noscow Conference resulted in the emergence of an inescapable dilemma. Hodge had decided to support a political faction that depended upon opposition to trusteeship for its popular appeal. Yet, the Moscow Decision demanded that the united States support some form of trusteeship for Korea. If Truman expected to successfully resolve the Korear dilemma, he would have to either convince Kim Koo and his supporters to accept trusteeship or abandon the conservatives entirely. The only other alternative was permanent partition.

$\forall I$

An emerging split between Truman and Byrnes made an objective appraisal of the Moscow Decision quite difficult. Jonathan Daniels is probably correct when he observes that the characters and perscnal histories of the two men precluded cooperation on a permanent basis. 85 For Leahy, the origins of Truman's opposition to Byrnes' dipiomacy rested in China policy. In November, 1945, he suggested that the same "communist-inolined influence" that led to the Hurley

\footnotetext{
84

New York Times, Jaruary $3,1.946,2: 8$ and 18:2;

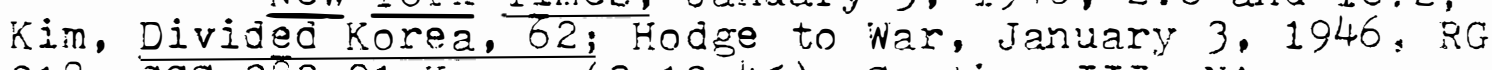

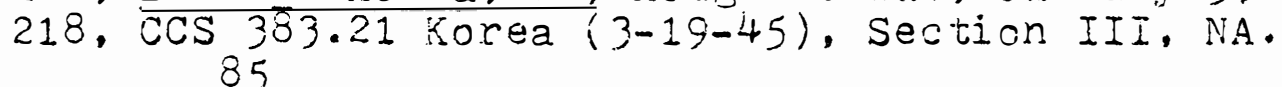
Daniels, The Man of Independence, 308.
} 
resignation was having an impact on byrnes. According to Leahy, Truman was concerned, surprised, and displeased over Byrnes' support for a coalition government in China. It is also possible that Truman had grown tired of the extent to which others commanded the policy-making process and sought to reassert control. In any event, Truman's dissatisfaction with Byrnes climaxed after the Moscow Conference.

On December 26, the President expressed agreement with Leahy's judgment that Byrnes was guilty of appeasement at Moscow. The appearance of compromise only masked a Soviet victory. 88 Truman later argued that "Byrnes lost his nerve in Noscow" and granted unnecessary concessions without his knowledge or approval. One could not compromise with Stalin and Truman was "tired babying the Soviets." Byrnes should have demanded the creation of a strons central government and positive action for economic rehabilitation. 89 On the

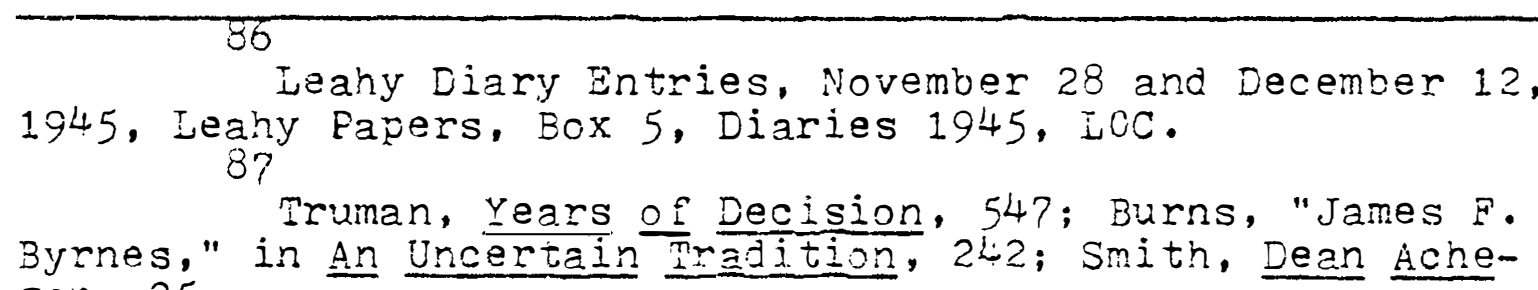
son, 25. 88

Leahy Diary Entry, December 12,1945 , Leary Papers, Box 5, Diaries 1945, LOC; Burns, "James F. Byrnes," in An Uncertain Tradition, 234; Westeriield, Foreion Policy and $\frac{\text { Party }}{89}$ Politics, 205 .

Truman, Years of Decision, 552; William Uillman, (ed.). Mr. President: The First Publication From the Personal Díries, Private Letters, Paoers, and Revea ing Interviews of Harry S. Truman (ivew York: Farrar. Straus and Young, 1952$), 21-23 ;$ Feis, Contest over Japan, 1.20; Laniels, The Man of Independence, 310; Burns, "vames $\vec{F}$. Byrres," in An Uneertain Iradition, 234. 
night of December 29, Truman conveyed his displeasure to Byrnes. When Byrnes qualified the American policy on Korea the following day, the Amerlcan Secretary was probabiy responding to Truman's criticism. Thus, the Administration decided at the outset of 1946 to adopt a new posture of verbal toughness in the hope that stalin would begin "to play the game the American way."

Truman's new approach initially focused in Korea on diluting the trusteeship provision of the Noscow Decision. Acheson, for example, informed the chinese that trusteeship would not be necessary, since it would only complicate Korea's future. For some unexplained reason, Acheson expressed confidence that the Soviet union supported the abandonment of a policy it had just agreed upor. 91 In response to Korean protests, the State Department referred critics to the Byrnes speech which indicated that trusteeship might not be necessary. In Korea, Hodge continued to acquiese in response to conservative criticism of the Noscow Decision. Korean politics now became even more polarized, since Kim Koo saw no need for cooperation with either the Soviet union or the People's Republic. 92 Ironically, Hodge

Reitzel, Kaplan, and Coblenz, United States Foreign Policy, 89.

Memorandum of Conversation, January 4, 1946, RG $59,740.00119$ (Control Korea)/1-446, NA. 92

RusseII to Yunkio Kim of the Dongi Noj. December 31, 1945, RG 59, 895.01/12-31.45, NA; New YorK Times, January $5,1946,5: 6$. 
came to view support for trusteeship as Communist-inspirej. only the conservatives appeared to reflect what the AVIG believed were truly popular desires.

In preparation for Soviet-American negotiations, Iruman decided to dispatch Secretary of War Patterson to Korea during January, 194́, on a fact-finding mission. Patterson engaged in extensive discussions with Hodge immediately upon his arrival and privately expressed satisfaction with the USAFIK comnander's abilities. He also spoke to several Korean leaders "dressed in black coats, swallow-tails, with striped trousers." At a press conference, the American Secretary stressed that Hodge had relied on the best talent in Korea for advice and was doing "a constructive job." Although he refused to specify when the major powers would grant complete independence, Patterson urged the Koreans to create and "maintain a united political front so that the world may know exactly what you want."

Significantly, Patterson refused to comment on a number of questions that the press had submitted prior to the conference. He would not respond to any inquiries regarding the nature of the trusteeship or how the foreign ministers raised the issue at Moscow. Nor would Patterson indicate the force levels of the American army during the remainder

\footnotetext{
Goodrich, Korea. 53.

Memorandum, Decomber 27, 1945 and Diary Entries, January 13 and 14, 1945, Patterson Papers, Box 23, General Correspondence, 1945-1947, Trips Overseas, LOC.
} 


\section{8}

of the occupation. 95 Such evasiveness did not satisfy American soldiers in korea. They had met on January 9 , in anticipation of Patterson"s visit, to organize action protesting the delay in demobilization. They even raised over two thousand dollars to finance a program to publicize criticism of the American refusal to spread the burden of Korean occupation. Patterson conferred with six soldiers regarding their grievances and expressed sympathy. He assured them washington intended to rapidly replace men presently in service with volunteers and draftees. After observine conditions in Korea, however. Patterson privately expressed the view that living conditions were adequate in terms of food, shelter, and health. 96

Patterson held a press conference upon his return to Washington and explained that American policy was aimed at assisting "the Koreans in getting an independent stacle government in order that the Japanese may not renew their designs there.. . for further aggressive warfare." 97 The Soviet Union certainly agreed with such sentiments, but disagreed as to those leaders most able to create a friendly

\section{5}

Nemorandum on Press Conference Guestions, January 13, 1946. Patterson Papers. Box 23. General Correspondence, Trips Overseas, IOC. 96

13, $1946, \frac{\text { New }}{18: 4}$ : York Dimary Entry, January $11,1946,44: 2$ and January Papers, Box 23, General Correspondence, Trips Overseas, LOC. $9 ?$

Press Conference Remarks, January 26, 1946. Patterson Papers, Box 21, General Correspondence, Press Conferences, LOC. 
and peaceful Korea. In the wake of Patterson's visit, the United States and the Soviet Union began negotiations which both hoped would resolve outstanding differences in Korea. Washington and Moscow expressed public confidence that the Moscow Conference formula provided a feasible solution to the Korean problem. Soviet-American cooperation would result in the successful realization of Korean independence and the return of economic recovery and political stability. More important, implementation of the Korean trusteeship would indicate mutual trust and confidence among the great powers. 98 The Soviet-American Conference represented the first test of the Moscow Decision, as the local commanders attempted to answer "urgent" questions. The JCS instructed Hodge to rely on Harriman's letter as the foundation for negotiations. His primary objective was to remove the 38 th parallel as a fortified barrier and establish a liason with the Soviet Commander to facilitate economic and administrative coordination. Any domestic reforms would await the achievement of unification. 99 Hodge had urged wider instructions, but the JCS rejected his request.

Hodge and Chistiakov arrived at an agreement on convening the Conference in seoul sometime during the third

\footnotetext{
New York Times, January 4, 1946, 20:2 and January $18,1946,18: 3 ;$ Izvestia, January 12, 1046, quoted in Beloff, Soviet Foreign Policy in the Far East, 160-161. JCS to Hodge, November 29, 1.945, RG 218, Leany Papers, Korea i946-1947, NA.
} 
week of January. The Soviet delegation arrived on January 16 and met immediately with American representatives to discuss the removal of the 38 th parallel. 100 After fifteen session, however, it was quite apparent that the two delegations disagreed in their interpretations of the Moscow Decision. The Soviets sought coordination of policy and the exchange of goods alone, while the Americans favored more complete administrative and economic integration. Moscow refused, for example, to discuss the free circulation of newspapers and uniform fiscal policies. In adoition, the Soviets would agree to offset fertilizer deficiencies in the south only in return for rice shipments to the north. The Americans responded that the United States sought something; more than coordination based upon bartar, while insisting that the south possessed no rice surplus. The Soviet, delegation greeted these arguments skepticaliy and refused to sacrifice complete control in north Korea.

Soviet unwillingress to accept the American approach for resolving "urgent" probiems quickly irritated Hodge, who

DSE, XIV, 343 (January 27, 1946), 111-112; New York Times, January $16,1.946,2: 5$ and January $17,1.946,17: 1$. 101

Department of State, Korea, 4; Department of State, The Record on Korean Unification, 5-6; Benninghoff to Byrnes, February 15, 1.940, FRUS, 1946, Vol. VIII: The Far East (Washington, D.C.: Government Printing Office, 1971), $3 \longdiv { 3 4 - 6 3 6 . }$

\section{2}

Gooce to Hull, January 29, 1946, RG 319, Planning and operations 337, Case 5, NA; U.S. Department of State, Korea's Independence, Far Eastern Series \#18 (Washington, D.C.: Government, Printing Office, October 1947), 4. 
complained that point four of the Moscow Decision included "weasle words." One can appreciate Hodge's unhappiness with the Soviet approach, since he blamed continued partition for his food and power problems in the south. Certainly, Moscow could have agreed to offset American coal and fertilizer deficiencies, but rising suspicion of American intentions prevented such a gesture. In addition, the Soviet deiegation was probably correct legally in that the Moscow formula did not envision complete zonal integration.

Despite Hodge's dissatisfaction, the final SoyietAmerican agreement on economic and administrative coordination was clearly encouraging. Rail, truck, and coastwide shipping trade between zones resumed, as well as nationwide mail service. The negotiators also reached agreement on the creation of a permanent liason between commands and uniform radio frequencies. The Soviets refused, however, to agree to joint control over transportation and communications, arguing that a definitive national arrangement for economic and administrative unity had to await the creation of a 1.04

provisional government.

\section{3}

Hodge to War, January 2.5, 1946, RG 218, CCS

383.21 Korea $(3-1.9-45)$, Section III, NA; New York Times, February 7, 1946,17:2. 104

Hodge to War, February 19, 1946, RG 218, CCAC 014 Korea (8-28-45), Section III, NA; The State Department argued later that Voscow agreed only to mail exchange, Guide to the U.N. in Korea, Far Eastern Series \#4? (Washington, D.C.: Government Printing Office, August 1951), 9; See also, Berger, The Korean Knot, 65. 
Moscow's unwillingness to eliminate the 38 th paraliel completely alienated Hodge. The USAFIK Commander informed Washington of his considerable apprehension that a similar divergence of interpretation would emerge durirg the nego-. tiations for the creation of a provisional government. He requested additional information regarding the commitments Byrnes had made at Moscow in order to be better prepared to meet a repetition of Soviet unilateralism. in particuiar, hodge favored the establishment of complete freedom of speech, press, and movement throughout Korea. If Moscow displayed reluctance, the American Commander intended to "discreetly let the Korean people know that the Soviets are failing to cooperate with the U.S. In breaking down the $38^{\circ}$ barrier." The state Department quickly rejected the strategy. It would only authorize Hodge's issuance of a public statement indicating that the United States sought a wider agreement with Moscow for zonal integration.

Hodge also continued to urge American support for the Kim Koo regime, despite its obvious arti-Sovietism. He suggested that Washington sponsor the KPG's participation

Hodge to War, January 18, 1946́, FiUS, 1946 , Vol. VIII, 611-612; Hodge to War, January $2 \overline{2,1946}$, RG 218, CCS 383.21 Korea $(3-18-45)$, Section III, NA; New York Times, Feorilary $7,1946,22: 5$.

Jupuy Nemorandum, Feoruary 13, 1946, RG 319 , P\&O 091 Korea MS, Section III, Cases 3-15, Box 21, NA. 
at the United Nations, but the State Department rejected the idea. Washington would approve Hodge's dispatch of private Koreans as observers, but only if it was vital to the USAFIK command. Discussions with former Civil Administrator in Korea Brainard Prescott confimed the wisdom of caution and impartiailty. Prescott stressed that Hodge was exaggerating the Communist threat and observed that Lyuh's group was "somewhat more truiy representative of a majority of the Korean people." ${ }^{10}$ Kim Koo was certainly not working for Soviet-American cooperation. While calling for a suspension of demonstrations and boycotts, Kim Kon insisted that Moscow and washington were not committed to the implementation of trusteeship. More important, he organized conservative parties into an "Anti-Trusteeship Committee" dedicated to preventing the fulfillment of the Moscow Decision.

Hodge publicly pursued a policy designed to still protests and end petty politics, warning that rioting and murder only ensured trusteeshic. The Avg took action to outlaw rightist youth groups guilty of inflicting violence on the left. In private cables, however, Political Advisor Benninghoff pointed in Iyuh's group as the solurce of unrest.

Dirn to SivCo: January 4, 1946, FRUS, 1946 , Vol. VIII, 606; Vincent ivenorandum, Jaruary 5, 1040, RG 59 , 740.00119 (Control Korea)/1-546, NA.

Benninghoff to Byrnes, January 23,1940 , FrUS,

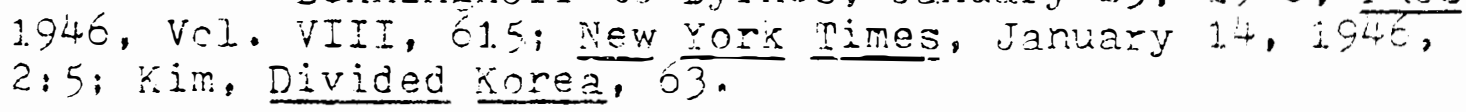


Far from being mere liberals, Iyuh's group was allegedly under Soviet control. 109 Quite obriously, Benninghoff and Hodge had the upcoming Joint Commission negotiations in mind and hoped to provide the KPG with optimum prestige. They urged Washington to refer to the Korean representative body working under the Joint Commission as an "interim government" rather than a "provisional government," arguing that Kim Koo's regime already held the latter title. 110 Acheson flatly rejected the proposal and ordered the American command to view the KPG as a political party alone and without any special status. The war Department supported the decision, but observed that "this confusion might conceivably give the US members of the Joint Commission some bargaining advantage in discussions with the Soviets establishing a 'Provisional Government." Hodge now sought to delay the convening of the Joint Commission until the conservatives had an opportunity to form a broader and more unified rightist coalition. American tolerance of rightist opposition to the Moscow Decision disturbed the Soviet Union greatly. On January 19, Tass denounced the ANG for allowing criticism of the Soviet

Benninghoff to Byrnes, January 22, 1946, FRUS, 1946, Vol. VIII, 613-614; New York Times, January 22,1946 , $19: 2$.

\section{0}

Benninghoff to Byrnes, January ?, 1946, FRUS, 1946, Vol. VIII, 608. 111

Dupuy Nemorandum, February 1.9, 1.946, RG 319, P\&0 014.1. TS, Section I, Case 1, Box 6. NA; Acheson to Benninghoff, January 12, 1946, and Hodge to War, January 22,1946 , FRUS, 1.946, Vol. VIII, 608 and 613. 
Union ard trustesship. Threedays later, it charged that Hodge was inspiring opposition to the Koscow Decision. Hodge quickly dismissed these accisations as faliacious. The USAFIK Commander stated publicly that Nosoow had no right to criticize him for cermitting freedom of expression in the southern zone. Yet, Fodge had actially done very little to deter Kim Koo. In fact, he privately opoosed the pursuit of trusteeship, arguing that deadlock was inevitacle because of the incompatibility of the Snviat and Korean attitudes toward international control. 11.3 Moscow continued to protest todge's permissive attitude toward dissent. It publicized the text of tha American proposal at roscow, which did not include provisions for a provisional government and wolid have delayed independence for ten years. Tass even forwarded the talse contention that the Soviet union had opposed trusteeship From the start, but American opposition to immediate independence forced volotov to accept trusteeship. Kennan speculated that the Soviets sought to discredit ali nonleftist elements as collaborators and reactionaries and thus 1.1 .4 obtain complete control over the orovisional government.

The Korean New York Times, January 23, 1945, 15:5; 3erger, Tre korean hinot, $02-53$

Hodge to War, January 25, 194t, Rij 210, Leahy Papers, Korea 19ú-1 git?, NA. 11.4 Kennan to Byrnes, January 25,1946 , gRUS, 1.946, Vol. IIII, 6́1.7-6́20. 
Acheson acted immediateiy to counter Soviet charges and issued a public statement jnsisting that the United States sought a united and. independent Korea. Byrnes had brought up the subject of the 38 th parallel at Moscow, rather than a provisional government, as the best means for facilitating the promotion of Korean welfare. Acheson argued that Byrnes and Molotov discussed the possibility that trusteeshio might not be necessary, but, if it was, the arrangement would last at least ifve years and perhaps longer. Acheson cabled this statement to seoul for use in clarifying the Soviet-American disagreement, but noted that the Tass account was accurate.

In the meantime, Harriman conferred with Stalin in an attempt to reassure the Soviet leader of American good faith. Stalin expressed concern over reports that the new American military governor Arthur I. Lerch was encouraging Korean opposition to the Moscow Decision. Harriman insisted that the rumors were erroneous and not consistent with American policy. Stalin remained unconvinced and requested a puolic disavowal of actions that contributed to anti-Sovietism. Mutual distrust and suspicion thus reached new levels of intensity on the eve of the opening of Soviet-American negotiations at the Joint Commission.

Acheson Press Conference Remarks, DSB, XIV, 334 (February 3, 1.946), 155; New York Mimes, January 26, 1945, 7:6; Vincent to Benningnot' January 25, 1946, RG 59 , 740.001 .19 (Control Koraz)/1-2546. NA. 116 Harriman to Byrnes, january 25,1946 , ERUS, 1946. Vol. VIII, 6́z2. 
Hodge's subsequent actions hardly contributed to an increase of Soviet confidence and trust in American intentions. Late in January, 1946, the American Commander gained Rnee's and Kim Koo's agreement to the liquidation of the KPG in return for the formation of a new "Representative Democratic Council." Preston Goodfellow, having recertly arrived in Korea as Hodge's advisor, became the principal architect of the auvisory body. ${ }^{11 ' ?}$ Not surprisingly, conservatives Jominated the Representative Democratic Council and Rhee was its chaiman. Hodge emphasized that the body ws not a provisional government, but a device for increasing Korean influence in the American occupation policies. 1.18 In reality, Hodge hoped to mobilize unity among the conservatives in anticipation of the Joint Commission deliberations. Benninghofi even recommended that the United States grant fifty milion dollars in aid to the newly-formed Korean group in order to bolster its prestige and offset rising Soviet, popularity. 119

Lyuh quickly denounced the Representative Democratic Council as undemocratic, unrepresentative, and contrary to the Moscow Decision. Such charges were obviously grounded

\section{7}

Benningnoff to Byrnes, January 23, 1946, ERUS, 1946, Vol. VIII, 22 ; Oliver, Syngman Rhee, 219. 118 The Korean $\frac{\text { New }}{119}+\frac{\text { York }}{65}$. Times, January 29, 1946, 1:2; Berger, Benningnofi to Byrnes, February 9,1946 and Benninghoff to Acheson, January 13, 1946, ERUS, 1946, Vol. VIII, 530 and 611 . 
in fact, since Rhee soon used the Council as the primary vehicle for the exercise of politioal influence in 120 The leftist reversal on the trusteeship issue lent credence to the charge that Iyuh was a Soviet puppet. During early 1946, the conservatives experienced a steady rise in popularity. American support for Rhee was largely responsible for undermining the political position of the People's Republic. In some respects the results were tragic:

By throwing United States support only to the right in a country which demanded and needed radical reform. American representatives in seoul 7 alienated a healthy segment of the left which could have been wooed and perhaps even won by a living exposition of American democracy. Excluded from office-holding, many militant korean radicals were pushed further left and closer to the Communists...121

Soviet leaders would have sought extensive leftist and Communist representation in the provisional government regardless of Hodge's actions. Yet, American support for the right and tolerance of opposition to trusteeship caused the Soviet union to become even more inflexible in its demand for a "friendiy" Korea.

During the fall of $19+5$, the Truman Administration was in search of a settlement that would permit the United States to withoraw from Korea. American leaders feared Soviet intentions in the peninsula and returned to the

120 Henderson, Politics of the Vortex, 282-285.
121 Paige, "Korea," in Communism and Revolution,


wartime policy of trusteeship as the best means for avoiding "sovietization." At the Noscow Gonference, Secretary Byrnes reiied upon compromise and accommodation to arrive at a satisfactory agreement. Unfortlinately, by the end of 1945 , many American leaders had concluded that further bargaining with the Soviet inion would be unwise and even dangerous. In addition, Truman feared that an attitude of conciliation would bring charges of appeasement from Congress.

iruman thus adopted a new approach that required Soviet acceptance of the American interpretation of the Moscow Decision. Such a policy possessed serious limitations. First, Soviet interests in Korea were far more important than those of the United States. Stalin certainly recognized that Iruman would not resort to military mears to impose his will. Second, Truman never formulated a concrete plan of action to produce the requisite military and economic power to force a settlement on American terms. The absence of any clear American interests in Korea and the limitations on American military resources meant that Truman's hardine would be little more than rhetorical 124 bombast. If Truman wanted to $\mathrm{be}$ tough with Stalin, Korea was surely the wrong place for a test of strengti.

122

Gaddis, The United States and the Origins of the Cold War, $281-290$.

Burns, "James F. Byrnes," in An Uncertain "iradition, 243; Curry, James F. Byrnes, 306. 1.24

Hamby, Beyond the Now Deal, 113-114. 
Chapter IV:

Patience With Firmness 
Truman's policy toward the Soviet Union experienced a fundamental reorientation during the first months of 1946. Previously, the united States had engaged in negotiation and compromise in an attempt to resolve outstanding differences with Moscow. Shortly after the Moscow Conference, Truman concluded that further concessions wolid be unwise and decided that it was time "tn get tough with Russia." Secretary Byrnes accepted the change and labeled the new approach "patience with firmness." "In Korea, the new policy meant that the United States would demand Soviet acceptance of the American interpretation of the Ninscow Decision. If Stalin refused, Truman intended to remain in occupation until noscow agreed to a settlement on American terms.

American actions in Korea during the remainder of 1.946 effectively illustrated the limitations of the "patience with firmness approach." It was difficult to avoid pessimism regarding tine future of soviet-American ne gotiations in view of American actions fostering opposition to trusteeship and Soviet unwillingress to permit conservatives

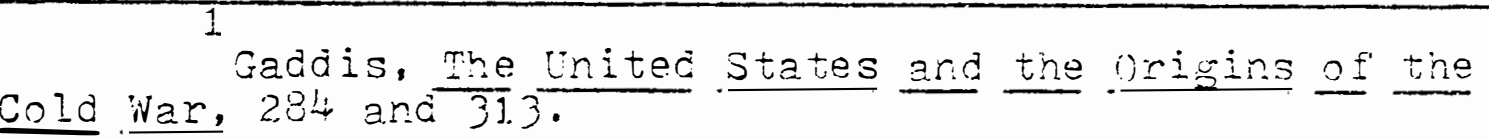


to obtain Dolitical power in Korea. Even Leahy recognized the probability of stalemate and creaicted a civil war during 1946. 2 Pernaps worse, Truman apparently believed that he could "out-wait" Stalin and force a Soviet retroat. Instead, Korea remained divided and Truman found "he could not by huffing and puffing blow the house dowr." 3 For Korea, "patience with firmness" only guaranteed the permanence of partition.

American military leaders clearly realized that more positive action was essential. The JCS expressed concern in January, 1.946, over the absence of long range plans for Korea, let alone a policy directive for the Joint Commission. General Full explained to Vincent that Hodge was a good man but needed intelligent political direction. Hodge's problems were, indeed, becoming more intense. USAFIK morale continued to be extremely low and the Alv officials still were unable to understand Korean society and poiitics.

Perhaps more important, tha Koreans were becoming more vocal in demanding the sale or distribution of previously Japanese-owned land holdings. Fodge had created the "New Korean Company" shortly after American arrival to reolace the "Oriental Develooment Company," which was a huge

Leany Diary Entry, January 1., 1946, Leahy Fapers, Box 5, Diaries 1.946, Lod.

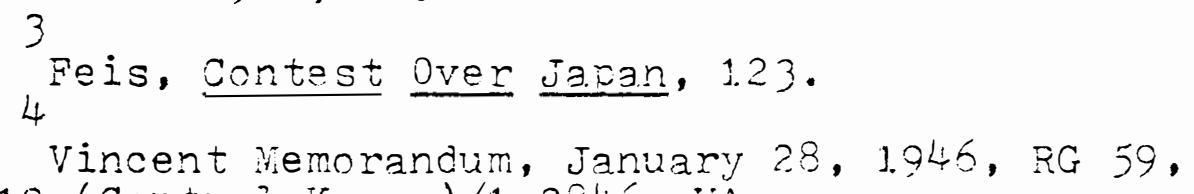


Japanese holding company ir control of shipyards, textile and shoe factories, iron mills, and chemical olants. In anticipation of the Joint Commission, Hodge requested permission to announce the sale of these possessions "in order to get beneficial local support and bargaining cower with the Russians." The State Department authorized orly the "transfer" of some farmlands, urban residences, and small businesses subject to the future provisional government's acproval of these transactions. The Aivg would maintain control over large Japanese industries and businesses, utilizing the profits for reparations and to offset the costs of occlipation.

In the absence of significant reform and long range plans, conditions in south Korea continued to deteriorate. Inflation remained high, living conditions poor, and wages inadequate. Hodge blamed his difficulties on Soviet obdurance and the State Department's refusal to follow in policy recommenciations. He demanded to know who was responsible for advising azainst immediate self-government and the abandonment of trusteeship. Warning that the Koreans were losing confidence in the United States, Fodge

Department of State, Korea 1945 to 1048, 28-31; Fenrenbach, This Kind of Har, 42; Lauterbach, "Ho dre"s Korea," $360-\overline{301 .}$

Bonesteel Memorandum, February 23, 1946, RG 31.9, Pro 091 Korea, Section I, Cases 1-1.4, 30X 87. NA; Eisenhower to MacArthur. Febmary $23,1.946$, FRUS, 1.946, Vol. VIII, $538-639$. Lauterbach, "Hodge's Korea," 361-362. 
unged the adoption of a positive policy to counter rising Soviet influence in the south. Koreans were so uneciucated and stubborn that they easily accepted and believed Sovist propaganda. Washington's policy of delay only increased the probability that Stain would obtain control over the entire peninsula. Fodge coserved pessimistically that "north and south will never be really united until the Russians are sure that the whole will be soundly communistic."

Moscow's initial policy in Korea had been cautious. But American acquiesence in the face of korean protests against the Moscow Decision forced a policy reappraisal. The Soviets considered Truman's actions in Korea as aggressive since the area was not vital to the national security of the United states. "To ensure control in a "friendly" Korea, the Soviet union placed its trusted clients into positions of authority in north Korea early in 1.946. Symbolic of the change was Chistiakov's decision to place Cho Mian-sik under nouse arrest. During october and November of 1945, the people had elected local. "People's Committees" based upon universal sufferage. 1.0 At a conference in Fyongyang during

NacArthur to JCS, Feoruary 2, 1.946, FRUS, 1.946, VoI. VIII, 628-630; Berger, The Korean Knot, 64-65; Forrestal observed at the time thet tode's main problem was his overreliance on "weal thy U.S.-educated Koreans," Millis (ed.). The Forrestal Diaries, 1.35; Lauterbach. "Hodge's Korea," 36 ?.

Sun, "A Preconceived Formula for Sovietization," in The Anatomy of Communist Takeovers, 48ó; romokins. American-

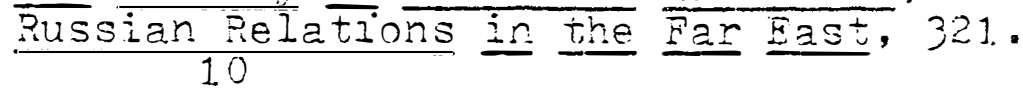

Beloif, Soviet Foreign Folicy in the Far East, 164- 
1.84

February, 1.946, representatives "elected" Kim Il-sung chairman oi the "Provisional People's Committee." Thile local elections reflected a considerable degree of popular participation in the selection of leaders, higher level a aministrative and political positions increasingly became the private preserve of Korean exiles. Yet, in contrast to American occupation policy,

the Soviet civil administration kept well in the background and gave the Koreans maximum experience in self-government. The Soviets made a determined efiont to see to it that the rank and file of the Korean administration as well as the mass of the people believed that they were resconsible for their own government.

Nioscow's public devotion to Korean self-rule averted popular charges of Soviet imperialism and alien domination. In actual fact, however, the Soviet Union maintained ultimate authority over events in the northern zone.

Nost Koreans favored sweeping social and economic changes. While the United States delayed action, the Soviet Union implemented a major program of land rejorm in varch, 1.946, expropriating the Japanese, collaborators, large Iandlords, and the church. 12 The North Korean regime aistributed this land without any payment requirement. Despite

165; Kim, Divided Korea, 96-97.

1.1

McCune and Grey, Korea Today, 180; John N. Washburn, "Russia Looks at North Korea," Pacific Affairs, XX, 2 (June 1.947), 1.52-1.50. 1.2 Kim, Divided Korea, 96; IncCune and Grey, Korea Ioday, 201-20?. 
oronibitions against sale and a high tax in kind, the people generaliy welcomed the ouster of the Japanese and the old ruling elite. ${ }^{13}$ hore important, possession of land gave the average Korean a stake in the new regime, while forcing the wealthy, the educated and those who had collaborated to flee southward. Langdon himself observed that the Soviet reforms have "fallen heavily on the unfortunate conservative and propertied classes, many of whom have taken refuge in our zone."

Ey June, 1.94ć, the Soviets had instituted the eight hour day, sexual equality, and nationalization of large industry, communications, transportation, and banking. Improvements in education and extensive ideological indoctrination produced a new elite dedicated to Korean political strength, economic prosress, ana reunification. ${ }^{15}$ A sense of mission and purpose characterized the North Korean military, police, bureaucracy, and communist party. During 1946, then, the Soviet Union had satisfied the popular desire for major reform and created the foundation for a Korean socialist state. With the exception of support for

Department of State, North Korea: A Case Studv in the Techniques of Takeover, 57; Washburn, "Russia Loks a North Korea," 1.56 ; Caldweli, The Korea Story, 63. 14

Langdon to Byrnes, August 23, 1946, FruS, 1.946, Vol. VIII, 728; Department of State, North Korea: A Case Study in the Techniques of Takeover, $6-7$.

Suh, "A Preconceived Formula for Sovietization," in The Anatomy of Communist Takeovers, 487; Nashburn, "Russia Looks at Nortin Korea," 1.56-1.58. 
trusteeship, roscow understood rorean society and politics much better than the United States.

Both the Soviet and American commanders thus sought to foster the emergence of a Korea that refleoted their own experiences and would be amenable to the international aims of their respective nations. Clearly, the United States was less organized and exhibited moro division of purpose, but, in many respectos, this was a self-inflicted wound. Nodego permitted the south Koreans to propagandize against trusteeship and denounce it as a form of foreigr domination. Yet, international control was at the heart of the Moscow Decision. 1.? Hodze believed that he could not abandon support for the conservatives without allowing a Soviet-domina tod minority to seize power. Ultimately, the united states would face an extremely difficult and unpleasant choice. Tmiman sould not simultaneously support the conservatives and naintain good faith in his relations with the soviet unjon.

American leaders remained confident that bilateral negotiations would achieve korean unification and independence. vincent publicly expressed the belief that the

Jon Ya?liday, "fhe Uritad Nations and Korsa," in IIthout Parallel, 1.1.2; Cho, Konea in Vorld Folitios, 1.31; Dalin, soviet Russia and the aar East, 257 .

aardrer, Introduction, in The Korean ian, 1.5; Veade, American Military Government in Lorea, 155. 
Joint Commission would constitute a successful test of Soviet-American cooperation in Asia. He stressed that the United States sought only the creation of a truly representative government and the rapid realization of Korean independence. "Korea," Vincent insisted, "must not become an international political football." Edwin Martin, Director of Korean Economic Affairs, observed that ecoromic unification remained the sole means for achieving economic recovery and political stability. He recognized, however, that the elimination of the 38 th parallel and the implementation of long-range plans would have to await the emergence of a Korean provisional government.

State Department planning for the Joint Commission began early in 1946. When Hodge requested instructions, however, the Administration had not completed its work. As a result, on February 1.1., the USAPIK Commander received an SWNCC policy paper that dealt only with point one of the Moscow Decision. Washington instructed Hodge to take no action beyond the formation of a provisional government. The SWNCC paper ordered the ANG to encourage "the various Korean political factions to reach fundamental agreement on the political, economic and social policies to be applied by the new government, including essential democratic reforms." Significantly, Mashington also instructed Hodse

Vincent and Vartin Commerts, Rauio Broadcast, NBC University of the Air, "Korea and the Far East," DSB, $X I V, 343$ (January $27,1.946), 1.04-11.0$. 
to rapidiy civilianize the military government and provide Iocal Koreans with the experience necessary to allow a rapid assumption of governmental responsibilities. In the event of a breakjown at the Joint Commission, Hodge would implement "Koreanization" in the southern zone alone.

Hodge's main concern was to obtain Soviet support for freedom of speech, press, and movement tinroughout the perinsula. If Moscow rejected this proposal, it woula be impossible to obtain an accurate cross-section of Korean ooinion. Thus, Hodge informed washington of his intention to base the American delegation's position on a demand for recognition of freedom of expression throughout korea from the outset of negotiations. Earlier in February, Hodge explained to Ambassador Karriman during the latter's visit to Korea that freedom of choice would oroduce a democratic government in Korea rather than a Soviet puppet. Uoon his return to yashington, Harriman conveyed to Truman Hodge's conviction that firmess was essential, because Stalin sought to extend Soviet ideology and territorial control throughout the Far East.

1.9 War to Hodge, February 1.1., 1.946, RG 31.9, P3:0 001. Korea IS, Section III, Case 3-1.5, NA; SWNiC Folicy Paper, January $28,1.946$, FRUS, 1.946, Vol. VIII, $624-62$ ?

NacArthur to Jos for Hodge, Eebruary $1.2,1.946$, FRUS, 1946, VOI. VIII, 632-633. 21.

Leany Diary Entry, February 21., 1946, Leany Papers, Diaries 1945-1.946, Box 5, LOC; Niew york Times, February $3,1.946,23: 1$. 
Soviet actions in north Korea alarmed Fodge, particularly after the creation of the "Provisional People's Committee." He believed that Lyun's party had joined Iorces with the northerners in return for the promise of political appointments in the puppet regime. Hodge explained that he would respond to the challenge in the following manner:

I plan to keep up prestige of the Korean Representative Democratic Council, make every effort to gain full backing of the Korean people, and discredit the Communists. This will probably get liberal and pink press of US on my back, but feel any other local action now would be iatal.

State Department officials expressed sympathy with Hodge's position and observed that the Soviets "are applying the same tactics they have applied in Eastern Europe in order to gain control. . through minority groups controlled by the Soviet Government." once again, the Truman Administration assumed that Soviet policy remained the same regardiess of geographic location. If Korean leftists were critical of American policy, they were acting under loscow's direct inflience and instruction.

Soviet-American relations in Korea were clearly on a collision course. Washington instructed rodge to issue a public statement indicating American determination to realize a free and independent Korea. It also approved Hodge's desire to insist upon the right of freedom of

Hodge to Har, Febmuary 24, 1945, FRUS, 1946. Vol. VIII, 641; Draft Nemorandum, Feoruary 28, 194t, RG 59, 740. 00119 (Control Korea),2-2846. NA; Nar to Hodge, March 1 , 1946, RG 218, CCAC 014 Korea, Section III, NA. 
expression in consultations at the Joint Commission. In the event of Soviet obdurance, Hodge would announce that Moscow had opposed free speech and elementary civil liberties. 23 The united states still believed that reunification would bring true economic health and political stability to Korea, but it was unlikely that the Joint Commission could sliccessfully end the partition. On Narch 6, Hodge announced his intention to allow all groups to express their opinions freely and not favor any particular faction or permit any single party to dominate. The Joint Commission would begin negotiations no later than Varch 1.3 and Hodge expressed hope for rapia progress.

Noscow's public criticism of American policy ir Korea indicated that success at the Joint Commission was unlikely. The Soviets dencunced Hodge's creation of the Representative Democratic Council as a violation of the Moscow Decision. In response, the State Department issued a statement denying any intention of unilaterally creating a separate government in south Korea. The United States was merely encouraging Koreans to participate in certain government functions in order to gain experience for the uitimate assumption of responsibilities after independence. 25 Noscon remained

\footnotetext{
JCS to MacArthur for Hodge, Fobruary 28, 1.946, BRUS, 1946́, VOI. VIII, 644. $2 ! 4$ New York Times, Narch 1, 1.946, 20:1, Harch?, $1946,2: 7$, and iarch 1.2, 1945, 1.5:5. 25 State Department Statement, "U.S. Folicy in Korea,"
} 
unconvinced and charged that Rhee had agreed to allow American businessmen ard financial groups to exploit the Korear economy and mineral resources. From the outset, it was quite clear that the Soviet Union would not permit Rhee to participate in the reconstruction of Korea. For the United States, Kim II-sung was equally unacceptable. During February, the northern and southern leftists and Communists formed a new "Democratic Feople's Front." Langdon expressed alarm over koscow's consolidation of control in the north and the increase in leftist agitation in the south. He predicted that korea would socn become "a. new Foland" in the oriert. 2? Truman agreed that the situation was dangerous. In a public address on April 6. 1946 , the President stressed that American efforts to foster rehabilitation and development in Asia were part of the American strategy for peace. Mile recognizing that the Soviet union possessed important interests in Asia, mruman insisted that hoscow had to respect the American desire for peace and security in the area. In reality, Truman hoped to improve American prestige and international

April 5, 1.946, DSE, XIV, 354 (ApriI 1.4, 1.946), 644. 25

Iangion to Byrnes, April 1.0, 1.946, Frus, 1.946,

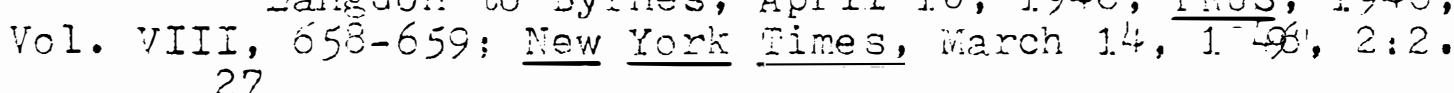
Langujon to Byrnes, rarch 19, 1.046, FPus, 1.946 , Vol. VIII, 6́48; New York Iimes, March 1.5, 1940, $5: 4$ and Varch $19,1946, \overline{1.4: 5}$. 28

تarry S. Truman, Army Day Adaress, Apriz 6, 1946, Public Pavers, Harry S. Truman. 1.946, 1.39. 
support at Soviet experse. If the United States was patient and firm, the Soviet inion would have no choice but to accommodate itself to American policy objectives.

on Varch 20, 1.946, the Joint Soviet-American Commission finally began its negotiations in seoul. General Terenty Shtikov's opering statement stressed that the provisional government had to reflect wide ropresentation and complete support for the Moscow Decision. In response, Hodge empriasized that only complete freedom of expression would ensure the creation of a democratic government. Thus, the Iines of disagreement were clear and, as in Eastern surope, Korea's fate hinged upon the ability of the great powers to resolve divergent interoretations of an international agreement.

Shtikov, during the early sessions, opposed the American proposal for nationwide consultations, favoring instead discussions within each individual zone. The smerican delegation, in its private cables, expressed dissatispaction with the Soviet position, viewing it as arbitrary. In adaition, Noscow's deternination to imolement the trusteeship asreement surprised American representatives in seoul. 31. During later

\footnotetext{
Curry, James E. Eyrnes, 309. 30

Hodge to Bjrnes, Werch 22, 1946, PRUS, 1946, vol. VIII, 652; New York Times, Varch 21, 1946, 24:2. 31.

Vincent to Williams, Warch 25, 1.946, RG 59, 50138
} 
sessions, Shtikov opposed any action that would treat Korea as a unit. He argued that the American proposai for a national "Consultative Union" was contrary to the hioscow Decision and unacceptable. Hoscow also rejected any suggestion of economic integration prior to the creation of a provisional government.

Despite these differences, the negotiators finaliy reached agreement on the first phase of the Joint Conmission's action, which would include consultation with partias, consideration of a platform, recommendation of a charter, and the choice of personnel for the provisional sovernment. The Joint Commission orgarized three subcommittees to dea.l with specific measures for attaining each objective, roscow was clearly willing to implement the roscow Decision, jut only if the United States agreed to a provisional government and trusteeship prior to reunification. Soviet Political Advisor G.i. Balasanov privately informed Langdon that roscow expected a successiul settlement in late hay.

Although there was ample reason for optimism, Hodge continued to issue pessimistic forecasts from seoul. Fe criticized Washington for its devotion to the efficacy of negotiations and its failure to consult him on tre

Korea/3-2.546, NA. 32 Korea, $/ 4-246$, NA. 33 Ibid.; New York Mimes, Varch 31, 1946, 14:1.. 
trusteeship policy. Byrnes" patience finally wore thin. In a letter to Patterson, he denied that Wlashington had failed to keep Hodge informed on the Noscow Decision. Byrnes confessed himself "somewnat perturbed by the attitude taken by General Hodge" in view of the relatively promising start in Joint Commission negotiations. The American Secretary of State ceminded Patterson that the United States was committed to the fulfilment of the Moscow Decision. Hodge's job was to cooperate with the Soviets, not to debate the wisdom of the trusteeship policy.

Patterson quickly responded to Byrnes and expressed agreement that interdepartmental coordination. was crlicial for the successflil formulation and implementation of American foreign policy. The secretary of war stated that during his recent visit to Korea Hodge's abilities had impressed him. He was confident of Hodge's earnest desire for cooperation. Even Harriman, Patterson explained, had been "so favorably impressed by General Hodge's ability and diplomacy" that the Ambassador was now expressing confidence in the possibility of a satisfactory solution to the korean problem. 3J Even the JCS expressed support for Hodge, observing that the State Department had probably not irformed the USAFIK

\footnotetext{
Byrnes to Patterson, April 1., 1.946 , ERUS, 1.946, Vol. VIII, 655 . 35 Fatterson to Byrnes, April 1.0, 1946, RG 59, 740.001 .1 .9 (Control Korea) $/ 4-1046, \mathrm{NA}$.
} 
Commander adequatelig. 36

An emerging deadlock at the joint commission scon overshadowed this dispute between the state and War Departments. Shtikov had made it quite clear that both commands had to agree on the parties for consultation and all such groups had to support the Moscow Decision. Soviet suspicion of American intentions increaseo when the American delegation announced that thero were five hundred legitimate parties and social organizations in south Korea eligible for consultation as compared to only forty in the north. When Shtikov objected to consultation with those groups hostile to trusteeship, Langdon stressed that Korean opposition to the Moscow Decision represented no legal criterion for the determination of legitimacy. Byrnes cabled support for the American delegation's rejection of the Soviet desire to exclude those parties opposing trusteeship.

fuite obriously, Woscow was using the trusteeship issue to exciude a sizable group of Konean leaders hostile to the Soviet union. Yet, the United States was in the unerviable position of insisting upon consultation with those individuals who sought to undermine the work of the Joint Commission. Vincent expressed sympathy for the Soviet position,

Craig Vemorandum, Narch 4, 1.946, RG 31.尹, P30 091., Korea, Section I, Cases 1.-14, Sox 87, NA. 37

Borton to Nilliams, April 2, 19,46, R.G 59, 50133 Korea/4-246, NA; Langdon to Byrnes, Apri1 5, 1.946́ and 3yrnes to Iangdon, 4pril 5, 1946, FEUS, 1046, Vol. VIII, 657-658. 
explaining that Stalin believed most Koreans supported the Hoscow Decision. Most Koreans opposed trusteeship "oecause of purposely distorted presentation by certain returned 'leaders' out of touch with the people, in order to get popular support to further their own ambitions." Byrres argued, however, that to disenfranchise an "overwhelming majority" of Koreans because of a disagreement over Korean readiness for independence would be unreasonable and undemocratic. The Joint Commission should refise to consult only with uncooperative extremists. In reality, fears of sovietization dictated the Administration's action. The United States believed that the exciusion ố the conservatives would ensire a Communist seizure of power.

Niany observers recognized that the abserce of published reports from the Joint Commission indicated probable difficulties in negotiations. Rumors of armed clashes at the 39 parallei added further alarm. on April 18, however, the deadock appeared broken with the publication oi a joint communique or consultation. The Joint Commission agreed to consult "truly democratic parties and social organizations" which signed a declaration pledging support for sovietAmerican decisions relative to the creation of a provisional government. bore important, the pledge included a provisior

Vincent to Byrnes. April 1.2, 1.946, PG 59, 5013 J Korea/4-1.246. NA; Byrres to Lanedon, Apriz 1.6, 1946. FuUS, 1.946 , Vol. VIII, 600-501. 39

New York Dimes: April 1.7, 1.946, 24:2. 
requiring all signators to support section three of the Noscow Decision, which specified trusteeship.

Hodge was satisfied with the compromise, since it appeared to allow rightist participation. The USAFIK Sommander now turned his attention to a more distasteful expectation. Fe believed that the Soviets would oermit consultation only with representatives of groups, rather than prominent individual laaders. Since "the southerr political structure includes almost equally leit. . and moderate-rightists, we would either have to nominate an unrepresentative slate for the south or expect its being outnumbered by combined strength of North ard South hoscow controlled groups." Hodæe recommended delay and consultation with "all schools of political thought irrespective of our estimate of their popular backing." In the meantime,

we shall build up evidence of exclusions of all but Ieftist parties in north and south and lack of racilities for Us to observe in the north. We will then demand either immediate lifting of 38 barrier and complete freedom in north for the political activities of mojerate parties on else acceptance of our viens in matter of composition of government, structure, etc.

If Moscow objected, Hodge believed that the "threat of fill publicity . - to which the Eussians have already shown their sensitivity" would force Soviet compliance。

\section{0}

Joint Commission Communique 75 , Apriz 1.8, 1.946, DSB, XVI, 395 (January 26, 1.947), i68-1.73. 41. Hodee to Har, April 20, 1.946, RG 31.9, Pso 09i, Korea, Cases 1-14, Section I, Box 87 , NA. 
Woscow soon indicated its strategy for determining the composition of the Korean provisional government. The Soviet Union argued with considerable justification that $a$ mere signature on a cledge provided no Euarantee of sipport for the roscow Decision. The Reprosentative Damocretic Council had already expressed publicly its opposition to trusteeship. Kim Koo and his supporters reserted havins to sign a decleration of support for a polioy they opoosad. Thus, Shtikov indicated his refusal to consult with those groups most vociferous in aritioism of the Nosoow Dacision. In response, the American delegation prepared for an open oreak with roseow over the issue of free expression. Acheson instructed the Noscow, Nanking, and Paris emoassies to stress American support anc Soviet opposition for an end to the 38 th parailel and freedom of speech throughout Korod in explairing the deadlock.

All Korean politicai Factions were becoming rostive over the absence of prograss at the Joint Dommission. Ierch assured korean conservatives that sioning the pledge would not orevent criticism of trusteeship. Leftists and communists denounced the United States for suroorting roationary elements and demanded the immediate withdrawal of all

\footnotetext{
Langdon to Byrnes, Apniz 14, 1.946, Bovs, 1.946. Vol. VIII, 660; New Yoris Times, Aorii 1.1. 1940, $3: 5$ aro April 23, 1046, 1.1.4. 43

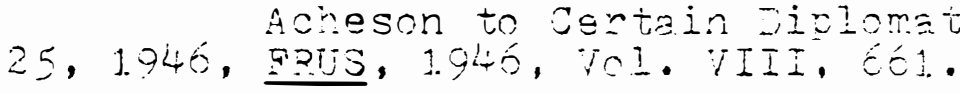


44

foreign troops. Scattered acts of violence and the discovery of assassination plots became common occurrences. (On April 27, Hodge predicted open warfare if the Soviet policy of delay and Communist underground activities continued. Te urged Soviet-American witharawal no later than January 1 , 1947, as the only means for achieving Korean incependence.

on Niay 7, Hodge informed washington of his intention to adjourn the Joint Commission sine die the following day Hodge offered several reasons to justify his action. First, American opposition to Soviet demands for the exclusion of parties not under its domination would bolster the morale of anti-Communist Korean nationalists, Second, supoort for free speech was a sound position internationally, since no nation would support penalizing individuals for opposing trusteeship. Third. Hodge reasoned that, if America forced Moscow to back down, popular pressure in the rorth would undermine the political position of the Soviet puppets. In conclusion, Hodge emphasized that, if "Korea is to be truly independent, the time for a showdown on Soviet oretentions is now." To acceot the Soviet position would result in minority rule and a violation of the Atlantic charter.

Langdon to Byrnes, April 30, 1.946, FRUS, 1.946, Vol. VIII, 563; New York Times, Aoril 28, 1.946 and Aprii $26,1946,8: 2$. 45

Iangdon to Byrnes, May 1.4, 1945, FRUS. 1946, Vol. VIII, 677; Dupuy ivemorandum, April 30, 1.946, R-G 31.9, PXo 01.4.1. TS, Section I, Case 1., Box 6, NA. 46 Fodge to Nar, Way ?, 1.946, RG 21.8, Leahy Papers. 
Quite obviously, the issue was far deeper than mene freedom of speech. Soth riashington and voscow viewed the Korean proclem in the larger context of their international competition. While the Soviet Union insisted upon the exclusion of those groups hostile to froscow, the united States demanded the inciusion of these same individuals as a. barrier to further Communist expansion. Veither side was willing to permit an "unfriendly" rorea.

\section{IV}

Deadlock at the Joint Commission corfirmed the permanence of partition and constituted the first step on the road to civil war. Langdon still hoped for a SovietAmerican agreement and urged Washington to cease arguing that trusteeship was not a vital ingredient of the roscow Decision. Not only dia hoscow view trusteeship as "something absolute and almost sacred," but Korean actions seemed to justify a period of foreign training and guidance. once convinced that the policy was not a barrier to independence, Langdon believed that the koreans would accept trusteeship. More important, with the creation of a provisional government and the withdrawal of the Red Army, the absolutist, reoressionist regime in the north would collapse. Mhus,

Korea 1.946-1.947, VA; Hodge to Viar, Nay 9, 1.946, PRUS, 1945, Vol. VIII, 665; New York Times, Vay $8,1945,1.0: \overline{5}$ 47 Saratian, "Hilitary Government: Korea," 352. 
Langdon's plan envisioned the emergence of a reunified horea if the great powers ayreed to a timetable for the completion of withdrawal by Feoruary, 1947 .

Lerch did not share Langdon's optimism regaraing the likelihood of xorean acceptance of trusteeship. In fact, Hodge's announcement of such a policy change would certainiy spark widespread rioting and disorders. Nor would the creation of a provisional government and the withdrawal of Soviet troops ensure the emergence of a democratic and indevendent Korea. Eerch recommended instead the creation of an "Allied Comnission" to supervise the restoration of Korean self-government and guarantee freedom of choice.

Washington rejected the recommendations of both Iangion and Ierch. Although the Administration appreciated rodge's difficulties, it did not believe that the time was right to oropose joint military withdraval. Stalin and the Koreans would view any indication of American departure

as a desire on our cart to rid ourselves of the responsioility ve have assumed in Korea. Despite protestations we might make to the effect that we had no intention of witharawing unless the Soviets withdrew simultaneously, those Koreans who now look to us for assistance. . . would despair and possibly seek security by aliening themselves with the soviets. The Soviets mold probably foster such an interoretation, and would themselves be encouraged to continue their intransigeance.

\footnotetext{
48 VIII, $677-670$. Langdon to Byrnes, May 8, 1.946, Frus, 1946, Vol. 49 VIII, 675 . Lerch Niemorandum, Nay 3, 1946, ERUS, 1946, 101.
} 
Washington insistad that the United States had to remain in occupation until Korea's independence was a certainty. "It would be most unfortunate," the War Department observed, "if the U.S. were to be placed in the position of naving freed Korea from Japanese domination only to facilitate subjugation, however veiled, by the Soviets."

Acheson informed Seoul on May 1.8, 1.946, that the United States would refuse to reopen Joint Commission negotiations until Noscow recognized the principle of freedom of expression. It was doubtful, however, that "patience with firmness" would alter the Soviet position. Truman believed that the wrongness of Moscow's position was obvious to all and international criticism would force Stalin to retreat. Wore important, Soviet support for consultation oniy with the advocates of trusteeship would discredit noscow inside Korea and compel the acceptance of the American stand. Noscow quickly indicated that the American strategy was not likely to succeed. on June 3, Pravda harshly criticized the United States for violating the roscow Decision and adjourning the Joint Commission without justification. The Soviets charged that Hodge was permitting reactionaries to to opoose the Hoscow Decision, while refusing to consult a number of parties that were truly democratic. Under no

\section{0}

Full and Bonesteel to macththur for hodge, way 1.1, 1946, RG 319, P\&O 01.4.1 IS, Section I, Case 1., Eox 6, MA. 51.

Acheson to Seoul, Way 1.8, 1.946, FRUS, 1.946, Vol. VIII, 680; New York Times, Way 1.1., 1946, 23:3. 
circumstances would the Soviet Union permit "imperialist forces" to use Korea "as a base and jumping-off place for an attack on our country." Noscow demanded complete support for trusteeship and rejected the legitimacy of those Koreans hostile to the Soviet Union. 52 It was clear that the Soviet-American impasse over Korea would continue. American occupation policy was also not contributing to a resolution of the Korean problem. Fodge still suffered from a lack of definitive guidance and was unable to inaugurate programs for the achievement of economic and political stability. His most striking failure was in the area of rice collection. The influx of refugees and the chaos of postwar conditions had created a serious food deficiency and Hodge instituted a program of forced requisitions to avert a crisis. The general public viewed the quotas as excessive and forcibly resisted collection. Hodge thus turned to the Korean police to enforce observance of the system. As a result, the police acquired farreaching powers for investigation and punishment, completely discrediting the AVG. Invariably, the police used its power to eliminate leftist opposition, frequently relying upon brutality and torture.

$$
53
$$

52

American Embassy in Noscow to Byrnes, July 1., 1.945, RG 59, 740.00119 (Control Korea),/7-146, NA; New Yock Times, Viay 1.6, 1946, 1.5:3; 3eloff, Soviet Poreign policy in the an East, 1.63 .

53

Vieade, American Military Government in Korea, 228229; New York mimes, August 6, 1945, 2: 
Hodge's concern for eariy American withdrawal prompted his heavy emphasis on the creation of an indigenous rorean militamy force. During February, 1.946, he opened a training school in seoul and solicited candidates from a number of quasi-military groups present in Korea since Iiberation. Hodge was so pleased with the results that he organized a "National Youth Association" to provide the manpower necessary for the eventual creation of a genuine Korean army. An jo-sang, graduate of jena and avowed admirer of Hitier's Nazi Youth, became the director of the new organization. Thile the united states provided the equioment and advice, An Ho-sang supplied a program of anti-Communist political indoctrination and strict discipline that lent itselif readily to rightist exploitation. By the summer of 1.946. Jouth groups of the left and right engaged in warfare and terrorism on a major scale throughout the zone. Patterson recognized the oritical nature of the situation and began to urge more decisive action. Late in Way, the SiNCo decided to authorize an election in south Korea for the creation of a Iimited ägree of representative government. The fascade of self-rule in the north, the SwNCC observed, claced fmerican military mile in south Korea in an unfavorabie light. Uoon the urging of the new

Government: Korea," 352; Fenderson, Politics of the Vortex, 142-144; Viccune and Grey, Korea Doday, 269. $5 !$

Sawyer and Hermes, Military Advisors in Korea, 12; Henderson, Politics of the Vortex, 1.41. 
American Ambassador in Noscow Walter Bedell Smith, Washington instructed Hodge to maximize the cooperation among Koreans in support of American policy. 55 Hodge appreciated the necessity for fostering the emergence of Korean political unity. In an attempt to demonstrate his impartiality, he ordered the closing of three rightist newspapers on charges of abusive, libelous, and inaccurate reporting. It was quite ciear, however, that the ANG was more concerned about the activities of the leftists. Iangdon noted that captured Communist documents indicated that Moscow intended to undermine American support, forge a united front, and seize control at the appropriate moment much as the Soviets had done in Eastern Europe. 57 Hodge complained that the Soviet. Consul General in Seoul was supervising a campaign of violence and terror to force American withdrawe?. At Hodge's urging, Byrnes instructed Smith to inform rolotov that, unless rioscow allowed an American Conslil General in Pyongyang, the Soviets would have to leave Seoul. As expected, Mosoow rejected reciprocity. Wuch to the pleasure

War Council Weeting Ninutes, may $16,1.946$. Fatterson Papers, General Correspondence, 1.945-1.947, Box 23, IOC; Leahy Diary Entry, April 26, 1946, Leahy Fapers, Diaries 1946, Box 5, IOC; SiniCe Vemorandum, nay 22, 1946, and Smith to Byrnes, niay 13, 1946, PQUS, 1946, vol. VIII, 680-6́81; Borton to wilizims, May 21., 1.946, R.G 59, 740.001.1.9 (Controi rorea) $/ 5-2146$, ivi. 56

VIII, 683-684. Emmons to Bymnes, May 22,1946 , FRUS, 1.945, Vol. 57 $700-703$. Langdon to Byrnes, June 7, 1.946, Frus, Vol. VIII, 
of Hodge, the Soviet Union announced that its Consul General would close on may $28,1.946$.

Iangäon fully supported the new American policy of "patience with firmness," believing it would force Woscow to compromise. Soviet strategy relied upon America's frustration and eventual withdrawal, which would permit a Communist seizure of power. Through unity, patience, and resolve, Iangdon observed, the United States could ioster the emergence of a strong, independent, democratic coalition and thereoy thwart the Soviet plan. The AlG had already begun preparations for the formation of a South Korean Interim Government (SKIG), while croadening the base of domestic political support for American policy. Such action did not satisfy Rhee and his supporters. Upon his departure from Korea, Preston Goodfellow strongly advocated immediate elections in south Korea alone and the transfer of governmental responsioilities to Koreans.

Edwin Paley's trip to north Korea during the early summer of 1946 was principally responsible for the

58

Smith to Byrnes, May 22, 1946, Byrnes to Smith, viay 24,1946 , and Smi th to Byrnes, June 5, 1.946 , grus, 1946 , VoI. VIII, $582-692$. 59

Iangaon to Byrnes, May 24, 1.946, Frus, 1.946, Vol. VIII, 685-689; Byrnes to Seolil, Nay 25, 1946, RG 59, 740 . 001.19 (Control Korea), $5-2546$, NA; New York Times, Way 24 , $1946,12: 2$. 
formulation of a more definitive American policy toward Korea. Fauley was Truman's representative on the Allied Reparations Commission and had expressed concern in December of 1945 regarding the reports of Soviet removals from Korea. () Decerner 7, Fauley had announced that a final assessment of reparations for Korea. would have to await an analysis of 60

the needs of the entire nation. In view of the temporary division of Korea, he suggested that a survey team inspect both the Soviet and American zones. On Warch 22, Pauiey formally requested Soviet permission to entec north Korea and determine the validity of reports charging large removals of industrial equipment from that area. Any removals would alter the requirements of recovery and require just compensation in zurope. If the mumors were false, only confirmation could ensure the preservation of Allied harmony.

Truman pubicly supported the croposal, arguing that only full knowledge of the resources and productive ability of nonth Korea would permit a orover formulation of a reoarations program ion Jagan and "any long range plan for the 62

poaceiul aonomy of East Asia." Initially, the soviat Union refused to reply. On May 1.3, Byrnes apain issued a

Fauley statement, Decomber ?, 1945, Mruman Pacers, PSn (Pauley), HSm. 61. PSi (pauley), HSTL. Truman, rarch 22, 1.946, Trumar. Fapers, Truman, Press Conferance Pemanks, may 2, 1946 , Public paoevs. Jarry S. Pruman, i.gís, $224-225$. 
formal request that Woscow allow Pauley to enter north Korea. To everyone's slirorise, two days later onistiakov granted cermission for the inspection.

Pauley compiled a detailed diary of his trip to the Soviet zone. Uoon his arrival on viay 29, Chistiakov assured him that the rumors of Soviet removals were without folndation. Fauley inspected a large number of pisiron, fertilizer, aluminum, and textile factories. The Soviets denied entrance only to a small area around Fungnam, arguing that the train ride to that area would require far too much time. While he did notice some generators crated for shipment, Pauley concluded that any looting was the product of illegal action on the part of the Koreans themselves. Upon inquiry, he found that many of those reporting Soviet removals had not actualiy witnessed such soviet action. After his return to seoul, Pauley reported that there was "no substantial industrial removals from the Russian-administered territory of Northern Korea." In marked contrast to ilanchuria, the Soviets were attempting to rehabilitate and restore north Korean industrial activity, rather than cripple recovery.

Pauley to Byrnes, May 1.0, 1.946, Memorandum, Undated, and Bymes to Pauley, Kay 1.5, 1.946, Robert I. Dennison Papers, Confidential, Sox 3, mite Fouse Nessages, Traffic 1946 , HSTI. 54

Pauley Diary Notes, June 20, 1946, Truman Papers, FSF (Pauiey), tSTL; Also in, Byrnes Fapers, File 503, CUI; New York times, June 6́, 1946, 1.0:3-4; Carter to violfe, tay 30, 1940, Dennison Papers, Confidential, Bok 3. FisTL. 65

Pauley Report. "Survey of Resources," JuIy 23, 
Pauley's final report to Truman had a decisive impact on the suosequent derelopment of America's Korea policy. It expressed concern that Korea was "not receiving the attention and consideration it should." The confrontation of democracy and Communism across the 38 th parallel. Fauley observed, meant that Korea was "an ideological oattleground upon which our entire success in Asia may depend." The Soviets recognized that the Korean economy was conjucive to the develooment of communism and intended to remain until its puppets possessed comolete control. Pauley warned that the loss of Korea would endanger the security of Japan and warned against any American concessions to the Soviet Union.

Pauley also offered a series of policy recommendations. First, the United States should inaugurate a propaganda campaign stressing Soviet violations of existing agreements, Second, the AllG should educate Koreans as to the advantages of the democratic system. Thind, American econonis aid to Korea For recovery was advisable. Finaliy, the United States should transfer a number of teachers and techniciana to Korea for the development of industrial growth. Unless the United States implemented a cositive program to meet popular neads and desires, eventual Soviet control over the entire peninsula was certain. Pauley's report impressed

1.946, DSB, XJ, 370 (Aligust 4, 1.946), 233-234; New York Dimes,

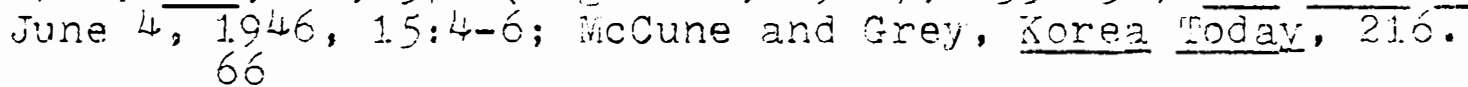
VIII, ?06-?08. Pauley to Truman, June 22,1946, ERUS, $1946, \mathrm{~V} 01$. 
Truman, who immediately arranged for a meeting with Byrnes to reassess American policy in Korea.

Early in June, 1946, Assistant Secretary of State for occupied Areas John H. Hilldring arrived at similar conclusions. He drafted a memorandum stressing the need to broaden the base of Korean participation in governmental affairs. Milldring based his recommendation on the following observation:

There is reason to interpret the collapse of negotiations in the Toint Commission as the result of a clash between united States insistence upon respect for the principle of freedom of speech and Soviet determination to prevent certain avowedly anti-Soviet Korean leaders from participation in a Provisional Korean Government. These leaders constitute a group of older emigre Koreans who have returned to Korea since the capitulation of Japan. They are not thought to be completely representative of Korean political opinion. nor are they felt to be essential to the establishment of Korean democracy or the attainment of United States objectives in Korea. On the other hand, their oresence on the political scene greatly increases the difficulty of reaching an agreement with the Soviet Union. For these reasons, it can be concluded that attainment, of united States objectives in Korea is on the whole hameered by their participation in korean politics.

Hilldring also recommended that the Arig continue to support coordination with the Soviets and attempt to resume Joint Commission negctiations. Hopefully, American observance of the Noscow Decision in combination with increased Korean

\section{7}

Ioid.; Truman to Acheson, July 3, 1.946, Truman Papers, PSF, BOX 1.60, Cabinet File, State Department, folder 2 (Acheson), HSTL. 
support for participation in southern affairs would force 68 Noscow to recognize the principle of freedom of speech.

Even economic advisor Arthur $c$. Bunce concluded that Hodge had to cease his overreliance on the extreme conservatives. In an article written for Pacific Affairs entitled "Can Korea be Free?," Bunce contended that Hodge's support for the right rather than the People's Republic had permanently polarized Korean politics. Perhaps worse, when Byrnes and Hodge chose to acquiese in the face of opposition to trusteeship, Soviet leaders became justiriably suspicious of American intentions. As a result, vioscow's definition of democracy as support for trusteeship was actually an attempt to oreserve national security and bar anti-Soviet Koreans from positions of power. Bunce concluded trat the deadiock would cease to exist only if "the U.S.S.R. could be convinced that the U.S. command does not intend to support any particular group of leaders and if the U.S.S.R. would open up the border so that the world ean know the conditions that exist in the north . .." Unless the Avg broadened the base of domestic support, distrust, fear, and misunderstanding in Soviet-American relations would continue. 69

Significantly, Fodge suporessed Bunce's article and rejected any request to allow its publication. As an

68

Hillaring ilemorandum for War Department, June 6 , 1.946 . IRUS, 1946, vol. VIII, 692-698.

Iangdon to Eyrnes, Text of Proposed Article, Jure 28, 1.946, RG 59,740.00119, (Control Korea)/6-2846, NA. 
American representative in Korea, Bunce's comments would completely discredit Hodge's claim of impartiality. Nore important, "patience with firmess" precluded an evenhanded analysis of the Soviet-American disagreement in Korea. For Hodge, the Soviet Union was not seeking to defend its national security, but pursuing a determined course of ideological expansion.

Truman placed American policy toward Korea on a more positive course during the summer of 1946, albeit belatedly Based upon Vincent's strong support for Pauley's recommendations, the President ordered Hodge to institute liberal reforms such as land redistribution and even nationalization of some industries. In addition, washington demanded that Hodge foresake his attachment to Korean clients in favor of a broader coalition embracing not only conservatives, but liberals and moderates as well. The War Department argued that broader Korean support would add substance to the American position and place pressure on Moscow to resume negotiations. The Administration would not consider a direct approach to Moscow at the government level unless political unrest in Korea reached crisis proportions.

\section{0}

Truman to Pauley, July 16, 1946, FRUS, 1946 , Vol. VIII, 713-714; War to MacArthur for Hodge, July 17, 1946, RG 319, Leahy Papers, Korea 1946-47, NA. 
Hodge decided to build the new coalition around Kimm Kui-sik. Kimm was well-suited for the role, since the old scholar-statesman had been the symbolic leader of the Korean left since world War I. Rumors quickly circulated that the AMG was preparing to create an interim council excluding extreme conservatives. It was obvious to all that the policy sought to increase popular slppont for the united states in the south and thus outflank the soviet inion. On July 1 , 1946 , Lerch announced a plan for the creation of a South Korean Interim Legislative Assembly (SKILA) that would be half-elected and half-appointed. He emphasized that the new body did not constitute a separate government, but was an attempt to discover Korean popular desires and foster supcort for American policies.

Such a policy, if implemented in september, 1945, mignt have contributed to the creation of a united, democratic, and independent Korea. The new moderate coalition's fortunes depended, however, on a negotiated settlement of SovietAmerican differences at the Joint Commission. 73 Juch an eventuality was no longer probable, altinough the wisdom and realism of the new American approach was a welcome change from past policy. Almost immediately, Lansdon reported

Benjamin Weems, "Benind the Korean Elections," Ear

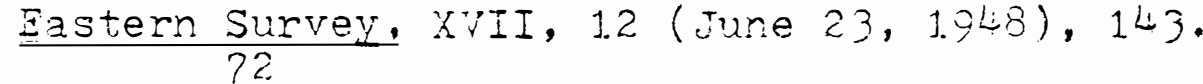

New York rimes, June 22, 1946, $2: 5$ and july 2 , $1946,1.7: 5 ; \mathrm{Kim}$, Divided korea, $69-70$. Fenderson, Politics of the jortex, 1.34. 
progress toward political unity. Kimm and Lyuh were able to join forces with relative ease, much to the chagrin of Rhee and $\mathrm{Kim} \mathrm{Koo.}$

In approving the SKILA plan, Hodge emphasized continued American support for the Moscow Decision. He predicted that the new program would foster the emergence of Korean democracy. Yet, elections alone would not resolve Korea's political problems, since the nation possessed no experience with democracy. The traditional reliance on community government decreased the likelihood that individual choice would prevail. Widespread illiteracy meant that the secret ballot was not possible, except at the final stage of an indirect election process. There also remained the disturbing problem of Syngman Rhee, who maintained considerable support because of Hodge's initial backing and his reputation as a patriotic leader. American Joint Commission delegate Edward Thayer recommended that Rhee "be gently eased out of the Korean political picture" since he "had outlived his period of usefulness." ${ }^{76}$ such was more easily said than done. After the SKILA announcement, the conservatives mobilized in an attempt to control the forthcoming elections. The extreme left, on the other hand, denounced American

\footnotetext{
Langdon to Byrnes, July 3, 1946, FRUS, 1946, Vol. VIII, 710-711; Kim, Divided Korea, 63. 75

$76^{\text {New }}$ York Times, July $10,1946,5: 1$.

Nemorandum of Conversation, Division of Japanese Affairs, July 16, 1946, FRUS, 1946, Vol. VIII, 715-716.
} 
policy as premature and in violation of the noscow Decision. Pak instituted an organized campaign to disrupt the KimmIyuh coalition, charging that the United States was playing a clever game to maintain control. Lyuh refused to succumb to such pressure and labored diligently to moderate leftist demands for rapid reform. 77 America's professed willingness to reopen negotiations with the Soviet Union also hampered Communist operations. Acheson publicly announced that the United States was prepared to resume the Joint Commission sessions at any time. Until negotiations resumed, however, the United States intended to encourage Korean participation in the military government and create conditions "under which political and economic democracy can flourish." Kimm and Lyuh thus experienced considerable success in reducing Communist political appeal and increasing leftist support for participation in the SKILA elections.

Hodge also implemented steps toward the creation of an SKIG, appointing Korean leaders to work with the various Arr bureaus in governing the country. Most south Koreans manifested a new sense of optimism over the opportunity to

77

Langdon to Byrnes, July 28, 1.946, FRUS, 1946, Vol. VIII, 720-721. 78

Langdon to Byrnes, August 2, 1.946, FRUS, 1.946 , Vol. VIII, 722-723; Acheson, "Anniversary of Korean Liberation," August 1.3, 1.946, DSB, XV, No. 373 (August 25, 1.946), 384; Velma Hastings Cassidy, "American Policy in Occupied Areas," DSB, XV, 372 (August 1.8, 1.946), 291; Communist involvement in a counterfeiting operation also discredited the party, New York iimes, July 30, 1.946, 7:1.. 
participate in governing thein cwn affairs. Enthusiasm resaraing the election of a legislature grew steadily. Leading Korean politicians joined Kimm Kui-sik in fostering political unity and anticipated virtual seli-government by early 1.947. At the same time, Hodge acted to resularize fiscal and economic policies, thus stimulating popular support for the AMG. The USAFIK aIso formed a Constabulary Army, supplied it with American equipment, and allowed it to participate in military mansuvers and anti-guerilla operations. By eariy 1.94?, the Constabulary had increased its prestige and effectiveness to the point where it could counter the police's frequent abuse of cower.

Communist leaders quickly recognized that American policy would soon rob tham of any influence in soitherm affeirs. Thus, Pak onganized a campaisn of strikes and disturbances to demonstrate jpoosition to separate government. The Communists also lised threats and bribes in an attempt to undermine the Kimm-Iyul coalition. Hodge quickly instituted a policy aimed at silencine communist opoosition throush closing newspapers ard arresting radical journalists. After a riot at Taegu in Octooer, loibs, hodge issued a warrant for Pak's arrest. While publicly

Werch to Shoeraker, Septemoer 16, 1946, Forar t. J. Johnsor Papers, Box 1. Correspondence, Genoral 1946-1071, HSML; New york Mires, September 1.5, 1946, 7:8; novune ane

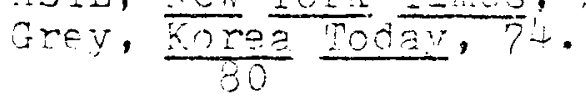

New York Simes, September 1.9, 1946. 1.3:2; Savyen and Germes, ilitary Avisors in xoras, $22-26$. 
claiming an impartial position, the USAFIK Commander allowed the police and youth groups to retaliate against the Communists. As a result, a vicious circle of violence prevaiied, as Korean rightist brutality provoked leftist retaliation thus producing further excesses.

Pising violence in south Korea jeopardized the success of Truman's policy of "patience with firmnass." The Communists were able to exploit continued inflation, persistent shortages, and the onerous rice collection program to undermine the popular support for the AVG. Despite murders, burnings, and sabotage, Kimm and Lyuh were able to marshal sufficient support for the creation of a "Coalition Committee" in support of American policy. Yet, Kimm and Iyuh found it increasingly difficult to foster political unity in an atmosphere of unrest, violence, and disorder. To a group of visiting American Congressmen, America's Korea policy appeared "urcertain, fumbling, confused . ..." In some respects, however, inaction was Hodge's only alternative, sirce intervention would bring charges of partiali by and repression from both sides.

81.

New York Times, August 25, 1.946, 23:5, September $29,1.946, \frac{1}{53: 3,3.12}$ Seotember? $1.946,1.6: 3,7 ;$ Caldwe11. The Korea Story, ó ; Kim, Divided Korea, 6́?

New York Times, 0otober 8, $1.946,1.0: 4$ and vctobor $10,1.946, \frac{12}{12 ;}$ ing don to Byrnes, November 1. 1.946, FRUS, 1946, Vol. VIII, $754-? 56$.

83

New York Times, Septambor 30, 1946, 1.2:2; Patterson to Hodge, (ctobar, 1946. Pattarson Fapors, General Correspondonce 1.945-194?, John P. Hodro, 3ox 20, LOC. 


\section{VII}

Hodge and Langdon soon reaiized that "Koreanization" was not sufficient to force Moscow to resume negotiations. In JuIy, 1.946, the USAFIK Commander expressed doubts that Soviet-American negotiations would resume in the near future and requested washington to relieve him of command. The State Department remained unwilling to authorize an approach to Noscow at the government level. Filldring argued that "the United States has more to gain by pursuing a positive constructive program in Korea than by demonstrating to the Soviets - - our anxiety to dispose of the Korean problem quickly." The SWNCC agreed, observing that Noscow would view such an approach as a sign ol weakness. 85 Washington also informed Hodge that trusteeship was a fundamental aspect of the Noscow Decision and the United States intended to support this provision. The Administration clearly refused to be impatient and expressed determination "to stick it out."

Many War Department officials shared Hodge's skeoticism

Hodge to War, July 1.4, 1946, NacArthur Favers, Box 5, Correscondence, VIP File, DMiL. 85

War Department Nemorandum, July 2.5, 1.946. R.: 31.9 , P\&0 091, Korea, Section I, Cases 1-14, 30x 87, NA; JCS Vemorandum, August $2,1.946, \mathrm{RG} 213$, COS 383.21. Korea $(3-19-45)$, Section VIII, NA. 86

Iincoin to Full, June 13, 1.946, RG 319, P\&C 092 TS, Cases 50-52, $30 x$ 30, NA; Killdring to SWNCd, July 25 , 1946 and Clayton to Iangdon, september 13, 1946, FRUS, 1946 , vol. VIII, 719 and $736-737$. 
regarding Tmuman's aporoach. Economic development of Korea would require a considerable degree of financial support ano the War Department's resources were inadequate for the task. Similarly, the Navy Department had indjcated its reluctance to furnish the necessary personnel for establishing a Korean Coast Guard. Probably in responso to War Dopartment complaints, mruman intervened. In a letter to Patterson, he oxpressed his conviction that the United States would have to remain in occupation of Korea for "a considerable longth of time." Successful implementation of Pauloy's recommendations would require adequate funds and experienced persornel. Iruman informed Patterson that he was instructing tho Navy Department to provide evory assistance necessary for the accompisisment of American objectives. The Stato Dopartment had aiready cromised complete support for Hodge. The President thon expressod confidenco that tho croation of political strongth and oconomic rocovery in south korea would compel "tho Soviets to mako the first stop towards tho rosumption of negotiations." 88

Hodgo and Iangdon rojoctod Truman's optimism and varnod that the United States could not ignora Koroan damands for immodiato rounification. If roscow continuod to raiuse to

\section{7}

Dupuy Nomorandum, Juno 13, 1.946́, 只 31.9, Ps0 091., Koroa, Section II, Caso 15, Sox 37, NA; Craig nomorandum, June 4, 1946, RG 31.9, P\&O 014.1. TS, Section I, Caso 1., Box 6. NA. 88

Truman to Pattorson, August 12, 1946 and JCS nomorandum, Auzust 2,1945, RG 319, CSA Koroa, WA. 
reopen the Joint Commission, America's position in Korea would soon become untenable. Bunce was far more sanguine about the cotential for successful imolementation of the Pauley recommendations. Fe agreed that the situation was difficult, but argued that, given sufficiont financial support, the United States could "outsit the Russians and sell democracy." These comments roinforced Washington's decision to persevere. It instructed the All to foster such policies as land reform, equal economic opportunity, trade unionism, and freedom of political expression.

Forrestal joined the state Department in expressing support for "patience with firmness." He pledged complete cooperation with the War Department in carrying out Pauley's proposals, but stressed "the desirability of clarifying the issues in the Far Fast in the minds of the Amorican public." Truman thus decided to issue a public explanation of the nature of American objectives in Korea. Acheson's statement omphasized that the United States was determined to fulfill tho Mosoow Docision, but not at the expense of the principle of national seli-determination.

89

Iancdon to Byrnes, August 23, 1946, PFUS, 1946, vol. VIII, 726 ; Hodge to War, August 8, 1946, J.S. Jivil Affairs Division Archivas, Record Groul 335 , VIDSCA 014 , Korea, 1.1. June 1.946, Section III, Box 249, NA. 90

Bunce to Byrnes, Alugust 26, 1946, FRus, 1946, Vol. VIII, 731.-733; Borton to Vincent, August 29, 1.946. RG 59, 740.0011 .9 (Control korea) $/ 8-2946$, NA. 01.

Forrestal to Truman, August $14,1.946$, James $v$. Forrestal Papers, Box 41 , "Momos to the thite House," PUI. 
American occupation was temporary and sought only to ensure Korean freedom of choice. Achesor stressed that the United States would yelcome honest criticism of its policies and favored complete Ireedom of expression. He urged Koreans to seek unity and cooperation for the realization of selfgovernment and to prevent a minority from seizing power.

Even if the Koreans supported Truman's oolicy, the successful implementation of Pauley's recommendations would require Congressional support, Langdon favored a Congressional resolution reaffirming American support for the Cairo Declaration and pledging "concrete assistance to the economy and educational rehabilitation of southern Korea. . .." Byrnes racognized that the new Korean policy would roquire considerabie financial assistance, but deniad Langdon's request. The Administration had not sufficiently cultivated Congressional support to achieve such a result. Then the United States presented the proposal to Congress, Byrnes promised to include Langdon's proposed resolution.

Truman's application of "patience with firmness" in Korea reflected a more basic trend in the American aporoach to relations with the Sovjet Union during the summer of 1946. Clark Clifford, who cecame special counsel to Truman

Acheson, "U.S. Mbjectives in Policy Toward Korea." August 30, 1946, DSB, XV, 375 (September 8, 1946), 462; NoN York $\frac{\text { Times, }}{93}$ August $31,1946,2: 1$ and September 1. 1946, 4:7. Langaon to Byrnes, September 14, 1.945, RG 335 , wDSCA 014 Korea, 11. June 1946, Section IV, Box 249 , NA. 
in July, added consistercy and a sense of pucpose to American anti-Sorietism in September with the completion of his "Russian Report." Whis document convinood Truman that granting concessions to Stalin only encouraged hoseow to soek furthor expansion. Voro important, Truman came to the roalization thet any ovidenco of indecision and vacillation on his oart reduced the Iikelinood of Conerossional slipport for "getting tough with Russia." The Frosident's decisior to cloarly vocalize Amprican opposition to soviot expansionism explains in largo measure Mmiman's dismissal of Socretary of Commerse Fenry A. Wallace. Congrossional suprort for Trumar's objectives in Korea and alsowneco was possible only if the Administration corvinced the nation that compromiso with sralin was no longer a viablo alternative.

Political factionalism and Communist-dineatad vioionoo in south koroa was, however, duickly undermining tho logio of Truman's aperoach. In addition, continuod Soviot control in the north wolld soon rendor rounification pormanontly impossible." As a result, the state Lovartmont continued to sook a rosumption of Soviot-Amorican nogotiations, while publicly exprossing its determingtion to bo vationt and firm. There acparad to bo roason for optimism aftor

94

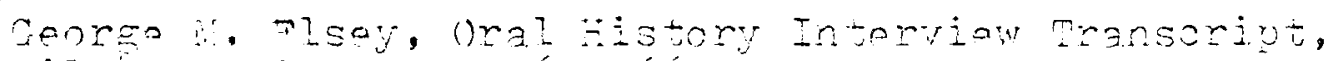

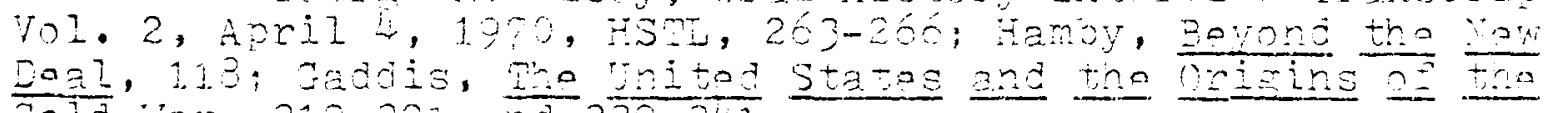
old $19 n, 31.9-32$. and $339-34$. Now York Dimes, octobor 1.1, $1046,1.0: 2$. 
Langdon visited the Soviet zone on Octobor 9, 1.946. During discussions, Soviot Political Advisor Balasanov informed Langdon that vioscow would never accept khee or Kim Koo for consultation because these two leaders were hostile to the Soviet Union. He also rofused to accept Americar aoproval of opposition to trusteesinip as compatible with support for the Hoscow Decisior. Langdon urged Balasanov to support the inclusion of Rhe and $\mathrm{Kim}$ Koo in consultation, arguing that both would eventually accept trusteoship. Balasanov violontly disagreed, but accepted a compromise nonotholess. Iangdon and Balasanov decided that a pledge not to undermine the work of the Joint Commission was sufficiont to warrant consultation.

Langdon roturned from Pyongyang with an oxtremely positive attitude. While in the north, he enjoyed not only froedom of movement, but also cordial and hospitable troatment. Fe quickly cabled the compromise agreement to fashington for aporoval. This would roquire all Koroan parties to promise not to "foment or instigate mass opposition" to oither the Joint Commission or the Moscow Decision. on october 26, howover, Chistiakov communicated to Hodge his willingness to rosume negotiations based only upon the "oxact fulfillmont" of the noscow Docision. ilth some justification, the Soviet leador obsorvad that it would bo

96

Langicon to Byrnes, October $9,1.946$ and Cotober $1.7,1946$, FRUS, 1946, VOI. VIII, 743-745 and 748 . 
counter-productive to discuss fulfillment of the Moscow Decision with Koreans whose pledge of support was "an empty doclaration." Chistiakov insisted that the trusteeship provision was fundamental and "democratic" partios supported it. The United States was responsiblo for the suspension of the Joint Commission and the Soviet Ceneral reminded Hodge that only the creation of a provisional government would open the door to reunification and recovory.

Hodge responded to Chistiakov on Novomber 1. and offered. the Langdon-Balasanov compromise as a basis for agreoment. The United Statos remained committed to the princiole of fropdom of expression, but Hodgo agroed that instigation of mass opposition to the Noscow Decision was improper and an abuse of free spoech. At the same time, the American Goneral attemptod to defond his provious actions. Ho insisted erroneously that the Vioscow Decision was not spocific on the nocessity for trustooship.

Chistiakov roplied on Novombor 26 and oxpljeitly stated that tho oxclusion from consultation of all Koroans who had proviously opposod trustoaship was ossential. Tho LangdonBalasanov compromise was not sufficient to guarantee that "roactionary parties and groups" would "rotroat from their hostile position towards the Moscow Eecision, but merely

1946 Ibid:; Langdon to 3yrnos, Novomoor 1, 1946, ERUS, 1946, Vo.1. TIII, 757-758. 98 VOI. VIII, 760 . Langdon to Byrnes, Novambar 2, 1.946, FXuS, 1946, 
curtail temporarily theic activities.. . so that they may have an opcortunity to take part in the consultation with the Joint Commission." Cristiakov insisted that the Soviet Union also supported freedom of speech, but pointed out that consultation with such groups would only hamper attempts to implement the Hoscow Decision.

Hodge quickly grasped at Soviet support for freedom of expression and suggested that the two nations were close to an agreement. Although exclusion of opponents of trusteeship violated the principle of freedom of expression, Hodge expressec his willingness to accept the soviet proposal of october 26 as the basis for discussion. The absence of any Soviet reply and the rigidity of Chistiakov's previous communications forced Bunce to conclude that illoscow had rejected the latest American proposal. As 1946 came to a close, it appeared that Soviet-American negotiations would never resume and Korea would remain a divided nation.

VIII

Hodge's efforts to build political stability in south Korea during the fall of 1946 were a total failure. The USAPIK Commander initially attempted to conperate with the

Langdon to Byrnes, December 12, 1.946, FPuS, 1.946́, Vol. VIII, 799-780. 100

"Proposals for Reopening Joint Commission," DSa, XVI, 395 (January 26, 1947), 1.68-1.73; Bunce to Vartin, December $31,1.946$, RG 59, 895.00/1.2-31.46, NA. 
"Coalition Committee." He organized a "Joint AmericanKorean Conference" to investigate the sources of the recent violence in the American zore. On October 4 , the "Coalition Committee" announced support for the creation of a legislative assembly, but attached certain conditions. The KimmIyuh group demanded the elimination of any American veto on legislation, exclusion of collaborators as candidates, recognition of the national authority of the body, and provisions for close observation and supervision of voting to 1.01.

ensure Iairness. Although Hodge's agreement to these conditions was doubtful, American policy was apparently experiencing a degree of success.

Cooperation was extremely short-lived, largely because Hodge completely mishandied the SKILA elections. On october 13. 1.946, Lerch announced that the Airg would conduct elections within five days. Lyuh immediately protested that recent disturbances provided a poor atmosphere for free choice and many leaders remained in hiding and would be unprepared for participation. Despite such cogent arguments, the AMG held elections from October 17 through 22 without disorder. Ierch announced that the SKILA would convene on November 3, thus signifying a major American success. Kimm and Lyur boycotted the election in protest over

\subsection{1.}

Langdon to Byrnes, November 3, 1946, and Langdon to Byrnes, November 14, 1.946, FPUS, Voi. VIII, 761.-768. 1.02 New York Times, October $16,1946,8: 5$. 
Hodge's unnecessary haste. As a result, and becalise Rree and Kim Koo controlled the administrative facilities, the conservatives scored a sweeping victory. Many collaborators gained election, while only fourteen of forty-five representatives were not extreme rightists. 103 The Aif constructed the election law to produce just such a result. Indirect election permitted the village "hetman" to control the selection of electors, while the taxpayer qualjfication meant over-representation for the Korean landlords. In the opinion of Aig official $\mathrm{E}$. Grant Meade, "tine majority of the people were in favor of the leit, but were too apathetic, cynical, and poorly organized to make a real contest of the election." In view of the intimidation, beatings, and mob-action of the previous month, no reasonabie individual could view the election as free. The "Coalition Committee" also charged police interierence, misrepresentation, and falsification of returns. The undemocratic and supericicial character of tine SKIIA election was apparent to all.

Hodge thus proceeded to undermine the position of the Kimm-Lyun group after diligently striving to foster its

103

Langdon to Byrnes, November 3, 1.946 , ERUS, 1.946 , Vol. VIII, 753 ; Neade, American MiIitary covernment in. Korea, 189; There is a complete list of ShILA members in the index to the USAFIK records, RG 8, ivacArtinu Papers. 104

NcCune and Grey, Korea Today, 78-80; veade, $\frac{\text { American Military Government in Korea, } 186-18 \text { ? }}{105}$

Mitche11, Second Failure in Asia, 1.8; Nocune and Grej, rorea Today, 80 ; Halliday, "The United Vations and Korea," in without parallei, 1.14-115. 
creation. Quite obviously, Hodge feared that the holding of truly free elections would produce a leftist victory. Communist dominance in the north meant that maximum rightist representation in the south was vital for the achievernent of some sort of balance. 106 Hodge did attempt to placate $\mathrm{Kimm}$ and promised to appoint more moderate delegates to the remaining forty-five seats, thus balancing the political complexion of the legislature. He asked Kimm to supply a list of perspective candidates and from it selected what one observer considered a fair cross-section of political thought. Yet, despite such efforts, the SKILA still pos-

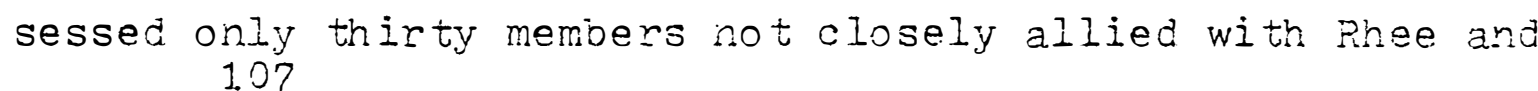
$\mathrm{Kim} \mathrm{KOO}$.

Hodge's appointments incensed Rhee. The conservative leader met with the USAFIK Commander and strongly oritiaized his actions. Hodge responded that he would not allow Rhee to either intimidate him or seize power illegally. Unaile to influence Hodge, Thee traveled to the United Nations in search of support. Upon arrival, he demanded that the United Nations obtain Soviet-American withdrawal and then admit a separate southern regime to the United Nations. Rhee's

\subsection{6}

Henderson, Folitios of the Vortex, 1.53-1.54; vieade, American Military Government in Korea, 1.86-j.87.

Langdon to Byrnes, ivovomber $24,1.946$, Langdon to Byrnes, November 3 and 14, 1946, ERUS, 1946, Vol. VIII, ?5́771 ; "Korea: Chronology of Principal Events, 1.945-1950," $\frac{\text { World Today, }}{1.08}$ VI, 8 (August 1.950), 321.

OIiver, Syngman Rhee, 229; Eerger, The torean 
activities threatened to undermine Truman's attempt to force Soviet compliance with the American interpretation of the Moscow Decision. Langdon speculated that Rhee was attempting "to steal the show at home," because the korean leader feared implementation of the Moscow Decision would rob him of political control. 1.09 To counter Rhee's strategy, the State Department instructed the AMG to reinforce the position of the "Coalition Committee" and the SKILA. In response, Hodge urged Rhee to announce the dissolution of the Representative Democratic Council, since "it no longer has any official status as an advisory body connected with the military government . . ." Hodge also ordered Rhee to return all equipment and vehicles that the ArG had loaned to the Council during its tenure of office.

Rhee quickiy accepted the American challenge to his authority. He issued a proclamation demanding immediate independence and national self-determination in south Korea alone. In the event of American refusal, inee instructed his followers to engage in violence and sitdown strikes to demonstrate that the United States was "helcless without

Knot, 70-71; Langdon to Byrnes, November 27, 1.945, FRUS, 1.946, Vol. VIII, ?72; New York mimes, December 6, 1.945 and December 1.1. $1.946,1.8: 4$. 1.09

Langdon to Byrnes, Decemoer 1.2, 1.946, Rpus, 1946, Vol. VIII, 775-778. 11.0

State Department Memorandum, December 1.3. 1.946, RG 59, 740.001.19 (Contro? Korez)/12-1.346. NA; NacArtrur fór Hodze to Vlar for Rhee, December 21, 1.946, RG 335. WDSCA 01. Korea, Section IV, 1.1 June 194ó, 3ox 249, NA. 
conperation oi his group." These were not idle threats. Aside from considerable popular support, Rhee also enjoyed control over those Koreans Hodge had appointed to positions in the SKIG. Understandably, the USAFIK Commander now appealed to Washington for assistance:

Rhee is nuisance in that he wants everything done his own imoractical way and wants to head separate Govt [sic] of South Korea. However, we cannot and must not overlook his potential to do irreparable damage unless carefully handled.

Hodge suggested that Goodfellow or Arnold approach Phee and convince him to foresake his attitude of confrontation. Washington decided instead to issue a statement disclaiming any American intention to create a separate government in south Korea. Hodge charged that "certain elements" were, through lack of knowledge or malicious intent, attempting to create the impression that the SrIIA was "a completely independent body designed as the forerunner of [a separate 7 government." He termed such assumotions "incorrect and dangarous," explaining that efforts to undermine American policy for "selfish political and personal gains" could only decrease the likelihood for korean unification, independence, and democracy. The Administration hoped that this strong statement of support for the Moscow Decision would deter Rhee from furthen attempts to 11.1

Hodae to Byrnes, December 31, 1.946, Frus, 1.946, vol. VIII, 735-786; 3unce to liartin, Lecember $3 \frac{5}{1}, 946$, RG $59,895.00 / 1.2-31.46, \mathrm{NA}$. 


\section{2}

create a separate government.

Unfortunately, Rhee refused to cease his attacks on the A MG and the Moscow Decision. Langdon reported that Rhee's "henchmen" were organizing a campaign of violence and obstruction designed to embarrass the united States. He urged Washington to issue a statement deploring such action and warning that opposition to the Hoscow Decision would preclude participation in any provisional government. The Administration quickly complied and printed Hodge's public order to Koreans to cease instigating opposition to the ANG. Significantly, Hodge's statement admitted that Korean dissidents engaged in "ill-advised political activity" were hampering progress at the Joint Commission. He expressed American sympathy for the Konean desire for indecendence, but warned that disorder, violence, and false propaganda only undermined international confidence in the Korean capacity for self-government.

American attempts to still Rhee's criticism were a complete failure. The old patriot now opened a personal

\section{2}

Hodge Statement, "U.S. Folicy Toward Unified Government in South Korea," January 4,1947 , DSB, XVI, 394 (January 19, 1.947), 1.28-129; New York Times, January 4 , $1947,8: 2$; Iangdon to Byrnes, January $5,1.947$, FRUS, 1947 , Vol. VI: The Far Fast (Washington, D.C.: Government Printing ()fice, 10,72), 596. 11. 3

Iangdon to Byrnes, January 1.7, 1.947. FRUS, 1.947, Vol. VI, 598-500. 11.4

Hodge Statement, "Activities of Dissident horean Groups," January 1.6, 194?, DSB, XVI, 395 (February 2, 1.947), 210; New York Times, Januamy 23, 194?, 1.5:1. 
attack on hodge, charging that the USAFIK Commander was responsible for the delay in granting Korean independence. In a personal letter, Rhee appealed to viacArthir for support in convincing Vashington to abandon the Joint Commission. He favored separate elections for a provisional goverment 11.5

in south Korea alore. The SKIIA then passed a resolution denouncing trusteeship and rejecting any attempt to compromise the principle of freadom of expression. Fodge complained that the great majority of Koreans opposed trusteeship and a fow rightist leaders were utilizing the issue to further "their own ends and rebuild a waning personal power." If the Joint Commission reconvened, Hodge admitted that the United States would have to support the exclusion of these groups from consultation.

Rhee's strategy was succeeding. The Unitad States could avoid a leftist-dominated provisional goverrment only through repudiation of the Noscow Decision. Hodge stressed that it was pointless to attempt to seli the idea of trusteesing to the Koreans:

The Koreans are insanely thirsty ior power and sovereignty. Although they are unfit for selfrule without guidance, they hypnotize themselves to believe that all ills, economic, political and social, would disappear over night if everything were turned over to them. They bitterly resent all control or talk of control.

\footnotetext{
1.1 .5

Rhee to MacArtrur, January 20, 1.947, MacArthur Papers, Box 8, Correspondence, VIP File, DNIIL. 11.6

Hodge to State, january $26,1.947, \mathrm{RG} 335$, WDSCA

01.4 Korea (1. Nov $45-31$ Jan 47 ), Section $v$, Box 249 , NA.
} 
Clearly, the creation of a separate government was not a panacea, because the korean leaders were incapable of cooperation. Thus, Hodge offered a dire prognosis:

Korea has developed into a real hot-spot of the orient, now rice for $a$ full-flodged civil war or unsurpassed savagery unless positive and cooperative international action is taken immediately. It is my carefuily considered opinion that unless the Joint Commission should successfully reconvene or positive action be taken in Korean situation on a national level wi thin the next two months, wo may lose the opportuniti of accomplishing our avowed mission in korea and will have iost the confidence of the Koreans.

Tragically, the USAFIK Commander could offer no specific recommendations for improving conditions or ending the Korean crisis.

$$
11.7
$$

Truman's policy of "patience with firmness" was then a complete failure. Soviet refusal to reconvene the joint Commission coupled with the worsoning economic and political situation in Korea convinced many American leaders that a policy change was imperative. The War Department, in particular, recognized that only Soviot-Americar withdrawal would lead to the elimination of the 38 th paralle 1 and the resolution of Korea's manifold problems. Unfortunately, American military and diplomatic capabilities in the area were extremely limited. Fodge hardly possessed onough ocwer to maintain a viable oosture in Korea, let alone appiy pressure on linoscow to moderate its position. Forhaps more

\section{1 .7}

Hodge to MacArthur for Var, January 20,194?, RG 335. WDSCA 014, Korea (1. Nov 46-33. Jan 4?), Section $v$, $30 \times 249$, NA. 
important, the ansiver in Korea was "simply another part of the solution of the worldwide conflicts of ideology betwoen democracy and communism." In the absence of a Soviet-American settlement in the very near future, the Nar Devartment favored withdrawal from the peninsula at the earliest possible date. 1.1.8

Soviet-American relations in Korea reached a totai doadlock at the outset of 1947 . Moscow rofused to permit extreme conservatives hostile to the Soviet union to obtain positions of authority in a Korean orovisioral govornment. Washington recognized, however, that the exclusion of the rightists would ensure a leftist victory. Truman's harsh words could not force the Soviets to moderate their stance; nor did holding firmly to principle increase the probability of a settlement. The reason for this unfortunate situation was, as Susan Hartmann explains, that "the Administration had developed a policy of verbal and diplometic firmness toward the Soviet union but had ragched no docision about deploying U.S. 1.19 deploying U.S. power to bolster this approach." The gap betweon American objectives in korea and the means availabie for achievement was significant and dangerous. Truman had to implement a positive policy or sacrifice any degree of credibility in the Soviet-American dispute over Korea.

\subsection{8}

Norstad Vemorandum, Novomoer 25,1946 , RG 319 , P\&O 337 TS, Jection I, Casas 2-24, Box 73, NA. 1.9

Susan nit. Hartmann, Truman and the 80 th Coneress (Columbia: Univorsity of inissouri Prass, $1.971 . \overline{\text { ), }} 48$. 
Chapter V:

An Avenue for Escape 
Soviet actions during the immediate postwar years convinced Truman that Stalin was determined to expand his political influence and territorial control beyond Eastern Furope. By the beginning of 1947, Truman had decided that Moscow's consistent "course of secretiveness, duplicity, obstructive hostility, and tacit ropudiation of agreements" demanded an American response. Yet, the popular demand in the United States for demobilization and a balanced budget seriously hampered the American ability to react. ${ }^{1}$ Perhaps more significant. Truman still hoped to limit the extent and duration of the American commitment to act positively in international affairs. After all, the United States could never protect every country from the threat of invasion and subversion without undermining its own national security and economic strength. only if each nation could develop the internal strength requisite for self-defense, could the United States assure the preservation of worldwide peace and stability at reasonable cost.

American policy toward Korea revealed clearly that Truman's attempt to "out-wait" Stalin was foolish. Not

Koenig (ed.), The Truman Administration, 5; Gaddis, The United States and the origins of the Cold War, $344-345$. 
only had Moscow refused to negotiate, but American occupation was becoming increasingly unpopular. "Koreanization" had begun, but Hodge's ineptitude had alienated the very group that Washington depended upon for the success of its policy. Rhee's activities presented a more persistent and dangerous problem. Inflation, power shortages, and insufficient food contributed to an economic crisis that discredited the AMG and spawned domestic violence. hodge observed in January, 1947, that most Koreans had abandoned any hope for the success of the Joint Commission. Washington's continued reliance on Soviet-American negotiations was only encouraging further dismay, discouragement, and declining Korean morale. ${ }^{2}$ American leaders attempted to improve conditions through the resumption of international triade and the encouragement of American investment in south Korea. Vincent explained that only economic interaction could foster prosperity and political democracy. 3 Yet, it was unlikely that businessmen would undertake such a risky venture, since complete Communist control seemed probable. As early as October, 1946. Hodge predicted that the North Koreans would invade the American zone within six months. He urgently requested additional troops and permission to terminate forcible rice collection, to strengthen

Hodge to War, January 17, 1947, Johnson Papers, Box 1, Korea-General File, HSTL. 3

Vincent, "American Business with the Far East," LSB, XV, 386 (November 24, 1946), 959-963. 
the rightist youth groups, and to publicly dencunce the Soviet linion for attempting to subvert the Aing. Hodge even addressed a personal letter to Patterson emphasizing the seriousness of the Korean crisis:

As you know. ... things are far from smootin. The two basic causes are that the Rorsars want their own country to themselves and that the Russians are constantly infiltrating their highly trained and indoctrinated agi.tators into our zone to take full advantage of eveiry possible point in the low level economic situation that can cause discontent as well as marufacture $a$ lot of points that are without the sligntist basis in fact. The international flavor is becoming heavy and there can be no question but 35 to the worldwide pusi of Comminism with the main all-out effort now Airectod against the United States. I hope our nation wakes up before we become too saturated with the Soviet brand of "democracy." 4

Despite such appeals, Washington reiused to approve Hodge's recommendztions. Both Vincent and MacArthur agreed that it would be "entirely inappropriate" to utilize the youth groups for defenso. Since Truman still hoped for a resumption of soriet-American negotiations, the State Department refusad to acouse Moscow publicly of subversion.

By early 1947 , however, many American leaders came to share Hodge's pessimistic attitude. The JCS Plarning Committee, for example, concluded that finerican withdrawal

ViacArthur for Hodge to Eisenhower, October 28 . 1946, ERUS. 1946, VOI. VIII, 750-751; Hodge to Patterson, Novemoer 5. 19to, Patterson Papers, Box 20, General Corrospondence, 1945-1947, John R. Hodge, LOC. 5

War Depertment remorandum, October 29, 1946, RG 319 , Pio 09a TS, jection $Y-A$, Part I, Case $35.30 x$ 31, NA; Vincent to Byrnes, Detober 29, 1946, FRUS, 1946, Vol. VIII, 751-752. 
would "leave Korea's politically immature people open to control through highly-organized Communist minorities." Yet, the study predicted that the Soviets would obtain at least indirect control throughout korea by 1956 regardiess of American actions. Faced with such a dilemma, Truman searched for an avenue of escape that would resolve the conflict between American prestige and security interests in Korea and the limitations on American power.

Soviet actions in North Korea during early 1947 added additional pressure on the Administration to alopt a new course of action. The "Provisional People's Committee" had virtually completed its reform program by the end of 1946 and held elections from November to March, 1947. As anticipated, there was only one candidate for each office to gain approval or rejection.? In February, a "Congress of People's Committees" convened to approve retroactively all previous reforms and adopt a national economic plan for the completion of nationalization and the consummation of agrarian collectivization. The Congress then created a permanent "Feople's Assembly," which in turn "elected" a Presidium and organized a Supreme Court. Clearly, Soviet

\section{3}

JCS Planners, "Estimate of Probable World Situation Up to 1956," October 9, 1946, RG 218, CCS 092, NA. Dallin, Soviet Russia and the Far East, 291; Beloff, Soviet Foreign Policy in the Far East, 166.

Dallin, Soviet Russia and the Far East, 292; Beloff, Soviet Foreign Policy in the Far East, 16Z; NoCune and Grey, Korea Today, 173; Kim, Divided Korea, 105-106. 
actions did not occur in a vacuum. Much as the united States fostered the emergence of Korean self-government, so too was Moscow fashioning a separate regime.

State Department officials continued to support the patient pursuit of previousiy established objectives. For them, negotiations at the Joint Commission remained the most promising course of action:

Our position in Korea is cleariy hopeless unless cooperation with the Russians can eventualiy be achieved. Unilateral action must be presented as a shortrun course which has been forced upon us. Our program, it should be emphasized, is a means of demonstrating to the USSR that cooperation is desirable.

Hugh Borton and Edwin Martin of the Division of Northeast Asian Affairs insisted that a friendly and prosperous Korea was crucial to Asian stability, but would be possible only after reunification. If the United States demonstrated its determination to fulfill its commitments and willingness to cooperate with the Soviet Union, Korea would eventually gain a democratic gevernment and national independerce.

Hilldring vocalized State Devartment policy toward Korea on March 10, 1947, before the Economic Club of Detroit. He emphasized that the United States could ill-afford to ignore events in Korea, because stability throughout Asia. was crucial for American national security. At the same time, the United States possessed a unique opportunity to

Gross to Borton, January 6, 1947, RG 59, 740.00119, (Control Korea)/1-647. NA; New York pimes, December 29 , $1946,19: 1$. 
demonstrate "what American democracy can accomplish in renabilitating the economic, social, and political life oi a country impoverished by four decades of bondage." Success in Korea would not only contribute to the improvement of Soviet-American relations, jut also foster the maintenance of the open door throughout Asia. Failure to fulfill America's moral obligation, on tne other hand, would produce "discouragement and disappointment to democratic peoples everywhere . . , and the damage to real democracy throughout the world would be incalculable."

- Hilldring then summarized American wartime commitments regarding Korea and recounted the course of Soviet-American negotiations under the Moscow Decision. He stressed Soviet responsibility for the continuation of the 38 th parallel. while indicating American willingness to reopen negotiations at any time. In the meantime, however, the United States would continue to fortify its position in south Korea and insist upon the achievement of its objectives. In closing, the Assistant Secretary of State expressed optimism that, despite numerous difficulties, a new Korea would emerge enjoying economic self-sufficiency, as well as political freedom and independence. 10 He failed, however, to outline the means that the United States would utilize to achieve this noble vision of Korea's future.

\section{0}

Hilldring Address, "Korea-House Divided," March 10, 1947, DSB, XVI, 403 (March 23, 1947), 544-547. 
War Department pressure was undoubtedly the most significant and persistent factor involved in Truman's decision to reconsider his Korea policy. During January, manpower and material shortages placed the continuation of American occupation in doubt. The War Department could no longer finance a commitment that had reached a cost of one million dollars per day. Hodge continued to cable pessimistic reports from Korea and strongly urged the development of a "positive line of action." Patterson decided to press the State Department for the acquisition of enough funds from Congress to prevent the necessity for American with drawal.

On January 22, 1947, MacArthur offered a. series of proposals for breaking the Soviet-American deadlock. His recommendations included the submission of the Korean issue to the United Nations; the formation of an international commission of disinterested nations to devise a plan for fulfilling the Cairo Declaration; a four-power conference to clarify the Moscow Decision; and finally, a high level Soviet-American conference to resolve basic issues preventing reunification and independence. Further delay, MacArthur warned, would be disastrous for the Korean people,

11

Norstad Memorandum, January 4, 1947, RG 319, P\&C 091. Korea, Section III, Cases 16-50, Box 87, NA; Hodge to War, January 17, 1947, RG 335, WDSCA 014, Koroa ( 1 Nov 4631 Jan 4?). Section V, Box 249, NA. 
Allied wartime commitments, and American prestige and 12

influence in Asia.

On January 23, General Iincoln forwarded a series of recommendations to Howard C. Peterson, Assistant Secretary of War. This memorandum rejected ViacArthur's proposals as premature, as well as the alternative colirse of immediate Korean independence. Iincoln proposed instead that the United States redouble its efforts to acnieve an agreement with the Soviet Union, while transferring administrative responsibility from Hodge to the State Department. Vincent read the memorandum and agreed that ViacArthur's recommendations were impractical because each would fail in the absence of Soviet cooperation: A new approach to Mioscow, on the other hand, was probably useless and would indicate American impatience. Vincent supported $a$ request to Congress for Iifty million dollars to continue American occupation. The State Department remained coniident that "patience with firmness" would end Soviet obdurance. 13

Patterson voiced the military's position at the SWNCC meeting of January 29. He explained that Korea was the "single most urgent problem now facing the War Department." After noting the inadequacies in transportation, electrical

12

MacArthur to War, January 22, 1947, RG 335, WDSCA 014, Korea ( 1 Nov 46-31 Jan 47). Section V. Box 249. NA. 13

Lincoln to Peterson, January 23, 1947, RG 319, P\&O 092 TS, 1946-1948, Case 85, NA; Vincent to Marsinali, January 27, 1947, ERUS, 1947, Vol. VI, 601-603. 
power, and fertilizer, Patterson complained that the absence of able Korean political leaders only magnified America's problems. In addition, further negotiations with the Soviet Inion would be pointless. Despite these problems, the SWNCC determined that continued occupation of Korea was essential. Truman's advisors decided to approach Congress with a request for financial assistance to prevent a potential economic and political collapse. The SWNCC also created a Special Inter-Departmental Committee composed of Arnold, Penfield, and $J$. Weidon Jones of the Bureau of the Budget to formulate a positive program for aid to Korea.

After studying the Korean problem, the Committee concluded that the continuation of present policy would produce an untenable USAFIK position. Granting independence, on the other hand, would only foster continued economic deterioration and lead eventually to Soviet domination. It seemed andesirable to refer the matter to the United Nations or the CFM, since such action would constitute an admission of failure and draw Soviet charges of bad faith. The Special Committee recommended instead a three-year program of six hundred miliion dollars to guarantee the strength of American occupation. Such a program would demonstrate to Congress Tmuman's determination to fulfill American commitments and to Moscow the extent of America's resolve.

\section{4} 15

Millis (ed.), The Forrestal Diaries, $241-242$. Memorandum of the Special Inter-Departmental 
Truman finally possessed an aggressive, positive program that would provide a stable basis for Korean independence and promote popular support. The Committee's recommendations constituted in essence a decision for the creation of a separate government. The study portrayed Soviet-American relations in Korea as a test of strength and assumed that, if the United States spent enough money, Stalin would be unable to match the effort and would have to retreat. Any sign of weakness would only undermine the policy. The United States, ran the Committee's recommendation, should also raise the Korean issue at the next CFM meeting in order to publicize Soviet inflexibility. The State Department supported the program, although it stili opposed any American approach to the Soviet government for a resumption of negotiations. 16

If Truman adopted the Special Committee's recommendations, he would have to obtain Congressional support. In 1946, however, the Republicans had registerod signipicant gains in the midterm elections. For the first time since 1930. the Democratic Party was in a minority in both the House and the Senate. As a result. Truman and his advisors feared Congressional opposition to foreign aid and military

Committee, February 25, 1947, FRUS, 1947, Vol. VI, 609-613: State Department Memorandum on Korea, January 13: 1947, RG 59, 740.00119 (Contro1 Korea) $/ 1-1347$, NA. 16

Ibid.; Vincert and Hilidring Viemorandum to Marshall. February 28, 1947, FRUS, 1947, Vol. VI, 613-619. 
expenditures. Such apprehension was justiried; Congress proceeded to cut six bilizon dollars from the budget to allow a reduction in taxes. 1 ? Truman benefited, however, from the presence of a new secretary of State. George $C$. Marshall enjoyed Truman's unqualified trust and respect, while inspiring confidence even among Congressional critics of the Administration.

Marshall's assumption of control at the State Department clearly pleased the War Department. American military Ieaders believed that Marshall would favor withdrawal from Korea at the earliest possible date. They urged Patterson to support the Special Committee's recommendations, al though they doubted Congressional approval of aid to Korea. The War Department also placed great emphasis on the need for a final approach to the Soviet government to reopen negotiations. Patterson conferred with Marshall and conveyed to him the views of the military. He stressed that witharawal was imperative, either in corjunction with the Soviets or after the creation of a separate south Korean regime.

\footnotetext{
17 18 Jones, The Fifteen Weeks, 90-91.

Daniels, The Man of Independence. 316; Alexander Deconde, "George C. MarshalI (1947-1949)," in An Uncertain Tradition, 248; See also, Robert H. Ferrell, George C. Marshall, Vol. XV: American Secretaries of State and Their Diplomacy, edited by Samuel Flagg Bemis and Robert Ferreli (New York: Cooper Square Publishers, 196?). 19

Norstad to Patterson. Febriary 25, 1947, RG 319, P\&O 092 IS, 1946-1948, Case 85, NA; War Department Intelligence Division Memcrandum, February 11, 1947, RG 319 , P\&0 091. Korea, Section III, Cases 16-50, Box 87, NA.
} 
In Korea, Langdon arrived at conclusions resembling those of the Special Committee. He recommended the building of a strong constitutional, representative, denccratic regime in the south under the leadership of Kimm Kui-sik. A constructive program of economic assistance coupled with "Koreanization" would foster the emergence of a genuinely moderate political majorjty. If successful, the American policy would prevent Rhee from seizing power and pressure the Soviet Union to cooperate at the Joint Commission. Hodge returned to Wasinington to urge the adoption of a more positive program in Korea. Patterson pressed mruman to meet with the USAFIK Commander to discuss the critical nature of the Korean situation. The Secretary of War considered Hodge "a splendid soldier" and stressed his "brilliant tighting record in the Pacific."

Truman conferred with Hodge in Washington on February 24, 1947. The USAFIK Commander focused his comments on the economic distress and political chaos in the American zone of occupation. yodgo empnaticaliy stated that only $a$ Soviet.-American agreement would provide for the rosolution of Korea's difficulties. Evidently, Hodge's comments impressed the President, since Pruman authorized one final

\footnotetext{
20

Langdon to Marshall, February 20, 1947, ERUS, 1947. Vol. VI, 607-608. 21 Marshall to NacArtiur, February 7, 1947, ERUS, 1947. Vol. VI, 606; Patterson to Truman. February $19,1,47$, Trumar Papers, OF 471, IIST; See also, Patterson Papers, General Correspondence 1945-47, John R. Hodge, Box 20, LOC.
} 
overture to the Soviet Union. In his public comments after the conference, Hodge strongly criticized Moscow for creating a powerful army in north Korea in clear viclation of the Moscow Decision. He speculated that the military force included five hundred thousand troops. This placed south Korea at the mercy of its northern neighbor.

Hodge also appeared on February 25 before the Senate Armed Services Committee. In his recollection of the testimony, Senator Harry Byrd remembered Hodge's warning that, in the event of American withdrawal, the northern regime would initiate an invasion to gain control over the entire peninsula. It is doubtful whether Hodge recommended continued occupation, but probably emphasized instead the need for a negotiated settlement. 23 At any rate, Marshall held $a$ press conference the same day and announced trat he had ordered a new study of American policy in Korea. The New York Times concluded that the Administration was intending to prevent the emergence of a "new Poland" in

\section{2}

Truman, Years of Trial and Hope, 323; New York Times. February $25,1947,1: 1$.

Patterson to Hodge, February 24, 1947, Patterson Papers, General Correspondence, 1945-1947, Jonn R. Hodge, BCx 20, LOC; Henderson contends that Hodge urged Congress to support continued American occupation. Politics of the Vortex, 150. The record he cites does not, however, provide such evidence, U.S. Congress, Senate, Joint Committee on Armed Services and Foreign Relations, Military Situation in the Far East, Hearings to Conduct an Inquiry into the Military Situation in the Far East and the Facts Surrounding the Relief of General of the Army Douglas MacArthur from his assignment in that, Area, Vol. III, 82nd Cong., ist sess., 2008 . 
Asia. It predicted that Marshail would raise the issue during the April CFM meeting in Mioscow. If the Soviets refused to cooperate, the United States would proceed to create a separate government in south Korea.

\section{III}

Truman confronted an extramely difficult situation in Korea during the early months of 1947. The crisis in Greece, however, forced the Administration to defer action on Korea and focus its attention on events in the eastern 25

Mediterranean. In response to the emergency, Truman delivered $h$ is famous March 12 speech to Congress requesting economic and military assistance for Greece and Turkey - of particular importance was Truman's pledge to "assist free people to work out their destiny in their own way." The "Truman Doctrine" pleased Leahy greatly, as Truman rejected isolationism with the "directness of a soldier and the 26

vision of a. statesman." Many scholars have accepted Leahy's evaluation and argued that the "Truman Doctrine" represented a revolution in American foreign policy. For them, the United States renounced isolationism in 1947 and

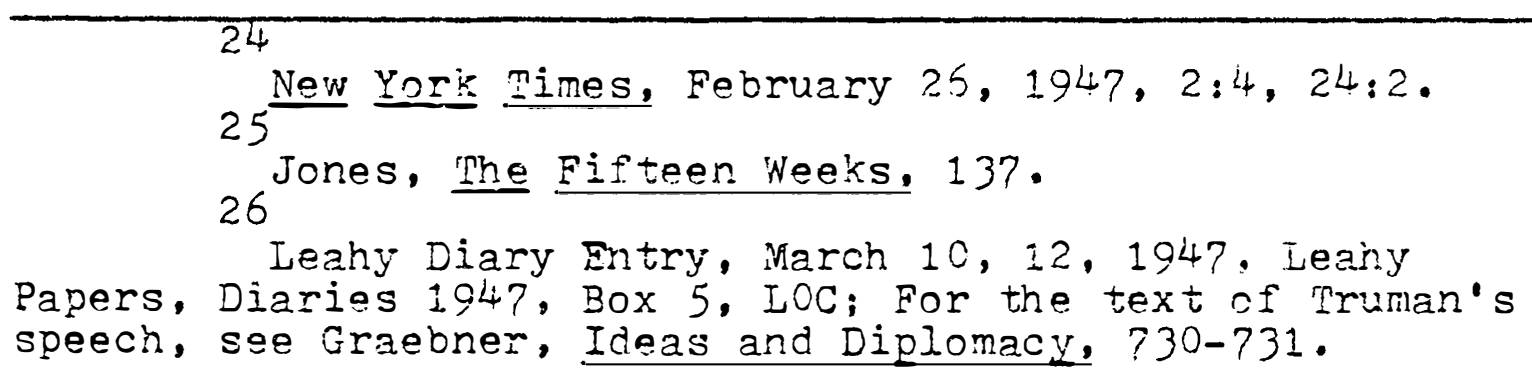


accepted the responsibility for preventing the expansion of Soviet power and ideology.

One must seriousiy question the conclusion that the "Truman Doctrine" really constituted a major turning point in postwar American dipiomacy. The United States had already indicated opposition to totalitarianism during world War II and had implemented certain measures to counter the Soviet threat. The failure of "patience with firmness" had forced an alteration in tactics, but the basic strategy remained intact. Truman now sought to contain the Soviet Union through the use of economic assistance and such a policy required Congressional support. Thus, the crisis in Greece and Turkey was merely the first occasion requiring Truman to request an appropriation of funds. The "Truman Doctrine" speech was then only the public enunciation of a previously adopted approach to the Soviet threat.

Many scholars have aiso ignored the essentially limited nature of the means Truman intended to use in countering the Soviet challenge. The President himself stressed that "our help should be primarily through economic and financial aid which is essential to economic stability and orderly political processes." At relatively low cost and without the loss

27

Selig Adler, The Isolationjst Imoulse (New York: Abelard-Schuman, 1958), 406; Rostow, The United States in the World Arena, 208; Ferrell, Goorge $\frac{\text { C. MTarshali, } 74-75 .}{28}$

Smith, Dean Acheson, 47; Gaddis, "Was the Truman Doctrine a Reai Turning Foint?," 389; Hartmann, Truman and the 80th Congress, 54; May, "Lessons" of the Past, 44. 
of American lives. Truman expected to halt Soviet expansion through a limited commitment to foster local self-defense. As a result, Tmiman and his advisors "regarded containment as an escape from the nightmarish choices of letting the Communist juggernaut go unhalted, or else going to war to stop it." Such an approach was, as Joseph Marion Jones explains, "not an illogical extension of lend lease." 29 Truman feared, however, that Congress and the American public would not accept the financial burdens that were entailed in the adoption of containment. The Republican Party had indicated its determination to reduce government spending and thus satisfy the traditional public desire for lower taxes. Such an emphasis on economy threatened to circumvent Truman's strategy. The President recognized that he had to educate the general pubiic to the necessity for accepting the responsibilities of world leadership. $30 \mathrm{He}$ thus decided to "scare heli out of the country" and portinay the Soviet threat to American security as immediate, dire, and global in proportions. The speech appealed to extreme emotionalism and described a worldwide and inescapable conflict between two ideologies:

At the present moment in world history nearly

29

Truman, Years of Trial and Hope, 106; Adler, The Isolationist Imcuise, 396-399; Jones, The Fifteen Weeks, 30

Leahy Diary Entry, February 27, 1947, Diaries 1947, Box 5. IOC; Gaddis, The United States and the crigins of the Cold War, 317 and $3 \overline{52}$. 
every nation must choose between al ternative ways of life. The choice is too often not a free une, One way of life is based upon the will of the majority, and is distinguished by free institutions, - . and freedom from political oppression.

The second way of life is based upon the will of a minority forcibly imposed upon tine majority.

Truman emphasized that the United States had to act to resist the Soviet strategy of conspiracy and subversion, because "totalitarian regimes imposed on free peoples, by direct or indirect aggression, undermine the foundations of international peace and hence the security of the United States." 31 In terms of rhetorical justification, the "Truman Doctrine" did represent a truly radical change in American diplomacy. Truman installed uncompromising hostility as the hallmark of America's approach to relations with the Soviet Union. Not only was there insufficient evidence to justify such a response, but the rhetoric of the Administration vastly oversimplified the choices confronting the nation. Kennan and Charles E. Bohlen strongly objected to Truman's overstatement of the nature and extent of the crisis. The two Russian experts urged specificity in the perception of

Quoted in Graebner. Ideas and Diplomacy, 731 ; Eric F. Goldman, The Crucial Decade-And After: America, 1945 1260 (New York: Random House, 1960), 59; Gaddis, the United States, and the origins of the Cold War, 352; Athan Theoharis, Seeds of Re Dression: Harry S. Truman and the origins of McCarthyism (Chicago: Quadrangle Books, 1971), 56-57; Westerfield, Foreign Poiicy and Party Politics, 222.

Gaddis, The United States and the origins of the Cold War, 352; Theoharis, jeeds of Repression, 31; iay, "Lessons" of the Past, 44. 
the Soviet threat, the formulation of an American response. and the justification of decisions to the public. Truman also recognized the rhetorical exaggeration of the "Truman Doctrine," but argued that it was necessary to shock Congress into action and obtain popular support.

Truman's elaboration of the containment policy actually implied a much wider commitment of American power and prestige than the President in fact intended. As a result, it misled the general public and the nation's political leaders as to the nature and extent of the Soviet challenge and the policy of containment. Gabriel Almond contends that the average American "can draw inferences and arrive at sober con lusions if he can trust his specialists to formulate the issues and. alternatives in such a manner that a reascned choice becomes possible." 34 Many observers rightly criticized containment as a sweeping overextension of American power and prestige. Congressmen charged that widespread intervention would place a heavy strain on the American economy, lead to the suppcrt of reactionary leaders, destroy the United Nations, and even provoke war with the Soviet Union. 35 Truman's rhetoric prevented a realistic appraisal of the situation and, as Alonzo

Hartmann, Truman and the 80th Congress, 58-59; Bohlen, The Transformation of American Foreign Policy, 87; Gaddis, "Was the Truman Doctrine Reaily a Turning Point," 400. 34

Gabriel A. Almond, The American People ard Foreign Policy (New York: Frederick A. Praeger, 1955), 7-8. 35

Harimann, Truman ard the 80th Congress, 60-64; Lippman, The Cold War. 
Hamby explains, "emotionalized the Cold war and made rational discourse between the U.S. and the Soviet Union still more difficult." 36

Initially, apprehension over the potentially disastrous results of containment was unjustified. Since Truman recognized and rejected the implications of his rhetoric, American interventionism remained under control. The Korean War convinced Truman and his advisors, however, that the Soviet conspiracy described in the Truman Doctrine speech was a reality. From that point onward, the presence of Communism justified any American attempt to suppress insurgent movements. At the outset, however, Truman actualiy envisioned a policy of "rational interventionism" relying wholiy on economic and financial assistance. Far from being revolutionary. Truman's policy of containment sought to preserve American security through a limited increase in an already reluctant commitment to act positively for the achievement of international peace and stability.

Containment was, in reality, a logical and somewhat realistic approach to the perceived Soviet strategy of subversion and intimidation. Truman and his advisors were aware of the limitations on American manpower and never

Hamby, Beyond the New Deal, 174; Reitzel, Kaplan, and Coblenz, United States Foreigr Policy, 10?; Theoharis, $\frac{\text { Seeds of Repression, } 56 \text {. }}{37}$

Steel, Dax Americana, 23; Richard J, Barnet, Intervention and Revolution: The United States in the Third Norid (Cleveland: The World Publishing Company, 1968), 9 . 
contemplated the lise of combat troops. Korea provides an excellent example of the essence of containment. since the United States, in 1947, began a long and difficult campaign to create a strong and stable government in south Korea. Containment would permit the United States to withdraw, but not force the abandonment of the area to the Soviets. The Administration anticipated that containment would resolve the Korean problem and end a policy of "confusion, delay, 38

and neglect." The application of containment in Korea would force the Soviet Union to compromise and thus permit reunification and independence.

\section{IV}

Acheson, during his appearance before the Senate Foreign Relations Committee regarding aid to Greece, confirmed that the Administration was contemplating a threeyear program of economic and technical assistance for Korea. The State Department program, in its final form, envisioned five hunored forty million dollars in aid to a newly elected provisional government. Civilian advisors would replace military officials within three months and Truman would appoint $a$ new political advisor with wider administrative and decision-making powers. The State Department transmitted the plan to Fatterson on March 28 38 New York Times, March 19, 1947, 22:3. 
with the intention of implementing the policy during fiscal year 1948. Unfortunately, Truman had such a difficult time obtaining Congressional support for aid to Greece that he decided to delay action on the Korean appropriation.

Rhee greeted the news of the "Truman Doctrine" speech with a great deal of satisfaction. He immediately wrote Truman, congratulating him for "this courageous stand against communism" and requesting the President to "instruct the American military authorities in Korea to follow your policy and abandon their efforts to bring about coalition and cooperation between nationalists and communists." Rhee insisted that Korea should be as much a "bulwark against communist expansion" as Greece. Rhee perceived that the Administration was moving in the direction of supporting the formation of a separate government and quickly requested Truman to appoint none other than Preston Goodfellow as the first American ambassador to Korea.

Washington's hostile attitude toward Rhee remained 39

New York Mimes, Warch 25, 1947, 8:1; Hilldring to vincent, March $\frac{15}{1947}$ and Vincent to Hilldring, March 27 , 1947. RG 59,740.00119 (Control Korea)/3-2747. NA; Acheson to Patterson, Marsi 28, 194?, FRUS, 1947, Vol. VI, 621-623; Acheson admitted the Iimited nature of the "Truman Doctrine" when he stressed that the Administration did not intend to help every nation. Although the principle was clear, action would depend on each individual case, Gaddis, The united States and the origins of the Coli Nar, 352 . 41

Lippman, The Cold War, 45-46.

Rhee to Truman, March 13, 1947, FRUS, 1947, Vol. VI, 620; Rhee to Truman, March 26, 1947, Truman Papers, OF 471, HSTL. 
unchanged. Despite American attempts to foster a negotiated settlement, the extreme right continued to criticize the Moscow Decision and the AMG. As a result, the State Department strongly opposed any action that might contribute to an increase in Rhee's political power. 42 It urged the War Department to refuse Rhee's requast for an interview with Fatterson for the following reasons:

It is believed that the large political support which Rhee commands among extreme conservatives, Rhee's personal ambitions which might combine with and influence his patriotism, $h$ is political naivete and the growing restlessness of the Korean people in the non-attainment of independence, combine to make Rhee Syng Man one of the most dangerous figures in Korean political Iife. - Penfield. - states that in his opinion Mr. Rhe has done more than any other Korean to make it difficult for U.S. Army in Korea. Mr. Penfield also feels that Rhee would make capital out of the fact that he had seen the Secretary of War and would broadcast this fact in Korea. thus building himself up....

Although the Administration was preparing to support the formation of a separate government in south Korea, it was clear that the United states hoped to avoid relying on Rhee's leadership in the venture.

Tragically, the United States could not ignore Rhee's political power. American support for Rhee and Kim Koo at the outset of occupation had provided a reservoir of

Brown to War, March 14, 1947, RG 335, WDSCA 014 , Korea ( $1 \mathrm{Fel}$ to $30 \mathrm{Apr} 4$ ?), Section VI, Box 250 , NA; James $\mathrm{K}$. Penfield Memorandum, Niarch 28, 1947, RG 59, 895.01/3-2847, NA.

43

War Department Intelligence Division Memorandum, Narch 26, 1947, RG 319, CSA 091 Korea. Case 8, NA. 
strength ior the extreme conservatives. Hodge had also created a Korean police force that he no longer controlled and was now under Rhee's direction. The extreme right dominated the National Youth Movement, which the USAFIK had trained and equipped. The Movement numbered approximately thirty thousand and was under the command of Lee Bum-suk, erstwhile Chinese army officer. Iangdon observed that most National Youth members were sons of wealthy landlords and businessmen, who invariably supported "those political parties which, by their agitation of the 'trusteeship' issue, - . have caused US-USSR relations in the country to become even more strained." After Hodge abandoned Rhee, it was hardly surprising that the old patriot used the tools the AMG had provided to maintain influence and power. Rhee also benefited from a small coterie of dedicated supporters in the United States. Although some were undoubtedly idealistic advocates of Korean independence, vincent believed that "the majority are individuals bent on deriving personal advantage from being associated with Dr. Rhee." ${ }^{45}$ Robert T. Oliver styled himself "special advisor" to Rhee and was particularly annoying for the state Department. During January, 1947, he met with Vincent and urged acceptance of Rhee's plan for recognition of a separate 
government in south Korea and the holding of national elections after Soviet-American withdrawal. If the United States supported Rhee, Oliver believed, Moscow would have no choice but to "come to terms for a Government for the whole of Korea." In the event of American rofusal, OIiver indicated his intention to undermine the Administration's support within Congress, while Rhee would instigate a general uprising against the AVG in Korea. Such threats only reinforced the state Department's already deeplyengrained distrust of Rhee's motivations.

Bunce quickly realized that wasington could not apply containment in Korea without proper preparation. Moderate elements were far too weak to contest rightist control of any election or civil administration. The recent SkILA election. Bunce observed, was a "rubber stamo affair" in which Hodge allowed the extreme right to control events "through propaganda and police force." He also criticized the USAFIK Commander for labeling all non-rightist groups as pro-Communist and thus forcing moderates into the Soviet camp. Only a Soviet-American agreement on trusteeship would prevent the emergence of a dictatorship under Rhee.

Yet, the Administration could not afford to delay

Vincent to Hilldring, January 27, 1947, ERUS, 1947. Vol. VI, 603-604; . J. Cummings to J. Fdgar Hoover, January 24,1947 , RG 59, 895.01/1-2447, NA. 47

Bunce to Marshal1. February $24,1947, \mathrm{RG} 59$, $895.00 / 2-2447$, NA. 
withdrawal. During early 1947 the USAFIK soldiers instigated a publicity campaign to dramatize the desperate situation confronting American occupation in Korea. SeveraI indivicuals complained in letters to newspapers and family of insufficient food, inferior medical treatment, inadequate housing, deficient clothing, and preferential treatment for officers. Perhaps worse, some criticized the AMG for inefficiency and corruption, charging military officials with brutality and illegal search and seizure. Hodge heard of these complaints while in Washington and immediately ordered an investigation. Subsequent reports concluded that complaints came from younger, newly-arrived soldiers who were lonesome and had exaggerated their grievances. 49 It was clear, however, that American occupation of Korea was rapidly becoming untenable.

Rising dissatisfaction with continued American presence in Korea convinced Patterson that withcrawal was absolutely essential. Fe criticized the State Department program for proionging occupation and forcefuliy advocated "a course of action whereby we get out of Korea at an early date and - . all our measures should have early withdrawal as their

40

Hodge to Seoul, March 3, 1.94?, RG 319, P\&0 312.1, Section XII-A, Case 467, NA; Sergeant Harry H. Savage to Truman, Marci 31, 194?, RG 59, 895.01/3-314?. NA; Eversull Report, April 1, 1947. RG 319, 091 Korea, Section III, Cases $16-50, \operatorname{Box} 87, \mathrm{NA}$.

Seoul to Hodge, March 6, 1947, RG 319, P\&0 312.2, section III-A, Case 467. NA; Ward to Mueller. April 1, 1947. PG 6. Box 1, Ward Memorandum, DMML. 
overriding objective." Patterson jucged the Korean situation "potentially explosive" and doubted if an aid program would improve conditions.

Hodge was certain that withdrawal was necessary, but recognized that the United States could not abardon south Korea precipitately. Upon his return to the American zone, he announced that the United States was about to implement a program of economic and political assistance. "If we can't get Russian cooperation," Hodge explained, "we must carry out our commitments alone." The USAFIK Commander denied that the United States was creating a separate government. The policy sought instead to foster freedom, denocracy, and scund government. Some observers, including the Koreans, believed Moscow would be unable to compete with the American program and would agree to reopen negotiations. When Lieutenant Genoral G.P. Korotkov replaced Chistiakov, they predicted that a turn toward conciliation was imminent.

Truman was not as anxious as Hodge to publicize American plans for Korea. On two occasions during the spring, the President denied having reached a decision on extending aid to the divided nation. 52 Truman clearly hoped that

Patterson to Peterson, April 7, 1947, RG 319, P\&O 091 Korea, Section II, Case 15, BoX 87, NA; Fatterson to Acheson, April 4, 1947, ERUS, 1947, Vol. VI, 626-627. 51

New York Times, April 1, 1947, 1?:4; April. 6. $1947,43: 1,4$ ipil $11,1947,18: 3$. 52

Truman Comments, April 3,1947 and May 15, 1947. Public Fapers, Harry S. Truman, 1947, 191 and 247. 
Marshall's final overture at Moscow would succeed and did not want to alarm Stalin. At the same time, the sdministration would not allow the United states to be mired in the Korean deadlock. As Vincent explained, "our program seems to us to be the only way of accomplishing" the reduction of our commitments "once we rule out the alternative of abandonment of Korea to USSR domination." The United States did not intend to match Soviet military forces in Korea, but would institute a three-year, phased withdrawal. If Moscow refused to cooperate, Trumar wolid submit the issue to the United Nations as a last resort.

Containment in Korea sought to sreate economic strength and political stability without overextending American commitments. Withdrawal wousd occur, but without severe damage to American prestige. A JCS study considered Korea as second only to the Philippines in its strategic unimportance to the national security of the United States. In terms of need, on the other hand, only Greece, Italy, and Iran surpassed Korea. Of particular importance, however, were the reasons that the JCS forwarded in support of the state Department's aid program for Korea:

as a result of the 380 parallel agreement, this is the cre country within which we alone have for almost two years carried on ideological warfare in direct contact with our opporents, so that to lose this battle would be gravely dotrimental to United States prestige, and therefore

53

Vincent to Acheson, April 8, 1947, RG 59,740. 00119 (ControI Korea)/4-847, NA. 
security, throughout the world. To abandon this struggle would tend to confirm the suspicion that the United States is not really determined to accept the responsibilities and obligations of world leadership, with consequent detriment to our efforts to bolster those colintries of Western Furope which are of primary and vital importance to our national security.

Korea's value in an armed conflict, rather than an ideological-diplomatic confrontation, was of minor importance. Thus, the JCS stressed that "current assistance should be given Korea only if the means exist after sufficient assistance has been given the countries of primary importance. . . for the inited States . ..."

Acheson informed Marshall on April 1.1 that the State Department program had received interdepartmental approval. A significant inclusion was the provision for transfer of control in Korea from the war to the State Department as of June, 1948. Press reports accurately summarized the nature and extent of the program. The United States could not afford to abandon Korea because of potential damage to its prestige, but Truman would not defend the peninsula in the 55

event of a major war. The Administration did not, however, anticipate the outbreak of hostilities in Korea. The SwNCC formulated a Korean defense program providing for only limited military assistance. The United States would supply $737-739$. JCS to SWNCC, Viay 5, 1947, FRUS, 1947, Vol. VI, 55

Acheson to Vilarshall, April 11, 194?, RG 218, CCAC 104, Korea, Section III, NA; U.S. News, X.X, 15 (April 11, $1947), 24-25$. 
only small arms and a limited number of radios, vehicles, and spare parts to a police-style Constabulary army consisting of twenty-five thousand men.

\section{V}

Marshall attended the fourth CFM meeting in Moscow during the spring of 1947. On April 2, the secretary of State forwarded for comment a proposed letter to Molotov requesting a resumption of the Joint Commission. Acheson responded that the letter should stress prior Soviet refusal to consult with a majority of Korean leaders. The Joint Commission could resume only if the negotiators recognized the principle of freedom of expression. If Moscow disagreed, then the United States could legitimately proceed to implement the Noscow Decision in the southern zone alone. $57^{\prime}$ Acheson appeared to consider Varshall's final initiative on Korea a mere formality.

Soviet-Americar negotiations in Moscow during April, 1947 were a dismal failure. In the wake of the adjournment of the CFM meeting, Truman rejected the logic and wisdom of high-level, bilateral negotiations with Moscow and chose instead to build "situations of strength" against the

\section{6}

SWNCC Ad Hoc Committee Report on Truman Doctrine, February 21, 1947, FRUS, 1947, Vol. VI, 72?-730. $5 ?$

Narshall to Acheson, April 2, 1947 and Acheson to Marshal1, April 5, 1947, FRUS, 1947 , Vol. VI, $624-625$ and 628-629; Korean War Documents File, Box 243. General, Fist. 
Communist advance.

The existence of a "Cold War" was now public knowledge and drew wide comment in the American press. Strangely enough, the spring of 1947 witnessed a Soviet-American reconciliation, albeit temporarily, on the issue of Korea. In all probability, Stalin agreed to one final attempt at a negotiated settlement in an effort to forestall the creation of a separate south Korean regime hostile to the Soviet Union. 59

Marshall's initial communication emphasized the absence of progress toward the realization of the Cairo Declaration. He blamed the Soviet Union for refusing to permit the economic reunification of the nation and thereby denying Korea political independence and self-government. In April, the American Commander attempted to reopen the Joint Commission, but the Soviet Commander refused to offer a favorable reply. The deadlock, Marshall insisted, was the result of Moscow's desire to exclude a majority of south Korean leaders from consultation based upon a unilateral definition of the word "democratic." He then recommended that, in the interests of Korea's well-being, the Joint Commission reconvene based upon respect for the principle of freedom of expression. In the meantime, Washington intended to implement the Mioscow

Coral Bell, Negotiation From Strensth: A Study in the Politics of Power (New York: A.A. Knopf, 1,53), 21.; DeConde, "George C. Marshall," in An Uncertain Tradition, 252. 59

Dallin, Soviet Russia and the Par Fast, 304; Cho, Korea in Norld Polities, 158 . 
Decision in its own zone of occupation. Quite obviously. the Truman Administration would not permit the Soviets to again engage in stalling tactics.

Molotov responded that the United States was responsible for the absence of progress at the Joint Commission, since it refused to comply with the provisions of the Moscow Decision. Economic and political reunification was crucial for Korean independence and prosperity, but was possible only after the creation of a provisional government. Molotov observed that the United States insisted upon consultations with individuals unwilling to support the execution of the Soviet-American agreement. After reciting Soviet-sponsored reforms in the north, he pointed to the absence of similar progress in the south. Since Moscow favored eventual Korean unification and independence, Nolotov agreed to reconvene the Joint Commission on May 20, but based only upon the "exact execution of the Moscow Agreement on Korea."

Marshall quickly recognized that Moscow intended to use the phrase "exact execution" for continued exclusion of those Korean leaders opposed to trusteeship. As a result, he again wrote Molotov and offered the American "interpretation" of the Moscow Decision to avoid any misunderstanding. The

60 Marshall to Nolotov, April 9, 194?, DSB, XVI, 407 (April 20, 1947), 716-717; New York Times, April 13, 1947, $47: 5$.

61 Molotov to Marshall, April 19, 1947, Frus, 1947, Vol. VI, 633-634; Also in, DSB. XVI, 409 (May 4,1947), $812-814$. 
United States believed that the Joint Commission should not deny any Korean representative consultation because of previously expressed views on the future government of Korea. provided each individual was willing to cooperate with the major powers. Marshall also expressed pleasure at the seviet indication of support for free elections and explained that the United States was considering "a constructive program for the rehabilitation of the economy of Korea and for its educational and political development." If ivolotov accepted the American viewpoint, Hodge would resume participation in the Joint Commission negotiations on May 20, 1947.

Molotov's reply stressed that the occupation commanders had adequately discussed the "conditions for consultation" at the Joint Commission. He thus accepted the American Commander's amendments to the Soviet proposal of November 26. 1946, which grovided for consultation with only those groups fully in support of the Moscow Decision. Signing Communique \#5 was suficicient for consideration, but the negotiators would exclude any party or social group that "fomented or instigated" active opposition to the work of the Joint Commission. Marshall quickly accepted Nolotov's proposal, since it was essentially the American position. Yet, it was clear that the extreme right would continue to oppose trusteeship. As iangdon explained, unless the Soviet

\footnotetext{
62

Marshall to Molotov, May 2,1947, ESB, XVI, 410 ( May 11, 1947), 947; Also in FRUS, 1947, Vol. VI, 638.
} 
Union approved complete freedom of expression, the right would not participate. The United States could then expect widespread disturbances and an absence of real progress at the Joint Commission.

American leaders were certain that the threat of economic assistance had forced Moscow to compromise. Trumar reiterated the American desire for a unified and democratic government, while expressing confidence that Marshail's actions were fostering such a result. "The best way to meet Communism North of the Thirty Eighth Farallel," The New York Times argued, "is to strengthen democracy south of the border, to show there that the latter is the better way of life, to prove that life, liberty and happiness can be better pursued in a democratic society than a totalitarian one." This editorial urged the Fresident to quickly form a strong and stable government in south Korea capable of attracting the enthusiastic support of north Koreans.

Hodge and Langdon were not as sanguine about the chances for success at the Joint Commission. It was uniikely that Nhoscow would permit any criticism of the Moscow Decision. The Marshall-Molotov compromise hardly constituted a Soviet

\section{3}

Molotov to Marsinall, May 8, 194?, Marshail to Molotov, May 12, 194?, and Langdon to Marshall, May 11, 1947. FRUS, 1947, Vol, VI, 639-640; see also, DSB, XVI, 41.1. (Nay $\left.\frac{11}{64}, 1947\right), 995-996$.

Truman Comments, Speciall Conference with Radio News Analysts Association, Fublic Papers, Harrv $S$. Truman, 1947. May 13, 1947, 240; New York Times. Aprii 13, 1.947, IV, 8:2, April 23, 1.94?, 24:2, and Aoril 25, 194?, 7:1. 
acceptance of the Anerican position. The Soviet delegation would still be able to exclude those groups that opposed trusteeship, but now the united States had an obligation to accept the results. Resumption of the joint Commission would find the American delegation in the awkward position of supporting the suppression of those groups whose freedorn of expression it had demanded during previous sessions.

American political commentators from both ends of the spectrum supported the adoption of a more positive course of action in Korea. American cccupation had, after all, been an unqualified failure. The partition had contributed to economic deterioration, while the absence of self-government spawned rising hostility toward the United States. Acceptance of the "Truman Doctrine" assumed that an effort to combat Soviet expansionism would require more than words. Although American conservatives were concerned about other nations "crowding forward, hat in hand," they joined liberals in recognizing that the depense of fmerican freedom required the exponditure of funds. Only a positive program of economic assistance and education in democracy would produce an independent and self-governing Korea.

Truman was confident that Vioscow would find competition

65

New York Times, May 1, 1947, 15:5 and May 12, 1947, 20:2; Beloff, Soviet Foreign Policv in the Far Fast. 168.

New Yo:k Times, May 18, 1.947, IV, 4:6; Time, XIIX,

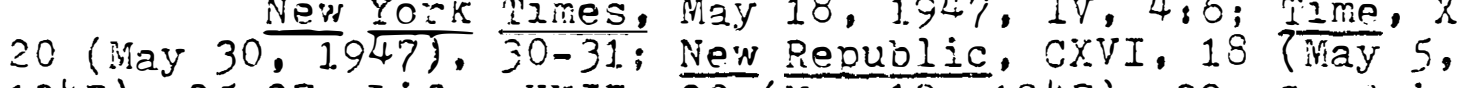
1947), 25-27; Life, XXII, 20 (May 19,1947), 32; Goodrich, Korea, 26-28; Laliterbach, "Fouge's Korea," 360 . 
impossible once the United States instituted its program for economic assistance. Rather than producing a settlement, however. Truman's strategy would only lead to a deeper Soviet-American stalemate. A genuine reconciliation was possible only after the two major powers arrived at a suitable basis for amicable relations. Patterson recognized the inescapable dilemma facing the united States in Korea. The Soviets possessed a stronger geographic position, while the United States had few strategic and economic interests in the peninsula. Yet, Truman and Marshail refused to accept Patterson's argument that continued occupation was not worth the expense. The Administration was determined to withdraw only after south Korea was capable of self-defense. In the prevailing "Cold War" atmosphere, neither Washington nor Moscow would pernit reunification unless Korea was "friendly" to its own individual national interests.

\section{$V I$}

Korean conservatives greeted the news of the MarshailMolotov compromise with extreme consternation and despair. Kim Koo announced his intention to reform the KPG and try to seize power. Lerch immediately denounced Kim's plan and barred the KPG from staging political meetings. The Representative Democratic Council then issued a statement

\section{6?}

Lauterbach, "rodge's Korea," 136-137; Millis (eả), The Forrestal Diaries, 273 . 
demanding immediate American withdrawal and transfer of authority to an interim government. Langdor rocominended that Washington ignore the proclamation, since it was ar obvious attempt to emoarrass the united States and sabotage the Joint Commission. He described Rhee and Kim Koo as "diehards" who pursued an intrarsigeant course because their "fate is cound up in the status ouo."

One can easily understand the reasons for Rhee's actions. He and Kim Koo feared that the Soviet Union and the political power of the Korean leftists would provent either of them from obtaining positions of authority in the now Korean government. Although the Korean desire for selfgovernment was genuine, the extreme right was actually exploiting the concept of trustepship to further its own ambitions. The new head of the American delegation to the Joint Commission Major Genera? Albert E. Brown a.tempted to moderate Rhee's attitude during several conferences, but experienced little success. Thus, Brown had to warn Rhee and $\mathrm{Kim}$ Koo that continued criticism of the Soviet Union and trusteeship would require exclusion from consultations.

New York Times, May 14, 1947, 10:2 and May 18 , 1947, 31:5; Hodge to Nar, Nay 17, 1947, RG 335, WDSCA 014 Korea ( 1 May to 30 Jun 47), Section VII, Box 250, NA. 69

Langdon to Marshall, Nay i?, 1347, and Iangdon to ivarshall, May 18, 1.94?, FRUS, 1947, VOI. VI, 644-645; New

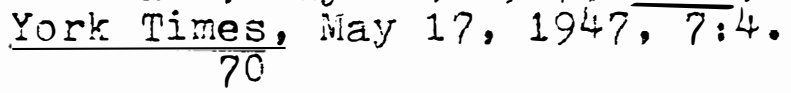

Langdor to Marshal1, May 21, 1947, RG 59, 740. 00119 (Controi Korea)/5-2147. NA; New York Iimes, iviay 19 , $1947,3: 5$. 
In response, Rhee accused Hodge of favoring a Communist victory in Korea and demanded a clarification of American policy which would permit opposition to trusteeship.

Hilldring instructed Hodge to assume a strong posture of opposition to Rhee's demands. The United States completely supported the Joint Commission and would not allow anyone to embarrass American policy. Nor would Washington authorize any statement modifying the terms of the Noscow Decision, since such action would only endanger the work of the Joint Commission. 72 Evidently, Rhee soon realized that nis strategy of confrontation was ill-advised, since his activities only reinforced America's determination to support the Moscow Decision. Realizing that his persistent denunciations were counter-productive, Rhee adopted a lower profile and toned down his criticisms. Hodge welcomed Rhee's turn toward moderation, arguing that there was now an even chance for conservative cooperation with the Joint Commission.

Soviet-American negotiations at the Joint commission resumed in a cordial atmosphere of informality and ease.

Langdon to Narshal1, May 21, 1947. FRUS, 1947, Vol. VI, 646-34?; Rhee to VacArthur, Nay 23, 1947, MacArthur Papers, Box 8, Correspondence, VIP File, Rhee, DNiL. 72

Hilldring to Hodge, May 21, 1947 and Marshail to Langdon, May 23, 1947, FRUS, 1947, Vol. vI, 647-648.

Hodge to Hizldring, May 26, 1947, FRUS, 1947, Vol. VI, 651-552; New York mimes, Nay 20, 10,47, 24:1; mime, XIIX, 2 ( June $2,19 \overline{47}), \frac{2014}{34}$

Vol. VI, 661 .

Hodge to MacArthur, iune 2, 1947, ERUS, 1947, 
The three subcommittees began to study the basic elements of the Moscow Decision. Almost immediately, the negotiators began to disagree on the conditions for consultation. The Soviets proposed sending invitations only to the thirty largest parties, while the remaining groups would just submit questionairos. The United States, on the other hand, opposed the formation of a selective "Consuitative Body" and sought discussions with all parties claiming a minimum of one thousand memoers in two or moro provinces. The Joint Commission could then choose a representative body of individuals to form a provisional government. Soviet delegation chief Shtikov requosted a postponement to consider these proposals. A report that the negotiations had indefinitely adjourned indicated the extent of pessimism surrounding the Joint Commission.

On May 31, Shtikov explained that the Soviet Union favorod limitations on consultation in the interests of expediting the proceedings. In addition, he proposed June 10 as a deadine for the completion of signatures on pledges of support for the Joint Commission. Brown cabled to washington his "definite impression that the Soviet delogation is under some driving compulsion to complete somothing concrete in the way of plans for provisional govt $\sqrt{\mathrm{s}} i \mathrm{c} / \mathrm{f}$ within the next 2 months." Moscow also sought to include in the

75

Langdon to Viarshall, May 23, 1947, FRUS, May 24, 1.947 , and May 30,1947 , ERUS, 1947, Vol. VI, 349-657; Neiv York Times, Nay 29,1947,1:1. 
questionaires a roquirement to bar Japanese collaborators from participation in the provisional government. The American delegation opposed this provision, explaining privately that the "wording . . is pure. . Labor Party (Communist) Iingo and would at outset align us on the Communist side." 76

Despite these differences of opinion, the joint Commission enjoyed steady orogress during the first wook of June and completed an agreement on consultation on Jure 7 . Moscow agreed to consilt with all parties that signed the communique pledging support for the Joint Commission. The United States agreed to include the issue of Japanese collaborators in the questionaires and also approved the formation of a "Consultative Body" because of "the soundness of the principle it represents." Applications for consultation were due for submission no later than June 23. After Subcommittee \#1 had studied the applications, it would compose a list of eligibie parties and extend invitations for consultations in Seoul on June 25 and in Pyongyang five days later. At the same time, any party or social group could submit a completed questionaire no later than july 1 dealing with the nature of the future Korean government. on July 5, the Joint Commission and the Koreans would begin work on a program for creating a provisional government and

Iangdon to Narshall, June 1,4 , and 6,1947 , FEus, 1947, Vol. VI, 658-666; New York Times, 1, 2, 3, and 5, 1947 , and June $7,1947, \overline{7: 5}$ and June 8, 1947, $27: 2$. 


\section{4}

the structure, principles, and platform of the final Korean government. The Joint Commission would then approve the subsequent proposals, after which it would recommend specific members of the provisional government.

Soviet willingness to compromise had a decisive impact on American strategy in Korea. The Truman Administration quickly concluded that the "Truman Doctrine" was responsible for Moscow's change of heart. Washington reasoned that Stalin was hoping an attitude of conciliation would

cause the US Government, or at least Congress, to be so optimistic as to abandon, in expectation of early agreement by the Joint Commission, the proposed program of economic, political and educational rehabilitation in our zone, mentioned by General inarshall. The Soviets would then have reason to hope that delay and obstruction in the Joint Commission will so discourage the US people, and the Korean people, as to assure eventual accomplishment of Soviet aims in Korea. 78

In all probability, Moscow did attempt to avert the application of containment in Korea through the adoption of a more conciliatory approach. The events during early June at the Joint Commission indicated a willingness to compromise. Yet, stalin probably was engaged in one final attempt to reunify Korea under a "friendly" government. Noscow

77

Langdon to Niarshall, June 7, 9, and 11, 1947 , FRUS, 1947, Vol. VI, 666-672.

Iincoln to Norstad, Nay 12, 1947, RG 319, P\&0 092, TS, Section V-A, Part I, Case 85, Box 31, NA. 79

Berger errs when he argues that the announcement of the containment policy caused Moscow to cease cooperation with the United States in Korea, The Korean Knot, 73. 
genuinely believed that the inited States intended to exclude those indivicuals from consultation who were nostile to the Moscow Decision. If the United States again insisted upon complete Freedom of expression, however, the deadlock would surely reappear.

VII

Some scholars have strongly criticized the Truman Administration for refusing to support Syngman Rhee. The policy of delay, they contend, meant that the subsequent south Korean regime was weaker than necessary. Yet. one must assess american actions in the context of the expected rewaros of containment. Truman and his advisors believed that American economic assistance wolld produce a truly democratic and stable Korean government without relying on the leadership of Syngman Rhee. Nore important, if the threat of economic aid brought about the Marshall-holotov compromise, similar tactics would evertually force the Soviets to agree to reunification as well. As a result, Truman authorized the formulation of an economic aid program regardless of events at the Joint Commission. Slich an approach, the President believed, vould colnter the Soviet strategy of $s$ tall and delay.

Dailin, Soviot Russia and tho Far Past, 298-299; Cho, Korea in World Politics, $134-136 ; \mathrm{Kim}$. Divided Korea. $74-75$. 
Soviet-American agresment on the terms of consultation cloanly surprised Rheo and Kim Koo. While the two leaders originally refused to cooperate with the Joint Commission, they now announced their willingness to participate. Yot, Rhe and Kim Koo continued to oppose the lioscow Decision and refused to attend a banquet honoring the soviet and American dolegations, Once again, Brown warnod tho oxtrome right that slich an attitude would preoludo consultation and sacrifice ary influence in the new provisional governmont. In rosponse, Rheo resumed his hostile posture and eriticized the United States for violating the principle of freedom of exprossion and intending to betray Korez. Kim Koo organized cemorstrations opposing trustesship and the oxtreme right oven tirnow dirt and stones at the Soviet delesation on june 24. Shtikov immediately protested, but Hodgo did notining. Such actions substantiatod the soviet argumant that the extreme conservatives were insincere when they plodgad to cooperate with the Joint Commission. When negotiations rosumed, Shtikov would certainly demand the exclusion of those rightists opoosed tho trustoosinip. Rhoo's antivitios thus placed Hodgo in an extremoly difficult position. Yo could not tolerato open dofiance of Amorican authority; yot repression would merely produce more violonoe. As a result, he did littio to cunish tho demonstrators, axcept publicly

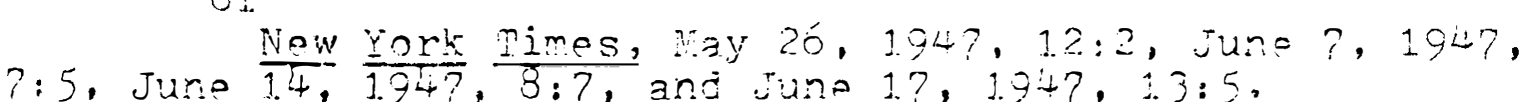


rebuking Kim Koo for his behavior. As expected, the extreme conservatives refused both to file applications for consultation and to fill out any questionaires. Hodge cabled Washington that Kim Koo was now planning a series of rail and electric strikes to demonstrate against trusteeship.

On Jure 25, the Joint Commission resumed its deliberations in an "extremely cordial" atmosphere. A preliminary "Consultative Body" composed of ovar f'our hundred Korean leaders was present. The negotiators had registered the results of the questionaires, which revealed the delicate nature of America's situation. While the leftist respondents manifested a high degree of unity, organizaticn, and purpose, the rightist element was completely divided. In the north, three parties and thirty-five social organizations filed for consultation, representing approximately thirteen milizion people. In the south, on the other hand, over four hundred parties registered with the Joint Commission and claimed a membersin of an incredible sixty-two million individuals. Slightly more than fifty percent of the respondents were rightist, but even Hodge admitted that, the results "obviously indicated duplication and padding." 83

Moscow also judged the number of parties seeking

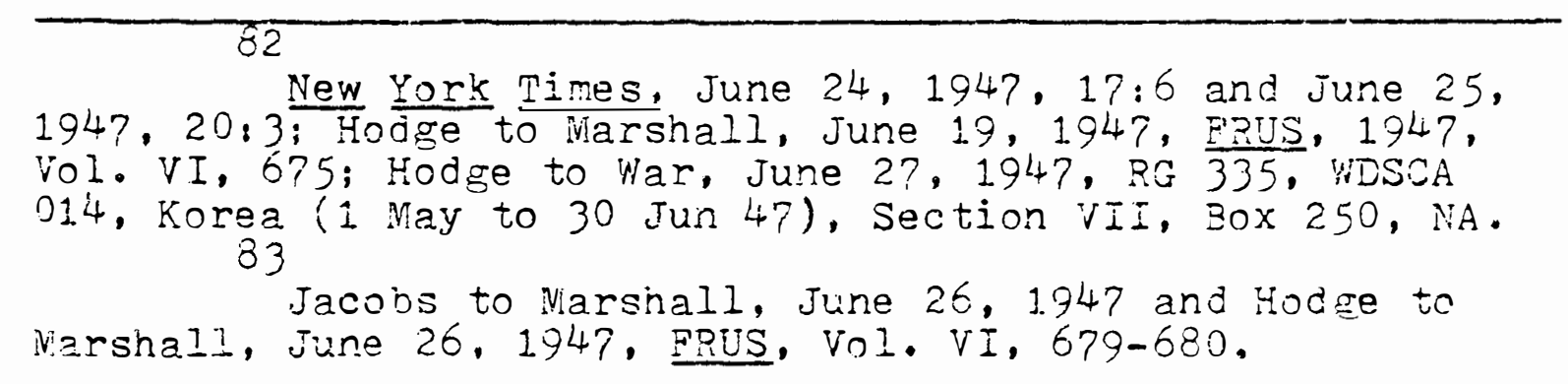


consultation in the south as inordinately high. The right was primarily responsible for the exaggeration, since twothirds of those groups registering were members of the conservative faction. If the Joint Commission disqualified only a small number of rightist parties, leftist control was certain. Thus, Shtikov insisted upon the exclusion of those parties belonging to the "Anti-Trusteeship Committee." In part, the rightist assault on the soviet delegation motivated Shtikov's action, since violent opposition to trusteeship seemed to demonstrate an unwillingness to cooperate. Yet, the American delegation realized that the disqualification. of the eight rightist parties in question would ensure a leftist majority in the provisional government. Marshall quickly approved Brown's desire to firmly oppose the exclusion of these parties.

America's dilemma in Korea was then quite clear. If the United States supported Rhee, reunification was impossible and true democracy improbable. If the United States agreed to compromise at the Joint Commission and exclude the most extreme conservatives, however, a leftist majority was certain. The situation seemed even more precarious after the American deiegation visited Pyongyang early in July.

Jacobs to Marshall, July 9, 1947, FRUS, 194?, Vol. VI, 688-689; Leon Gordenker, The United Nations and the Peaceful Unification of Korea: The Politics of pield Doerations (The Hague: Martinus Nijhofi, 1959). 10 . 85

Jacobs to Marshall, June 28, 1947 and Marshall to Jacobs, July 2, 1947, FRUS, 1947, Vol. VI, 681-682. 
Joseph E. Jacobs, the new Political Advisor, reported the creation of an authentic Communist satellite regime similar to the Soviet puppet governments in the Balkans. The existence oI a strong army and police force meant that even if the Joint Commission successfully formed a representative provisional government the northern Communists could easily impose their will upon a divided southern populace. Jacoos explained that the right accurately perceived its only chance for surrival in frustrating the Joint Commission and obtaining American support for a separate government. American problems in Korea were not confined to the reemergence of deadlock at the Joint Commission. During late May, 1947, Roger Baldwin of the American Civil Iiberties Union arrived in Korea to "observe the progress of democracy." Conditions in Japan favorably impressed Baldivin, but he arrived in Korea at the very moment when political agitation was at its peak. As a result, Baldwin witnessed an incredible amount of violence and terrorism. He attributed popular dissatisfaction to the absence of land reform, the creation of a repressive police force, and the utilization of Japanese collaborators in the AMG. The United States had to adopt a definitive program in Korea for the creation of political democracy and economic progress,

Jacobs to Marshall, July 7, 1947, FRUS, 194?, Vol. VI, 690-691; Jacobs' previolis diplomatic assignment had been in Albania. Washington expected his experience in Eastern Europe to strengtien the American delegation at the Joint Commission, DSB, XVI, 415 (June 15, 1947), 1178. 
Baldwin conciluded, rather than continuing to rely upon the tactics of political repression.

Baldwin's observations received a considerable amount of attention in the American press. Time observed that "a lack of U.S. policy, an inept military government and factionalism among Korean politicians has produced a 'reign of terror." Hodge's militaristic approach, the magazine argued, had produced a "police state" in which law and order were artificial. The United States also relied too heavily on the right and suppressed the left, thus forcing truly moderate and democratic elements to choose sides. Time blamed the National Youth Movement for much of the violence and unrest in Korea. The organization's staunch nationalism was responsible for most of the agitation against trusteeship and the Joint Commission.

Baldwir himself wrote an article in The Nation, warning that in the absence of genuine reform a Soviet victory in Korea was inevitable. Anti-Communism was not enough to produce real democracy, while terrorism only facilitated the emergence of Communist control. Baldwin strongly urged the United States to protect basic civil liberties and broaden the basis of "Koreanization" to include more moderate

New York mimes, June 27, 1947, 13:4; Baldwin Memorandum on Korea, Enclosure \#1, Jacobs to Marshall, June 26 , 1.947 , $\mathrm{RG} 59.89,85.00 / 6-254 ?$, NA.

(June 30, $\frac{\text { Time, }}{1947)}, 2$ (JuIy 14, 1947), 22-23 and XIIX, 26 
281.

political elements. American economic aid and political guidance were also necessary for the emergence of political unity and responsible government. Baldwin concluded that "our answer to the challenge of communism can only be a working democracy, capable of satisfying the needs and claims of a desperate, brave, and long-suffering people." 89

Jacobs and Hodge believed that Baldwin's visit was far too short to allow a proper appraisal of the American predicament. Baldwin had ignored the magnitude oi the Communist threat and the sinister nature of the Soviet strategy confronting American occupation in Korea. In their conversations with Baldwin, Jacobs and Hodge stressed that it was necessary to limit popular freedom in the interests of security. Yet, both American leaders admitted that Baldwin's criticisms were "fair and reasonable." 90

American representatives in seoul now concluded that a Soviet-American agreement was impossible. Jacobs contended that the Soviets were "either stalling for time or wish to reach a deadlock" at the Joint Commission. Stalin would accept a settlement only if it guararteed complete Soviet control throughout the peninsula. ${ }^{91}$ Rhee agreed with

89 Roger Baldwin, "Our Bluncer in Korea," The Nation. CLXV, 5 (August 2, 1947), 119-121. 90

Hodge to MacArthur, May 24, 1947. Enclosure \#2 and Jacobs to Marshall, June 26, 1.947, RG 59, 895.01/ $6-2647$, INA. 91

Hodge to Marshall, July 3, 1947 and Jacobs to Viarshall, July 8, 1947, FRUS, 1.947, Vol. VI, 585-587 and 
such conclusions and immediately resumed his campaign of opposition to coperation with the Joint Commission. Hodge reported that Rhee's demands for a separate government were receiving considerable popular support. Severai conservative leaders announced their intention to cease cooperation with the Joint Commission. An increase in violence and terrorism were also contributing to the deterioration of American prestige. Hodge warned Washington that unless it abandoned its faith in a negotiated settlement the United States would never achieve its objectives in Korea.

VIII

Nany American leaders continued to hope that economic aid would prodice a strong south korean regime and thus force the Soviet Union to cooperate. On June 3, 194?, Acting Budget Director Frederick J. Lawton approved the two hundred fifteen million dollar assistance program for Korea. In forwarding the plan to Truman, Lawton explained that the State Department "feels that economic improvement in South Korea will help to overcome Soviet reluctance to reunite the two zones." In addition, reunification would facilitate the achievement of economic self-sufficiency,

693-694; New York Times, July 6́, 194?, 22:3. 92

Hodge to Marshall, July ?, 1.947 and MacArthur for Hodge to Niarshall, July 9, 1947, ERUS, 1947, Vol. VI, 691692 and 696; New York Times, July 3, 1947, 2:2. 
thereby reducing the cost and duration of American assis93

tance. The strategy of containment thus promised complete success at relatively low cost. America's Korean policy reflected a much larger program of "peaceful revisionism," 94 in which containment would act as a liberating force. Through the use of economic aid, the United States would compel Noscow to accept the American vision of postwar reconstruction in Korea and elsewhere in the world. State Department officials had also prepared a Presidential message to Congress requesting approval for aid to Korea. 95 Unfortunately, circumstances prevented Truman from implementing containment in Korea during 1947. In the first place, Chiang Kai-shek was pressing the Administration for economic and military assistance. The President, however, was apprehensive on the matter of support for Chiang cecause of Communist victories over the nationalists. If Truman refused aid to Chiang, he would have far more difficulty in obtaining an appropriation for Korea. Second, Truman recognized that Congress would be parsimonious irrespective of 471, ISTL. Lawton to Truman, June 3, 1.947, Truman Papers, OF Lawton to Truman, June 3, 1.947, Truman Papers, OF
94 .

Bell, Negotiation From Strenzth, 23; James Irving Hancock, "The Impact of the Korean War on American Wilitary Strategy," Unpublished Naster's Thesis (University of Virginia, 1967), 16 . 95

Draft of Speech, June 3. 1.947, Truman Papers, OF 471 (Miscelianeous), HSTi. 96

Tang Tsou, America's Failure in China 1941.-1950
(Chicago: University of Chicago Press, 1.963 ). $446-453$. 
of the nation involved. If the Administration submitted too many requests in Asia, it would endanger the Marshall Plan for European recovery. In any event, Truman did not have to make a final decision on requesting aid for korea. On June 27, Senator Arthur $H$. Vandenberg informed Acheson that he would oppose any new authorizations for foreign assistance during the remainder of that Congressional session. 97 Suddenly, Truman confronted not orly a deadlock at the Joint Commission, but also Congressional refusal to support the application of containment in Korea.

Truman and his advisors decided to delay action at the Joint Commission while they searched for another avenue for escape from the Korean dilemma. Marshall announced that the United States had no intention of terminating negotiations or altering its policy of support for the Noscow Decision. He also instructed Hodge to inform Korean Ieaders that only cooperation with the Joint Commission would produce reunification. The united States would not consider the formation of a separate government until the complete collapse of Soviet-American negotiations. Marshali also emphasized that the United States was determined to defend the rights of every group willing to cooperate with the Joint Commission and to support the Moscow Decision.

\footnotetext{
$9 ?$

Acheson to Varshall, June 27, 1947, RG 59,740. 00119, (Control Norea)/6-2747. NA; Acheson to "Jim," August 1950, Acheson Papers, 3ox 65, Correspondence, HSTI. 98 New York Times, July $17,1947,10: 6$; Jacobs to
} 
America's Korea policy nevertheless began to turn during the second week in July toward the formation of a. separate government. At the Joint Commission, the American delegation absolutely refused to accept the Soviet position on the exclusion of any group from consuitation. Hodge observed that Shtikov's demand for the exclusion of conservative parties which refused to renounce the "Anti-Trusteeship Committee" was a "leftist ruse" designed to prevent rightist participation in Korean seif-government. He cabled Washington his intention to insist upon complete freedom of expression for all groups, even at the risk of permanent adjournment. Hodge then removed the ban on demonstrations against the Moscow Decision. The extreme right hailed the action as indicative of an end to appeasement. Fevi observers failed to discern America's apparent willingness to accept the inevitable failure of negotiations.

Rhee's tactics were partially responsible for the increasing rigidity of American policy. His campaign against the Soviet Urion, trusteeship, and Hodge attracted the support of many conservative leaders who represented those very groups Moscow sought to exclude from consultation. The American delegation found it necessary to defend the principle of complete freedom of expression, since only the

Viarshall. July 9,1947 and Marshail to Jacobs, July 14, 1947, FRUS, 1947, Vol. TI, 697 and ?01-703,

Hodge to Narshall, July 10, 1947, FRUS, 1947, Vol, VI, 697-?00; New York Times, July 12, 1947, 4:? 
participation of these conservative leaders would prevent a leftist dominated provisional government. Yet, even Jacobs admitted that these rightist leaders were "for the moment apparentily separated from the leadershie of Syngman Rhee and Kim Koo but7 in fact still sympathetic if not subservient to their policies and leadership." ${ }^{1.00}$ clearly, the Soviet demand for exclusion of several conservative parties was legitimate under the terrs of the Marshall-molotov agreenent. In July, 1947. Fhee's opoosition to trusteeship reached a climax. During discussions with Hodge, Rhee explained that he would neither support nor participate in any government that the Joint Commission sponsored. On July 19,3 rigitist fanatic assassinated Ifuh, thus demonstrating unmistakabiy the price entailed in the oursuit of moderate objeciives. Few Koreans could henceforth oppose Rhee's strategy and cooperate with the Joint Commission without placing their lives in aanger. 1.01 Jacobs observed that Iyun's death had completed the polarization of horsan politics. Rhee now predicted publicly the eventual formation of a separate government under his leadership and enjoying American economic assistance ard miiitary

\subsection{0}

Hojge to viarshall, July 15,1 , gi? and vacoos to Marshall, July 16, 194?, ERUS, 104?, Vol. VI, 703-?0?; Now york Times, JuIy 10, 1947,10 : 6 and July $22,1947$.

Hodge to Marsizil, July 17, 194? ard Jacoos th

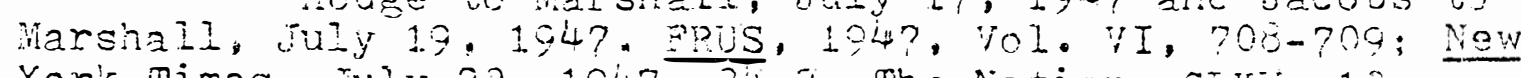

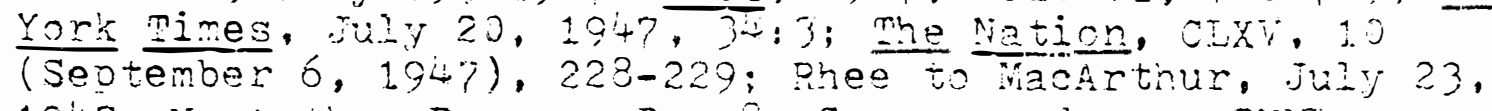
1947, nacirtiur Papors, Box 8 , Conrespondence, Ma. 
protectior! Significantly, Jacobs cabled Washington that the situation was deteriorating so rapidly that American support for Rhe was now the only available option. 1. 02 Lyuh's assassination permanently eliminated the alternative of forming a separate government under the leadership of a genuinely moderate political coalition. Rhee's control of the SKIG and the SKIIA precluded the possibilitj of truly free elections. He also dominated the police and the National Youth Movement which ensured his own rise to power. Ironically, the American attempt to support the Joint Commission and a moderate coalition had alienated khee, who was no longer responsive to American advice and influence. 103 Bunce insisted that washington had to decide quickly whether to support the extreme conservatives and thus sacrifice moderate cooperation or attempt to create a genuine middleof-the-road coalition as the foundation of a separate government. In reality, by the fall of 1947 , the United 104 States had no choice but to support Syngman Rhee.

Jacobs believed that decisive action in Korea was long overdue. On July 25 , he requested permission to present a series of final proposals at the Joint Commission to

\section{2} Vol. VI, 710-711.

Jacobs to Varsiall, July 21. 1947, FRUS, 1947, 103

Tompkins, American-Russian
Jacobs to $\frac{\text { Relations }}{\text { Varshall, }}, \frac{\text { in }}{\text { June } 20}, \frac{\text { the }}{1947}$, Far
1.947 East, 334 i 104 $7-2247, N A$. Bunce to Martin, July 22, 1947, RG 59, $895.00 /$ 
break the deadlock. In the absence of Soviet acceptance, Jacobs recommended referral of the matter to the Council of Foreign Ministers. It was clear that Moscow was not interested in a settlement because its tactics of delay were successfully undermining America's position in Korea. The State Department responded that it was already giving urgent consideration to a number of alternative courses of action in the event of an indefinite prolongation of the SovietAmerican stalemate. Washington promised Jacobs a definitive reply within one week and ordered seoul in the meantime to "use all appropriate measures to insure continuance of negotiations." 105

Hodge accepted further delay only with a great deal of reluctance. He observed that the Communists

now draw hundreds of thousands of followers from non-Communist Korean nationalists who hate trusteeship but who wish to move forward.... I must emphasize that this is now the most powerful single political group in Korea.

The USAFIK Commander feared that continued American inaction would seriously undermine his position, while only advancing the Soviet objective of obtaining complete control. Conservative agitation for complete independence coupled with Soviet-sponsored leftist subversion was seriously endangering the security of American occupation. Hodge warned that if Washington allowed the further deterioration of his 105

Jacobs to Marshal1, July 25, 194?, FRUS, 1947, Vol. VI, 731-733; Borton to jacobs, July 25, 1947, RG 59, 740.00119 (Control Korea), /7-2547, NA. 
position the United States would have to acquiase eventually in the face of a complete Communist victory.

Trusteeship, Hodge explained, was the fundamental cause of America's predicament. Noscow had cleverly maneuvered the United States into a position requiring support for trusteesinip. Consequently, the American delegation was in the unenviable position where every plug for the success of the Joint Commission is, in effect, a plug for the Communist controlled group and where in defending the right of Koreans to appear before the Joint Commission and freely express themselves, we are defending many conspirators against the success of the Moscow Decision who actually wish negotiations to fail. For Hodge, there existed only one alternative. He urged Washington to adopt a posture of complete support for the extreme conservatives, since the emergence of a moderate coalition was no longer feasible. Such an approach demanded an effort to "stamp out communism in South Korea even at the cost of bloodshed." While creating a separate government in tha American zone, the United States could submit the issue of Korean reunification to the United Nations for action. State Department officials now recognized that the formation of a separate government was probably unavoidable. In the then prevailing atmosphere of terror, extortion, and destruction, democracy could never ilourish. In addition,

106

Hodge to Nar, July 27, 1947, RG 213, CCS 383.21 . Korea (3-19-45), Section 11, NA; Hodge to Var, July 27 , 1947, RG 59, 740.00119 (Control Korea)/7-2747, NA. 1.07

War Department Summary, August i, 1947, RG 319, P\&O 092 Korea TS, Section V-A, Part I. Case 85, Box 31, NA. 
Washington still hoped to prevent a complete victory for Rhee's "corrupt minority." Washington therefore instructed Hodge to implement measures for the elimination of police corruption and youth group violence. Such action was certainly admirable, but came too late to counter the predominant position of the extreme right.

State Department officials on July 29 finally completed work on a new American policy for Korea. John M. Allison of the Division of Northeast Asian Affairs was responsible for writing the draft of a proposal outlining a course of action to meet each of three contingencies. First, if the Soviets broke off negotiations at the Joint Commission pricr to August 5 , the United States would request an urgent CFM meeting. Marsinal would then propose that the United Nations supervise free elections for the creation of a legisiaturs in each zone. These Korean leaders would then solect representatives to serve in a provisional government that would speak for the entire nation. After consultations with the four major powers, the new Korean government would arrange for the withdrawal of foreign troops and the acquisition of economic aid for recovery. If Noscow refused to cooperate, the United States would submit the issue to the United Nations and implement the same program in scuth Korea.

\footnotetext{
108 $7-2447, N A$ Borton Viemorandum, July 24, 1947, RG 59, 895.00/ 109
}

Vol. VI, ?34-735. 
A second contingency provided for action in the event that incscow persisted in its refusal to cooperate at the Joint Commission beyond August 5. After that date, Marshall would suggest that the Joint Commission formulate a report summarizing its progress toward the fulfillment of Korean self-government. The proposal would also provide for the implementation of the program outlined above and the submission of the Korean issue to the United Nations.

Possible Soviet refusal to respond to any American initiative was the final contingency. Under such circumstances, the United States would proceed to form a separate government in the American zore and, on September 10, 1947, refer the issue of Korean reunification to the United $\mathrm{Na}$ tions. In forwarding the proposal to the SWNCC, the Ad-hoc Committee stressed that continued inaction would only produce more violence and rising public pressure in the United States for immediate withdrawal. To abandon korea under such circumstances would not only ensure a communist victory, but "discourage those small nations now relying upon the U.S. to support them in resisting internal and external Communist pressure." 110

While Truman's advisors pondered Allison's recommendations, the American delegation continued to cooperate with the Soviets at the Joint Commission. Brown attended a

110 Ibid.; Ad-hoc Committee to SwNCC, Aligust 4,1947, FRUS, $1947, \frac{\text { IOI. }}{\text { VOI. }}$, $35-741$. 
leftist gathering held in honor of the soviet and American delegates and pledged support for the Moscow Decision. He also stressed that the United States intended to protect the opponents of trusteeship. A promise of cooperation was sufficient to warrant participation in the formation of a provisional government. 111 In response, the "Anti-Trusteeship Committee" issued a statement pledging support for the Joint Commission. At the same time, it demanded the right of "honest expression of difference to any measure should it infringe upon Korean national sovereignty or interfer with Korean internal politics." 112 The Soviets were now even more vehement in demanding the exclusion of the extreme right. On July 29 , Shtikov rejected the final series of American proposals. Jacobs cabled Washington urgently requesting new directives. Soviet-American negotiations at the Joint Commission had completely collapsed. 113

IX

In August, 1947. Truman adopted Allison's recommendations in an effort to bypass the stalemate at the Joint

\section{1 \\ 1947 \\ New York Times, July 27, 1947, 7:5 and Juiy 28,} 112 Letter from the "United Council," July 28, 1947. DSB, XVII, 425 (August 24, 1.947), 400 ; Jaco os to Marshall, JuIy 31,1947 , FRUS, 1947, VOI. VI, 736. 113 Jacobs to riarshall. July 30, 1947, and August 2, 1.947, FRUS, 1947, Vol. VI, 736-737; New York Times, August $8,1.94 ?, 8: 1$. 
Commission. Patterson and Forrestal had quickly approved the plan, presumably in the belief that it would speed withdrawal. On August 6, Hilldring forwarded the Allison memorandum to Marshall and recommended approval as well. Truman's advisors hoped that the United States could termirate military government and replace Hodge with a Civilian Administrator during the first six months of 1948 . In preparation for the new American initiative, the State Department issued a series of statistics regarding the joint commission. The statement was an obvious attempt to portray the Soviet Union as an advocate of minority mle in Korea.

On August 12, Ambassador Smith presented Marshali's letter to Molotov proposing that the Joint Commission formulate a report on the progress of Korean independence. The Secretary of State emphasized American support for freedom of expression and representative self-government. Since previous attempts to realize Korean sovereignty had experienced little progress, Marshall recommended a SoviotAmericar conference on August 21 to discuss the course of negotiations at the Joint Commission.

In Korea, Brown immediately proposed that the two delegations begin work on a joint report. Shtikov resporded

\section{4}

Hilldring viemorandum, August 6,1947 , FRUS, 1947, Vol. VI, 7it2; Hilldring to Lovett, August 8, 19,47, RG 59, 895.00/8-847. NA; Joint Commission Commissioner Statement, August 10, 1947. ESB. XVII, 423 (August 10, 1947), 296-297. 115

Marshall to Smith, August 11, 1947, ERUS, 194?, Vol. VI, 748-749; DSE, XVII, 425 (August 24, 194?), 393-399. 
that he did not possess authority to engage in a discussion of the matter. American leaders in Seoul suspected another Soviet attempt to stall and urged Washington to proceed with the aggressive implementation of the American strategy. Brown informed Shtikov that the American delegation would formulate a unilateral response subject to change if Moscow decided to participate.

Washington also took steps to bolster Hodge's position. Jacobs had noted that Koreans were losing respect for the USAFIK Commander because the AVG tolerated extremist criticism of the United States. The new Undersecretary of State Robert Lovett thus approved for release a statement denying: rumors that Hodge was not implementing American policy. After the American demarche of August 12, however, the United States had little to fear from the extrome right. Only the left remained critical of American policy, since separate government servod Rhee's purposes. Thus, Hodge ordered the police to conduct a serios of raids against the extreme leftists, seizing. subversive documents and imprisoning a number of major Communist leaders. Jacobs defended such action as vital to the creation of a strong, Americanoriented southern regime. The time had come, Jacobs argued,

116

Jacobs to Marshall, August $1.4,1.947$, and August 19, 1947, FRUS, 1947, Vol. VI, 753-757. 11 ?

Fodge to Viarshall, Sugust 11, 194?, Jacobs to Narshall, Augist 12, 1947, and Lovett to Jacobs. August 15 , 1947, FRUS, 1.947, VOI. VI, 747-754. 
to end "provisional" policies and create a governmental structure. Hodge thoroughly agreed and requested permission to close all remaining leftist newspapers. He observed that "the time for politeness, accepted as weaknass by the Communists and by the Russians, is ended." 118

American delegates at the Joint Commission completed work on a separate report on August 20 and immediately forwarded the document to Washington. As expected, it emphasized the American defense of freedom of expression in contrast to the Soviet determination to achieve minority rile. Molotov's answer to the American proposal arrived in Washington three days later. It began with a denunciation of the recent arrests and imprisonments in the southern zone as "abnormal and inadmissable." The Soviet leader reiterated that Moscow supported consultation with only those individuals who fully supported the Moscow Decision. At the same time, Molotov accepted the American proposal for a joint report in the interests of Korean independence.

Shtikov immediately indicated his willingness to begin consideration of a joint report, but the American delegation had obviously registered a fait accompli. Brown then delivered a blistering denunciation of the Soviet delegation

118

Jacois to Marshall, August 14, 17, and 21, 1947, FRUS, 1347, Vol. VI, 753-761; Hodge to war, Auglist 25, 1.94?, RG 218, CCS 383.21 Korea $(3-19-45)$, Section 11, NA. 119

Hodge to Marshall, August 20,1947 and Lovett to jacobs, August 23, 1947, FRUS, 1947, Vol. VI, 757-760 and 764-70́5. 


\section{6}

for its protests against the recent arrests in the south. He charged Shtikov with exploiting a false issue to mask Moscow's refusal to accept broad consultations with all legitimate Korean groups. More important, the Soviet Union was sponsoring the infiltration of subversive elerents into south Korea and the United States was only engaged in legal self-defense. Brown agreed to release these prisoners, if the Soviets freed political prisoners in the north and agreed to a formula for wider consultations at the Joint Commission. Jacobs privately observed that American attendance at future sessions was pointless in view of Shtikov's "uncompromising, untenable, and intransigeant" attitude.

Evidently, Lovett agreed that Moscow was stalling and wrote Molotov on August 26 denying that Hodge was engaged in "oppression and persecution." He then charged the Soviet Union with violating the Marshall-Molotov compromise, since it refused to consult with all parties signing the required pledge to cooperate with the Joint Commission. Since further discussions in Korea were pointless, Lovett recommended a

a four-power conference to convene in Washington on September 9 for consideration of the joint report. At the same time, the United States would recommend the adoption of the Alisison plan, which Lovett outlined in his letter to violotov. of particular importance was the provision that the elected

120

Jacobs to Marshall. August 20,22, 25, and 26, 1947, ERUS, 1.947, Vol. VI, 760, 762-763, and 766-769. 
legislature would reflect the two-to-one popliation superiority of the south over the north.

Soviet-American negotiations at the Joint Commission remained hopelessly deadlocked. Jacobs observed that under present conditions it would be difficult to maintain negotiations beyond August 31. The formulation of a joint report was absolutely impossible, while shtikov refused to consider any program for elections unless the Joint Commission excluded the opponents of trusteeship from cansultation. Brown strongly criticized the Soviet delegation for refusing to accept truly free elections. He also rejected Shtikov's demand for equal representation of each zone in a united legislature. Such tactics, Brown explained, "wolid change the normally substantial rightist-moderate majority throughout North and South Korea to an overwhelming and unrealistic leftist majority." 122

Moscow made plain its refusal to accopt the American strategy in Molotov's letter to Lovett of Septemier 4 . The Soviet leader criticized the United States for refusing to foster the emergence of a democratic government in Korea. He explained that America's refusal to support the Joint Commission and to terminate repression of truly "democratic"

\section{1}

Lovett to Smith, August 26, 1947 and Lovett to Jacobs, August 27, 1947, FRUS, 1947, Vol. VI, 771-775; The text of both the Molotov and Lovett letters appear in DSB, XVII, 427 (September 7,1947 ). 122

Jacoos to Marshall, August 26, 1947 and Septemoer 3. 1947, PRUS, 1947, VOI. VI, 769-778. 
parties in the south only consolidated the "abnormal situa123

tion." At the Joint Commission, Shtikov refused to accept the American desire for a detailed joint report. Fe would agree only to a summary of the twelve decisions of the commission. Thus, in accordance with the Allison plan, Truman instructed Marshall to present the Korean issue to the United Nations General Assembly on September 17, 1947. The President explains in $h$ is memoirs that korea appeared to be one area where the United States could withdraw without serious danger to American national security. In essence, the Administration had decided to "turn the problem over to the $\mathrm{U} . \mathrm{N}$. and to get out of the way in case of trouble." 124

Some scholars have criticized Truman for deciding to withdraw from Korea at the earliest possible date. In viow of the monumental problems facing the United states, however, one can certainiy sympathize with the American desire to disengage. Korea was, after all, a frazile and complex issue, tangential to the main thrust of American Dostwar policy. Congressional unwilizingness to provide financial support for containment, coupled with the limits on American manpower and material, meant that Truman had

\section{3}

Molotov to Marshall, september 4,1947 , FRUS, 1947, VoI. $\because I, 779-781$; DSB, XVII, 430 (September 28, 1947). 124

Jacois to Marshall, September 5, 1947, FRUS, 1947, Vol. VI, 782; Mruman, Years of Trial and yope, $3214 ;$ Muccio, oral $\mathrm{History}$ Interview Transcript, Decenber 27, 19?3, HSTI, 13-14.

1.25

Henderson, Folitics, of the Vortex, 150. 
few alternatives other than disengagement. The real tragedy of Truman's decision to withdraw was that sucoess required support for the extreme right. After 1947 , the realization of a genuine democracy in Korea vas virtually impossible. Frustration played a significant role in the development of America's Korea policy. Truman himself complained to Edwin A. Locke jr. that "Korea, of course, is in a bad way and we feel sorry about it but nearly every place where the Russians have a thing to do with affairs, political or otherwise, there is a mess." American efforts to find a negotiated settlement only served to magnify the problems of occupation, while increasing demands in Korea and the United States for withdrawal. Jacobs warned that unless Washington found a solution to the Korean dilemma "we may have to abandon the country willy nilly." ${ }^{1.28}$ Thus, Truman decided to rely on the United Nations to bridge the gap between the objective of reunification and the absence of available means to achieve success. 1.29 Truman believed that he had finally discovered an avenue for escape.

\footnotetext{
Kim, Divided Koroa, 78-79; Fenderson, Politics of the Vortex, $1.51 .-1.53$.

Truman to Locke, August 1.5. 1947, mruman Papers, OF 471.

Jacobs to Marshall, September 8, 1.947, FRUS, 1.947 , Vol. VI, 763; New York Times, September 1.0, 1.94?, 26:1. 129

Denis Stairs, The Diplomacy of Constraint: Janada, the Korean ilar, and the United States (Toronto: university of Toronto press, 19?4), 1.7; vinacke, The United States in the Far East, 65 .
} 
Chapter VI:

The Dilemma of Withdrawal 
Congress was extremely reiuctant to approve the expansion of American foreign policy commitments during the immediate postwar years. As a result, Truman was unable to apply the containment policy in korea during 1947 and turned to the United Nations in an effort to resolve his predicament. The President's reliance on the international organization had increased following the Iranian Crisis of early 1946. He recognized that the United States could refer problems to the United Nations and expect to enjoy the support of a sizable majority for its objectives. As early as May, 1947, the Administration had considered advocating Korean elections under United Nations supervision and observation. Such action would indicate American good faith, a desire to fuifill international commitments, and support for international cooperation. Korean unification was not sufficiently vital to American security to warrant unilateral action, but the issue provided an excellent

Douglas to Marsinall, June 11, 1947, FRUS, 1947, Vol. I: The United Nations (Washington, D.C.: Government Printing Ofice, 1973), 755-756; Robert G. Wesson, "The United Nations in the World Outlook of the Soviet Union and the United States," in Soviet and Ameriean Policies in the United Nations, edited by Alvin 2. Rubinste in and George Ginsburgs (New York: New York University Press, i.970), 6-7. Rusk to Gross, May 9, 1.947, RG 59,895.00/5-94?, liA. 
opportunity to assume an unequivocal position in support of national self-determination before the world community. In addition, if the west demonstrated its unity and resolve, stalin might agree to a suitable settlement in Korea.

It was extremely unrealistic for Truman to expect the Soviets to accept Lovett's proposals. Stalin certainly recognized that he would be in a minority at a four-power conference as well as at the United Nations. Political and psychological pressure of this sort would only harden the Soviet position. An attempt to legislate an agreement on Korea, rather than reaching a settlement through methods of mediation and compromise, would merely eliminate the chances for a successful agreement. Truman believed, however, that he had no alternative. He expected the United Nations to implement policies that the United States was unable to execute through its own efforts. The United Nations, given a. volatile issue of this sort, possessed no agencies or powers sufficient to complete its assigned task. only a Soviet-American agreement or a Korean civil war would bring

Goodrich, Korea, 40; Reitzel, Kaplan, and Coblenz, United States Foreign Folicy, 176-1.77; Halliday, "The United Nations in Korea." in Without Parallel, 119; Daniel $S$. Cheever, "Keeping the Peace: An Interpretation of Soviet and American Security Policies," in Soviet and American Policies. in the United Nations, 143 .

Stairs, The Diplomacy of Constraint, 17; Cordenker, The United Nations and the Peaceful Unification of Korea, 12: linsoln Bloomfiald, The United Nations and U.S. Foreiger Policy: A New Look at the National Interest (Boston:

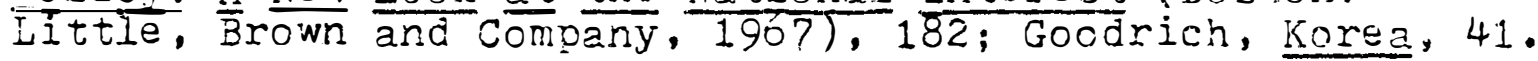


reunification, but the Truman Administration refused to accept the reality of either course.

Communist successes in China during the summer of 1947 indicated that the United States could remain in occlipation of south Korea only with great difficulty. Truman clearly recognized the connection between the two countries and America's overall position in Asia. On July 11, he announced that General Aibert $C$. Wedemeyer would visit China and Korea on a fact-finding mission pursuant to a general reappraisal of American policy in these areas. "While in China, wedemeyer cabled Marshall that the Soviet union was engaged in the masterful pursuit of complete control throughout Asia. 0 . Edmund Clubb agreed, observing that once Moscow seized Manchuria "the last missing segment in the Soviet 'cordon sanitaire" of sympathetic political groupings about its Asiatic frontiers will have been fitted into piace." Such reports only confirmed Washington's suspicion that Stalin would expand into any area of Asia where conditions were favorable.

After surveying conditions in Korea, wedemeyer concluded that "the same sinister forces that militate against

\footnotetext{
5

Marshall Memorandum, July $8,1.947$, Truman Papers, White House Central Files, Confidential, Box 34 , State Department Correspondence, 1946-47, Folder 9, HSTL; DSB, XVII, 420 (july 20,1947$), 1.49$. Wedemeyer to Varshall, August 3, 1947, Clubi Memorandum, August 3, 1947, and JCS to SwNCC, June 9, 1947, FRUS, 194?, Vol. VII: The Far East: China (ivashington, D.C.:

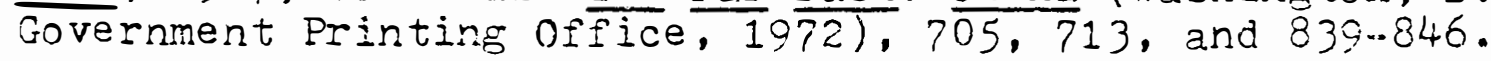


a program of democratization and rehabilitation in other areas of the world. . . are present in Korea." The Soviets were responsible for the instigation of riots, rebelitions, and terrorism in south Korea, while building a sizable puppet army in the north. Although outright invasion was unlikely, Wedemeyer believed that Korea had to develop sufficient military strength to combat infiztration and slibversion. Any attempt at cooperation and conciliation would not only fail but also further the Soviet objective of political expansion and economic enslavement. Nor could the United States withdraw prematurely, because such action would ensure total Soviet control. Wedemeyer warned against any "ideological retreat" in Korea, since such a policy would only increase Soviet prestige and undermine America's position in Japan. Wedemeyer recognized, however, that the creation of a Korean democracy involved a number of unique and difficult problems. Both the Korean police and the National Youth Novement had committed countless acts of violence, extortion, brutality, and intimidation, obtaining the universal hatred and distrust of the korean people. Yet, the AMG had to rely on these same elements to maintain law and order. Wedemeyer stressed that, in the absence of major reforms, a truiy free

Wedemeyer to Ambassador Stuart, September $3,1.947$, FRUS, 1947, V0l. VI, 765 .

Wedemeytr Report, September 19, 1947, FRUS, 1047, Yol. VI, 796-802; Also in, U.S. Congress, House, Committee on Foreign Affairs, Revort to the President September 1947, By Lt. General A.C. We demeyer, 82 nd Cong., 1 st sess., 1951. 
election was impossible, since the extreme right would cortrol the outcome. Wedemeyer emphasized that "every possible opportunity must be used to seize the initiative in order to create and maintain bulwarks of freedom." He recommended extensive American economic assistance and the formation of an American-officered "Korean Scout Force." If the United States acted positively, the Soviets would eventually accept a "neutralized" Korea as a buffer zone in northeast Asia.

Other American leaders shared Wedemeyer's judgment that the United States could ill-afford to abandon Korea. Francis B. Stevens of the Division of East European Affairs ärzied that certain ideological imponderables were more important than Korea's strategic value. He opposed withdrawal on political grounds, expiaining that Korea

is a symbol to the watching world both of the East-West struggle for influence and power and of American security in sponsoring the nationalistic aims of Asian peoples. If we allow Korea to go by defalilt and to fall within the soviet orbit, the world will feel that we have lost another round in our match wi.th the Soviet Union, and our prestige and the hopes of those who place faith in us will suffer accordingly. In the Far East, the reliance of national movements on American support would be seriously shaken, and the consequences might be far reaching.

A comple te Communist victory in Korea would only serve to reinforce stalin's devotion to the strategy of subversion and indirect aggression for expansion in other areas.

\section{Inid.}

Stevens Memorandum, September 9, 1947, FRUS, 1947, Vol. VI, 784-785. 
Strategic considerations dominated the attitude of most of Truman's advisors in regard to Korea. Both the Policy Planning Staff and the Division of Northeast Asian Affairs recommended American withdrawal because of Korea's minor importance to national security and the extent of American commitments in other areas. On september 1.5, the SHNCC requested the JCS to comment on the relationship between Korean occupation and American security.

In the meantime, Washington asked Jacoos to provide his views on the future course of American policy in Korea. America's Political Advisor replied that a decision was not possible until the Administration determined whether Korea was vital to American security. In the event that Truman decided not to apply the "Truman Doctrine" in Korea, Jacobs recommended a. graceful witharawal and a settlement with the Soviet Union. He predicted subsequent anarchy and considerable bloodshed, but philosopnically offersd the following realistic observation:

In any event we cannot give democracy, as we know it, to any people or cram it down the ir throats. History cries loudly that the fruits of democracy come forth only after long evolutionary and revolutionary processes involving the expenditure of treasure, blood and tears. Noney cannot buy it; outside force and presure [sic7 cannot nurture it.

Regardless of ultimate action, Jacobs appealed to washington for a quick decision. He concluded that further delay would

11

Ibid.; SWNCC to JCS, September 15, 1947, David Lloyd Papers, Box 10, Korean Documents, HSTL. 
make the entire Korean question academic.

Despite Sterens' warnings, the JCS concluded that "from the standpoint of military security, the United States has Iittle strategic interest in maintaining the present troops and bases in Korea..." 13 while any American offensive on the Asian mainland would bypass Korea, American military leaders argued that an enemy position on the peninsula would be vulnerable to air attack. In addition, the USAFIK could contribute to national security more efiectively if the Administration deployed it elsawhere. More important, in the absence of a major socio-economic rehabilitation program, the JCS believed that disorders and unrest would render the American position in Korea untenable and force withdrawal under humiliating circumstances. 14 on september 24 , Kennan informed Butterworth of the JCS position. He urged the State Department to inform seoul of the decision "to cut our losses and get out of there as gracefully but promptly as possible." 1.5

$$
1.5
$$

\section{2}

Jacobs to Marshall, September 19, 1947, FRUS, 1947, Vol. VI, 804-807.

13

Forrestal to Marshall, September 26, 1947, Iloyd Papers, Box 10, Korean Documents. HSTL. 14

JCS to SWNCC, September 26, 1947, Secretary of the Army files, Record Group 165, 091. Korea TS, U.S. Department of the Army Archives, NA; Also in, FRUS, 1947, Vol. VI, 817818; Truman released the documert during the 3.952 Fresidential campaign, November 2, 1952, Public Papers, Harrv $\mathbf{S}$. Truman, $1952,323$. 15

Kennan to Butterworth, September 24, 1.947, FRUS, 1947 , Vol. VI, 814. 
Lovett informed Nolotov on September 16 of the American decision to place the Korean issus on tre United Nations agenda. Marshall's speech before the General Assembly the following day focused attention on Moscow's refusal to grant freedom of expression as the principal reason for the Korean impasse. The Secretary of State explained that the United States sought internationaI action to remove the 38 th parallel, which was responsible for economic deterioration and the absence of independence 16 in Korea. On september 18. Lovett cabled to Lake Success

- the American proposal, which provided for United Nations supervised elections within six months of adoption. The subsequent legislature, reflecting the southern poplilation superiority, would formulate a constitution and appoint a provisional government. A United Nations Temporary Commission on Kcrea (UNTCOK) composed of eleven nations would supervise the elections, ensure freedom of choice, and report its findings to the General Assemoly.

American lezders clearly understood the dangers involved in a decision to withdraw from Korea. Truman and his advisors were sensitive to the warnings of wedemeyer and Stevens, but lacked the resources necessary for the

Lovett to Molotov, September $16,1.947$, Frus, 194?, Vol. VI, 790; Narshali, "A Program for a More Effective United Nations," DSB, XVII, 429 (September 28, 1947), 619; New York mimes, seotember j.8, 19.47, 24:1, 3:1.

Lovett to Austin, September 18,1947 , FRUS, 19,47, Vol. VI, ?94-?95. 
successful implementation of a more positive program. The Administration hoped, however, that if the United Nations could create $z$ Korean provisional government Congress might approve a program of economic assistance. 18 In the absence of financial support, as Leahy observed, the "feasibility of [Nedemeyer's] recommendations will, . . , have to be considered particularly in relation to U.S. commitments 19

elsewhere in the world." If Truman had to abandon Korea, the Communists would probably seize control of the entire peninsula, thus damaging American prestige in Asia. For Truman and his advisors, the dilemma of withdrawal was all too apparent.

American leaders recognized that the United Nations might not find an answer to the Korean dilemma. As a result, the new secretary of the Army, Kenneth C. Royall, traveled to Korea during late september on a fact-finding mission. During subsequent aiscussions, Hodge expressed agreement with the JCS that Korea possessed Iittie strategic value for American security interests. He therefore favored witharawal.

1.8

NcClintock to Rusk, September 16, 1.947, RG 59, 895.00/9-1.647. NA; New York Times: September 1.8, 1.947, 5: 3; Cho argues that Truman sought relief from an unwanted burden, but such an evaluation is misleading, Korea in world Folitics, 205 .

Leahy to Truman, Undated, Truman Papers, PSF 32, (China-Foreign 1.948), HSTI. 
but only if such action did not damage American prestige ana occurred over a nine month period. The United States would also have to train and equip a strong constabulary army prior to departure. Because economic self-sufficiency was impossible, Hodge supported a five-year program of financial and economic rehabilitation. The United States had to block further Soviet expansionism; thus the expense of technical advice and economic improvement was wholly justified.

Hodge tinen provided a rationalization for America's dependence on the extreme right. The conservatives engaged in "strong-arm" tactics, he admittea, but they had eliminated leftist control over the labor movement. With an end to work slowdowns and sabotage, "the increase of street cars operating in Souel sic/ from 20 to 1.00 within. . a month" had been a significant development. On the other hand, Hodge expressed consternation over State Department conierences with 01 iver and Ben C. Limb, stressing that "government officials in Washington should have nothing to do with the supporters of Syngman Rhee." Finally, Hodge raised the issue of southern dependence on northern electrical power, noting that Vioscow could shut off the electricity at any time and use it as a political weapon. The USAFIK Commander suggested that Washington approve a delay in complete repayment of electrical equipment. The Soviets, he argued, would continue

Dupuy to Norstad, October 2, 1947, FG 319, P\&O 091 Korea, Section III, Case 106, Box 89, NA. 
to supply power as long as Moscow received the coveted material in return. The Administration agreed to the strategy, but later condemned the Soviet Union for shutting of $f$ the electrical power.

Royall's mission revived American interest in a program for economic development. American military leaders began to reject outright abandonment as a proper course of action. The Army Department now favored a one billion dollar program of economic aid and technical advice over a five-year period. only economic rehabilitation would permit the united States to withdraw safely and "thus far the US has done little more than hold its own." Continuation of present policy, on the other hand, was intolerable, since korea would be a permanent and unprofitable liability. The Army Department anticipated that through interdepartmental coordination and Congressional cooperation the United States could build an "ideological bridgehead on the Asian mainland."

Moscow now provided an additional reason for American withdrawal. At the Joint Commission, Shtikov recommended mutual Soviet-American disengagement to allow the Koreans to organize a provisional government through their own efforts. Brown responded that such a proposal was unprecedented and he did not possess sufficient instructions. More important,

$$
22^{\text {Ibid. }}
$$

Army Department Memorandum, September 23, 194? and Economic Report on Korea, September 23, 1947, RG 319, P\&0 091 Korea, Case 106, Box 89, NA. 
the United Nations was now responsible for Korea's destiny. One can easily understand Soviet motivations. Noscow was aware that the northern zone was stronger economically and militarily. United Nations consideration of Korea, on the other hand, could only damage Soviet prestige and prevent a complete victory. An anticipated American refusal to withdraw would thus transfer the onus of intransigeance from the Soviet Union to the United States. The Soviet proposal served to strengthen the argument of those American leaders favoring rapid withdrawal.

Moscow was also attempting to force American departure prior to the application of containment in Korea. On October 10. Nolotov informed the United States of Soviet opposition to United Nations consideration of the Korean issue. He charged the United States with consistently opposing the Moscow Decision and supporting reactionary Korean leaders. Now the United States had even refused to agree to mutual witndrawal. As a result, Molotov concluded that SovietAmerican negotiations were no longer feasible. One week later, Lovett notified Molotov that military withdrawal was an integral part of Korean independence and both issues were in the hands of the united Nations. 24

23

Jacobs to Marshall, September 26, 1047, FRUS, 1947, Vol. VI, 816; New York Times, September 27, 1947, 1:6; Zunce to Martin, September 28, 1947, RG 59, 740.001.19 (Contro1 Korea)/ $/ 9-2847$. NA. 24 Molotov to Marshall, october $1.0,1.947$ and Love tt to $5 \mathrm{mith}$, Octo oer 1?, 1947, FRUS, 1947, Vol. VI, 827 and 836. 
Lovett and Charles E. Saltzman, who had recently

replaced Hilldring, had already recommended that the JCS and the Policy Planning Staff formulate plans for withdrawai in the event that the United Nations failed to resolve the Korean dilemma. Moscow's proposal only hastened consideration of the matter. Both Marshall and Harriman doubted. whether the United States could leave Korea without inflicting considerable damage on American prestige. The Soviet proposal did, however, provide an excellent opportunity to withdraw without appearing to abandon the American client. Both the Policy Flanning Staff and the State Department agreed that the American position in Korea was untenable in the face of the Soviet-sponsored northern regime. A great deal of money and effort alone would result in the creation of a strong and stable south Korean state. Kennan, Rusk, and Allison recommended the incorporation of the Soviet proposal into the Amerisan program at the United Nations. The United States would then leave Korea, but not at the price of appearing to "scuttle and run."

Significantly, several American commentatcrs disagreed with the Administration's private evaluation of Korea's

\footnotetext{
25

State Department Memorandum, September 24, 194? RG 59,740.0011.9 (Control Korea)/9-2447. NA; Millis, (ed.),

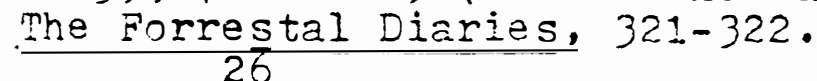

Butterworth to Iovett, October 10, 1947, FRUS, 1947, Vol. VI, 820 ; on october 1.3, Washington reque sted hodge to supply information on troop requirements during the Korean elections and a schedule for rapid withdrawal, RG 319, P\&0 091 Korea, TS, Section V, 3ox 22, NA.
} 
strategic importance. An editorial in Colliers explained that "it is better to have the division between Communists and freedom drawn in Korea rather than, say, between North $2 ?$

and South Dakota or at the Mississippi." The United States had a moral obligation to ensure Korean freedom and independence. To withdraw would guarantee a complete Communist victory, thus constituting a betrayal of American commitments. Failure to halt the Soviets at the 38 th parallel would destroy American prestige and eliminate the influence of the United States in Asia. Some observers insisted that only major economic and social reforms were an adequate answer to the Soviet challenge. The United States had to adopt a more positive program, because economic aid and political advice, "rather than bullets and jails, are democracy"s most effective weapons." Democracy could never flourish in an atmosphere of police repression, political graft, high taxes, and mandatory rice collection.

$$
\text { American commentators not only discerned Truman's }
$$

desire to withdraw, they also perceived the consequences of such action. Noscow had created a northern military force capable of moving south and conquering the entire peninsula

28 Colliers, CXX, 16 (October 18, 1.947), 76+. $29^{\text {New York }}$ Times, September 27, 1947, 14:2. Nark Gayn, "Cold War: Two Police States in Korea," New Republic, CXYII, 1.1 (September 15, 1947), 15-16; Thoburn T. Brumbaugh, "Soviet, Nightmare in Korea," Christian Century, LXIV, 37 (September 10, 1347), 1.077-1078; Saturday Evening Post, CCXX, 10 (September 6, 1947), 26-2?. 
after America's departure. Many observers urged Truman to reject the Soviet proposal for mutual withdrawal and apply the necessary funds, material, and men to protect Korea from Soviet expansion. Unless the United States indicated its resolve in Korea, German and Japanese security would be in danger. Yet, the Administration recognized that if the USAFIK remained the Soviets could leave and then charge the United States with imperialism. While the United Nations could not force Moscow to disband the northern army, it could hardy tolerate continued American occupation. American success in Korea still depended lipon the United Nations. On October 17, chairman of the American delegation Warren Austin formally presented the proposal for Korean independence. The plan provided for elections no Iater than March 31, 1948 under United Nations supervision and mutual withdrawal following the formation of a provisional government. 32 The following day, Brown recommended a recess of the Joint Commission in anticipation of United Nations action. Shtiliov responded that the Soviet delegation intended to withdraw from the negotiations permanently,

\section{0}

Business Week, 944 (October 4, 1947), 1.09-110; New York Times, October 14, 1947, 26:1. Time, I, 14 (October 1.0 , 1947), 31; Nation, CIXV, is (November 18, 1947), 500. 31

Jacobs to Marshall, Deto der $8,1.947$, FRUS, 1.947 , Vol. VI, 825; Christian Century. IXIV, 41 (October 10, 1947), $1197-1198$. 32

Austin to Lie, October 17, 1.947, FRUS, 1.947, Vol. VI, 832-835; Also in, DSB. XVII, 434 (October 26, 1947), 820-822; New York Times, October 18, 1947, 14:1. 
because the United States refused to implement the Noscow Decision. On October 23, the Soviet delegation left Seoul and Soviet-American negotiations terminated officially. Subsequentiy, the Soviet Union formally proposed at the United Nations mutual withdrawal from Korea. 33 Thus, the peaceful unification of Korea was now entirely in the hands of the international organization, if it chose to act.

American efforts to break the deaklock at the Joint Commission had a profound effect on domestic politics in Korea. Initially, the Koreans responded as Truman and his advisors expected. Molotov's rejection of a four-power conference to revise the Moscow Decision brought a raft of unfavorable, anti-Soviet comment. 34 Rhee, Kim Koo, and $\mathrm{Kim}$ Sung-soo quickly recognized the significance of the breakdown in Soviet-American negotiations. The extreme right initiated a high-powered campaign to force the United States to grant immediate elections for a separate government. During late August, the SKILA passed a law providing for elections within eighty days after announcement. Hodge

33

Jacobs to Marshall, October 18 and 20, 1.947. ERUS, 1947, Vol. VI, 836-83? and 842-843; New York Times, October. 21, 1947, 11:2; Tompkins, American-Russian pietations in the Far East, $330-331$.

New York Iimes, September 1.1, 1.947, 15:2; Jacoos to

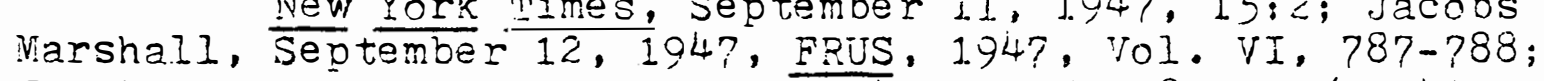

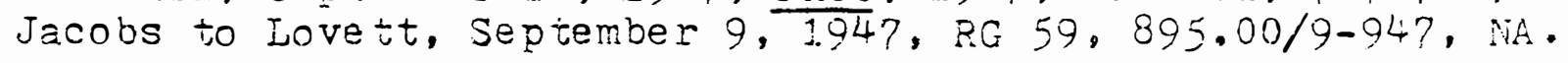


agreed on the need for haste, observing that "the Koreans are enthusiastic over prospect of election and any delay would subject US to widespread criticism." The USAFIK Commander still detested Rhee, but belioved that only the victory of the extreme right would prevent an eventual. Communist seizure of power. Early in September, Lerch approved the SKILA election Iaw, despite American dissatisfaction with certain of its provisions.

Rhee not only sought immediate elections, but also Korean representation at the united Nations. During conversations with Penfield and Saltzman, Ben C. Limb requested that Washington appoint Louise Yim and himself as Korean delegates to the United Nations. Lovett immediately rejected the proposal, arguing that such action would require northern representation as well. 36 Jacobs supported the decision, complaining that Rhee's activities had become "a thorn in our flesh." The old patriot's demands for precipitate elections and a separate government only made American policy more difficult to implement. 37 Despite

Hodge to JCS, August 23, 1947, RG 335, NDSCA 014 Korea ( 1 JuI to 31 Aug 4?). Section VIII, Box 250 , NA; Jacnbs to Marshali, August 17 and 23,1947 , FRUS, 1947, Vol. VI, 755 and 763; New York Times, September 5, 19,4, 5:8; Hodge to JCS, September 27, 1947, RG 319, P\&0 091. Korea TS, Section III, NA. 36

Memorandum of Conversation, September 23, 194? and Lovett to Jacobs, September 25, 194?, ERUS, 1947 , Vol. VI, $911-812$ and $815-816$. 37

Jacobs to Iovett, September 30,1947 and october 2, 1947. FRUS, 1947, Vol. VI, 819-822. 
American pressure, Rhee continued to asitate for immediate action, since he realized that delay could only reduce his chances for a successful assumption of power.

Rhee's relations with the AMG continued to deteriorate during October, 1947. The extreme conservatives staged a demonstration outside Hodge's headquarters protesting the absence of Korean representation at the United Nations. On october 8 , Hodge issued a public statement that no Koreans would attend sessions at the United Nations. In addition, the United States would not announce a date for the elections until the United Nations acte ${ }^{38}$ Rhee was furious and denounced Hodge for fostering the revival of Communism in the south. He warned the AMG that it could expect work slowdowns and "a great deal of trouble" if elections did not occur in the near future.

Jacobs observed that Rhee was afraid he would be unable to win truly free elections and therefore intended to exploit his control of the police and youth groups to obtain total power. Few observers could ignore that arbitrary arrests and prolonged imprisonment had removed any leftist challenge to Rhee's dominance of any electoral contest. Jacobs complained that Rhee's actions and the conservative response to the questionaires revezled that even the most

Jacobs to Marshall, October 8 and 9, 1947, FRUS, 1947. Vol. VI, 824-826; New York Times, October 8, $1947,11$. 39

Jacobs to Marshall, October 10 and 29, 1947. FRLis, 1947. Vol. VI, 829-830 and 848 . 
educated Koreans possessed no conception of basic principles 40 of Western democracy.

Reports from seoul hardly stimulated confidence in the future of America's Korea policy. Washington began to consider the formulation of a program to create a Korean army, while enlisting civilian advisors and acquiring emergency power units for Korea. The Administration delayed final action on these matters until the United Nations acted on its 41.

proposal. The Department of the Army expressed considerable apprehension over the logic of an American attempt to train and equip a large south Korean army. It feared that the United States would be unable to continue such assistance over a prolonged period. Termination would produce the very ill-will and loss of prestige it was intended to prevent. The American experience in China also indicated that the lack of expertise would cause the Koreans to abuse the equipment and render it useless after two years. Such waste would be unwise in view of America's vast responsibilities.

In the meantime, Truman and his advisors proceeded with plans for withdrawal and ecoromic aid. On October 24 , the

Jacobs to Marshal1, Dctober 21, 1.947, RG 59, 740.00119 (Control Korea)/10-2147, NA; Jacobs to Marshall, October 24, 1947, RG 59,895.00/10-2447, NA. 41

Dupuy Memorandim, October 24, 1.947, RG 31.9, 091

Korea, Section I, Case 1., Part I, 3ox 20, NA; Draper to Hodge, October 26, 1947, 091 Korea, Section II, Part I, Case 2, NA.

Scott Niemorandum, October $16,1.947$, PG 319 , PaO 091 Korea TS, Section I, Part I. Box 20. NA. 
President called for a special session of Congress to provide funds for the United States to "assist Iree men and free nations to recover from the devastation of wax, to stand on their own feet, and to help one another, and to contribute their full share to stable and lasting peace." On Novemoer 10. Nedemeyer, now Director of Planning and operations, informed ViacArthur and Hodge of his decision to support withdrawal from Korea during the fall of 1948 regardless of United Nations action. He requested their comments on the logic of implementing such a proposal only in south Korea, if Moscow refused to join in simultaneous disengagement.

Hodge responded that Moscow would never couperate with the United Nations and support reunification. He thus utged preparations for the creation of a separate government in south Korea. The USAFIK Commander stressed the necessity for creating a strong constabulary army and implementing a program of economic assistance. Only a strong and stable southern regime could withstand pressure from the north. Hodge also noted that Rhee would support such a program, since it promised independence and self-government. In addition, the probable leftist boycott of separate elections would ensure a Rheeist electoral landslide. Hodge fearod that Rhee's victory would mean the emergence of a reactionary fascist regime, but he hoped that the election of several

Truman Radio Address, October 24, 1947, Eublic Papers, Harry S. Truman, 1947, 478-479; wedemeyer to WacArthur and Hodge, October 1.1, 1947, ERUS. 1947, Vol. VI, 856. 
moderate leaders would temper Rhee's extremism.

44

Hodge's recommendations presented a blueprint for the use of containment as a Iiberating force in Korea. The USAFIK Commander urged Wasnington to adopt the five-year rehabilitation program that the AVG had formulated during Royall's visit the previous september. A well-staffed American Embassy could then supervise the utilization of such assistance and report periodically to Washington on the progress of recovery. Once the solith Korean government developed internal economic and political strength, Fodge predicted that "national feeling among the north Koreans may be aroused and sufficient pressure brought to bear upon tine Soviets to compel them to permit. . . an amalgamation of the two areas." More important, Hodge's program wolild allow the United States to withdraw. He cabled a timetable for departure, stressing that the schedule snould be flexibie so that change would be possible in case of an emergency. Washington was receptive to Hodge's recommendations, but was concerned about the USAFIK Commander's inability to maintain stability in Korea and control Rhee. The JCS decided not to relieve Hodge immediately as long as delay did not unduly hamper American withdrawal. General Dwight D. Eisenhower argued that Hodge's knowledge and experierce

44

Hodge to JCS, November 21, 194?, P.G 319, P\&O 091 Korea TS, FW 38, MA. 45

Ibid.; Seedlock Miemorandum, November 28, 1947, RG 31.9, 09i Korea TS, Section I, Case 1, Box 20, MA. 
were an advantage, while saltzman observed that his removal would only register a victory for syngman Rhee. The state Department remained dissatisfied with Hodge's performance. Butterworth believed that Hodge possessed a pessimistic attitude and low morale. His tolerance of "police state" tactics in south Korea would alienate the UriTCOK and discredit the United States in the United Nations. Interestingly enough, the American military was not sympatinetic with such arguments and suspected that Butterworth was "laying the necessary groundwork to place the blame for ultimate US failure in Korea at the doorstep of the Army."

State Department officials had good reason for concern. On December 3, an alleged supporter of $\mathrm{Kim}$ Koo assassinated rightist leader Chang Duk-soo. Penfield was appalled and demanded vigorous action for the restoration of law and order in the American zone. Washington instrueted Hodge to crack down on the police and force them to preserve stability 48

rather than abuse their power. Langdon responded that he would assume personal direction over the investigation of Chang's death and press the Korean police for tine release of

46

Eisenhower to Viarshall, December 3, 1947, Saltzman to Marshall, December 4, 1947, and Marshall to Eisenhower, December 4, 1.947, FRUS, 1.947, Vol. VI, 868-869. 47

Benjamin Taylor Vemorandum, December 8, 1947, RG 319, P\&O 091 Korea TS, Section $V$, Case 31., Box 22, NA. Penfield to Hodge, December 11, 1947, RG 59, 895.00/12-1147. NA; Lovett to Langdon, Lecemicer 1.1, 1947, FRUS, 194?, VoI. VI, 857-868. 
purely political prisoners. He reminded Washington, however, that Korea was "politically excited, restive, and frustrated, and economically on a subsistence margin." Some consideration for these disruptive factors was essential, if Washington was to evaluate properly the AMG's performance.

Langdon blamed Rhee for the turbulence in south Korean politics. He strongly urged Lovett to confer with Oliver and Limb to obtain Rhee's cooperation with American policy at the United Nations. Lovett attempted to comply with Langdon's request, but experienced little success. More important, American leaders realized that nothing could "prevent Rhee from running away with the election." A realistic assessment suggested that the United States might just as well begin to support the old patrict sooner rather than later. The Truman Administration could only hope that Rhee would be more amenable after he had to depend for survival on American aid and technical advice. Thus, washington instructed the AMG to concentrate on creating the appearance of an atmosphere of free choice that would satisfy the UNTCOK and guarantee international support.

Kimm Kui-sik's activities were primarily responsibie for

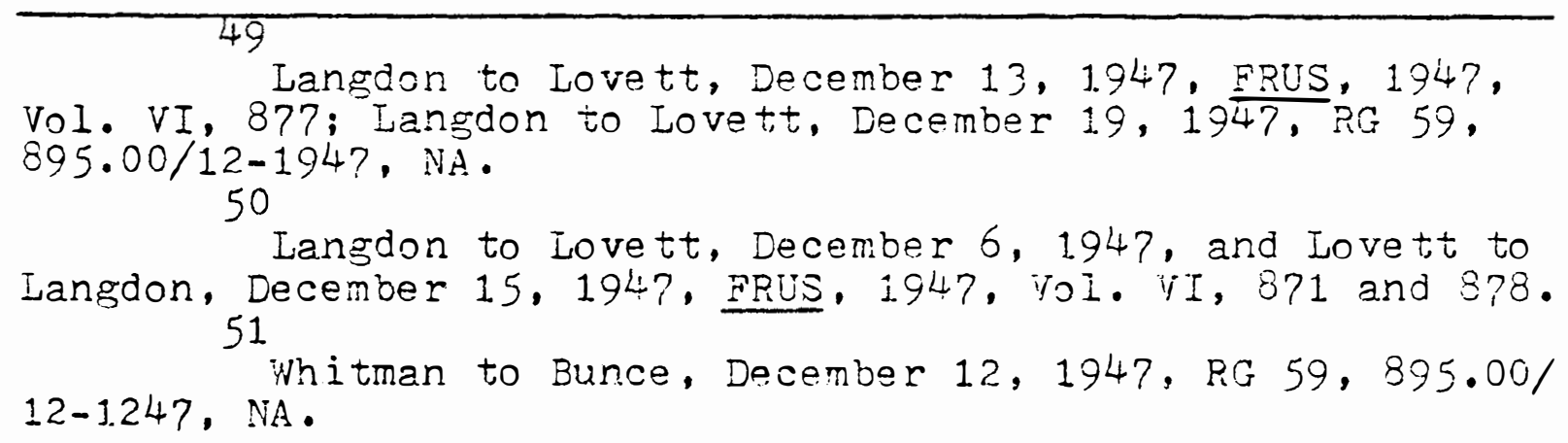


Rhee's increasing reliance on terrorism and assassination. On December 20, Kimm formed the "National Independence Federation" and called for the convening of a North-South Conference to eliminate the partition of Korea. Kimm emphasized that only the Koreans themselves could end partisan strife and unite in support of independence and reunification. Continued occupation only meant more economic deterioration, the absence of political freedom, and the persistence of chaos. Finally, Kimm arguad that the arrival of the UNTCOK would not bring reunification, but would only harden the division at the 38 th parallel.

Rhee and Kim Koo immediately recognized that such a moderate party would be a huge political threat if it obtained broad political support. As a result, the extreme right began to direct its activities against those individuals who expressed support for either cooperation with Kimm or the UNTCOK. Kim Koo's implication in Chang's assassination indicated the nature of the strategy. Hodge observed that Rhee was an expert in terrorism, beatings, extortion, and assassination, as well as other activities "comparable to those of Al Capone in Chicago." He appealed to Washington for more troops, since the arrival of the UNTCOK would probably produce complete anarchy. 53

\section{2}

Iangdon to Viarshall, December 30, 1.947, RG 59, $895.01 / 12-3047$. NA. 53

Langdon to Marshall and Hodge to JCS, January 3 , 1.948, RG 59, 895.00/1-348, NA 
Korea was only part of a larger Amorican policy problem doaling with the determination of Soviet intontions. On November 7, Narshall presentod to the cabinet a roport on the world situation which the Folicy Planning Staff had propared. The Secretary of Stato stressed that Moscow did not want war, but sought to use tactics of indirect aggression and subversion to extend its influence into areas of instability. Asia was particularly susceptible to the strategy, because the area was the victim of considerable chaos and uncertainty. Marshall then offered his comments on conditions in Korea:

there is no longer any real hope of a gonuinely peaceful and free democratic development in that country. Its political life in tino coming period is bound to be doninatod by political immaturity, intolerance and violonco. Whoro such conditions prevail, the Communists aro in the ir element. Therefore, we cannot count on native Koroan forces to help us hold the line against Soviet expansion. Since the territory is now of decisive strategic importance to us, our main task is to extricate ourselves without too great a loss of prestige.

Marshall urged that plans Ior countering the Soviet threat be careful and realistic, reflecting American capabilities. In Asia, Soviet military and economic power was limited and subject to American control if effectively challenged.

On November 4, the United Nations Political Comittee

54

Policy Planning Staff Paper \#13, November 6, 194?, TRUS, 1.947, Vol. I, 770-777. 
approved the American proposal on Korea, including a provision for Soviet-American withdrawal within ninety days after the creation of a provisional government. Although American military leaders were apprehensive over the appearance of undue haste, Truman clearly had to demonstrate support for the Soviet proposal to disengage as soon as possible. 55 Ten days later, the General Assembly aporoved the resolution by a wide margin. Thus, the United Nations agreed to attempt success where the Joint Commission had failed. With the formation of a Korean government, the United States and the Soviet Union would withdraw, thus signaling the fulfiliment of the Cairo Declaration.

American leaders were obviously pleased that the United Nations had decided to become involved in Korean affairs. It appeared that international action might break the stalemate. Few observers mentioned that Moscow had already indicated opposition to United Nations action and $i$ ts intention to boycott the American program. 57 In addition, the nine members that the United Nations selected to serve on the Temporary Commission certainly would not contribute to Soviet support. Australia, China, France, Canada, El

\footnotetext{
55

Memorandum, November 4, 1947, RG 319, P\&O 091 Korea, Section III, Cases 16-50, Box 8?, NA. 56

Austin to Marshall, November 14, 1947, ERUS, 1947, Vol. VI, 85?-859; Tomokins, American-Russian Relations in the Far East, 331.; "Korea: A Chronology," 322. ber $5,1947,26: 2$. Nork Times, October $18,1.947,14: 1$ and Novem-
} 
Salvador, and the Philippines all possessed close economic, political, and military ties to the United States. Only Syria and India would be able to resist American diplomatic pressure, while it was unlikely that the final member, the Ukraine, would serve at all. Quite obviously, the United Nations had chosen a plan of action reflecting the political imperatives of American foreign policy.

Niarshall immediately instructed the AMG to issue a statement of support for the November 14 resolution and the UNTCOK. He also ordered Hodge to prepare for elections in accordance with the SKIIA election law and contact the Temporary Commission to determine a specific date for the balloting. Hodge complied on November 19, urging all Koreans to cooperate with the United Nations and expressing his hope for success. Privately, Jacobs speculated that the Soviets might cooperate. He intended to utilize the Joint Commission machinery to assist the UNTCOK. 59 Jacobs also requested permission to begin registration and administrative preparations for the election. Lovett rejected this proposal, since the Administration refused to implement any action prior to the arrival of the UNTCOK in Korea. 60

\footnotetext{
Gordenker, The United Nations and the Peaceful $\frac{\text { Unification of Korea, }}{59}$.

Marshall to Hodge, November 17,1947 and Jacobs to Marshall, November 19, 1.947, FRUS, 1947, Vol. VI, 860-86?. 60

Langdon to Lovett, December 22,1947 and Love tt to Langdon, December 23, 1947, FRUS, 1947, Vol. VI, 879-880.
} 
American calition was warranted, since many nations had expressed dissatisfaction with the course of events in in Korea and opposed United Nations consideration of the matter. Dr. H.V. Evatt of Australia, for example, conferred with American leaders and argued that Korea was a question for Soviet-American resolution or, as a last resort, a Japanese peace conference. Marshall disagreed and observed that the United States had turned to the United Nations only to break the deadlock at the Joint Commission. The Secretary of State stressed the determination of the united States to fulfill its commitments and not "scuttle and run." United Nations delegate John Foster Dulles expressed his hope that the United Nations could elicit Soviet cooperation in the achievement of Korean independence. Evatt remained unconvinced. Obviously, Australia would not be alone in desiring to remain uninvolved in the Korean issue.

Canada harbored even more serious reservations about participation in United Nations action on Korea. Prime Minister Mckenzie King opposed involvement so strenuously that a cabinet crisis occurred in December, 1947. Truman even delivered a personal request to king not to witndraw from participation in the UNTCOK. King responded that only nations directly concerned with Korea's destiny should be

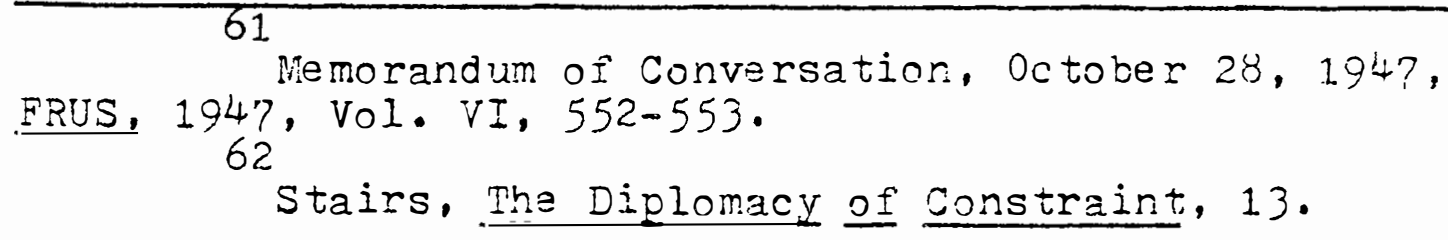


involved. He also believed that the UNTCoK was embarking on a "fool's errand," since Soviet cooperation was extremely unlikely. As a result, the United Nations would Iail to achieve anything except complete embarrassment. If the major powers could not agree, King asked pointedly, how could the small nations find an answer to the impasse.

Canadian obdurance completely surprised the United States. One official speculated that "King was making this issue a declaration of independence to show that Canada reached its decision independently of United States." He went on to observe, however, that the Canadian boycott would be intolerable and the United states should permit King simply to avoid appointing a representative. Thus, the issue would quietly disappear. Truman disagreed and instructed Lovett to deliver another direct appeal to King for Candadian cooperation. A "calculated policy of boycott," Lovett explained, would defeat the entire United Nations program and only advarce Soviet interests. Canada's prestige and support for the November 14 resolution were crucial to the successful realization of Korsan independence. Most important, the United States and Canada had to avoid any appearance of discord in the ir mutual relations.

\footnotetext{
63

A therton to Marshall, December 27, 1947, ERUS, 1947, Vol. VI, 880-882.

Vol. VI, 887 .

Reber Memorandum, December 30, 1947, FRUS, 1947, Love tt to King, December 30, 1.947, FRUS, 1.94?,
} 
King immediately dispatched Foreign Vinister Lester 3. Pearson to Washington to discuss the matter. Pearson explained that King feared the consequences of United Nations involvement in such a volatile issue. Even the British agreed that Korea was of secondary importance and would unjustifiably hamper cooperation in the Security Council. Canada also oposed the apparent American desire to exclude representatives of north Korea from the United Nations debate. Lovett appealed to Pearson to support at least minor Canadian participation in the UNTCOK that would avoid adverse publicity. Pearson now expressed sympathy for the American position and recommended that Truman address a personal appeal to King requesting a reversal of Canada's position.

Truman approached King again with an appeal for cooperation. The President emphasized that the United Nations resolution on Korea was intended to produce a settlement, not to increase Soviet-American tension. Without Canadian participation, the UNTCOK would be unable to achieve Korean independence. Nore important, the international community would misunderstand a Canadian boycott and question the viability of the United Nations. Truman asked King to consider the "larger picture" and avoid speculation regarding Canada's determination to support the United

Vol. VI, 883-885. 66

Love tt hemorandum, January 3, 1948, FRUS, 1948 , Vol. VIII: The Far East and Australasia (Washington, D.C.: Government Printing Office, 1.974), 1079-1081. 
Nations. Although Truman admitted that a Soviet boycott of the UNTCOK was Iikely, he scmehow predicted that the presence of the Temporary Commission would lead to the realization of Korean reunification and independence.

Evidently, Truman's diplomatic pressure was a success, for King agreed to appoint a Canadian representative to the UNTCOK. But King emphasized that if Soviet cooperation should "not be forthcoming, and the Commission not return its mandate to the united Nations in view of the impossibility of carrying out that mandate in the whole of Korea, our representative will be told to withdraw from the Commission." King privately expressed his opinion that he would not permit the United States to use Canada and the United Nations as an appendage of the State Department. Even King's conditional support satisfied Truman, who quickly conveyed his gratitude to the Prime Minister for the Canadian change of heart. He explained that international support for the UNTCOK might compel Noscow to permit entry into the northern zone. Significantly, Truman exposed his inner expectations when he stressed the UNTCOK's freedom of action. If Moscow refused to conperate, the United Nations colid still observe elections in south Korea alone.

\footnotetext{
67

Truman to King, January 5, 1948, ERUS, 1948, $\mathrm{V} 0 \mathrm{l}$. VIII, $1081-1083$. 68

Wailes to Lovett, January 9,1948 , FRUS, 1948,
} Vol. VIII, 1084; King to Truman, January 8, 1948. Truman Papers, White House Central Files, Confidential, Box 35 , State Department Documents 1047-1948. Folder 11, HSTL. 
Truman reminded king that a strong south Korean government would constitute a major step toward democracy for the 69

entire nation.

Truman thus obtained international support for the pursuit of Korean independence and reunification under the United Nations supervision. At the same time, the Administration was able to complete a scheduls for withdrawal that would end an expensive and unsuccessful involvement. The Departinent of the Army speculated that elections would occur no later than March 31, 1948 and a national assemily would convene by May 15. After the formation of a provisional government on August 15 , the United States could complete withdrawal within ninety days. During the interim, the Administration would present a request to Congress for financial support for occupied areas which would include provisions for aid to Korea. Patterson expressed hope that such limited assistance would not only facilitate American withdrawal, but also place Korea on the road to economic self-sufficiency.

During the last month of 1947 , Truman began to believe that mere withdrawal was not enough. As a result, he ordered the State-Army-Navy-Air Force Coordinating Committee

69

Truman to King, January 24, 1948, ERUS, 1948, Vol. VIII, 1086-1087; Stairs, The Diolomasv of Constraint, 16-1?. 70

Schuyler to Arnold, December 30, 1947, RG 319, P\&O 091, Korea, Section V, NA; War Council Neeting Minutes, December 5, 1.947. Patterson Papers, General Correspondence 1.945-1947, BOX 23, IOC. 
(SANACC) to formulate a program for the creation of a strong Constabuiary army and the implementation of a multi-year program for aconomic development. The United States wolid withdraw only after it preserved its political, economic, and security interests in Korea. Truman anticipated the emergence of a strons south Korean government enjoying the support of the United Nations and able to withstand pressure from the puppet regime in the north.

\section{V}

Some scholars have criticized Truman for exploiting the United Nations and attempting to withdraw from Korea without appearing to abandon American commitments. The Administration allegedly lacked the determination necessary for the successful achievement of American objectives. " T2 Truman and his advisors believed, however, that military cccupation was not essential, because the Communists would never stage an open invasion. As Ieahy explains, Truman's diplomatic advisors were confident that "the U.S.S.R. does not intend to accomplish its political purposes by the use of armed force but will continue its efforts by infiltration and underground activities." 73 As long as these tactics were

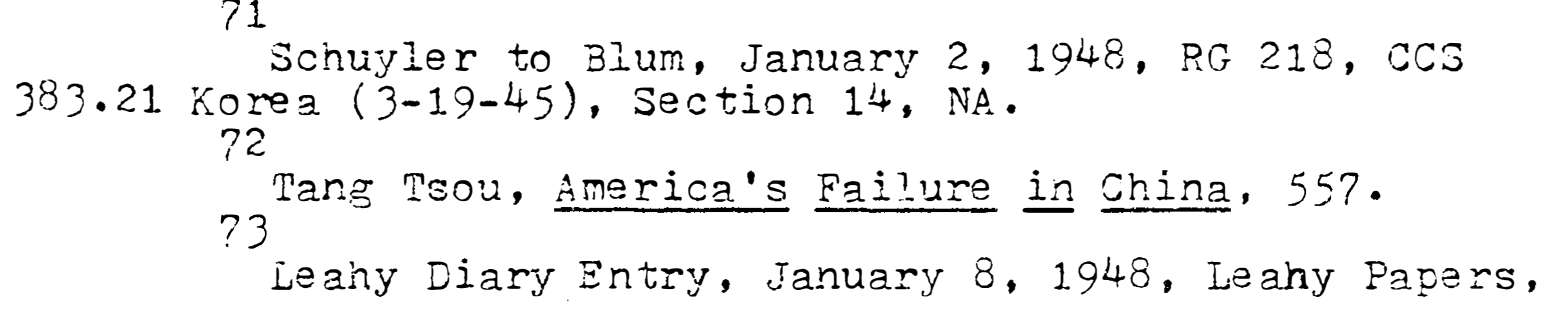


successiul, the north Koreans wolld undoubtedly support the Soviat strategy as an eifective venicle for the achievement of reunification under Communist domination. Political stability and economic recovery in the south, on the other hand, would frustrate Moscow and discredit Stalin's strategy in the Soviet zone. If Korea developed enough strength for self-defense, it would experience economic recovery and emerge as a viable, democratic, western-oriented nation in Asia worthy of emulation.

On January 8,1948 , the United Nations Temporary Commission on Korea arrived in seoul. Hodge greeted the Commission along with an extremely large crowd that one observer described as "a rightist show." Leftists boycotted the welcoming ceremonies, while the Communists attempted to organize a general strike and a campaign of sabotage in protest of united Nations action. The extreme lest demanded immediate American withdrawal and declared that it would not cooperate with the UNTCOK. Hodge acted to preserve law and order, declaring a curfew and warning against any violence. At the same time, Hodge provided the Commission with office Diaries, $74448-1950$, Box 6, ICC.

Iincoln Bloomfield criticizes the United States for not pursuing a "political strategy" against hoscow that would "unbalance the nonmilitarv equiliorium in our favor," The United Nations and U.S. Foreign Policy, 219. This was, howe ver, the essence of Truman's approach in Korea. 75 New vork Times, January $9,1948,1: 5,12: 3$ and January $1.0,1948,1.8: 3,22: 3$. 
space, housing, transportation, and food. Thus, while the leftist leaders either were in hiding or in prison, the rightists dominated government services upon which the UNTCOK would depend for its very physical existence. Under these circumstances the Commission could maintain impartiality only with great difficulty .

Moscow's attitude remained the crucial question confronting the entire operation. Many observers believed that the Soviets would not defy the overwhelming support for international action and would permit reunification during 1.948. 77 Marshall, on the other hand, anticipated Soviet refusal to cooperate. He instructed Langdon to impress upon the Commission that it had the power to hold elections in south Korea alone. ${ }^{78}$ Narshall's appraisal found early substantiation, since the Ukraine refused to participate in the activities of UNTCOK. The El Salvadorian delegate was late in arriving in Seoul as well. Despite such difficulties the UNTCOK met quickly and decided to approach the occupation commanders with a request for cooperation. At the same time, the Commission expressed regret over the Ukrainian refusal to participate and requested the release of all political prisoners. It also organized two committees; one was to ensure

Gordenker, The United Nations and the Peaceful $\frac{\text { Unification of Korea }}{77} \frac{\text { The }}{52}$.

$78^{\text {New }}$ York Times, January $10,1948,1.4: 2$. VIII, 1083.

Marshall to Langdon, January 6, 1948, FR.US, Vol. 
the existence of a free atmosphere in Korea and the other to determine which individuals would participate in consultation with the Temporary Commission.

Hodge promised his complete cooperation in concucting free and unfettered elections in the American zone that would reflect the will of the majority. 80 To no one's surprise, Korotkov refused to respond to the Commission's communication. Secretary General of the United Nations, Trygre Iie, inquired as to the Soviet attitude toward the UNTCOK. Soviet delegate Andrei Gromyko then reminded Lie that Moscow had already expressed its "negative attitude" toward the UNTSOK"s 81

activities. The Iuture of United Nations action in Koroa

thus became a matter of serious doubt.

Rhee was certain about his proper course of action in the face of Soviet intransigeance. He immediately demanded separate ejections and the creation of a south korean security force. 82 For the first time, the United States found that its objectives were identical with those of Rhee. Significantly, Kim Koo now split with Rhee and joined Kimm

18, $1948, \frac{\text { New }}{\text { IV. }} \frac{\text { York }}{10: 2}$. Times, January 13, 1948, $2: 3$ and January Vol. VIII, Jacobs to Mar $1085-1086$.

Russia and the $\frac{\text { Nowk }}{\text { Far }}$ Tast. $309 ;$ Department of State, The

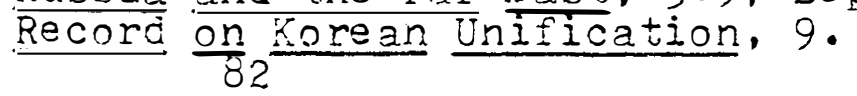

New York Times, January $28,1948,2: 3$; Jacobs to Viarshall, January 30,1948 , FRUS, 1948, Vol. VIII, 1088-1089. 
Kui-sik. Both leaders demanded immediate Soviet-American withdrawal and refused to accept anything less than rationwide elections. Kim Koo's motives are difficult to understand. It is possible that he sincerely opposed separate elections, fearing that such action would merely harden the partition. In all probability, however, Kim Koo came to the realization that Rhee would dominate separate elections and would then refuse to share power.

Kimm Kui-sik impressed the Commission delegates during subsequent consultations. The moderate leader stressed that if the UNTCOK desired truly free and democratic elections "it will take considerable time to make necessary preparations." In the event Woscow prevented the UNTCOK from entering the north, Kimm strongly urged the Commission to refer the entire matter back to the Interim Committee of the United Nations for reconsideration. Several memuers of the UNTCOK were receptive to Kimm's viewpoint. In addition, Moscow's uncooperative attitude prevented consultation with such northern leaders as Kim II-sung, Kim Tu-bong, and Cho Man-sik. Thus, a number of the Commission delegates favored delay until the UNTCOK could confer with the Interim Committee. Jacobs complained privately that the Commission was giving too much credence to Kimm's opinions, since the

83

Jacobs to Marshall, February 10, 1948, FRUS, 1948, Vol. VIII, 1101-1103; Kim, Divided Korea, 79-80. Jacobs to Marshall, January 29, 1948, ERUS, 1948 , Vol. VIII, $1087-1.088$. 


\section{7}

moderates possessed iittle popular support. He believed the extreme right represented the majority attitude in Korea.

Rhee and his supporters quickly instituted a propaganda campaign to convince the UNTCOK to sponsor elections in the south without further delay. On February 19, the South Korean Interim Legislature passed a resolution urging the immediate formation of a separate government. In response, Kimm Kui-sik and several of his followers walked out of the legislative body in protest, symbolically indicating the shift of American support to the extreme right. The AvG now anticipated a seventy percent rightist victory if the UNTCOK held elections and an almost complete sweep in the event of a leftist boycott.

Communist activities also contributed to the ever increasing power of Syngman Rhee. In January, 1948, the extreme laft organized a "General Strike Committee" to instigate violence, work stoppages, and sabotage throughout the southern zone. Within four months, political unrest resulted in almost three hundred deaths and over ten thousand imprisonments. Hodge informed washington of $h$ is desperate need for more troops to maintain domestic order. Unable to supply additional men, the United States approved VacArthur's

85

Jacobs to Marshall, February 2, 1.948, FRUS, 1948 , Vol. VIII, 1.089; New York Times, January 23, 1.943, 1.2:6. Gordenker, The United Nations and the Peaceful

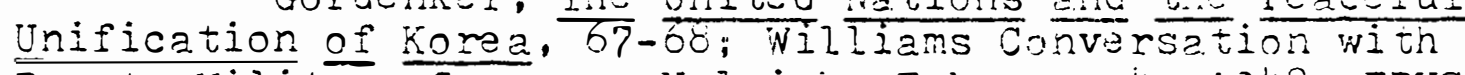
Deputy Vilitary Governor Helmick, February 4, 1948, FRiS, 1948, VoI. VIII, 1092-1093. 
request to increase the size of the Constabulary army to 8 ?

fifty thousand men.

Leftist tactics of opposition were a complete success. Two Commission delegates in particular, George Patterson of Canada and S.H. Jackson of Australia, began to exert strong pressure on the UNTCOK to investigate Hodge's "police tactics." Jacobs complained that bickering among the Commission members and criticism of the AMG was delaying the creation of a separate south Korean government. If the UNTCOK would support the American policy, such dissidents as Kim Koo and Kimm Kui-sik would bow to the inevitable and support elections in south Korea alone. Jacobs observed that only Liu Yu-wan of China and Jean-Louis Paul-Boncour of France were realistic enough to accept the fact that elections would be imperfect and would not include the north Koreans.

Rhee understood that the Commission might decide to delay action. He warned Hodge that the absence of separate elections would spark widespread demonstrations and unrest. The old patriot blamed Hodge for Korea's problems and threatened mass strikes to force the United States to remove the USAFIK Commander. Jacobs observed that the United

Millis (ed.), The Forrestal Diaries, 375; Sawyer and Hermes, Military Advisors in Korea, 28-29; Gordenker, The United Nations and the Peacefui Unification of Korea, 66. Jacobs to Marshall, February 2 and 8,1948 , FRUS, i948, Vol. VIII, 1089 and 1095-1097. 89

Jacobs to Marshall, Feoruary 10, 1948, FRUS, VoI. VIII, $1948,1099$. 
States could not ignore such threats, because Rhee possessed

a large following. Yot, Rhee's popularity

has nothing to do with love or veneration for the man . ... It is . . the result of a wide belief that Rhee is the source of all present and future political power in south Korea, the supreme protector of vested interests and the existing order of things, and that he is the man on whom to stake all one's fortunes.

Both Jacobs and iodge expressed alarm that the referral of the Korean issue back to the Interim Committee would result in disaster. Seoul appealed to Washington to convince the United Nations not to delay action any longer.

Events in north Korea added urgency to the need for action in the American zone. American liason officiers in Pyongyang reported that the north Koreans were preparing festivities in anticipation of the announcement of a new constitution and elections for a permanent government. On February 16, the "People's Committee" proclaimed its intension to form a separate government within the next few months representing all Korea. 91 In their public statements, the north Koreans declared that they would not cooperate with the United Nations, since the UNTCOK was a tool of the United

\footnotetext{
90

Jacobs to Narshal1, February 9,1948, RG 59, $895.00 / 2-948$, NA. 91 Jacobs to Viarshall, January 31,1948 , ERUS, 1948 , Vol. VIII, 1088-1.089; New York Times, February 1.4, 1948, $1.0: 2$.
} 
States. They also demanded immediate American withdrawal and called upon south Koreans to resist the creation of a separate government. Leahy no doubt expressed the Truman Administration's reaction when he privately denounced tre north Korean action as a clear defiance of the United Nations and an example of soviet satellization. 92

These events only reinforced the UNTCOK's apprehension. The Commission members quickly concluded that separate elections mignt be unwise, since they would ensure the permanence of division and the probability of civil war. On February 6 , the UNTCOK decided to refer the Korean issue back to the Interim Committee, in view of the negative attitude of the Soviet Union. The Commission chose Indian de legate K.P.S. Nienon to return to New York and recommend that the United Nations authorize only the election of consultants for the determination of a future course of asticn. Jackson also forced his colleagues to include a provision that any government emerging from separate elections would represent only the southern zone and not all of Korea.

Jacobs criticized the UNTCOK action as hasty and unfair, based "almost solely on testimony given by immature Koreans

92

Jacobs to Marshail, February 24, 1948, FRUS, 1948, Vol. VIII, 1129-1131; Time, II, 8 (February 23, 1948), 34; Goodrich, Korea, 50; Daliin, Soviet Russia and the Far East. 310; Leahy Diary Entry, February 1.6, 1.948, Leahy Papers. Diaries $1.948-1950$, BOX 6, LOC. 93

Iacois to Miarshall, February 5 and 6,1948 , FRUS, 1948, Vol. VIII, 1093-1.094. 
- . completely overlooking the need for unity on a sensible, coherent plan for salvaging what may yet be salvaged from their country." Leftists also disliked the decision and organized strikes in the railroad, telegraph, and shipping industries. The AMG reported over one hundred incidents of violence ard sabotage. Hodge denounced the demonstrators as Soviet "stonges" and arrested several thousand protesters. Such action caused Jackson to urge the inclusion in the UNTCOK report of an appraisal of conditions in south Korea emphasizing hodge's penchant for political repression. The Commission rejected this proposal. Nenon thus traveleo to New York with little information and fewer recommendations.

Jacobs blamed the Commission's uncooperative attitude on a "British Bloc" which was allegedly conspiring to implant American troops in Korea indefinitely. India, Canada, and Australia, with the assistance of Syria, were thus "playing into Soviet hands" and delaying action for free elections and extensive reforms in south Korea. Jacobs speculated that jackson was a Communist sympathizer and was merely exploiting the issue of civil liberties to advance his ulterior motives. Syria, on the other hand, opposed separate elections to gain leverage regarding American policy toward Palestine. 95 only china and the Philipoines realized

Jacobs to Marshall, February 8 and 13, 1948, ERUS, 1948, VoI. VIII, 109 ? and 1109; New York Times, February ह, $1948,1: 1$ and February $11,1943, \frac{10}{10}, \frac{1}{2}$ 95 Jacobs to Marshail, February 12, 19,48, ERUS, i948, 
that Mossow would never allow reunification except as a result of invasion from the north. The UNmCOK majority refused to antagonize the Soviets on what appeared to be an issue of secondary importance. Hodge insisted that logic dictated separate elections, since further delay would only cause a loss of confidence in the south.

World leaders nad not failed to notice the rising violence and disruption in Korea. The Interim Committee decided that, in the interests of peace and stability, it would consider Menon's report earliar than it had originally intended. The Interim Committee thus faced the distasteful choice of either submitting to a Soviet ve to or solidifying the Korean partition. 97 Nost members of the Interim Committee believed, however, that supervised elections would produce democracy for the majority of Koreans and possibly stimulate a northern decision to join the south. Withdrawal and inaction, on the other hand, would probably result in a complete northern victory after a bloody civil war. Marshall instructed the American Embassies in each Commission member's country to urge support for separate elections as the lesser evil. The British response was typical of those nations

Vol. VIII, 1105; Hodge to Marshall, Fecruary 14, 1948, FRUS, 1948, Vol. VIII, 1.1.10. 96 Langdon to Marshall, February $1.7,1.948$, FRUS, 1948, Vol. VIII, 1114. 97

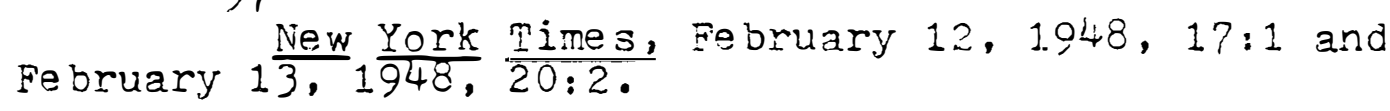


opposed to separate action. London believed that the American policy would harden the partition, but agreed to support separate elections as a last resort.

Viarshall informed Austin on February 18 that there was considerable opposition to separate elections. But he approved American support only for a brief adjournment to examine the UnTCok report. The United States would then insist upon the fulfillment of the November 14 resolution in those areas open to observation and press Canada and Australia to accept the American position. When venon presented the Commission report. American delegate Philip Jessup urged the Interim Committee to support elections for a government in south Korea alone. 99 Menon responded that, despite the absence of freedom in both zones, Korea would be ready for independence only after reunification. The Interim Committee declared a ten day recess to consider the American proposal and Menon's report. Marshall informed Langdon that the United States would press the Interim Committee members to accept the American position when the body reconvened. Menon's report irritated Hodge. The Commission's action

Marshall to Certain Diplomatic Offices, February 9, 1948, Butler (Australia) to Warshall and Gallmarn (Great Britain) to Marshall, February 12, 1948, FRUS, 1948, VoI. VIII, 1.098-1099 and 1.1.03-1.105. 99

Marshall to Austin, February 18, 1948, FRUS, 1948 , Vol. VIII, 1116-11.1? 100

Marshall to Largdon, February $20,1.948$, ERUS, 1948 , Vol. VIII, 1124; Gordenker, The United Nations and the Peaceful Unification of Korea, 70 ; New York Timss, qobruary 20 ,
} 
was "typical of the general failure of UNTCOK to understand in any degree the "cold war' as waged in Korea . ..." Jackson and Patterson were willfully distorting the record, supporting the Communist strategy, and preventing positive action to advance Korea's welfare. While criticizing the absence of freedom, the two UNTCOK delegates were opposing measures for the creation of a stable Korean government that would act in the interests of the people. The Commission's fumbling and indecision. Hodge declared, was facilitating a Soviet victory. Such action was a clear example of appeasement. Hodgo's dissatisfaction was actually a manifestation of his desire to leave. Separate elections would hardly resolve Korea's problems, but it would permit the United States to withdraw.

While the Interim Committee studied Menon's report, Viarshall applied considerable pressure on foreign governments to accept the American position. The Secretary of State denied that south Korea bordered on chaos, al though he admitted conditions were less than ideal. He stressed that the Koreans would not accept mere consultation, since tre people favored elections instead. Narshall's tactics were successful. On February 23, Britain indicated its willingness to accept the American policy and denied any desire to

$1948,1: 1$ 101

Lodge to Marshall, February 20, 1948, FRUS, 1.948, Vol. VIII, 11.25-1127; New York Times, February 22, 1948, VI, $5: 8$. 
ninder American objectives. India also succumbed, largely because the United States stressed that elections would produce a government for all Korea, not just the south. Warshall reasoned that once a legislature emerged representing two-thirds of Korea, Noscow would cease its opposition. The UNTCOK could then supervise the creation of a united, independent, and democratic Korea. Thus, the United States convinced two of the most influential Interim Committee members that separate elections would promote rather than hinder the implementation of the November 14 resolution. 102 Jessup confidently recommended on February 24 that the UNTCOK observe elections in those areas of Korea accessible to the Commission. He observed that such action would allow a majority of Koreans to attain democracy, while further delay would oniy bring a Communist seizure of power. ${ }^{103}$ Two days later, the Interim Committee approved the American proposal without amendment. Yet, Canada and Australia voted against the resoiution and eleven nations abstained. Jessup's advocacy greatly impressed supcorters of. the

\footnotetext{
102

Marshall to British Emoassy, February 21, 1.948. British Embassy to Marshall. February 23. 1948. Marshall to Indian Embassy, February 24, 1948 and Indian Embassy to Viarshall, February 26, 1.948, FRUS, 1948, VOI. VIII, 1.124 1125 and $112 ?-1128$. 103

Austin to iarshall, February 24,1948 , FRUS, 1948, Vol. VIII, 1128-29; New York Times, February 25, 194ठ, 8:3. 1.04

DSB, XVIII, 453 (ilarch 7, 1948), 298; New Iork Times, March 27, 1.948, 1:4; Syria abstained as we li $a s$ Colomía, Venezula, Panama, Egyct, Iraq, Afghanistan, Saudi Arabia, Norway, Denmark, and Sweden.
} 
proposal, but Narshall's diplomatic pressure and the recent coup in Czechoslovakia were of far greater importance. The United States was then able to convince the Interim Committee that United Nations astion mignt result in the complete resolution of the Korean dilemma. 1.05

\section{VII}

American plans for withdrawal continued during the early months of 1.948. In January, the SANACC considered the Hodge proposal for the creation of a security force and the implementation of economic recovery programs. The JCS and MacArthur had agreed upon the formation of an elementary military organization of "basically riflemen supported by simple weapons requiring little tecinical knowledge or maintenance, . .." 1.06 American military leaders thus began to accept the state Department's argument that precipitous withdrawal from Korea was uracceptable because a Soviet victory would seriously damage American prestige. 1.0? Yet, the Army Department pressed the State Department to Formulate definitive plans for providing financial assistance

105 Gordenker, The United Nations and the Peaceful
Unification of Korea, $71-75 ;$ New York Mimes, February 27, 106

Nedemeyer to MacArthur, January 13,1948 and Hall Memorandum, January 5, 1948, RG 319, P\&O 091 Koroa TS, Section I, Case 1, Box 20, NA. $10 ?$

Forrestal to Truman, February 1.7, 1.948, Truman Papers, PSF 156, Cabinet (Commerce to Defense, HSTI. 
to south Korea. It was important that the Administration request Congressional support for a rehabilitation program prior to March 1., 1948, if American withdrawal was to pro108

ceed on schedule.

State Department officials were suspicious of the apparent desire of the military to withdraw from Korea regardless of conditions at the time of departure. Butterworth stressed that the United States had to avoid any implication of attempting to "scuttle and run." Although the State Department would support withorawal by November 15. Butterworth emphasized the need for flexibility. For example, unless south Korea possessed an adequate security force prior to American departure, its survival was dubious. Marshall seriously doubted whe ther the Army would permit sufficient time to train a south Korean army powerful and disciplined enough to prevent a north Korean irvasion. The State Department thus decided to begin immediate shiement of arms to korea and incorporate more koreans into the USAFIK for training.

Undersecretary of the Army William H. Draper was dissatisfied with the State Department's attitude. Marshall and his colleagues, Draper observed, seomed to consider

1.08

Seedlock Memorandum, January 31, 1948, RG 319, P\&o 091 Koraa. TS, Section III, Cases 3-1.5, NA; Vaddocks Vemorandum, February 9, 1948, P.G 319, CSA 091 Korea TS, NA. 109

Butterworth to Narshall, warch 4,1948 and Allison Vemorandum of Conversation, Warch 5, 1948, FRUS, 1948 , Vol. VIII, 1137-1.1.41. 
support for a firm withdrawal date as synonymous with "appeasement." Draper effectively summarized the Army's position during his testimony before the House Committee on Foreign Affairs. The Undersecretary explained that the United States could not maintain occupation of Korea indefinitely. Sooner or later, the Koreans themselves would have to solve their problems. ${ }^{1.10}$ one can certainly appreciate the attitude of the American military. During February, 1948, the JCS concluded that the United States could not block a Soviet military thrust into Europe and thus requested a nine billion dollar supplement to the defense budget. Truman rejected the request becalise he believed that the United States could not counter Soviet expansionism everywhere and still maintain fiscal and economic strength. 111 Sucr limitations on spending meant that withdrawal was essential from those areas less vital to American security.

Truman thus authorized the JCS to instruct hodge to begin preparations for withdrawal. Hodge responded that if withdrawal was to begin on schedule-August 15, 1.948-

\section{0}

Biddle to We demeyer, March 5, 1948, RG 319, P\&O 091. Korea TS, Section III, Cases 3-15, Box 21, NA; Herbert Iruks, Harry S. Truman and the Russians 1945-1.953 (New

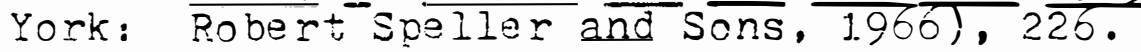
1.11 Warner R. Schilling, "The Politics of fiational Defense: Fiscal 1950," in Strategy, Politics and Defense Budgets, by Warner R. Schilling, Paul Y. Hamond, and GIenn H. Snyder (New York: Columbia University Press, 1.962), 41; Truman, years of Trial and Hooe, 331 . 
a final directive was necessary prior to Nay 15. He also believed that because of his long-standing disagreement with Rhee he should, as the USAFIK Commander, leave Korea immediately after the new Korean government assumed controi. In addition, Hodge stressed that Korea would require heavier equipment militarily to ensure its survival in the event of an open invasion. 112

Truman received the final SANACC recommendations for withdrawal from Korea on April 2, 1948. The proposal, National Security Council Paper \#8 (NSC-8), outlined steos for the realization of an independent south Korean nation that would reflect popular desiros and possess a sound economic and educational system. The paper noted that Moscow had created a separate government possessing a strong army, while serious economic problems plagued the southern zone. It recommended a one hundred eighty-five million dollar aid program for fiseal 1949 and the expansion, training, and equipping of a Constaoulary army that would be effective "against any but an overt act of aggression by north Korea or other forces." ${ }^{113}$ at the same time, NSC-8 provided that the United States would withdraw from Korea no later than December 31, 1948. In conclision, the paper

\section{2}

Army to VacArthur, Viarch $18,1.948$, ?G 319 , P\&O 091 Korea TS, Section I, Case 1., Box 20. NA; Hodge to Dupuy, warch $28,1.48$, RG 319, P\&0 091. Korea TS, Section IV, Cases 16-30, Box 22, NA. 113 Souers to Truman, SANACC Report, April 2, 1948 , FRUS, 1948, VOl. VIII, 11.53-1159. 
declared that the United States should "not become so irrevocably involved in the Korean situation that any action taken by any faction in Korea or by any other power in Korea could be considered a casus belli for the U.S."

Truman's decision to approve NSC-8 was indicative of his desire to pursue a middle road in responding to the Soviet challenge in Korea. The United States could not "cut and run," since such a policy would constitute a betrayal of comitments. American allies and adversaries alike would criticize the United States for exploiting the United Nations as a cover for abandonment. Nor would Truman gliarantee the political independence and territorial integrity of Korea against military aggression. Instead, the Administration would attempt to apply containment in Korea and build indigenous military power, economic strensth, and political stability. The policy assumed that the Soviets would not instigate blatant aggression and that the north Koreans eventually would realize the advantages of reunification. on April 8, Washington dispatched to seoul instructions for implementing NSC-8. Hodge enthusiastically began to prepare for withdrawal before the end of 1948 .

Royall and Draper immediately traveled to south Korea in the company of four American economic experts to formulate a specific assistance program. After three days of

\footnotetext{
11.4 $115^{\text {Ibid. }}$ Sawyer and Hermes, Military Advisors in Korea, 30.
} 
interviews with Hodge and prominent Korean businessmer and political leaders, the Committee observed that the Koreans were anxious to assume control over the in own destiny. The Committee's report forwarded the following conclusion:

For a time after withdrawal . . the new independent Korean Government will require continuing American aid, advice, food and raw materials in order to maintain at least the present ration level and to achieve necessary rehabilitation and governmental effectiveness. This assistance we feel should be provided for an interim period, with steps taken to assure that it is properiy utilized. The committee believes that firm support by the United States and the United Nations to the new Korean Government will inestimably help to develop participation in future Far

- Eastern trade on a basis valuable to the Korean people and to their neighbors.

Thus, the Army Committee decided that financial assistance alone was sufficient to provide Koreans with the means to exploit its own resources and train technicians for the maintenance of self-sufficient economic growth.

State Department officials formulated an aid proposal embodying the arguments and recommendations contained in the Army Committee's report. The United States would continue financial assistance through fiscal 1949 to ensure safe American withdrawal with minimal loss of prestige. If the new Korean government "shows more vitality than thej expect it will," the Truman Administration would consider the

\section{6}

U.S. Department of the Army, Economic Fosition and Prospects of Japan and Korea and the lieasuros Raquirod to Improve Them, by Percy $H$. Johnston, Paul G. Hoffman, Robert $\vec{F}$. Loree, and Sydney 4 . Scheuer. U.S. Army Committee Report, April 26, 1948 . 
implementatjon of a major recovery program during fiscal 1950. Truman aperoved the approach and the State Department forwarded the bill to Jacobs for comment.

America's decision to combine economic assistance with military disengagement in Korea reflected Truman's attitude toward the relationship be tween foreign policy and defense. The President was essentially a fiscal conservative, who desired not only a balanced budget, but surpluses to decrease the national debt. This emphasis on economy in government alarmed Forrestal, who insisted that the United States faced a critical period in Soviet-American relations. On May ?, 1948, Truman and his advisors discussed the defense budget. The President stressed that American foreign policy was premised upon the expectation of peace rather than war. As a rosult, higher defense spending was not justified.

Truman's attitude toward defense spending reveals clearly his reliance on American economic power to counter the Soviet challenge. In a letter to Forrestal, Truman emphasized that "military strength is dependent on a strong economic and a strong industrial and productive capacity."

\section{7}

Love tt to Jacobs, April 16, 1948, FRUS, 1948, Vol. VIII, 1179-1.180; Seedlock Nemorandum, April 16, 1948, RG 319, P\&0 091. Korea TS, Section IV, Cases 16-30, Box 22, NA. 118

Truman, Years of Trial and Hoce, 40; Schilling, "The Politics of Naticnal De fense, "in Strategv, Politics and Defense Budgets, 136-137.

Millis (ej.), The Forrostal Diaries, 431-432; Schilling, "The Politics of National De fense," in Strategv, Politics and Defense Budgets, $144-1.45$. 
Any unfavorable impact on the economy, Truman explained, was intolerable. Unless international sonditions deteriorated and Soviet-American tension increased, the Administration intended to hold the defense budget at a ceiling of fifteen billion dollars. 120 For Truman, economic aid and technical advice would serve to protect American security interests in Korea and elsewhere.

\section{VIII}

Hodge was skeptical about the feasibility of the new American plan. Early in March, he predicted that north Korea would invade south Korea to prevent the formulation of a separate rogime and "to effectively eliminate any hope of escape from their power." 121 Many Koroan leaders shared Hodgo's apprerension and demanded an American guarantoe of south Korea's security. The USAFIK Commander began to pross the UNTCOK for an announcoment of a specific date for elections. After consultations be tween liodge and Meron, the UNTCOK convened to consider the matter, despite Patterson's absence. The Commission informally approved Hodge's recommendation that the UNTCOK supervise elections on llay 9 .

Truman to Forrestal, Vay 13, 1948, Hoyt S. Vandanberg Papers, Box 40, Budget 1.947-48, LCC. 121

Hodge to JCS, March 6, 1948, RG 21.8, CCS 383.21 Korea $(3-19-45)$, Section 15 , NA. 122

Langdon to Viarshall, February 20, 1943, FRUS, 1948, Vol. VIII, 1121-11.22; Now York Times, fiarch $3,19+3$, 


\section{4}

As a result, Hodge was able to announce the decision on Marcin 1. the anniversary of the robellion of 191.9. Three days later, Hodge indicated that the elections would utilize the secret ballot; all individuals over 21 years of age would be eligible to vote. Since freedom of choice was absolutely essential. Hodge warned that he would not tolerate any 123

terrorism or intimidation.

Patterson, upon his return from Japan, was irate. He insisted that the Interim Committee had only "recommended" supervision of separate elections. Nore important, the UNTCOK had taken action without his consent. When the Commission refused to clarify its decision, Patterson walked out in a huff. Menon immediately reversed the UNTCOK's decision and as 124 decision and agreed to reconsider the entire matter. was now Hodge's turn to be enraged, since it appeared that he rad acted without the knowledge of the Commission.

Patterson was concerned that the threatened boycott of moderate and leftist Koreans would ensure a complete victory for the extreme right. Both the Australian and Canadian Ambassadors in the United States complained to the

1. $3: 1$.

123

New York Times, Narch 2, 1948, 13:1; Election

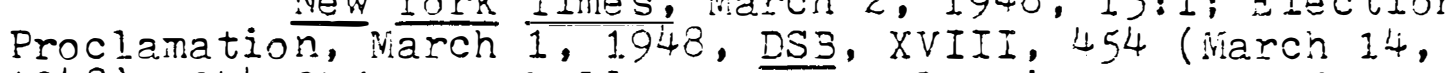
1948), 344-345; Narshall, "Korean Elections to Conform to Views of Interim Committee," March 10, 1948, DSB. XVIII, 455 (March 21., 1948), 475; Stairs, Diplomacy of Constraint, 22. 124

New York Times, March 9, 1948, 12:7 and Warch 10, 1948: 5:3; Gordenker, The United Nations and the Peaceful Unification of Korea., 79 . 
State Department that Hodge had exceeded his authority. The UNTCOK's instructions precluded supervision of elections unless it was clear that an atmosphere of freedom prevailed in south Korea. American diplomatic officials resconded that Hodge had coordinated with the Commission in announcing the election date. The UNTCOK's reversal had now caused an unnecessary delay, while fostering the moderate and leftist boycott that the Commission was attempting to prevent. Marshall addressed an appeal to Trygue Lie to not permit a "disgruntled minority" to prevent Commission action. The American Secretary of state emphasized that the refusal of the UNTCOK to supervise elections in the near future would produce an incredibly dangerous situation.

Nenon reconvened the UNTCOK on March 12 to reconsider its previous action. Jackson immediately recommended revocation of the Commission's original decision in view of the probable electoral boycott. The UNTCoK should instead leave Korea on April 15 after recommending a national conference for the holding of national elections and reunification. Jackson strongly opposed any action that would bar northern participation and harden the partition. PaulBoncour rejected the proposal and urged rapid fulfillment

125

Butterworth Memorandum, Warch 9, 1948, Allisor Memoranoum, Narch $9,1.948$, and Narshall to Langdon. March 3 , 1948. FRUS, 1948, Vol. VIII, 1136-11.37 and $1143-1.145$.

Vol. VIII, 1.149 . Marshall to Austin, March 11, 1948, FRUS, 1948 , 
of the initial decision to supervise separate alections. Syrian delegate Djabi then offered a compromise that would permit the Commission to supervise elections in south Korea on May 9 only if a free atmosphere existed.

$$
127
$$

In an extremely crucial vote, the UNTCOK decided to accept the Syrian compromise, although Canada and Australia opposed the plan. As a result, the inited Nations was morally obligated to support the government that emerged from separate elections. Leon Gordenker perceptively indicates the significance of the Commission's action:

Now it had abandoned the aim of unification before or through a national election; instead it was virtually committed to the program sponsored by the United States. Such cold war allies of the United States as Australia and Canada had grave doubts about the wisdom of 1.28 this program in terms of the welfare of Korea.

Truman and $r_{i}$ is advisors had reason to be pleased. Sontainment in Korea now possessed international sanction. The UNTCOK would observe American implementation of the program and then certify the legitimacy of the results.

American leaders in seoul were already preparing for elections in south Korea in accordance with the SKIIA election law. While staggered elections would allow the understaffed UNTCOK to observe all polling places, the PMG

127

Langdon to Marshall, Niarch $1.2,1948$, FRUS, 1.948, Vol. VIII, 1150. 3.28

Iangdon to Marsha.1., March 1.2, 1.948, FRUS, 1948, Vo1. VIII, 1154-1155; Gordenker, The United Nations and the Peaceful Unification of Korea, 83-85. 
considered such an approach overly expensive and dangerousiy prolonged in duration. Thus, the Commission would make spot checks during simultaneous elections throughout the American zone. The AlrG also appointed an electoral board early in March composed of fifteen members, twelve of whom belonged to Rhee's political party. At the same time. American officials initiated a campaign to criticize all Korean leaders threatening to boycott the elections. Refusal to participate was a disservice to Korea and benefited only the Communists. It was clear that the united States did rot want a complete rightist sweep, since an unrepresentative government would not enjoy complete international support.

Truman and his advisors were now obsessed with preventing any delay in Korean elections. Severa? Korean religious groups urged a one day postponement-llay 9 was a Sunday-but the United States refused. Langdon blamed American missionaries for this unwarranted interference. As a result, Marshall pressed churches in the United States to instruct the ir representatives to support the scheduled election date. 130 Finally, the Administration grudgingly acquiesed in a postponement of the elections to Nay 10 , largely because of an anticipated solar eclipse on May 9 .

129

Langdon to Narshall, Warch 6, 12, and 1.7, 1948, FRUS, 1948, VoI. VIIT, 1142, 1151, and 1.155; New york Times, Narch 14,1948 , IV. $8: 2$. 1.30

Langdon to Marshali, March $9,10,48$ and Marshall to Langdon, March 11, 1948, RG 59, 895.00/3-948, NA. 
Koreans would view this as a bad omen. Upon receiving this news, Niles Bond of the Division of Northeast Asian Affairs discerned some Soviet conspiracy at work. In a marginal. note, he expressed amazement at "the lengths to which the Commies will go!" ${ }^{131}$ Such comments indicate the mood in Washington during the spring of 1948 .

Hodge acted quickly to maximize Korean participation in the elections. The USAFIK instituted an incredibly high-powered program to educate Koreans on the democratic process. The AMG used radio broadcasts, classroom sessions, pamphlets, loudspeakers, train exhibitions, and handbill distributions to inform the people "better than they have ever been informed of anything in the ir history." 132 The campaign was a huge success. On April 1.4, the ArG could report that over ninety percent of all eligible voters or approximately eight million people had registered. Hodge quickly observed that these statistics proved the existence of a strong desire among the people for elections despite Communist threats of violence. 133 One AlvG official was far more candid in his observation that in the absence of the American propaganda campaign force would have been

131

Jacobs to Marshall, March 24, 1948, RG 59, 5013B Korea/3-2448. NA; Jacobs to Miarshall, April 4, 1948, RG 59, 895.00,4-448, NA: New York Times, Apri1 4, 19,48, 11:6. 132 $895.00,14-848$, NA. Jacobs to Marshall, April 8, 1948, RG 59, 133 Jacobs to Marshall, April 1.3, 1948, RG 59, $895.00 / 4-1348$, NA; New York Times, Aprii 14, 1948, 8:3. 
1.34

necessary to octain voter registration.

IX

Moscow hardly looked favorably at the events transoiring in south Korea. As a result, the soviats decided to attempt to force the United States to recognize the legitimacy of the northern regime. On March 17, Korotkov informed Hodge that in view of American bad Iaith the Soviets would no lorger mediate between the United States and the koreans regarding electric power. The Soviet commander forwarded a letter from $\mathrm{Kim}$ II-sung indicating that the north Koreans would terminate electricity on April 15 because the United States had not paid its bills. In response, Hodge explained that equipment for payment was available in seoul and requested a conference to discuss the matter. He insisted, however, that the Soviet commander was the only legitimate authority in the north and refused to negotiate with the north Koreans.

on Narch 25 , a more serious crisis confronted Hodge when the northern "Democratic Coalition Eront" proposed a NorthSouth Conference to arrange for nationwide elections and the withdrawal of all foreign troops. The conference would convene in Fyongyang on April 14 and the northerners invited

\footnotetext{
134

James I. Stewart, Intelligence peport, April 22, 1948, RG 59,895.00,/4-2248, NA. 135 Vol. VIII, 1158 .
} 
thirteen southern representatives to attend, including Kimm and Kim Koo. Kimm responded favorably and asked Hodge to provide credentials and transoortation. The USAFIK Commander understandably refused to either aid or hinder participation in the conference. 1.36

News of the North-South Conference alarmed Lovett, who feared that a moderate-ieftist boycott would cause the elections to appear to be a private affair of Syngman Rhee. He recommended a strong propaganda campaign to discredit the northern proposal. Fodge thus issued a public statement charging the north Koreans with attempting to deceive the south Koreans and seize control. Only free elections would provide a popular mandate for action to determine Korea's destiny. Hodge argued that the apoointed representatives to the Conference were mainly subversives and "stooges" who represented no one but themselves.

Jacobs judged the Conference a "clever ruse." He argued that Kimm's support for it was the product of frustration over not possessing enough political support to gain election. Any reasonable person knew that the Conference was doomed to fail and was a "fool's paradise." Jackson and 1.36

Jacobs to Narshall, Warch $29,1.948$ and Hodee to Marshall, April 5, 1948, FRUS, 1948, Vol. VIII, 1162 and 11.69-1.170; New York Times, Narch 27, 1948, 1:?; Time, II, 14 (Apri1 5,1948$), 29$. 137

Love tt to inarshall, April 5, 1948 and Langdon to Viarshal1, April 6, 1948, FRUS, 1948, Vol. VIII, 1.1.70 and 11.72-1.174; New York Times, April 7, 1948, 14:2 and April 1.0, $1948,4: 2$. 
Patterson, however, encouraged Kimm and Kim koo to attend and promisad to postpone separate elections in the event of suc138 cess. Prior to departure, Kimm requested that the north Koreans accept certain conditions. The Conference was not to advocate dictatorship. nationalization of all incustries, foreign military bases, or less than free elections. When the north accepted, Kimm and Kim Koo traveled to Fyongyang and arrived in the northern capital on April 21.

After a week of discussions, it was clear that the North-South Conference was indeed a sham. It producad a constitution and governmental structure modeled after the Soviet Union. It also issued a proclamation blaming the United States entirely for the 38 th parallel and denourcing separate elections in the south. The Conference called upon all true Korean nationalists to demand American withdrawal. Although Kimm was far from satisfied with the results, he returned with a promise from Kim Il-sung that the north Koreans would support free elections and not terminate electrical power. In return, Kimm and Kim Koo agreed to boycott the southern elections.

Communist leaders then intensified the program of

\section{8}

Jacobs to Marshall, April 9 and $22,1.948$, EnUS, 1.948, Vol. VIII, 1.1.77-1.178 and 1.1.80. 139

$22,1948,2 \frac{\text { New }}{2: ?}$ York Times, April 21, $1.948,14: 3$ and April 140

Jacobs to Narshall, Aprii 30,1948 and way 3 , 1948, FRUS, 1948, Vol. VIII, 1185-11.91; New York Times, Nay $1,194 \overline{8,1}: 6$ and Nay $6,1.948,15: 3$. 
violence and subversion. They sought to use threats of rioting and assassination to convince the UNTCOK not to supervise the elections. ${ }^{141}$ At least the chaos would hold down voter turnout. The Korean police, in turn, increased its anti-leftist repression, while Hodge placed the Constabulary army on permanent alert. In addition, the SKIG organized a series of "Community Protective Associations" to maintain local law and order. These bodies soon degenerated into youth gangs armed with clubs and axes, which roamed the countryside terrorizing the people. ${ }^{1.42}$ During the first four months of 1948 , police and extremists killed over two hundred fifty people. An additional hundred were victims of indiscriminate violence in April, including eight election officials and two candidates. Violence peaked during the week before the election, when over three hundred individuals died, only thirty-two of whom were policemen. Police exercised influence and intimidated voters in more subtle ways. The AVG required Koreans to register for the election at the same place where food ration cards were obtained. Blackmail was hardly unusual, while beatings, 141 Jacobs to Narshall, Nay ?, 1.948, RG 59, 895.00/ 5-748, NA; Dallin. Soviet Russia and the Far Fast, 311.

Henderson, Politics of the Vortex, 157; Department of State, Korea 1.945 to $19.98, \frac{19}{1.5}$. 143

Jacobs to Marsinall, April 27, 1948, RG 59, 895.00/4-2748, NA; New York Times, April 28, 1948, 1.7:1; Henderson, Politics of the Vortex, 156 ; Stairs, Diplomacy of Constraint, 25 . 
robbery, threats, and imprisonment were the order of the day. The UNmCOK members were concerned that Korean extremists were exerting improper poitical pressure on the people. More important, the United States seemed unable to control in any way the actions of the police and youth groups. To argue that south Korea possessed an atmosphere condusive to freedom of choice was patently absurd.

Predictabiy, the extreme right dominated the list of candidates for the May elections. The subsequent legislative body would not reflect a representative cross-section of Korean political opinion. Of nine hundred thirty-eight candidates, the $A N G$ estimated that more than three-fourths were under the cortrol of Rhee and Kim Sung-soo. 145

Twe lve candidates ran unopposed, including Rhee. Significantiy, Rhee's supporters on the National Election Committee rejected the application for candidacy of one Daniel Choi, who sought to oppose Rhee. Despite such blatant unfairness and tampering, the Commission members arrived at a compromise that permitted the UNTCOK to supervise the elactions. On April

144

McCune and Grey, Korea Today, 228-230; Gordenker, The United Nations and the Peaceful Unification of Korea, 145

Jacobs to Marshall, April 27, 1948, RG 59,895.00/ 4-2748. NA; Benjamin Weems, "Behind the Korean Elections," Far Eastern Survey, XVII, 12 (June 23, 1948), 142; C. Clyde Mitchell, "Land Reform in South Korea," Facific Affairs, XXII, 2 (June 1949), 151.; NcCune and Gre $\mathrm{y}$, Korea Today, 2.27228 . 1.46

Allen, Korea's Syngman Rhee, 94; Gordenker, The United Nations and the Poacoful Unification of Korea, 98 . 
28, five members vote that a "reasonable degree of free expression" existed in south Korea. Canada, Alistralia, and Syria refused to participate in the charade and abstained. 147 Hodge's extremely cooperative attitude partialiy explains the UNTCOK's willingness to proceed with the elections. For example, the ANG agreed to alter the election law, eliminating a controversial "run-off" provision and allowing previous criminals and illiterates to vote. The failure of the North-South Conference to arrive at an acceptable solution to the Korean dilemma had a decided impact on the Commission as well. Regardless of the reasons, the UNTCOK had undertaken an impossible task. Before and during the elections, observation groups had far too little time to make intense investigations and "could hardly do more than show themselves and hope to attract complaints and significant, information." 1.48 The united States probably would have proceeded to hold elections anyway, but the Commission's participation was a tremendous propaganda victory. Symbolically, the United Nations was now responsible for Korea's destiny.

Elections occurred on schedule and resulted in a rasounding victory for Syngman Rhee. Jacois observed that

147

Jacobs to Marshall, April 28, 1948, FRUS, 1.948, Vol. VIII, 1184; Gordenker. The United Nations and the

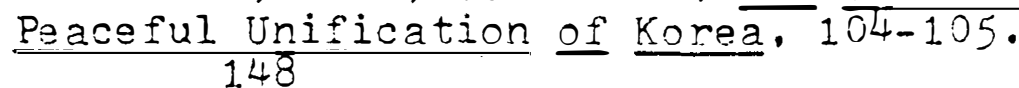

Reeve, The Republic of Korea, 31; Cordenker, The United Nations and the Peaceful Unification of Korea, 88 and 95-96; Department of State, Korea 1.045 to 1948, 1.5 . 
Koreans cast the ir ballots in a calm, quiet, and orderiy atmosphere. He judged the procedure and organization of the elections as truly democratic, devoid of coercion or intimidation. Over ninety percent of all registered voters cast ballots and, in several areas, all balloting was completed within the first four hours that the polling places were 1.49

open. American observers quickly noted that the results surpassed the record of long-established democracies in the realm of voter participation and was indicative of korea's readiness for independence and self-government.

Jacobs, in his private communications, was far more reserved in his judgments. He noted that the organization and efficiency of the elections was unprecedented and "should give rise to a certain degree of caution and reservation in our appraisal of that efficiency." The criticism was certainly just, since the United States never ceased to emphasize that such high voter turnout in the Soviet Union proved the undemocratic nature of its alections. Jacobs also offered the honest admission that the united States was partially responsible for Rhee's electoral victory. As the American Political Advisor explained, past "American actions

\section{9}

Jacobs to Marshall, May 1.2, 1.948, RG 59, 895.00, 5-1248, NA; New York Times, May 1.1, 1.948, 1.1.2; Gorłenker, The United Nations and the Peaceful Unification of Korea, 105-106; Tae-ho Yoo, The Korean War and the United Nations: A Legal and Diolomatic Historical Study (Louvain: Liorairie De sbarax, 1965), 19. 150 New York Times, May 11, 1948, 11:2 and Nay 22, $1948,14: 2$; Caldwell, The Korea Storv, 3 . 
have done much to bring the dominance of the Rhee-rightist political Eroup. - and to discourage not only Communist but also non-Rhee, non-Communist groups from participation in the elections."

$$
151
$$

Korean elections in May, 1.948, we re hardly a reflection of the popular will. 1.52 In reality, most koreans cast ballots for independence, rather than any particular candidate. After being ignored for so long, the masses now enthusiastically engaged in contact and communication with their leaders and enjoyed a "sense of participation." 153

In addition, the police and youth groups either convinced the average Korean to vote or coerced him into participation. On the day of the election alone, political violence led to forty-four killings.

Still, the United States had made the elections a test of the viability of democracy in Asia and the ability of the United Nations to resolve international problems. The outcome pleased Marshall. He congratulated the koreans on their

\section{1}

Jacobs to Marshall, May 13,1948 , FRUS, $1.948,1195-$ 1197; Jacobs to Varshal1, May 1.2, 1948, RG 59, 895.00/5-1.248, NA.

1.52

NicCure and Grey, Korea Today, 229; Almost incredibly, Cho insists that the korean elections were an indication of political maturity, Korea in World Politics, 208. 153 Divided Korea, 81 .

Henderson, Politics of the Vortex, 21.7-218; Kim, Jacobs to Marshall, Nay $10,1.948$, FRUS, 1948, Vol. VIII, 1192: Kim Yong-jeung, "The Cold War: The Korean Elections," Far Eastern Survey, XVII, 9 (May 5, 1948), 101-1.02; New York Times, Nay 1.0,1948, 1:1. 
election and observed that the "fact that some 90 percent of the registered voters cast their ballots, despite the lawless efforts of a Communist-dominated minority to prevent or sabotage the election, is a clear revelation that the Korean people are determined to form their own government by democratic means." 1.55 Niore important, elections permitted Washington to proceed with its schedule for withdrawal. On ivay 22 , the JCS ordered MacArthur to implement the oreparatory phase of the operation-code-named "Crabapple," Almost immediately, American dependents began to leave Korea, while Hodge transferred surplus equipment to the constabulary.

Some American observers were not so sanguine about the future of Korean affairs and the nature of the American victory. Soviet sponsorship of a separate northern regime meant that a blcody civil war, rather than peaceful reunification. was in the offing. It was also apparent that police terrorism and a leftist boycott constituted "a perverted application of democratic principles of free elections." American reliance on the United Nations could not disguise the reality of the situation. South Korea enjoyed approximately the same freedoms as their northern neighbors, but without the benefits of economic stability and at least the

155

NarshalI Statement, March 12, 1948, ISB, XVIII, 465 (Nay 30, 1948), 700; New York Times, Nay 3, 1948, 20:3; See also, State Department, Koroa 1945 to $1948,1.5$. 156

Gilchrist Memorandum. Way 19,1948 and Lawson Memorandum, May 25, 1.948, RG 31.9, P\&O 091. Korea TS, Section I, Case 1. Part III-A, NA; New York Times, May 21, 1.948, 7:3. 
appearance of reform.

In the wake of the Korean elections, Truman believed that international diplomatic support and an American program of eccnomic assistance for a separate south Korean government would provide the answer to a dilemma that had confronted the United States since 1945. At the same time, Moscow's refusal to cooperate with the United Nations and permit nationwide elections had damagod the prestige of the Soviet Union in the international community. The United States, on the other hand, had demonstrated its devotion to the principles of democracy and national self-cetermination. If the resultant south Korean regime developed political strength and economic prosperity, the United States would reap even greater benefits. More important, once the north Koreans realized the superiority of the Western model of political and economic development, they would overthrow the Communists and seek amalgamation. Truman believed he had resolved the dilemma of withdrawal. Containment was then a liberating force that would not only halt Soviet expansion in Korea,. but achieve peaceful reunification as well.

\section{$15 ?$}

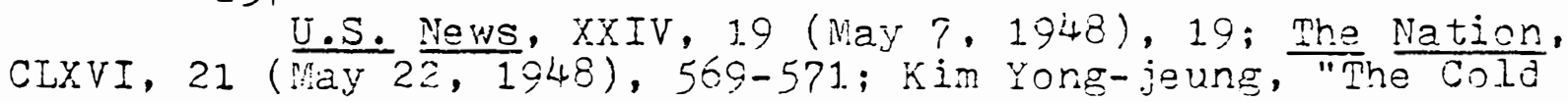
War: The Korean Elections," 102 . 
Chapter VII:

Test Case of Containment 
America's Korea policy after Way, 1948, concentrated on fostering the emergence of a strong and progressive democratic state in south Korea. With the benefit of hindsight, some scholars have strongly criticized the Truman Administration for creating an anti-Communist government in Korea and then refusing to supply it with sufficient moral and material support to ensure its survival. Such an appraisal ignores the actual nature and intent of American actions in that country. Truman and his advisors were still uncertain regarding the magnitude of the Soviet threat to international peace and stability. In addition, they wanted to Iimit the extent of the American commitment to use its power and prestige to counter the crallenge. Through the use of economic aid and technical advice alone, Truman hoped the United States could confront and eliminate the threat of Communist expansion in Asia.

Events in China largely determined the Administration's approach to American policy in Korea. Truman's strategy

Cho, Korea in oㅣd Politics, 244; Ferrell, George

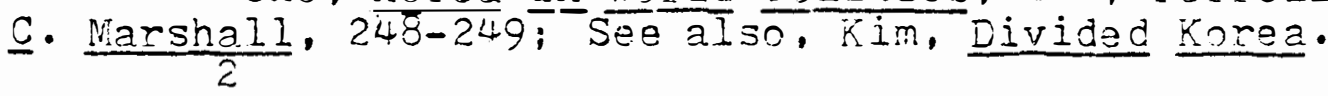

Norman A. Graebner, "Global Containment: The Truman Years," Current History, LVII, 336 (August 1969), 77-83; A than Theoharis, "The Rhe toric of Politics," in Politics and Policies of the Truman Administration, 210-211. 
depended upon the successful application of national selidetermination and tine energence of substantial popular support for a government favorable to the policies of the United States. Chiang Kai-shek failed to maintain the support of the masses because of nis unwillingness to respond to popular demands for reform. In Korea, on the other hand, Truman believed that the United States had a second chance in Asia to build a popular and democratic government worthy of emulation. Increasingly, the Administration came to view Korea as not only a bulwark of democracy but also the test case of containment in Asia.

South Korea's experiment in democracy experienced an inauspicious beginning. On May 1.4, the north Koreans shut off electrical power and Hodge immediately protested the action. After the Soviets refused to mediate, the USAFIK Commander insisted that moscow could not divest itse if of responsibility in its zone of occupation. He expressed willingness to fulfill American obligations for repayment, but only after the Soviets restored power. The United States obviously expected the northern action. Two power barges were on hand to meet the emergency.

\footnotetext{
Jacobs to Narshall, May 22, 1948, Frus, 1948, Vol. VIII, 1203-1.204; "U.S. Urges Soviet Command to Resume Electric Power," June 16, 1948, DSB, XIX, 471. (July 1.1., $1.948), 50-51$; New York Times, May 14, 1.948, $1: 8$ and June $16,19+8,1.7: 3$

We demeyer Memorandum, May 4, 1.948, RG 319, F\&O

091. Korea, Section IV, Cases 50-65, Box 87, NA; Saltzman to Draper, April 24, 1.948, FRUS, 1948, Vol, VIII, 1.1.81.
} 
Bunce observed that the north Korean action was a clear political maneuver designed to embarrass the new southern government and force the United States to recognize the north Korean regime. In addition, the adverse effect on the south Korean economy would discredit the United States and facilitate a Communist seizure of power. 5 clearly, the power termination benefited Syngman Rhee far more than the north Koreans or the Soviet Union. The average Korean in the south would now find it difficult to trust either vioscow or the northern regime. Perhaps more important, Kimm and Kim Koo had relied on Kim II-sung's promise to maintain electrical power and the decision to terminate it destroyed the careers of Rhee's two main adversaries.

Despite the power difficulty, the Korean leaders moved rapidly to form a separate government in the south. Several newly-elected representatives were members of the SKIG, which issued a statement just prior to the election denouncing Soviet obstructionism and domination in the north. Jacobs expressed agreement with the statement's accuracy, but questioned the logic of insulting Korea's "powerful and unforgiving neighbor." He went on to offer an extremely revealing observation:

Bunce to Marsha11, May 1.5, 1.948, FrUS, 1.948, Vol. VIII, 1.1.98-1199; State Department, Korea 1.945 to 1948 , $35-36$.

\section{6}

(Vay 1.7, $\frac{\text { New }}{1.948} 8$ ); Park Times, Nay 1.?, $1948,18: 2 ;$ mime, LI, 20 tion, 225 . 
It is, however, characteristic of the historical protegee psychology of the Korean official, who is insecure in his office and condition and must cling to the skirts of the strong power which he determines will dominate the situation. . . . This psychology in the past and today unfortunately finds expression in egging on the protector against the rival so he will destroy the latter. It would be obtuse to deny that this Korean psychology has not entered into and obstructed a settlement of the Koraan question. or influenced local Soviet and American objectivity.

On May 29, 1948, the new legislature met secretly and overwhelmingly elected Rhee as chairman of the body. It was clear to all observers that the new Korean government would be decidedly anti-Soviet.

Korea's neis legislative assembly formally convened in its opening session on May 31, 1948. Hodge delivered an address appealing to the north Koreans to hold democratic elections and join the south. He suggested that the legislature leave one hundred seats vacant for the northern representatives and establish a Iiason with the UNTCOK to foster reunification. Finally, Hodge urged the legislature to be patient and devote sufficient time to the formulation of an effective constitution and governmental structure.

It was difficult to voice optimism regarding the future of independence and democracy in the Pepublic of Korea (ROK). The extreme conservatives in control of the new legislature

Jacobs to Marshall, Nay 1.9, 1948, FRUS, 1.948, Vol. VIII, 1201-1202; ivew York Times, Nay 29, 1940, 4:4. 8

Hodge, Address to the Korean Assembly, Released May 27, 1948, DSB, XVIII, 468 (June 20, 1948), 800. 
had to be willing to seek a reconciliation with the moderates and institute genuine reforms. Still, Koreans now possessed their own leaders and some observers considered self-government an accomplishment in itself. 9 During private discussions, Rhee assured Jacobs that he would strive for a reconciliation with the left and seek reunification. He emprasized, however, that the ROK's success would depend upon the continuation of American assistance and support.

Rhee acted quickly on Hodge's recommendations and appointed a five man liason for cooperation and coordination with the UNCOK and the AMG. The Commission returned to Seoul on June $?$ and voted three days later to make itself available for consultation. 11. Yet, the UNTCOK remained badly divided and unable to adopt a firm position on the most controversial issues. The necessity for constant compromise meant that the UNTCOK had Iittle alternative other than to perform an essentially passive and negative role. A more active approach would only reveal the Commission's deep division. Virtually all the UNTCOK members agread, however, that the new Korean government was not national in character.

9

Weems, "Behind the Korean Elections," 146; New York Times, June $2,1948,28: 2$. 10 VIII, 1210 Jacobs to Marshall, May $30,1.948$, FeUS, 1.948, Vol. 11

Jacobs to Marshall, June 9, 1.948, Ppus, 1.948, Vol. VIII, 1217-121.8; ESB, XVIII, 468 (June 20, $\overline{1.948}$ ). 12

Gordenker, The United Nations and the PeacefuI Gordenker, The United
Unification of Korea, $128-129$. 
Despite the legislature's protests, the UNTCOK would recognize the ROK's authority as legitimate only in south Korea.

Hodge charged the Commission with vacillation and appeasement for its refusal to support the ROK without qualification. He predicted that the caution and timidity of a minority of Commission members was undermining the future of the ROK and increasing the likelihood of a delay in American withdrawal. If Washington did not exercise diplomatic pressure to alter the situation, Hodge warned that the United States would face a further deterioration of conditions. As a result, Marshall again expressed concern to the home governments of the Commission and urged recognition of the ?OK as national in character. He denied any attempt to dictate policy to the UNTCOK, but stressed that failure to support the ROK would confirm the permanence of partition and destroy past progress toward independence. Marshall's diplomatic pressure again experionced a degree of success. Although the Commission refused to recognize the ROK as a national govornment, it decided to attend the next session of the legislature and announce support for the new Korean regime. In addition, the UNTCOK voted on June 25 that the elections were "a valid expression of the free

1.3

Jacobs and Hodge to Marshall, June 11, 1948 , FRUS, 1.948, Vol. VIII, 1218 . 1.4

Hodge to Marshall, June 20, 1948 and Marshall to Indian Embassy, June 22, 1948, FRUS, 1948, Vol. VIII, 1219 and $1223-1.224$. 
will of the electorate in those parts of Korea which were accessible to the Commission. . which. . constituted approximately two-thirds of the people of Korea." ${ }^{15}$ Canada, Australia, and Syria strongly opposed this judgment and Jackson even walked out of the meeting in protest. Despite such division, Salvadorian delegate Miguel Valle addressed the Korean legislature on June 30. He announced that the Commission considered the new Korean government legitimate and was ready for consultations. Rhee expressed appreciation for the UNTCOK's support. He also hoped that it would soon supervise elections in the north and that these reprosentatives would then occupy their seats in the "National Assemily." 1.6

Factionalism quickly emerged as the dominant characteristic of the Korean legislature. Although the vast majcrity of representatives were sympathetic toward Syngman Rhee, Kin Sung-soo controlled the votes of seventy-five deiegates. As a result, if Kim Sung-soo disagreed with Rhee, the smaller factions would control events and force roliance on instable and short-lived coalitions. 1.7 Jacobs also observed that the

15

Hodge to Marshall, June 28, 1948 , FoUS, 1948, Jol. VIII, 1.229; New York Times, June 2?, 1948, $1 \frac{1.5}{2: 5 .}$

Jacobs to Marshall, June 30, 1948, and July? , 1.948, ERUS, 1.948, VoI. VIII, 1231 and 1.234; New York Times, June $30,1948,13: 4$ and july $1,1948,22: 3$; Carl Berger lamely argues that "as the first genliine poplilar election in all of Korea's history, it is difficult to oriticize the conclusions of the Commission," The Korean Inot, 81 .

Jacobs to Marshall, May 22, 19!8, RG 59, 895.00, 
various party platforms revealed a considerable "lack of realism and of the 'eyes shut' idealism which characterizes Korean political and economic thinking and of Korean . . fondness for the high-sounding written symbols of abstract virtue." Rhee's program, for example, appeared radical. He favored industrial nationalization, land redistribution, a planned economy, and heavy taxation of wealth. In view of Rhee's past history, it was difficult for most cbservers to accept his proposals at face value.

Initial debate in the Koroan Assembly centered on the nature of the governmental structure and constitution. Kim Sung-soo and his supporters favored a parliamentary system modeled after the governments of Western Europe. Since his party represented the interests of business and landomers, Kim Sung-soo envisioned a major influence in the korean government through the control of powerful positions in the cabinet and the bureaucracy. Rhee, on the other hand, favored a strong executive and a governmental structure resembling that of the United States. Thus, from the outset, the lines of opposition be tween. Rhee and Kim Sung-soo were clear and cooperation would be difficult.

On July 12, the National Assembly completed work on the

$5-2248, N A$

18

Jacobs to Marshall, JuIy 8, 1.948, RG 59, 895.00/

7-848, NA; Time, II, 21 (Niay 24, 1.948), 36 . 19

Jacobs to Viarshall, July 1.2, 1.948, RG 59,895.00/ ?-1248, NA: Kim, Divided Korea, 11.8 . 
constitution. On the surface, the Republic of Korea was a traditional democracy, based upon the popular election of representatives to a unicameral legislature for a two-year term. The Assembly in turn elected a President to serve for a four year period. The President appointed the Premier and a cabinet subject to the legislature's approval. The chief executive also selected judges to a supreme court, but the body did not possess the power of judicial review. Thus, the Korean system appeared to combine elements of both the American and European models of democracy.

Several peouliarities existed in the scheme which posed a potential threat to democratic operation. For example, the legislature could not alter the provisions of the President's budget proposals; it could only approve or roject. More important, the constitution reflected the traditional Japanese tendency toward a powerful executive and a centralized bureaucracy. The President possessed extensive powers for the formulation and implementation of policies in the absence of coordination with the legislature. After declaring a state of national emergency, the chief executive could rule by decree, appropriating money and passing laws without the Assembly's approval. Thus, a single man or party could exploit the constitution and obtain complete control of

New York Times, July $14,1.948,22: 3$; State Department, Korea 19t5 to 1948, 17-18; Faul S. Dul1, "South Korean Constitution," Far Eastern Survey, XVII, 17 (September 8, 1948), 205-206. 
the Korean government. At the same time, the President could not dismiss the legislature if it disagreed with his policies. In the event that the executive and the legislature found cooperation impossible, prolonged deadock and executive rule was a virtual certainty.

\section{II}

Korea's progress toward democracy and independence was a matter of extreme satisfaction for Truman. Fe emphasized that the United States was fulfilling its obligations in good faith, while Noscow was striving to impose its will on the Korean people. Soviet tactics, Truman explained, justified unilateral action. Stalin could terminate the sovist boycott of the UNMCOK's activities at any time and thereby inaicate his willingness to fulfill his commitments. Truman declared that Korea represented a test of Soviet intentions:

On its own initiative, the Soviet Union . . can permit the people of North Korea to work with their compatriots in the south in creating an independent and democratic nation. If the Soviet Union genuinely desires to make a contribution to peace and recovery in the world, it can prove it in korea.22

Truman's expectation of a change in Soviet policy toward Korea was naive, since the creation of the ROK only reduced

Jacobs to Marshall, July 27, 1948, RG 59, 895.01./ 7-2748. NA; Dull, "South Korean Constitution," 206-207. 22

Truman, Commencement Address at the University of California, June 12, 1948, Fublic Papers, Harry S. Truman, $1948,339$. 
the likelihood that Moscow would permit reunification.

mruman and his advisors now began to consider a change of personnel in Korea. On April 27. Narshall recommended that the President appoint John J. Huccio of Rhode Island as Ambassador. A career Foreign Service officer, Muccio obtained his experience in Latin America, Asia, and finally Berlin. Muccio later speculated that Truman chose rim because of his experience in a divided Germany dealing with a military occupation. The argument seems cogent, since his principal task in Korea was to supervise the transfer of authority from the AViG to the new Korean government.

American military leaders also decided to reolace Hodge at the earliest practicable date. Upon his arrival in Korea in April, Draper realized that Rhee's electoral victory was inevitable. It was essential to have a USAFIK Commander able to cooverate with Rhee. Hodge's continued presence would produce tension and be awkward for the new government. The ICS chose Mlajor General John B. Coulter, Hodge's executive officer, as the new USAFIK Commander, because Coulter had remained uninvolved in local politics. Yet, the JCS did not want the appearance of placating Rhee. Washington thus instructed MacArthur to delay the announcement until Hodse was ready to leave south Korea.

Marshall to Truman, April 27, 1948, FPUS, 1948, VoI. VIII, 1183-1.184; John J. Muccio, orai yistory Interview Transcript, February 1.0, 1971, HSTI, 5-6. 24 Butterworth to Lovett, May 11, 1948, ERUS, 1948, 
Washington also cortinued to impiement "Crabapple" during the early summer of 1948. Royall ordered the shipment of a one-year supply of training ammunition for small arms to Korea and a six-montin supply of ammunition, equipment, and replacement parts following American withdrawal. He then informed Marshall of these decisions and of Hodge's readiness to transfer the direct administration of American responsibilities to the state Department on September 2 , 1948. Royall urged Marshall to organize a diplomatic mission capable of beginning effective operation at the earliest possible date.

Army Department officials we re clearly determined to withdraw from Korea on schedule, regardless of conditions in the peninsula at the time of departure. Lovett refused to submit to such pressume. While tentatively approving the Army schedule for withdrawal, he stressed that NSC-8 calied for flexibility and coordination of American policy with the United Nations. The Army could begin to implement withoraval but Lovett emphasized that it had to be prepared to suspend, adjust, or delay the operation on a moment's notice.

Vol. VIII, 1.192-11.94; Gilchrist liemorandum, Way 1.3, 1948, RG 319. P\&0 091 Korea TS, Section III, Cases 16-30, Eox 22, NA. 25

Lawson Nemorandum, June 9, 1.948, RG 319, P\&0 091.

Korea, Section $V$, Case 66, Box 88, NA; Royall to ilarshall, June 23, 1.948, RG 31.9, P\&0 091. Korea TS, Section III, Cases 3-1.5, Box 21, NA; Saltzman to Lovett, JuIy 30, 1.948, FRIS, 1948 , Vol. VIII, 1265.

Lovett to Royall, July 8, 1948, FRUS, 1948, Vol. VIII, $1234-1235$ 
Reports from Seoul seemed to justify State Department caution, since Hodge complained that the Korean populace was not evidencing sufficient loyalty to the new legislature. He observed that the Korean leaders were not concerned with the general welfare of the nation, but with "personal and individual power, by fair means or foul." More important, in the event of an insurrection, the USAFIK would be too understrength to prevent a Communist seizure of power.

Political competition in the legislature and the absence of complete UNTCOK support for the ROK convinced Jacobs that the United States should delay withdrawal. The legislature would not complete the formation of a government until July 30, but Army plans depended upon the completion of the ROK thirty days earlier. Jacobs urged Marshall to

bring this fact strongly to attention Dept $\overline{\text { sicl, }}$ of Army so that its operational plans based on that date will be delayed accordingly until September 157 and thus prevent this phase of our planning and operations from getting our Sic7 of line with political phases. By all means no action to implement william Day should be taken as resulting publicity will complicate if not jeopardize our hope that UNTCOK will give formal. approval to new government.

Marshall complied with Jacobs'recommendations. He also began to exercise pressure on the Commission member's home governments to extend some form of recognition to the ROK. The Secretary of State emphasized that if the United Nations refused to support the $R O K$ as a national government, Moscow 27

Hodge to Bradley, June $17,1.948$, RG $31.9, P \& 0$

091 Korea, Section $V$, Case 65 , Box 88, NA. 
would create a separate regime in the north and tinus render the Korean partition permanent.

In Moscow, Smith realistically observed that the United Nations could not prevent the creation of a puppet regime in north Korea. Stalin would simply ignore the UNTCOK if it recognized the new south Korean government. 29 on July 11 , Kim Il-sung announced that the People's Committee would sponsor elections throughout Korea on August 25. At the same time he indicated that work on the constitution was near completion. This document provided for a national. government with its capital in Seoul. The north Koreans also exhibited a new national flag, complete with the "hammer and sickle." Kim II-sung denounced the United States for crezting a police state in the south and demanded immediate American withdrawal. 30 United Nations recognition of the RoK now assumed added importance.

North Korea's claim to legitimate rule throughout korea alarmed Jacobs. He feared that Australia, Canada, and India would now recommend the abolition of the UNTCOK after the 31 inauguration of the ROK. His apprehension was certainly

\footnotetext{
Jacobs to Marshall, July 9, 1948, RG 59, 501BB Korea/7-948, NA; Marshall to Certain Embassies, July 10 , 1948 , FRUS, 1948 , VoI. VIII, 1.235-1.237. Vol. VIII, 1.240 . 30 Jacobs to Narshall, July 1.1, 1.948, ERUS, 1.948, Vol. VIII, 1.238-1.230; New York Times, JuIy 12, 1.948, 10:3. 31. Jacobs to Marshall, July 1.6, 1948, FrUS. 1.948,
} 
warranted. During July, all three nations informed the United States that they would oppose recognition of the ROK prior to final United Nations action on the Commission's report. Aside from the questionable nature of the May elections, the se governments pointed out that recognition of southern control over the north would be unrealistic. Inilateral and precipitate action would also alienate other United Nations members and detract from a sympathetic attitude toward the southern regime. ${ }^{32}$ North Korean actions may have urged caution upon these nations, but the formation of a Communist regime in the north reinforted Chinese, Philippine, and Salvadorian support for American policy. Even France joined the advocates of recosnition, arguing that it would be wise to view the ROK as national in character. Ambassador Jessup realized that it would be extremely difficult to obtain United Nations recognition of the ROK as a national government. He preferred instead to concentrata or gaining the cooperation of the UNTCOK in supervising the transfer of governmental power from the ArG to the new Korean government. American pressure for recognition would only alienate the United Nations and endanger policy objectives

Vol. VIII, $1.243-1245$

King to Narshall, July 13, 1948, Nielson to Marshall, July $1.4,1943$, Neminger to Narshall, July $1.4,1.948$, Donovan to Marshall, July 19, 1948, and Douglas to Varshali, july 19, 1948, FRUS, 1.948, Vol. VIII, 1.239-1242 and 1.247-49. 33

Stuart to Marshall, July 15, 1948 and Lockett to Marshall, July 16, 1948, FRUS, 1948, Vol. VIII, 1234 and 124.5. 
of the United States in other more important areas. State Department officials remained convinced, however, that the United States should press the United Nations to recognize the national character of the ROK. Washington decided to refer Jessup's recommendations to Jacobs for comment.

Jacobs strongly disagreed with Jessup and urged action at the other extreme. He favored immediate American recognition of South Korea regardless of United Nations action. Any sign of American weakness or vacillation, Jacobs insisted, would undermine the sizable popular support that the Rhee government then enjoyed. Although Canada and Australia would object, Jacobs was confident that the Interim Committee would support the American action and even follow suit. ivarshall decided to adopt a middle course. The United States would delay recognition, but would increase pressure on the UNTCOK to view the ROK as the national government of Korea. Marshall also approved Jasobs' recommendation that a representative of the new Korean government traval to the United Nations and attend sessions.

Truman and his advisors were then sensitive to any action that might detract from United Nations support for the ROK. Truman thus appointed Vuccio as "special

Jessup to Varshall, July 20,1948 and Butterworth to Lovett, July 2.0, 1.948, ERUS, 1948, VoI. VIII, 3.248-1.249. 35 Jacoss to Marshall, July 24, 1948, FRJS, 1.943, Vol. YIII, 1255-1257; Butterworth vemorandum, August 2, 1948, RG 59, 50183,8-248, NA. 
representative of the President," rather than ambassador. Muccio possessed full authority to negctiate agreements, but Washington withheld more extensive powers until the United Nations acted. Simultaneously, the American delegation at the United Nations formulated a letter from Hodge to the UNTCOK informing the Commission of the successful creation of a Korean government. Hodge would represent the United States at the inauguration of the new Korean government on August 1.5, the anniversary of Japan's surrender. The USAFIK Commander's departure and Muccio's arrival would then symbolize the restoration of Korean sovereignty.

Whils Washington attempted to increase international support for South Korea, Rhee's actions continued to embarrass the United States. Jacobs observed that the old patriot was assuming "more and more messiah pose and speaks in first person of what he will do." Rhee was sure to be the first President of South Korea and Americans in Seoul feared that he would exploit the constitution and the governmental structure to create a dictatorship. In addition, Rhee's "loose bombastic utterances" against the Soviet Union and Communism would have a disastrous effect on American policy in the

\section{6}

Harshall to Jacobs, July $27,1,46$, jovett to Pruman, July 28, 1948, and Jessup to Marshali, July 26 , 1948, FRUS, 1.948, Vol. VIII, 1262-1.264. 
United Nations. Still, American leaders realized that the United States would eventually have to arrive at, a suitable basis for cooperation with Rinee.

Americans accurately predicted the Assembly's choice of

a President. The legislature promulgated the constitution on July 17 and three days later it satisfied Rhee's life-long ambition and elected him President of the Republic of Korea. Rhee assumed office with an incredible degree of power. No one rivaled his prestige and political support. 38 Rhee also owed nothing to the United States, since Kodge had attempted to Iimit Rhee's rise to power.

Infortunately, Rhee attempted to exploit his position and the bureaucracy for personal gain. He appointed only his close political supporters and trusted functionaries to government posts. ${ }^{39}$ More important, Rhee completely ignored $\mathrm{Kim}$ Sung-soo and his supporters, as well as those individuals who served under the AMG. Kim Sung-soo felt betrayed and immediately organized a strong, stable, and cohesive party to oppose Rhee's strategy for domination. Its first act of defiance was to reject Rhee's choice for Premier, arguing that Kim Sung-soo deserved the appointment. Thus, personal

\section{7}

Jacobs to Narshall, July 18, 1948, RG 59, 5013B/ 7-1848, NA; Seedlock liemorandum, July 2?, 1.948, RG 319, P\&O 091 Korea, Section V, Case 65, Box 38, NA. 38

$$
39 \text { New York Times, July } 20,1948,12: 2 \text {. }
$$

Hencerson, Politics of the Vortex, 160-161; Kim insists that Rhee's appointments produced skillful administrators who Dossessed broad support, Divided Koroa. 1.9. 
and political factionalism emerged at the outset tc comolicate South Korea's future.

$$
40
$$

On August 4, the legislature approved Rinee's cabinet selections, including the compromise candidate Lee Bum-suk as Premier. Two days later, Rhee informed Hodge that the newly-formed government was prepared to assume complete administrative control over southern Korea. He also appointed a Iiason to the UNTCOK for consultation and coordination regarding the transfer of authority. The ROK President expressed nis wish for the continuation of "felicitous" relations with the United Nations.

Rhee now began to press the United States to delay withdrawal. He insisted that the United States could not leave until the ROK possessed the military capability for self-defense. Hodge and Jacobs agreed. They insisted that the announcoment of departure would have a devastating effect on Korean morale and would sacrifice all previous gains in the southern zone. Washington could expect the Communists to renew agitation and subversion following American withdrawal in an attempt to seize control forcibly. Hodge stressed that "we should stand firm everywhere on

\section{0}

Wuccio, Dral History Interview Transcript, HSTL, 7: Reeve, The Republic of Korea; Henderson, Politics of the Vortex, 291; New York Times, July $27,1948,1.4: 3$. 41

Jacobs to Marshall, August 6 and 10, 1948, FRUS, Vol. VIII, 1.948, 1.266-1267 and 1.270; New York Times, August, $10,1948,12: 1$. 42

New York Times, August $6,1.948,4: 2$. 
Soviet perimeter, including Korea, until we know more clearly what actions will be taken in Ceneral Assembly and what will be outcome of our present negotiations with respect to Berlin . ..." 43

Such advice convinced the state Department that premature withdrawal was unwise. In response, the Army Department complained that indecision and confusion in the State Department indicated its refusal to accept responsibility for American policy in Korea. Military leaders demanded that the State Department comply with NSC-8 and cease hampering
44 American withdrawal. The Army Department also complained that the Economic Cooperation Administration (ECA) refused to exhibit any interest in Korea whatsoever. It strongly urged Truman to appoint an experienced and capable administrator for the Korean aid program possessing long-range instructions. If the Administration permitted military government in Korea to continue, such a course would embarrass the new Korean government and substantiate Soviet charges of American imperialism.

Jacoos to Niarshall, August 12, 1948, FRUS, 1.948 , Vol. VIII, 1272; Hodge to JCS, August 12, 1948, RG 21.8, CCS 383.21 Koraa, Section 16, NA. 44

Schuyler to Wedemeyer, July 28, 1.948, RG 31.9, P\&0 091 Korea TS, Section IV, Cases 1.6-30, NA. 45

Vemorandum for the Secretary of the Army, July 1.6. 1948, RG 319, P\&O 091 Korea TS, Section IV, Cases 16-30, NA; Saltzman later argued that the Army was not anxious to transfer authority in Korea to the State Department. He was obviously in error, Saltzman, oral History Interview Transcript, June 28,1974 , HSTI, 9 
Significantly, the Army Department was far more confident than the State Department over the probable success of containment in Korea. During Muccio's orientation, military leaders stressed that stalin would not instigate an open invasion of South Korea, but would pursue instead a strategy of subversion and indirect aggression. Since American actions in Korea had placed Moscow on the defensive, the Army Department believed that there was reason for considerable optimism:

Syngman Rhe was, as a result of the Army's substantial effort in training and equipoing the South Korean Forces, in a strong bargaining position to talk with the North Koreans on unification. Mr. Muccio was appraised of the latest intelligence estimate, which placed the North Korean forces at approximately 50,000.. . and that this meant that parity had now been achieved be tween the two forces in general terms as a. result of the undoubted superiority of the U.S. arms in the possession of the South Koreans, when compared to the ones in the possession of the North Koreans.

American military officials thus encouraged Muccio to assume complete control over the responsibilities of the united States in Korea, since occupation was no longer essential. Muccio's response confirmed Army suspicions that the State Department was dragging its heels. Muccio explained that the diplomatic branch was being dilatory "owing to a feeling that the Congress did not want state to handle programs of this nature." He agreed, however, to support a

H.A.B. to Schuyler, August 9, 1.948, R.G 319, P30 091. Korea TS, Section V, Case 31, NA. 
wider role for the State Department in supervising Korean economic recovery. Draper rejected the validity of this argument and charged the state Department with attempting to shun its responsioilities. If state's attitude of indifference continued, the Army threatened to remove all military equipment from Korea intended for the Constabulary army. The Army argued logically that if the state Department did not consider Korea sufficiently important to generate any interest in its political and economic stability it would be foolish to place a substantial military investment in jeopardy.

Truman was apparently aware of the dispute. On August 1.6. he ordered the departments involved to decide which agency was best able to manage Korean ronabilitation. During subsequent discussions, the Army insisted upon the rapid elimination of its responsibilities in Korea. Lovett, on the other hand, insisted that the State Department did not possess enough trained personnel to supervise the program. He also reiterated that Congress wanted to exclude the diplomatic branch from involvement in economic assistance programs. Paul G. Hoffman, ECA Director, expressed sympathy for Lovett's position, but strongly supported the Army's contention that the military should not administer an

Schuyler Memorandum, August 9,1948 , RG 319, P\&O 091 Korea IS, Section V, Case 31, Box 22, NA. 48 OF 471, HSTI.

Truman to Lawton, August 16, 1.948, Truman Papers, 
49

aid program.

Hoffman soon roalized that the ECA was the logical candidate to supervise the Korean assistance program. He emphasized that a small-scale operation would be a waste of time and money. Yet, he doubted whe ther Congress would "continue to pour money into Korea, which was a rather questionable investment." Nevertheless, he agreed to accept responsibility for Korean aid, provided that the Budget Bureau approved the decision. Thus, Hoffman broke the deadlock between the Army and State Departments. On August 25 , Truman issued orders that the Army was to transfer its responsibilities to the ECA as of January 1, 1940. Hoffman thus began to gather personnel and organize an aid mission for Korea. He also ordered the formulation of a definitive aid program for inclusion in the 19,950 budget.

\section{IV}

On August 1.2, 1948, the United States announced formally the appointment of Muccio as presidential representative to Korea. The statement emphasized that the Iruman Administration considered the Rhee government as the political

49

C.V.R.S. to Schuyler, August 20,1948, RG 31.9 , P\&0 091 Korea TS, Section V, Case 31., Box 22, NA. 50

Lawtor to Truman, Indated, Truman Papers, OF $47 \%$, HSTL; Truman to Varshal1, August 25, 1948, Truman Fapers, White House Central Files, Confidential, Box 35, State Department Correspondence, 1948-1949, Folder 13, HSTL. 
authority envisioned in the November 14 resolution. Few observers failed to discern that the United States had extended defacto rocognition to the ROK ard was attempting to seize the initiative from the Soviet Union on the Korean issue in the United Nations. ${ }^{51}$ Several commentators expressed extreme optimism over the progress of American policy in Korea. U.S. News even argued that Rhe 's prestige and able leadership wolid now allow the United States "to pull out of Korea as the victor on this battlefront of the "cold war." The editorial speculated that "in due course" the north Koreans would obtain control over their own affairs and join the south Koreans to form a united nation.

American military government officially ended on August 15 with the inauguration of the Republic of Korea. Truman was delighted and credited Hodge with the "outstanding success" of bringing freedom to the downtrodden Korean people. "By your skill, iritiative, and diolomacy," Truman explained, "you have overcome seemingly insurmourtable obstacles and you have earned the gratitude of the people, both of the United States and of Korea." 53 At "Policy Toward New Korean Government," August $1.2,1.948$, DSB, XIX, 477 (Aligust 22, 1948), 242; New York Times, August 13, 1.948, 1.:2. 52 III, 8 (Aug.S. News, XXV, 6 (August $6,1.948$ ), 20; Time, 53 PPF 3920, HSTI. Truman to Hodgo, June 23, 1948, Truman Papers, 
least on the surface, national self-determination had triumphed and Koreans could now determine their own destiny. NacArthur attended the inauguration and delivered a speech emphasizing that the 38 th parallel "must and will be torn down. Nothing shalI prevent the ultimate unity of your people as free men of a free nation." American foreign policy had seemingly produced a. broadly-based government that enjoyed international support. Korea would illustrate the berefits of peace and democracy not only to the Communists in the north, but to the rest of Asia as well.

Rhee's government commenced operations, however, under the worst possibie circumstances. Despite Truman's optimistic comments, the AMG had been largely a failure and few Koreans appeared completely satisfied with the American performance. Although health, education, and the food supply had improvod. Hodge's administration had not built political and social unity, but fostered instead a splintered nation under rightist control. Police tactics and youth gangsterism dominated everyday affairs and prevented the emergence of real democracy. America's Korea policy lacked 55 competent officials and long-term plans.

Perhaps more important, the United States had been

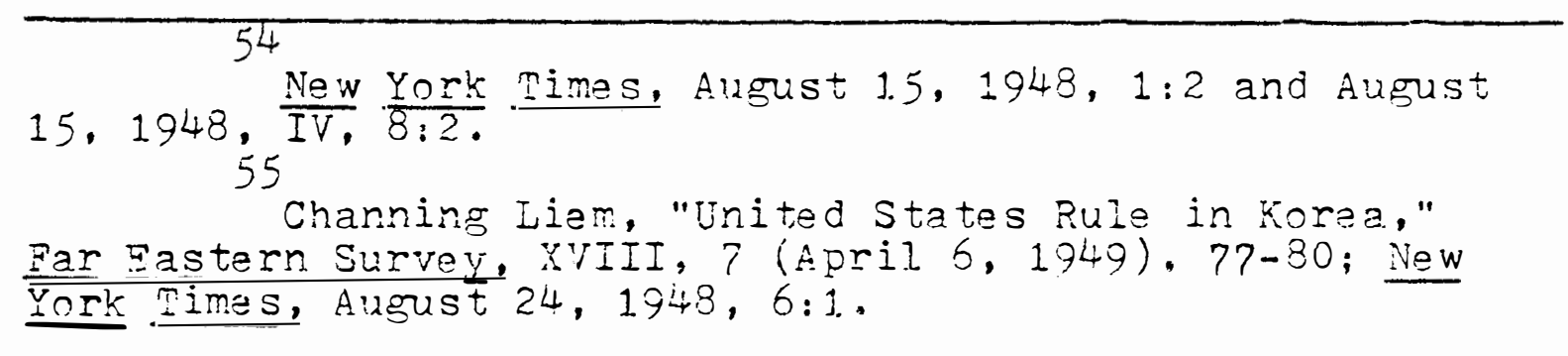


unable to remove the 38 th parallel and actually solidified the partition. In an effort to counter the northern military threat, the United States organized the Provisional Korean Military Advisory Group (KNAG) on August 1.5 to train the Constabulary army. Composed of two hundred forty men, the Provisional KMAG attempted to create and equip a military force of sufficient strength to deter an invasion from the north. The ROK also confronted the more sericus and immediate problems of power deficiencies, overpopulation, and a Iimited industrial capacity. 57 Korea's future, much Iike itsw past, presented a bleak picture.

Truman's strategy at the United Nations also sxperienced difficulties. The UNTCOK submitted its report on July 25, which indicated that a "reasonably free atmosphere" existed in Korea during the May elections. Yet, the Commission recommended that the United Nations not extend its presence or expand its roie in Korea. While it approved the American creation of a Constabulary army, the UNTCOK strongly urged termination of the United Nations involvement after the United States withdrew. Jacobs quickly cabled Nashington that only the UNTCOK's presence would deter and restrain the Soviet "stooges" to the north and inside south Korea.

\section{6} 57

Sawyer and Hermes, Military Advisors in Korea, 35.

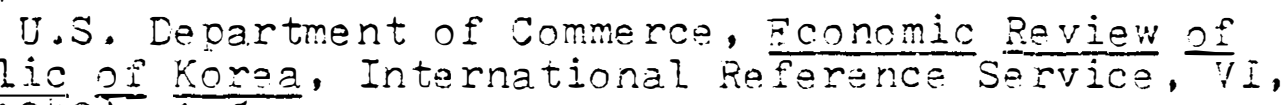

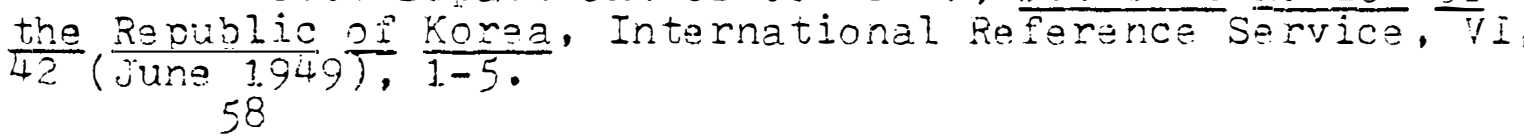

jacobs to inarshall, August 18, 1948, FRUS, 1948 , 
Marshail thus instructed Austin to urge the United Nations to authorize the extension of the commission' $z$ tenure in Korea. The United States believed that the Mincor would contribute to the RoK's prestige, stabilize raiations with the north, and facilitate political stability and social improvement throughout the peninsula.

Rhee's first crisis revolved around the nature of the agreement with the United States for the transfer of governmental authority. The Promier and Foreign Minister both threatered to resign if the USAFIK remained in control of the police and the Constabulary until the complotion of withdrawal. Rhee blamed Hodge for including this rorovision in the transfer agreement intentionally just to "devil rim." Hodge observed that "Rhee and his Austrian vife, - . retain all of the bitter hate fixation for me personally that they have ever had." Houge strongly urged that Nuccio arrive no later than August 23 , even if a transier agreement remained unsigned. Once in Seoul, Muccic could then inform Rhe that the united States would not exterd economic or military assistance until the Korean government aporoved the terms of the agreement. The State Department accepted Hodge's recommendations and imnediately dispatched

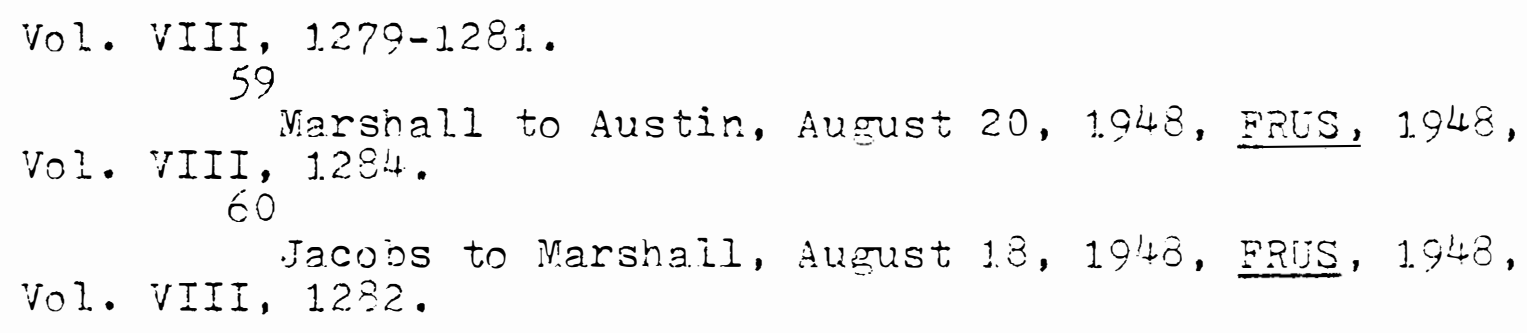


Muccio to Korea. Hodge could now transier authority to Muccio and Coulter, thus ending three years of personal frustration and failure.

Muccio's first remarks indicated his belief that the delay in Korean independence was not the result of Korean actions or those of Korea's "real friends." He hoped that, under its new constitution and the leadership of Syngman Rhee, Korea would achieve rapid reunification, sovereignty, independence, and admission to the united Nations. Evi.dently, Hodge's strategy succeeded, since Rheo signed the transfer agreement the day after viuccio arrived. The United States would permit the ROK to assume control over the police on septemier 3 , but would maintain control of the Constabulary. The USAFIK would simultaneously transfer surplus equipment to arm a force that would be small, mobile, and we Il-trained for the maintenance of internal security. Finaliy, the United States would begin withdrawal at "tho earliest practicable time."

61

Hodge to Narshall, August $18,1.948, \mathrm{RG} 319$, Leahy Papers, Korea 1948, NA; Hodge to JCS, August 21., 194. $\bar{R} G$ 21.8, CCS 383.21. Koroa $(3-1.9-45)$, Section 1.6, NA; Now York Times, August 24, $1.948,6: 1,7: 1,7: 2$. 62

Vol. VIII, Jacobs to $1.226-2.287$. 53

"Military and Security Measures Effective Unti. Completion of Withdrawal of United States Forces From Korea," Treaties and Other International Acts Series, No, 1918 (Washington, D.C.: Government Printing office, 1949); Jacobs to Marshall, August 24, 1.948, FRUS, 1948, VoI. VIII, 1287; New York Rimes, August $25,1948,1.4: 3$. 
As indicated earlier, American leaders rescheduled withdrawal from August 1.5 to September 1.5, 1.948. The State Department refused, however, to approve orders authorizing departure even at this later date, insisting that NSC-8 provided for flexibility and did rot preclude further delay. More important, Butterworth argued that the American public now favored a strong stand in Korea. rather than precioitate withdrawal. In addition, Hodge and Jacobs nad urged dolay until the United Nations acted on the UNTCOK report and received a Soviet response. The Army Department remained adament and refused to permit indefinite prolongation of military occupation in Korea.

American officials finally arrived at a comoromise. The USAFIK would commence withdrawal on September 1.5, but would remain ready to halt the operation at any point during implementation. Washington ordered Hodge not to refer to the imminence of American disengagement upon his own devarture from Korea. Instead, he wolild merely announce that the realization of Koroan self-government now cermitted the United States to "regroup" in preparation for a reduction of force levels in Korea. The Army Department a.greed to these instructions reluctantly, since the Chinese Communists had just achioved complete control in Manchuria. American milj.tary leaders believed that the united States

Butterworth Momorandum, August 1.7, 1948, FRUS, 1948, Vol. VIII, 1276-1.278; Hodge to JCS, July 24, 1.948. RG 218, CCS 383.21. Korea (3-1.9-45), Section 16, NA. 
position in Korea was now unterable. Despite such fears, Hodge left Korea expressing superficial optimism and predicting that a working democracy in South Korea would weaken Soriet dominance in the north.

Having reached agreement on withdrawal. Hoffman, Saltzman, and Draper now turned their attention to formulating plans for the economic aid mission to Korea. Initiation of withdrawal obviously pleased Draper. He pledged his compiete support for the ECA's efforts. Hoffman, however, was far from satisfied and questioned the logic of the entirs venture :
The whole problem is one of State Lepartment foreign policy. It has no economic justifica- tion. He would hold out hope that korea would offer any kind of economic bulwark. He gathers that it has no strategic importance from a mili- tary point of view. ECA will look to the state Department for leadership in the profram to be carried out. He regards the operation as a 66 holding one-making zood on pledges to Korea.

Administration officials docided that the State Departmont and the ECA would formulate a plan for aid to Korea and jointly submit it to Congress for approval. Thus, Congress would have to decide whe ther the expenditure was justified. In the meantime, financial support for American operations

65

JCS to MacArthur for Hodge, August 27 , 1948, RG 218, CCS 383.21. Korea $(3-1.9-45)$, NA; Wedemeyer to Secretary of Defense, August 30, 1.948, RG 31.9, P\&0 091. Korea TS, Section I, Case 1, NA; New York Times, August 29, 1943, $7: 5$. 66 Truman to ivarsial1, August 25, 1948, ERUS, 1.948, Vol. VIII, 1.288-1.289; Claxton Memorandur, September. 1. 1948, RG 59, 895.50 Recovery/9-148, NA. 
in Korea would continue under a recent Congressional appropriation bill for Government Aid ard Relief in Occupied Areas (GARIO). $6 ?$

\section{V}

Rhee clearly recognized that the survival of his regime depended ucon American economic assistance. He formally requested such aid on september 3, as well as military assistance. Muccio favored granting the request, but insisted that any technicians or advisons serving in Korea possess complete freedom of action to ensure the efficjent utilization of the aid. It was coubtul, however, if the legislature would acceot any conditions for the reception of American aid. The Assembly already indicated opposition to the "Korean-American Financial and Property Sattlement" because it contained provisions for Korean payment of the costs of American occupation. In all probacility, Rhes would not be able to obtain the legislature's supcort for anything less than complete autonomy. As viuccio explained, the "President has an all-too-ready tendency of ignoring the National Assembly instead of taking the bull by the

Public Law 793, U.S. Congress, House, Committeo on Appropriations, Backaround Information on Korea, $H$. Rept. 2495 pursuant to $\mathrm{H} . \overline{\mathrm{K}} \cdot 20 \delta$, 81.st Cong., 2nd sess., (Jul j 1.j., 1.950). The bill carried an oxpiration date of June 30, 1.949. 68

Muccio to Varshall, September 3, 1.948, FRUS, 1.948 , Vol. VIII, 1.289; Muccio to Marshall, October 1.8, $\overline{1.948}$, RG $59,895.00,110-1.848$, NA. 
400

59

horns and leading it."

Economic deterioration continued to plague South Korea. Deficit spending and blackmarket prices produced high inflation that would hamper economic development. The widespread popular beilef that trouble with North Korea was inevitable also contributed to an atmosphere of uncertainty regarding the RoK's future. Relations botween the oxocutive and the legislature were entirely unsatisfactory. The Assembiy passed the National Traitors Act and began to order the arrest of any individual suspected of prior collaboration with the Japanese. The legislature concentrated on prosecuting those bureaucrats and policemen loyal to Syngman Rhee, thus restricting further the opportunities for cocperation between the executive and the legislature.

Rhe immediately retaliated against the recalcitrant Assembly and anyone attempting to limit his porers. The police inaligurated a campaign of political repression wagod in the name of national security and anti-Communism. Rhe 's functionarios closed down newspapers and imprisoned political leaders critical of the government. In particular, Rhee concentrated on eliminating all vestiges of overt leftist

\section{9}

Muccio to MacArthur, Septembar 6, 1948, NacArthur Papers, Correspondence, 3ox ?, VIp File, John J. Muccio, Dirivit. 70 Jones to Harshal1, September 15, 1943, PG 59, $895.01 .19-1.548 . \mathrm{NA}$.

73. Jacobs to Marshal1, August 25, 1.948, RG 50, 895.00/8-2548, NA; Kim, Divided Kore?, 123. 
401.

activity in South Korea. Thus, the ROK rapidly assumed the appearance of a police state that bore iittle resemblance to the liberal democracy Truman and his advisors were striving to create in South Korea.

Events in North Korea during the fall of 1948 presented another threat to the success of the test case of containment. On August 25, North Korea sponsored elections, allegedly nationwide, for delegates to a "Supreme Korean People's Assembly." During the first week in September, this body met in Pyongyang and promulgated a constitution. The Assembly then "elected" a "Supreme People's Council" and chose Kim Tu-bong as chairman. Kim Tu-bong then called upon Kim Il-sung to form a cabinet which would constitute the ruling authority of the Democratic People's Republic of Korea (DPRK). The new North Koroan government claimed to represent the entire nation and indicated its intention to send delegates to the United Nations.

Kim Il-sung's first act was to address letters to both Truman and Stalin requesting recogrition and the withdrawal of foreign troops. On September 1.9. Stalin expressed Soviet support for the new government and recognized it as the national government of Korea. Te also indicated that rioscow

Nuccio to Narshall, Septemoer 14, 19:48, RG 59, 895.00/9-1.448, NA; Mitchell, Second Failure in Asia, 29-30. 73

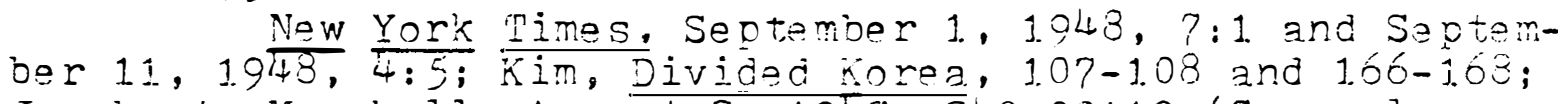
Jacobs to Marshall, August ?, 1.947, 740.001.9 (Control Korea)/8-74?, NA; Berger, The Korean Knot, 82-83. 
would comply with Kim's request and withdraw from the north before the end of 1948. Stalin then urged the united States to follow suit. 74 Apparently, the se events caught Truman completely off guard. Stalin's maneuver had, however, placed the United States in a particularly precarious position. North Korea was clearly stronger than South Korea militarily, economically, and politically and the Soviets could withdraw without hesitation. Truman could not act with such alacrity. American withdrawal would place the existence of the ROK in serious jeopardy. The southern reliance on American military protection would not contribute to international recognition of the ROK as the legitimate ruler of the entire nation. Wuccio immediately recommended that Washington ignore the request, arguing that only the Sovist Union possessed the authority to propose withdrawal. The United States should avoid any indication that it considered tre DPRK a legitimate government. 70 Truman accepted Nuccio's advice. He addressed a letter to stalin taking note of the soviet decision to recognize the DPRK and withdray from Korea. The President went on to observe that these matters were an integral part of the larger issue of Korean reunification

Kohler to rarshall, September 19, 1948, PRUS, 1948, Vol. VIII, 1.306; "Position on withdranal of Troops From Korea," Septemicer 30,1948, DS3, XIX, 484 (October $10,1.948), 456$; Truman, Years of Trial and yode, 323. 76 New York Times, September 20, 1948, 1:5, 24:1. . Muccio to Marshall, September 1.d, 1948, ERUS, 1948 , Vol. VIII, 1.305-1.306. 
and independence. The United liations would have to supervise both witndrawal and the determination of Korea's legitimate ruler. If In Seoul, Muccio assured Rhee that the United States would not abandon the ROK and would coritinue to supply military and economic assistance.

Rhee now sought to postpone America's departure from Korea inde Initely. He dispatched Chough Fyong-ok to Washington to urge the Truman Administration not to abandon Korea "when the battle was only half won." While in the United States, Chough stressed that American withdrawal would only invite a Communist invasion from the north. 79 During September, John Myung Chang, the new Korean Ambassador to the United States, joined Chough in Washington and also oressed Truman to delay withdramal. Chang argued that the Rok could withstand a northern invasion and Communist subversion with American assistance and advice. He then expressed appronension regarding the United Nations. The anticipatad attendance of the northern representativos at the noxt unitod Nations session would endanger the ROK'S chances for recogrition and subsequent admission to the international

Lovett to Vuccio, September 20, 1948, FRUS, 1948, Vol. VIII, 1.307-1308; "Position on Vithdrawing occunving Forces from Korea." September 20, 1.948, DSB, XIX, 433 (00tober 3, 1.943), 440; Now York Times, September 21, 1348 , $1.6: 3$.

\section{8}

Muccio to Marshall, Septemioer 21., 3.948, EqUS, 1948, Vol. VIII, 1.308-1.309. 79

Lovett Memorandum, September 23, 1948 , FRUS, 1.948, Vol. VIII, 1.309-1.31.1. 
404

80

organization.

Washington clearly recognized that South Korea was in grave danger. The Army thus instructed Coulter to minimize all equipment removals from Korea during withdrawal.

Although it was still desirable to "button it lip as soon as practical," disengagement should not occur without providing the ROK with the ability to survive. Such action would not satisfy Rhee. Muccio reported from Seoul that the ROK Fresident intended to exert heavy pressure on the unitad Nations to request the united states to remain in military occupation of South Korea. 81.

Fen observers failed to perceive the signiticanco of what had transpired. Two governments now existed in Korea committed to the destruction of its rival. Soviet-American withdrawal was imminent and civil war seomed inevitable. Neithar side would tolerate compromise and conciliation, thus precluding negotiations. The Soviet and American clients wore committed from the outset to forcible imposition of their own political and economic system on the entira peninsula. Unfortunately for the united states, the superiority of the DPRK army meant that Amorican

80

Love tt ilemorandum, October 13, 1948, ERUS, 1.948 , Vol. VIII, 131.4-131.5; Truman approved Chans"s appointment based uxon Lovett's recommendation, Truman to Lovett, August 24, 1.948, Truman Papers, White Souse Central Files, Confidential, Box 35, Correspondence 1947-48, Folder 13, FSTL. 81.

Holge to Coulter, September 1\%, 1.948, RG 319, P\&) 091 Korea, Section $V$, Case 65 , 30x 88, NA; Mucc io to Marshall, November 9, 1.948, PRIS, 1.948, Vol, VIII, 1.323. 
withdrawal would be fatal to South Korea. The Soviet puppet, a nime article observed, was like "a cat smiling at a canary." The New York Times insisted that the United States could not disengage until the new government had developed adequate means for self-defense. 82

Events inside South Korea went from bad to worse during the fall of 1.948. On the night of October 1.9, a small group of Communists, who had infiltrated the Constabulary army, stagod an uprising in Cholla Namdo, a province in the southern-most portion of Korea. Approximately two hundred soldiers joined the rebellion in protest over alleged officer abuse. Foasants and workers responded favorably to the uprising because of dissatisfaction with economic deterioration and police corruption. The force quickly swelled to throe thousand and proceeded to seize control in the town of Yosu, setting up "poople's courts" to try and execute policemen, army officers, and government officials.

The Yosu Robelizion soon sproad to Suchon, as rebels seized ammunition conters and burnod police stations. Nanyr

82

Yoo, The Korean Var and tho Unitod Nations, 22;

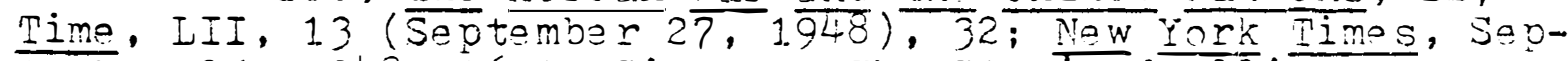
tember 25, 1.948, 1.6:1.; Simmons, The Strained Ali iance. New York Times, October 21, 1.948, 1.6; nuccio to Marshal1, October $28,1.948$, ERUS, 1948, Vol. VIII, 1.31.7131.8; 0'Byrne Nemorandum, November 15, 1948, RG 319, P\&0 091 Korea, Section $v$, Case 65 , Box 83, NÁ. 
Koreans joined the insurgency in anticipation of an imminent North Korean invasion. The rebels released all political prisoners and punished anyono suspocted of supporting the Rhee regine. They raised the North Korean flag in Suchon and pledged support for the DPKK. The Communists thus obtained control over a sizable portion of Soutin Korea, seizing a number of banks, schools, and food distribution centers. American officials in secul feared that civil war 84 had entered its first phase.

Coulter was determined to remain uninvolved in the Yosu rebellion. The Provisional KMAG acted quickly, howevor, to mobilize loyal Constabulary forces and move against the insurgent strongiolds. Terrain conditions, and the fact that robels woro American uniforms and used Amorican aguipment, made the Constabulary's task oxtromely difficult. On october 2?, govornment forces began to countor-attack and an incrodible sloodbath ensued. House-to-house fighting in Yosu spared few individuals and the RoK army's rotaliation against the rebels was marcilass. Government forcos a ither beat to death or axecuted anyone even suspectod of sympathy towaro the insurgonts. The Constabulary succossfully queliod the revolt and gained valuable experience in conducting anti-guerilla operations.

$$
85
$$

34

Now York Timas, Octobor 25, 1948, 1.2:2; Iifo, XXY, 20 (Novembar $15,1.948$ ), $55-58 ; 0 \cdot 3 y r n e$ inemorandum. 85

1.9 (Novambor Lork Mimas, Octobor 27, 1.948, 26:3; Timo, III, 
The Yosu Rebeliton shocked the Truman Administration, since 3 considerable portion of the general public reacted favorably to the uprising. Nost of the rioters were not Communist sympathizers, but responded to agitative speeches focusing attention on legitimate popular grievances. Nore important, the incident revealed the ease with which the Communists could infiltrate the Constabulary and exploit dissatisfaction. Although loyal Korean military units operated well, it was clear that it would be some time before complete law and order prevailed. Muccio noted the nature of the crisis confronting the newborn regime:

If the government and nation arose to the occasion, the Rebeliion would become the spark which drew all but the Communist elements in the nation together. . . . If, on the other hand, no firm stand were taken for reform, if efforts a.t change were virtually branded "treason", if a new spirit of patriotism were not infused into the people, the situation could rapidly deteriorate into mass lucertainty, discontent and anarciny.

Most knowledgable observers perceived that the Rhee government was at an early crossroads. Only political unity and moaningful roforms could increase povular confidence in the ROK and combat propaganda from the north.

North Korea's obvious ability to exploit such disturbances as the Yosu Rebellion increased the possibility of November, New york mimes, october 25 , 1.948, 12:2; Early in The Korean Knot, 86.

Muccio to Marshall, November 16,1948 , TQ 59 , $895.00 / 11-1.643$, NA. 
an invasion. As muccio explained, it was "more than probable that if the internal South Korean situation worsens to the extent Iikely under continuous NorthKorean-inspired disturbances, the North Korear army would intervene under the banner of restoring order and aiding 'democratic' elements of the population." Rhee recognized the possibility of such an occurrence and immodiately instituted a policy designed to eliminate $a l l$ political opposition to his regime. In cooperation with American advisors, the government purgod the Constabulary of all suspected leftists.

Far more important, the Assembly passed the viational Security Act which in essence established martial law in South Korea. The ROK dismissed school teachers and government administrators suspected of disloyalty, while it, censorad newspapers and imprisoned dissident editors. Thus, the Yosu Rebelizon sericusly weakened popular confidence in the young and inexperience regime. In an atmosphere of suspicion, insecurity, and fear, it would with difficulty achieve poitical stability. The ROK's future was in serious doubt. 89

Khee's probloms increased the pressure on Mruman to expand American support for South Korea. In the absence of

\footnotetext{
83

Muccio to Marshall, Novemben. 4, 19,4, PG 59, $895.00 / 1.1-448, N A$. 89

rienoerson, Politias of the inrtex, is2-1.54; U.S.

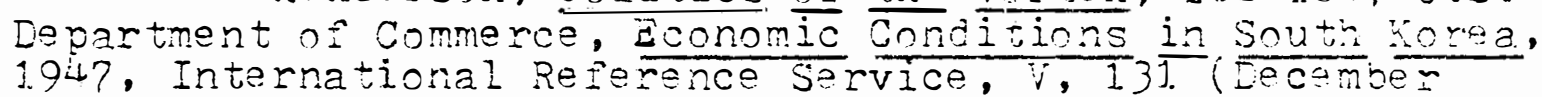

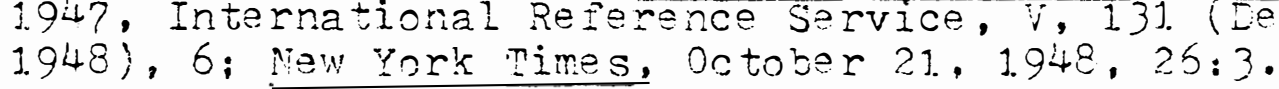


large-scale economic and military assistance. few individuale believed that the ROK could withstand Communist internal and external challenges. Both Muccio and Coulter now began to have second thoughts about the logic of American assistance to the Rhee regime. Rhee's inability to manifest any administrative skill or governmental competence produced fears that the RoK would squander American aid ofter withdrawal. 90 that the ROK would squander American aid after withdrawal. Early in November, Wuccio Iinally concluded that only continued American military protection could forestall the ROK's demise. The domestic situation was "grave" and he predictos a northern invasion in the spring of 1.949. The United States had to remain in occupation to provide South Korea with a "period of grace" for the development of economic rehabilitation and political stability. 91 Coulter was uncertain regarding the wisdom of delayed withdrawal. He stressed the possibility of an invasion even if the United States did not disengage and

should it occur. . US troop involvement would have international repurcussions. Presence of US troops would have a stabilizing effect. However, a token force could be overrun with consequent loss of face here and throughout the world. Retention of US troops in Korea beyond present schedule must be weighed as to its effect on the overall policy of the US Government. Therefore, decision must be made by higher authority in light of

Muccio to Marshall, october 26, 1.948, RG 59, 895.01./1.0-2648, NA; Sawyer and Hermes, in Korea, $40-41$. 91. Muccio to narshall, November 12,1948 , ERUS, 1.948, VoI. VIII, 1325-1327. 
all factors.

Truman thus faced an extremely difficult problem. The necessity for withdrawal was obvious, but the slibsequent collapse of the South Korean government after America's departure seemed unacceptable.

Communist successes in China added another element to the forces impelling the United states to delay withdrawal. The Nationalist Chinese never ceased warning the Koreans that the United States was preparing to abandon the ROK to the Soviet Union. 93 Rhee thus addressed a letter to Truman appealing for the continuation of American occupation until the constabuiary achieved enough strength for self-defense. In addition, an unequivocal statement of America's commitment to defend South Korea would reassure Koreans and prevent the loss of hope. Rhee also wrote to MacArthur pleading for tanks, patrol boats, combat aircraft, ard machine guns to assist, South Korea in its fight, against Communism. Rhee insisted that "the mere appearance of their existence at our disposal will give the people assurance of their security." Representatives in the Assembly now joined Rhee in

\footnotetext{
92

Coulter to JCS, November 1., 1.948, RG 21.8, CCS 383.21 Korea $(3-1.9-45)$, section 1.8 , NA. 93

Jacobs to 3ond, Detober 22 and 27,1948 , PG 59 , 501.3B/1.0-2748, NA; New York Times, Novemoer $1.0,1.948,1.5: 2$; Jacobs to farshal I, October $1.8,1948, \operatorname{Rg} 59,501.35 / 1.0-1.843$, NA . gis Muccio to Narshall, November 19, 1948, FRjS, 1.948, Vol. VIII, $1331-1.332$; Rhe to Nacerthur, November 29,1948 , viactrthur Papers, 3ox 8, Correspondence, VIP Pile, Din.
} 
requesting that the united States delay withdrawal. The legislature voted overwhelmingly to appeal for continued American military occupation of the peninsula. Lee Bum-suk strongly criticized the Unitod Statos for stripping its forces down to an unacceotable level in order to permit withdrawal at a moment's notice. Thus, the South koreans wero able to unite in demands for American military protection. They stressed that the united states should not permit a repetition of its China policy that acquiosed in the face of Soviet expansionism.

Saltzman completed preliminary work on the state Department aid proposal for Korea on Septomber 7, 1948. The program focused attention on the necessity for a multiyear plan to develop economic stability and self-sufficient growth, rather than continued reliance on annual relief appropriations. The aid program would begin early in 1949 and envisioned one hundred eighty million dollars in economic assistance for fiscal 1950. Saltzman stressed that NSC-8 respected the need to prevent the fall of Korea to the Soviet Union, if it entailed a serious loss to American prestige. Hoffman supported Saltzman's proposal, arguing that implementation would permit American withdrawal and

\footnotetext{
Novemier $24,1.48, \frac{\text { Nork }}{3: 5 .}$, November $21,1943,30: 1$. and
} 
at the same time eliminate the wasteful expenditure on relief rather than self-sufficiency

Draper clearly favored the program, sirce it indicated the State Department's apparent willingness to deal directly with the Korean issue. Yet, he was dubious over Congressional willingness to accept such a program. Ever Lovett considered the plan "too rich for my blood at the moment." Se feared that Korean aid and other such programs would place an excessive strain on the American economy. Or the other hand, Lovett recognizod that the united states could not abandon Koraa and therefore approved the Saltzman program. Fe pledged full support to Hoffman and the two leaders agreed to copperate in the formulation of a congressional proposal omphasizing the political justification for Korean aid. The program also provided for flexibility and periodic review, reserving the American right to terminate assistance at any time.

Truman clearly belioved that despite the formation of a rival Communist regime in north Korea the United States could successfully achieve its policy objectives in that area. America's Korea policy would require only a limited profram of economic assistance and not the application of

\footnotetext{
96

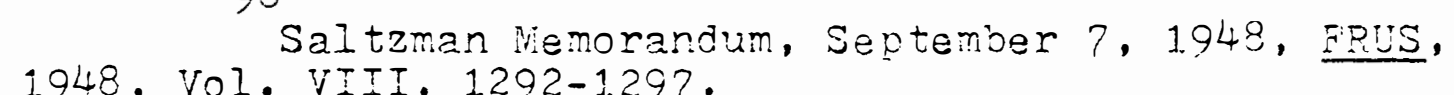
1948, Vol. VIII, 1292-1.29?.

Hoffman to Lovett, ootober 1., 1.948 and Lovett to Hoffman. September 1.?, 1948, FRTis, 1.948, Vol. VIII, 1.304-
} 1305 and $131.2-131.3$. 
military power. Truman's approach was the reflection of the President's persistent vision of a limited American role in postwar international affairs. Despite the Berlin Crisis, he concluded during the fall of 1.948 that the international situation did not preclude a further reduction in the size of the armed forces and the defense budget. Despite strong objections from Forrestal, Truman and Marshall both insisted that the United States should concentrate its efforts on financial aid and arms for Europe.

On December 9, 1.948, Truman and his advisors decided to cut the defense budget for fiscal 1.950 and also reduce the ceiling on military expenditures for the following year. Truman made this decision despite warnings from the jCS that such Iimitations would preclude the oreservation of American national security. 99 Thus, after 1947 , the trend toward decreased military commitments was clear and unmistakable. Truman's attitude toward defense spending corresponded perfectly with nis expectations regarding the oromise of containment. Through the application of economic and financial assistance, rather than American military power,

Millis (ec.), The Forrestal Diaries, 497-498 and 508-51.2; Schiling, "The Politics of National Defense," in Strateg., Politics, and Defense Budgets, 191-193; Cocriran, Frumar and the Crisis Presidencv, 286-28?; Fancock, "The

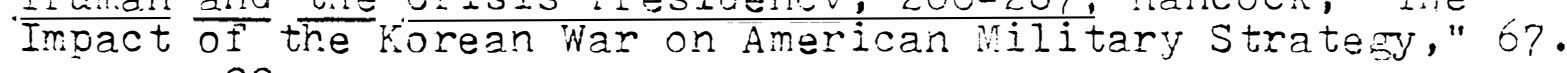
99

Vandenberg to Forrestal, October 7, 1948, Vandenbers Papers, Subject Bile, Box 4i, I,CC; Ieahy Diary Entry, November 4, 1.948, Leahy Papers, Diaries 1948-1.950, $30 x 6$, LOC; Schilling, "The Politics of National Defense," 6́2-63; Milis (ed.), The Eorrestal Diaries, 535. 
the United States could help other nations to develop the internal strength necessary for self-jefense. It was not until the Korean War shattered the logic and assumptions of containment that Truman established a powerful American military capability and deployed it on a global basis.

Truman had every intention to reduce the American military commitment in Korea. Unfortunately, in the wake of the Yosu Rebelizion, iviuccio's recommendations and Korean appeals forced the Administration to delay. ilarshall. Lovett, and Saltzman all voiced opposition in November, 1.948, to fixing a specific date for the completion of withdrawal. In addition, they aroued that the absence of United Nations action meant that the January 1.5 deadine was unrealistic. ${ }^{1.01}$ Lovett and Marshall urged postponement because complete disengagement at that time would be premature and prejudicial to American security interests. Thus, Washington ordered MacArthur to halt disengagement and maintain one regimental comoat team of seventy-iive hundred men in Korea until the United Nations recommended withdrawal.

Wuccio and Coulter were then able to reassure Rine that the United States did not intend to abandon the RoK.

\footnotetext{
1.00 1.01

Millis (ed.), The Forrestal Diaries, 538.

Saltzman to Wedemeyer, November $4,1.948, R G 59$, $5013 B / 1.1-448$, NA. 102

Lovett to Marshall, November 5, 1.948, and Saltzman to Wedemeyer, November 9, 1.948. FRUS, 1.948, Vol. VIII, 131.9 and 1.324 ; rCS to viacarthur, November $1.5,1.948,2 G 21.8$, CCS 383.21. Korea $(3-19-45)$, Section 1.8, M.
} 
On November 1.7, Muccio pubiicly announced that the Unitad States would not leave Korea until the United Nations assumed responsibility for the future welfare of South Korea. Under no circumstances, the American Ambassacior emphasized, would the United States permit North Korea to conquer the ROK. 1.03 In his private cables, however, Muccio expressed Iittle optimism over the chances for South Korea's survival. Only internal economic stability and political unity would ensure a viable government. The RoK's chronic economic problems coupled with Rhee's aictatorial tactics preverted the development of these necessary ingredients. Thus, American military power alone could prevent an eventual Communist victory.

Coulter added credence to Muccio's conclusions, arguing that only popular support would guarantee the success of the ROK. The United States had nrovided sufficient military aid and advice for South Korea to withstand a northern invasion, but only the Koreans themselves could develop the will to fight for their own freedom. Coulter believed Rhee was responsible for an atmosphere of nervousness and a lack of self-confidence that hampered self-defense. Both he and Muccio hoped that the delay in withdrawal would provide enough additional time for South Korea to develop the

1.03

Muccio to Marshall, November $1.8,1948$, RG 59 , 740.00119 (Control Korea)/1.1.-1.848, NA. 104 iTuccio to Narshall, November $19,1.948, \operatorname{RG} 59$, $895.00 / 11 .-1.948$, NA. 
internal strength requisite for survival. 1.05

In the meantime, the Administration completed work on the economic assistance agreement. Significantly, both the Army and the ECA focused attention on limiting the scope and nature of the commitment to aid Korea. Military leaders, for example, opposed a categorical statement that aid to Korea was vital to American national interests. Such a justification would have serious "psychological implications" on the Koreans and might decrease self-reliance because:

An oriental mind would literally interpret and readily misconstrue this statement as an unconditional guarantee of continued full support. Future circumstances may not warrant such a construction. It would be difficult then to repudiate. 106

State Department officials were also tepid in their appraisal of the extent of success that the United States could anticipate from economic assistance. Rusk doubted whether American aid would produce political independence, basic aivil liberties, economic self-sufficiency, and a stable finarcial structure. He emphasized that, since the United States was "using economic assistance as a political prop, . . we should have language that will enable us to play by ear without embarrassment." 1.07

\footnotetext{
1.05

Coulter to JCS, November $1.2,1.948$, PG 218 , CCS 353.21. Korea $(3-1.9-45)$, Section 1.8. NA. 1.06

MacNamara Nemorandum, November 8, 1948, RG 31.9,

P\&O 091. Korea, Section $V$, Case 65, 30x 88, MA. 1. 07

Eichholz to Claxton, November 1.5, 1.948, RG 59, FW 395.50 Recovery/1.1-1548, NA.
} 
Despite such hesitancy, the united states negotiated an economic aid agreement with South Korea on December 1.1, 1.948. In all probability, Truman believed that an indication of continued American support would reassure the United Nations and silence charges of abandonment. That same month, Paul Hoffman and the ICA mission arrived in Yorea to determine the extent of Korea's needs. Press reports indicated that the United States would seek Congressional approval for three hundred million dollars over a three year period. Interestingly enough, Hoffman suggested publicly that more aid would be avalable in the event of reunification. Thus, the Administration olearly anticipated that the promise of economic berefits in the soutn would stimulate popular demands in the north to join the RoK and end the partition. Ioffman expressed confidence that Congress would avorove the Korean aid bill.

American aid to Korea was ostensibly a response to Rhee"s request for ecoromic assistance. The Korean-American zereement provided that mruman would determine the amount of such aid and appoint a representative to advise roreans on how to maximize the Dositive impact of American assistance on the Korean economy. In return, Rhee agread to achieve a balanced bidget, a stable currency, a favorable balance of trade, and maximum productivity. He would also remove all

1.08

14. New York Times, Decenoer 1.1. 1943, 1:4, December 
public and private barriers to trade. The United States would enjoy "most favored nation" status and priority in the allocation of raw materials. In the event of any abuses, the United States reserved the right to terminate aid to Korea without notice. Thus, Truman followed closely the recommendations of his advisors and tied the promise of aid to Korean performance. 1.09

\section{VIII}

At the United Nations, the American delegation endeavored to mobilize international support for recognition of the ROK as the government envisaged in the November 1.4 resolution. The American proposal provided for SovietAmerican withdrawal and reunification under the authority of the Rhee regime. It also insisted upon the complete support of the United Nations for the southern regime as the only legitimate government in Korea. Britain quickly informad the United States that it could not support the American proposal. London opposed recognition of either North or South Korea as a national government and favored only the acceptance of the UNMCOK's report without any further action. Such an approach would at least result in United Nations support for the RoK as the legal government

1.09

U.S. Department of State, "Economic Cooperation with Korea Under Public Law 793-80th, "Treaties and Other International Acts Series, No. 1.908 (Washington, D.C.: Government Printing (office, 1949). 
south of the 38 th paraliel and non-recognition of the Sovietsponsored regime in the north. Canada supported the British proposal. Yet, Patterson expressed the hope that qualified support for the ROK would not preclude continued American assistance to the Rhee government.

America's final position paper on Korea, however, stocd firmly behind the ROK as the only legitimate government in the peninsula. The United States insisted that the ROK representatives were eligible for participation in the United Nations debate. The proposal also favored rapid Soviet-American withdrawal, but only after the united Nations verified the dissolution of all non-ROK military and administrative organizations in the peninsula. It provided for a new United Ilations Commission on Korea (UNCOK) to supervise the incopporation of north Korea into the Republic of Korea and to report on the progress of reunification to the General Assembly. The UNCOK would not include Canada, Syria, or hopefully India, since each of these nations had indicated disinterest in Korea's future. Finally, the United States intended to express support for the UNTCOK'S recommendations and not oppose the appearance of representatives from the DPRK.

\section{0}

Rusk to Iovett, September $10,1.948,31$ iss to Marsha11, Septemier 1.1., 1948, and Bond Nemorandum, September 1 1! 1948 , RRUS, 1948, Vol. VIII, 1.300-1.302. 1.1.1.

Jacoos to Bond, October 1.8, 1943 , PG 59, 501.39, 1.0-1.848, Na; U.S. United Nations Position Paper, Óctóder 22, 1.948 and Butterworth to Lovett, November 5, 1.948, ERUS, 
On October 30, the United Nations Folitical and Security Committee began to consicer the UNTCOK report. The Commission's firdings stressed that, in the absence of a negotiated settlement, a civil war and forcible reunification would follow Soviet-American withdrawal. While the UNTCOK noted American cooperation and Soviet obdurance, it indicated that both nations and the prevailing atmosphere of international tension had produced the Korear impasse, Cnly reunification wolid ensure Koraan political, social, and economic progress, but the Commission offered no plan for achieving this result. The United Nations row faced a serious dilemma. An attempt to fulfill its moral obligation to the RoK would probably increase Soviet-American tensions, lead to involvement in a civil war, and not contribute to the peaceful reunification of the Korean peninsula.

While the United liations Committee studied the UMrouk report, both the ROK and the DPRK applied for membership in the international orfanization as the legitimate revresentative of all Korea. 11.3 In conjunction with Australia and China, the United States formulated a resolution recognizins the Rhee government as the legal representative of Korea. The new Commission would also observe the growth of democracy

1.948, VoI, VIII, 1.31.5-131.6 and 131.9 . 1.12

"Korea; Commission's Report," DSS, XIX, 488 (November?, 1.948$), 576$. 1.1. 3 New York Times, November 13, 1.943, 6:6. 
421

in a reunified Korea and provide a vehicle for consultation. Within ninety days after the approval of the resolution, the UNCOK would observe and verify Soviet-American withdrawal 114

from Korea. To obtain Australian support, the Truman

Administration abandoned its claim that the RoK was the

national government of Korea. The United States also agreed

to support the findings of the UNTCOK, although Truman was

hardly satisfied with the Commission's attemot at

impartiality.

Ultimately, the United Nations Committee rewarded the American policy of patience and diplomacy when it voted unanimously to reject the Soviet proposal to invite the DPRK to participate in debate. Some American commentators did not aporeciate the extent of the American success and

demanded United Nations recognition of the national character of the Rhee government. 116 The American delegation realized, however, that any United Nations support for the Rhee regime would be of considerable valide. If the United States adopted an extreme position and held to it intransigeantly, 3. Sizable number of nations would react unfavorably and place even minimal progress for American aims in jeopardy. Even Rhee understood that partial United Nations supoort

1.14

Varshall to Lovett, November $1.6,1948$, ERUS, 1948, Vol. VIII, $1.327-1328$

11.5

Viarshall to Iovett, Novembe: $1.5,1948$, FRUS, 1.948 , Vol. VIII, 1.329-1.330. 116

New York Times, November $30,1948,25: 2$. 
was preferable to impartiality. Further delay at Lake Success only benefited the DPRK plan for subversion and seizure of power. Rapid action was preferable tc a dilatory approach even if the support was qualified and ambiguous.

On December 6, 1948, the United Nations Committee voted to support the ROK as the only legal government in Korea and reject the DPRK's claim to legitimacy. At the same time, it decided not to recognize the national character of the Rhee regime, since it only controlled half of the peninsula. Each nation would have to decide individually the nature and extent of its policy on recognition. The Committee then amenced the American proposal to provide for withdrawal "as soon as pracicicable" of foreign troops from Korea after the General Assembly approved the resolution.

John Foster Dulles delivered a strong speech on December 7 appealing for United Nations approval of the resolu-. tion and arguing that it would be "unthinkable that the United Nations should in any way disown the consequences of its own creative program." He stressed that the prestige of the United Nations was at stake in Korea and only the moral solidarity of the peaceful nations could ensure the viability of the international organization. If the unitad Nations continued its involvement in korean affairs, the

1.1.?

Dulles to Narshall, December $6,1.948$, FRUS, 1948, Vol. VIII, 1.335 .

118

New York Iimes, Decemiver 6, 1948, $2: 2$. 
strategy of violence and subversion would fail and peaceful reunification would occur. 119

Again, American diplomatic pressure was effective. The United Nations Committee voted approval for the American resolution with only six nations in opposition and two abstentions. The approval of the General Assembly quickiy followed on December 1.2, despite the strong opposition of the Soviet Union. The United Nations thus overwhelmingly rejected Moscow's proposal to disband the Comission on Korea and passed instead the American-Australian-Chinese prooosal. The vast majority of the United liations members thereby recognized a moral obligation to South Korea and considered inaction to be an unpalatable demonstration of 120

impotence and insensitivity.

Dulles immediately expressed his pleasure over the action of the General Assembly. The United Nations, he explained, had thus rejected the northern strategy of intimidation in favor of reliance on the pok and peaceful negotiations. The new Commission on Korea would be smaller than its predecessor, excluding both Canada and the Ukraine. It wolld arrive in Korea within thirty days and begin to cooperate with Solith Korea. for the achievement of peaceful

11.9

Dulles Address, December ?, 1948, DSE, XIX, 404 (December 1.9, 1.048), 758-760; New York Times. Decerber 9, 1948, 22:3. 120

Lulies to Narshall, December 9, 1948, FPus, 1.943, Vol. VIII, 1.336; Niw York Times, December 8, $1.948,30: 2$, 
reunification. The United states noped that the UNCoK would be able to foster the realization of an equitable and democratic solution. With an end to the unnatural division of the perinsula, the maintenance of two large, costly and dangerous military establishments across the parallel would no longer be necessary.

American observers were jubilant over the United Nations decision to support the Republic of Korea. As a result of the action, the United States could shift responsibility for Korea's security to the United Nations and withdraw its troops from the peninsula with complete international suppori. At the same time Truman could embark upon a pian for economic rehabilitation and military strength in South Korea and thus enable the infant regime to survive. For Dulles, the international acceptance of the American strategy possessed far wider significance:

Overwhelming Assembly vote on rorea starts Solith Korea off with as much political and moral backing as can be mobilized through UN. Apart from horea, believe Korean case in Assembly nas contributed to more friendly relations between Far Eastern peoples and the US.1.23

Clearly, the event constituted an American diplomatic victory

1.21

"U.N. Pecognizes Reoublic of Korea," DSB, XIX, 493 (December 12,1948$), 728 ;$ Dulles to ivarsinall, December $12,1.948$, ERUS, 1948, Vol. VIII, 1.336; State Department,

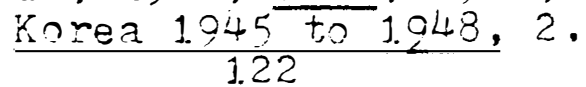

Vepartment of State, The Pecord on Korean Unifi-

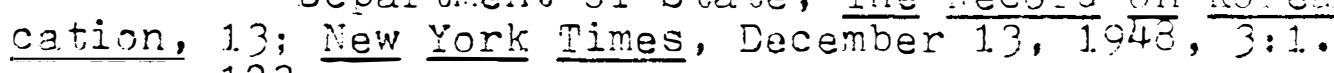
1.23

Dulles to Narshall, December 13, 1.948, RG 59, 501.23/1.2-1.348, NA. 
over the Soviet Union in the Cold War. The international community judged the American client as legitimate, wrile dismissing North Korea as a Soviet puppet. ${ }^{1.24}$ Success in Korea mignt even initiate a series of similar advances elsewhere in Asia and thereby prove containment's value as a Iiberating force.

America's success in obtaining United Nations support for the Rhee regime obviously displeased the Soviet Union. Stalin had, however, prepared for such an eventuality. The Soviets now instituted a campaign stressing the significance of their departure from Korea before the end of 1948. Both Pravda and Izvestia emphasized that the United States also had to end military occupation of Korea or reunification would be impossible. Reports from Pyongyang indicated that the Red Army was rapidly transferring its arms and housing facilities to the DPRK army in preparation for departure. Thus, Moscow could focus on the independence and strength. of North Korea in contrast to a South Korea requiring American military protection for its very existence.

IX

Truman formally recognized the Republic of Korea on

1.24

1.25 New York Times, December 1.0, 1948, 24:2. Berger, The Korean Knot, 84 and 88-89; Wuccio to inarsha11, December $1.3,1.948, \frac{.0 G}{3} 59,740.0011 .9$ (Control Korea) $/ 1.2-1.248$, NA. 
January 1, 1.949, as the legitimate government of all Korea. While pledging complete support for the activities of the UNCYK, the President declared that the United States would not withdraw from South Korea until Rhee possessed enough strengtin for self-defense. 1.26 avents in the united states and at the United Nations obviously pleased Rhee. Nevertheless, Chough Pyong-ok expressed concern to Butterworth and Bond that Communist successes in China would leave the RoK surrounded. In responding to Chough, 3utterworth emphasized that South Korea had to develop internal unity and pursue a dynamic policy of progressive reform, thus achieving strong popular support. Chough countered that the implementation of such an eniightened program was difficult when a nation was fighting for its very existence. Butterworth insisted that popular needs and desires had to come first or the ROK would find itself in the same predicament as Nationalist 1.27

China. Thus, the State Department conveyed to Korea in clear and unmistakable terms that popular support, not military power, was the key to developing internal strength and the ability to resist Communism.

Communist successes in China had a decisive impact on American attitudes toward Korea zt the outset of 1.949. As

\subsection{6}

Press Pelease, January 1, 1949, DSB, XX, 497 (January 9, 1949), 59-60; New York Times. January 2, 1.949, 1:?

\section{7}

Nemorandum of Conversation, January 5, 1.949, FRUS, 1949, Vol. VII: The Far East and Australasia, Fart II (iasinington, D.C.: Government Printing ()fice, 1975), 940-941. 
early as December, 1948, the State Department concluded that withdrawal from Korea was ill-advised, if the operation resulted in a Communist invasion of the POK. Such an event would greatly advance the Soviet arive to conquer Japan, "a target of prime importance to world communism." To abandon Korea would not only undermine the security of japan, but destroy the confiderce and morale of all Asian nations. rihe Ambassador to China, J. Leighton Stuart, strassed that some decisive American action was imperative to counter the loss of prestige that the United States would suffer with the collapse of Chiang. Fe urged the Administration to seize the initiatire diplonatically and even militarily in Korea.

Predictably, the Army Department did not agree, since it was aware of the Iimitations on American capabilities. on November 8 , Royall rejected Narshall's request for a two-year supply of maintenance and replacement equicment. In vien of the budgetary limitations on the Department of the Army, Royall explained, oniy a new Congressional appropriations bill could sipply such equipment. 129 The Army was also unhappy over the postponement of withdrawal-now code-named "Twinborn." In the wake of United Nations action, the Army once again requested finzl authorization to execute the plan

Bishop to Sutterworth, December 1.7, 1.042, Fous, 1948, Vol. VIII, 1.33?-1.340; Stuart to varshall, Eecember2?, 1.948, FoUS, 1948, Vol. VII: The Far East: China (Vashington, 129

Guthrie Viemorandum, December 22,1948 , RG 319, P\&O 091. Korea. TS, Section I, Case 1. NA. 
for witndrawal at the earliest possible moment. Royail found consolation in the knowledge that Truman wolld announce the transfer of authority in Korea from the USAFIK to the ECA in January, 1.949, regardless of American disengagement. In Korea, plans progressed for development of a viable security force. On December 15, Rhee announced the creation of a new National Department of Defense to coordinate police, military, ano coast guard operations. 130

On December 2.2, Draper again approached the State Department, reminding it that NSC-8 required American withdrawal from Korea as early as practicable. Since the paninsula was not worth a major war, the USAFIK vould be a liability in the event of a major conflict. Even MacArthur, Eraper explained, had indicated that in the event of a major war the Soviet Union would destroy the USAFIK with ease. He recommended that Washington approve NacArthur's oroposal to withdraw no laten than March 31., 1.949.

MacArthur now added his voice to those activeiy urging American disengagement from Korea. Fe inFormed Washington that although he would order a delay in withdrawal in accordance with instructions he did not consider it a requirement of his assigned mission "to secure or to make

Lawson Nemorandum. December 2, 1948, PG 319 , P\&O 091. Korea, Section IV, Cases 50-65, Box 8?, NA; Sawyer and Termes, Military Advisors in Korea, lit. 1. 31 .

Draper to Saltzman, Eecember 22, 1.948, Fous, 1.948, Vol. VIII, 3.341.-1.343; Zierath Nemorandum, January o, 1949 , RG 31.9, P\&0 091. Korea TS, Section $\forall$, Case 31., Box 22, NA. 
plans to secure Southern Korea." MacArthur's attitude disturbed Butterworth, who expressed concern to the Army Department that premature withdrawal from Korea would have a disastrous effect on the morale of the Japanese. He urged a redefinition of American objectives in Korea under NSC-8. The Administration thus decided to request MacArthur's comments on the broad military, political, and psychological aspects related to withdrawal. Truman's Korea policy was on the verge of a significant alteration.

On January 1.7, Lovett referred the Korean matter to the National Security Council for reconsideration. The State Department placed great stress on Vuccio's request for a delay in withdrawal of "several montin" to eliminate the certainty that invasion would follow American departure from Korea. OnIy continued American military presence would provide the "breathing space" necessary for Rhee to create political stability and economic rehabilitation. After Korea resolved its manifold problems, the United states could withdraw safely and without fear of a communist onnquest of the ROK. Rhee's request to delzy American military withdrawal permitted Nuccio to argue that the United States could justify its actions to the international community.

1.32

Butterworth to Lovett, January 10, 1049, EzUS, 1.949, Vol. VII, Part 2, 942-944; Army Department remorandum, January 1.0, 1.949, RG 31.9, P\&O 091. Korea IS, Section I, Cases 5-1.5. Box 1.62, NA. 1.33

Saltzman to Draper, January 25, 1.949, BRUS, 1.949 Vol. VII, Part 2, 944-945; Acheson did not even want to 
MacArthur's juagment played a crucial role in the Administration's reevaluation of its korea policy. Subsequently, commentators strongly criticized Truman for ignoring NacArthur's views and authorizing withdrawal. In reality, the Administration requested NacArthur's advice and delayed withdrawal in defiance of the General's recommendations. On January 19, MacArthur cabled Washington his view that the United States should withdraw from Korea no later than llay 10, 1949-the anniversary of the first Korean election. He emphasized that "in event of any serious threat to the security of Korea, strategic and military considerations will force abandonment of any pretence of active military support with consequent irreparable damage to Us prestige." Not only could the United States not protect South Korea, but it was unlikely that it could sufficiertly train and equip the ROK army to ensure the sovernment's survira?.

discuss withdrawal, but only the political and military aspects of formulating a new position on Korea, Acheson to Royall, January 25, 1949, Truman Fapers, Korean Nar Documents File, Box 1., Department of State, Background. HSTL. 1. 34

MacArthur testified in 1951. before the Senate Cormittees investigating his dismissal that Washington had decided upon withdrawal alone and he had not participated in the decision becalise he had no responsibility for that area. He stated that he did not even remember if he concurred in the decision. Clearly, racArthur was distorting the truth. WacArthur Testimony, Military Situation ir the Ear east, Vol. I, 3 ? and 243 . 1. 35

NacArthur to JCS, January $19,1949, \mathrm{R} g 319$, F\&O 091. Korea TS, Section V, Case 31, 30x 22, NA; Schnabel, Policy and Direction, 30; Truman, Years of Trial and inse, 
431.

By early 1.949, nacArthur had also concluded that Soviet control over the Asian mainland was inevitable. He trus favored establishing a defensive position on those islands circling the Asian continent. The United States should supply only "economic aid ard indirect military assistance" to those friendly governments on the mainland still resisting Soviet domination. The General made public his arguments early in march, 1949, during an interview with British journalist $G$. Ward Price. At that time, MacArthur made the following observation:

Now the Pacific has become an Anglo-Saxon lake and our Iine of defense runs through the chain of islands fringing the coast of Asia. It starts from the Philipoines and continues through the Ryrikyi Archipelago, which includes its main bastion, okinawa. Then it bends back through japan and the Aleutian Island chain to Alaska.

Despite the fall of China, MacArthur believed that Jaran was secure; but he apparentiy accepted the eventual loss of Korea as well. 1. 36

Diolomatio factors contributed to the military reasons in bolstering the argument for withdrawal. After all, the United Nations had recommended departure, and defiance of the resolution would undermine American international prestige. The United states could also expect rosoow to use American presence as a propazanda device to discredit the $20 K$ as a tool of American imperialism. On Eeaember 30 ,

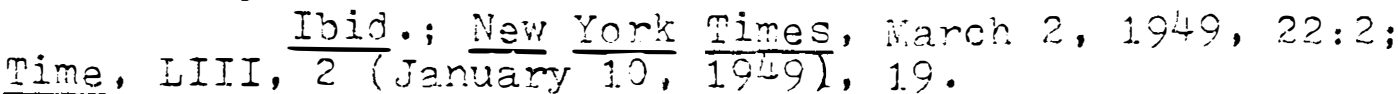


1943, the Soviets announced the completion of withdrawai and called upor the United states to comply with the Uaited Nations resolution as well. Noscow denounced continued American cccucation and plans for economic aid as tools of foreign subjugation and exploitation of Korea. If Truman authorized a delay in withdrawal, he risked a major propaganda victory for the Soviet union.

Truman and his advisors addressed attention to a reconsideration of America's Korea policy at the 36 th meeting of the National Security Council on March 22, 1949. After recapitulating events of the previous yean, the State Department reaporaisal emphasized the rew Korean goverrment's lack of sufficient military and economic strength to defend itself from the challenge of the soviet puppet resime in the north. It reasoned that Moscow sought complete domination over the entire peninsula in order to undermine the strategic and political position of the Inited states in China and Japan. If the United States withdrew abruptly, this "disengagement would be interpreted 35 a betrayal by the U.S. of its friends and allies in the Far gast and misnt contribute substantially to a fundamental realignment of forces in favor of the USSR throughout thet cart of the world." Such an event would also mean a Communist conquest of the ROK, which would destroy the prestien and insluence

$13 ?$

Nuccio to Acheson, January 6, 1949, 805.00/ 1-549, NA; Ncceoree Bundy (ed.), The Pattern of Resconsibility (Boston: Houghton Mifflin, $19 \overline{52}$, 28? 
of the United Nations and force smaller nations to seek an accommodation with the Soviets. 1.38

NSC-8/1. thus concluded that despite the aosence of guaranteed success American national interest demanded continued economic, technical, military, and diplomatic support for the Republic of Korea. Withdrawal wolid remain a basic objective, since the united Nations had called for the removal of all foreign troops. Both kacArthur and Muccio supported American withdrawal, if the United States met certain conditions. First, the United States had to train, equip, and supply a security force in Korea sufficiently powerful to act as a deterrent to attach and able to maintain internal order. Second, the ECA had to implement a three-year program of technical and economic aid for development. Third, the United Nations had to continue political support as 3 boost to Korean morale. Such a plan would not preclude the possibility of invasion, but further postponement of withdrawal would not diminish the risk of attack either. In fact, NSC-8/1 observed that further delay would "perpetuate the additioral rist that U.S. occupation forces remaining in Korea might be either destroyed or obliged to abanion Korea in the event of a major rostile attack, with serious damage to us prestice 1.39 1.38 Section $I-4$, Ni.

NSC-3/1, March 1.6, 1.949, RG 31.9, pzo 091. Korea, 1.39

Ioid.; Royall to Acheson, January 25, 1949, RG 319. P\&0 091 Korea TS, Box 1.63, NA; See also, U.S. Department 


$$
434
$$

Truman approved a revised form of NSC-8/1. on March 23. The United States thus adopted a policy of continued support for the creation of self-government througnout korea based upon freedom of choice. The Administration lindertook a more positive commitment to provide assistance for the emerzence of economic strength in three years and military security prior to withdrawal. The United States would supply enoligh. arms and equipment for a security force of over one hundred thousand men. The American Ambassador would possess central control over all activities in Korea and strive for cooperation with the UNCoK. The United States would withdraw its troops from Korea no later than June 30, 1949. America's departure would in no way imply any lessening of interest in the fate of Korea.

American military leaders were determined to effact withdrawal without delay. The modifications in NSC-8/1 reflected such an attitude. For example, the State Devartment favored withdrawal only after the inited states had consulted the UNCOK and the ROK and transferred alI necessary military equipment to the Constabulary army. In final form, however, Truman's plan provided for departure by June 30 regardless of any other contingency. In addition, the final

of State, The Fight Against Aggression in Korea, Far zastern Series \#3? (Washington, D.C.: Government Frinting Difice, Autumn 1.950$), 6$. 1.40

Part 2, 969-978. NSC-8/2, Marci 22, 1949, ERUS, 1.949, VoI. VII, 
plan set specific iimits on the size of the army $(55,000)$, coast guard $(4,000)$, and police $(35,000)$. The United States would equip these forces with light weapons alone. NSC-8/2 explicitly precluded the creation of a Korean navy. Quite obviously, the Army Department feared Rhee's potential for seeking forcible reunification and thereby instigating a casus belli. On April 2, 1949, Washington issued orders for the final withorawal of the USAFIK.

Truman's action regarding NSC- 8 represented a compromise between the conflicting views of his diplomatic and military advisors. The Army Eepartment strongly believed that witndrawal from Korea was imperative at the earliest possible date. Even MacArthur urged disengagement, arguing that such action would not undermine japan's security because "our only possible adversary on the Asiatic Continent does not possess an industrial base near enough to supply an amphibious attacking force." 1.42 Muccio, on the other hand, recognized that the ROK was too weak to survive without American protection. He strongly advocated occupation "through June 1.949 , by which time it expected Korean security forces will be sufficiently organized and trained to cope with internal subversion and any act of

\footnotetext{
NSC-8/2; Sawyer and Hermes, Military Advisors in Korea, 38; Waddocks to Chief of Staff, March ?, 1.949 and Maddocks to Secretary of Army, March 22, 1949, RG 319, PRo 091. Korea MS, Sections I-A and I-C, Book 1., Box 163, MA.

nuocio, oral History Interview Transcript, HSTL, 9-1.1. Niew York Times, Narch 2, 1949. 22:2.
} 
aggression from north exclusive of overt soviat or Manchurian $1 .+3$

involvement." Truman insisted in his memoirs that the United States had provided enough training and equioment to the Constabulary army to ensure self-defense and permit withdrawal. Wedemeyer later offered a more cogent explanation when he frankly observed that "it was just a question of not having enough bodies to go around."

American leaders in Washington and Seoul. were mildiy optimistic regarding South Korea's future during the first months of 1.949. The ROK army had operated successfully against Communist guerillas, while Rhee had dismissed two cabinet ministers particularly distasteful to the Assembly and the United States. American military aid and economic assistance could only foster further internal strength. Truman also considered success in korea of inoraased importance after the American fizilure in China. Perhaps more significant, mruman and his advisors hoped 3. strong Korea would "convince other wavering Asiatic nations that thare is more to be gained by embracing the ideologies of the pest than those of the East." 145 Thus, South Korea remained Truman's test case of containment in Asia.

\subsection{3}

Muccio to Acheson, January 27, 1949, ERUS, 1.949, Vol, VII, Fart 2, 94t7-952. 144

Truman, Years of Mrial and uove, 329; Miiitary Situation in the Far East, Vol. IV, $23 \hat{2} 5-2327$.

Hucc io to Acheson. January 1.0, 1949, Ro 59, 8?5.00/1-1.049, NA; Colliers, CXXVIII, 8 (February 19, 1.949), 20-21. 
Chapter VIII:

Prelude to Civil war 
Korea emerged in 1.949 as a microcosin of the SovietAmerican confrontation. Although the united States had fostered the realization of Korean self-government and obtained international support for the Ror, Truman and his advisors could not have been completely satisfied with the situation. Ko rea possessed all the ingredients necessary for a bloody civil war. Both North and South Korea were determined to achieve reunification at any orice and orly American and Soviet troops, neithar of whom desired a military confict, prevented the outbreak of hostilities. Soviet-Americar wi.thdrawal would eventually open the may to a costly strugrle for control. Unfortunate?y, for the United states, the IPPK was stronger and would certainly emerge victorious in any armed clash.

International support, American economic aid, and the successful defeat of the Yosu Rebellion all contributed to an increase of self-confidence in the Rhee government as 1.948 came to 3. close. Á series of ageressiva government statements during necembar were indicative of this nowly

Andre Fontaine, history of the Cold iar, Vol. II (New York: Fantheon 300ks, 1.969), ?4. 
emergent optimism. For example, Foreign Minister Chang Taik-sang announced on December 18 that the LPRK constituted "Iost territory" and the ROK intended to recover it at the earliest possible moment and at all costs. If the Communists prevented the people from fulfilling their desire for relirion Chang explained that South Korea would turn to military conquest to achieve reunification. Finally, the Rok would not tolerate any negotiations with the illegitimate communist regime in the north.

Both Wuccin and Coulter strongly opposed such statements as overly aggressive and unnecessarily provocative. The American Ambassador expressed his dissatisfaction to Rhe immediately, stressing that such pronouncements were illadvised and contrary to the American policy of peacesul reunification. Still, Chang was certainly expressing the views of the RoK Presicent. Rhee had requested a large number of combat planes and coast guard ships with maintenance supplies for six months. Coulter forwarded the plan. to Washington, but urged disaproval of the aircraft provision probably because of its primarily offensive military character. 3

Rhee quickly realized that agrressive statements would jeopardize all emerican aid to Korea and thus diminish the New York Times, December 19, 1.948, $1.2: 3$.

Folk Memorandum, December 24, 1.948, RG 319, Psio 092, Section X, Case 1.39, NA. 
the charces for eventual achievement of his objectives. He thus decided to dismiss $h$ is foreign minister in an effort to reassure the United States. Nevertheless, the incident had a profound and lasting impact on the Truman Administration. Under no circumstances would the United States provide the R!K with sufficient military power to stage an ofiensive into northern Korea. At the sane time Moscow proceeded to ensure that the DPRK maintained a position of military superiority. The event was then an early indication that, while the major powers were satisfied with half a loaf in Korea, the Koreans themselves were not.

Rhee and his cohorts now intensified their campaign to increase American military assistance to the ROK. During February, 1949, Royall and Nedemeyer visited Korea on a fact-finding mission, holding extensive discussions with Korean leaders. Prime Minister Lee Bum-suk stressed that, as the situation in China deteriorated, "Korea should be increasingly inportant as a stepping stone for offensive action." Fe therefore recommended strongly an increase in American miritary assistance to the ROK to overcome the temporary superiority of the DPRK. In response, viedemeyer recited the central theme of Truman's containmert colicy, emphasizing that "the greatest oontribution tinat the Koreans could make to the overall world situation would be

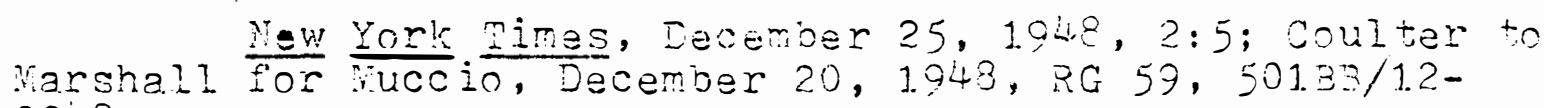
2048 . NA. 
to establish stability in their homeland, to develop a happy, industrious people; a strong government along democratic Iines." He stressed that Korea's highest priority was the creation of economic strengtr, not a large military establishment that "would make a. disproportionate drain on the country's economy."

Rhee refused to accept such arguments and expressed his intention to attemot forcible reunification at the earliest possible date. The ROK President informed Royall that he would favor withdrawal of American troops only if the United States enlarged the military advisory group and increased the amount of military assistance. Rhee insisted that "if North Korea were invaded by South Korea, a large proportion of the North Korean Army would desert, .." He concluded that Korea's principal difficulties were the proulct of vacillation in the state Department, which had already "played a strong part in the loss of china."

These comments convinced Royall that American withdrawal was imperative. Muccin disagreed, arguing that the United States could not disengage until it had convinced South Korea that it did not intend to abandon the infant regime. If the South Koreans felt secure and confident,

Army Department remorandum. February 3,1949 , RG 31.9, CSA 091 Korea TS, NA; New York Times, Eebruary 9 , $1.949,1.5: 2$.

6

Royali viemorandum, February $8,1.949$ and nuccio Nemorandum, February 25, 1949, FRUS, 1049, Vol. VII, Part 2, 955-959. 
441.

the RoK would achieve economic self-sufficiercy ard popular support. The Provisional KVAG Commander, Brigadier Genaral William I. Roberts, substantiated ruccio's analvsis. He insisted that the ROK warranted American supoort because its soldiers were loyal to the government and would fight to defend the nation.

Nuccio harbored mixed emotions regarding Rhee. While recognizing his wide popularity, the American Amoassador observed that Rhee possessed limited administrative talent. Perhaps worse, the old patriot was aristocratic anc "very obstinate." Rhee's main concern was to ensure his cwn colitical survival and to discredit anyone who threatened his authority. During January, 1.949, Rhee bagan a campaign to foster political unity under his comolete control. The Rok President appealed to the National youth rovement and Kim Sung-sco's Democratic Party to forsake their independent existance and join his party. Such political pressure disturbed Nuccio, who observed that "the Fresident has intimated that the unification of non-Communist xolitical vanties which he has beer urging is only to be desired if the ret result is a coalition supoorting him as president."

Ibid.; Muccio wrongly recollects that Royali and Wedemeyer visited Korea late in 1.948. Oral History Interview Transcript, HSTI, 9-1.2; Truman, Years of Trial and Yove. 329; Army Department Memorandum, February $8,1.949, \frac{2 G}{R G}$, CSA 091 Korea TS, NA. 8

Muccio, Oral History Interview Transcript, FSTI, 11.-1.4; Now York Dimes, December 23, 1948, 1.1.2; Nuccio to Acheson, January 24, 1.949, RG 59, 895.01/1.-2449, NA. 
A powerful opposition party now emergad to challense Rhee. Emoassy Chargie تverett F. Drumright referred to the faction as the "Young Group" and stressed the extreme nationalism of its leaders. It demanded American withdrawal because of its strong hostility toward foreign domination. The "Young Group" also opposed the ECA program, the KoreanAmerican Financial and Property Settlement, ard Rhee's desire to give the United States the Banto Hotel for its embassy. Ultimately, the faction expected to acnieve reunification peacefully . Drumright viewed these leaders as extremely unrealistic, being

inclined to apportion blame equally upon friend and enemy. $\cdot$. While strongly non-Communist themselves, they do not clearly recognize the nature of Sovietism. They ascribe to it decent, self-sacrificing intentions of furthering democracy and true independence. They do not know the real facts of life concerning Soviet satellite states the world over, and the impossibility of compromise with the Soviets, without complete loss of independence, democracy, and, perhaps, life itself.

Irumrient expressed hope that eventually these critics of American policy would recognize the magnitude of the Soviet threat and agree to cooperate with Phee.

American diplomatic representatives in seoul attempted to foster korean political unity and support for khee. Iice Consuls David Fark and Gregory Zenderson conferred with the leaders of the "Young Group" and stressed Soviet refusal to

Srumricht to Acheson, Pebuary 1.1., 1.949, 9059, 740.00110 (Control Korea)/2-1.140, NA. 
permit democracy in the north. quite logically, the horean Assemblymen then observed that if a negotiated reunification was impossible, then civil war was inevitable. In response, ifark and Fenderson indicated that the ultimate objective of containment in Korea was Iiberation:

Korea was a minature of the world. As Korea was split, so was the world. However, it was not certain at all that war between Russia and America was the inevitable outcome of this. Vany Americans felt that after a number of years of tension, the Soviet Union might come to its senses, compromise, and change toward peaceful paths. That was the hope on which American foreign Dolicy was based.

Mark and Henderson agreed with the "young Group" that Korea was an area of tension, but insisted that oivil war was not unavoidable. When Moscow abandoned its attitide of obdurance, Korean reunification would occur.

\section{0}

\section{II}

American leaders were still interested in maintaining international support for the Republic of Korea. The Urouk chairman Egon Pantshofen-wertheimer was dubious regarding the wisdom of continued United Nations action in Korea in view of Soviet intransigeance. nuccio immediately exerted pressire on the Commission to support American policy and assist the ROK. He stressed that the mere presence of the UNCok bolstered the morale of the Rhee regima, while

\footnotetext{
Ibid., inclosures.
} 
444

11.

detering a DPRK attack. Evidently, Wuccio's actions were effective, since the UnCoK on February 1.2 recognized the legitimacy of the ROK and declared its commitment to promote Korean reunification.

Rhee made it quite clear, however, that he would not tolerate international scrutiny of or interference in south Korea's domestic political affairs. The UNCOK was to provide moral and diplomatic support for the ROK and investigate the undemocratic nature of the DPRK, but ignore criticism of Rhee and evidence of political repression in the south. Thus, antioathy between the ROK and the UNCOK emerged almost immediately. In February, 1.949, Rhee announced his complete opposition to any UNCnK attempt to contact the northern regime. Such action, he argued, would constitute tacit recognition of the communists and an affront to the $R(K$. The UNCOK was obviously in a quandry, since Moscow had made it clear that the DPRK was in control of its own affairs. The Commission decided nevertheless to accept Rhee's interpretation and address an appeal for cooperation directly to

11.

Muccio to Acheson, February 9, 1.949, RG 59, 501.35! 2-949, NA; Nemorandum of Conversation, February 7, 1.949, FRUS, 1949, Vol. VII, Part 2, 953-955.

1.2

1.3 New York Mimes, February 1.3, 1949, 47:5.

Nuccio to Varshall, December 7, 1948, RG 59, $895.00,12-748$, NA; Gordenker, The Inited Nations and the $\frac{\text { Peaceful inification of rorea, } \frac{1.48-1.53}{1.4}}{4}$

Muccio to Acheson, Feoruary 1.5, 1949, 20 59, 50123! 2-1.549, NA; New York Times, Febrliary 19, 1.949, 4:3. 
the Soviet Union, offering its good offices for settrement of the Korean oispute. 1.5 At the same time the UnCor

indicated that it would remain in South Korea to verify American withdrawal.

Rhee's aggressive tendencies concerned the Commission as much as North Korean belligerence. Upon arrival, the French delegate inquired as to the American attitude toward forciole rounification under Rhee. Wiccio assured him that any such attempt was contrary to American policy. Yet, Muccio was clearly aware of the danger of a southerr-initjated attack. On February 1.8, Rhee appointed five governors for rule in the north after reunification. He argied that his action would bolster morale in the south and improve the ROK's claim to be a national government. Muccio scoffed privately at Rhee's naivete in thinking that it would be easy to conquer the north. He observed that the Korean division was no different from the partition of Germany. Rhee also refused to permit non-government approved Korean citizens from engaging in contacts with the Uidok. He stationed police outside the Commission headquarters to monitor $a l l$ visitors. Rantshofen-Wertheimer strongly protested such interference in the commission's activities. He reminded the united states that the UNCok's job was not

Nivccio to Acheson, February 1.8, 1.949, RG 59, 501.33/ $2-1.849$, NA: New York Times, Eebruary $22,1949,3: 6$. 1.6 muccio to Acheson, Pebruary $26,1949,8 G 59$. $895.01 / 2-2649$, I.A. 
only to foster reunification, but also to supervise the development of Korean democracy. The UNCok sought broad consultations with Koreans to ensure the emergence of democratic institutions. 1 .? Drumright conveyed these comolaints to Rhee, but the ROK President was unmoved. Rhee insisted that divisive elements would only weaken his government. Drumright argued that the ROK should attempt to hide rothing and permit full freedom for investigations. Rhee a.greed to strive for cooperation, but stressed that the chinese axperiance proved it was impossible to attempt compromise and reconciliation with Communism.

America's Korea policy fared much better at the United Nations. In February, 1.949, both the ROK and the DPRK applied for admission to the internationai organization. The United States registered a major diplomatic victory when the Security Council voted to reject the DPRK's aoplication in favor of referring the RoK's claim to the vembersing Committee. Soviet delegate Jacob walik immediately denouncei the vote as an examole of Anzlo-American dictation. The United Nations majority decided nevertheless that Soviet defiance of the UNTCOK's actions precluced support for the Soviet client. On February 24 , the Gembership Committee

\footnotetext{
1.?

Wark ana Henderson Vemorandum, Naron? $?, 049$, RG $59,50133 / 3-7 \div 9$, NA. 1.8

Drumright to Acheson, February 24,1949 , ?0 59 , 501.33,i2-2449, riA; Drumrizht to Acheson, Feoruary 12 and 23. 1.949, FRUS, 1.949, Vol. VII, Pert 2, 950-961. and 964-965.
} 
forwarded the ROK's application to the security council with its recommendation for approval. Irumright expected a Soviet veto, but explained that such action world "have advantageous effect of further alienating korean people from Soviets and rendering more difficult Soviet attempts attain hegemony whole country." To no one's surprise, Hoscow did veto the resolution for admission on Aoril. 1.3. Washington immediately charged the Soviet union with again blocking orogress toward Korean independence.

$$
1.9
$$

In the meantime, North Korea intensified its campaign 20

of border viclence and guerilla action. phee believed that only American military assistance, not the presence of the UNCok, would provide security from a potential invasion. As a result, he again dispatched Chough Pyong-ok to Washington to press Truman for the equipment necessary to arm a larger defense force. Drumright strongly aisapproved of Rhee's reliance on military vover as the key to Korean survival. Je observed that Communist Đuerillas had been able to survive regardless of military operations:

Despite the efforts of overwhelming superior opposing forces of men and eauipment in the Korean police and army, they could knock out provinces of South Korea one by one, at their

"Korean Mlembership in the united Nations," JSE, $\mathrm{XX}, 503$ (February 20, 1949), 227; DSB, XX, 51.1. (Aprii 1?, 1.949); New York Times, Feoruary 3, 1940, 1.2:4 and Feoruary 17. 1.940, 3:3; Erumriont to Acheson, varch 1.?, 1949, Fuss, 1.949, Vol, VII, Eart 2, 96́7; See also, FRS, 1.949, VoI. VII, Part 2, cir3-0,44.

20

New York Times, Eebruary 5, 1949, 5:2. 
leisure. All the speeches, political jockeying, ECA imports and brave olans of Koreans and Americans in Secul would not cancel the reality of a country gradually moving toward increasing turmoil.

Only the development of internal economic and political strength, Drumright argued, could remove threats to Korean national security.

Drumright's arguments hardy convinced Rhee. In Narch, Ambassador Chang provided Acheson with a memorandum outining the nature and objectives of Chough's mission to the United States. The Rhee government would request sufficient military assistance to attain "military parity" with North Korea. This was an indispensible ingredient, Chang argixed, for creating a "psychology of safety." The memorandum inent on to discuss two historic Korean gols; unification, without which complete economic and political independence was impossible, and strength "to contribute our due share as a bastion of democracy in the Far east in combatiing the overexpanding Communist forces." The ROK insisted that only a program of extensive military aid, similar to the American approach in Greece, mould permit the South Koreans to fulfill 22 these objectives.

Washington finally decided to impress upon Rhee the Iimited nature of the military aid program contemplated for

\footnotetext{
Drumright to Acheson, Narch $1.4,1.49, \mathrm{RG} 59$, $895.00,3-1.449, \mathrm{NA}$ 2.2

Achason femorandum, Narch 2L, 1.949, RG 59, 895.20 Missions, $3-2449$, NA.
} 
Korea, as well as America's determination to withdraw. In part, Washington feared that the American administrative and logistical preparations would constitute a premature announcement oí America's departure. Achesor believed that the cooperation and support for withdrawal of the RoK and the UNCOK was vital to the success of the operation. Thus, he instructed huccio to inform Rhee and tre UNOOK of American intentions to disengage within the "next few months." The Secretary of state stressed that it was vital to avoid any emoarrassment resulting from rumors pricr to the official announcement. At the same time it was essential to avoid any indication of forced departure in the face of Korean opposition.

On April 4, Ruccio informed Rhee that the Truman Administration had adopted a new policy in regard to Korea. After realizing the defensive nature of the RoK army envisioned in NSC-8/2, Rhee expressed dissatisfaction. He insisted that reunification would require a more extensive comitment of cower. The majority of northerners, Rhee explained, despised Communist rule. even the army would join a revolt when Rhee "gave the signal." The Rok needed airplanes and combat ships to guarantee victory, while continued vacillation would cause the lorth Koreans to lose faith in the ROK's commitment to liberation. Hucoio

\section{3}

Acheson to Seoul, tpril 5, 1949, RG 59, 895.20 Miesions, $/ 4-549$, NA; trmy to racArthur, April $9,1.49$, RG 31.9. P\&0 091. Korea MS, Section 1-A, Book 1., Box 1.63, NA. 


\section{0}

assured Rhee that the united States intended to provida military equipment, but would no longer del $\exists y$ withdrawal. The Constabulary army had achieved an adequate level of training and efficiency to permit American departure within

a. few months without fear of a DPRK invasion.

Wuccio met with Rantshofen-wertheimer the same day and expressed hope that the UNCOK would observe American withdrawal and varify compliance with the December 1.2 resolution. The UNCOK chairman favored instead that the United Nations dispatch a military observation team to serve the desired purpose. Other Commission members opoosed American disengagement entirely and advocated continued occupation for an additional five years. The Unook's reaction must have pleasea Synghan Rhee.

Aware that American withdrawal was certain, choush and Chang demanded the immediate implementation of an economic and military aid program. Butterworth and Bond assured the two Koreans that the united States cid not intend to either overlook or neglect Korea's interests and needs. Fowever, the demands on American foreign aid were indeed great and few nations were satisfied with thein portion. Buttermorth

\footnotetext{
24

Nuccio to Acheson, April 5, 1949, RG 59, 740.001.9 (Control Korea), $14-540$, NA. 25 Memorandum of Conversation, April 8, 1949, RG 59, 740.00119 (Control Korea)/4-349, NA; New York Mimes, April 1.9, 1.349, 1:6; Rantshofen-Nertheimer made this proposal in Pebruary and Vashington approved it in narch, Erumright to Acheson, February 1.8, 1.949 and Acheson to Muccio, March 22 , 1.949, ERUs, 1.949, Vol. VII, Part 2, 963 and 959.
} 
pointed out that the United States was far more concerned with the "necessity of preventing the korean Government, in its struggle against Communism, from losing the support of the people by becoming static and anti-progressive." The ROK continued to insist that only military pover, or disarmament of the DPRK army, would ensure Korean security.

Rhee now formally requested arms from the United States sufficient to equip an additional one hundred tholisand trooss and five hundred more American military advisors. Acheson was hesitant to grant such a request. He aporoved instead the formal establishment of KMAG as a means to boost Korean morale. Roberts informed Rhee that he would choose the best members of the USAFIK to staff the permanent advisory group. In the published announcoment, the United States emphasized the tremendous success of previous fmerican aid and ajyice in tre creation of a Korean security force. The Frovisional KMAG had fostered korean security and this justified its continued existence aiter withdrawal. As KnAG Commander, Roberts expressed his determination to successfully orecere the Constabulary army for self-defense, thus permiting the United States to withdraw safely. 28

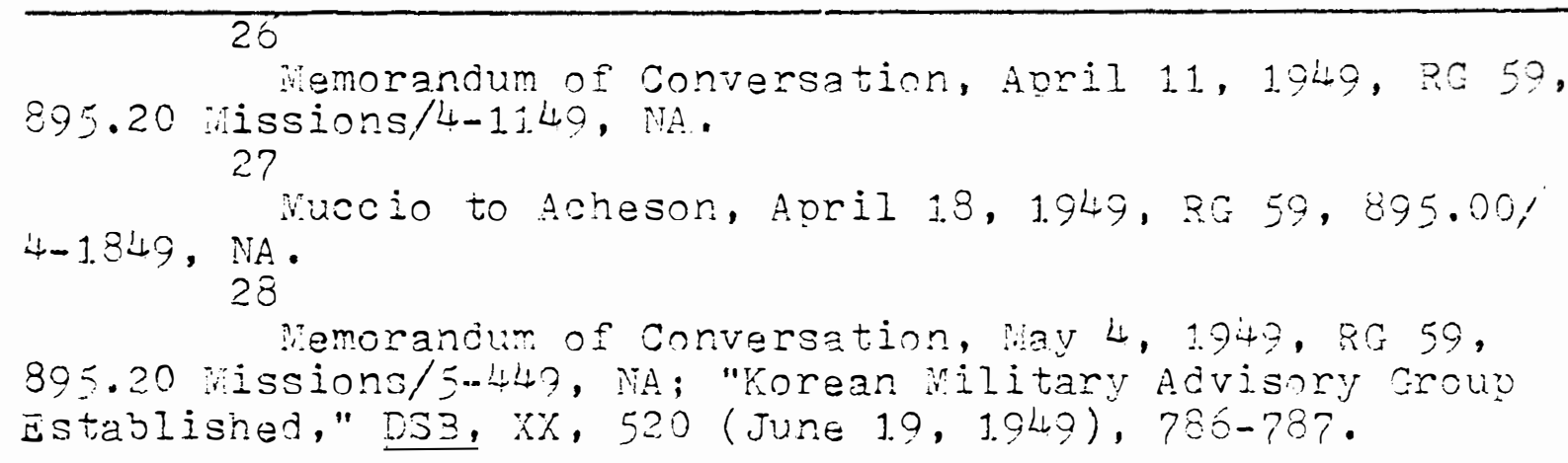


Nuccio was initially successful in his attempts to convince Rhee to support withdrawal. At a press conference, the ROK President expressed agreement that the Constabulary army was sufficiently powerful to rapel any attack from the 29

north. Events in China obviously alarmed Rhee. Iith the Communist offensive across the Yangtze River in Aoril, 1949, Rhee developed second thoughts regarding the wisdom of American withdrawal. He inaugurated a public campaisn to force the United States to guarantee South Korea's protection in the event of attack. Rhee sought a reaffirmation of the Korean-American Treaty of 1.882, as well as supplies and equipment for a navy and airforce. In a frantic letter to Viacthur, Rhee predicted a DPRK invasion in the very hear future and apcealed for more military assistance. Fe warned that South Korea was engaged in a "fight for its life" in. blocking the soread of Communism for the rest of the free world. At the United Nations Chough proposed American occupation for ar additional year until the Rok possessed enough strenzth and stability to forestall invasion.

\section{9}

Butterworth to Acheson, ipril 1.8, 1.949, FRUS, 1.949, Vol. VII, Part 2, 992-993. 30

Vuccio vemorandum, Nay $2,1.949$, FRUS, 1949 , Vol. VII, Part 2, 1.003-1.005, Muccio to Acheson, vay 7 , 1.349, RG59,50133/5-749, NA; New Ynrk Times, Nay 7, 1949, $4: ?$.

31.

Rhee tn MacArthur, may 22, 1.949, NacArthur Papers, Correspondence, Bnx 8, VIF File, DNit; Pnss to Acheson, Tune 
Rhee's change of hemrt severely undermined the ability of the United States to withdraw. Muccio concluded that Mashington would have to authorize additional military aid for an airforce and navy if it expected to obtain Rinee's consent to departure. He began to oress the Administration to grant these requests. 32 Muccio's apparent refusai to support witharawal without this supplementary assistance dismayed American military leaders. The Army Department emphasized that withdrawal on schedule was impossible unless the State Department agreed to the preliminary implementation of "Twinborn." Secretary of Defense Louis Johnson addressed a letter to Acheson complaining that previous postponements "have already created serious logistical and budgetary problems." Fe unged the State Department to support withdrawal and zvoid "further delay and indecision in this matter." ${ }^{33}$ In rasponsa, the state Department approved the reduction of "Twinborn's" security classification to "restricted" and NacArthur instructed seoul to implement

1. 1.949, RG 59, 501.38/6-1.49, NA; New York Times, Vay 8, $1.949,29: 4$. 32

Wuacio to Acheson, April 22 and $26,1.949$ and ra. 3 and 6, 1949, ERUS, 1949, Vol. VII, Part 2, 994-99? and $1.005-1.006$ and $1.008-1009$. 33

Lawson to Royall, April 29, 1940, and iay 1.3, 1.49, P\&O 0,1. Korea TS, Section I-A., Book 2, 30x 1.63, NA; Folk Nemorandum, May 26, 1.940, RG 31.9, P\&0 091. korea, Section II, Cases 21-40, Box 548, NA; Gray to Acheson, April 29, 1.949 and Johnson to Acheson, Way 4, 1.940. Truman Fapers, Korean War File, Box 1, Background, Folder on Withdravel, WST; Vuccio to Acheson, April 29, 1949, ERLS, 1949, Vol, VII, Part $2,998-999$. 
the final stage of the withdrawal operation.

In the meantime, the South Korean press began to openly criticize the United States for its determination to leave and to demand an American pledge of protection for the RiK. Editorials even blamed Washington for the 33 th parallel and the existence of a Communist regime in the nortin. 35 These reports incensed Acheson, who instructed mucoio to convey his "deep concern" to Rhee. The United States considered such public pressure "not only as grave breach ordinary diplomatic courtesy but also as sharply inconsistent with spirit mutual friendliness and good faith . . ." Acheson also warned that such action "may well have serious adverse consequences in terms pending requests economic and military aid for Korea." If Rree continued to make "ill-considered" statements and "unrealistic" aid requests, the united states might decide to terminate all assistance to the RnK.

Nuccio had already told Rhee that he was "disturbed and even shocked" at the "tone and content" of recent press statements. During subsequent discussions, Rhe agreed that it was perhaps a mistake to try to force washington's hand,

\footnotetext{
Acheson to Nuccio, May 9,1949 . Acheson to johnson, vay 1.0, 1.949, Mucc io to Acheson, Nay 11, 1.949, and zutterworth to kaddocks, riay 1.3, 1949, Fous, 1949, Vol. VII, Fart $2,1.01 .1-1.01 .5,1.01 .8-1.01 .9$, and $1.022-1023$. 35

Muco is to Acheson, Nay 7, 1.949, Exis, 1.949, Vol. VII, Part. 2, 1.01.-1.01.2. 36

Acheson to Nuccio, iray 9, 1.949, Truman Fapers, Korean War File, Box 1., Background, Folder on Withirawal, SSTS.
} 
but "he did not think it wrong make Korean position olean to American people." 37 on Nay 21. Muceio expressed consternation regarding publicity surrounding an emerging KoreanAmerican dispute or withdrawal. When Rhee callad his Foreign Vinister in for comment, Ben Limb, "in a shrill voice," charged the United States with "selling China down the river." He insisted upon the right to comment and publicize American colicy failures in repeating the mistakes made in China. Muccio suggested that if this was Rhee's attitude then perhaps the American Embassy should close and he should leave Seoul. The Defense Minister later apologized for Iimb, but the incident revealed clearly the correlation between American policy in China and Korea for the ROK. Yet, Mao's viatory in China obviously olaced South Korea in a precarious position. On the anniversany of Korean elections, a hostile enemy confronted the ROK and was dedicated to its extinction. Battle-hardened Koreans were beginning to return from China to North Korea and it was impossible to ignore the growing likelinood of invasion. Delaying American withdrawal had added to the success of the KNAG in training the Constabulary, but the United States refused to postpone departure any longer. The New Yorle Times opposed Truman's approacr and recommended positive

Yuccio to Acheson, hay 1.2, 1049, FRUS, 1949, Vol. VII, Part $2,1.021 .-1.022$. Nemorandum of Conversation, Vay 21, 1949, R? 59 , 740.00119 (Control Korea) /5-21.40, NA. 
guarantees for South Korea's military protection.

Truman and his advisors preferred to increase the oommitment of the United Nations to defend the ROK's security. on May 4, 1.949, Acheson informed the American celegation at the United Nations of the decision to withdraw no later than June 30. He argued that technical, economic, and Iinited military assistance to South Korea would provide adequately for the ROK's self-defense. Disengagement was merely in compliance with the December 12 resolution and constituted no lessening of American interest in Korea's future. The ECA program and KMA, Acheson observad, were indicative of the firmness of American commitments. At the same time the United States endeavored to improve relations between the ROK and the UNCOK. Austin spoke to chough and stressed the diplomatic power and prestige involved in meintaining support in the United Nations. Since the United States could not interfer with the Commission's interpretation of its cuties and responsibilities, Rhee had to accept the UNCoK's approach to ensure amicable relations.

On viay 1.9, 1.949, the Commission approached lioscow for the final time, requesting transportation and assistance to enter the northern zone. In the absence of a response, the

\footnotetext{
39

$1.949,1.8: 1$. New york Iimes, Nay 8, 1949, IV, 1.0:2 and Nay 12 , 40

Achason to American Lelegation at the united

Nations, Nay 4, 1.949, PC 59. 501.33/5-449, MA; Webb to Seoul, Nay 4,1949, RG 59, 50133/5-449, NA.
} 
UNCOK attemoted to terminate its role in Korea while it. ensured America's continued presence in the peninsula. At a Korean State dinner on May 21, Rufino Luna, delegate from the Fhilipoines, publicly announced his government's opposition to American withdrawal. The Comission had been unable to verify Soviet departure; nor had it been able to foster democracy in North Korea. Luna concluded that the United States was under no obligation to terminate its occupation, since the United rations had not fulfilled its December 12 resolution. Two days later, the Unok voted not to be responsible for the timing of American withdraval, since it had played no role in soviet departure. The Salvadorian delegate even opposed observation and favored the immediate termination of the Commission's role in Koraa. On June 3 , in accordance with Trygve Iie's instructions, the UNCOK voted to cease considaration of the use of military observers, thus effecting the complete frustration of American policy objectives in Korea.

Hay, 1949, was tragic for America's Korea polioy. As

\footnotetext{
Vuccio to Acheson, May 20, 1949, Frus, 1949, Vol. VII, Part 2, 1031-1.032; New York Mimes, Nay $20,1049,1.0: 5$. 42

Austin to Acheson, nay $4,1.949$ and Acheson to Austin, May 5, 1949, FRUS, 1.949, Vol. VII, Pant 2, 1.0061.008; Mccio to Acreson, ay 23, 1949, RG 59, 501.39/5-2349, NA; New York Times, Nay 23, 1.949, 9:5. New York Mimes, Yay 24, 1949, 1.7:5; Nemorandum of Conversatio., nurire 2,1949 , RG 59, 50133/6-249, NA; Gerdiner nemorandum, Nay 6,1949 and nuccio to Acreson, ray 20 , 1040, ERUS, 1.949, VoI. YII, Part 2, 1010-101.1. and 1.033; hucoio to Acrieson, June 3, 1949, RG 59,50183,6-349, NA.
} 
Mucoio explained, the fall of China and American withdraval had created incredible insecurity in the Rhee government. While engaging in "inept and anxious" attempts to force American guarantees of protection, Rhee had instituted a campaign of political repression. Despite such problems, the United States continued to stress the success of united States policy in Korea. Popular support for Rhee and the effectiveness of self-government represented "a substantial gain for the good cause of democracy."

Despite difficulties with the ROK and the UMCOK, it was clear that American withdrawal was irreversable. Ihe United states had transferred the remaining arms, amminition, communication equioment, jeeps, trucks, machinery, and soare parts of the USAPIX to the Constabulery army. The Hay york Times oredicted that the last American trocos would leave Korea at the end of July in defiance of the wishes of the PnK. 45 Faced with the inevitable, Limb held a press conference and in a surprising reversal of opinion observed that the Constabulary armir possessed enoligh strength "to coniver North Koraa within three days." nuccio observed that shor ramarks were "a refreshing contrast to the steacy stream of

\footnotetext{
44

Wuccin to Acreson, June 1.j, 1.949, RG 59, 895.00/ 6-1.349, NA; Nea york Times, Naj 1.2, 1.94, 30:3. 45 New York Mimes, nay $29,1.949,1 . ?: 2$.
} 
official comment of late" which focused attention on Korean weakness. In private, however, the Rhse regime contimied to press the United States to delay withdrawal. Iimb apoealed to Ëmbassy Secretary J.P. Gardiner for delay, arguing that the United States had not given enough advance notice.

Washington now exoressed concern that Rnee's efforts to delay withorawal were undermining South Korea's security. In June 2, Acting Secretary of State James 2 . Webo handed chough an aide memoire protesting the RoK's distribution of erronecus information depracating the extent of Ameriaan military assistance and the size of the Constabulary. Rhee's derogatory posture, Webb explained, called into question America's good faith while it undermined Korean morale. Emphasis on Korea's weakness only served Communist purposes and invited disaster. The United States was determined to withdraw and believed that no amount of military aid could protect South Korea unless the peovle were determined to resist Communist expansion.

Muccio discussed the contents of Webb's protest with Rhe on June 6. The Rok Fresident informed luccio that he no longer opposed American withdrawal because the retention

46

Tuccio to Acheson, June 3, 1949, RG 59, 740.00119 (Control Korea) $15-349$. NA; Nemorendum of Conversetion, Jure $4,1.949$, RG 59,740.0011.9 (Control Korea)/5-449, YA; Nuccio

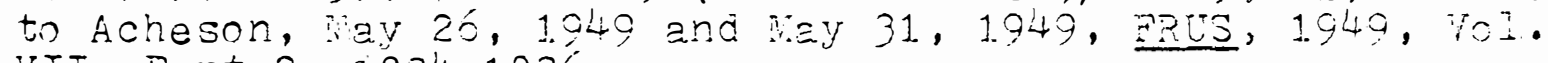
VII, Part 2, 1.034-1.036.

47

VII, Part 2, 1.037-1038.

Webt to Huccio, June $3,1.949$, ERUS, 1.949, vol. 
of a large "us military force Korea did not 'mean much' and that statement committing US 'stand jy' Korea would be more effective and preferable." During subsequent discussions, Rhee proposed the formation of a "Pacific Pact" similar to NATO and dedicated to halting Communist expansion. It was clear, however, that the Truman Administration would never adopt such a course. The United States did not anticipate a North Korean attack and was confident that, the development of South Korean political and economic strength alone would produce reunification. Truman was committed to the realization of Korean indepeldence, but his strategy precluded reliance on American military power.

Yet, the threat of civil war remained real. During the UNCOK's visit to the parallel in June, the North Korean security force fired on the Commission, removing any hope that the Commission would be abie to enter the northern zone. Rantshofen-Wertheimer informed Gardiner that the UNCOK should withdraw after it observed and verified American departure. "The "Young Group" urged the UNCoK to remain, fearing that the absence of reunification would lead to civil war after the Commission departed. Kim Yak-soo and

Mucoio to Acheson, iune 6, 1.949, FRUS, 1949, Vol. VII, Part 2, 1.039; 1uccio to Acheson, June ?, 1.949, RG 50, $501.38 / 5-749, \mathrm{NA}$ 49 $501.33 / 6-249$ Viemorandum of Conversation, June 2, 1949, RG 59, 50

Garciner to Acheson, June 20, 1.949, PG 59, 501.83/ 6-2049, NA; New York mimes, June 1.6, 1.949, 4:6. 
461.

his supporters argued that the united States and the Soviet Union should remove all military advisors, since only this would permit reunification. As a result, the commission agreed to appeal again to the DPRK for an end to its intransigeance. The UNCOK proposed internationally supervised elections throughout Korea for a unified government.

These attempts at reconciliation infuriated Rhee. Even the Assembly denounced the Un:CoK as a "Communist fifth column" whose presence in Korea was contrary to the national interest. In response, the "Young Group" expressed strons opposition to American economic and military aid, arguing that only international action would remove the partition. On June 21, Rhee ordered police to arrest six members of the "Young Group" on a charge of conspiracy to overthrow the government. The followins day, police arrested Kim Yak-soo and alleged that he was attempting to foster a communist seizure of power. 52 on June 26 , an army officer assassinated Kim Koo in an apparent attempt to demonstrate the price of dissent. Rhee denied complicity in the killing, since the assassin was a previous supporter of Kim Koo. Yet, aryore supporting a negotiated settlement with the north could not fail to grasp the significance of the trend of events.

51.

10w York Pimes, June 19, 1.940, 12:5 and jure 30, $\frac{\text { Unification of horea, }}{52}$ 164- 1.55 .

53 New York Mimes, Ture 22, 1.949, 3:4.
Mew York Mimes, June 23, 1.949, 3:6, June $26,101: 0$, 
Muccio immediately complained to Phee that such strongarmed tactics detracted from korea's image in the international community. The PoK President responded that arrests were unfortunate but necessary because Korea was "fighting for life against communist menace." The government had to eliminate any potential source of rebelison or succumb to a. communist seizure of oower. Drumright questioned Rhee's Logic, arguing that Kim Yak-soo had contributed a great deal to the strengthening of the RoK. Although the "Young Group" was not acting to deter a Communist takeover, "their criticisms, if over-emotional, generally had a plausible basis; and their support of such popular measures as the local admiristration and land reform bills, against the conservatives, was instrumental in passing the legislation." Rhee refused to listen to the American representatives in Seoul. In July, police arrested seven more Assemolymen in another attempt to stifle criticism. Drumright now celieved that Rhee was in complete control of the legislature. North Korea's threat to South Korea justified a de mee of dictatorial rule. In anticipation of American witrdramal, the DPRK accelerated its campaign to weaken the Rok. On june

3:5, June 27, $1949,1.2$, and Jure $23,1.049,10: 2$; Wencerson to Acheson, June 29, 1949, RG 59, 895.00/6-2949, NA; Mcocio to Acheson, June 27, 1.949, FPSS, 1.949, vol. vI 54 Nuccio to Acheson, June 25, 1.949, 20 50, $895.009 !$ $6-2549$, NA; Drumizht to Acheson, July 1.1., 1940, PG 59,

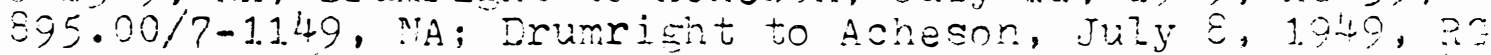
59, 895.003/7-840, NA; Fencerson to Acheson, Ju7y 9, t9is, PG $59,895.00 / 7-340, N A$. 
28, 1.940, the DPRK announced the formation of the "Democratic Fatherland Front" which was iedicated to the forcible reunification of korea under Communist control. In addition, the Communists in North and South Korea joined forces in a ne:v "Worker's Party" with Kim Il-sung as Ghairman and Fak Fieuryong as Vice-Chairmar. On July ?, the DPRK called for national elections no later than September 1.5, 1949. North Korea also urged South Koreans to revalt and oust Rhe from power as the necessary precursor for reunification. Phee quickly denounced these Communist appeals and termed them ridiculcus. 55 American commentators speculated that the North Koreans expected to use elections as a device to cotain complete control over the peninsula without military action. After riots, subversion, and bloodshed weakened the Ror, the vastly superior Nonth Korean army could invade and conguer South Korea with relative ease. American military leaders mere definitely aware of the possibility of invasion. The Jos had given detailed consideration to the matter in 3. paper formilated just prior to withdrawal. The paper reaffirmed that Korea was of little strategic value and American occupation was impractical and ill-advised. 5 ? Besides, the Mruman Administration did not

\footnotetext{
Kim, Eivided Korea, 169-1.70; Vew York Iimes, July $8,1.949,1.7$ and July $\frac{1040}{1.949}, 5: 8$. 56 57 New York Times, july 1.0, 1.940, IY, E:3.

JOS to CSA, June 23, 1.949, RG 218, ocs 383.21.

Korea $(3-1.9-45)$, Section 20 , NA; Schnabel, Polioy ang
} 
believe that the Communists contemplated open military aggression across an established boundary.

A comprehensive study of alternative courses of future action in Korea accompanied the final JCS authorization for withdrawal. The study considered three "immediate" proposals of possible acion. First, it rejected direct negotiations between the POK and the DPRK for a settlement as useless. Second, it dismissed the option of organizing a Korean underground task force to operate in the north and exploit Communist weakness through instigating a popular rebellion. North Korea might use the operation to justify not only continued subversion in the south, but also an open invasion. American military leaders could agree only on the third aternative, which provided for American warships to maks periodic visits to Korea. Nuccio had already supported such action as an indication of American concern. on Juiy 8 , an American cruiser and two destroyers arrived at pusan for a three-day "good will visit."

The remainder of the reoort discussed a variety of options open to the united states in the event of an overt North Korean attack. Significantly, the JCS assumed that the EFRK did not possess "the capability of sustained end comprehensive military operations without Chinese Communist

$\frac{\text { Diraction, }}{58} 50$

Army Department iremorandum, Jure $27,1.94$, FRUS, 1.949, Vol. VII, Part $2,1.046-1.057$; Bol te Memorandum, June 23, 1.949, RG 31.9, CSA 091. Korea TS, NA. 
and Soviet-fanchurian aid and support." In the event of such a full-scale Communist assault, the United States would have to react or lose the entire peninsula by default. The JCS recosnized that the international community would oriticize the United States if it refused to defend the RoK. In addition, the fall of Korea would mean that American rehabilitation attempts had been futile and wasteful. Thus, tre report outlined a series of actions that the united states would implement if the Communists launched a major assault. America's first action would be the immediate evacuation of American nationals and military advisors from rorea. The United States would then refer the matter immediately to the United Nations and request an emergency session of the Security Council. Such action would emphasize the international character of the situation and aroid the onus of unilateral American action. Despite the probability of delay, inaction, and a Soviet veto, the united states could ignore the United Nations only at the risk of destroying the international organization. rore important, referral of the matter to the united rations would force roscow to publicly declare its intentions.

Nilitary leaders oponsed, however, any more positive course of action. The ICS dismissed the alternative of undertaking a "police action" with united Vations sanction and multingtional participation. Although such a course would certainly bolster the United Nations and might even 
deter future aggression, the JoS apeculated that the necessity for Congressional approval woild entail disastrous delays. American participation would also result in a serious depletion of manpower and material resounces in Korea at a dangerous moment in Eurovean affairs. Thus, the JCS would sanction military participation in a "police action" as a last resort alone ard only with "complete cooperation and full participation by other members." Unilateral military action was the central feature of the entire paper. Such a "task force," the ids observed, wold commard universal respect, inspire anti-dommunist movements to resist totalitarian control, and, in addition, "might have sufficient deterrent effect to cause North Korean withdrawal to the 38 th parallel and obviate nolice action engagement." On the other hand, American interventior. would reestabish United states responsibility for Korea. after the Truman Administration had strugoled for Iive years to extricate itself. Perhaps worse, the JCS prophatically warned that American intervention might force communist China to align itself openly with the DPRK and thus "lead to a long and costly involvement of U.S. forces in an undeclared ivar." Thus, the JCS determined that the reestablishment of an American military force in Korea would constitute unsound polioy possessing serious military imolica-. tions. Unilateral American action would justigy joviet charges of imperialism and might lead to a world war. 


\section{7}

Finally, the JoS considerad the logic of extending to Korea a positive guarantee of military protection. While such action might dater loscow, the policy would require the conversion of indirect economic aid to direct supply of large amounts of military equioment. The JCS insisted that it would be "militarily undesirable and strategically unsound" to subtract military aid from areas with a hisher priority than Korea. The United States wuld also be supporting a regine that appearej urable to maintain popular supcont. In conciusion, the JCS argied that, in contrast to Greece,

Korea is a liberated area wich did not contribute to the victory and it is in the opinion of the Joint Chiefs of Staff of little strategic value. To apply the Truman Doctrine to Kore? would require prodigious effort and vast expenditure far out of proportion to the benefits to be expected.

If economic aid alone was insufficient to crotect the RoK, it was not worth the cost of positive military defense.

Rhee would have disagreed strenuously with the conclusions of the jus. Throughout june, the Rhee regime sporsored mass demcrstrations against Americen military vitrdrawal and stressing the value of the RoK as a bastion of democracy in Asia. By the end of the month, North Korean refugees in particular demanded more American military aid and a positive suarantee of protection, aince these individuals believed that the Communists nad merked them

The JoS revort is located in RG 165, 091 rorea, 1.949, $\mathrm{NA}$ 
for immediate execution. Despite such action, the last American combat troops left Korea on June 20, 1949. The UNCOK observed and verified American withdrawal, but the DERK denied the Commission's request to cross the parallel and certify Soviet departure as well. Drumright no doubt expressed the feelings of many Americans in Senul when he observed that the Koreans now "shared the emotions of a second-string quarterback who suddenly finds himself carrying the ball after months of criticizing from the bench."

Truman's Korea policy depended for success upon Congressional willingness to finance his aid program. The goth Congress had been willing to support Truman's foreign policies only when the President raised the spectre of Soriet, expansionism. 62 As a result, Truman had increasingly come to rely on America's obligation to protect freedom throughout the world in the face of the Soviet union as justificatior: for his policies. Truman frequently injected lare doses of moralistic rhetoric into clearly constructive crograms to ensure passage. Anti-Communism was as imoortant as Arthur

\footnotetext{
50

Drumright to Acheson, July 5, 1.949, RG 59, $895.00 / 7-549$, NA.

63.

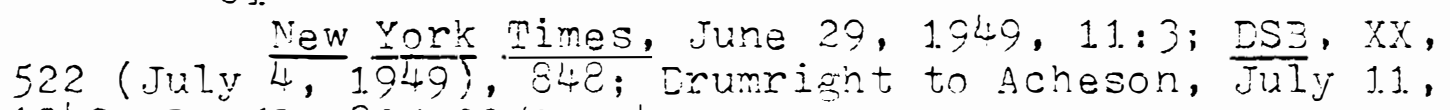
1949, RG 59, 895.00/7-11.49, NA. 62 Hartmann, Truman and the 80th Gongress, 21.4-21.5.
} 
H. Vandenberg to the future of Truman's bicartisan foreign policy.

Truman's electoral victory in 1.948 effactively ended bipartisanship in foreign affairs. During 1949, Mruman's critics returned with increasing regularity to the china issue as a venicle for discrediting tha Aministration. The Republican Farty pointed to the victory of Communism in China as indicative of mruman's inability to halt Soviet advancea. Republican criticism underlined the importance of containment in South Korea. Success in that area would constitute a refutation of republican charges.

American withdrawal from Korea and Trumar's refusal to issue a firm statement of military protection appear lo gical only in the context of larger policy objectives. A positive military commitment nas impossible, since the Truman Administration believed that the containment of communism did not require the direct application of American military misht. As Truman expleined in his menoirs:

We knew that Rhee's govornment would be in grave danger if the military units of North konsa were to start a full-scale a.tack. Fon trat reason, we wanted him to make his own area as stable as it could be made, and, in addition we wanted to bring a measure of prosperity to the peasants

\footnotetext{
Famby, Beyond the New Deal, 354; Theoharis, Seeds $2 \pm \frac{\text { Reoression, }}{34} 32$.

Richael Gunin, John Eostar Fulles: A Statesman

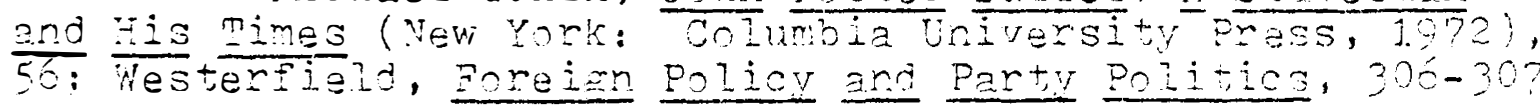
and 333; Adier, The Isolationist Impilse, 304; Tang Tasu, America's Eailure in China, '89.
} 
that would make them turn their back on the Communist aæitators. 65

Economic strength and popular support alone had to oroduce Korean security. Eventually, North Korea would rejoin the South because of its superior political and economio system, If Truman complied with Rhee's demands for "positive guarantees," on the other hand, Chiang's supporters could argue with complete justification that similar action in China would have orevented a Communist victory.

Truman's strategy was then extremely delicate, since it relied on the fragility of the IPRK and the unlikelihocd of a Communist invasion. It also required the development of democracy in South Korea and policy-makers insisted upon progress despite the disparity between American exvectations and Korean reality. Congress recognized this and many representatives were loath to soend money in an area that apoeared doomed to extinction. Supporters of Chianzalso used the Korean issue as a bludæaon to score political points against Truman for his failure in China. The Administration comoleted work on its Korean Aid Bill in Ture, 1.949, but quick aporoval seemed unlikely. In fact, Truman submitted the Korean proposal to Congress at the height of the acrimonious debate over America's Cnina policy.

\footnotetext{
65 Truman, years of Trial and yooe, 330. $6 ?$ Goodrich, Korea, 80-81. and $94-95$. Nesterfield, Eoreizn Policy and Party Eolitics, 353.
} 
Truman's proposal provided for one hundred fity million dollars in economic and technical assistance. In an accompanying press release, the Administration indicated that the United States possessed a special responsibility for Korea which justisied the continuation of its aid program. The statement also represented the first cfficial mention that American withdrawal would occur in the very near future. Truman's decision to announce withdraval simultaneously with 3. oroposal for strengthening the Korean economic aid program was hardly accidental. The press release pointed to the olar as proof that "this withdrawal in no way indicatas a lessenino of United States interest in the Repubiic of korea, but rather another step toward the normalization of relations with that republic and a compliance on the part of the united States with the - . December 1.2 resolution of the Gereral Assembly." The inited states intended to rely on the Wuor for the eventual achievement of a free and writed Korea. American Leaders recognized that bongress would not readily approve the Korean aid prozrain and expected considerable oritioism. As a result, Webb urged Truman to send a special message to Congress emphasizing the vital importance of aid to korea and the recessity for immediate paisade. The State Depantment had alraady drafted a statement and obtained the aporoval of the dCA and the sureau of the

\section{8}

Frass Release, June 7, 1940, ESE, KK, 520 (June 19, 1949), ?81; Hatorial Note, ERTS, 1.tiv, Vol. VII, Eart $2,1039-1040$ 
69

3udget. Truman complied and transmitted a personal appeal for the continuation of aid, arguing that such action vas of vital importance to the successful achievement of American foreign polioy aims. Without American assistance, Truman argued, the ROK would collapse "inevitably and rapidly." Truman's message emphasized that the united states would pursue economic necovery, rather than mere relief. Yodeled after the Marshall Plan, the program would cost only sightly more than continued reliance on relief assistance 3lone and would eventually produce self-sufficiercy. Pruman then indicated the wider implications of his korea policy in a remarkable statement that deserves quotation at lengtr:

Korea has become a testing sround in which the validity and practical value of the ideals and principles of democracy which the Republic is putting into practice are being matched against the practices of communism which have been imposed upon the people of north korea. The survival and progress of the Republic tomard a self-supporting, stable economy will have an immense and far-reaching influence on the people of Asia. Such prograss by the youno Republic will encourage the people of soutrern and southeastern Asia and the islands of the Pacific to resist and reject the Communist propaganda with which they are beseiged. voreover, the Korean Republic, by demonstrating the success and tenacity of democracy in resisting communism, will stand as a beacon to the people of northern Asia in resisting the contro? of the communist forces which have overrun them. 
Truman's statement provides an excellent example of the nature and objectives of containment in Asia. The Acministration believed that all Asians, if given the choice, would select the American rather than the soviat model of economic and political development.

Congressional hearings on the Koraan Aid Bill also demonstrated the nature of American expectations in Korea. on Jume 8, Webb appeared before the House Committee on Foreign Affairs and explained that, in the absence of American assistance, a Communist victory was inevitable. The

- loss of this "outpost of freedom" would destroy worldwide faith in the superiority of democracy and corfidence in American commitments. Hoffman supported ilebb's arguments and outlined the specifics of the Administration's threeyear program. He insisted that it would be cheaper than mere relief over the "long haul." Vore important, Foffman reasoned that "Union between the north and south of the country can be achieved on satisfactory tems only if the Government and economy of south Korea beoome so ciearly vigorous and sourd as to convince the people of north Korea that their best interests lie in union." "Thus, the Truman Administretion promised not only to ocrtain but also

72 Inid.; Yev York Times, June 8, 1.949, 1.6.

"Tebo Testimony, U.S. Concress, House, Committae

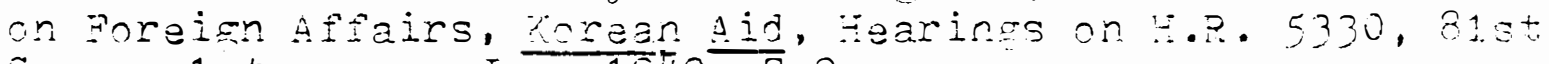
cong., 1.st, sess., June 1.949, ?-o. ?3 Foffman Testimony, Korean Aid, $9-20$. 


\section{4}

to defeat Communism in Korea.

Administration spokesmen portrayed Truman's Korea policy as a means to preserve American prestiæe in Asia and achieve Korean reunification at a relatively low cost. As Hofiman explained, "the way to get Korea and other countries . . off our back is to get them on their feet." Johnson, the ECA representative for Korea, observed that previous American aid had produced a sense of unity and purpose in Korea. Aside from economic improvement, the new Korean government also enjoyed increased politica : unity and stability because of such capable political leaders as Syngman Rhee and Kim Sung-soo. Johnson concluded that the Administration's policy would permit the United states "to get out of Korea as quickly as possible and as cheaply as possible and at the same time to insure the continuation of the new-born Korean Republic."

Republican critics quickly seized upon the Korean Aid Bill as a. means to attack Truman's China policy. These Congressmen insisted that China was as much a symbol of democracy in Asia as Korea, yet the Administration had done little to prevent the victory of Communism over Chiang. Walter Judd told webb that "korea is the first of the rat holes that we will have io pour money into all arouna china. if we do not plug up the basic rat, hole in China." Both

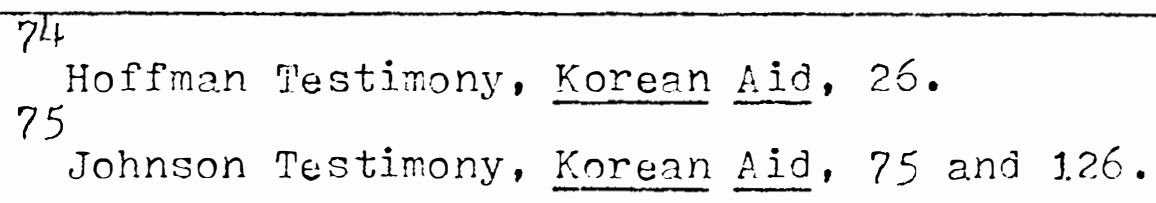


Judd and Lawrence Smith of Wisconsin stated their opposition to the Korean aid program unless the state Department clarified its policy throughout Asia.

on June 1.5, Webb adnitted that the failure of democracy in China was indeed unfortunate, but insisted that the result was not the product of insufficient American aid, Chiang had refused to reform his government and thus lost the confidence of his pecple. In Korea, on the other hand, the Unitad States could contribute to the spread of democracy, wille supporting the activities of the united lations. The best weacon against Soviet expansionism, Webt angued, was American attempts to foster economic development and self-eoverment in the underdeveloped areas of the world.

Republican critics of the Administration rejected the arguments of the Administration. Congressman dohn D. Lodere insisted that it was meaningless to "talk simply acout now economic aid will help them to resist communism and then make up our minds that we intend to diminish our forces - .." rwo days later, iodge referred to an article in Time magazine which placed the size of the Vorth Korean army at two hundred thousand troops. This communist militery threat coupled Mith internal political division in the Rn meant that the "anti-communist position was flimsier than the grass roof of a korean house." An American military leader responded that tre Time revort exarsenated the Webo Testimony, Koreen Aid, 1.1.2-1.1.7. 
seriousness of the situation and insisted that south Korea was capable of se?f-defense. Congressman Judd vehamenty disagreed. Fe chared Truman with attempting to use the Korean Aid Bill as a cover for abandoning worea.

Congressional refusal to pass the Korean Aid $3 i$ il greatly disturbed Truman. Fis power to provide funds to Korea under GARIO would terminate on June 30 and the President thus issued an urgent request for action. On June 20 , Truman met with Congressional leaders to convince them that passape was an absolute necessity. Korea was the last "foothold of democracy" in northeast Asia and the poople throughold Asia would be less willing to resist Soviet pressure if the RoK collepsed. "Its survival as an independent, democratic country or its collapse and aubission to communism," Truman explained, "mill make a very great disference in the way in which the people of areas now overwun by Communism resist or submit to it." Congressionel Democrats emerged From the conference expressine cetermired support for the bill. Truman had convinced these leadens that Korea was the last symbol of democracy in Asia and thus crucial to the success of American policy in that area.

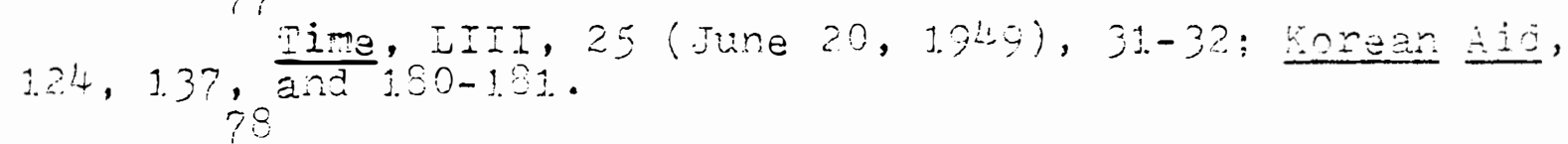
Hemorandum for Truman, june $1.8,1949$, pq 50 , 
Acheson appeared before the Congressionai Commitice on June 23, 1949, in a final attempt to win Republican supuort. He emphasized that Korea could resist communist oressure without positive guarantees of military protecuion. American troops could not ensure sorean independence unless the Koreans themselves acted vigorously to create economic selfsufficiency. If the United States abandoned Korea and refused to continue economic and military aid, the ror would collapse in two to three months. Achesor reiterated Truman's argument that the will of Asian veoples to resist Sommunist expansion depended upon the suryiva! of Korea. If Congress did not pass the Korear Aid aill before Jure 30, South Korea and the rest of Asia would confront an "almost insuperable task in maintaining Ireadom and indepencenca." Despite Acheson's appeal, it was clear that cormess would not act prior to the deadire. As a result, Actins Budget Direotor Lawton suggestad that Truman request twenty-five million dollars in supolemental assistance $=0$ tivo months. The "stopsap" measure would ensure continued

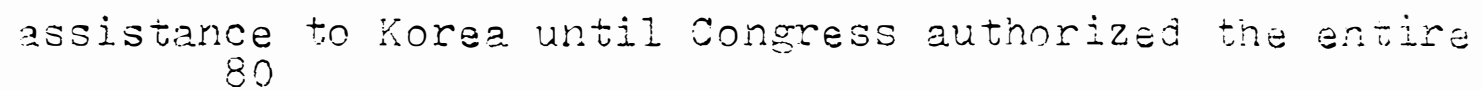
package. On June 30, both Houses approved a inint resolution emoodying Truman's plan, but for only one month. on

895.50 Recovery/6-1849; Vew Yor' Times, Tune 21, 1.049, 1.3:1. .

79

80 New York Dimes, June $24,1949,2: 6$.

Iawton to Trumar, June 28, 1.949, Frederick t.

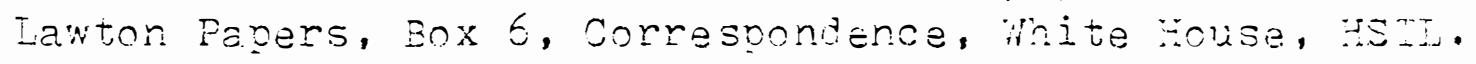


August, 1. Corgress extended the bil1 to october 1.5; it appropriated another thirty million doliars on october 29 to finarce aid to Korea throum February 15, 1.950. It was clear that Truman's aid program for Korea was in serious trouble.

Trurian's intense political pressure produced scme early successes. Despite Republican oponsition, the House Foreign Affairs Committee approved the Korean Aid $3 i 11$ on July 1., 1.949. In its report, the Commititee stressed that the program was precise and "tightly knit," focusine on recovery rather than relief. lore important, the United States could terminate assistance at any time if tha Koreans misused Americar aid. The Committee emprasized that a "crisis of freedom" confronted not only zurope, but Korea as well. At the 38 th parallel in Konea "as no where else the contest has been clearly drawn betiven two mutually exclusive viewpoints about the relation betwen perple ard their government."

Sigrificantly, the fiva Rapliolican memoers of the Committee remained hostile to the Korean Aid Bill and issues a revealing minority report. Although thein motives were

31.

U.S. Conerese, House, Committee on Foreinn lfarins,

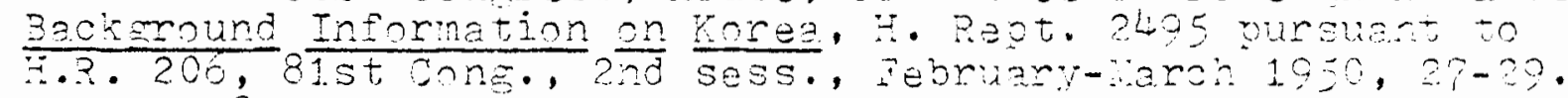
82 liew York Rimes. July 1, 1949, 6:7; J.s. Dansmess, Louse, committee an Poreign Aftairs, ty to korea, 2 Parts,

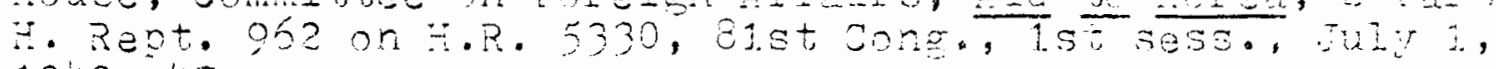
$1949,47$. 
clearly partisan, their rationale for oponsition repressnted a valid and realistic critique of Truman's Korea policy. The Republicans stressed that Korean political factionalism and domestic violence meant that a program of economic aid was "foredoomed to failure." Iruman's advisors had admitted that South Korea mould be incapable of self-deferse if the communists launched a major assault. Yet, American trooos had withdrawn from the peninsula "at the very instant when logic and common serse both demanded no retreat . . ." "unless this nation is prepared to meet force with comparable force." the report declared, "economic assistance cannot of itself insure the safety or the integrity of South Korea." In fact, the Korean Aid Bill would "only enhance the orize to be taken by force of arms and internal intripue."

Republican critics went on to stress that the conditions responsible for the success of the rarshall Plan were totally absent in Korea. In contrast to Euroce, the united States and Asia possessed no "strong interlocking national interests and economic destinies." Thile rores moud be the "logical. 'showcase' for the wares of democracy in the orient," the minority report argued that the Koreans would be unable to withstand the aroressive political tactics of moscom because of the "surrounding climate of rampant communism." the Truman Administration had to develop a comprehensive Asian

U.S. Congress, Gouse, Committee or. Foreign Affairs, Minority Report, Aid to Korea, 2. Parts, H. Rept. Gó2 on Z.R. 5330, 81.st Cone., 1.5t sess., Tuly 1., 1.929. 
policy and cease its reliance on "piecemeal and stopgap legislation." ma Republicans emphasized that the construction of a "dike of sand" in Korea would not stem the "tides which threaten to wash away the foundations of every constitutional government in Asia. . ." if Congress aporoved the bill and Truman's gamble failed Korea's demise would inflict monumental damage on American prestige.

Truman and his advisors clearly anticipated Republican criticism. Clark Clifford informed Truman that strong leadershin alone would counter the Republican stratesy of exploiting the korean issue for the purpose of attacking the Aoministration's China policy. Le reommended that the Fresident meet with Conzressional Democrats and impress upon them the importance of aid to Korea. Affirmative action had become "a rather urgent matter" in view of the rising Republian opposition to the bill. Democrats in the House agreed with Olifford's analysis and warned oruman that the floor debate vould be interse and the final vote extremely close.

Rhee endeavored to fostar Congressional support for aid to Korea. In public statements the RoK President pledged that Koreans would fignt "to the last man" in defense of

\section{Ibid.}

Clifford to Rruman, July 8, 1949, "Support for tha Korean Aid Orogem," Clarr ". Clifford Papers, official Fils: cconomic Assistance to Korea, تSTi Mew vork Mimes, Jily 2 , 1.940, 1.2. 
their Iiberty. Rhee also promised never to permit a communist to join his abinet, since the House altered the aid bill to provide for termination of assistance if Korea obtained a coalition government. Mucoin explained that the "ROK warmly welcomes amendment" because it removed Rhee's "abiding fear" that Truman would force a "coaition with North Korean regima in order oring about unification."

Phee also indicated his intention to reduce Jommunistinspired subversion and terrorism in South Korea. Too ofter, however, his vigorous anti-Commurism coincided with political motivations. On July, Rhee ordered the arrest of. Geversil newsmen who had cooperated with the UrOCK and al lagedly expressed opinions following "the Communist line." " such political repression infuniated Acheson. The secretary of State immediately instructed Muccio to confer with Rhe end strass the damage that these arrests were inflicting on Korea's image in the united liations. Pernaps more important, Acheson complained to wucoio that "such arbitrany action servas to strengthen hands opponents perding Koraan aid moogram and mare final approval . . much more difficult." Quite obviously, Congressional supsort for Koraan aid

Mev York Times, July 2., 1049, 4:3; huccio to Ache-

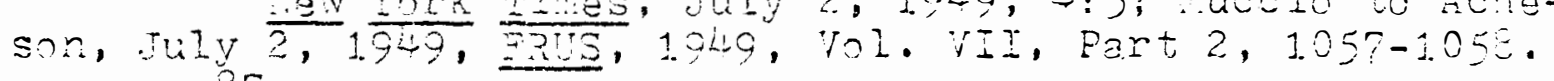
$8 ?$

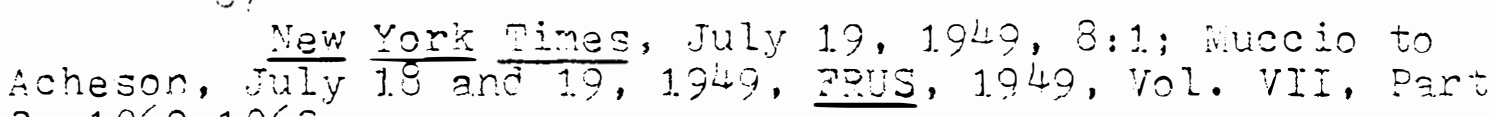
2. $1.062-1.063$. 88

Acheson to ruccio, july 1.8, 1.940, Ra 59, 5013:! $7-1.849$, NA: NEN Yark Eimes, TuLy $23,1.949,4: 5$. 
was unlikely unless the Administration proved that South Korea was capable of survival. In ar effort to bolster his position regarding Asian poliay, Truman decided to release the famous "ihite Faper" on China. Not only did the "White Paper" attempt to demonstrate that chian:'s fall was beyond American control, but Acheson also expressed hope that the Chinese people would eventually rejact their new Communist leaders. American strategy assumed that free penole would choose leaders who wore best able to vocalize their beliefs and care for their neads. Significantiy, the Vedemejer Report ô 1947 did not provide a strong recommendation for Rhee and his cohorts. Not surprisingly, the Administration suppressed the portion of the report pertairine to Korea because of its "comments upon the situation in worea and upon oertain aspects of the Korean leaders' activities - .." inuman and his advisors clearly wanted to minimiza the information available to the Amerian public indicatin similarities betmean the chinese ard Korean situations.

Fighting at the 38 th parallel intensified during the summer of 1940. Pre New Vork Mimes conaluded that ronth

Clifford to Truman, rey 17, 19La, Mrumen peyers,

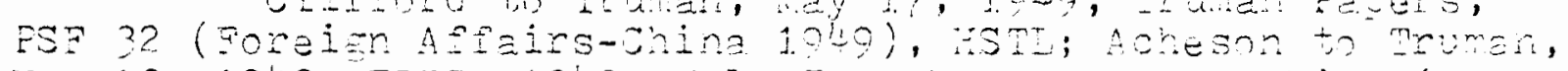

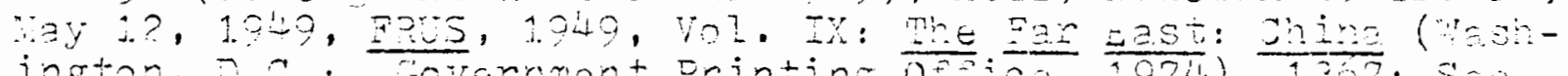
ington, D. C. Governent printine 0fice, 1974), 1.367; Sae

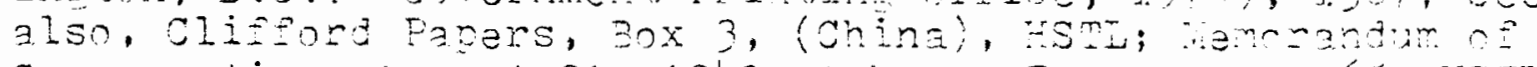
Conversation, Ausust 31, 1949, Aoheson Eapers. 30x 65, ys. 
Korea was probing southern defenses in search of a waakness. Rhee anticipated an invasion at any moment. The kof thus increased its pressure on Truman to expand America's commitment to defend South Korea. Chough conferred ivith Acheson in July and requested sufficient military assistance to increase the size of the Constabulary army to one hundred thousand men. Fe also sought "a. specific assurance that the United States would come to the defense of the Republic of Korea in the event of an armed attack against it." In. Seoul, Rhee became more outspoken in demanding a. "Pacific Pact" anc invited Chiang and the President of the Philippines to visit Korea and discuss the matter. Chiang arrived on Ausust 6 and after discussions the two leaders expressed support for an anti-Communist alilance in Asia. Rhee was engaged in an obvinus attempt to force Truman to increase the American commitment to defend Korea rather than exposing himself to Republican charges of inconsistercy.

Truman resisted Rhee's demands, since he recognized that American interests in Korea were not as important as

Ouccio to Acheson, July 29, 1940, 只 59, 50133, 7-2949, NA; New York Mimes, Austet 4, 1.949, 1.1.2 and August $5,1.949,2: 6,1.8: 2$. 91.

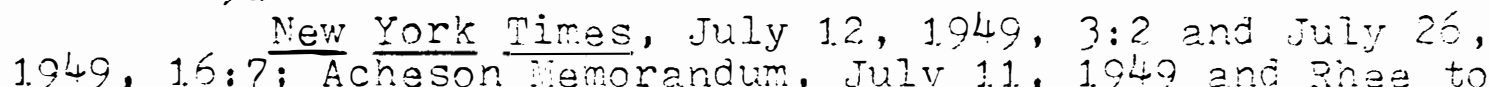
Truman, August 20,1949 , ERIS. 1949, vol. VII, Perte, $1.058-1.059$ and $1.075-1.076$.

Drumright to Acheson, August 1.0, 1.949, RG 59 , 895.00/8-1.049, NA; ruco io to Acheson, Aurust 1.6, 1940, Rc 59, 80,5.00 Rhee/8-1.649, NA; Reitzel, Kaplan, and Ooblenz, United States Foreien Folicy, 2.2.5. 
those in surope. At a press conference in August, Truman refused to comment on the 20sic of Rhee's scheme. 93 The President clearly believed that such Asian states as rorea and the Philippines possessed Iimited military power and less political strength. American military advisors argued that the ROK had to reduce the size of its army to a force level that its economy could supont. Truman addressed a persoral. letter to Rhee stressing that "the security of the Repuliso of Korea can best be served by the development of an efficient, comoact korean force rather than by amassing larse military forces which would be an insupportable burden on the economy of the country."

Washington dia not, nowever, i nore Korea'a basic militery neads. On July 25, Mrumar raquested rilitary assistance for several nations, including south korea. In his message to congress, the President explained that the RoK corironted a serious threat of invasion and required American equipment for its survival. The Administration's propram envisioned "a small force to protect korear interral security and defand it against outside aggression short of full-scale war." 95 Truman based his recommendations on a

93

Truman Press Conference Remarles, Ausust 11, 10Lg, Public Favors, Harry S. Truman, 1.949, 421.

Tsou, America's Eailure in Crina, 50?; Poberta to

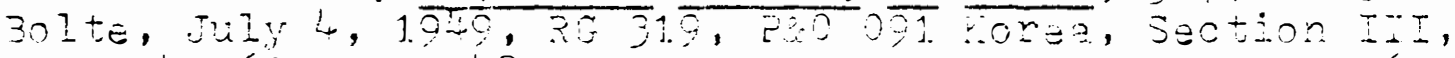

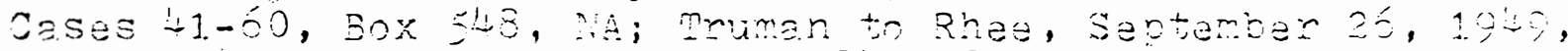
ERIS, 1940, 10L. YII, Part2, 108-1085. 0

Special ressame to corroses, july 25,1940 , E.01:20 
number of considerationa contained in a orivate Army Department memorandum. Pirst, if the Lnited states Iinited Korea's supply of reserve military equipment, Rhe would be unable to launch an invasion of the north. Second, the Constabulary army had been wasteful in its use of military supplies and would now have to exercise restraint. Finally, in the event of a North Korean attaok, the united States would lose less equipment to the communists.

Truman remained committed to an essentially non-militany approach to the soviet challenge in Asia. In July, 1.glta, the Administration rejected Kennan's orocosal to form a small, unifiad task force, hishly qualified, mobile, and velltrained for dealing with "orushfire wars." " American leaders dij not anticipate a full-scale soviat-sponsored invasion of Horea. NacArthur shared hashington's jud oment. During conversations with several 4rerican congresomen in September, he offared the following observation:

South Korea is in no danger of being overrun. by North norea. . . However, if Solith Korea tries to take over North Konea retaliatory measures could certainly be expected. If the United States by default fails to support South Korea the consequences will be

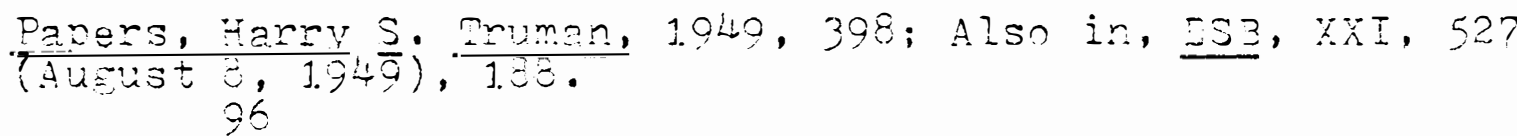
Lawson nemorandum, July 1.9, 1.940, RC 319, P\&O 091. Korez TS, Section I, Cases 5-1.5, 30x 162, NA. $9 ?$

Graeoner, "Global. Cortainment," 78-80; Daul Y. Hammond, "NSo-68: Prolo gue to Pearmament," in stratery, Politics, and Defense Budrets, $287 ;$ Rostow, The United states in the Norla Arena, 229 . 
most devastating to the inited States interests. MacArthur doubted that noscon would instigate open warfare in Korea as long as its control over North Korea and Yanchuria remained unchallenged. The Soviet union would not benefit from conquest of the entire peninsula, since control over the nocth alone preserved its secunity.

American leaders in seoul were cleanly afraid of Phe' agerassive attitude toward reunification. During August, Roberts reported that South Korea was responsiole For recent border incidents, because the army had established salients north of the parallel. Ye warned Rhe that if tina Rix launched an offensive "all advisors will pull out and the LA sDigot will be turned oif." Roberts strongly opvosed any sxpansion of the American military aid program to Korea. In September, he vigcrously opoosed the por's request for tanks, heary artillery, and more ammunition. Such action would be costly and would not contribute to a measuracle increase in Korean security. Nore important, Roberts urged rejection "so as not to encourage an invasion of north Korea oy south Korean armed forces."

Roberts offered other reasons in support of his position. For example, the Pok wanted tanks wighing Fonty-six

\footnotetext{
8 7ol. IX, 545-545.

Roberts to Bolte, fucust 19, 1949, Ra 319, Pao 091. Korea, Section III, Gases $41-60$. 30x 549, NA; Jǘ for 301te to Royall, September 12, 1940, ?c 319, pro 091. Korea, ns, Section I-E, Enx 1.63, $\mathrm{X}$.
} 
tons, but korean briçe capacity was thirty tons. At a

June press conference, Roberts went into more detail:

Nechanization is unnecessary ir. this colintry as

it is too hilly, too many mountains, and rice

rields. Tanks could only be used on rnads. .

- They can be stopoed by obtacles, mines,

bazookas and AT guns. . . Cadgets do not

win wars. Good solid infartry training under

gond officers will adequately defend Korea].100

Thus, the united States rejected the Korean request for heavy

military equipment. It was determined instead to produce

relatively small, efficient force, well-schooled in umerisan

military techniques. The Administration would support only

essential military assistance for the maintenance of internal

security and an effective deternent. The policy reiled on

the princiule of self-help, which precluded "the idea that

any particular nation has a vested right in any portion of that assistance.

Rhee's economic problems soon overshadowed the threat of a North Korean invasion. His obsession with national seclirity placed a heavy strain on the nation's financial

resources. Increasingly, Rhee turned to expanding the currency and borrowing heavily to finanoe anti-subversive pperations. Deficit spending inevitably produced incrediole

Roberts to 3olte, Sectember 1.3, 1949, p. 31.9, Pio 091. Korea, Section III, uases 41.-60, 30x 548, MA; Roberts Fress Conference Somments, june 1.5, 1943, 2. 59, 740.001.1.9 (Sontrol Korea)/6-1.419, ri4. 1.01.

Gray to Secretary of Deferse, September 13, 1949, RG 31.9, CSA OG1. Korea TS, NA; Sawyer and Hermes,
Advisors in Korea, 1.00; Sohnabel, Policy and Direotion, 36, 
inflation and extreme financial instability. At the same time Rhee refused to expand the government's tax base and permitted many wealthy individuals to avoid paying taxes altogether. By the end of 1949 , the RoK's indebtedness to the Bank of Korea was sixty-five percent hishar than the law allowed. Descite increased food production, South Korea's trade remained badly imbalanced. Insufzicient power and inadequate managerial skill manified korea's already serious economic crisis.

Economic deterioration and unorecedented inflation disturbed Eutterworth, who observed that reports from rorea "read like china 1.948!" Unless Rhee instituted major fiscal reforms, disastar was inevitable. 3utterworth instructed Muccio to apply "continuing and effective pressure" on the RIK to institute determinsd measures of reform in the area of taxation and public finance. Fe recognized that Rhee would not be neceptive to American pressura, but hoped that, maccio coula realize some measure of success.

Evidently, Wuccio immediately informed phee of arerican

1.02

"Economic Develocments in South Korea," Par East Economic Review, VII, 1.6 (octnber 20, 1940), 519-521.;

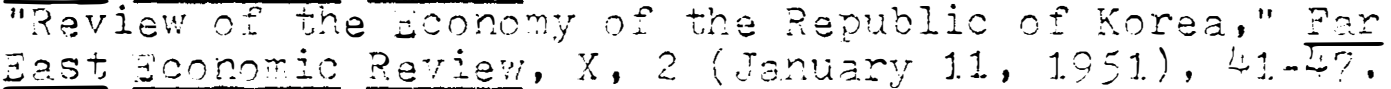
East economic Rerien, $X, 2$ (Tanuary 1.1, 1.951), 41.-4? Naw York Times, Taruary 1. 1.950, 74:3; U.S.

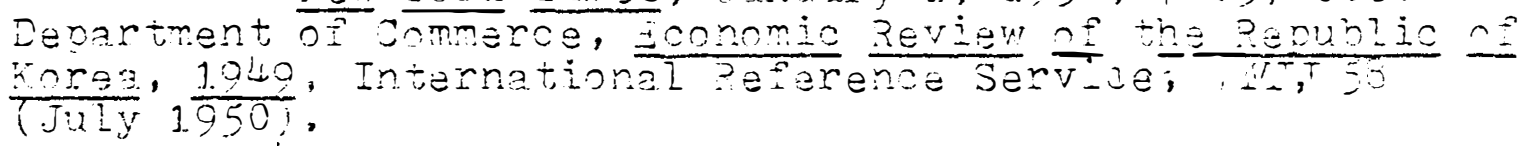
1. 04

Zutterworth to hucoio, December 1.3, 1040, RG 59, 395.51/1.2-1349, NA; Acheson to ruccio, December 30, 1940, EUS, 1.40, Vol. VIL, Part 2, 1.1.1.2-1.1.1.4. 
concern. Durine lote December, the guA reportad that Rhe had ordered some restrictions on government spending and promised to tighten whe tax coliection system. Yet, the ICA observed thet more extensive reform was necessary. Inisss the RoK balanced the budget, cortrolled spending, and restricted currency and credit, the United states would have tn terminate aid. Truman's test case of containment was on the verge of a serious crisis at, the outset of 1.950 . The Rok had to develog a sound and realistic fiscal policy or mounting inflation would destroy South Konea's economic stability. In the absence of reform, only a vast increase in American aid would prevent poittical chaos and a repetition of the China debacle. 1.06 All of Rruman's efiorts in Korea had sought to avert just such a situation.

\section{VIII}

nwuman and Acheson vare quite specific regarding American policy in Asia during january, 1950. The Administration had decided that the mainiand Ghinese mold invade Faingen in the near future and destroy the last 1.0 ? remants of the Chians regime. Mruman announced his 
determination to remain uninvolved in the Chinese civil war on January 5, 1.750. Although the united states would continue economic aid to Taivan, Anericen military aid and advice would cease. Such an approach proved that the ijnited Statas possessed no gredatory designs on chinese territory and sought no soecial privileges or military bases. Achasor. denied that the statement constituted ary reversal of American policy. Wre United states, he explained, had recognized Taiwan as Chinese territory during the war and would not violate its past agreements. Far more important, Acheson insisted that military aid would not help the nationalists. The United States could not give "a will to resist and a purpose for resistance to those who must provide it for 1.08

themselves."

Acheson's remarks on China were but a prelude to his now farous-an much maligned-spech before the Naticna? Press Club on January 12, 1950. Subsequentit, scholars have too often focused attention on Acheson's reierence in the speech to the American "defense perimeter." "Iith the benefit, of hindsight, observers argued that the exolusion of South Korea invited a communist attack. 109 such an

yilitary Situetion in the gar ast, 1672-1675, 2295, and 1.08

Truman statement and Acheson Clarification, january 5,1950 , DSB, XK, 550 (Jenuary 16, 1.950), 79-21.; Iime, KXIII, 2 (January 1.3, 1950), 23-24; Tamby, 3evona the ren $\frac{\text { Leal }}{109}, 368$.

Soanien, 
analysis diverts attention from the fact that the soeach represents one of the most sienificant statements of American pnlicy in Asia ever dalivered. It defines in unmistakable terms the nature of American expectations in Forea and their relationship to the central thrust of mruman's Asia polioy at the outset of 1.950. The Fress club speech defines in detail the esserce of containment as a liberating forea. In his speech, Acheson contends that the principle issue in Asia was the struggle against economic privation and foreign domination. Asians considered national indeperderce and self-government as the indispensible ingredients in the resolution of these two problems. Acheson argued trat the United States had always sought to foster is ian indevendence while the Soviet union had attempted to rob Asians of control over their own affairs. The inited states opoosed Communism not for any selfish reasnn but because it was the spearhead of Russian imperialism and the soviet strategy of domination. Acheson stressed that American efforts had to concentrate on avoiding any action that obscured the nature of Soviet tactics.

Acheson's attitude toward the military capaoilitjes of

the Knrean tar, 21; 3erger. The Forean Ynot, p7; Richard Bovere and Arthur Schlesiroer Jr. The General and the

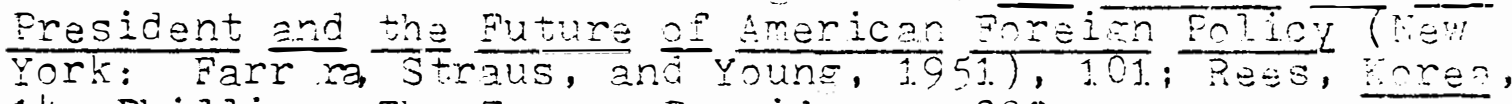
1.4; Phillios, The Truman Presiancy, 293.

11.0

Acheson tdaress, "Irisis in dsiatth examination of United States Policy," January 1.2, 1.950 , DSB, XXII, 550 (January 16,1050$), 1.1 .-1.8 .8$ 
the United states in Asia was eminently realistic. Beyond Japan, the Ryukyus, ard the Philiooines, "it must be clear that no gerson can guarantee these areas against military attack." In the event of open aggression, Achescn observed, "the initial reliance must be on the people attacked to resist it and then upon . . the United Nations which so far has not croved a weak reed to laan on by any people who are determined to protect their independence against outside agaression." Acheson then insisted that the military threat was not as immediate as the challenge of "subversion and penetration." Communism exploited conditions of economic dislocation and social loheaval to advarce the Soviet design of world domination.

Thus, Acheson stressed that economic stability alone would permit asian nations to withstand the Soviet chellenge. Through American ecoromic aid, technical skill, and administrative advice, Asian nations could develop democratic instioutions capable of fulfilling popular wants and desires. But American assistance alone was not enough, since the Asian leaders themselves had to demonstrate the will to improve conditions. In china, for example, chiang had rot fostered the improvement of political and economic conditions and the chinese people had brushed him asioe. For Acheson, his strategy in esia was the only logical. alternative. Ye pointed to Korea as an anea where the United States could utilize economic assistance and fnster the 
development of iemocracy. In Korea, "a very good chance" existad for successful resistance to communist expansion. To refuse such aid to Korea. would be "utter aefeatism and utter madness." Acheson's Asian strategy would succead in Korea because, in contrast to China, the Pok wanted American aid and would use it effectively. The Secretary of State concluosd that "we have a greater opportunity to be effective" in Korea than anywere else on the Asian mainiand. Acheson's speech reoresented a realistic approach to Amerioan oroblams in Asia. It was also coutious and judicious in its analysis op the relationship botween communism and nationalism. As Tang Tsou explatns, Aoheson's policy "semed to avoid any immediate risk nf war, dreven easily deansible line to protect America's vitel interests, and contained a Iong-term program for 4 sia wioh could oe implemented by peaceiul means." 1.2 It made little sense to advocate intervention in Asia's internal affains mor such a policy would only alierate people hostile to imperialiam. The united states could, however, extend an offer of friendship and assistance. Acheson reasoned that Asian nationalism would defeat Russian imperialism with American aid and then reward the United States with its political suponrt, America's Asian strategy was unquesinnably constructive

1.1.1.

See also, icheson Comments, February 1.3, 1.954. Princeton Semirars, Achesor Papers, Pael 1, Pae 2, YST, 2. 1.1.2 Nay, "The Nature of Foreien Policy," 6́ól-6́ć; Tsou, Americe's gatiure in China, 536. 
but also naive and excessively optimistic. As Alonzo Hamby explains, Truman and his advisors

were less perceptive in their belief that liberal democracy could eventually dominate or exercise a suostantial influerce within the region. Fiberal democracy was essentially a vestarn concept tied to cavitalism and not easily grafted on to hsian nationalism. . . tine oropressive solutions of onnciliation and economic aid were more realistic than blind anti-communism, byt hardly likely to produce tha hapoy results which so many sesmed to think possible.1.1.3

Derisps worse, Truman's naivete prevented a clear urëerstanding of the domestic nature of the emersing civil van in Korea. Both Rhe and Kim Il-sung were dedicated to forcible reunification for personal political reasors. The victory of eithar leaden would not ensure the emergence of democracy in the reunited Korean nation.

In outlining the "defense perimeter," Acheson also revealea his oorcern that Rhee might instigate military aggression against the rorth in an effort to soed the process of reunification. The Secretary of state was attemoting in part to caution the South Koreans that the United States would not absolutely guarantee the military security of the Rok. ${ }^{1.1 .5}$ Yet, icheson's Press club Speech represented orly

1.1 .3 1.3.

Yamby, Beyond the Yow Deal, 370 .

Gordarker, The United Mations and the peaceful Unification of korea, 1.1 .5

Nay, "Lescons" of the past, 65; Gardrex, Irtro-

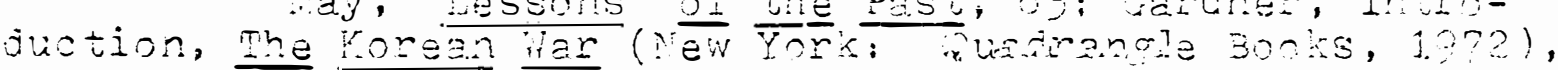

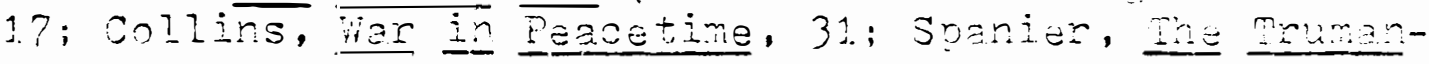


the oublic enunciation of a strategy that Truman had oursued in Korea with varying degrees of intensity since 1.946. As Muccio later explained. Acheson's remarks were not a mejor policy departure. Truman had always stressed economic assistance in Asia, rather than military power.

Philip Jessup conveyed Acheson's warning directly to the koraars in an address to the Assembly on the very day of the Press cluo Speech. Drumright argued that it was "the most candid speech made by an American official since the end of the occupation." The American Ambassador emphasized that progress toward an improved standard of living required an atmosphere of personal ireedom and guaranteed divil

liberties. In addition, he stressed that the RoK dia not require an increased military cacability because strength is not simply a matter of arms and force. It is a matter of economic eronth and scoial health and vizorous institutions, public and orivate.

South Korea had to inaugurate e vigorous program to increase colitical freedom and economic stability if it roped to survive in the face of the communist challenze.

Fachrthur Controversy and the Korean Var, 1.7-1.9; Xennan Comments, February 13, 1.954, Princeton Seminars, Achesor.

Papers, Reel 1., Tape 1., YSTI, 2. 1.1.6

Nucoio, Oral Histnry Interview Transcriot, February 10, 1.9?1, TSTi, 1.6; Reitzel, Kaplan, and coolenz, Urited. $\frac{\text { States Foreisn. Prlicy, } 2 \text {. }}{1.1 .7}$

Erumright to Achason, January 28,1950 , EQUS,

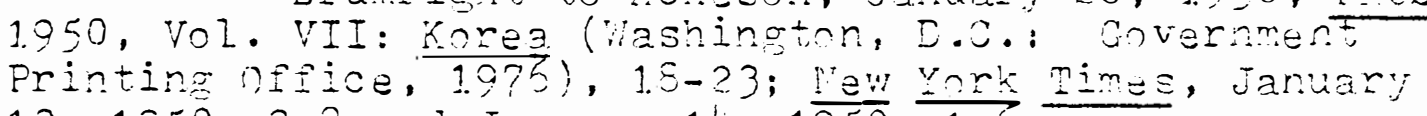
$1.3,1.950,3: 8$ and January $1.4,1950, \overline{1.6}$. 
Rhee was quick to criticize Acheson's public porouncements and Jessup's warning. The RnK President denied that Korea faced an economic crisis or that the Rrk did not enjoy full popular support. During private discussions, jessuo informed Phee that the United States was concerned about the high rate of inflation in south forea. Fe indicated his expectation that upon his return to washington "ve would have reports from Ambassacor luccio that. . all of the major problems confronting Korea would have moved formart to a solution." iessup also reiterated America's refusal to participate in a. "Pacific Pact." Apparently, Jessup was successful in reassuring the Koreans of American concern despite the abserce of positive guarantees. Rhee promised the American Ambassador that "he was going to take active steos to control" inflation. 1.18

Republican politicians quickly recognized that they could exploit the issue of aid to korea as a means of focusing public attention on Truman's failure in china. on January b́, 1950, Dulles wrote Vandenbera criticizing Trurar.s decision to Ioreswear involvement in the Chinese civil war. Ye emprasized that icheson's precipitate action vas illadvised, since "there is not left any chance for consuruotive ]. 1.8

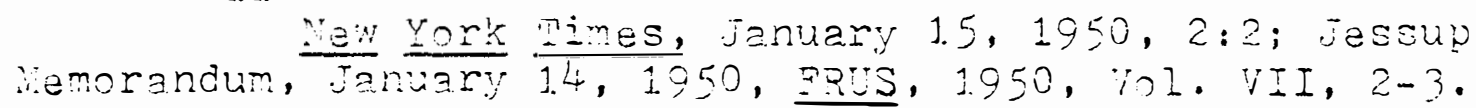


action." Dulles argued that the Repuclicans had to abandon bipartisanship and "must cry over spilled milk!" 119 For Eulles and other Republicans, tre situation in Koraa was identical to that in Cnina. Since soviet Commurism was monolithic and global in proportions, Truman nad to rely on more than mere economic aid to combat the threat.

Republicar opoosition to Truman's Foreign policy reached a peak with the emergence of rourthyism. Concern over national security and loyalty in the government rendered avid support for Acheson's Press Club stratery impossible. Republicans reconnizad the political power of the China issue and presaed their advantage. 1.20 or January 1.9, 1.9.50, the youse defeated its version of the Korean aid oill by one vote, dealing an apparently fatal blow to the chances for successful application of containment in Korea. Whe lew York mimes temed the action "unexpected" and "stinning," correctly noting the connection between the vote and sepublican dissetisfaction with Truman's china nolicy.

House action to defeat the Korean Aid aill shockes Rhee and his adrisors. The Rne Fresident insisted thet the

1.1. 3

Dulles to Tanderbers, january 6, 1950, DuIles Papers, cinina 1.950, Pui. 1.20

Westerifeld, Foreicn Policy and Party politios,

366; Tsou, America's Failure in phine, $523-524 ;$ iruks,

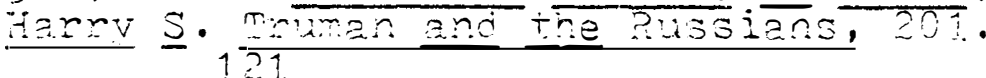

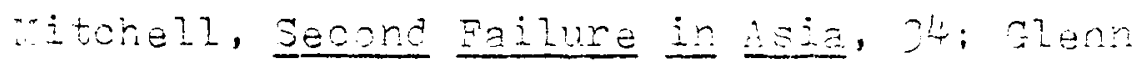

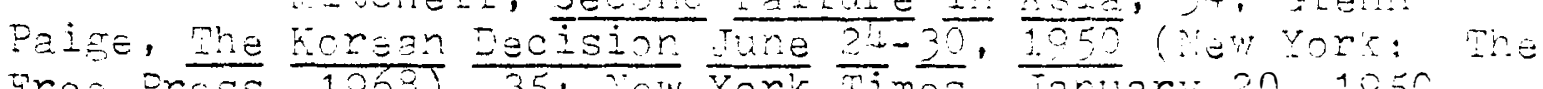

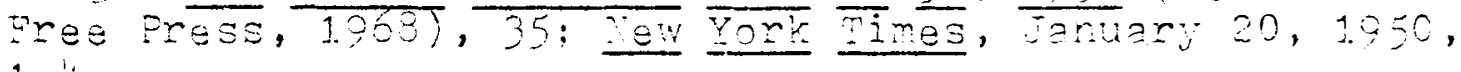
1.: 4 . 
bill was vital to the survivel of Kores es a "bastion of anti-communism." American officials in Seoul also expressed disapoointment. Bunce observed that aid would continue for the immadiate future, blit the "pipeline" would soon "run dry" and force the termination of several vital programs. In Washington. Ambassador Chang exoressed concern to 3uttervorth that the defeat of the aid oill coupled with the Fress club Speech constituted an American decision to abandon South Korea. Butteworth assured Charg that the Administration remained dedicated to supoort for the ark and intended to press congress to reverse its position.

Truman acted immediately and issued a public statement expressing "concern and dismay" at the rejection of aid to Korea. In addition, he authorized a personal letter from Acreson to Confress aroealing for speedy rectification of the damage done to American national interest in refusine to approve the Korean Aid Bill. Acheson stressed that a furdamental aspect of American policy was "that in those areas where a reasonable amount of American aid car make the differenoe between the maintenance of national inderencence and its collacse under totalitarian vressure, we should extend such zid within prudent assessment of our canabilities." Achesor insisted thet ronee was o test of American intentions and the international community would interprat "oun conduot

$1.2 ?$

ary 21, 1050, york mimas, January 20 , 1950 , 4: 7 and JanuFRTS, 1950, Vol. VII, 1.1.-1.4. 
in Korea as a measure of the seriousness of our concern with the freedom and welfare of peoples majntaining their incependence . .." So withhold aid to Korea, Acheson warned, muld guarantee the collapse of the Rnk, producing disastrous effects throughout Asia and elsewhere.

Congressional leaders resonnded quickly to Truman's and Acheson's arguments. Tom connally, Chairman of the Senate Foreign Relations Committee, anrounced that Congressional leaders mould utilize the senate authorization bill on Korean assistance to resubmit the plan, but with orovisions for aid to china as wall. He stressed that korea was a "testine ground for democracy," badly in need of a osychological lift. Even Republican senators arreed that the Fouse action was counter-productive. Knowland, Smith ard Vandenberæ all expressed support for senate action in fevor of aid to konea.

On Fobruery 1., 1.950, the Fouse Aporonriatinns Committee reported favorabiy or an amended version of the Senate aid bill for rorea. Desuite Acheson's strenuous opoosition, the Fouse Republicans forcad the inclusion of a provision for aid to China. In addition, the act provided for complete termination on june 30,1950 of all assistance. Still, the

\subsection{3}

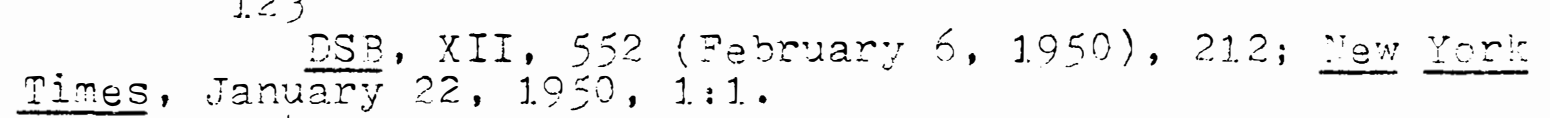
1.24 ary 21., 1950, 1.2; Vandenbero to 4cheson, January 21, 1.950, Acheson Povers, $30 x 65$, Jamorandum of Conversations,

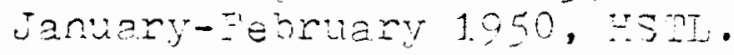


Senate had achieved a compromise with the recalcitrant rovse Republicans and produced a bill permitting Iruman to spend the remainder of the aid requested for koree in thine, 1940. Truman and several Democrats were unhappy about the nesd to include aid to China in the Korean Aid Bill, jut they haj no other choice but to accept the provision.

On Feoruary 9, 1.950, Eexublican critics reversed their position and voted support for the compormise. The folloning day, the Senate passed the measure unanimously and without: comment. There remained, however, a residue of oprosition to the Administration's program. Mary Congressmen argued that the United States oould not impiement containment without creating fiscal insolvency. In adcition, these critios charged that Iruman was not pursuing a uniform and complete program in Asia. In the end, however, most American rolitical laaders agreed with Jacob Javits that the United States had a commitment to aid Korea, since ali "Asia is watohins this test case." mhe united States had reversed its polioy of indifference, but the extent of its determination to support the por remained a matter of doubt.

31. 1950, 2:5, Ferruary 1., 1950. 13:2, ard February 2, 1950, 26:2; "Econonic Assistance to Jertain Areas of the Fer asat," DSE, XXII, 558 (Narch 1.3, 1950), 405; U.S. Jonrresa, Jouse, Committee on Appropriations, Ecommid Assiatarce to gertain Areas in the Far aast, H. Rept. 1.5?1. to accompany s. 31.9 Eqilure in Shina, 538 .

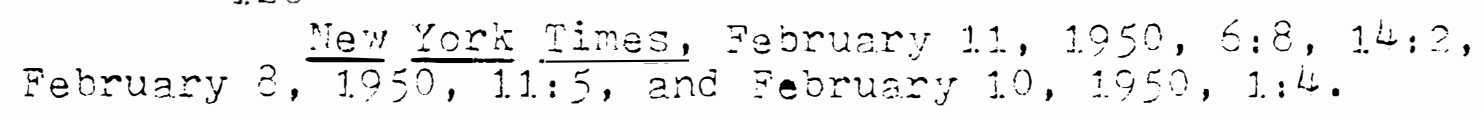


501

Despite Truman's efforts in support of the RoK, conditions in South Korea continued to deteriorate. The Assembly exploited the rejection of the aid bill in the united states to resume its criticism of Rhee. Critics alleged trat only an end to dictatorial and undemocratic tendencies in korea would bring popular support and ensure continued Americar. aid. They jocused zttention on corruption in the government and the absence of freedom in Korea's educatinnal institutions. The Assembly now turned in earrest to a constitutional amendment to limit Rhee's power. In February, the lezislature began to consider an amendment making the cabinet subject to its own control. Rhee opposed the plan, arguing that it would unjustifiably weaken the executive and produce chaotic changes in the rorear administrative apparatus. The deadinck between Rhe and the Assenioly on tris issue prevented cooperation in any other area.

During the second week in Varch, the legislature voted on the amendment. At the same time the government waged an interse campaign of threats and propaganda to dafeat the measura. Rhee ordered tre police to disband the Assemoly if it passed the amendment. Fignting broke out on the flon of the lagislature as opponents of the amandment attemptad to close debate. On Yarch 1.3, the measure lailed to obtain the necessary two-thirds support, but oniy one hundred

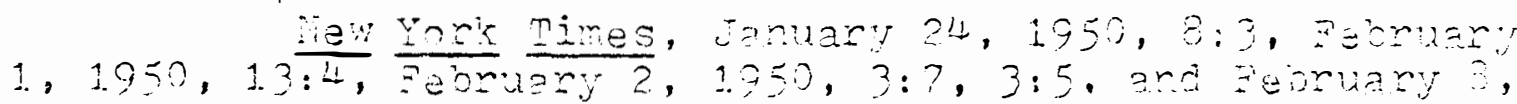
$1.950,12: 4$.
} 
tivelve delagatas cast yotes,

Rhee now counterattacked. The Rok President proposed the creation of a second house in the legislature, anguing that a unicameral assemoly was "extranrdinarily dangenous." Fe also ureed an amendment to the constitution to permit popular election of the president. Finally, Rhae recommended a postoonement of legislature elections scheduled for vay, 1.950. until the Assembly passed his budget and tax proposals. Folding elections at that time, Rhee observed, vould divert attention from more vital matters. 129 The UNok immediately indicated its opposition to these recommandations. It urged Rhee to hold elections on schedule, fearing that a prolonged delay would croduce a violent popular reaction.

Simultaneously, rashington decided that it could no lonser tolerats the deterioration of the economic situation in South korea. On varoh 23 , Hoffman informed khe that, unless he restored Konean economic stability, the united States might tominate Furbher economic aid. In rasponse, Rhee formally announced on April 1., 1.950, that he mas onstponing elections until November. Only if the Assembly

\section{8}

New York Mimes, warch 1.0. 1950, 1.4:1. and warch

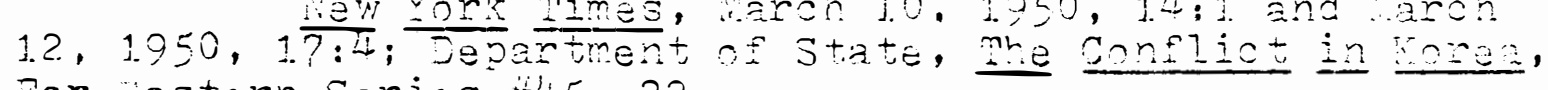
Far azstern Saries $45,22$. 1.29

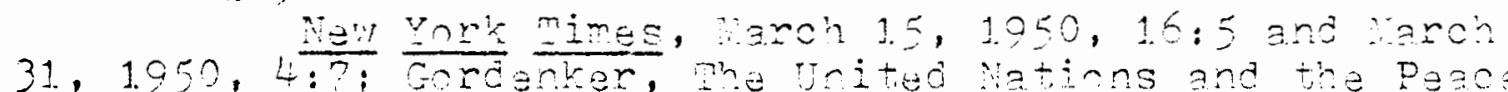

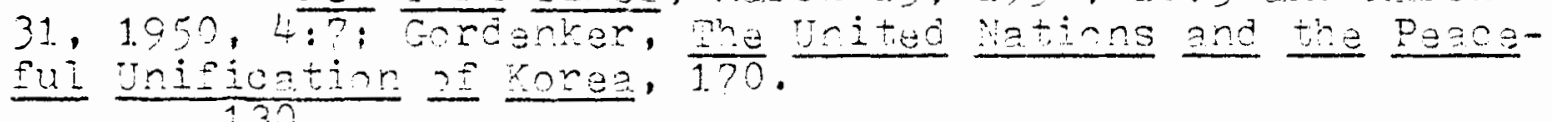
Nev Yark Times, Naron 27, 1950, 7:4; cordenker,

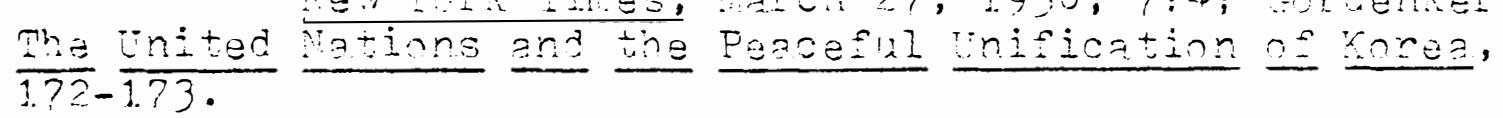


approved his budget would conditions improve and American aid continue.

Acheson favored economic reforms, but not at the expense of the appearance of democracy. As a result, he acted quickly to force Rhee to implement reforms without postponing elections. On April 3, Eean Rusk presented Ambassador Chang with what, amounted to an ultimatum. Unless the ROK instituted "drastic measures required to curb inflation," it could expect no further American assistance. In view of Korea's economic crisis, Achason explained, the EA program was not effective. The message also daplored Rhee's decision to postone elections since "united states aid, both military and economic, to the Republic of rorea has been predicated upon the existence and growth of democratic institutions within the Republic." 1.32 Mashinaton clearly recogniaed that continued colitical and economic deterioration would destroy mruman's stratexy for forean reunification.

Rhee recogniaed immediately that he could not defy the United States. On April 1.1., his rome Ninister annouroed that the government would sponsor elections on schedule.

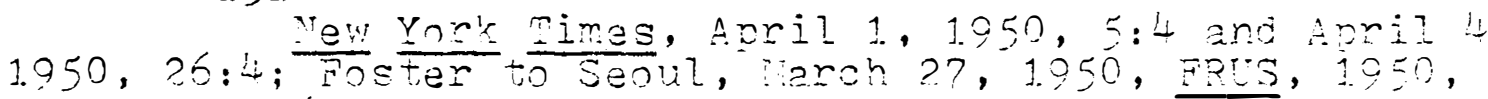
VOI. VII, 36-37.

1. 32

Press Relegse, April 7, 1950, "U.S. Joroenned Dver Xorea's Uountine Inflation," ESE, XXII, 563 (Axil 1.?, 1.950), 602; wuccio recommended the inclusion of the section demanding elections, Apuil 1. 1950, PRUS, 1950, Vol. VII, $39-40$. 
Rhe also indicated his intention to act vigocously to increase texation and balance the budget. Nuccio expressed oleasure at the ROK's decision to comply with Ameridar desines and predicted improved conditions. The Assembly alsc manifested a conciliatory attitude. It aporoved Rhee's budget which contained provisions for a sharp increase in taxes and priaes in 1.33 taxes and prices in state monopolies. The New Yonk Pimes commenced the Rnk for its couracoolis action, arguing tret, reform justified the continuation of assistance in 195i. Trapically, Forea appared in April, 1950, to be a miniature china of three gears earlier. joonomic and political deterioration seemed to be only the orelude to invasion and ciril war. In contrast to mruman's expectations, the Rok had become a "situation of weakness" and such areas vrovided "an irresistable invitation for the Soviet covernment to fish in. . . troubled waters." ${ }^{1.35}$ Perhape more imountant, Administratinn critics and tre general pubiic never comprenended the nature of Truman's strategy in rorea and elsewhere in Asia. iven if the ration understnod ore polioy, it is doubtul whether it possessed sufficient patience to support the policy lons enoligh to ensure success.

1.33

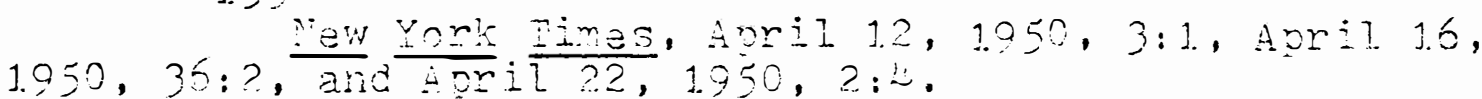
1.34

1.35 New York rimes, April $27,1950,23: 1$.

Bundy (ed.) The Pettern of pasonnsibility,

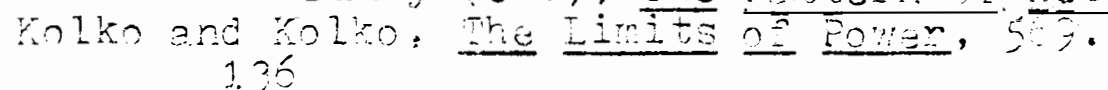
Smitr, Dear Achesen, 137. 
Chapter IX:

America's Reluctant Crusade 
American leaders expressed a degree of optimism in the spring of 1.950. Although the Soviet Union had demonstrated atomic capabilities and Communism had triumphed in China during 1949 , the United States anticipated an improvement in international affairs. Truman and his advisors had begun to consolidate a wide range of piecemeal measires implemented in the years following 1.946 into an integrated response to the Soviet challenge. The Administration remained committed to containment both in surope and in Asia as the heart of postwar American foreign policy. nore important, Iruman still believed that containment would act as a liberating force, particularly in Korea.

Truman's foreign policy rested upon three assumptions. First, although still somewhat imprecise, the Administration perceived Soviet foreign policy as tied to a firm and sweeping aggressiveness. Second, the united states believed that the international Communist movement was "at the service of the Russian State." Finally, ard most important, it assumed that "Communism as a force in the domestic oolitics of all countries, feeds on economic, social and national insecurities; Fades as these lessen." To deal with such $a$ threat, the Truman Administration concentrated on improvinz 
the economic and social well-being of the non-Communist peoples to reduce the darger of communist subversion. The United States thus deemphasized military techniques and remained committed to the creation of worldwide economic and social stability as the most effective method for ensuring American security.

By the spring of 1.950 , the United States still sougnt, to limit the extent of the nation's comnitment to act positively in international affairs. Truman and his advisors believed that only strength-moral, economic, political, and military-could deter Soviet aggression. Yet, such State Department officials as James $\ddot{~}$. Webo also argued that no single nation could provide unilaterally the strength required to counter Soviet thrusts. Such an effort to neutralize Soviet power would lead inevitably to economic suicide. The "free world" could create such strength only "if all nations which have an identity of interests contribute as best they can through self-help and mutual aid, to the common strength of the whole group." Wejo emphasized that economic strength and social progress were the crucial ingredients in the Western security quotient. An effective military force was important, but possible only "without excessive strain on our productive forces."

Richard 2 . Nelistadt to Stephen J. Spingarn, June \&, 1.950, Stephen J. Soingarn Fapers, Box 1.8, International Affairs: Foreign Policy Folder, HSTL. 2 Webb Comments, Way 1.5, 1.950, "Freedom Budaet, Panel," 
After the outbreak of the Korean var, many observers criticized Louis Johnson for cutting the "muscle" rather than the "fat" from the defense budget. Yet, as Westerfield explains, "the basic decisions were made in the wite house by presidential advisors who were struggling in a relatively peaceful international climate to balance defense and foreign aid requirements against oolitically profitable weliare measures without raising taxes or seriously unbalancing the budget." Containment, with its reliance on local selidefense and limited American aid, suited the capabilities of the United States, as well as Truman's priority on domestic affairs in his deliberations during 1950.

"New Left" historians err when they argue that prumar. was pursuing a strategy of forcible reunification in the spring of 1950. The United States lacked the power and the will to pursue such an objective. In addition, Truman and his advisors did not, expect the Soviet Union to instigate an attack in Korea or anywhere else. Truman actually permitted American military forces to remain decidedly understrength. Scholars have stressed how wrong the Administration

Frank Pace Papers, Speech File, HSTL. 3

Charles S. Wurphy, Oral History Interview Transcript, lay 1.9, 1.970, HST, 1.36; David Beil, oral History Interview Transcript, Septemoer 1.2, 1.968, HST, 1.32-133.

Westerifield, Foreion policy and Party politics,

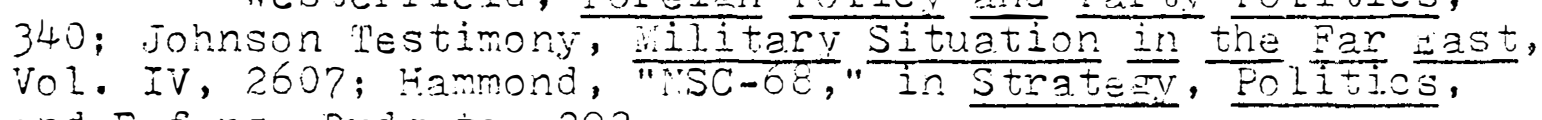
and Defense Qudgets, 293. 

underestimation of the danger. In reality, the Trunar Administration was convinced that economic aid was sufficient to build "situations of strength" and contain Soviet power.

Some scholars have stressed that the fall of China and the Soviet acquisition of atomic power in 1.949 altered the American appraisal of its foreign policy. Actually, little changed regarding the strategy of containment prior to the Korean War. In January, 1.950, Truman approved the building of a hydrogen bomb and the formulation of a reappraisal of American foreign policy. These decisions represented an escalation in rhetoric and concern, but not in policy.' The now famous NSC-68 did, however, provide the basis for believing that it was necessary to increase military capabilities. The document argued that the Soviet threat was global, because locai Communist movements were the main tools of soviet expansionism. If Truman aporoved a fifty billion dollar defense budget. American military cavabilities would mateh this perception of the soviet challenge. Yet,

5

Appleman, South to the Naktong, North to the Yalu, 49; Schnabel, Polic y and Direction, 43.

6

Reitzel, Kaplan, and Cnclenz, United States Foreign Policy, 259; Cochran, Truman and the Crisis Presidency, 30?; Rostow, The United States in the World Arena, 224-22.5; Faige, The korean Decision, 57 .

Hammond, "risc-68," in strategy, Politics, and Defense Sudrets, 289-292; Bell, Negotiation From Strensth, 8

Ibid.; Truman, Years of Mrial and Hope, 311.-31.2; 
Truman never implemented NSC-68 until the Korean War confirmed his suspicions.

American military strategy remained unchanged in the spring of 1.950. Truman and his advisors were unable to arrive at a consensus on the nature and objectives of soviet foreign policy. The President even encouraged his advisors to question the assumptions of NSC-68, stressing that the program "definitely was not as large in scope as some of the people seem to think." wuite clearly, there was an absence of certainty among American leaders as to whether Soviet aims were global. Refusing to act on its suspicions, the Truman Administration dia not take positive steps to produce the power required to meet such a challenge. The rhetoric of globalism remained, but, in the absence of the Korean viar, the importance of NSC-6́ would "have been only historical, to mark, but not to effect, a change in the climate of opinion in Washington . ..."

Political factors also prevented Truman from abandoning his devotion to containment as a liberating force. Mot only did the Administration perceive the Snviet challenge, but the Republicans never ceased reminding Truman that his

Gaddis, "ilas the Trumar Doctrine a Real Turning Point?," 396; Turphy, Oral Kistory Interview Transcript, iray 1.9, $1.970,1.84$. 9 Truman to Lawton, lay 2.3, 1.950, Lantor Paners, Vemoranda to HST, 4 genda and Notes, $30 x$ b, 世ST. 10

Fammond, "NSC-68," in Strategr, Eolitics, and Defense Budgets, 370 . 
failures in China. proved the need for strong action. In an effort to foster some degree of bipartisanship, Truman decided in April, 1.950, to appoint John Foster Dulles as "special counsel" to the President on foreign affairs.

Dulles met with Truman on April 28 to discuss his new assignment. At that time, Dulles warned the President that his presence would not shelter the Administration from criticism. He went on to observe

that there should be some early affirmative action in the field of foreign affairs which would restore the confidence of the American people that the Government had a capacity to ceal with the Communist menace. . . . If we could really get going, the American people would fall in behind that leadership and attacks like Mcćarthy's would be forgotten.

Dulles recards that Truman expressed sympathy and agreement with this position and assured him that he would inform Acheson of these views.

There can be little doubt that Dulzes was referring to Truman's China policy when he spoke of "affirmative action." Dulles believed that Truman's approach had greatly undermined popular confidence and left the Soviet union with the initiative. He strongly believed that, a series of such "disasters can probably be prevented if at some doubtful

1.1.

Louis I. Gerson, John Foster Dulles, Vol. XiII: American Secretaries of State and Their Dinloracy, edited by Samuel Flag Bemis and Robert A. Perrel T Tew York: Coover Suluare Pubishers, 1.967), 62 . 1.2

Dulles Memorandum, Ápril 28, 1.950, Dulles Papers, HST-1.950, PUI; Gerson, John Foster Dulles, 51.; Druks, Farry S. Truman and the Russians, 227 . 
point we quickly take a dramatic and strong stand that shows our confidence and resolution." Taiwan possessed certein strategic advantages that would permit the united states to demonstrate its resolution without resorting to a major war. Dulles favored "neutralization" of the island in the event of a Communist attack.

3y the spring of 1.950, the United States was prepared to react firmly to any challenge to the status quo. Truman's words and Republican criticism permitted no other response. American leaders suspected that Soviet intentions were global, but lacked positive proof. Thus, Vasinington refused to implement a program of military defense that such an evaluation demanded. Truman remained tied to containment as a liberating force and South Korea, despite its problems, was the test case of this policy in Asia.

America's Korea policy benefited greatly from the continued involvement of the United Nations in the peninsula. During late September, 1.949, the United States had formally proposed the continuation of the Unook, but with broader powers. The new Commission would ouserve conditions in Korea and report any developments "which might lead to or China-1.950, Drid.

Dulles vemorandum, iay 1.8, 1950, Dulles Papers, 1.4

Bell, Negotiation From Strangth, 1.? 
otherwise involve military conflict. . .." Rather than merely being available for consultation, the UnCor wolld formally offer its "sood offices" to both sides for the achievement of reunification. Mithin one week, the unitad Nations Political Committee approved the American olan. It also rejected a. Soviet proposal to abolish the UNok and declare its prior activities in Korea an illegal interference in internal affairs.

Muccio clearly recognized that the UNCoK's mission was doomed to failure. "A miracle would be in oroer," he admitted, "to remove the 38 th parailel and unify the country at the stroke of a pen." Washingtor apparently did not share these misgivings. The Truman Administration believed that the UNCOK would have a deterrent and stabilizing effect. If war broke out, the commission woula report who was responsible for the conflict. 1.6 on october 21., 1.949, the General Assembly voted overwhelmingly in favor of the American proposal to continue the UNCok. 1.? Once arain, the United Nations had chosen to support American foreion policy and view South Korea as lesitimate and not an

\section{5}

Charles Fahy, "The Position of Korea in International Affairs Today," September 29, 1.949, DS3, XXI, 530 (October 24, 1949), 625-6?6; Jan yark aimes, September 30 , $1949,5: 7$ and 0 atober $4,194, \frac{1}{5}: \frac{1}{5}$

Muccio to dohesnn, october ?, 1.949, RG 59, 895.00, 1.0-?49, Nï; New York Times, october 1., 1.949, 1.2:2. 1?

DS3, XYI, 540 (November $7,1.949), 605 ;$ New Yon Times, Detober 22, 1.949, 6:1.; FRUS, 1.940, Vol. VII, Fast 2 , 1090-1.092; On tha second UNChit Turkey replaced Syria. 


\section{3}

unpopular regime dependirg upon the United states for its existence.

After its arrival in South Korea, the UNCoK became increasingly concerned about the intensification of the guerilla war in the ROK. In February, the DPRK Iired on the Commission during its visit to the 38 th parallel. Whe UNCOK Chairman Kasim Gulek urged Trygve Lie to send trained military observers to watch developments in view of the threat of invasion. Lie complied, dispatching a team of eight observers. 18 This decision obviously pleased the United states. By rarch, 1.950, however, Washington begaw to seek the Commission's cooperation in supervising the Way elections for the RoK Assembly.

On April 24, Rhee's government invited the UNCOK to observe the upcoming elections. Despite the chinese delegate's initial hesitancy, the Commission ultimately agreed to supervise the balloting, much to the satisfaction of the United states. 1.9 Yet, the Commission possessed fewer men and less adequate facilities for ooservation than it did in 1.948; its activities were cursory at best. Rnee also instituted a campaign of political repression to weaken his opponents. Juring May, police arrested over one thousand suspected subversives, including fifty canidates and one

\footnotetext{
18 $25,1950, \frac{\text { New }}{32: 1} \frac{\text { Vork }}{\text { and }} \frac{\text { Times, February } 1.7,1.950,3.3: 5 \text {, Feoruary }}{\text { Marci } 3,1.950,1.0: 5 .}$ New York Times, May 1.2, $1950,3: 6$.
} 
Assemblyman. Rhee urged voters not to support candidates sympathetic with the Communists. On election day, an atmosphere of law and order prevailed, vermitting the UNCOK to certify the legitimacy of the results.

Korean elections in Viay, 1.950, encouraged the United States, since the event gave the appearance of democracy in the nation. In some respects, there was reason for optimism. Rhee's campaign of violence and intimidation had alienated the people and voters elected only forty-eight supporters of the President. Those candidates who experienced police repression received the most support. The persistence of political unrest and economic dislocation, howsver, were the primary factors determining the outcome. of two hundred Assemblymen, only thirty-one gained reelection. In the main, Korean political moderates emerged as the victors. The United States could claim that the outcome indicated "a significant refutation of the charge that south korea was a completely intimicated state, at the mercy of Rhee's police and strong-arm squads." While the atmosphere was hardly ons

Gordenker, The United Nations and the Peaceful Unification of Korea, 1.79-1.81; New York Times, vay 26, 1.950, $9: 2$ and liay $\frac{1}{27}, \frac{1950}{1.9} 4$; Henderson, polities of the vortex, 258; Nalter Lafeber, America, ?ussia, and the Cold tar 21

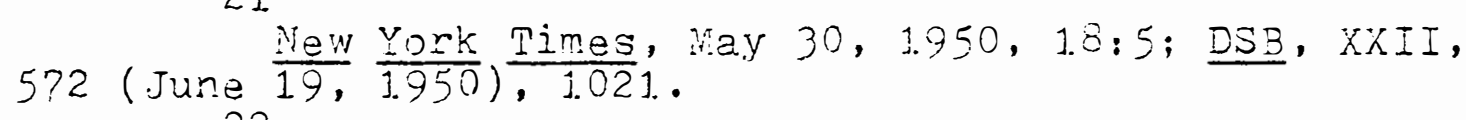
22

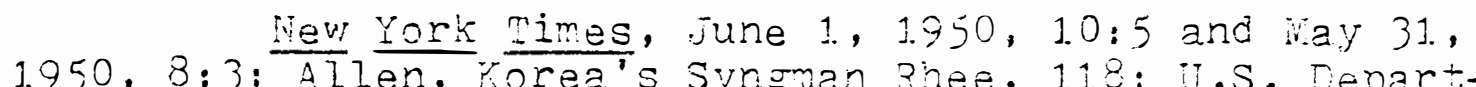
1.950, 8:3; AIlen, torea's Syngman Rhee, 1.1.8; U.S. Department of the irmy, $\frac{\text { Korea-1950 (Washington, D.C.: Govern- }}{\text { ment Printing Office, } 1.952)}$, 8 . 
of Ireedom, it was true that Rhee had permitted elections and an unfavorable outcome at that. The New York Times judged the elections a step in the direction of geruine democracy.

Korean elections certainly had a favorable impact on the United States Congress. On May 7, the House and Senate approved by wide margins the Korean aid orogram for 1.951. . Not only was aid to Korea "a moral must," but Congress agreed that the ROK was crucial to American security interests in the Facific. Success in Korea would lead to similar advances for democracy elsewhere in Asia. Mruman. drew extreme pleasure from congressional willingness to supvort the Korean Aid Bill. He explained that such aid indicated American support and friendship for newly independent nations. American economic aid to Korea, Truman argued, would constitute "a blow for freedom" and a setback for Communist expansionism.

Steadily improving conditions in South Korea encouragea the Administration. Speaking before the Senate Appropriations Committee, John w. Foster of the $\mathrm{ICA}$ pointed to the Viay elections as evidence of a healthy trend toward political

New York Times, June 2, 1.950, $22: 3$ and June 4 , 1950, IV, 2:3; Gunther, The Riddle of Hactrthur, 1.88-1.89; Rees, Korea, 20; Zerger, Ihe Korean knot, 99; Calduel1, The Korea Story, 40 .

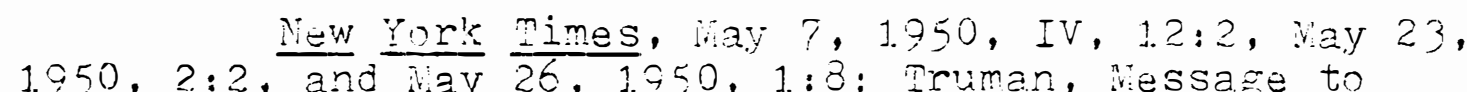
Congress, june 5,1950 , Puilic Papers, Harry s. Iruman, $1.950 .453-45.5$. 
freedom and democracy in South Korea. In adjition, the Rhee government had acted "honestly and courageousiy" to meet the inflation crisis, implementing policies designed to reduce government spending, increase taxes, contract the money supply, and eventlialiy balance the budget. Foster noted a cramatic increase in industrial and agricultural productivity particularly in the areas of rice, fish, coal, textile, railroad, and electricity production. The new anti-Rhee legislature apceared committed to reform, giving hope for a more stable, efficient, and popular government. By 1.952, the Utited States anticipated the emerpence of a stable political system and a virtually self-sufficient economy.

\section{III}

Truman and his advisors believed that South Korea. was making a positive contribution to the American defense strategy. Although the RoK was not vital to American national security, the Administration recognized that a Communist conquest of the entire peninsula would threaten

\section{5}

Foster Testimony, June 13, 1.950, U.S. Congress, Senate, Committes on Aporopriations, Foreian Aid Aourooriations for 1951, Hearings on raking Appropriations for Foreign Aid For the giscsl year ending June $30,1.951$ and for Dther Furooses, 31.s' Cong., 1.st sess., 1.950, 305-306; Department of state, The Record on Korean Unification, 1.4; Devartment of state, A Hstorioa? summary, 20; See also, Varguerite Higoins, War in Korea (Garden city: coubleday and Compan, 1951), 1.52; "illiam steuck, "Cold har kevisionism and the Origins of the knrean Conflict: The kolko Thesis," Paoific Historical Revien, XLII, 4 (November $1.973), 54 ?$ ? 
Japan. On january 26, 1.950, the Administration announced the signing of a Korean-American military aid agreement, which also authorized the permanent existence of KiAG. American military assistance to Korea was ostensibly designed to relieve the threat of military aggression from the north and foster a sense of security in the south. Such action received seneral pubilc approval, since most observers reconnized that South Korea needed reassurance of American support in the wake of the defeat of the Korean Aid gill. Time magazine emphasized that the moral obligation of the united states to the R!K precluded any thought of "tossing khee and his associates to the communist volves . ..." Under the Mutual Defense Aporopriations Act, Fruman had dispatched a survey team to Korea in late Lecember, 1.949, to jetermine South Korea's needs. Nuccio had been strongly urging the Administration to increase the Rok's military capabilities to include a navy and airforce. zvidently, the American Ambassador convinced the survey team which returned with a recommenation to increase assistance from ten to twenty-seven million dollars. Yet, the survey team noted that unless the ROK acted to foster economic recovery

Sawyer and Hermes, ililitary Advisors in Korea,

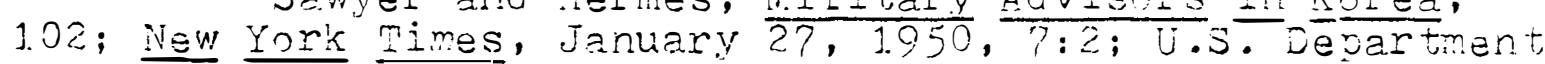
of state, "mutual Defense Assistance: dorsemert Between the United States of America and Korea," Treaties and Other International Acts Series, No. 21.9 (Vashington, D.C.: Governmen: Printing Oİice, 1.950$)$. 2.? Time, LV, 6 (Feoruary 5, 1.950), 1.7; Christian
Century, LXII, 5 (Feoruary 1. 1.950), 1.32. 
arn increase in military aid was pointless.

After Congress passed the Korean Aid Bill, American leaders turned attention toward acquiring an increase in military aid for South Korea. jarly in riay, the state Department proposed the extension of an additional six million dollars in military aid to the korean army and coast guard. Muccio and Roberts had already formulated a specific plan covering Korean needs and intended allocation of the funds to supplement the survey team's report. The Secretary of Defense requested that the JCS comment on the plan. In resoonse, the JCS reminde Johnson that it would be difficult to justify additional funds on military grounds because "Korea. is of little strategic value to the United States." Yet, the JCS would accept the croposal "if political considerations are overriding." Thus, on the eve of the Korean attack, American military advisors agreed to additional military aid for the RoK only as a means of bolstering morale and improving internal stajility.

Truman clearly demonstrated a desire to supoly the South Koreans with military supolies sufficient for selfdefense. On June 1., 1.950, he requested Congressional

Acheson to Muccio, December 9,1949 , ERTS, 1.949, Vol. VII, Part 2, 1.1.07; NIDAF Survey Team peport, Foruary 5 , 1.950, RG 31.9, P\&o 091. Korea., Section IV, Cases 60-, Box 549 , NA. 29

Leven C. Allen to JCS, vay 26, 1.950, RG 21.3, Cos 383.21. Korea, Section 2.1. NA; Nemorandum for the Secretary of Defense, Undated, RG 21.8, CCS 383.21. Korea (3-1.9-45), Section 21. NA. 
approval of a military aid appropriation for 1.951., which included a provision for several million dollars in military equipment for Korea. Truman stressed that American aid was vital to the achievement of local self-defense against Soviet expansionism. Noscow's determination to dominate the entire globe, he argued, was clear. Thus, Truman again emoloyed global phraseology to justify support for an essentially limited policy designed to avert the direct application of American military power.

Increasing border violence between North and South Korea. seemed to justify more military aid to the RoK. Yet, the United States was in an extremely difficult position. As Muccio later explained, "if we gave Rhee and his cohorts what, they wanted, they could have started to move north the same as the north started to move south." American leaders had then decided to limit Korea's military capabilities and thus reduce the chances of an attack northward. In the spring of 1.950 , the ROK possessed no tanks, combat planes, or heavy artillery. In addition, the united states limited its stock of ammunition to reduce defense spending. 31 . In

U.S. Congress, House, Committee on Appropriations,

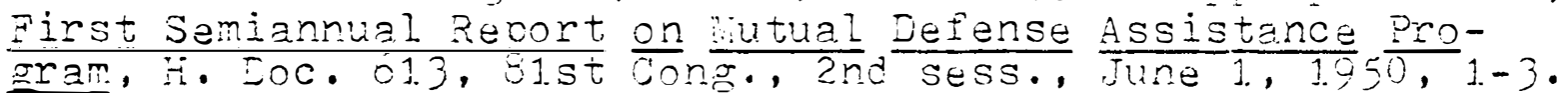
31.

Muccio, Oral History Interview Transcriot, December 2?, 1.9?3, Fist; Senator Green Comments, Military Situain the Far East, vol. III, 21.5; jonn Dille, Suostitute Tor Yoo, The Korean Kiar and the United Mations, 27 ; Nenderson,

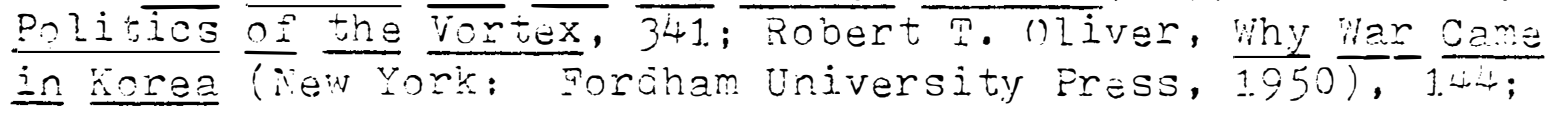


April, Roberts ordered the gradual curtailment of gavisory functions in korea. He and many of the other KMG officars were near the end of their tours of duty and would soon Leave Korea. Thus, the future of KMA was in doubt, but American military leaders believed the Rok army was sufficiently trained and equipped to withstand a North Korean 32

attack. Jpon leaving Korea in June, 1.950, Roberts described the South Korean army as the "best damn army outside the United States." 33

Subsequently, many observers argued that the United States did not assign enough importance to Korea's protection in American security planning. As a result, the Administration ignored warnings of an imminent invasion and, in fact, provided the "green Iight" for the northern attack. The evidence is, however, overwhelming that the American policy of caution was wise. 34 If Rhee possessec encugh military power, there can be no doubt that he would have

Robert Lackie, ConPlict: The History of the Korean $\frac{\text { War }}{1.950-}$ Truce Tent and Fishting Front, 8; Rovere and Schlesinger, The Genera? and the Fresident, 1.10 .

Sawyer and Fermes, Military Advisors in Korea, 112; Collins, "Iar in Feacetime, 43; 301te to Ro Bertis, Decernber 28, 1.949, रुG 31.9, P20 091 Korea, section IV, Jases 61.-, Box 549, NA. 33

Quoted in Robert D. Heinl, victory at High Tide:

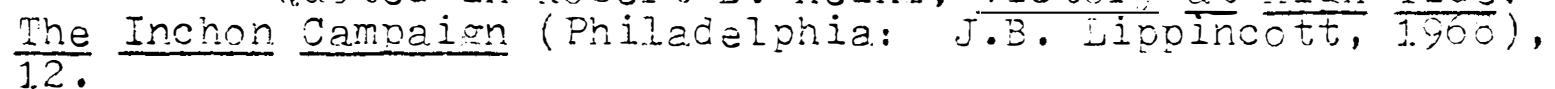
34

Paiche, The Gorean Decision, 351; Courtney whitney, NacArtinur: His Renogzous Hith History (New York: Altred A. Knopi, 1.956), 31.0; Yoo, Mhe Korean Var, 27. 
launched an assaut for forcible reunification. During March, 1.950, he declared that the ROK would not long ignore the "pleas" of its "northern orothers" for "liberation." Rhee's appeals for additional military assistance to counter the danger of a nortinern invasion always appeared to mask $h$ is aggressive intentions.

Truman and his advisors clearly were concerned about the danger of a North Korean attack. The Administration's request for additional military assistance indicated its determination to increase the RoK's ability ior self-defense, although the program would require from six to rire months for implementation. Ironically, America's decision to strencthen South Korea's military establishment probably created considerable alarm in Pyongyang. Rhee's statements and actions reinforced the belief that delay only reauced the likelihood of a successful invasion for reunification. Yet, North Korea's fears were hardly justified. The Inited States had no intention of supporting an RoK adventure. Edgar A.J. Johnson indicated as much when he agreed with one Senator's observation that American policy solight to

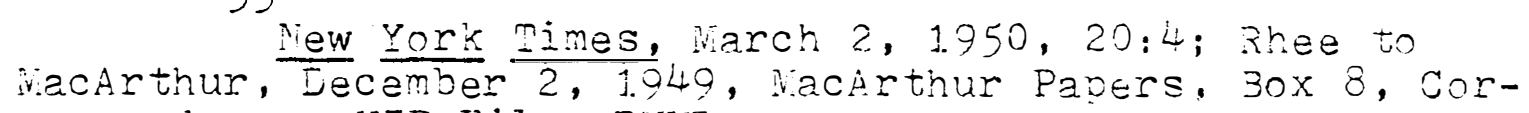
respondence, VIP File, DMnL. 36

Revisionist historians rightly observe that Rhee's aggressive attitude created fears in North Korea, Kolko and Kolko, The Iimits of Power; See also, Karunakar Gupta, "iow Did the Korean War 3egin?" The Chine quarterly (OctoberDecember 1.9?2), 71.4; Althougn this proviues a viable explanation for the attack, it does not justify the EFRK's blatant aogression. 
"set up a government controlled economy until the Soviet problem is solved and hope against hope it will hold out." North Korea's military capability was unquestionably superior to that of South Korea in June, 1950. The RoK army possessed approximately one hundred thousand men, but equipment and arms for a force only two-thirds that size. Uch of the equipment in South Korea's possession was unserviceable and lacked replacement parts. The DPRK, on the other hand, possessed approximately one hundred thirty-ive thousand well-trained and highly-organized infantry troops. In addition, the DPRK army benefited from over two hundred tanks, an equal number of combat planes, and a large supply of heavy artillery. Overall, the South Korean military establishment was larger in numbers, but only with the inclusion of the police force-numbering over fifty thousand men. In terms of war-making capabilities, however, north Korea's superiority was beyond question.

Several other factors contributed to North rorea's advantageous position in the spring of 1.950. In july, 1.940, ten thousand seasoned and experienced horean soldiers returned from China after helping the Communists deiteat the

Johnson Testimony, June 1.3, 1950, Foreimn Aid Aoprovriations for 1.951., 34-35; Department of state, The $\frac{\text { Fight Axainst Axression in rorea, }}{36}$.

Appleman, South to the raktong, yorth to the Yaiu,

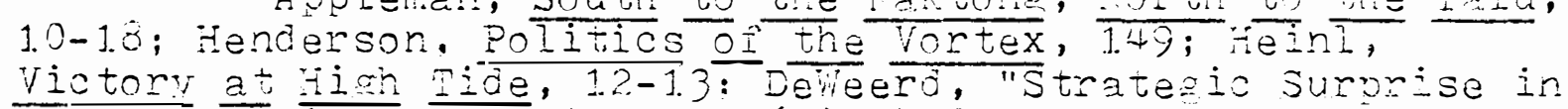

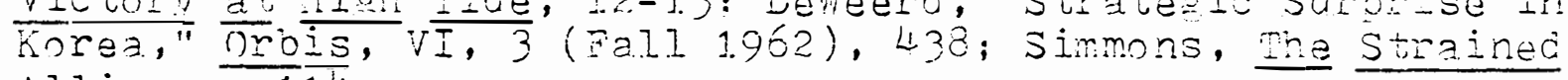
Allianee, 1.1.1. 
forces of Chiang Kai-shek. 39 More important, during april and Vay, 1.950, the Soviet Union had shipped to the DPRK an ample supply oi trucks to make the iorth korean fighting force extremely motile. In addition, hoscow shipped the tanks and heavy guns-which the DPRK had not possessed previously - that would provide the edge over South Korea in a military engagement. North Korea also experienced success in its propaganda assault to increase opposition and hostility in South Korea toward the Rhee regime.

During his appearance before Congressional committees in June, Muccio ursed that the United States maintain South Korea's military capability "on an effective derensive Level of equality, in mancower, equipment, and training, in relation to those which immediately threaten it." He emphasized that the RoK confronted "an aggressive Sovietdominated Communist regime which is publicly committed to the destruction of the Republic, by force of arms if necessary." The khee government was both willing and able to forestall a Communist seizure of power. Muccio noted that the RoK had virtually elimirated communist operations in the south. Continued success internally and effective

39

Drumright to Acheson, llay 1.1, 1.950, Frus, 1.950 , Vol. VII, 83-84; Schnabel, Dolicy and Direction, 3?; Department of State, North Korea, 1.1.5-1. o; Lafeber, America, Russia, and the Cold War, 95 .

Department of State, North Korea, 1.7 and 1.1.4; Alzen s. Whitine, China Crosses the y alu: The Eecision to $\frac{\operatorname{trnter}}{1.900)}, \frac{\text { the }}{43}$. 
deterrence externally demanded a sizable increase in South Korean military power and carity with the North.

Ruite obviously, Truman and his advisors would never provide Rhee with the military power that vuccio considered essential for Korean self-defense. One nust assume that the American Ambassador was acting, without Truman's knowledge and approval-or asking for more than was necessary in an effort to ensure the achievement of minimum needs. A large-scale military aid program for Korea was impossivle in view of the limitations Iruman had claced on deIense spending in January, 1.950. Perhaos more important, American sirategy focused attention on the pursuit of international stajility through economic aid, reliance on the United Nations, and the development of local military capailities for self-defense.

Muccio recognized that Rhee's iaith in American support was crucial to the success of containment. He wrote to Vacarthur in June, 1.950, comolaining that Secretary of Defense johnson's refusal to visit Korea during the spring had causea considerable bitterness in seoul. Fe urged

\footnotetext{
41

ruccio Statement, June 9, 1.950, "rilitary Aic to Korean Security Forces," DS3, XXII, 573 (june 26, 1.950), 1.048 . 42

Truman, Viessage to Congress, iune 1., 1.950, Public Papers, 保ry S. Iruman, 1950, 445-446.
} 
Macerthur to convince Johnson that a visit of only one day, while the secretary was in Tokyo for consultations, would Ereatly contribute to assuaging Rhee's fears of American indifference to Korea"s fate. In a letter to Rush, iluccio observed that the "visits of the five Senators and ten Representatives to Korea last autumn, and that of Dr. Jessuo last January, . . , had an excellent effect both in informing the visitors and in affecting Korean judgment about united States intentions and in caising Korean morale." zviderce of "strong continued interest" was as crucia? as economic and military aid to the survival of Solith Korea.

Evidently, the Truman Administration accepted ruccio's arguments, for Washington dispatched John Eoster Eulles on a fact-finding mission to the RoK. Dulles left the United States on June 1. $\downarrow$ and four days later surveyed the situation persorally at the 38th parallel. He expressed admiration for the "great strides" that the RoK had made toward democracy ard economic prosperity. The following day, Dulles addressed the Korean legislature and stated that Korea was "in the front line of freedom." Snuth Korea's success in building a representative democracy proved that the task of opposinz Soviet expansionism was not hopeless. Eulies then

\section{3}

Mccio to iracArthur, June $4,1.950$, RacArthur Fapers, 3ox ?, Correspondence, VIP File, DML; Wuccio to Rusk, Jurie 1., 1.950, Fits, 1.950, vol. VII, 96-97. ESB, XIII, 57? (June 1.9, 1.950), 998; Mew York Tines, June $\vec{d}, 1.950,1.3: 5$, June $1.5,1.950$, and June 1.9 , 1.950, 3:. 
reaffirmed America's confidence in the power of containment as a liberating force:

As you establish here in South Korea a wholesome society of steadily expanding well-being, you will set un peaceful influences which will disinterrate the hold of Soviet Communism on your fellows in the north and irresistably draw them into unity with you.

As long as Korea continued to strive for political and economic strength, the United states would provide material and moral support for the "Great Korean Experiment." Dulles concluded his remarks with a pledge that "You are not alone."

Dulles' observations convinced him that the Republic oi Korea had made tremendous progress during the previous year. Iater, he expressed dissatisfaction with those observers who stressed the imperfections in South Korea. He was particuLarly critical of George M. McCune's Korea Today, as the following comments delivered to William I. Holland of the Institute of Pacific Relations indicate:

The British Ninister, who had had wide experience in eastern countries, told me on june 21.st that in all his wide experiences he had never seen as encouraging an experiment in democracy. I think it was unfortunate that the book merely recorded the early frailties, and not the maturing growth.

VicCune's portrayal of Korea's plight as the product of a power strugele between the major powers was especially open to question. Dulles believed that such an interpretation

Dulles Address, "The Korean experiment in Representative Government," June 1.9, 1.950, DSB, XXIII, 574 (JuIy 3, 1.950), 1.2-1.3; New York Times, June 20, 1.950, 20:3. 
would not promote insight among the American people.

Newspaperman Hilliam R. Watthews of the Arizona Daily Star was a close friend of Dulles and accompanied him on his Asian assignment. Natthews also expressed surprise that the Korean people possessed such a high deæree of vitality and ambition. In addition, he noted the commitment of the Korean army to defend the ROK, predicting that "it could within the next year take the offensive and take over Horth Korea." After conferring with Rhee, Natthews expressed the rather starting conviction

that the Republic of Korea will within a year launch the offensive to take over Morth Korea and unite the country. The President as much as said so. He said it had to be done whether it provoked war or not. He thought it could be done within a few days, because the pente of North Korea will rise up to help out, the minute they see liberation is under way . . . If he can do it without our help, he will do it. If he can do it with our helo he will do it. The attempt is going to be made. . . . The President told about how the people of North Korea were getting impatient. re insisted that an attempt to unify his country was not agoression.

According to Hatthews, the confidence of American diplomats in seoul was indicative of this rising optimism throughout South korea. Far from being a lost cause, Korea was successfully protecting itself against soviet expansion.

The Dulles Hission to aroe definitely reassured the

46

Yulles to Holland, sugust 1.?, 1950, and septemider 7. 1950, Duiles Fapers, Korea 1.9:0, PiL.

Matthens to Dulles, Jure 20, 1.950, Dulles Fapers, 3ox 1.42, Corresponcience, Pui. 
48

Truman Administration. Despite the optimistic appraisa? of Dulles, many commentators insisted that South Koraa vias 49

near collapse in June, 1.950. After all, the Korean people had just reoudiated Rhee at the polls and oniy the threat of termination of American aid had forced economic reforms. Ferhaps more important, during early 1.950 violent clashes at the 38 th parallel had increased in number and intensity. The Rok repelied these thrusts only with great difficulty. Between June, 1.949, and June, 1.950, almost twelve hundreo 50

such incidents occurred. Administration spokesmen

insisted that the RlK army dealt effectively with these

incursions. Yet, Rhee constantly pointed to the threat of invasion. By ray, 1.950, the Korean Defense minister warned that a DPRK attack was imminent. 51.

\section{8}

Revisionist historians have argued that the Fulles mission witressed the completion of plans for a South Korear attack on the rorth. There is absolutely no evidence to support such speculation. See I. F. Stone, The Hidden His$\frac{\text { tnry }}{1.952}$ of , the Gorean War (New York: Wonthly Review press 49

Kim, Divided Korea, 1.73; Witchel1, Second Filure in siat, 9-1.0; Dorothy Woodman, "Korea, Formosa, and Worid Peace," Political quarterly, KXI, 4 (october 1.950 ), 368 ; Gupta, "Fow Did the Korean Viar Bezin?," 71.4. 50

Muccio, Oral tistory Interview Transcript, Tebruary 1.0, 1.971, HSTL; Department of the Army, Korea-1950, ?; Defterd, "Strategic surprise in the Korean var." $439 ;$ jam 3. Ulam, Expansinn and Doexistence: The ustory of Soviet Foreirn Folicy 1.91.7-1.967 (new York: Fraeger Tubishers, 1.900), 51.8; Beraer, Whe korean knnt, git; charles villouehby and John Chamberlain, acArthur 1.91-1951. New York: NcGraw-

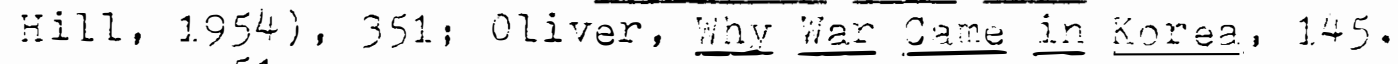
51.

Foreich Aid Aporopriations dot for 1951., 31.?-31.8;

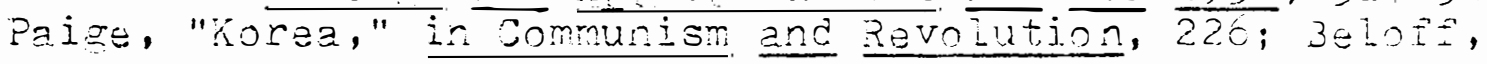


In the spring of 1.950, the DPRK did aecide to achieve reunification, either peacefully or, if necessary, with force. One can argue that North Korea was oursuing a course of duplicity to mask its real intentions, but the fact remains that the $P P R K$ attempted to realize its objectives initially without resort to war. On June $7,1.950$, the "Fatherland Front" issued a statement cenouncing the ha.y elections in South Korea and proposing nationwide elections on August 5 through 9, 19,90. The North Korean proposal included provisions for the exclusion of Syngmar Rhee and Lee Bum-suk from participation and the UVCok from observation in the elections. The resultant national legislature would convene in Seoul on August 1.5. 1.950-the anniversary of the end of world iar II in Korea. 53 As one might expect, the ple immediately denounced the plan and expressed its determination to boycott the proceedings. The Unonk Chairman, A.B. Jamieson of Australia, greeted the proposal entinusiastically and recommended a meeting to discuss the proposal.

On June 1.1., 1.950, North Korean representatives met, with

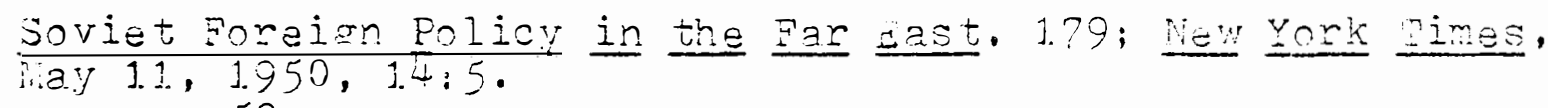
52

Berger, The Korean Knot, 1.00; Steuck, "Jold har Revisionism and the Origins of the Korean Conflict," 555. 53 Muccio to Acheson, June 9, 1.950, FRUS, 1950, vol. VII, 98-99; Ne: Vork Times, June $9,1950,1.5: 4$.

Muccio to Acrescn, June 10, 1950, Frus, 1950, vol. VII, 101-1.02; "ev York limes, June 1.0, 1.950, 4:4. 
the UNCOK at the 38 th parallel. They presented the UMCoK with copies of the North Korean appeal, but they were not willing to discuss it in detail. After an exchange of gunfire and some confusion, the North Koreans expressed complete opposition to any United Nations participation in Korean reunification. Soon after the meeting concluded, three men crossed the 38th parallel and entered South Korea. carrying a "Peace vanifesto." The RoK promptly arrested these representatives of the "Fatherland Front" and thus indicated Rhee's unswerving opposition to any LPRK plan to obtain a reconciliation.

North Korea's strategy seemed to rest upon the assumption that the people of South Korea had become so frustrated with continued partition that they favored reunification ever under Communist control. Ore widespread rumor al.lezed that, on June 3, 1950, a group of South Koreans submitted a petition to the $R$ OK favoring raunification at all costs ard supported with over five million signatures. The LPRK hoped to spark support for a reconciliation on their terrs through reliance on these "peace overtures." As a Pinal effort to prove its sincerity, the "Fatherland Front" oroposed, on june 1.9, the merger of the two legislatures for the purpose of drawing up a new constitution. This plan

55

Nuccio to Acheson, June 1.1., 1.2, and 1.3, 1.950, PRUS, 1.950, Vol. VII, 1.02-1.04; New York Times, June 1.1., 1.950, 26:3; Berger, The Korean Knot, 1.00-1.01; Beloff, Soviet Foreign Policy in tire Far zast, 1.81.-1.82. 
included provisions for the arrest of all "traitors"-an obvious reference to Rhee. The ROK wolld obviously never accept such a proposal.

There can be no doubt that it was the North Koreans who initiated the Korean Civil war. On the morning of June 25. 1.950, the EPRK army launched its assault along six invasion routes and the RoK could provide little resistance to the larger and better-equipoed North Korean forces. The final decision for war did not come until the last two weeks before the attack, when North Korea began to move its army into position. In all probability, the DPRK still anticipated the possibility that the "peace stratery" might. succeed, since rorth Korea did not recall its military forces from weekend pass until the night before the attack. When the Iinal assault came, North Korea. was confident of victory because of its military superiority and its expectation of sympathetic povular recapticn.

Stone, The Hidden History of the Korean Viar, 1.9; Schnabel, Policy and Sirection, 9; Beloff, Soviet Foreion Policy in the ara tast, 1.82.

Fontaine, Fistory of the Jold Var, Vol. II, 1.0; Gunther, The Riddle of Vacdrthur, 1.67; Spanier, The TrumanMacArthur Controvers and the Korean VIar, 1.5; Faige, Whe rorean Decision, 349; Edar o. Baliance, Korea: $1.950-1 . \overline{953}$ Tramden Connecticut: Archon Books, 1.969), 1.5; Rutrerford i. Foats, Decision in Korea (Vew York: The Wacsride Company, 1.954), 8; This is, of course, only a short list. 58

Appleman, South to the Naktong, North $\frac{\text { to }}{\text { the }} \frac{\text { thalu }}{\text { the }}$, $10-20$; Stelck, "Cold Var Revisionism ard the origins of the
horean Jorflict," 556 ; hevisionists have argued that these hasty preparations prove North Korea did not initiate tine assault, Stone, The Hidien History of the Korean var, 1.3; 
Administration officials, interestingly enough, received reports in the spring of 1950 that a Communist attack was imminent, but were unsure of the location. American leaders in Washington and seoul dismissed Korea as a probable target for invasion, believing that such a thrust, was more likely in Indochina. At the VacArthur Hearings, Acheson explained that this was the product of America's confidence in the validity of the assumptions supporting containment:

The view was generally held that since the communists had far from exhausted the potentialities for obtaining their objectives through guerilla and psychological warfare, political pressure and intimidation, such means would procably continue to be used rather than overt military azoression. •. . Now, the same situation that existed in Korea existed in a number of other places, where the possibility of attack existed, but it was not believed that the attack would take place at that time.60

Containment's logic meant that hoscow wolld never revert to open aggression to further its expansionist ains. Thus, tha Korean far shattered the very foundation upon which the entire postwar American strategy rested. After June 25, 1.950, American involvement in international affairs could

Gupta contends that Soutin Korea crossed the parallel and seized Haeju orior to any North Korean operations. The Rrk had indicated its determination to invade the forth and the town was on the shortest route to Pyongyang, "How Did the Korean War Beofin?" 699-?1.4. 59

Wernan, nemoirs 1925-1.950, 485; Truman, Years $0=$ Mrial and $9 ?-1.01$.

60

Acheson Testimony, lilitary Situation in the Fer dast, Vol. III, 1.991. 
no longer remain limited to ecoromic aid and technicai advice. Since the Communist threat was now essentially military and far more aggressive, Truman had to alter American foreigr policy accordingly.

American leaders, as well as the Eeneral public, immediately concluded that the Soviet union had ordered the attack. Adam B. Ulam summarizes well the judgment of later commentators when he observes that to beliave "the North Koreans would have attacked on their own is inconceivable." After all, North Korea had been a Soviet cuppet ever since 62 its creation in 1.945 . Allen $s$. Whiting provides a more specific explanation for the logic of assuming that Stalin ordered the North Korean attach on South Korea:

virtually no decisions, certainly not that of the June 1.950 invasion, could be made without Soviet knowledge and, in all probability, Soviet advice. Some sectors of the economy, such as oil and shipping, came under direct Russian control through joint-stock comoanies. 63 American policy-makers interoreted the joviet-iorth loreen

\footnotetext{
Ulam, expansion and coexistence, 51.8. 52
}

Department of State, North Norea, 5; 0'alizano, borea, 27; James cGovern, po the valv (New york: Hillian orrow, 1.972), 1.4; Philive-Mosely, "Soviet Policy and the ifar," journal of International Afiairs, VI, 2 (Spring 1.052$)$, $1.0 ?$.

\section{3}

Whiting, China Crosses the Yalu, 42 ; See also,

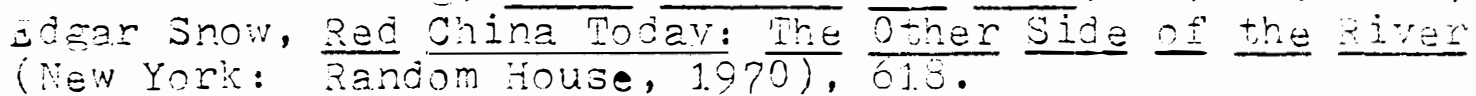


Agreement of Jarch, 1.949, as proof that the DFRK was subordinate to Hoscow. By 1.950, the Vorth Koreans had modeled their political and economic system after the Soviet Union and rioscow controlled all foreign trade with North Korea. In addition, Soviet-trained Koreans dominated the government, the army, and the Communist party. Although the Soviet Union no longer maintained troops in lorth worea, most observers believed that $\underset{64}{\mathrm{~S} t a l} \mathrm{in}$ possessed complete control through covert means.

There is abundant evidence available to support the conclusion that Moscow ordered the attack. The Soviet Union had provided technicians, military equipment, and various other supplies to North Korea during the postwar period. In the absence of continued aid, the EPRK could not hope to sustain an invasion and complete the conquest of the south. Although the number of Soviet military advisors in vorth Korea had declined from one hundred fifty in 1948 to l.ess than eight in 1.950 per division, the Soviet Military Mission in Fyongyano remained in existence. The conclusion setmed inescapable that Soviet officers were at least aware $0 \mathrm{f}$ the operation and probably directed the attack.

$$
66
$$

\section{4}

Department of State, North Korea, 1.03, 1.1.4, and 120; Mosely, "Soviet Policy and the war," 1.07; Ulam, Expansion and Coexistence, 51.3; Paige, The Korean People's

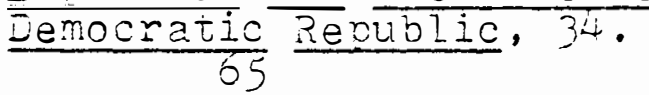

Collins, War in Peacetime, 3-4; Kim, Eivided Konea, 1.74; hostow, The United states in the Horld Arena, 230. 66

Department of State, North Korea, 1.14; Steuck, 
Some scholars have relied on the Korean war to substantiate the argument that the Soviets alvays seize the initiative wher presented with an opportunity to extend its ó?

area of control. A somewhat more limited explanation focuses attention on Stalin's concern over American military power in Japan. The united States was then in the orocess of negotiating a peace treaty with Japan and stalin allegedly hoved to forestall a japanese-American defensive alliance. George F'. Kennan speculates that a Communist victory in Korea might have crated neutralist tendencies in Japan and thus denied the united states a military base of operations. Korean unification under the DPRK, Ulam argues, "vould lead many Japanese to conclude that Communism was indeed the wave of the future, at least in Asia." "59 sven if japan decidec to strengthen its alliance with the United States, the unificztion of Korea would provide substantial compensation. Soviet control over the entire koraan peninsula would offset the

"Cold Var Revisionism and the Origins of the Korean Conflict," 553 ; 0'Ballance, Korea, 1.04-1.05. 6?

Dspood, Iimited War, 164-1.65; Fehrenbach, Whis Kind of Var, 53; Ulam, Expansion and Coexistence, 51. उ; kees,

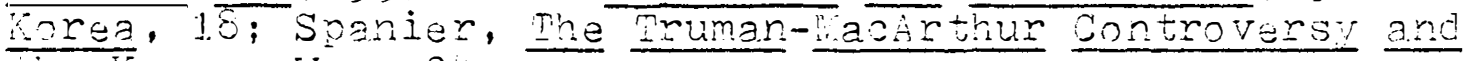
the Korean $\frac{\operatorname{cor}}{60}$, 24 .

Kennan Comments, February 1.3, 1.954, Prinoeton

Seminars, Acheson Eaoers, Reel 1. Tape 2, ATt, 7-5; Kennan,

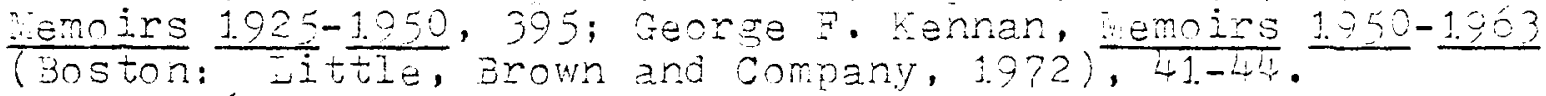
69

vlam, Expansion and Cosxistence, 520; See also, Steuck, "Cold har Revisionism and the Vrigins of the rorean Conflict," 558-559; Fontaine, Fistory of the Cold lar, vol. II, 1.04; Prilizis, The Druman Presidency, 293 
military advantages of a Japan firmly planted in the 70

Hestern camp.

One serious problem complicated the easy and losical assumption of Soviet culpability. Soscow's representative at the United Nations was not present at the time of the Korean attack. William Steuck contenas that the Soviet Union intentionally absented itself from the security Council to prove with firality that the United Nations was impotent and not an effective means for collective security. ${ }^{71 .}$ Stalin aid not expect the security council to adopt a positive plan of action. If the inited lations did act, toscow's absence was cause for declaring any vote illegal. Others have pointed out that hoscow had enough time to react, but chose not to return to the urited lations until August 1., 1950. Either Stalin considered the United Mations disdainfully unimoortant or he chose to avoid open critioism for soviet agsression in the Security council.

Lafeber, Arerica, Russia, and the onld iar, g?; Feis, Contesto Over Japan, 1.45; Louis J. Halle, The Cold $\frac{\text { Tar }}{\text { as }}$ Korea, 1.o; rarshall D. Shulman, Stalin's Eoreign Policy Rezooraised (Cambridge: Marvard University Fress, 1.03), 1.44; Gunther, The Riddle of WacArthur, 1.74; Whiting, China 1.1. ; Alexander L. George, "American Policy-iaking and the North Korean Aggression," in Korea: Oold War and Iimited

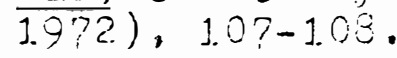

71.

Steuck, "Cold War Revisionism and the oriogns of the korean Conflict," 51.4 .

72

Mo sely, "Soviet Polioy and the Var," 1.j.1. Robert Leckie, Conflict, 48. 
Another significant question involved in the korean attack was the role of China. In December, 1.940, Mao Tsetung traveled to lloscow for the purpose of consolidating the Sino-Soviet alliance. Some ooservers insist that, during these discussions, the two Communist leaders agreed upon a. strategy for the conquest of Korea and the rest of Asia. china expert Allen s. Whiting observes that it was "highly unlikely" Ifao was not aware of the Korean operation. Yet, he also notes that economic weakness and the continued existence of Chiang's regime on Taiwan meart that ao must

- have harbored reservations resarding the logic of such a venture. Whiting concludes that China "lacked direct responsibility for its initiation or outcome," but ggreed reluctantly to support the operation.

Despite all this speculation, it remains extremely difficult to determine with any desree of certainty the precise nature of the coordination betiveen Moscow, Peking, and Pyongyang. There is no proof that hoscow possessed foreknowledge of the DPok invasion, let alone having ordered and directed the entire operation. ${ }^{25}$ In the spring of 1.950 , only three to eight Soviet advisors remained with each unit

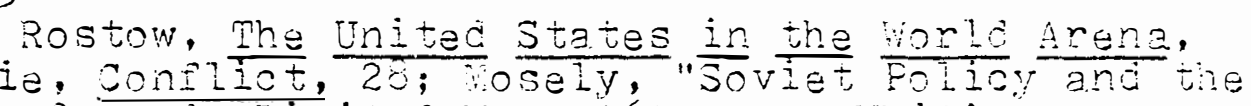
169; Leckie, Conflict, 28; osely, "Soviet Folioy and the these conclusions, Orina crosses the Yalu, 29 and 36 . 74

1.83.

$$
\begin{aligned}
& 75 \text { Witing, China orosses the Yalu, } 19 \text { anc } 45-46 . \\
& \text { Beloff, Soviat Foreign Policy in the Par easto, }
\end{aligned}
$$


of the DPRK army. Ferhaps more important, unless the North Koreans were determined to use force to reunify Korea, Stalin could never compel them to invade the south. The Korean conflict was more a civil war than an outside aggression.

A considerable amount of information points to the improbability of Soviet active support for the North Korean invasion. First, if Stalin wanted to deter a strong Japanese-American alliance, overt aggression in Korea was certainly a foolish strategy for achieving this result. Such a. flagrant attaok on the status quo would only reinforce Jacan's dependence on American orotection and Truman's determination to defend the Japanese islands. As John Gunther observed shortly after the attack, "the korean War proved that . . the overwhelming majority of Japanese are loy.l to the occupation."

roscow also suffeced a serious loss of international prestige in the wake of the Korean invasion. The Soviet Union sacrificed a considerable degree of support and sympathy among neutral nations, who believed that the DPRX was acting under Stalin's orders. Stalin had been engaged in a "peace offensive" since 1.94a, carefuliy cultivating cordial relations with non-aligned nations. By the spring

Lloyd $C$. Gardner, "Truman Era Foreion Polioy:

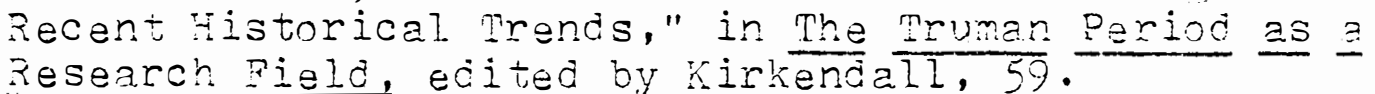
$\frac{\text { Research Field, ecited by Kirkendall, } 59 .}{77}$ Cunther, The Riddle of MacArthur, 1.63 . 
of 1950, many states viewed NAn as provocative and considered a rearmed west Germany as a threat to international peace. The Korean invasion reversed a trend favorable to the Soviet inion and producad serious doubts regaraing Stalin's sincerity.

Outright invasion not only destroyed Stalin's postwar political strategy, but also contradicted the pattern of Soviet military action after 1.945. Stalin had avoided acventurism in the cold war, relying instead on the tactics of infiltration and subversion. The Korean attack represented . sharp contrast with Moscow's essentially cautious approach. It remains the only case in the postwar period of an overt lise of Commun.ist armies across an internationally recoenized frontier. 79 rore important, the invasion alarmed the ivest and caused the United states to embark on a largesoale and rapid program of rearmament. In view of the costs involved, one must question whether stalin placed sich $a$ hioh oriority on rorean unification.

Shulman, Stalin's Foreign Folicy Reaporaised, 1.40-144; Halle, The Colo tar as History, 1.9; Tilbur Hitchook, "North horea jumps the Gun," Current iistory, XX, 1.1 .5 (narch $20,1.951.), 137-1.38$; Bel1, negotiation From Strength, 21.3; Dryove Iie, In the Cause of peace (row York: acmilian, 1955$)$, 329 . 79

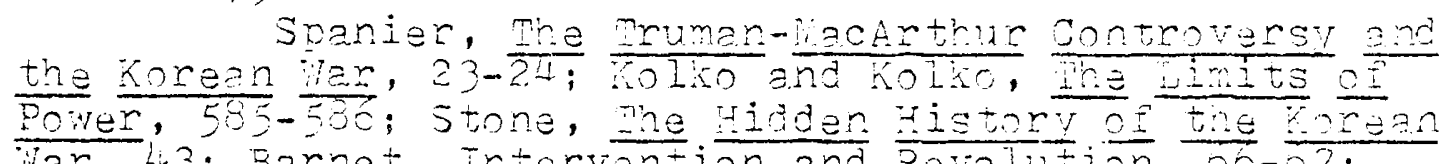
iar, 43; Earnet, Intervention and pevolution, ob-o?;

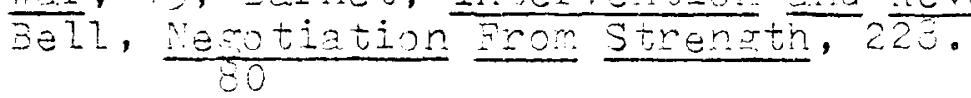

Hitchcock, "North Korea Jumps the Gur," 1.38-1.39; BeIl, Nerotiation From Streneth, 228. 
Events at the Inited Nations produced arother unfavorable cursequence of the Korean conflict for the Soviet Inion. The international organization soon emerged as the staunch defender of South Korea against the northern ageression. Cartainly Stalin could not have welcomed this turn of events, since the opportunity to discredit the united Nations would not compensate for the damage inflicted upon Woscow's imaze internationally. Perhaos viorse, the Korean conflict transformed the United Nations, albeit temoorarily, into an anti-Communist alliance. Assuming that stalin desired Chinese representation in the international organization, the invasion virtually eliminated any chance of Peking's admission. There remains only one reasonable explanation for Moscow's failure to have its representative at the Security council at the time of the attack-Stalin had no knowledse that the invasion was to occur on June $25,1.950$.

\section{$V I$}

Substantial evidence exists to support the conclusion that Kim Il-sung and his cohorts were responsibie for the attack on South Korea. As wilbur H. Zitchcock explaired shortly after the asseult, "ihe soviet Union ir fact aid not initiate the war, Eand, far from throwing the switch, was just as surprised as was the vestern innld when the

31 .

Sirmons, The Strained Alliance, 1.22-1.23; Fitchcock, "Nortin "orea Jumps the Gin,"1.43. 
North Koreans threw the switch!" 82 By 1.950, certain events decreased the Iikelinood that the DPRK's reliance on subversion and infiltration alone would result in successiul reunification. First, the elections in South Korea seemed to indicate progress tcward democracy. Second, aconomic conditions were beginning to improve. Third, the United States nad decided to increase military aid to South Korea. Finally, Acheson's Press Cluc Speech probably impressed Kim Il-sung far more than it did Stalin. The North Koreans did not think that the United States would defend South Korea in the aftermath of an invasion.

Commentators who stress Soviet responsibility for the Korear conflict obscure the essentially domestic nature of the dispute. 3oth Koreas nated each other and were merely waiting for the first opportunity to engase in a war of liberation. The North Korean attack was nothing more than a local decision to turn to force for the achievement of reunification after subversion failed. Both sides were determined to end the partition and were more than willing to use force to obtain this objective. One can hardzy disagree with Derna Frank Fleming's conclusion that Syngnan

\footnotetext{
82 83 $22 ?-228$ Hitchoock, "North Korea Jumps the Gur," 142. Paige, "Korea," in Communism and Revolution, 84

Fitahcock, "North Korea Jumps the Gun," 142; Flemine, The oold fiar and Its orioins, Vol. II, 605-605; Gordenker, The united iations and the peaceful unificatirs of Korea, 241.
} 
Rhee did not start the war "only because the Reds beat him to it."

Mao's victory in China had a decided impact on Kim Il-sung and his cohorts. "To accuse the North Koreans of being unwilling to take the same risks as the Chinese communists before them," Joungwon A. Kim observes, "woula be. tantamount to charging them with cowardice." June, 1.950 , seemed a particularly good time for the invasion. Hoscow had recently sent new military equipment and the elections had weakened Rhee's political position. 8 ? Nore important, there exists abundant evidence that the North Koreans expected the people of South Korea to welcome the assault ano join in a rebellion against the Rhee regime. The North Korean army, for example, halted after crossing the parallel and took three days to travel the fifty miles to seoul. Clearly, Kim II-sung was waiting for the southern populace to support his "war of liberation." Unforturately, the surprise invasion, following talk of peaceful unification, bewildared and disillusioned many koreans. In the wake of

\footnotetext{
86 Fleming, The Cold War and Its origins, 606. 37 Kim, Diviaed Korea, 1.73.

Hitchcock, "North Korea Jumps the Gun," 1.42:
} aavid Horowitz, Free Horld Colossus (New York: Yill and Wang, 1.955$), 1.21$.

Barton J. Bernstein, Commentary, in The Pruman Period as a Research Fielo, 180; Strobe Taloott, trans. and ed., Khrushchey Remembers, vol. I (Bostnn: Little, 3rown and Company, 1.970), 369; Hecio, Oral ت̈istory Interview Transoript, December 27, 19?3, USTL, 1.0-1.1. . 
the attack, virtually all sympathy and tolerance for Communism in South Korea varished.

Robert K. Simmons provides the most effective explanation for the North Korean attack of June 25,1950 . He argues that Stalin had agreed to suoport Kim II-sung's attempt at forcible reunification, but had set tre date for the thrust as August 7, 1.950. At that time the Soviet Union would have returned to the United Nations and prepared an appropriate public response to the charge of aggres90 sion. The DPRK attack was premature, coming six weeks before schedule, because of an internal political cispute between Kim II-sung and Pak Heun-yong. After Rhee's campaign against the radicals forced Fak and his sucporters to flee northward, the southern Communists began to press for an invasion of the RlK. Pak stressed that tine task would be relatively easy, in view of popular unhapoinass with Rhee, rising sympathy for the leftists, and the strong popular desire for some kind of a settiement. lorth Korea's leaders finally ordered an assalit for one of two reasons. Kim may have sought to outflank Pak politically and receive credit for the anticipated

\section{Paige, "Korea," in Communism and Pevolutinn, 239. 90 \\ Simmons, The Strained tllianod, 1.23 and 1.25; Ṡs} also, Robert $\mathrm{K}$. Simmors, Comments, Ghina auarterly AprilJune 1.9?3), 356.

Simmons, The Strained Allience, 1.04-1.06; Rojert K. Simmons, "The Korean civil var," in tithout parallel, edited by Baldwin, 149. 
successful reunification. On the other hand, Pals may have Forced a vote on the issue to undermine Kim's political position. If Kim opoosed the decision for invasion, he would be guilty of vaciliation and weakness after the attack succeeded. $^{92}$ In either case, the rather aorupt decision for war explains the North Korean army's lack of complete mobilization on June 25. This scenario also effectively explains Hoscow's absence from the United Nations on the day 0 i the attack. 93

Stalin had Iittle room to maneliver in the aftermath of the surprise attack in Korea. It is true that noscow did not prevent the DPRK from attacking and supolied considerable amounts of military equipment for the operation. But, as Frank Baldwin explains, this fact does not prove "that the attack was conceived in Noscow as part of world communism's timetable to destroy the west." 94 In reality, the North Koreans were acting in their own interests in opting for forciole reunification. Political infighting in Pyongyang, not Stakin's orders, determined the timing of the operation. The Korean invasion was also not entirely unprovoked, since Rhee's rhetoric indicated his implacable

Simmons, The Strained Alliance, 1.08; Simmons,

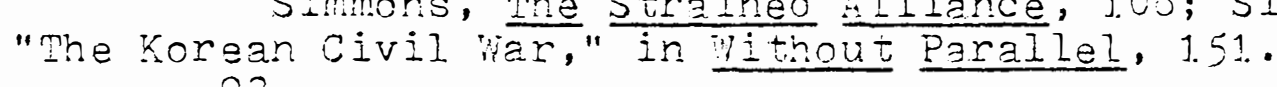
93

Kenneth Ireram, Fistory of the Cold VIar (Eondon: Darwen Finlayson, 1955), 208; Stone, The tide thistory of the Korean War, 54; Department, of State, North Korea, 1. 1.5 Baldwin, Introduction, in without Parallel, 1.4- 


\section{5}

hostility to the DPRK. 95 Although one cannot condone such

a blatantly aggressive act, one can certainly understand the reasons for the North Korean invasion. Open warfare between the two Koreas was the logical and inevitable outgrowth of the Korean civil war.

Nikita Khrushchev's memoirs, though hardiy an incontrovertible sourca, provide substantiation for the Simmons' scenario. Khrushchev explains that Kim Il-sung came to Noscow in the fall of 1.949 and applied heavy pressure on Stalin to aporove an attack on South Korea. Kim stressed that at the "first poke" militarily, the South Korean penple would instigate an internal rebellion against the Rhee regime. "Naturally," Khrushchev insists, "Stalin couldn't oppose this idea," without undermining "Nosoow's reputation as a staunch defender of revolutionary movements. Yet, Khrushchev notes, "Stalin had his doubts" and "was worried that the Americans would jump in, but we were inclined to think that if the war were fought swiftly-and Kim Il-sung was sure that it could be won swiftly- then intervention by the USA could be avoided."

If Khrushohev's account is accurate, Stalin asreed to

\footnotetext{
5

Paige, The Korean Decision, 349; Simmons, "The Korean Civiz Wian," in Without Earallel, 1.4k and 150. 96

H.A. Deweerd, "Lessons of the Korean "War," Yale Rəview, KI (Surmer 1.951). 593 .

malbott, trans. and ed., Knrushchev Rememicers, Vis. I, 367-368.
} 


\section{6}

the Korean invasion only with a considerable desree of reluctance. He hoped that the international community would view the conflict as an internal dispute in which the DPRK was engaged in the liberation of its countrymen. If Stalin rejected fim's plan, the possibility clearly existed that North Korea would launch an attack in defiance of the will of the Soviet Union.

Truman and his advisors were unable to engage in a carefully measured and closely reasoned evaluation of the Korean conflict. The Administration viewed the attack in the context of the Soviet-American confrontation. Paeviously, noscow apeared to be concentrating its efforts on expansion in europe, but stalin now evidently decided to shift his emprasis to Asia. The use of direct military means, however, was by far the most disturbing aspect of the entire affair. In his initial response to the attack, Truman exclaimed that the invasion "makes it plain beyond all doubt that the international communist movement is orepared to use armed invasion to conquer independent, rations." 1.00 For the Administration, the DPRK assault was

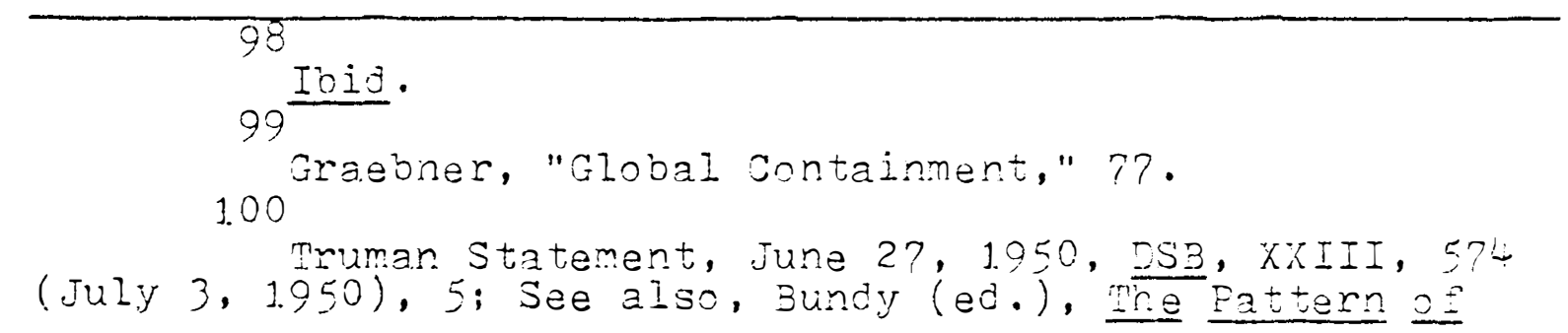


not aimed at the limited goal of reunification, but was nothing less than the first thrust in a Soviet-directed "Grand Design" for world conquest.

American foreign policy operated under serious handicaps in June, 1.950, which virtually precluced unemotional and coldiy rational action. The attack was a complete surprise and only swift action would preserve the survival of South Korea. Understandably, the Administration hastily accepted the most obvious assumptions and drew simplistic conclusions. Within a few days, Truman reversed Acheson's carefully considered Asian policy, divorced it from national security considerations, and adopted a global approach to 1.03

the Soviet challenge. Acheson, for example, began from the premise that "the Soviet Union has comolete domination over the Government of North Korea." The Secretary of State considered the attack a dire threat to American security and world peace. Somewhat simplistically, he observed that Stailn's "dagger thrust pinned a warnin: notice to the wall which said: "Give up or be conquered!"

Responsibility, 245 . 101 History, 23?

Smith, Dean Acheson, 189; Halle, the Cold tar as

Paige, The Korean Decisinn, L; Fehrenbach, This Kind of War, 1.62; Pid gway, The Korean Har, 229-230.

Kennan, Memoirs 1.925-1950, 396; Fleming, whe

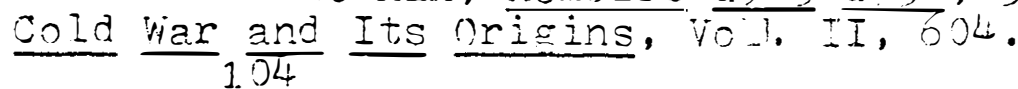

Acheson Testimony, Military Situation in the Fan east, Vol. III, 1936 and 1.73 .5 . 
American leaders considered the Soviet challenge in Korea as largely symbolic in nature. After all, the protection of South Korea bore no direct relationship to the national security of the united States. Instead, the North Korean attack constituted a challenge to American prestige and credibility. 1.05 Truman could not permit the DPRK to overrun South Korea. Not only did the United States have a moral commitment to defend the ROK's sovereignty, but "the worid regarded Korea as an American protege, and American prestige in Asia hung in the balance." 1.06 If the United States allowed the ROK to collapse, few nations wolid place confidence in American pledges of support. Thus, the issue in Korea was essentially political, rather than military. For the Administration, the lessons of Manchuria, Ethiopia, and Munich were of paramount importance in determining America's reaction to the Korean crisis. If the United states did not halt Soviet expansionism in Korea, Stalin would merely continue to increase the area of Cormunist domination. As Acheson explained in June, 1951:

As a people we condemn aggeression ot any kind.

1.05 Charles Loforen, "Confress and the Korean Conflict," Unpublished Fh.J. Dissertation, Stanford University, 1.96́, 1.3; Spanier, The Truman-vecArthur Controversy and the

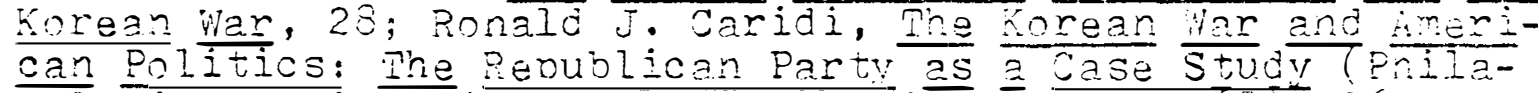
can Politics: The Rebublican Party as a Case Study (Ṕ:

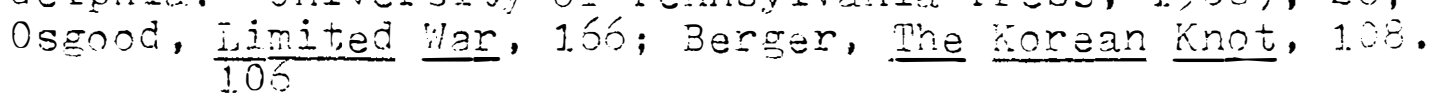
Fehrenbach, whis Kind of Har, 80; See also, povere and Scrilesinger, The General and the Fresident, oc; Kennan, Vemoins $1.925-1.950$, 486. 
We reject appeasement of any kind. If we stood with our arms folded vhile korea was swallowed uo, it would have meant abandoning our principles, and it would have meant defeat of the collective security system on which our safety ultimateiy depends.1.0?

If the United states successiully repelled azgression in Korea, Stalin would respect the strength and determination of the "free world" and abandon further "aggressive moves." Acministration spokesmen focused a considerable amount of attention on the global nature of the Korean argression. John Foster Dulles was perhaps most effective in expressing tha Administration's appraisal of the meanins of Koraa. Fe stressed that "one thing is certain, they dia not do this purely on their own out as part of the world stratery of international communism." South Korea had been experiencing great strides toward political democracy and economic stability. The Rhee eovernment, Lulles observed, had recently instituted land reforms and sponsored truly democratic elections. This "promising democracy" in thia embarrassed Stalin and his cohorts, who "found that they could not destroy it by indirect gogression, becalise the political, economic, and social life of the Republic was so 1.07

Acheson Testimony, Military Situation in the Fer East, Vol. III, 1.71.5; Truman, vears oI Trial and Fone, 34c; zalance of power," The Political cuarterly, XXY, 1. (JaruaryWarch 1.954), 23; Bundy (ed.), The Pattern of Resconsidility, $250-251$. 1.08 Lulies, CBS Interview, "A Militaristic ixneriment," ESZ, XXIII, 575 (JuIY 1.0, 1.950), 49-50. 
scund that subversive efforts, which had been tried, had 1.09

failed." The very success of containment in Korea, then, compelled Stalin to alter his tactics and turn to overt agoression.

Truman and his advisors suspected that Stalin would now revert to open military invasion in other areas. If the Soviets attacked South rorea because of its progress, there was a strong "possibility Soviet application similar reasoning to western Europe" and Taiwan. 1.1 .0 This alteration in Communist tactics appeared to demand a similar change in American strategy. "Korea shows," Dulles explained, "that Communism cannot be checked merely by building up sound economies." The United States nad to implement positive measures to strengthen the "free world" militarily, as well as economically. Dulles reasoned that "Since international communism may not be deterred by moral principies backed by potential. might, we must back those principles with military strength-in-being, and do so quickly." Since Stalin had indicated his intention to use armed force to 1.09

Dulles, July 31., 1.950, "Korean Attack opens lew Chapter in History," DSB, XXIII, 579 (Aughst 5, 1.950), 20?21.0; Dulles, "A rilitaristic experiment," 49-50; Dulles, "To Save Fumanity from the Deeo Abyss," New vork Times iracazine, July 30, 1950, 34; See also, Theoharis, Seeds of Repression, 62 .

Washington to mokyo, June 27, 1950, WacArthur Papers, RG 6, Korea. File 1., Dint. 1.1.1.

Dulles, "Korean Attack opens a New Chapter in History," 207-21.0; Dulles, "U.S. Military Action in Korea," July ?, 1950, DS3, XXIII, $576($ July 7, 1.950), 88-92. 
destroy "wholesome" nations, the United States had to develop the capability to respond militarily and on a global basis in defense of the status quo.

Americans generally supported Truman's decision to defend South Korea. The public quickly accepted the Admiristration's argument that Communism was monolithic and roscow directed its actions. The Cold war atmosphere facilitated a favorable reception even of the use of combat forces in 1.1 .2

deferse of the "free world." joseph and Stewart Alsop probably provided the oest sumary of the American response when they observed that noscow's real "goal is to make the living death of the slave society the universal condition of mankind, from the shores of the Atlantic to the islands of Japan, Irom the icy cliffs of Spitsbergen to the brieht sands of Cape Comorin." ${ }^{1.1 .3}$ The Alsops concluded that the United States had to rearm guickly and strengthen its alliance structure or Stalin would seize all of Asia. In due course, Europe vould fall as well and the very survival of the united States would be in doubt. only if the inited statas idas willinæ to take risks and make sacrifices would it be aiole to win the "titanic struggle for world domination."

\subsection{2}

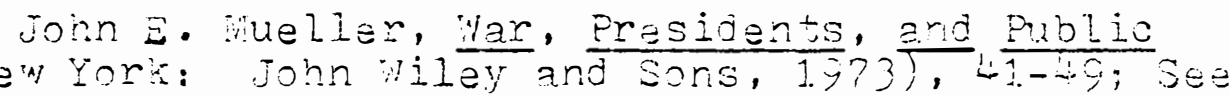

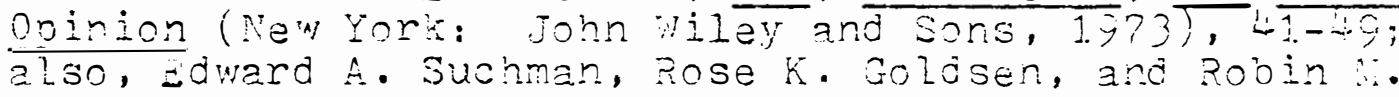
"Hiliams Jr., "Attituces Toward the Korean Var," Public opinion ovarterly, XVII, 2 (Summer 1.953), 1.71.-1.84. 1.1. 3 joseph and Steinart ilsno, "Whe Lessons of Korea," Saturday evening Fost, JCXXII, 1.0 (September 2, 1.950), 
Other journalists quickly appropriated the Administration's analysis of the meaning of the Korean invasion. Iime observed that there was "no doubt that moscow's guiding hand 1.1 .4

was present." Iven The Nation declared that North Korea's attack was "in the fashion made memorable by Aajolph Hitler." Wost commentators believed that the united states faced a "new Munich" and had to take decisive action to forestall another world war. 1.1 .5 If the United States remained inactive, Stalin would merely aggress again. "To let Korea go," Commonweal, explained, "would be to encourage sorties against the other weak spots adjacent to Soviet territory and sour on Soviet agæressiveness and enslavement." If the "iree world" threw back North Korean aggression, however, the internatinnal community would achieve renewed confidence in its ability to resist Soviet domination.

vost American observers hailed Truman's rapid and decisive action in response to the Korean crisis. Iife Nelcomed Truman's decision to intervene and fight communist expansion. It congratulated the president for his courage.

1.1. 4

Time, IVI, 1. (july 3, 1.950), 14-1.5; See aiso, The

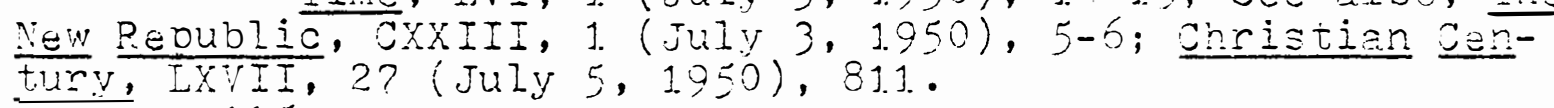
1.15 The Nation, SiI, 1. (July 1., 1.950), 1.5; See a?so, Zusiness 1.1.6́

Commonweal, XLI, 1.3 (July?, 1950), 307-308; Seo

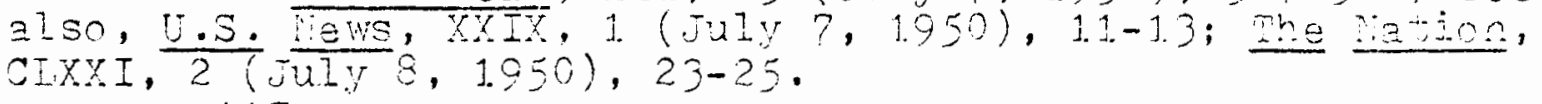
1.1.? Life, XXIX, 2(July 1.0, 1.950), 35 . 
noted that the "T.S. had davdled, temporized, compromised in Asia. Jut the Rec attrok in Korea had at last shocked it renounce containment and institute more positjve masures to alter the balance in Asia. Commonweal aggressively supportad a "policy which says bluntly to the Soviet Union that the time of legal fiction is passed and that the united states is at the head of a Iiberation movement, [Michl may convince the Russian leaders that they have gone too far." 1.1 .9

American foreign policy assumptions in 1950 precluged a rational gssessment of the korean conflict. As a reslitt, the Administration's public pronouncements on the war seriously misled the American public regarding the relationship between the war and the national security of the united states. Truman and his advisors ignored the domestic origins of the For th rorean assault and corcentrated instead or a giobalist interpretation. As Philio Jessuc observed in Ausust, 1950:

America is facing the most dangerous period in its history. It is of litmost importance trat Americans see clearly who and what are responsible for the dangers we face. Abrve all, the force of world communism and its leagers-the men in the Kremin-are reaponsible. 121 .

Saturaar Time, IVI, 1 (July 3, 1950), 1L-1.5; See also, Saturdar yening Eost, CXxII, 4 (July 22,1950$), 10$. 1.20 Commonweel, iti, j.5 (July 21. 1950), 359-362. Hichael S. Wwedt, "Mhe Var Rhetoric of Harry 3 . Truman During the Korear. Conflict," Unoublished Ph. E. Dissertation, Unitiersity of ransas, 1969. 1.21 Jessup Radio Interview, August 2?, 1.950, ES3, 
All events in Korea prior to June, 1950, indicated that civil war was likely, if not inevitable. Yet, when war finally occurred, American leaders concluded that the korean assault was a Soviet-directed challenge to international security and peace, rather than a limited threat to the status quo.

Truman attempted to Iimit direct involvement in the Korean civil war despite the fact that the lo assumptions demanded a more radical response. Only when North Korea threatened to overrun South Korea did Truman decide to use American troops to save the Rok. For the President, the global nature of the struggle was olear:

Right now, the battle in Korea is the front line in the struggle between freedom and tyranny. But the fighting there is part of a larser struggle to blild a world in which

a just and lasting peace can be maintained.1.22

Military strength alone, and the willingness to use it to resist Communist expansion, would preserve world peace and American security. As Acheson explained, "peace and security cannot be obtained by sacrificing the independence of nations to agaression." 1.23 mus, the Korean Var marked the besinnino of America's rellictant crusade to defend the vorld militarily against the threat of Soviet domination.

XXIII, 583 (September $4,1.950$ ), 374-378. 1.22

Pruman Radio Addrass, September 1., 1.950, DSg, XXII, 584 (September 1.1., 1.950), $407-41.0$. 1.23

Acheson Address, June 2?, 1.950, "Act, of Aggression in Korea: Peview of UN and US Action to Restore Peace," DSZ, XXIII, 75? (july 3, 1.950), 43-46. 
Conclusion 
American foreign policy reached a watershed in June, 1950. Prior to that date, Truman and his advisors remained uncertain regarding the nature and magnitude of the Soviet threat to the national security of the united States. The North Korean attack on South Korea convinced American leaders that the Soviet challenge was global and woula rely on open and armed agoression to expand the area of Communist control. As Truman explained in his memoirs:

In Korea, however, the world faced a new and bold communist challenge. Here for the first time since the end of World War II the Communists openly and defiantly embarked upon military force and invasion.1.

Such a dire threat demanded an extreme response. In the wake of the Korean attack, globalism emerged as the central feature of America's aporoach to international affairs.

For nearly two centuries, the United States had sought to limit its obligations to act positively for the preservation of world peace. American diolomacy after world ilar II represented no major break with this tradition. Although Truman and his advisors recognized the challenge of Soviet ideology and power, they hoped that the Unitad States could

Truman, Years of Trial and Lone, $464 ;$ See also, Acheson Comments, Datober 1.1.1953, Princeton Seminars, Acheson Papers, Reel 6, Tape 1., Hard, 2. 
rely on limited means to counter the threat. Containment was, in reality, an alternative to a complete commitment of American power and prestige in the struggle against the Soviet union. Truman intended to rely primarily upor economic aid and technical advice in an effort to build "situations of strength." The ultimate objective was to create the capability for local self-defense and thus remove the necessity for using American military power. Such a policy was relatively inexpensive and demanded few obligations for positive action in defense of the status quo.

Truman's approach to postivar international affairs was aimed ultimately at the elimination of the Soviet threat, but without resort to military means. American policy in Korea provides an excellent example of the essence of Truman's program. From 1945 to 1.950, the goal in Korea remained the creation of an independent, united, Westernoriented nation that would possess a progressive and democratic governmert. Truman had utilized various tactics and strategies for achieving this objective. he scught first to unilaterally liberate and occupy Korea, permitting the United States to reconstruct that nation without Soviet interference. When Stalin sent the Red Army into the peninsula, Truman had no choice but to seek a negotiated settlement. Unfortunately, Moscow refused to accept a trusteeshio agreement on American terms and stalemate ensued. After 1946, Truman decided that negotiations with the 
Soviet Union would not remove the 38 th parallel in Korea. He thus turned to containment as a liberating force. If the United States could create a prosperous South Korea, North Korea would realize the advantages of the American model of development and welcome reunification under South Korea's control. By June, 1950, the Administration's rhetoric portrayed South Korea as a successful test case for containment in Asia and "rollback" of the Soviet sphere of control seemed imminent. The North Korean invasion only confirmed Truman's belief that containment had been a success. The Communists had turned to outright aggression and military conquest only after subversion and infiltration failed.

Truman and his advisors drew other important conclusions from the North Korean attack. Policy Planning Staff member Paul Nitze effectively summarized the global nature of the Administration's reaction:

We rather looked at it as being a chess game, where if the other fellow took a pawn, this might vary well then lead to the bishops and the knights being involved, and evantualiy the rooks and the queen, ....2

Many of the global assumptions that American policy-makers had raised in NSC-68 now seemed accurate. As Achescr later explained, "Korea moved a great many things from the realm of theory. - into the realm of actuality and, .

Nitze Comments, October 1.1., 1953, Princeton Seminars, Acheson Papers. Reel 6, Tape 1, HSTL, 4; See also, Seyom Brown. "Korea and the Balance of Power," in Korea: Cold War
and Iimited War, edited by Cuttman, 250; Fleming. Whe Cola iar and Its orígins, ós9. 
urgency." ${ }^{3}$ The Soviet Union now appezred determined to conquer the entire world militarily. If the united states did not respond effectively, its own national security would ultimately confront grave danger.

Korea also firmly established in the American mind the notion of the Communist monolith. Previously, the Administration believed that nationalism was stronger than Communism, as Acheson's Press Club Speech demonstrates. Now, Truman and his advisors operated on the assumption that Moscon led "a powerful Communist bloc of nations. . bent upon seizing every opportunity to extend its sphere of control." Shortly aiter the outoreak of the Korean war, one State Department publication observed that "every single delegate in the United Nations knew that one gesture from vioscow, and the fighting in Korea would stor." sfter 1.950 , the United States was consistently unable to view military challenges to the status quo as anything less than

A.cheson Comments, Octojer 11., 1.953, Frincetor.

Seminars, Acheson Papers, Reel 6, Tape 1. HSTt, 1; See also, Lafeber. "Crossirg the 38th Parallel: The Cold War in Nicrocosm," in Reflections on the Cold Nar, 32; Gardner, Introduction, 4 The Korean War. 3 .

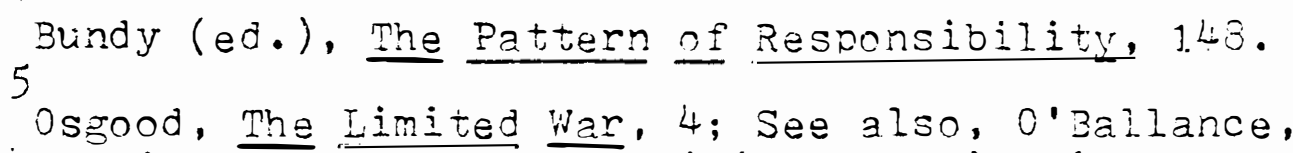
Korea, 1.47; Simmons, "The Korean Civil War," in Witrout Parallel, 1.56; Adlai E. Stevenson, "Korea in Ferspective,"

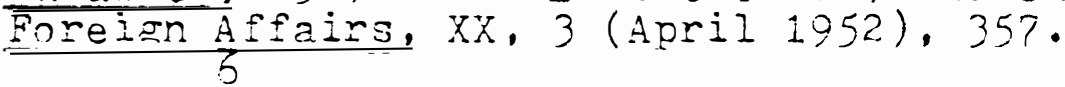

U.S. Department of state, Guide to the U.N. in Korea, Far Eastern Series \#47 (Nashington, D.C.: Covernment Printing office, August 1951), 16. 
Communist-inspired aggression.

Truman and his advisors also assumed that Koraa provided new validity for the Munich analogy. As Dean Rusk reasoned in August, 1950 :

To leave this attach unopposed would mean acts of aggression in other olaces and would almost certainly mean general war. To prevent a general war it was essential that those who are flirting with the idea of aggression be told immediately that they wolld encounter the organized rasistance of the entire world. The issue in Korea is world peace.?

Although American intervertion in Korea was risky, inaction in the face of aggression would guarantee a worse situation. Small nations would lose faith in the United States and Stalin would instigate rew adventures in search of further 8 conquest. In addition, appeasement in Korea would destroy the Unitad Nations just as surely as Manchuria shattered the Leapue of Nations. "On the other hand, if the "free world" confronted a superior Communist adversary and defeated it, Stalin might refrain from challenging the status quo.

Rusk Statement, "Battle Report," August 20, 1950, Mebb Papers, Box 23, HSTL; See also, 0sgood, The Limited War. 1.6́; Stevenson, "Korea in Perspective," $\overline{35}$. 8

Acheson and Johnson Testimony, Military Situation in the Far east, Vols. III and IV, 1.71 .6 and 2585; ralle, The cold War as History, 208; Brown, "Korea and the Balance of power," in KoFea: Cold War and Iimited War, 250; Wilijam T.R. Fox, "Korea and the Struggle for Europe." Journal of International iffairs, VI, 2 (Soring 1952), 1.31; Eruks, Harr. S. Truman and the Russians, 270

Arnold Wolfers, "Collective Security and the iar in Korea," Yale Review, XLIII, 4 (Summer 195\%), 495-496; Poats, The Korean War, 298; Mitchell, "Counter Strategies in the Cold ivar," 7 ; Stevenson, "Korea in Persuective," 349. 
After the outbreak of war in Korea, American leaders concluded that only superior conventional military power would deter Soviet expansionism in the future. Truman's actions after June, 1950, constituted something of a revolution in American defense policy. 1.0 Acheson observed that the Korean conflict "was in part an opportunity to adopt openly a policy urgently recommended in private for some months previously." ${ }^{1.1}$ NSC-68's adoption and implementation seemed not only logical, but imperative if the united States was to preserve its national security. Konea thus ushered in a new period of large defense budgets and high taxes. American foreign policy turned into a hard shell of military production and deployments and security diplomacy.

American diplomacy daveloped decidedly militaristic attitudes after 1950. While military expenditures sepresented only ten percent of foreign aid in 1.950 , by 1953 this figure had risen to sixty-seven percent. The united States

1.0

Vinacke, The United States and the Far zast, 8081; Druks, Harry S. Truman and the Pussians, 20 ; Finters, "Collective Sacurity and the War in Korea," 492; vicGovern, To the Yalu, 1.98 .

Bundy (ed.), The Pattern of Resoonsibility, 7?.

Almond, The American People and Enreign Policy, Xv; Frederick J. Lawton, (Oral History Interview Transcript, JuLy 9, 1963, HSTI, 20; Cochran, Harry Truman and the Orisis Presicenoy, 348-349; 3ell, Negotiation from Strentin, 54; Lafeber, America, Russia, and the Cold ivar, 1.04; rancock, "The Impact of the Korean War on American 'ilitiary Stratezy," 30: Simmons, "The Korean Civil War," in Without Parallel, 1.57; Graebner, "Dean G. Acheson," in An Uncertain Tradition, 272; Mclellan, Commentary, in The Truman Period $3 s$ Research Fiela, isc. 
commitment to aid such Asian states as Indochina, Taiwan, 1.3

and the Philippines expanded greatly. The change in American policy toward Europe was even more profound. Prior to 1950, NATO's development had been rather slow, casual, and inefficient. 1.4 Now, the United States dispatched American troops to Europe and created a unified command. In addition, the United States strongly advocated the rearmament of West Germany. 15 previously, America had relied upon the creation of economic stability as the principal means for halting Soviet expansion in Europe. After 1.950, Truman placed great reliance on military power and Congress supported this marked change in defense policy regardlass of cost. Such a significant change in American foreign policy was the product of several factors. liost important, the Korean war constituted a major shock for American leaders. Few observers expected such an attack, but once it occurred

Rostow, The United States in the Norld Arena, 257; Brown, "Korea and the Balance of Power, "249 and 258; Gardner, Introduction, in The Korean War, 11.; Smith, Dean Acheson, 31.5-316; Bohlen, The Transformation of American Foreign Poicy, 1.14 .

\section{5}

Bundy (ed.), The Pattern of Resoonsibility, 76.

Steel, Pax Americana, 53 and 129; Lafeber, America, Russia, and the Cold War, 102; Rees, Korea, 445; Lafeber, "Crossing the 38 th Paraliel," in Reflectinns cn the Cold Vlar, 24?; Kaner, "I.F. Stone and the Korean War," in Cold War Critics, 247 .

Bundy (ed.), The Pattern of Responsibility, 7?-80; Be11, Negotiation From Strength, 38-40; 3ell, "Korea and the Balance of Fower." 29; Gardner, Introduction, in the Korean Nar, 11.-1.3; Bonlen, The Transformation of American Foreirn PoIicv, 1'. 
American prestige and credibility hung in the balance.

John Foster Dulles explained shortly after the attack:

of course, intervention implies a risk of war.

But then that was surely a clear implication of

the "Truman Doctrine" equivalent to a blank

check for ONE WORLD WAR with date unspecified and left for the Russians to fill in. You cannot state that you will protect free peoples everywhere against unprovoked aggression and hope that ro occasion will arise forcing you to nonor your signature.18

American leaders believed that stalin would continue to rely on the strategy of subversion. The outbreak of war in Korea shattered this assumption and "put in question whether the free morld was bluffing in the threat to counter violence with violence."

Truman responded quickly and decisively to the Soviet challenge in Korea. The President had demonstrated his preference for courageous and decisive action in the past and sought to avoid any hint of vacillation in the Korean affair. For Truman, Korea was a test of wills with roscow and he was determined to "hit them hard." 20 Truman thus personalized the issues involved in Korea, which produced an extreme response. His reaction was quite typical. As Bert

\footnotetext{
Collins, War in Peacetime, 41.; Rostow, The United States in the Norld Arena, $\frac{\text { Ar }}{1.9} 36$.

Dulles to Felix Norely, July 6, 1950, Dulles

Papers, rorea File, PUL. 19 20

Halle, The Cold War as History, 75-76.

Cochran, Harry Iruman and the Crisis Presidency, 313; Falle, whe Cold tian as History, 80; Rostow, The United States in the iorld Arena, 235 .
} 
Cochran observes, "There is no blinking the fact that when Truman] was crossed or frustrated, his instinct was to lash out like a madcap bar room brawler."

Political factors also played a role in determining the President's actions. The Republican Party had been highly critical of the Administration's foreign policy. Truman could not avoid positive action in Korea without inviting a storm of partisan protest. 22 Even after American intervention the political attack on the Administration intensified. In August, 1950, Republican critics denounced Truman for refusing to prosecute the war more vigorously ${ }^{23}$ Yet, Truman contributed to this breakdown of support with his global justification for American intervention. As Athan Theoharis observes, "to countenance military and political restraint - . seemed to be either a misunderstanding of the seriousness of the Communist threat or a dereliction of duty." Rerublican criticism had a decided impact or the Administration's conduct of the war. By 1952, Acheson was under slich heary attack that he "had to spend most of his

\footnotetext{
21

Cochran, Harry Trumar and the Crisis Presidency, 206. 22

Koenig (ad.), The Truman Administration, 7 ; Samuel Lubel1, The Future of American Politics (New York: Farpar and Row, 1.965$), 29 ;$ Gardner, Introdiction, in The rorean War, 4 . 23

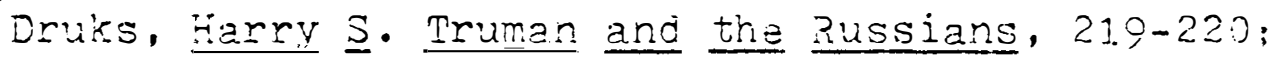
Spanier, The Truman-iacartiur Controversy and the Korear War, 63; Caridi, the Korean iar and American Poitiics, 54-55. Theoharis, Seeds of Reoression, 65-66.
} 
time demonstrating his anti-communism, and $2 \dot{5}$. had no room for any kind of flexibility in negotiation." In addition, it hardered the American attitude and led directiy to the decision to cross the 38 th parallel. Truman's need to demorstrate his anti-Communist credentials precluded carefully measured and reasoned analysis and acticn.

Truman's overreaction to the Korean conflict had a disastrous impact on the general American public. His emphasis on the global nature of the war meant that "without a study of the Korean Conflict itself, it was difficu?t to know. . what was happening in Korea." 2 ?ather than stressing Korea's importance to American national security and prestige, Truman focused attention irstead on the nigh idealism of American aims. ${ }^{28}$ spanier notes the dangers involved in such an approach when he states:

Whereas interests can, however, be compromised principles cannot. Their integrity, indeed their survival, can be guaranteed only by the total destruction of the enemy and the complete elimination of the evil wich threatens to 
contaminate, if not abolish them. Anything less than the fuil apolication oi "righteous power," and the achievement of complete victory, creates an embarrassing discrepancy between expectations and reality, and leaves in its wake disillusionment. 29

Yet, Truman's declining popularity and deteriorating political position almost required an idealistic appeal. In order to obtain public support, Truman oversold the importance of American intervention in Korea. In the process, the Administration misled and manipulated the American people.

Nore important, Truman's rhetorical justification for Korean intervention again placed the United States in the vanguard of a worldwide crusade for the achievement of universal principles of Iaw and justice. " The Administration considered the Korean incident as proof that Moscow was the essence of svil and determined to impose its political, economic, and social system in a piecemeal fashion on an unwilling world. ${ }^{32}$ The United states reacted strongly to this threat, shrouding its justification in tones of crusading zeal. As Seyom Brown observes, Korea "marked a

Spanier, The Truman-lacarthur Controversv and the
Korean $\frac{\text { War }}{30} 270$.
George $\mathrm{N}$. Elsey, Oral History Interview Transcript, Varch 9, 1965, HSTI, 87-88; 3arton J. Berratein, Commentary, in The Truman Poriod as a Research Field, 1.77; Edwin C. Hoyt, "The United States Reaction to the Korean Attack," American Journal of International Law, IV, 1. (January 1.961.), ?0; William Aopleman Williams, The Tragedy of American Diolomacy (New York: Deli Publishing Company, 1.972), 273. 31. Osgood, Limited War, 1.66 . 32

Paige. The Korean Decision. 352. 
globalization of containment in terms of operational commitments as well as rhetoric." 33 without iruman's global analysis of the nature of the Soviet threat, subsequent American leaders would have had difficulty justifying positive action in such places as Indochina and Taiwan. Globalists believed after Korea that the Soviet-American struggle would quite literally determine the fate of the world. In such a confrontation, all available means had to be used to halt the Soviet advance, including military power.

Ernest R. May correctly emphasizes the crucial importance of the "lessons of the past" in determining Truman's actions. American leaders in 1.950 had Iived through the interwar period and remembered vividly Hitlerite agoression. For Truman and Acheson, Soviet expansionism was identical to Hitlerism and apoeasement could not remove the threat. "We have learned bitterly and tragically from two calamitous world wars," Truman explained in his memoirs, "that any other course would lead to yet.another world war." Inuman's

Brown, "Korea and the Balance of Power," in Konea: Cold War and Iimited War, 255; See also, Gardrer, "Truman Era Forei policy: Recent tistorical Trends," in The mruman Period as a Research Field; Middleton, The Compact History of the $\frac{\text { Korean war. 231.232. }}{34}$

Almond, The American People and Foreizn Policy, 159; Steel, Pax Americana, 302; Lofgren wrongly blames Cor:gress for failing to focus on the vital problems involved in Korea. In reality, Truman's globalism prevented clear understanding of the war, "Congress and the Korean Conflict," 232. 35 Vay, "Lessons" of the Past, 85-86. 
reliance on history meant that the Administration's deliberations did not indicate any serious analysis of the alternatives. There was never any question that the United States would ensure the survival of South Korea. History and colicy assumptions, rather than a realistic assessment of America's national interests, determined Truman's decision to intervene.

A belief in the existence of a Communist monolith and the validity of the Wunich analogy precluded an accurate assessment of the meaning of Korea. The North Korean assault was, in fact, a manifestation of Asian nationalism. Richard J. Barnet notes the relatively typical nature of the incident when he observes that "contemporary wars have been rights for the rights of various political groups with former colonial appendages of Europe to take political power and to exercise it on their own terms." 37 Both Koreas considered their counterparts an illegitimate usurper and were determined to establish control throughout the peninsula. Truman viawed North Korea's aspirations in the larger context of America's global competition with the soviet union. 38 In some respects,

$$
36
$$

Truman, Years of Trial and Hooe, 464 ; Vay, "Lessons" of the Past, 33 ; Graebner, "Global Containment," $\overline{77}$. Barnet is a New Lefthistorian, he accents the traditional view that Moscow ordered the North Korean invasion. 38

Barnet, Intervention and Revolution, 26; Baldwin, Introduction, in without Farallel. $1.6 ;$ Halie, whe onld War as History, 1.90; Ambrose, Rise to Globalism, 307. 
Korea represerts an early example of the breakdown of the bivolar postwar international system. Both Koreas sought to araw the major powers into what was essentially a local ispute and exploit 39 ispute and exploit them for their own advantage.

Ancther significant outgrowth of Korea was that the conflict delayed any attempt at a Soviet-American rapprochement for almost two decades. The "Truman Doctrine" started this process of hardening America's attitude toward the efficacy of negotiations, but the Korean War convinced policy-makers that Stalin did not want a diplomatio settlement. The framework of American foreign policy became increasingly rigid and the nation's policies and programs far more inflexible. Norman A. Graebner perceptively summarizes this point when he states:

The administration's fundamental refusal to recognize the power revolutions of the forties, either in zurope or Asia, carried with it an illusion of ominipotence which seemed to guarantee the ultimate victory of the wiest, over its communist enemies. Yet, the nation could erect no force commensurate with the princioles and pressures that determined its objectives abroad. . . Unable to employ either its power or its diplomacy, the ration could escape its diplomatic and intellectual dilemma only by assuming a world of unrelenting hostility in which diplomacy had no place. 41

Bell, "Korea and the 3alance of Power," 29.
40 Hertmann. Truman and tre 80th Congress, 21.6; BeIl, "Korea and the Balarce of Power," 29; Reitzel, Kaplan, and Coblenz, United States Foreion Policy, 302 and 323 ; Graebner, Ideas and Diplomacy, ?21. 41.

Graebner, Cold War Diplomacy, 50; See also, Denis if. Brogan, "The Illusion of American Omnjpotence," Farver's, 
In the wake of Korea. American foreign policy moved far to the right. Only after several vears would leaders emerge who did not consider regotiations a waste of time.

Dean Acheson later explained that Korea proved the viability of collective security. Stalin's "Korean check" had not "bounced" on the "bank of collective security," but had been paid in full. The American secretary insisted that, as long as the United States accepted the challenge of soviet aggression, world peace was secure. If the Soviet union. was unable to expand, it would eventually become frustrated and either "mellow" or "wither away." "Time is on our side," Acheson argued, "if we make good use of it." Such an approach not only made negotiations superfluous, it also prevented the acceptance of any alternative to a continuation of the status quo. Forcible change would undermine the American security system. Yet, the very essence of diolomacy is the search for adjustment and compromise, but mruman rejected this maxim. Unfortunately, his analysis of rorea obscured the realities of power because it promised victory

CCV, 1231. (December 1.952), 21.; Norman A. Graebner, The New Isolationism: A Study in Politics and Foreign Policy Since 1.950 (New York: The Ronald Press, $\frac{19}{1.95} 5$, 21. 42

Famoy, Beyond the New Deal, 429; Bell, Negotia-

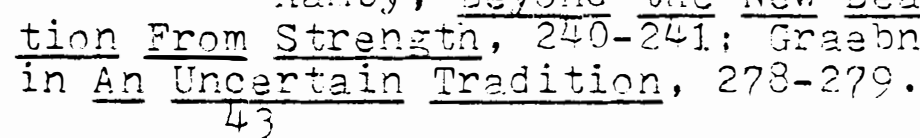

See quotation cited at the outset of this stury, Bundy $(\underset{44}{e d .})$, The pattern of Resonnsibilitiv, $253-254$.

Quoted in Spanier, The Truman-MacArthur Controversy and the Korean Var, $250 ;$ Rees, Korea, 449. 
through continued stalemate and inaction. 45

At the same time, Korea poorly prepared the American people to confront and understand the actual nature of the Soviet-American confrontation. Truman's interpretation meant that the general public could not accept a limited view of Stalin's objectives nor the reality that the united States could not "wish" the Soviet union out of existence. Kennan notes that this reaction finds its roots in American tradition:

Our adversaries, in the ingrained American way of looking at things, had always to be demonic, monstrous, incalculable, and inscrutable. It was unthinkable that we, by admitting that they sometimes reacted to what we did should confess to a share in the responsibility for their behavior. 46

It was Truman's obligation to counter such notions and educate the American people to the impossibility of obtaining perfect security. Instead, Truman consistently refusec to formulate goals that were rooted in historical national interests and within American poiver to achieve. American policy was, after 1950, even more tied to ideas of morality and invincibility than before the outoreak of war in Korea.

In the final analysis, the Korean conflict destroyed all vestiges of uncertainty and vacillation in American foreign

\footnotetext{
Iipoman, The Cold War, 50; Steel, Pax Amenicana, 310; Bell, "Korea and the Balance of Power, 3.7. 46 4? Kennan, Memoirs 1.925-1950, 198. Graebner, The New Isolationism, 4-5 and 248 .
} 
policy assumptions regarding Soviet intentions. After 1950, the United States believed that Stalin sought world conquest and this threat demanded an extension of American commitments to defend the status quo. No longer would America withdraw from a world of turmoil or limit its involvement in international affairs. Ronald Steel reveals the essential disadvantage of such an approach when he states:

Every spot on the globe is not equally vital to American interests. . . . Like all great powers, we are interested in orises whereever they occur. Jut all crises are not equally important to olir security, and it is on the basis of national security that an enlightened foreizn policy must rest. 49

Instead, Truman inaugurated a global approach to the problem of ensuring Arerican national security. After Korea, every challenge to the status quo assumed the character of a nev Soviet threat to Norld peace, which the United States could tolerate oniy at grave risk.

American intervention in the Korean conflict came after Truman had labored long and hard to extricate the United States from the peninsula. The action was not entirely ill-advised and inappropriate, since the cestruction of the Rok would clearly undermine American prestige and credibility in the international community. Unfortunately, Truman decided to interpret and justify American policy in globsl

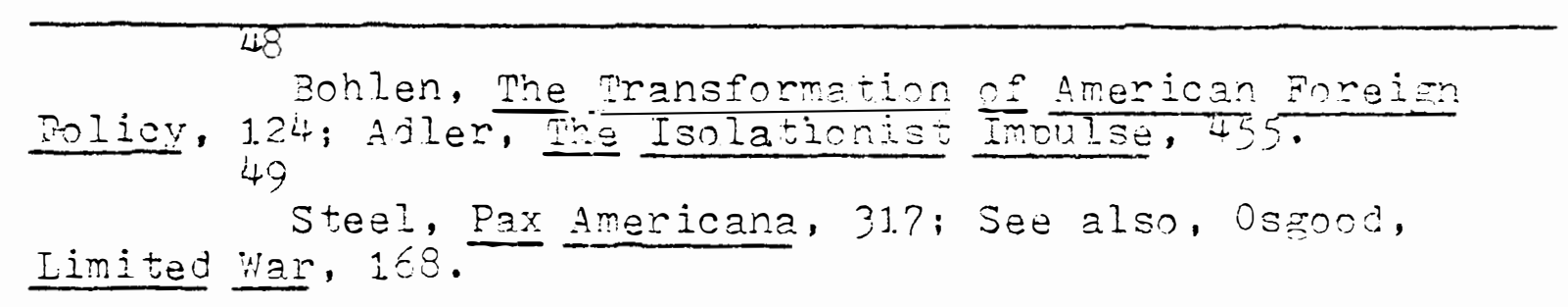


terms anoj with disastrous consequences during later years. After 1950, the United States increasingly tied its national security to cliants, agents, and satellites throughout the world. These "unassailable barriers" possessed inherent weaknesses and presented the United States with a series of insoluable dilemmas. American foreign policy, as Walter Iippman predicted, would frequently confront the distasteful choice of having "either to disown our puppet which would be tantamount to appeasement and defeat and the loss of face or must support them at an incalculable cost on an unintended, unforseen and perhaps undesirable issue." Truman ignored the dangerous implications of his globalist approach. In - the aftermath of the Korean attack, the United States rejected the necessity for balancing ends and means in foreign afiairs and embarked reluctantly upon a glocal crusade to defend the status quo. 50

50

Iippman, The Cold ian, 16. 
Primary and Secondary

Source Bibliographies 


\section{Primary Sources}

\section{Nanuscriot and Archival Collections}

Acheson, Dean G. Harry S. Trumar Library. Independence, Missouri

Byrnes. James $F$. Clemson University Library. Clemson, South Carolina

Clifford, Clark M. Harry S. Truman Library. Independence, Nissouri

Donnison, Robert I. Harry S. Truman Library. Independence, Missouri

Dulles, Jonn Foster. Princetch Univorsity ibrary. Princeton, New úersey

Flsey, George $\mathrm{H}$. Harry $S$. Truman Library. Indopercience, ivissouri

Finletter, Thomas $K$. Farry $S$. Truman Iibrary. Independence, Missouri

Forrestal, James $v$. Princeton University Library. Princeton, New Jorsey

Hechler, Kenneth. Harry S. Truman Iiorary. Independence, Missouri

Hull, Cordell. Iibrary of Congress. Washington, D.C.

Jessup, Philip. Library of Congress. Washington, D.O.

Johnson, Edgar A. J. Farry S. Truman Library. Independenco, Missouri

Jones, J. Neidon. Harry S. Trumar Eibrary. Independence, Missouri 
Lawton, Frederick J. Harry S. Trumar Library. Independence, Missouri

Leany, william D. Library of Congress. Washington, D.C.

Lloyd, David. Harry S. Truman Library. Independence, Missouri

Locke, Edwin A. Jr. Harry S. Truman Library . Independence, Missouri

MacArthur, Douglas A. MacArthur Memorial Iibrary. Norfoli, Virginia

Vatthews, Francis P. Sarry S. Truman Library. Independence, Missouri

Murphy, Charles S. Harry S. Truman Library. Independence, vissouri

Pace, Frank Jr. Farry S. Truman Iibrary. Independence, Missouri

Patterson, Robert P. Library of Congress. Washingtor, D.C.

Spingarn, Stephen J. Harry S. Pruman Library. Independence, Missouri

Stettinius, Edward R. Jr. University of Virginia Library. Charlottesvilie, Virginia

Truman, Harry $s$. Marry S. Truman Iibrary. Independence, Vissouri

U.S. Departinent of the Army Archives. Army Stafi Eiles. Record Group 319. National Archives. Washington, J.C.

- Civil Affairs Division Files. Record Group 335. National Archives. Washington, D.C.

- Secretary of the Army Files. Record Group 165. National Archives. Washington, D.C.

U.S. Department of State Archives. Record Group 59. National Arohives. Washington, D.C.

U.S. Joint Chiefs of Staff Archives. Record Group 218. National Archives. Washington, D.C.

U.S. Office oi Strategic Services Archives. Record Group 226. National Archives. Washingtor, D.C. 
Vandenberg, Hoyt. Library of Congress. Washington, D.C. Neob, James $\mathbf{5}$. Harry S. Truman Library. Independence, Missouri

Memoirs, Personal Accounts, Collections,

Acheson, Dean G. Present at the Creation:
State Department. New York: W. W. Norton, 1.959 .

Byrnes, James F. Speaking Frankly. New York: Harper and Brothers, 1947 .

Collirs, J. Lawton. War in Peacetime: The History and Iessons of Korea. Boston: Houghton Miffin, 1969.

Eden, Anthony the Reckoning。 Boston: Koughton Mifflin, 1956 .

Grew, Joseph $C$. and Walter Johnson, ed. Turbulent Era: $\frac{A}{2}$ Diplomatic Record of Forty Years 1904-1.24 5 .

Hillman, William, ed. Mir. President: The First Publication From the Personal Diaries, Private Letters, Paders, and Revealing Interviews of Harry S. Truman. New York: Farrar, Straus and Young, 1952. Huil, Cordell. The Memoirs of Cordell Hull. 2 Vols. New

Kennan, George F. Memoirs 1925-1950. Boston: Little, Brown and Company, 1967.

- Memoirs 1950-1963. Boston: Little, jrown and Company, 1972.

Koenig, Louis $W_{.}$ed. The Truman Administration: Its Princioles and Practice. Mashington Square: New York University Press, 1956.

Leahy, William D. I Was There. New York: MicGraw Hill, 1950 .

Lio, Trysve: In tho Cause of Peace. New York: Macmillan, 1955 .

Macarthur, Douglas A. Reminiscences. New York: NicGraw Hill, 1964 . 
Millis, Walter, ed. The Forrestal Diaries. New York: The Viking Press, 1951 .

Ridgway, Natthew B. The Korean War. Garden City: Doubleday, 1967 .

Rosenman, Samuel I., ed. The Public Papers and Addresses of Franklin D. Roosevelt. Vols XI-XIII. New York: Random Fouse, 1950 .

Stimson, Henry L, and NcGeorge Bundy, ed. On Active Service in Peace and War. New York: Harper and Brothers, 1947 .

Talbott, Strobe, trans. and ed. Khrushchev Romembers. Vol. I. Boston: Little, Brown and Company, 1970.

Truman, Harry S. Memoirs. Vol. I: Years of Decision. Garden City: Doubleday, $1955^{\text {. }}$

- Memoirs. Vol. II: Years of Trial and Hooe. Garden City: Doubleday, 1956 .

Oral History

Beil, David 5 . Oral History Interview Transcript, April 20, September 1.2, and October 16, 1968. Harry S. Truman ilbrary. Independence, Missouri

Bruce, David K.E. Oral History Interview Transcript, Warch 1. 1972. Harry S. Truman Library. Independence, Missouri

Clubb, 0. Edmund, Oral History Interview Iranscript, June 26, 1974. Harry S. Truman iibrary. Independence, Missouri

Draper, William $\mathrm{H}$. Jr. Oral History Interview Transcript, January 11. 1972. Harry S. Truman Liorarjo Independence, Missouri

Flsey, George $\mathrm{M}$. Oral History Interview Transcript, February 1.0 and 17,1964 , Miarch 9,1965 , July 10 and $1.7,1.969$, and April 4, July $?$ and $1.0,1.970 .2$ Vols. Farry $s$. Truman Library. Independence, Missouri

Finletter, Thomas $K$. Oral History Interviow Transcript, January 20 and February $15,1.972$. Harry S. Truman Iibrary. Independence, Missouri 
Gilpatric, Roswell. Oral History Interview Transcript, January 1.9, 1972. Harry S. Trumar Library. Independence, Missouri

Lawton, Frederick J. Oral History Interview Transcript, June 17 and July 9, 1963. Karry S. Truman Library. Independence, Missouri

Leva, Marx. Oral History Interview Transcript, December 6 , 1969 and June 12, 1970. Harry S. Truman Iibrary. Independence, Missouri

Muccio, John J. Oral History Interview Transeript, February 10 and $18,1.971$. and December 2?, 1.973. Harry s. Truman Library. Independence, Missouri

Murphy, Charles S. Oral History Interview Transcript, Nay 2, June 3, and July 24, 1963, May 21, June 24, July 15 and 25, 1969, and May 19, 1970. Harry S. Truman Liorary. Independence, Missouri

Pace, Frank Jr. Oral History Interview Transcript, January 1 and 22, February 17 and 25 , and June 26, 19?2. rarry S. Truman Library. Independence, Missouri

Rigdon, William M. Oral History Interview Transcript, July 1.6, 1970. Harry S. Truman Iibrary. Independence, Missouri

Saltzman, Charles F. Oral History Interview Transcript, June 28, 1974. Farry S. Truman Library. Independence, Missouri

Tubby, Roger. Oral History Interview Transcript, February 10, 1970. Harry S. Truman Iibrary. Independence, Missouri

\section{Official Publications}

J.S. Congress. House. Committee of Conference. Conference Report or Foreign Economic Assistance Act $\frac{\text { Af } 1.250 .}{31.5 t}$ Cong., and sess., May $19,1950$.

- Committee of the Whole House on the State of the Union. Message From the President Relative to "Situation in Korea." T. Doe. 546. 31st Cong., 2nd sess., Jlily $\frac{19}{19}, \frac{K 50}{1950}$. 
U.S. Congress. Jouse. Committee on Appropriations. Supolemental Estimate for Assistance to the Republic

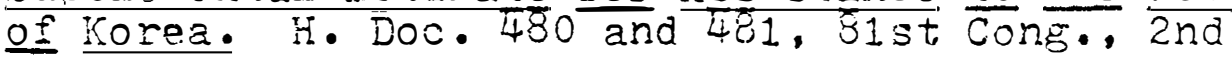
sess., February 2?, 1950 .

- - - Supplemental Estimate of Appropriation Continuing for Two ivonths the Present Program of Assistance to the Republic of Korea. H. Doc. 247, 81st Cong., 1st sess.. June 29, 1949. - Committee on Foreign Affairs. Aid to Korea. 2 Parts. H. Rept. 962 on H.R. 5330, 81st Cong., 1st sess., July 1, 1949。

- H. Rept. 2495 Pursuanground Information on Cong., 2nd sess., JuIy 1.1., 1950.

nomic Cooperation Act of $\frac{A}{19} \frac{B i}{48}$. Fe to Amend the Fco7378, 81.st Cong., 2nd sess., February-March, 1.950.

Certain Arojas in the Far Fast. He Rept. 1.571 to accompany S. $2319,81 . \overline{\text { st }}$ Cong., 2nd sess., February $1,1.950$.

- First $\frac{\text { Semiannual }}{\text { Prosram. Reort on }}$ 81.st Cong., 2nd sess., June $1,1.950$. - - Korean Aid. Hearings on H.R. 5330, 81st Cong.. 1s t sess.. June 1949. Foonomic Aśistance. 5 providing for Foroign accompany H.R. 7797. 81st Cong., 2nd sess., Viarch $22,1.950$.

- Senate. Committee of Conference. Conference Roport on Foreign Fconomic Assistance Act of 1950 . S. Rept. 168 on H.R. 7797, 81st Cong., 2nd sess., Nay 18. 1950.

- Committee or Aopropriations. Foreien Aid Appropriations for 1951. Hearings on Haking Appropriations for Foroign Aid for the Fiscal Year Ending June 30, 1951. and for Other Purposes, 8 ist Cong., 1st sess., 1950. 
U.S. Congress. Senate. Committee on Appropriations. Whird Deficiency Aopropriations Bill for 1.249. Hearings on H.R. 5300: Aid to Korea and Securities and Exchange Commission, 81st Cong., 1st sess, 1.949 .

Committee on Armed Services. Discussion on Foreign Military Aid and the Korean Situation. Hearings on $\mathrm{S} .3875, \mathrm{~S} .3727-$ Part 2, and H.R. 5074, 81st Cong., 2nd sess.. Juiy 6, 1950.

- Report to the President September 1947. By It. Ger. A. C. Wedemeyer, 82 nd Cong., 1st sess., 1.951.

with Reference to the Korean Statuation Edwin W. Pauley the korean Situation. 81 st Cong., 2nd sess., August 3. 1950 .

- Committee on Foreign Relations. Aid to the Republic of Korea. S. Rept. 748 on S. $2 \overline{319}$, 81 st Cong., 1st sess., July 22, 1949.

i950. 2 Pärts. S. Rept. Foreign Economic Assistance, Cong., 2nd sess., 1950.

Problem, Documents $1.243-1.953 \cdot$ S. Doc. $\frac{\text { Inited States }}{74}$, $\frac{\text { Korean }}{83 r d}$ Cong., 1st sess., July 30,1953 .

Joint Committee on Armed Services and Foreign Relations. Military Situation in the Fer East. Hearings to Conduct an Inquiry into the Military Situation in the Far East and the Facts Surrounding the Relief of General of the Arriy Douglas MacArthur from his assignment in that Area, 5 Vols., 82nd Cong., 1.st sess., 1951.

- Substance of Statements Made at Wake I sland Conference on october 1.5, 1.950. Compiled by Omar N. Bradley, 82nd Cong., 1st sess., 1951 .

U.S. Department of the Army. Economic Fosition and Prospects of Jaban and Korea and the Veasures Reguired to Improve Them. By Percy $\mathrm{H}$. Johnston, Paul G. Hof iman, Robert F. Loree, and Sydney H. Schever. U.S. Army Committee Report, April 26, 1948.

- Korea-1950. Washington, D.C.: Government Printing office, 1952 . 
U.S. Department of the Army. Military Advisors in Korea: KMAG in Peace and War. By Robert $K$. Sawyer and Walter G. Hermes. Washington, D.C.: Government Printing office, 1962.

- Policy and Direction: The First Year. By James F. Schnabel. Washington, D.C.: Government Printing office, 1972 .

- South to the Naktong, North to the Yalu (JuneNovember 1950 ). By Roy 5. Appleman. Washington, D.C.: Government Printing Office, 1961.

- Truce Tent and Fighting Front. By Walter $G$. Hermes. Washington, D.C.: Government Printing office, 1966.

U.S. Department of Commerce. Economic Conditions in South Korea, 1.247. International Reference Service, $V$, 1.31 (December 1.948).

- Fconomic Review of the ReDublic of Korea. International Reference Service, VI, 42 (June 1949).

- Fconomic Review of the Republic of Korea, 1949. Internaticnal Reference Service, VII. 58 (JuIy 1.950).

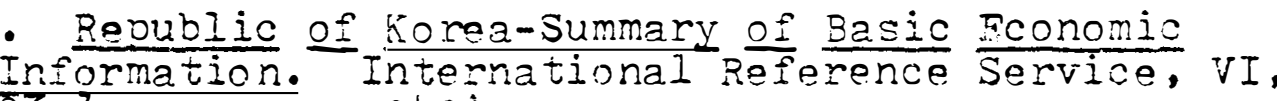
86 (september 1.949$)$.

U.S. Department of State. The Conflict in Korea: Dvents

Frior to the Attack on June 25. 1950. Far Eastern Series $\$ 45$. Washington, D.C.: Government Printing Office, 1951 .

- Decartment of State Bulletin. Vols. V-XXIX, $1.941-1953$.

- "Economic Cooperation with Korea Under Public Law 793-80th Ccngress." Treaties and Other International Acts Series. No. 1908. Washington, D.C.: Government Printing Office, 1949.

- The Fight Against Aggrossion in Korea. Far Eastern Series \#3? Washington, D. D.: Government Printing Office, Autumn 1950 .

- Foreign Relations of the United States, Arrual Tolumes Pertaining to Koroa and the Far zast, 19411.950. Washington, D.C.: Government Printing Office, $1958-1976$. 
U.S. Department of State. Foreign Relations of the United States. The Conference of Berlin (Potsdam) 2 Vols. Washington, D.C.: Government Printing ()ffice, 1960.

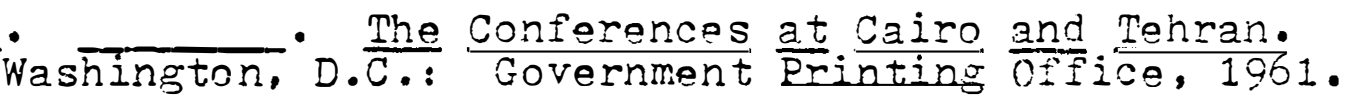
- The Conferences at Mialta and Yalta 1.245. Washington, D.C.: Government Printing Office, 1955.

Quebec 1943. $\frac{\text { The }}{\text { Washington, D.C.: }} \frac{\text { Conferences }}{\text { Government }} \frac{\text { Washinting }}{\text { Prington }}$ office, 1970.

- Guide to the U.N. in Korea. Far Eastern Series \#47. Washington, D.C.: Government Printing Office, August 1.951 .

- A Historical Summary of United States-Korean Rejations 1.834-1962. Far Eastern Series Washington, D.C.: Government Printing Ofiice, November 1962 .

- Korea. Office of Public Affairs. Washington, D.C.: Government Printing office, August 1951.

- Korea 1945 to 1.948: A Roport on Political Developments and Economic Resources with Selected Documents. Far Eastern Series \#28. Nashington, D.C.: Government Printing office, October 1.943.

- Korea's Independence. Far Eastern Series \#1.8. Washington, D.C.: Government Printing Office, October 194 ?

- Military and Security Measures fffective Until Completion of ivithdrawal of United States Forces From Korea." Treaties and Other International Acts Series. No. 191.8. Washington, D.C.: Government Printing office, 1949 .

- "Nutual Deforse Assistance: Agreoment Between the United States of America and Korea." Treaties and Other Internaticnal Acts Series. No. 21.9. Washington, D.C.: Government Printing Office, 1950.

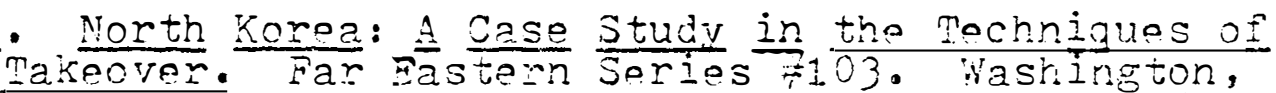
D.C.: Government Printing office, january 1961. 
U.S. Department of State. The Record on Korean Unification 1.243-1960: Narrative Summary with PrinciDal Documents. Far Eastern Series 101 . Washington, D.C.: Government Printing office, 0ctober 1.960 .

- United States Policy in the Koraan Conflict July 1950-February 1.951. Far Fastern Serios \#4. Washington, D.C.: Government Printing Office, September 1951 .

- United States Policy in the Korean Crisis. Far Eas tern Series \#34. Washington, D.C.: Government Printing Office, July 1950.

U.S. President. Public Paders of the Presidents: Harry S. Truman, $1445-1953$. Washington, D.C.: Covernment Printing Orfice, 1961-1966. U.S. SCAP. Political Orientation $\frac{\text { Of }}{\text { Soptember } 1948} \frac{\text { Tan }}{2 \text { Vols. Washington, D.C.: }}$ 1945Government Printing office, 1949 .

\section{Newsoapers and Periodicals}

Business Week

Catholic World

Christian Century

Colliers

Commonwe al

Iife

The Nation

The New Reoublic

The Now York Times

The Saturday Evening Fost

Time

U.S. Neins and World Reoort

The Washinetor Post 


\section{Contemporary Articles.}

Alsop, Joseph and Stewart Alsop. "The Lessons of Korea." Saturday Evening Post, CCXXIII, 1.0 (September 2,

Altstedter, Norman. "Problems of Coalition Diplomacy: The Korean Experience." International JournaI, VIII, 4 (Autumn 1953), 256-265.

Baldwin, Roger. "Our Blunder in Korea." The Nation, CLXV, 5 (August 2, 1947), 119-1.21.

Brogan, Denis w. "The Illusion of American Omnipotence." Harper's, CCV, 123,1 (December 1952), 21.-27.

Bunce, Arthur C. "The Future of Korea: Part I." Far Eastern Survey, XXIII, 8 (April 19, 1944), $\frac{\text { Far }}{67-70 .}$ - "The Future of Korea: Part II." Far Fastern Survey, XXIII, 10 (hiay 17, 1944), 85-88.

Dennett, Tyler. "In Due Course." Far Eastern Survev, XIV, 1 (January 17,1945$), 1-4$.

DeWeerd, H.A. "Lessons of the Korean War." Yale Review, XL (Summer 1.951.), 592-603.

Dubin, Wilbert B. "The Political Evolution of the Pyongyang Government." Pacific Affairs, XXIII, 4 (December 1950), 381-392.

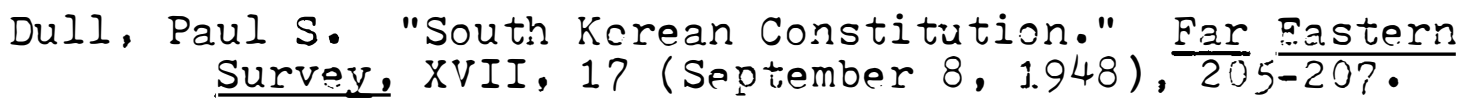

Dulles, John Foster. "To Save Fumanity from the Dee? Abyss." The New York Times inagazine (July 30 , $1950), 34+$.

"Economic Development in South Korea." Far Eastern Fconomic Review, VII, 16 (October 20,1949), 519-521。

Gradjdanzev, Andrew J. "Korea Divided."
Survey, XIV, 20 (October 10, 1945), $\frac{\text { Far }}{28} \frac{\text { Fastern }}{1-283 .}$

Grey, Arthur L. Ir. "The Thirty-Eighth Parallal." Foreign Affairs, XXIX, 3 (April 1951), 482-487.

"Gromyko Statement July 4, 1950." Current History, XIX, 109 (September 1950), 167-170. 
Hartmann, Frederick H. "The Issues in Korea." Yale Review, XII (September 1.952), 54-66.

Hitchcock, Wilbur w. "North Korea Jumps the Gun." Current History, XX, 115 (March 20,1951), 1.36-144.

Kim, Yong-jeung. "The Cold War: The Korean Flections." Far Fastern Survey, XVII, 9 (May 5, 1948), 101-102.

"Korea: A Chronology of Frincipal Events, 1945-1950." World Today, VI, 8 (August 1950), 319-330.

Kunz, Josef L. "Legality of the Security Council Resolutions of June 25 and 27, 1.950." American Journal of International Law, XIV, 1. (January 1.951), $137-141$.

Lauterbach, Richard E. "Hodge's Korea." Virginia Quarterly Review, XXIII, 3 (June 1947), 349-358.

Lawson, Ruth $C$. "The United Nations Faces Var." Current History, XX, 115 (March 1951), 158-162.

Liem. Channing. "United States Rule in Korea." Far Dastern Survey, XVIII, ? (April 6, 1949), 77-80.

MeCune, Shannon. "The Thirty-Bighth Parallel in Korea." World Politics, I, 2 (January 1949), 223-232.

Miliis, Walter. "Sea Power: Abstraction or Asset?" Foreign Affairs, XXIX, 3 (April 1.951), 371.-384.

Mitchell, a. Ciyde. "Land Reform in South Korea." Pacific Affairs. XXII, 2 (June 1949), 144-1.54.

Mitchell, Donald w. "Counter Strategies in the Cold War." Current History, XXIII, 131. (July 1.952), 7-12.

0liver, Robert $T$. "Korea: A Progross Roport (I)." Current History, XVII, 97 (JuIy 1.949), 1.33-136.

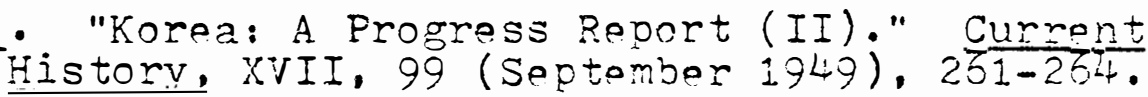
- "The Republic of Koroa Looks Ahoad (I)." Curront History, XV, 85 (Seotember 1.948), 156-161. - "The Republic of Korea Iooks Ahead (II)." Current History, XV, 86́ (oc to ber 1948), 21.3-221.

- "Tug of War in Korea." Current Historv, XIII, 74 (october 1947), 221-225. 
Parr, 5. Joan. "Korea-Its Place in History." Political Quarteriy, XXIII, 4 (October 1952), 352-367.

"Review of the Fconomy of the Republic of Korea." Far Fast Fconomic Review, $X, 2$ (January 11,1951 ).

"Review of Korea's Postwar Fconomy,"
Review, $x, 8$ (August 23,1951$), \frac{\text { Fast }}{230-237}$. Fconomic

Sarafan, Bertram D. "Military Government: Korea." Far Fastern Survey. XV, 23 (November 20,1946), 349-352.

Schlesinger, Arthur M. Ir. "The New Isolationism." Atlantic Monthly, CLXXXIX, 5 (inay 1952), 34-38.

Smith, Beverly. "The white House Story: Why We Wont to War in Korea." Saturday Fvening Post, CCXXIV, 1.9 (November 10,1951$), 22-23+$.

Stanley, G.F.G. "The Korean Dilemma." International Journal, VII, 4 (Autumn 1952), 278-282.

Stevenson, Adlai .. "Korea in Porspective." Foreign Affairs, XXX, 3 (April 1952), 349-360.

Suchman, Rdward $A$. and Rose K. Goldsen and Robin M. Williams Jr. "Attitudes Toward the Korean War."
Opinion Quarterly, XVII, 2 (Summer 1953), $\frac{\text { Puble }}{171-1} 84$.

Sunoo, Hagwon and William N. Angus. "American Poiley in Korea: Two Views." Par Tastern Surver, XXV, 15 (July 31,1946$), 228-231$.

Warner, Albert I. "How the Korean Decision Was Vace." Harcer's, CCII, 1213 (June 1951), 99-106.

Washburn, John $\%$. "Russia iooks at North Koroa." Pacific Affairs, $K X, 2$ (June 1947), 152-150.

- "Soviet Russia and the Koroan Communist Party." Pacific Affairs, XXIII, 1 (March 1950), 59-64.

Wooms, Benjamin. "Behind the Korean Flections." Far Fastern Survey. XYII, 1.2 (June 23, 1948), $\overline{142}-146$.

"White Paper on Koraa." Curront History, XIX, 109 (September 1950), $1.70-174$.

Woodman, Dorothy. "Korea, Formosa, and Norld Peace." Political quarterIy, XXI, it (October 1950), 364-373. 


\section{Secondary Sources}

\section{Books}

Adler, Selig. The Isolationist Impulse. New York: AbelardSchuman, 1958 .

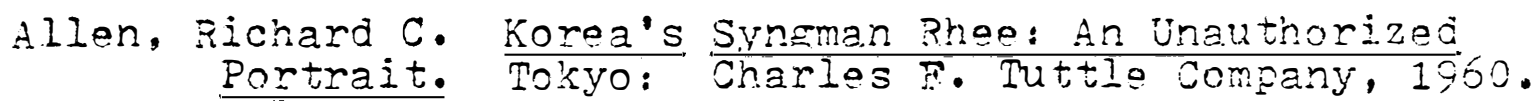

Almond, Gabriel A. The American Poople and Foreion Policv. New York: Frederick A. Praeger, 1965.

Ambrose, Stephen 8. Rise to Giobalism: American Foreian Policy 1338-1970. Baltimore: perglin 300ks, 1972.

Barnet, Richard I. Interventicn and Revolution: The Unitad States in the Third Worid. Cleveland: The world Be11. Coral. Nezotiation From Strengtin: A Study in the
Eolitics of Power. New York: A.A. Knopf, 1953.

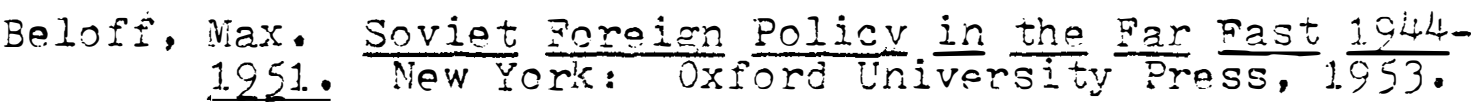

Berger, Carl. The Korean Knot: A Military-Political History. Philade Ionia: University of Pennsylvania Pross, 1957 .

Bloomfield, Iincoln. The Unitod Nations and U.S. Foroinn Policy: A New Look at the National Interest.

Bohlen, Charles 7 . The Transformation of Amorican Foreisn Policy. Hew Fork: in. Norton, 1909 .

Eundy, Moceorge, ed. The Pattern of Resonnsiciliti. Boston: Houghton riffilin, 1.952 . 
Caldwell, John C. The Korea Story. Chicago: Henry Reznery, $19 \overline{52}$.

Caridi, Ronald J. The Korean War and American Politics: The Republican Party as a Case Study. Philadelphia: University of Pennsylvania Press, 1968.

Cho, Soon-sung. Korea in World Politics: An Fvaluation of
American Responsibility. Berkoley: American Responsibility.

Cochran, Bert. Harry Truman and the Crisis Presidency. New York: Funk and Wagnails, 1973.

Curry, George. James F. Byrnes. Vol. XIV: American Secretaries of State and Their Diplomasv. Edited by Samuel Flagg Bemis and Robert $\vec{H}$. Ferrell. New York: Cooper Square Publishers, 1065.

Dallin, David J. Soviet Russia and the Far Fast. New

Daniels, Jonathan. The Man of Independence. Philadelphia: J.B. Lippincott, 1950 .

Dille, john. Substitute for Victcry. Garden City: Double day and Company, 1954.

Druks, Herbert. Harry $\mathrm{S}$. Truman and the Russians 1945-1953. New York: Robert Speller and Sons, 1966.

Fehrenbach, T. This Kind of War: A Study in Unprebaredness. New York: Vicmilian, 1.963 .

Feis, Herbert. The Atomic Somb and the End of World War II. Princeton: Princeton University Press, 1.960. Princeton Nar and Peace: The Potsdam Conferonce. Princeton: Princeton University Press, 1.960. - The China Tangle: The American Fffort in China From Foarl Farbor to the Marshall Mission. Princeton: Frinceton University Fress. 1953.

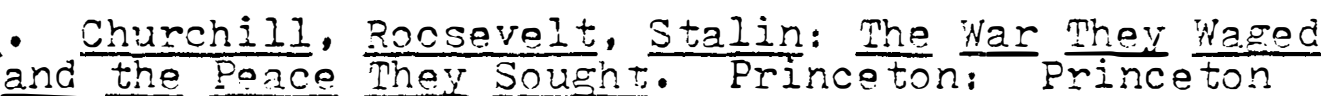
University Press, 1970 . - Contest Over Japan. New York: W.W. Norton, 
Ferrell, Robert H. Georae C. Marshall. VoI. XV: American Secretarios of State and Their Diplomacy. Fdited by Samuel Flagg Bemis and Robertif. Ferroli. New York: Cooper Square Publishers, 1966.

Fleming, Denna Frank. The Cold War and Its origins. 2 Vols. Garden City: Dcubleday and Company, 1.961.

Fontaine, Andre. History of the Cold War. 2 Vols. New York: Pantheon Books, $19 \overline{69 .}$

Gaddis, John Lewis. The United States and the Origins of the Cold War 1941-1247. New York: Columia University Press, 1972 .

Gerson, Louis I. John Foster Dulles: VoI. XVII: American Secretaries of State and Their Diolomacy. Fdited by Samuel Flagg Beris and Robert $\mathrm{H}$. Forrell. New York: Cooper Square Publishers, 1967.

Goldman, Fric E. The Crucial Decade-And After: America, $1945-1960$. New York: Random House, 1960.

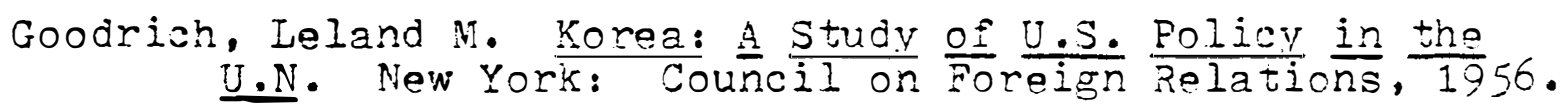

Gordenker, Leon. The United Nations, and the Peaceful Unification of Korea: The Politics of Field operations 1247-1250. The Hague: Martinus Nijhoff, 1959.

Graeiner, Norman A. Cold War Diolomacy 1245-1260. Princeton: D. Van Norstand, 1962.

- Ideas and Diolomacy. New York: Oxford

University Press, 1964.

- The New Isolationism: A Study jn Politios and Foreign Policy Since 1950. New York: The Ronaid Press, 1.956 .

Guhin, Wichael A. John Foster Dulles: A Statesman and His Times. New York: Columbia Unive $\overline{r s i t y}$ Iress, $1 \overline{972}$.

Gunther, John. Tho Riddle of NacArthur: Jaban, Korea
the Far Fast. New $\frac{\text { Nork: Harper and Brothors, }}{1.951 .}$ Halle, Louis J. The Cold War As History, Now York: Harper
and Row,

Hamby, Alonzo I. Eevond the Now Deal: Harry S. Truman and American Liberalism. Now York: Columid University Press, 1.973 . 


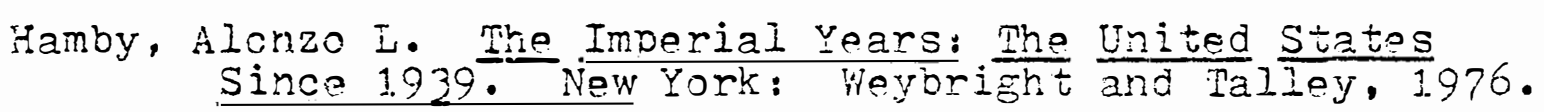

Hartmann, Susan M. Truman and the 80th Congross. Columbia: University of Missouri Press: 19 ?1.

Heinl, Robert D. Victory at High Tide: The Inchon Camgaign. Philadelphia: J.B. Lippincott, 1968 .

Henderson, Gregory. Korea: The Poiltics of the Vortex. Cambridge: Harvard University Press, 1968.

Higgins, Marguerite. War in Korea. Carden City: Doubleday and Company, $1 \overline{951}$.

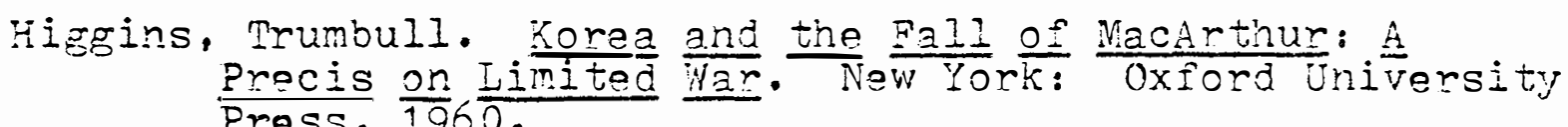
Press, $\frac{0 n}{1960}$. Nand

Horowitz, David. Free World Colossus. New York: Hill and

Ingram, Kenneth. History of the Cold War. Iondon: Darwen Finlayson, 1955 .

Jones, Joseph Varion. The Fifteen Weoks (February 21-June 5 , 1.242). New York: Harcourt, Brace and World, 1955.

Kim, Joungwon A. Divided Korea: The Folitics of Development 1.945-1972. Cambridge: Harvard University Press, 1.975 .

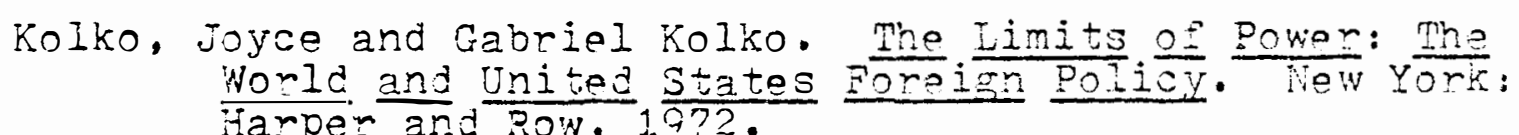

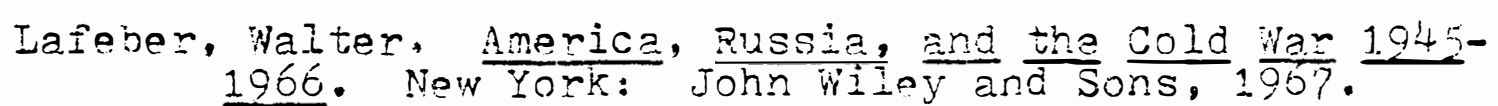

$\begin{aligned} \text { Leckie, Robert. } & \text { Conflict: The Histony of the Korean War } \\ & 1950-1953 \text {. New York: G.P. Putnam's Sons, 1.962. }\end{aligned}$

Lee, Chong-sik. The Politics of Konoan Nationalism. Berkeley: University $\frac{\text { California Pross, }}{\text { Of }} 1963$.

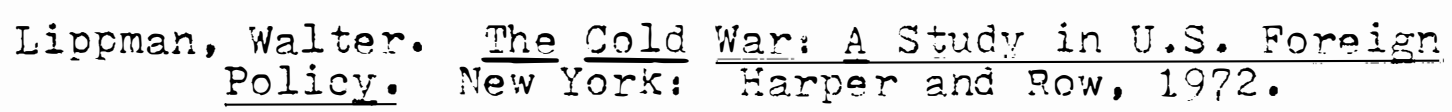

Iubell, Samuel. The Future of Amonican Politios. New York: 


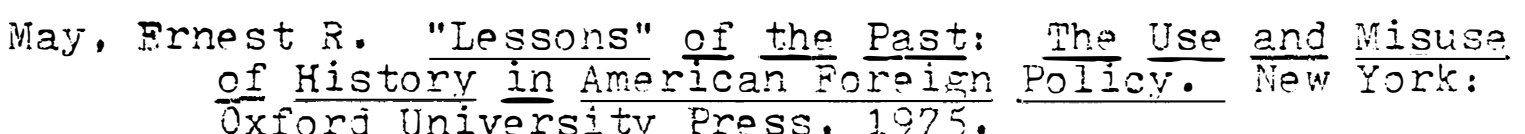

MeCune, George M. and Arthur L. Crey Jr. Korea Today. Cambridge: Harvard University Pross, 1950.

MeGovern, James. To the Yalu. New York: William Norrow, $19 ? 2$.

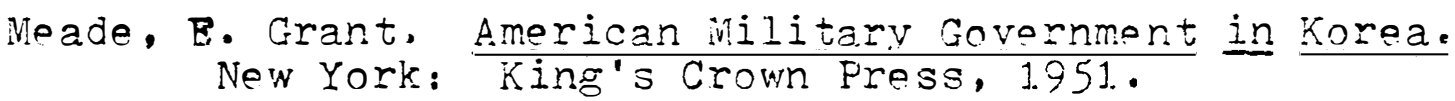

Middleton, Harry I. The Comoact Tistory of the Korean War. New York: Hawthorn Books, 1.965.

MitcheIl, C. Clyde. Korea: Second Eailure in Asia. Washington, D.C.: The Public Affairs Institute, 1951.

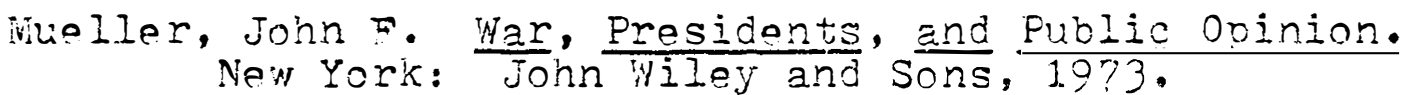

O'Ballance, Sagar. Korea: 1.950-1.953, Famcien, Connecticut: Archon Books, 1.969.

Oliver, Robert T. Syngman Rheo: The Man Berind the Myth. New York: Dodd Yiead and Company, 1.955. - Vordict in Konez. Lebanon: Sowors Printing Company 1.952 .

- Why War Came in Kore3. Now York: Fordham University Press, 1.950.

Osgood, Rovert 5 . Limited War: The Challenge to American Strategv. Chicago: University of Chi ago Press. 1957 .

Paigo, Glenn. The Korean Decision June 24-30, 1950. New The Free Fress, 1968.

- The Korean Peode's Democratic Republic. Hoover Institution Studies 1.1. Stanford: Hoover Institution, 1966.

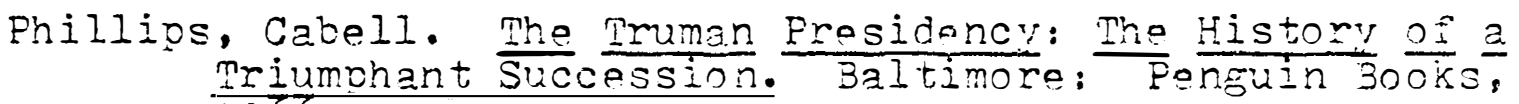
1056 .

Poats, Rutherford M. Decision in Koroa. New York: The Mc Bride Company, 1954. 
Rees, David. Korea: The Iimited War. New York: St. Martin's Press, $19 \overline{964}$

Reeve, W.D. The Republic of Korea: A Political and Fconomic Study. Loncion: oxford University Press, 1963.

Reitzel, William, Norton A. Kaplan, ard Constanco G. Coblenz. United States Foreign Policy $1245-1.255$. Washington, D.C.: The Brookings Institute, 1956.

Rose, Lisle A. Dubious Victory: The United States and tho End of world War II. 2 Vols. Oberlin: The Kent State university Press, 1973.

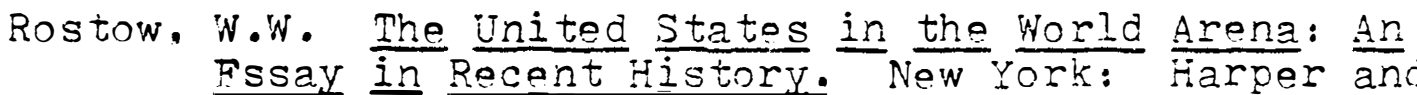
Brothers, 1950 .

Rovere, Richard and Arthur M. Schlesinger Jr, The Goneral and $\frac{\text { the }}{\text { Policy. }} \frac{\text { President }}{\text { New York: }} \frac{\text { and }}{\text { Farrar, Straus, and Young, 1951. }}$

Schilling, Warner R., Paul Y. Hammond, and Glenn F. Snyder. Strategy, Politics, and Defense Budgots. New York: Columbia University Press, 1962.

Sheldon, Walt. Holl or High Water: NacArthur"s Landing at Inchon. New York: Niacmillan, 1968.

Shulman, Marshall D. Stalin's Foreign Policy Reaporaised. Cambridge: Harvard University Press, 1963.

Simmons, Robert $R$. The Strained Allianco: Peking, PyongWang, Noscow and the Politics of the Korean Civil

Smith, Gaddis. Dean Acheson. Vol. XVI: Amorican Secretaries of State and Their Diolomacy. Faited by Samuel Flagg Bemis and Robert $H$. Ferreli. New York: Cooper Square Publishers, 1.972 .

Snow, Edgar. $\frac{\text { Rod }}{\text { New Yhina Today: }} \frac{\text { The Other Side of the River. }}{\text { Random House, } 1970 .}$

Spanier, John W. The Tmumar-MacArthur Controversy and the Korean War. New York: W. Norton, 1965.

Stairs, Denis, Tho Diolomacy of $\frac{\text { Constraint: }}{\text { Korean war, and the Unitod States. }}$ Toronto: the Univorsity ôt Toronto Press, 1974. 
Steel, Ronald. Pax Americana. New York: Viking Press, 1972 . Stone, I.F. The Hidden Mistory of the Korean War, New

Theoharis, A than. Seeds of Rooression: Harry S. Pruman and the origins of veCarthyism. Chicago: Quadrargle Press, 1971.

Tompkins, Pauline. American-Russian Relations in the Far Fast. New York: Macmillan, 1.949.

Tsou, Tang: America's Failuro in China 1041-1250. Chicago: University of Chicago Press, 1963.

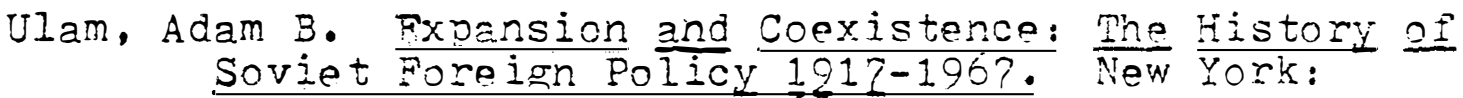
Praeger Publishers, 1968 .

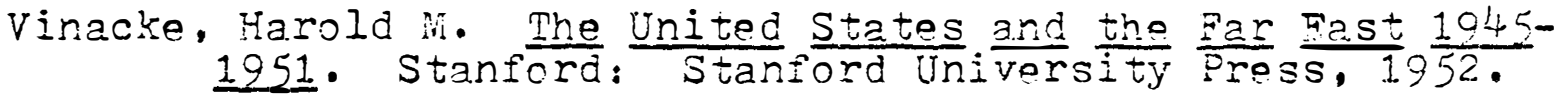

Nalkor. Richard I. F.R. Stettinius. Vol. XIV: American Secrotaries of State and Their Diblomacy. Fited by Samuel Flago Bemis and Robert if. Forroll. New York: Cooper Square Publishers, 1965.

Westerfiela, $\mathrm{H}$. Bradford. Foreign Policy and Panty Politics: Pearl Karbor to Korea. New haven: Yale University Fress, $\frac{1.355 .}{1.5}$

Whiting, Allen s. China Crosses the Yalu: The Decision to sity press, 1.960

Whitney, Courtney MacArthur: His Rendezvous Hith History. New York: Alfred A. Knopi, 1950.

williams, William Appleman. The Tragedy of American Diolomacy. New York: Dell Publisning Company, 1.972.

willoughby, Charles and John Chamberlain. MacArthur 10411951. New York: McGraw Fill, 1954.

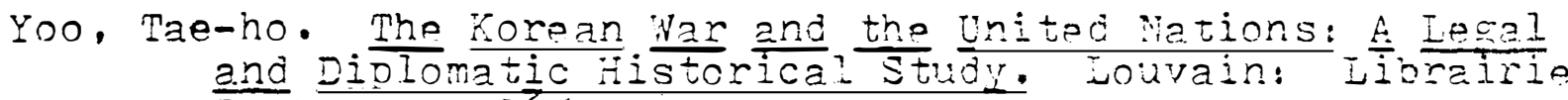
Des barax, 1955 . 
Collections of Articles.

Balowin, Frank, ed. Without Parallel: whe Amorican-Korean Relationshio Since 1945. Now York: Pantheon Books, 1.974.

Bernstein, Barton J., ed. Politics and Policies of the Truman Administration. Chicago: quadrangle $300 \mathrm{ks}$, 1970.

Gardnor, Lloyd C., ed. The Korean War. New York: Quadrangle Books, $19 \overline{72 .}$

Graebner, Norman A., ed. The Cold War: $\frac{\text { Ideological Conflict }}{\text { iexington: }}$
or Power Struggle? - An Uncertain Tradition: American Secrotaries of State in the Twentieth Century. New York: Wiccraw

Guttmann, Allen, ed. Korea: Cold War and Limited War.
Lexington: D.C. Heath, 1972.

Kirkendal1, Richard S., ed. The Truman Poriod as a Research Field: A Reaporaisal, $\frac{1.2}{2}$. Columbia: $\frac{\text { University }}{2}$ of Missouri Press, $19 ?^{4}$.

Mosely, Philip $\mathbf{3}$, et. al. "The Koroan Fxporience." Journal of Intornational Affairs, VI, 2 (Spring 1.952),

Rubinstoin, Alvin $z$ and Goorge Ginsburgs, ods. Soviot and
American Policies in tho unitod Vations. NevYork: American Policies in tho Unitod:

Articles Contained in Largor Colloctions,

Kanor, Norman. "I.F. Stone and the Korear War." In Cola War Critics: Alternatives to Eoreian Poljoy in the Truman Years. Edited by Thomas $G$. Patterson. Chicago: 2uadrangle $300 \mathrm{ks}, 1971$.

Lafebar, Walter. "Crossing the 38th Parallol: The Cold Nar in Microcosm." In Roflections on the Cold War: A Quartar Century o Amorican Foroign Eolioy - Fi ted by Lynn F. Milier and Ronald if. Frue sson. Fniladelpnia: Temple univorsity pross, 1.974. 
Lichterman, Martin. "To the Yalu and Back." In American

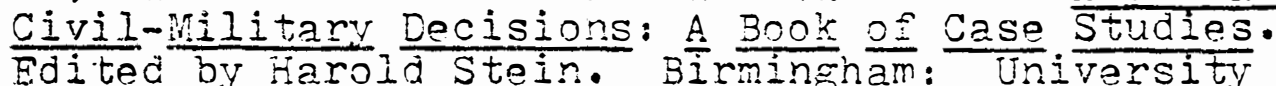
of Alabama Press, 1963.

Paige, Glenn D. "Korea." In Communism and Revolution: The Uses of Political Violence. Fited by Cyril F. Black and Thomas P. Thornton. Princeton: Frinceton University Press, 1.964.

Suh, Dae-sook. "A Preconceived Formula for Soviatization: The Communist Takeover of North Korea." In The Anatomy of Communist Takoovors. Editod by Thomas T. Hammond. New Haven: Yale University Press, 1975.

\section{Articles}

Bell, Coral. "Korea and the Balance of Fower." The Political Quarterly, XXV, 1 (January-Narch 1954), 1.7-29.

Brzezinski, zbigniew. "How the Cold War Was Playod." Foreign Affairs, II, 1 (October 1.972), 181-209.

DoWeerd, H.A. "Strategic surprise in the Korean War." orbis, VI, 3 (Fall 1.962), 435-452.

Gaddis, John Lewis. "Was the Truman Doctrine a Real Turning Point?" Foreign Affairs, LII, 2 (Janliary $1.974), 386-402$.

Granoner, Norman A. "Global Containment: The Truman Years." current History. IVII, 336 (August 1969), 77-83.

Gupta. Karunakar. "How Did tho Korean War 3egin?" The China Quartorly (October-Decembor 1972), 699-716.

Haas, Innest B. "Types of Collective Security: An Fxamination of Oporational Conceptions." American Political Science Review, XIIX, 1 (March 1955), $40-62$.

Hoyt, Fdwin C. "The United States Reaction to the Korear. Attack." American Journal of Intornational Law, LV, 1 (January 1.961), 45-76.

Lee, Chong-sik. "Kim Il-song of North Korea." Asian Survey, VII, 6 (June 1.967), 374-382. 
Lofgren, Charles A. "Mr. Truman's War: A Debate and Its Aftermath." Review of Politics, XXYL, 2 (April 1.969), 223-241.

May, Ernest R. "The Nature of Foroign Policy: The Calculated Vecsus tho Axiomatic." Daedalns, XOI, 4 (FaIl 1.962), 653-667.

Mclelian, David S. "Dean Acheson and the Korean War."

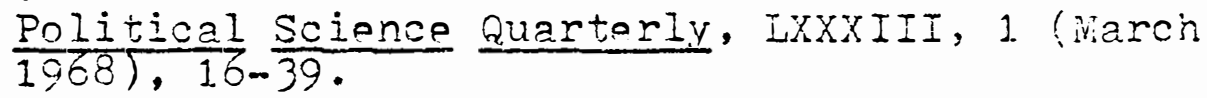

Simmons, Robont R., Chong-sik Lee, w. Skillend, and Kamunakar Gupta. "Comment." China quarterly (April-June 1.973), 354-368.

Stueck, Nilliam. "Cold War Rovisionism and the origins of the Korean Conflict: The Kolko Thesis." Pacific Historical Review, XIII, 4 (November 19?3) 53 ? 575.

Wolfers, Arnold. "Collective Security and the war in Korea." Yale Review, XIIII, 4 (Summer i9?4), 481496.

\section{Theses and Dissertations}

Hancock, James Irving. "The Impact of the Koroan War on American Military Strategy." Unpublishod Mastor's Thesis. Univorsity of Virginia, 1967.

Lee, U-Gene. "American Folicy Toward Korea 1.942-1.947: Formulation and Fxccution." Unpuolishod Ph.D. Dissertation. Gecrgotown University, 1.973.

Lofgran, Charles A. "Congress and the Korean Conilict." Unpublished Ph.D. Dissertation. Stanford University, 1.973.

Marshall, Thomas Lee. "The Strategy of Conflict in the Korean Nar." Unoublished Ph.D. Dissertation. University of Virginia, 1.969.

Norris, William G. "The Korean Trustooship 1.941-1947." Unpublished Ph.D. Dissertation. Iniversity or Texas, 1.975 .

Twedt, Nichael S. "The War Rhotoric of Harry S. Truman During the Korean Conflict." Unpubijshod Fh.D. Dissertation. University of Kansas, 1959. 